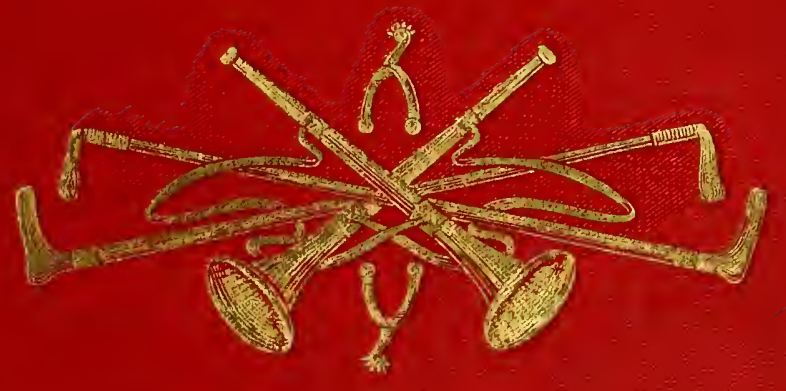




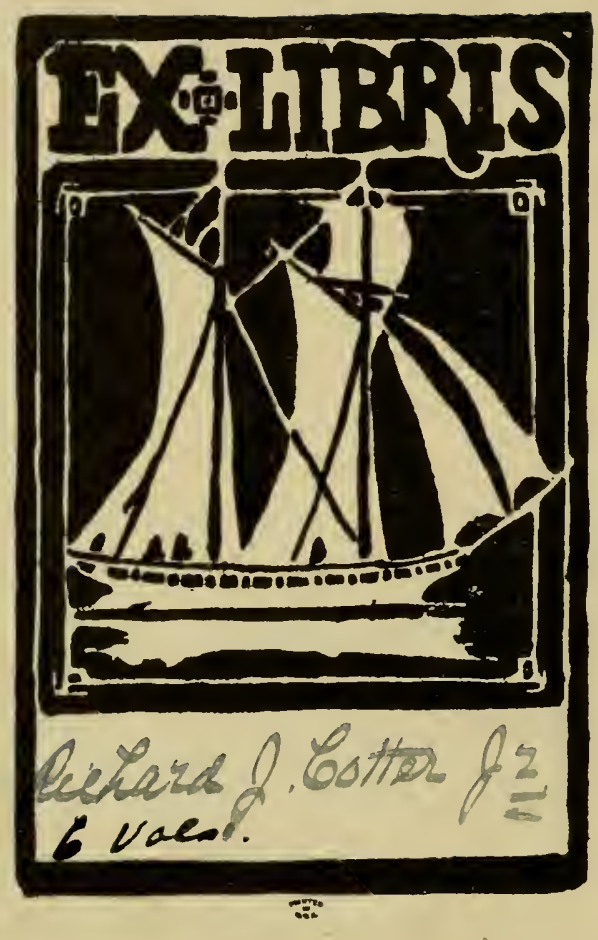



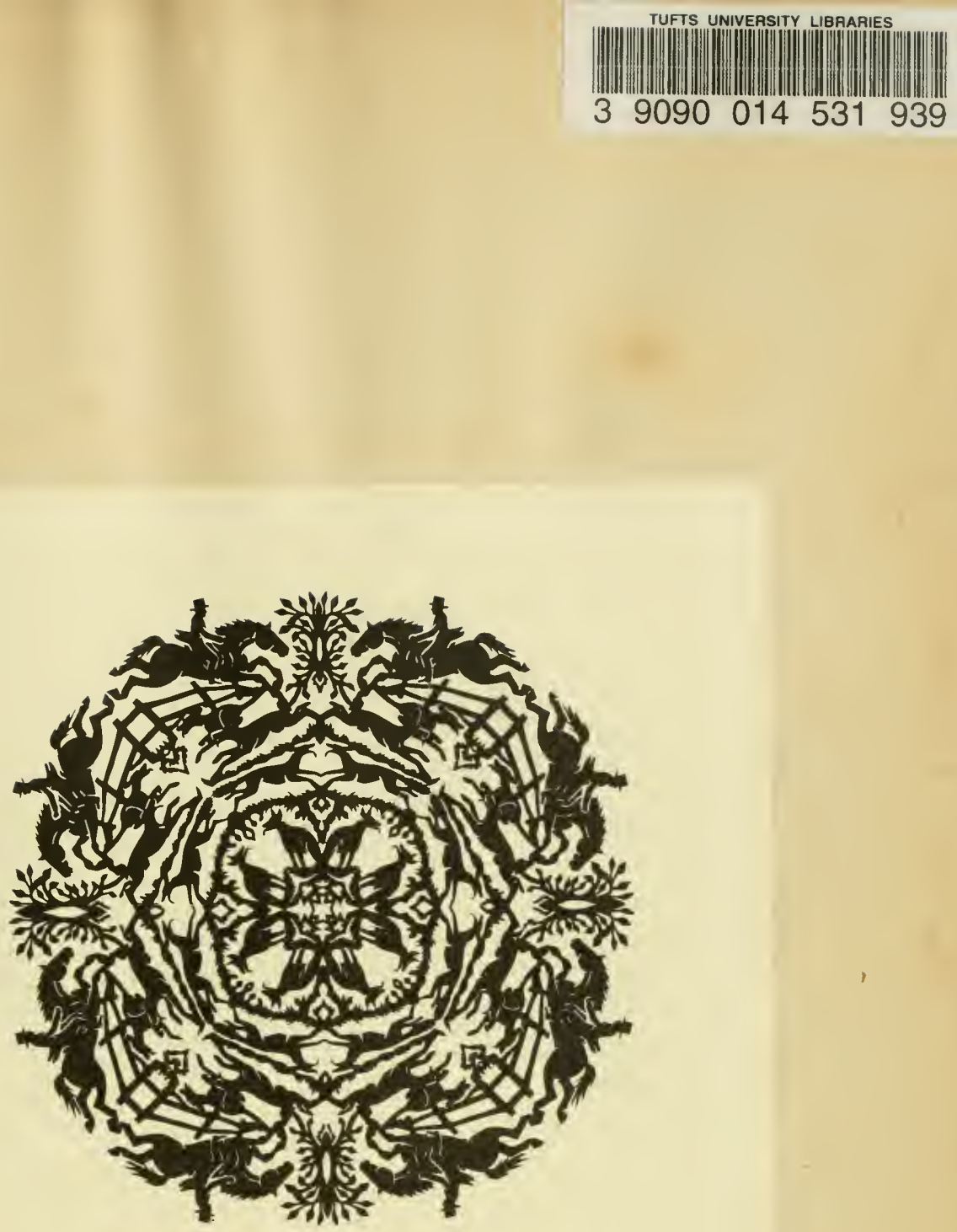

JOHN A.SEAVERNS 


This edition is limited to 500 copies for sale in Great Britain. 
NIMROD'S HUNTING TOURS 




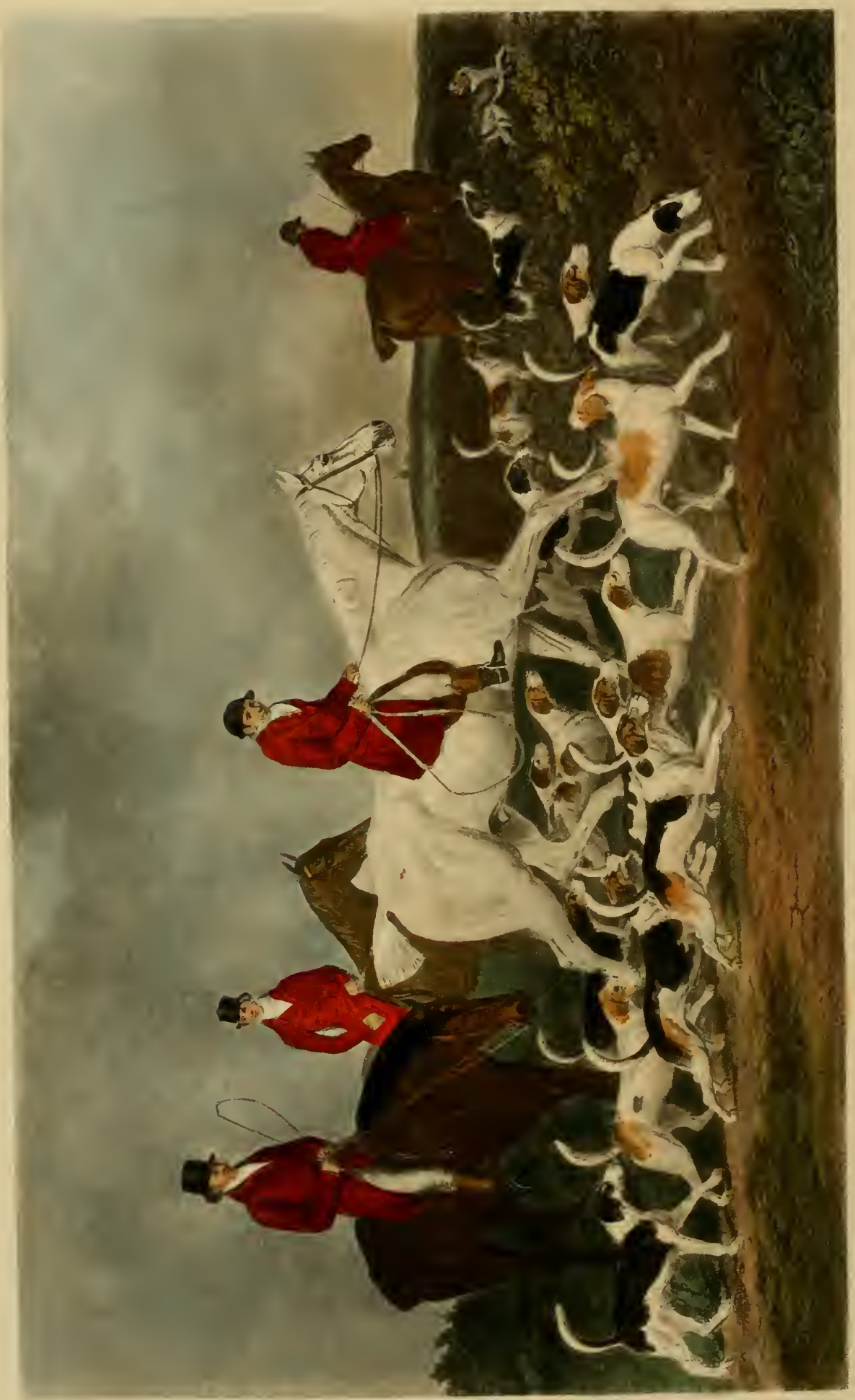




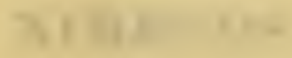

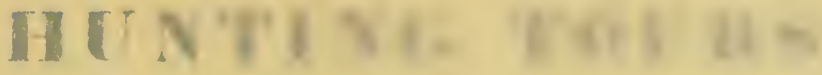

I HARGFH:
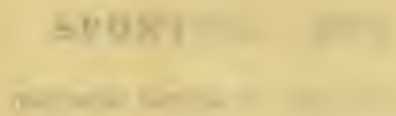

\section{rrack Hatars of}

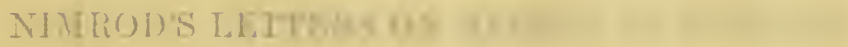

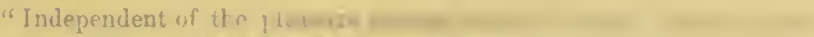

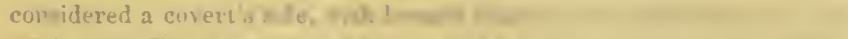

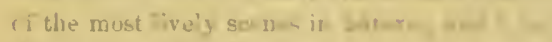

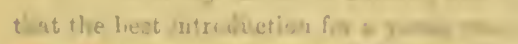
traseul cavis to b fuune a Bil

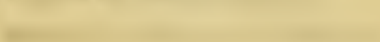




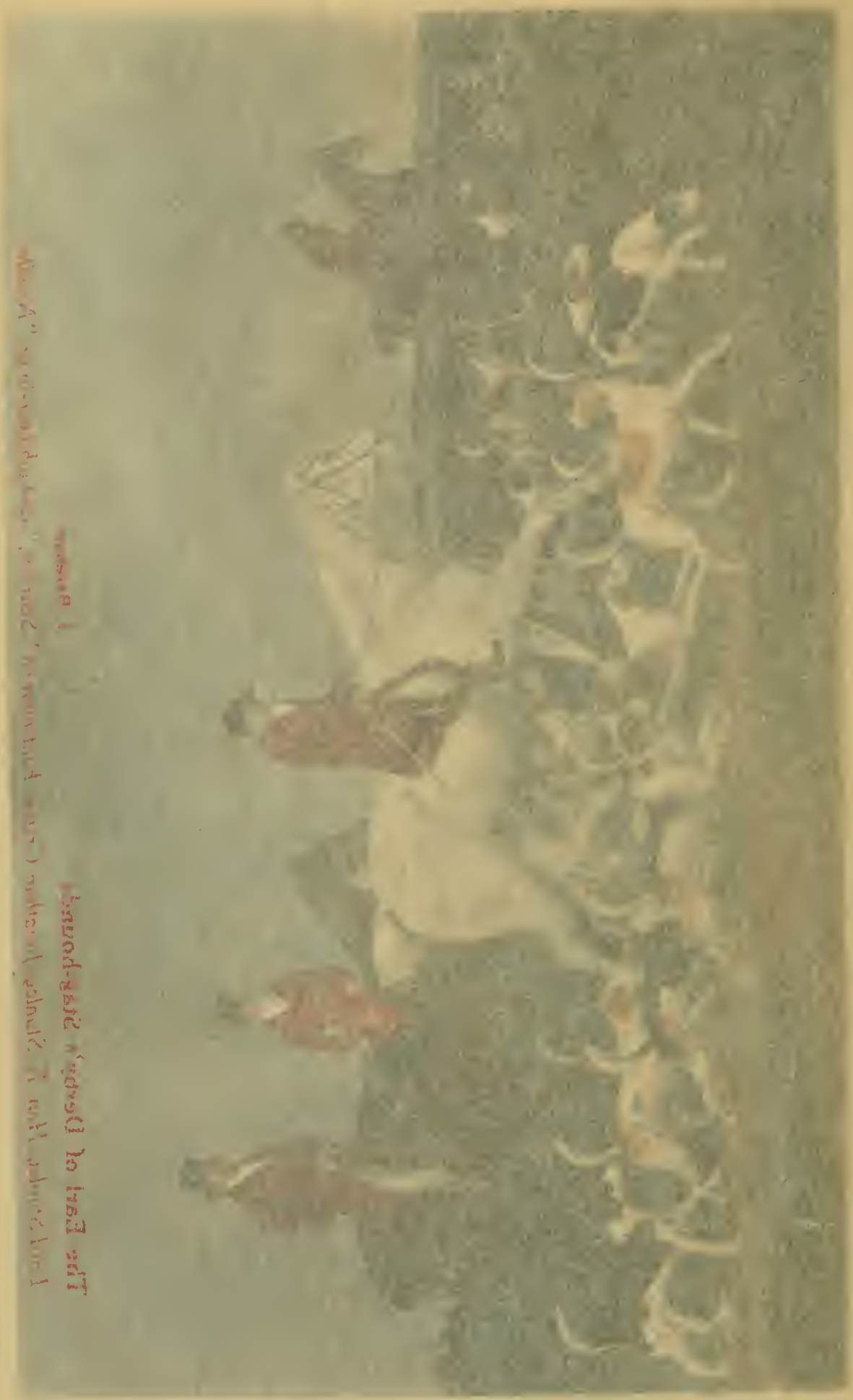




\section{NIMROD'S \\ H U N T I N G TOURS,}

INTERSPERSED WITH

CHARACTERISTIC ANECDOTES, SAYINGS, AND DOINGS

$=\quad$ or

SPORTING MEN,

INCLUDING NOTICES OF TIIE PRINCIPAL

\section{Crack litoers of Englant,}

TO WHICII ARE ADDED

NIMROD'S LETTERS ON RIDING TO HOUNDS,

WITH

ANALYTICAL CONTENTS AND GENERAL INDEX OF NAMES.

Illustrated with 18 Plates in Colours, after Ben. Marshall, Jas. Barenger, R. B. Davis, Wm. Barraud, WM. Webb, H. B. CIIAlon, James IVARD, R.A., ETC.

"Independent of the pleasure arising from the Chase, I have always considered a cover't's side, with hounds that are well attended, to be one of the most lively scenes in nature; and $I$ have no hesitation in adding, that the best introduction for a young man of fortune and fashion of the present day is to be found at Billesdon Coplow or Oadby toll-bar."

Niniod on Riding to Hounds.

\section{LONDON}

KEGAN PAUL, TRENCH, TRÜBNER \& CO., Ltd. DRYDEN HOUSE, GERRARD STREET, W. 
LONDON :

PRINTED BY GILBERT AND RIVINGTON, LIHITED,

ST. JOHN'S HOLSE, CLERKENWELL. 


\section{ADVERTISEMENT}

IVhen Nimrod's "Letters on 'Hunting" first appeared in the pages of the Sporting Mayazine, it was intended that they should be collected and published in a separate volume. The death of the then Proprietor, however, with several other causes which it is unnecessary to particularize, prevented that intention from being carried into effect.

On the first appearance of these Letters many characters were introduced that had either retired from the Sporting World, or had, departed for "that bourne from whence no traveller returns:" but if the allusions to by-gone days were then considered of interest, they must of necessity be more so now, as reminiscences of men, who, unlike the Squire Wrestcrns of the olden time, constituted Hunting a science, and combined the courtesies of Elegant Life with the socialities of the Old English Gentleman.

The writings of Nimrod are too well known to need any apology for thus collecting them into one volume :-they embrace a mine of information and a fund of entertaining anecdote on sporting subjects and character's unexampled in the annals of the Chase: in addition to which, to use a favorite term of Blackuoor, the writer has more gumption in his style and observations than any other Chronicler of the events he records.

It was at first intended to arrange the counties alphabetically, and to give a continuous history of each pack of hounds from the 
commencement to the conclusion of the Letters : but this was found to be impracticable, as the intervening connexion would necessarily be omitted; and this is so interwoven with the progress of the narrative, that its interest would in that case be materially diminished. The "Tours," therefore, are now given as they originally followed each other, without the addition of a single line, but with the omission of all extraneous matter not connected with Fox-7unting.

Many of the Hunting Men of that day have also been elevated in the scale of society; but it has been deemed advisable to retain the name of the individual as he was then designated: so that it is only necessary to say, that the Earl of Darlington at the time Nimrod wrote is the Duke of Cleveland of the present day; the Lord Anson, Earl of Lichfield; the Colonel Berkeley, Lord Seagrave, \&c., \&c.

Ninrod's Letters on "Riding to Hounds," with an Analytical Contents and List* of all the Sporting Characters introduced, are added, thus rendering the volume the most interesting hitherto published on the subject of the Criase.

* This has been enlarged and made complete in the present edition. 


\title{
ANALYTICAL CONTENTS
}

\author{
LEICESTERSHIRE,
}

The conntry for fox-hunting-its advantages over other countries-Mr. T. Smith-Mr. Lindo-" the Clipper"-Mr. Meynell-Lord Sefton .

\section{OXFORDSHIRE.}

Line of country - the hills-Duke of Beaufort's hounds and establishment - University men-riders in the Hunt-Lord Edward SomersetLord Granville Somerset-Mr. Holloway-Mr. J. Codrington-Mr. Evaus-Mr. Meyrick-Mr. Rawlinson-Sir T. Mostyn-his country (the Bicester) and establishment-his huntsmen, Shaw, Stephen Goodall, and Tom Wingfield-the Brill country-Lord Jersey-Sir Henry Peyton-Sir Elward Lloyd--the four Messrs. Drake-Mr. Harrison-the Chipping Warden country

\section{WARWICKSHIRE}

Is a hunting country - the Stratford, the Edgehill, and the Meriden countries - the Stratford Club-Mr. Corbet, of Sumdorn, as a master of hounds-his hunting establishment-his huntsman Will Barrowvalue of horses in his Hunt-Mr. Lockley-Mr. Best-Mr. Richard Bradley-Mr. Stroud-Trojan-Champion-aneedotes of Mr. Corbethis devotion to fox-hunting, hospitality, gentlemanlike conduct in the field, and civility to farmers-Walter Stubbs, Esq., his enthusiasm in the field, and anecdotes relating to - characters and hard riders in the Hunt-Mr. Robert Canning-Mr. E. G. Morant-Mr. John HawkesSir Gray Skipwith-Mr. R. Winniatt-Mr. Boyeott . . . . .

\section{SURRET}

As a hunting country-Mr. Haigh-the "veteran" Cochran-Mr. Percivall-Mr. Hobson-Capt. Harvey-Mr. Dyer-Mr. Holt-the Union pack-Christopher Atkins-Colonel Jolliffe's hounds-Roffey, the hnntsman-pedigrees of some leading hounds in the pack . . .

\section{SUSSEX}

As a hunting country-Colonel Wyndham, and reputation of his packEast Sussex Subscription pack under Colonel Cator-Mr. Burrell- 
Major Keen-Colonel Henry Wyudham-Robert Bartlett-the Brookside Harriers under Mr. H. Carr-Dr. Hooker-difference between hunting parsons and a parson who hunts-aneedotes of a Bishop-Mr. Hodson of Lewes . . . . . . . . . .

\section{CLOSE OF THE SEASON 1823-4.}

Mr. Chute's hounds-Sir John Cope's hounds-a fortnight's hunting with Mr. Ward's hounds-description and character of his pack-the hound Sovereign-the Craven country-madness in the kennel-Will Neverd the huntsman-Will Hedden the whipper-in-several capital runsfeeding hounds-anecdote of the Rev. Fulwar Fowle-characteristic one of Mr. Hemsted of Newbury-horses in the Hunt-Mr. Lambort, a "man of Kent"-Mrs. Ward a true friend to fox-hunting . .

\section{DORSET AND DEVON}

As hunting countries-Sir Arthur Chichester's hounds, hunted by John Horlock-Mr. Incledon-the Rev. Dr. Troyte's hounds-the Hon. Newton Fellowes-Stephen, his huntsman-"A Day with the Eggesford Hounds," a poem, describing a run with Mr. Fellowes's houndsMr. Templer, and his system of hunting and keeping foxes-the Chumleigh Club-the Rev. Henry Taylor-the Rev. John RussellMr. Templer's method of educating horses-hospitality and good fellowship in Deron-anecdotes of Colonel Kelly, \&c. . . . . .

\section{HAMPSHIRE.}

The H.H. or Hampshive and the Hambledon Hounds.

Mr. Villebois' establishment-the H.H. Club-an unparalleled instance of a pack all got by one hound and four bitches-particular horses adapted for the country-Foster the huntsman-Sawyer and John Jennings the whippers-in-Mr. Villebois as a master of houndsextent of his country-a brilliant day's sport-riders in the HuntMessrs. Knight, the two Captains Greenwood, Mr. Scott, Mr. Baring, jun., Mr. G. Butler, Major Barrett (brother-in-law to Mr. Villebois), Mr. D. Murray, Mr. Smythers, Mr. Wilkinson, and Mr. Wyse-Mr. Smith, master of the Hambledon hounds, and riders in that countryAdmiral Colpoys, Sir W. Hoste, Captain Collier, Major Ridge, Captain Close - the Club-Anecdote of Captain Bridges . . . . .

\section{A TOUR IN 1825,}

Embracing Accounts of the Hounds of Sir Thomas Mostyn, the Old Berkeley, Duke of Grafton, Duke of Beaufort, the Warwichshive, Colonel Berkeley, Lord Anson, the Quorn, Duke of Rutland, and Mr. Nicoll.

Sir Thomas Mostyn's Oxfordshire country-sport with his hounds-Bob Westall and his horse-the Old Berkeley country under Mr. Harvey Combe and Mr. Marjoribanks - Mr. Combe as a rider to and mastor of 


\section{ANALY'TICAL CON'TEN'IS}

houuds-character of the hounds-Bob Oldaker-extraordinary leap by Sir H. Peyton and Mr. Becher-the Dake of Beaufort's houndsPhilip Payne as a huntsman-brilliancy of condition of the pack, and rums with them-Mr. Webb-visit to Sir Loftus Otway-Colonel Berkeley's hounds and country-the Warwickshire-Jack Wood the huntsman-Lord Middleton's method of hnnting a country-visit to Mr. John Lucy-antiquity of his family-Mr. Knightley-Mr. ShirleyMr. Payne of Selby-Lord Anson's Atherstone country, and characters in the Hunt-Billy Breton with Mr. Adderley's hounds-Mr. Adderley a second Allworthy-anecdote of Shaw-Mr. Edmund Peel as a riderRobert Thurlow-Lord Anson as a rider and huntsman-anecdotes of Mr. Leech of Carden - visit to the Quorn-accident to Mr. Osbaldeston - his devotion to fox-hunting-the Widmerpool conntry-larking between Mr. Maher and Captain Standon-the Duke of Rutland's hounds-Goosey the huntsman-Quorndon Hall, and the Quoru country and kennels--Mr. Osbaldeston as a master of hounds-changes in Leicestershire-imposing assemblage at the start-proofs of nerre exemplified by Captain Stwart, Mr. George Marriott, Jack Shirley, Mr. White-Melton Mowbray-the old Club-Mr. John Musters-Mr. Thomas Edge-siugalar anecdote of a hunter called Gayman-description of the formidable ox-fences, "doubles," brooks, thorn fences, favourite coverts-Mr. Cradock's artificial coverts, and elegant compliments paid to him-Mr. Oldacre's gorse-coverts-Mr. Mnnday's in the Seggs-hill country-extraordinary" shooting of Captain Rosscrack riders in Lieicestershire-Mr. Maxse, Sir Harry Goodricke, Mr. Holyoake, Lord Plymouth, Mr. F. Grant, the Earl of Kintore, Captain Ross, Captain Standon, Sir Watkin Williams Wynn-death of Tom Penn, Sir Watkin's pad-boy . . . . . . . . . .

\section{A FOR'TNIGHT IN THE NEW FOREST.}

Mr. Nicoll as master of the honnds, both in field and kennel-the countryanecdote of Mr. Chudleigh Haynes-Joe the whipper-in-Sir Francis Burdett as a rider to hounds-Mr. Harbin-the lions of the ForestSir Hussey Vivian an excellent friend to fox-huntiug, with trophies to his well-earned fame-Mr. Vivian (father of Sir Hussey)-anecdotes of Mr. Butler-concluding acknowledgments to the Sporting World .

\section{THE SECOND TOUR,}

Embracing Accounts of the Warvickshire Hounds under Mr. Hay$\mathbb{M} r$. Boycott's-the Shropshire under Sir Bellingham Grahamthe Cheshive under Sir Henry Mainwaring-Sir Richard Puleston's the Northamptonshive under Mr. Musters.

The Duke of Beanfort's hounds-the Warwickshire-Ufton Wood-Mrs. Shakerley on her splendid horse Golden Ball-Marquis Herrera-Mr. Hay, his hounds and men-Will Boxall the whipper-in-Iord AnsonLeamington-Major Moray-Mr. Boycott's establishment-Shrewsbury 
Hnut meeting-Sir Bellingham Graham's hounds-changes at Sundor’ Castle-death of Will Barrow, and epitaph in Uffington church-yardthe Young Club-IVill Staples' method of feeding hounds-the kennel and stables-visit to Halston-Mr. Mytton's preserves-ale and wine cellars- his harlequin tricks and larking with his horses-his kennelhis character as a sportsman, daring exploits, and proposed epitaphSir Bellingham Graham as a master of fox-hounds, a horseman, and performer over a country, and liberality in all his hunting establishments-spirited subscription of Sir Francis Burdett-instance of Sir Bellingham's extraordinary pluck-his stud-John Pnlfrey the Baronet's groom-Will Staples and Jack Wrigglesworth the two whippers-inSir Bellingham's son Godfrey-Shropshire hospitality-Mr. Mytton again-mirarulous aneclote of an Oxonian-Hardwicke, the seat of Lord Hill-Sir Edward Smythe a strict preserver of foxes-a "washball seat"- the Vicar of Prees-curions exhibition of his stud-Mr. Henry Lyster on his famous mare "The Doe "-description of a fine run by Sir Bellingham-division of his pack, and character of his hounds-Shropshire as a hunting country-hospitality of the yeomen -more of Mr. Mytton's eccentricities-crack riders in ShropshireMr. Lyster, Mr. Henry Lloyd of Aston, and his brother Mr. Lloyd of Dongey, Connsellor Slaney, Mr. Wynne, Mr. Smythe Owen, Mr. John Hill, Mr. Newton, and Mr. Kenyon-the Cheshire hounds nnder Sir H. Mainwaring, and linnted by Will Head-their condition and character-riders in the Hunt-Mr. James Tomkinson, and his brother Major Tomkinson, Mr.: Domville Poole, Lord Delamere, \&c.-pecnliarity of costume in members of the Hnnt-character of Will Headanecdotes of Mr. Leech of Carden--Cheshire farmers good preservers of foxes-Sir Richard Puleston's honnds and conntry-his character as a master of hounds-his colloquial wit-interesting anecdote relative to His late Majesty George the Fourth-the Northamptonshire honnds under Mr. Musters - the palm of snperiority as a huntsuan and rider to hounds assigned to Mr. Musters-several brilliant runs with his pack-the conntry-condition of the hounds-bis kennel and stables-among Northamptonshire riders are Mr. Vere Isham, Mr. Davey and singular accident to, Mr. Ambrose Isted, Mr. Walley, Mr. Parsons, Mr. Merrick, and Mr. Whitworth-farmers devoted to sporting-close of the Tour

\section{THE YORKSHIRE TOUR,}

Containing Accounts of the Raby Pack, the Fork and Ainsty, the Hurvorth, the Holderness, the Badsurorth, f*c., under the respective management of the Earl of Darlington, Mr. Ralph Lambton, Mr. Lloyd, Sir Tatton Sykes, Mr. Matthew Wilkinson, Mr. Thomas Hodgson, and Lord Hauke: and concluding with a Tisit to Leicestershive and the Nev Forest.

Arrival at York-its antiquities-Mr. Swann's kind attention-Mr. Ridsdale an excellent ricler to honnds-his extraordinary performance on 


\section{ANAI,I'TICAL CONTEN'IS}

the road-his racing stables-York and Ainsty hounds and kennel-

Naylor the huntsman-Mr. Lloyd the master-history of the country hunted by him-description of the V stiles-visit to Sir Bellingham Graham at Whitwell-Sir Tatton Sykes' hounds and country-lis passion for riding a race-splendid meet of Lord Darlington's hounds, and his Lordship's devotion to the sport-Newton House, stables, and offices-his Lordship's character as a sportsman-Operations of the Raby Pack-high standard of his hounds-his whippers-in-anecdote of Will Price-serious accidents to Mr. Fenton and Dick (the whipper in)-Lord Darlingtôn's method of personally feeding his houndssingular instinct in a fox-hound-characteristic anecdote of the ruling passion exemplified in Dick-the sign of the "Four Alls" at Burniston -Officers in the 5th Dragoons-Ripon famous for the manufacture of steel spurs-Thorp Hall, the seat of Mr. Milbanke, son-in-law to Lord Darlington-the Bedale Club-the Rev. John Monson-visit to Sedgefield, the head-quarters of the Lambton Hunt-flattering invitation to Nimrod-Mr. Lambton's hounds and breed-visit to John BurrellMr. Lambton's feeder-Mr. Billy Beckwith-dialogue between Nimron and John Burrell-John's eccentricities-sport with Mr. Lambton's hounds-country about Long Newton-Elstob whin-Billy Williamson -ludicrous scenes-Mr. Davison's "Two-hundred-and-fifty guinea" horse-Dreams the presage of joyful news confirmed-the Sedgefield Club-room, uniform of the Club, and rules and regulations-salubrity of Sedgefield-Hardwicke Hall, the seat of Mr. Russell-Sir Charles Turner's celebrated hunting song of "Old Casar, or Sixty Years since" -Mr. Lambton's stud of hunters-severe accident to Mr. Lambtonhis general character a pattern for an English Gentleman, and ranked, as a huntsman, as a premier artiste-comparison between Mr. Musters and Tom Sebright as huntsmen-the Sedgefield country-crack riders - the Hon. Capt. George Dundas, Billy Williamson, and Mr. Harland -Mr. Bowser's Harriers-visit to Mr. Duncombe Shafto at Whitworth -Mr. Thomas Shafto a conspicnous character in the Lambton Hunt -anecdotes of him-the Hurworth hounds under the management of Hr. Matthew, commonly called Matty, Wilkinson-bis character as a master of hounds-Mr. Wyvill-Hornby Castle the seat of the Duke of Leeds-Mr. Wilkinson at fault in killing a fox from Lord Darling. ton's coverts-Lord Lonsdale's opinion on this subject-brilliant run with Lord Anson's hounds-Mr. Loraine Smith-Mr. M. Wilkinson's family, and high estimation in which he is held in the country-his passion for the chase, and characteristic anecdotes-lis whipper-in and feeder Tommy, and his wife-the Hurworth country-the Holderness hounds, nnder Mr. Hodgson-Lord Mountsandford-Mr. Jackson's hospitality-Mr. Bethell's seat at Rise-visit to Mr. Watt at Bishop Burton-the Holderness Club-Mr. Hodgson's extraordinary attachment to his pack-his kennel-Pilot, an extraordinary hound-the country-the farmers staunch preservers of foxes-Will Danby the whipper-in-among hard riders in the Hunt are, Mr. Medford a clipper, Mr. John Bower, Mr. Alexander Macdonald, and Lord Hope- 
toun-anecdotes of Mr. Hodgson-another visit to the York and Ainsty-Naylor the huntsman again-visit to Raby Castle-Lord Cleveland a sportsman in the real acceptation of the term-he has no fellow in his passionate fondness of hunting, and everything appertaining to the noble scitnce-his natural talent and highly-cultivated accomplishments - the Fox and Hounds kept by Bob Williams, for many years head whipper-in to the Raby pack, and Bob's characterthe Marquis of Cleveland's kindness to his servants-Tommy Hodgson, his Lordship's groom-his Lordship's stud of horses, stables, \&c.-Mr. Trotter the best horseman in the field-brilliant turn-ont from the Castle-serious accident to Billy Williamson-Major and Captain Healey-the Marchioness of Cleveland, and her daughters Lady Augusta Milbanke and Arabella Vane, constant attendants on the pack-dining-room at Raby Castle-the kennel-refutation of foxkilling Lords and their keepers-several runs described-several clipping riders in the Raby Hunt, the gentlemen of the black cloth quite as conspicuous as the red-Mr. John Monson, Mr. Milbanke, Mr. Newton, Mr. Henderson, Mr. T. Maude, Captain Baird, Sir Bellingham Graham, Mr Wharton, Colonel O'Callaghan-the Badsworth pack under Lord Hawke-Jack Richards the huntsman-Lord Harewood's honnds-singular accidents to-arrival at Melton-the Carberry Hill Fox-Lord Alvanley's return to Melton Mowbray-Mr. Maher's Picton -Croxton Park races-runs with Mr. Osbaldeston's hounds-Sir Edward Mnstyn on the "Clipper"-Little Shanrock-Yorkshire as a hunting and sporting conntry has no parallel-native laconismcelebrated Hunting Song, "Howell Wood, or the Hounds of Old Raby for me!"

\section{VISIT TO THE NEW FOREST.}

Mr. Ward one of a large party of sportsmen-mirth and good humour the order of the day-anecdotes of Mr. Ward . . . . . .

Concluding Acknowledgments to the Sporting World, and return Hous

LETTERS ON RIDING To Hounds . 


\section{LIST OF COLOURED PLA'TES}

The Earl of Derby's Stag-hounds, Lord Stantey, Hox. E. Stanley, Joxathan Griffin, Huntsman on "Spanker," Whipper-in on "Noode," By Jas, Barenger . . .

Hugo Meyneld, Esq., 1794, with his Huntsmax "JaCK RAVEX" AND HIS HOUND "GLIDER" . . . .

James Shirley, Huxtshan to the Bramshild Hounds, by R. B. Davis . . . . . . . . . . " , 75

Dedicated to Sir JoHn Cope, Bart.

John Ward, Esq., on "Blue Ruin," with his Fafourite Hound "Betsy," By William Barraud, ExgRated BI

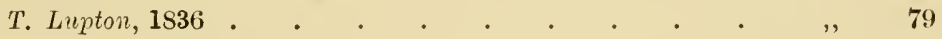

T. Wingfield, Huntsman to the Bucknel Hounds, By $R$. $B$. Davis . . . . . . . . . . . . 125 Dedicated to the Hox. TrRwhitt Drake.

J. Lambert, Huntshan to the Cottesmore Hounds, by $R$. $B$. Davis Dedicated to the EARL OF LONSDALE.

T. Goosey, Huntsman to the Befvolr Hounds, by $R$. $B$. Daris . . . . . . . . . . Dedicated to the DuKE OF RUTLAND.

John Shirley, Huxtshan to the Burtox Hodnds, bx R. $l$. Davis Dedicated to Sir Richard Sutton, Bart.

W. Long, Huxtsuan to the Badinton Hounds, by $R$. B. Davis Dedicated to the DUKE OF BEAcForT.

Johx Mytton, Esq., of Halston, Salop, ox his Fayourite little Horse "Baronet," Who carried Him for Nine Seasons witil Hodnds (after He had used Hia as ('harger in the Hussars), with his Hound "Hudibras," From ax ENgRAVING by $W$. Giller, after $I T$. Webb . 


\section{xri LIS'T OF COLOURED PLA'TES}

W. Head, Huntshan to the Donnington Hounds, by $R, B$. Davis . . . . . . . . . . . To face 221 Dedicated to the Marquis of Hastixgs.

George Montford and W. Derry, Huntsuan and First Whip to the Meiton Hounds, By R. B. Daris . . . , 233

Dedicated to Roland Errington, Eso.

Sir Mark Masterman Sykes, Bart., frou an ENgraving bi Wm. Ward, A.R.A., AFter H. B. Chalon . . . . , " 241

Ralph John Lambton, Esq., his Horse "Undertaker" and Hounds-" Calling Hounds out of Cover," 1820, from an Engraving by C. Turier, after James Waril, R.A. .

ebright, Huntsian to the Miltox Hounds, by $R . B$.

Davis . . . . . . . . . . . ,

Dedicated to the EARL of Fitzwilliair.

The Earl of Darlington and his Fox-Hounds, By Benjamin Marshall . . . . . . . . . . . . . . , , 331

The DeAth of ToN MOODY . . . . . . . . . . . , , 353

THE BURIAL OF TOM MOODY. . . . . . . . . . , , 373 


\section{INTRODUCTION}

IT is an accepted fact in that extensive and entertaining field, the annals of sporting literature, that the first and foremost of all sporting writers-in himself the pioneer and creator of this ingenious order of the literature and annals of the Chase-was the "illustrious topsawyer," as the immortal Jor'rocks has described him, "Mr. Happerley-Nimrod," otherwise the "great original " Charles James Apperley, who brought his brilliant abilities as a keenly thorough and allobserving sportsman, with his scholarly faculties as an accomplished scribe, to the jllumination of the spirited branch for which he personally must be held so largely responsible. Of all the gifted Nimrod's profuse contributions to the history of the sport he loved devoutly and understood so entirely, the very cream of his contributions-as the self-appointed historian of the Hunting Fieldmust pre-eminently be realized in his earlier "Letters on Hunting," first contributed, under the famous pseudonym of "Nimrod," to the pages of the Sporting Magazine, starting early in the years of grace 1821-1826. At that time the historical veterans of the Chase, for the most part, were more than mere traditions of the noble science; and the great sporting delineator in person was admitted to the inestimable advantage of actually "studying from the life" the illustrious heroes who have pre-eminently fostered the sporting supremacy of Old England, and whose names are recognized as the sponsors for all that was greatest, most heroic, and worthiest of preservation in the palmy days of past sport.

"Nimrod" was in himself unique as "the first of sporting chroniclers," and, further, in his luck in living in times when the illustrious worthies who raised Fox-Hunting to this high perfection of sport were still there to be seen in the hunting-field, and alike at their own 
high-class hunting establishments; practical, workmanlike, and thoroughly devoted to their beloved pursuit; the unique enthusiasm of their careers as devotees of the Chase, to which they consecrated all their manly exertions, their extraordinarily vigorous "staying powers," their fortunes, and their entire lives; for, to their tastes and inclinations, hunting was "the breath of life," and the only pursuit worth living for:

In these memorable " Hunting Tours, interspersed with characteristic anecdotes, sayings, and doings of sporting men, including notices of the principal Crack Riders of England," the gifted chronicler soared at liberty in those realms he was fully qualified to analyze and scientifically annotate.

Inspired by his famous theory, "Independent of the pleasure arising from the Chase; I have always considered a covert's side, with hounds that are well attended, to be one of the most lively scenes in nature; and I have no hesitation in adding that the best introduction for a young man of fortune and fashion of the present day is to be found at Billesdon Coplow, or Oadby toll-bar," as set forth in his " Essay on Riding to Hounds," "Nimrod," fortunately, contrived to alight upon his true vocation, and its richest realization is found in the "Hunting Tours." Very precions are these excursions, in sober truth, and, all too early in their developments, were found over costly to carry forward to their logical sequel. Nimrod was a man of genius and imagination above mere sordid figures; he was equal to the highest, the most superlative flights, and like the subject of his best biography, "Jack Mytton" (who first appear's in these incomparable "Tours"), merely wanted a trifle of a couple of hundred thousand pounds per annum to enjoy carrying out his ideas of enjoyment thoroughly. En prince was the qualification in harmony with Apperley's superior faculties; some sort of royal bargain-according to times and circumstances-was arranged as the first step in Nimrod's aspiring literary career. The proprietor of the Sporting Magazine agreed to provide the sinews of war; in a word the gifted scribe, perfectly qualified for his undertaking, was to be horsed, servanted, foddered, kept-with all expenses found-at the cost of the "Mag."; a capital arrangement, presuming the expansion of the circulation could, in those primitive days, have kept 
pace with the "special contributor's" expenses. His qualifications for the part demand a word of explanation, for even a "Nimrod" cannot burst full-blown upon an appreciative sporting public. Imagination was a distinct asset in the Apperley funds, and passed evidently as an inheritance from father to son. The paternal Apperley was a scholar and gifted with literary attainments; we have the evidence of the son to show that. However gifted and culturea were Nimrod's attainments in the classical groove, in which antique field-amongst sporting writers-he figures most conspicuously, and, as in other respects, set the fashion for pomp of learned quotations (generally apposite and felicitous), upon his own showing he was the poorest of dullards by comparison with his learned progenitor.

The family traditions centred round the environments and influence of the famous Sir Watkin Williams Wynn; to the sixth Baronet "the gentleman of literary attainments" filled the office of travelling tutor, and, on returning from their "Grand Tour" (the customary curriculum mid-way in the 18th century), settled down near Wrexham, Denbigh, having married a Miss Wynn. From this union, with six sisters, and an elder brother, was born our first sporting author, in the year 1778 it is stated.

"My father" was a personage to the imagination of the future "Nimrod." He wrote in the Sporting Magazine his parent "was a literary man, corresponded with Dr. Johnson (some of whose literary style he acquired), read Greek before breakfast, and being himself a scholar, he fondly hoped he should have made one of me; but in the weakness of his affection, being unable to say 'no,' his hopes were blasted. He suffered me to follow fox-hounds in a red coat and cap, like 'Puss in Boots,' before I was twelve years old; so, instead of a scholar', he made me a fox-hunter, which, in my humble opinion, was a much better thing."

In this conclusiou the outcome has proved that Nimrod's perspicacity was prophetic, for his early intuition in the sporting branch proved a signal qualification in developing the first of sporting abilities, amounting to undoubted genius, at the expense of the sporting side, which was sufficiently munificent to stand the comparison. Nimrod thought it becoming to disparage the richness of his classical acquirements, all of which he cleverly contrived to 
combine with this exceptional sporting training; but, thanks to the paternal instructions, he also acquired a wealth of classical luggage which came forth in his subsequent writings to such a conspicuous extent that another sporting genius, of a livelier vein than even the sportive "Nimrod," was impelled to turn these antique proclivities on his part to playful satire, and irreverently christened his somewhat overloaded but practical rival-"the great Pomponius Ego!" There is, an exacting critic might object, a lavish redundancy of classic quotations over-weighing Nimrod's lucubrations, otherwise completely lively, workmanlike, and apposite, with the sporting zest amounting to genius in the felicity of its practical application. This is a characteristically favourite quotation of Apperley's:-

"Without a genius, learning soars in vain, And, without learning, genius sinks again;

Their force united crowns the sprightly reigu."

It was in "the Shires" that Nimrod enjoyed the grand advantage of graduating. About the beginning of the last century he followed the paternal example in espousing Miss Wynn, of Wern, a lady of ancient family in Merionethshire; previous to his marriage he had been further in touch with the great family, having held a commission in Sir Watkin Williams Wynn's regiment of "Ancient British Fencibles." He was paymaster to the regiment at the time it was disbanded. On his marriage Apperley resided for a short time in Merionethshire, thence removing to Belton Hall, near Rugby, in Warwickshire. This was his training and happy hunting ground; and the adjoining counties, with his own, afforded him unexampled opportunities for studying "the noble science" of the Chase, under the historical luminaries of Fox-Hunting records-Warwickshire being at that time hunted by the great $\mathrm{Mr}$. Corbet, Leicestershire by Hugo Neynell, and Northamptonshire by John Warde. What better professional training could "Nimrod" acquire for his future discourses beyond the twenty years he enjoyed of these unique experiences? He dealt largely in horses at this time, from whence, indeed, the principal source of his income must have been derived. The next stage introduces Apperley as the tenant of Beaurepaire House, near Whitchurch, in Hampshire, everything being upon an ambitious scale at this establishment, including a superior mansion, 
with walled gardens, vinery, conservatory, pleasure ground, gardener's house, a park, consisting of 100 acres of pasture land; sporting over upwards of 2,000 acres, including about 400 acres of covert.

He then turned farmer, taking a couple of farms on the estate. It was at this time that Apperley had the happy idea of turning his sporting experiences to the best account in the literary line; for this purpose he entered into an engagement with the proprietor of the Sporting Magazine to contribute his "Letters on Hunting," under the pseudonym of "Nimrod," which soon became renowned in the sporting world. He made tours professionally into almost all the hunting counties in England at the expense of the magazine; the proprietor found the cost of his horses, servants, and everything at an average outlay, during the six seasons he was so engaged, of fifteen hundred a year. "The Hunting Tours" therefore represented an outlay of Nine Thousand pounds in working expenses, and they contain the best of Nimrod's experiences, commencing with the élite headquarters of Leicestershire with all "the great Masters"; Oxfordshire and Warwickshire followed under similarly favourable auspices; Surrey, Sussex, the Hunting Seasons of 1823-4 treated exhaustively; Dorset and Devon; Hampshire and the H.H., or Hampshire and the Hambledon Hounds; the Tour of 1825, embracing accounts of the Hounds of Sir Thomas Mostyn, the old Berkeley, Duke of Grafton, Duke of Beaufort, the Warwickshire, Colonel Berkeley (Lord Seagrave), Lord Anson (Earl of Lichfield), the Quorn, Duke of Rutland and Mr. Nichol ; a fortnight in the New Forest; the second Tour embracing accounts of the Warwickshire Hounds under Mr. Hay, Mr. Boycott's, the Shropshire under Sir Bellingham Graham, the Cheshire under Sir Henry Mainwaring, Sir Richard Puleston's, the Northamptonshire under Mr. Musters; the Yorkshire Tour containing accounts of the Raby Pack, the York and Ainsty, the Hurworth, the Holderness, the Badsworth, \&c., under the respective management of the Earl of Darlington (Duke of Cleveland), Mr. Ralph Lambton, Mr. Lloyd, Sir Tatton Sykes, Mr. Matthew Wilkinson, Mr. Thomas Hodgson, and Lord Hawke; concluding with later visits to Leicestershire, and to the New Forest with Mr. John Warde. 
These Tours, written in the freshness and fulness of vigour, were probably the happiest of Nimrod's productions, and established the celebrity of his name. They constitute a mine of wealth in the direction indicated, the historical annals of the Chase; and for the remainder of his career and writings, "Nimrod" was perforce thrown back largely upon these resources. These chronicles must be recognized as an epitome of the noble science at its bravest. It was part of the spirited proprietor of the Sporting Magazine's original speculation that the Tours should be collected and published in a separate volume. As the financial results proved somewhat disastrous-Nimrod retiring to France from prudential motives; and the proprietor of the mag. finishing his career; and "several other causes unnecessary to particularize" supervening, that intention was not carried into effect till after an interval of ten years; when, in 1835, “Nimrod's Hunting Tours" were modestly issued in a collected form, without illustrations or embellishments, by M. A. Pittman, Warwick Square. Curiously enough, this unpretending volume is comparatively little known, and rarely met with in any form, even in booksellers' catalogues; and while, in the present day, the current interest in the early chronicles of sport has caused many of Nimrod's later writings to be re-issued in more attractive forms,- his magnum opus has remained obscure, and almost a shadowy tradition, outside the pages of the rare and now most costly sets of the old Sporting Magazine.

“ Nimrod's writings," says a contemporary expert (R. S. Surtees), in a memoir of his eminent rival and ancient colleague, "were eminently serviceable to the Sporting Magazine, though undoubtedly attended with a heavy expense; which, however, with judicious management, might have been modified, and his services retained with advantage to himself and to the proprietor. Such, however, was not the case; and after much bickering with the proprietor of the magazine, he left Beaurepaire House, and took up his abode at Calais. From this time the less fortunate part of Nimrod's life may be dated; the materials of his further writings being henceforth-as regards the sporting materials, at least--drawn from his Tours and previous experience." 


\section{IN'TRODUC'TION}

As a chronicle of sterling sport, admirably carried out, "Nimrod's Hunting Tours " must be regarded as the text-book and veritable history of the palmy days wherein lived and moved, with the characteristic vigour of their pursuit, the luminaries who have shed the light of their achievements upon the Annals of the Chase. These respected worthies were fortunate in their historian, for Apperley was a rare combination of the brilliant writer allied with the thoroughbred sportsman; and the present production must be recognized as the unique outcome of all these exceptional circumstances combined. Moreover, the result is a no less unique avenue for sporting illustration, richly furnishing opportunities for pictorial embellishment, which, strange to say, is now for the first time attempted. Nor bave we gone far afield in our selection of pictures, the materials being contained so profusely in the text; we have confined the pictures exclusively to examples referred to by the writer, and specially alluded to in the literature of the Tours. The various subjects reproduced, like the narrative, are strictly historical and actually contemporaneous; the great Masters and their no less eminent Huntsmen-alike ardent devotees of sport-are figured from the authoritative original pictures to which they respectively lent their countenances, as the illustrations which embellish the present version abundantly show for themselves. 



\section{NIMROD'S \\ HUNTING TOURS}

\section{LEICES'TERSHIRE}

Leicestershire may justly be denominated the Montpelier of hunting countries: in the eye of a sportsman it is the Vale of Cashmere, and in comparison with it all others retire longo intervallo.

Both nature and art have contributed to render Leicestershire, the country for for-hunting. To the former, it is indebted for the depth and richness of its soil-favourable to holding a scent; and to the latter, for the large size of its enclosures, for the general practicability of its fences, for the greatest portion of the land being old pasture, and for the numerous gorse coverts made for the purpose of breeding and preserving foxes.

There is another circumstance also which gives Leicestershire a decided advantage over other countries; and that is, the few larye cover's which the better part of it contains, thereby affording such room for sport, that if a fox once gets away, and is a good one, a run (barring accidents) must be the consequence. He has nowhere to hide his head-he must fly for his life. Woodland foxes are generally supposed to be better and stouter than those bred above ground; but every one who has hunted in large coverts must be aware what an advantage both hounds and horses must have by coming away at once with a fox from is small piece of gorse, over those which may have been, perhaps, three or four times up and down a large covert, where the hounds have had to contend with strong underwood, and the horses with deep and boggy ridings, to say nothing of the 
certainty of gentlemen getting well away in the one case, and the chance of not getting away at all in the other.

In a quick thing with hounds, a good start is everything; and in Leicestershire it is our own fault if we do not get it. This advantage, however, is too often abused. Mr. Meynell was once heard to describe a run, and he began thus: "The fox came out of the gorse close to my horse's heels, then came Cecil Forester, then my hounds."

These artificial coverts being, of course, properly arranged as to distance from each othel', a burst is secured. If the fox live to reach one of them, a check for a minute or two may take place; but this check may be beneficial to the sport of the day. Hounds and horses get a puff, tail hounds come up, and those who were not fortunate in getting away with the pack, secure a place. The fox, finding delays are dangerous, and that he has nothing for it but to fly, makes his point for some distant earths, the attainment of which nothing but death will prevent.

Having said this, it is not to be wondered at, that, besides being encroached upon by other hounds, Leicestershire, though a small county, should contain three packs of fox-hounds, which are attended by the best and hardest riders in England; to which it may be added, without any reflection upon other establishments, that no other country could find such hounds to ride to. What benefit must they derive from such a country!

To say nothing of the benefit arising from hounds being never out of the sight of the huntsman and whippers-in, unless (as it sometimes has happened) they run away from them, there is another advantage which it enjoys above all others; and that is, when, at the end of the season-from the effect of long-continued drought, aided perhaps by harsh cutting winds and hot sun, all others, where fallows are to be hunted over, are hard and dry, and incapable of holding a scent, or being ridden over with safety either to a horse or his rider-this county is as capable of shewing a run as at any other period of the season. As a proof of what I have said, I have only to mention a day's sport which I saw when Mr. Smith (the Tom Smith) had the Quorn hounds, which, I have no doubt, is fresh in the recollection of many who witnessed it, for it was a brilliant one, and such as no other country in the world could have 
shewn on that day. It was on the 17th of April; and, as Tom Wingfield (then whipper-in to $\mathrm{Mr}$. S.) observed, "a kind of day more fit for growing cucumbers than for hunting." It was, however, allowed to be the second-best day's sport of the year.

The place of meeting was Slawston Town, in the Market Harborough country; but there was no fox in the gorse. In our road across the country to try another corert, one jumped out of a hedge-rôw, and was killed after a burst of sixteen minutes, without a check-best pace-heads up, and sterns down. We killed him near to Shacon Holt covert; and as soon as the hounds and horses had recovered their wind, we drew the Holt. Without waiting to be found, away went a gallant fox, and, putting his head nearly straight, was also killed at the end of twelve miles (point blank), in fiftyeight minutes, with only one trifling check, about eight minutes before he died.

The country he went over could only be compared to Newmarket Heath inclosed with strong fences; but many had reason to wish that neither the fences nor the enclosures had been so large. That, there was much distress among the horses, it is needless to observe, after the description I have given of the day and the pace. Mr. Smith rode the famous Jack-a-lantern in his usual style; but at one time his light was out: he stopped: but whilst $\mathrm{Mr}$. Smith waited for Tom Wingfield, whom he saw coming up, with the view of a change for the better, the good old horse recovered his wind, and came up to us at the check. Seeing Mr. Lindo on "The Clipper" encouraging the hounds to a scent at a gateway, he was beginning to rate us, saying that the hounds had been pressed upon, and that we only wanted a puff for our horses. At this moment the chase was renewed, and Lindo, turning round, aptly remarked that " he had had his puff, or he would not have been there." The fox lived about eight minutes longer; and Mr. Smith, observing two couples of his young hounds leading, appeared transported with delight. $\mathrm{He}$ never turned his horse's head ten yards to the right or to the left for an open gate, or for a gap, but rode by the side of his pack, cheering them to their fox (which he knew must die), in a manner and at a pace that I shall never forget: neither shall I ever forget the fever we were in, from the exertion of such a run on so warm a 
day. I could hear the pulsation of my temples as I could that of my horse's heart.

The fences in the Market Harborough country are the strongest in Leicestershire. The richness of the soil throws the quick to a great size; and to guard against the bullocks in the summer season, very few weak places are to be found. If a horse be not a superior fencer, and good at timber, he has no business there. The inclosures also are large, which is very trying to horses. An anecdote on this subject is related of $\mathrm{Mr}$. Smith. He observed to a friend of his that "he never saw him out in the Harborough country." His friend replied, that " he did not like it, the fences were so large."-" Oh," said Mr. Smith, "there is no place you cannot get over, with a fall." Perhaps, however, he thought rather more of a fall than Mr. Smith did.

The first year I was in Leicestershire was the last of MIr. Meynell's, and the first of Lord Sefton's hunting the Quom coụntry. In mentioning the name of Mr. Meynell, I feel a degree of respect due to it, which all sportsmen must acknowledge and appreciate. So long as fox-hounds and fox-hunters are to be found in England, it will never be forgotten; neither is there a kennel which is not, at this moment, indebted to him for some of its best blood. As, however, I may have occasion to mention the name of this justly celebrated sportsman again, I shall only add, that, as a master of a pack of fox-hounds, Mr. Meynell never has been excelled. Independent of his knowledge of everything relating to hounds and to hunting, his conduct in the field was such as should be handed down as an example worthy the imitation of every master of fox-hounds. From his rank in life, and from the sphere in which he moved-to say that he was well bred and polite to his equals, and to his friends, is saying nothing; but towards every man who hunted with his hounds he conducted himself with that general urbanity and condescension which alone secure to a person in his situation the esteem of the country, and, with it, the foxes. In his time, a man's life was not more secure from violence and murder than was that of a fox.

To every man who is a fox-hunter, it is well known how much it is requisite for a master of hounds to stand well with the yeomen and farmers of his country. They have much in their power, and 



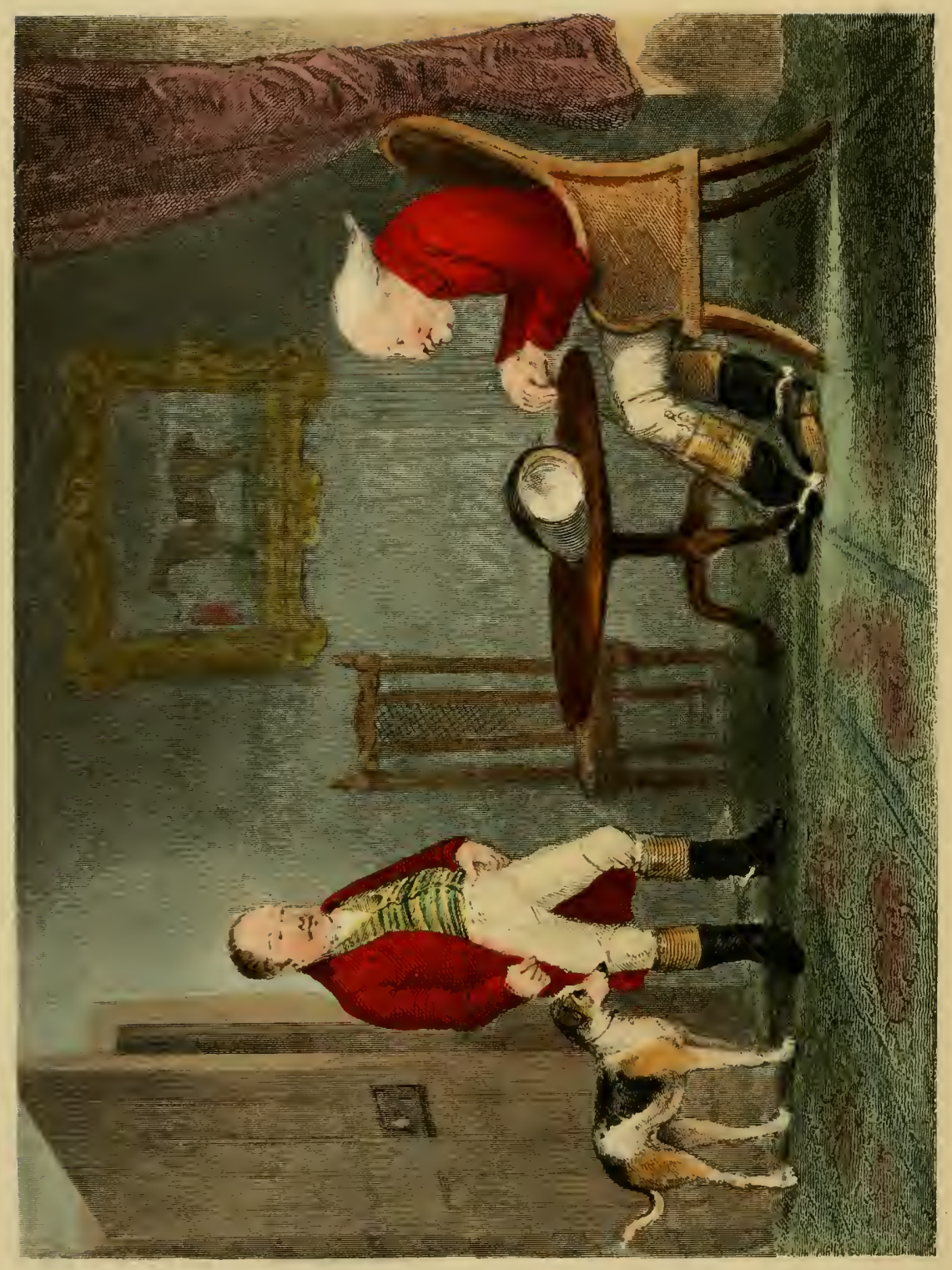




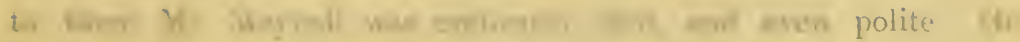

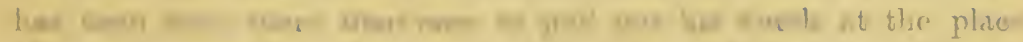

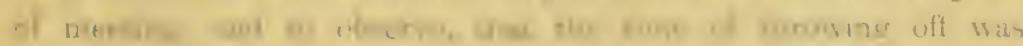

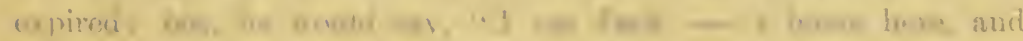

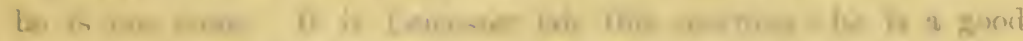

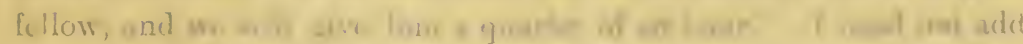

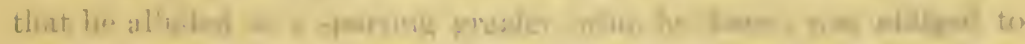

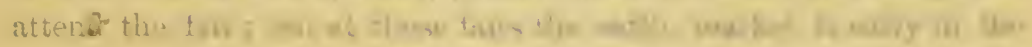

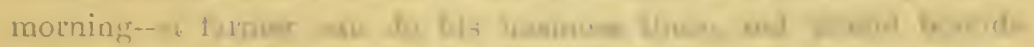

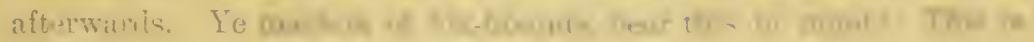
the wy to prest in . nomo \&."'

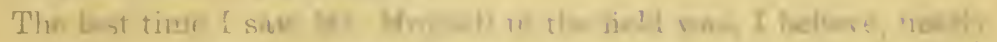
the las tine of his be.

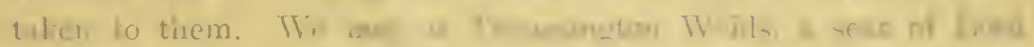

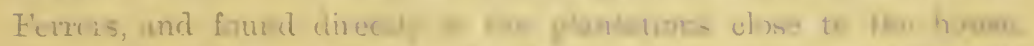

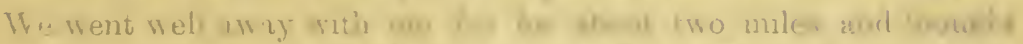

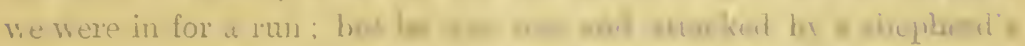

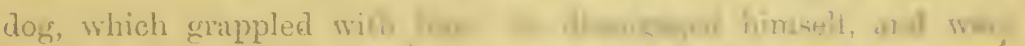

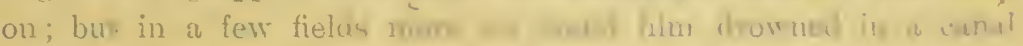

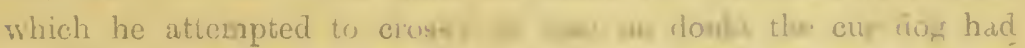

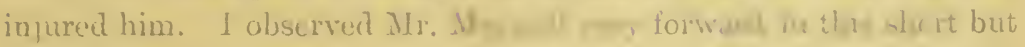
sharp burst, frequently chetelms he weit. An wr wew irawing

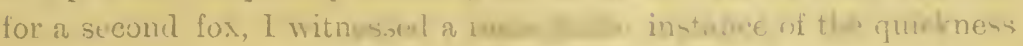

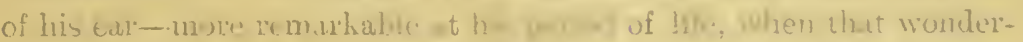
ful organ is seldum so corret. Th- we nds werf sh a s mail cerert, wout one hundred yard from $\mathrm{k}$, ine whell ne strod, which

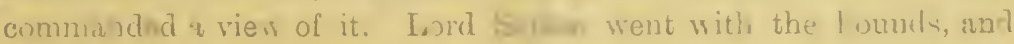
sturalrlose 1 the gorse. I horme he, hut he spoke cautiously. "These mis in cheer to him, so he mopected; - but "one worl"

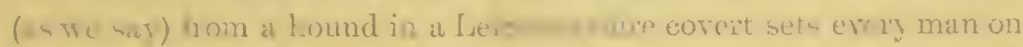
the sion for : tort It is like the an a bugle to prepare for the

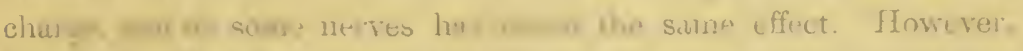

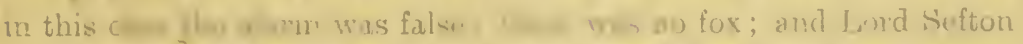

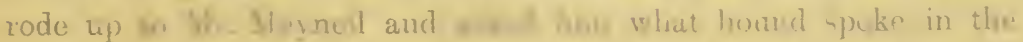

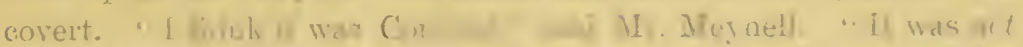

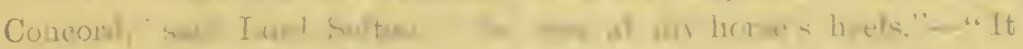

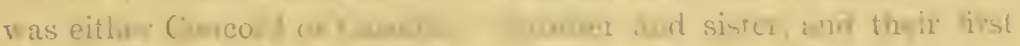




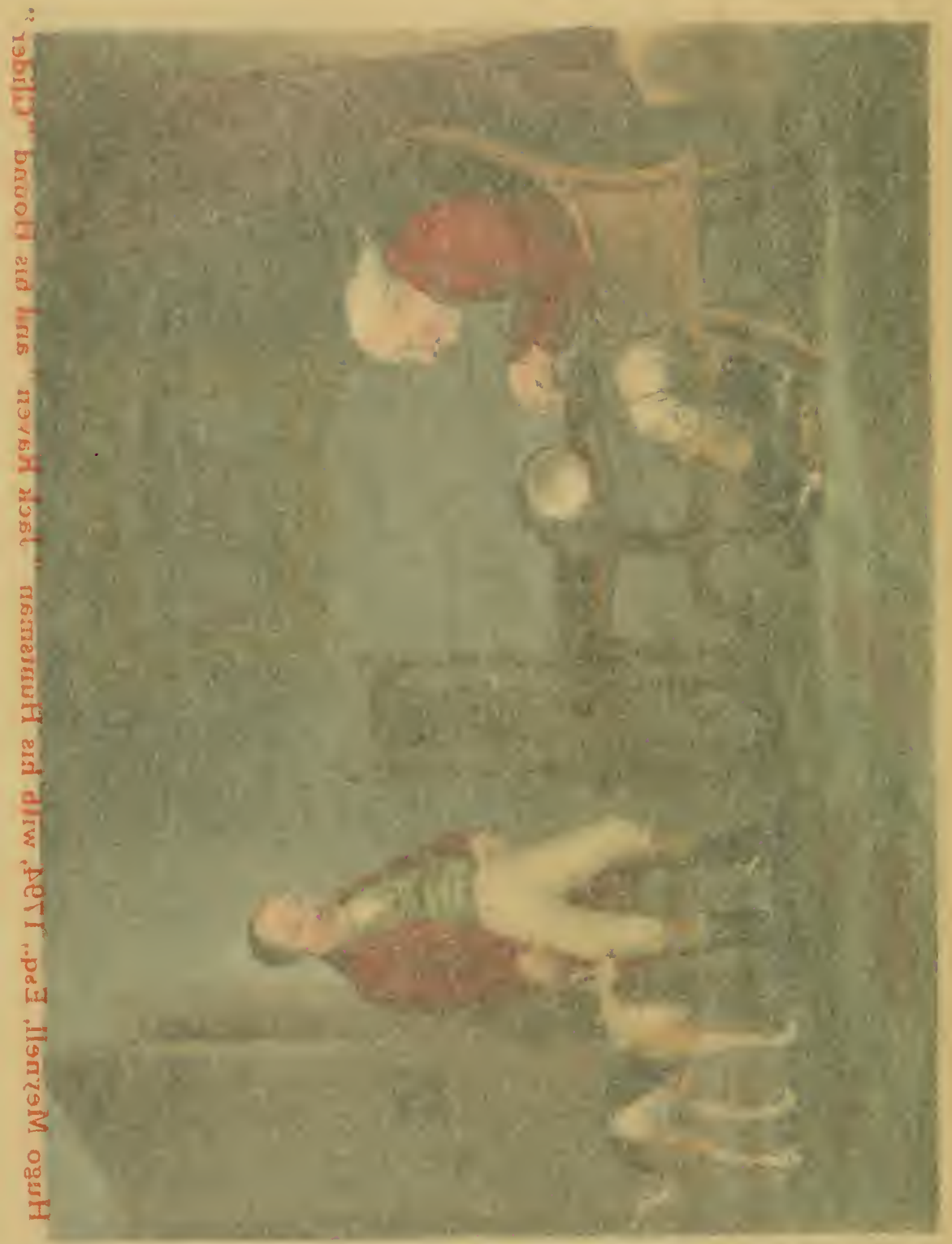


to them Mr. Mernell was uniformly civil, and even polite. He has been seen more than once to pull out his watch at the place of meeting, and to observe, that the time of throwing off was expired; but, he would say, "I see Jack —_'s hor'se here, and he is not come. It is Leicester fair this morning-he is a good fellow, and we will give him a quarter of an hour." I need not add that he alluded to a sporting grazier, who, he knew, was obliged to attend the fair; but at those fairs the cattle market is early in the morning - a farmer can do his business there, and attend hounds afterwards. Ye masters of fox-hounds, bear this in mind! This is the way to preserve a country!!

The last time I saw Mr. Meynell in the field was, I believe, nearly the last time of his being with hounds: it was after Lord Sefton had taken to them. We met at Thrussington Wolds, a seat of Lord Ferrers, and found directly in the plantations close to the house. We went well away with our fox for about two miles, and thought we were in for a run; but he was met and attacked by a shepherd's dog, which grappled with him: he disengaged himself, and went, on; but in a few fields more we found him drowned in a canal which he attempted to cross; so that no doubt the cur dog had injured him. I observed Mr. Meynell very forward in this short but sharp burst, frequently cheering as he went. As we were drawing for a second fox, I witnessed a remarkable instance of the quickness of his ear-more remarkable at his period of life, when that wonderful organ is seldom so correct. The hounds were in a small covert, abont one hundred yards from the place where he stood, which commanded a view of it. Lord Sefton went with the hounds, and stood close to the gorse. A hound spoke, but he spoke cautiously. There was no cheer to him, so he was suspected; - but "one word" (as we say) from a hound in a Leicestershire covert sets every man on the alert for a start. It is like the sound of a bugle to prepare for the charge, and on some nerves has much the same effect. However, in this case the alarm was false; there was no fox; and Lord Sefton rode up to Mr. Meynell and asked him what hound spoke in the covert. "I think it was Concord," said Ml. Meynell. "It was not Concord," said Lord Sefton; "he was at my horse's heels." - "It was either Concord or Caroline" (brother and sister, and their first 
year), replied Mr. Meynell. In five minutes the point was decided. Raven, the huntsman, came by us with the hounds. Lord Sefton asked him the question. " Concord, my Lord," was his reply.

Mr. Meynell's eye to a hound was not less quick than was his ear. It has been asserted that on seeing a pack of strange hounds drawn to feed, he could call almost all of them afterwards by their names.

Leicestershire never witnessed more splendour than during the period of Lord Sefton's hunting it. The price of horses (and he set the example) was never higher than in his time, and, I conceive, will never be so high again. From five to eight hundred guineas was a common price for a hunter that could go forty minutes best pace, and even more was asked and given. Mr. Lorraine Smith had a magnificent horse, called Hyacinth, got by Hollyhock. He asked a thousand for him, and I believe Lord Sefton offered nearly all the money. He had, afterwards, the misfortune to break a blood-vessel under Mr. Smith, and died in the field. His Lordship, of course, for his great weight, was obliged to get the best of horses, and price was only a secondary consideration: the first was, to procure the horse that could carry him; and such animals as his Plato, Rowland, and Gooseberry, were at any time difficult to find. $\mathrm{He}$ had always three out each day for his own riding. Young Raven (son to the huntsman) rode one of them, and the other was ridden by a groom, both good horsemen, and riding in his Lordship's stirruplengths. One of them was always close to him, so that the moment he perceived symptoms of distress, he jumped upon the second horse. The third was kept at a proper distance, going easily to himself, till an opportunity presented itself of getting up to his Lordship, in case he also should be wanting, Lord Sefton had one of the best grooms that England could produce. His name was Potter. His horses were always high in flesh, but strong in work, which is the perfection (if not the sine qua non) of condition for horses that carry high weights. Good flesh is strength. His Lordship had a quick eye to hounds, and his nerves were very good, though he avoided timber if possible. Considering his weight, however, he went brilliantly over a country.

With all these advantages, it is generaliy believed that he found 
himself unable to get horses that could carry him up to his hounds when they went their best pace, and for that reason he gave them up, and took to the road; where his merits are too well known to require any observation from me, he being allowed to be one of the steadiest and most masterly coachmen in England.

When Lord Sefton retired from the sporting world, it lost one of its brightest stars. The splendour of his establishment gave to spectators more the idea of an imperial hunting party in a foreign country than that of an English pack of fox-hounds. It brought to our recollection Dido's hunting party to the godlike Æneas. If the covert was accessible to a carriage, he always appeared in his barouche-and-four, accompanied by several others; and ladies were often of the party, though they never quitted the carriages. His hounds were perfect, and well might they be so. The celebrated John Raven hunted one pack; and the no less celebrated Stephen Goodall (afterwards many years huntsman to Sir Thomas Mostyn), hunted the other, both pupils of Mr. Meynell.

Mr. Beckford observes, that were he obliged to have either a good, huntsman and a bad whipper-in, or a bad huntsman and a good whipper-in, he should decidedly prefer the latter. Of what importance then must he have considered a good whipper-in; and what advantages must Lord Sefton's hounds have possessed in having two such whippers-in as Joe Harrison and Tom Wingfield, besides other assistance; for a feeder was always out well-mounted, as also Young Raven, on one of Lord Sefton's spare horses, both ready to act when wanting.

The command which these hounds were in could only be compared to that of a regiment on parade. A whip was scarcely ever used; and as far as a "yo-go-it" could be heard, nothing more was wanting to bring them back. A horn also was scarcely ever heard to sound. I was particularly struck with the latter circumstance, having never heard it for six days in succession; and it was only had recourse to on the seventh, in consequence of Stephen Goodall, whose voice was never strong, giving a blow for a hound, called "Cruiser," who was missing in a fog. This, in some degree, is connected with the nature of the country, for we all know that in woodlands a horn is as necessary as a hound. 


\section{OXFORDSHIRE}

IF I may be allowed the expression, there are three packs of foxhounds which partake of the county of Oxford-the Duke of Beaufort's, Sir Thomas Mostyn's, and Mr. Codrington's. The river Cherwell is the line of demarcation between the two former packs; and $\mathrm{Mr}$. Codrington has a small portion of it on the southern side, in addition to his Berkshire country. The best part of it, however, may be said to be pretty equally divided between the Duke and Sir Thomas, his Grace haring what is termed "the Hills," and Sir Thomas the Vale. The Duke has also what he calls his "Home Country," in Gloucestershire and Wiltshire, which he hunts from his seat at Badminton; and Sir Thomas has a part of Northamptonshire.

Perhaps there never yet was a hunting song in which the chase was not over hills and dales. The variety of the ground not only gives a poetical feature to the description, but may also be intended to imply, that in all countries there are hills and valleys, which is true enough, for without one there cannot be the other. In the present instance, however, the word "hills" is peculiarly applied to a large tract of country in Oxfordshire, Gloucestershire, and Wiltshire. If you ask a farmer in the Vale of Gloucester, what is become of his neighbour Mr. Such-a-one, he will tell you "he is gone to live upon the Hills." This is giving good latitude, for these hills extend for upwards of fifty miles across the country.

The soil on these hills being apt to be thin, and the land for the most part arable, we cannot expect it to hold so good a scent as a rich loamy vale consisting of good old pasture; nerertheless, as the substratum is chiefly chalk or lime, it lies better than might be expected; and taking into account the advantages derived by hounds being in an open country, free from riot, and always within reach of 
assistance, a series of good sport is not unusual on the Oxfordshire Hills.

The hill country is easy to ride over as far as fencing is concerned, and is particularly suited to persons whose nerres have lost a little of their steel. Some of the bruising riders from Leicestershire and other places have called it a "humbug country;" by which they mean to imply that there are no fences which cannot be got orer withoui a certain fall. It is true, that, taking the hills in general, an accomplished hunter is not often wanting. There are no doublesno ox-fences-no stiles with foot-bridges, and no timber, unless you like it, except sheep hurdles, which ought not to throw a horse down (unless blown) with a horseman on his back. A quick well-bred horse that can go well upon wind, leap four feet in perpendicular height, and face a brook now and then, is all that is requisite herebut he must be well bred. When I say a horse is only required to leap four feet in height, I do not mean to say that higher walls are not met with: but the top stones are so loosely placed, that if he do not clear them, they fly before him. The Oxfordshire and Gloucestershire walls are not like what we hear spoken of in the Sister Kingdom, as "coped and dashed, and six feet high," but are without exception the safest fences that are ridden over-not only for the reason just given, but also from the circumstance of the horse never being deceived by a blind ditch on one side, or a squire-trap on the other. The greatest danger arises from the quarries, out of which the stone is procured to build them. They are opened close to the side of the wall, which in that place is generally lower than any other part, and consequently tempting to ride at. It is, therefore, sometimes necessary to "look before you leap," though a man who is accustomed to the country knows how to guard against the danger. In many places there are small apertures in the walls, either for the purpose of letting hares pass through them, or for water-courses; and a sportsman cannot do better than ride at them where they are to be found, if the wall is high, as through them he can see the ground on the other side.

Horses unaccustomed to walls cut a bad figure at them at first; but the raps on the shins which they get soon make them clear them. I have often been astonished at seeing a horse take half the wall 
with him into the next field, and not have a mark on his legs. Horses which have been accustomed only to the hills ofe often unsafe fencers in any other country, as they are apt to leap high, but not to extend themselves sufficiently to clear a wide ditch.

However easy it may appear to a man coming out of a stiff bruising country to ride over these hills, he will find it is not so easy to his horse, and all his judgment will be required to make the best of his ground. In the first place, although the ground cannot generally be said to be deep, yet it must be recollected it is for the most part ploughed, so that it is often very heavy and greasy. In the second place, the pace is quick, from there being nothing to stop the hounds or horses, and the up-and-down-hill that so often occurs is very trying to horses which carry weight. Many a hunter would cut a bad figure in a burst of thirty minutes with the Duke's hounds over these hills, though he might make a very respectable one over a deep vale; and, on the other hand, the little spirting thorough-bred horse that would "do the trick here" would leave one of his legs behind him in some of the sloughs in Sir Thomas Mostyn's country.

There is a very peculiar circumstance attending these hills which has often been a matter of observation; and that is, whenever a fox has reached them, after a run over a lower country, the scent has generally failed on running over them. This must be attributed partly to atmospheric causes, and partly to the difference in the mean temperature of the earth.

Having given a description of the Oxfordshire Hills, I shall proceed to the pack which hunts them.

The Duke of BEAUfort's hounds are of long standing in the county of Oxford. They were kept many years by the late Duke; and nothing can exceed the respectability of the establishment. Their present kennel is at Heythorp, the magnificent seat of the Earl of Shrewsbury, which the Duke has rented these last three seasons (1819-22). The house has all the conveniences requisite for his Grace's establishment; and the noble park affords most excellent exercise-ground for hounds and horses. The situation is rather on the outside of the country, which is an inconvenience; but it is not of so much consequence in this instance, as it might be in many others, owing to the travelling for hounds being so good, and so 
clean, which is no trifling advantage to them, as well as to the horses which follow them.

The first thing which strikes a stranger to the Duke's pack is the cleanliness and brightness of their skins. This is in some measure to be attributed to local circumstances. The skin, however, of most animals, particularly of hounds and horses, may be said to be their complexion; and thence we may infer that these hounds are in good condition, which the stoutness of their running also establishes. Philip Payne has hunted them for many seasons, and is a good and judicious huntsman, though now getting slow, from that cause which will make us all slow in our turns. Philip is at least sixty years of age; and, by his universally good conduct as a servant, has obtained the good will of all the Beaufort family, who are remarkable for kind treatinent of their servants, as also of all who attend the Hunt. The Duke himself is particularly polite and indulgent to his field, and in every respect worthy of being at the head of a pack of foxhounds.

There is something in the appearance of the Duke of Beaufort's establishment which conveys an idea of what fox-hunting was half a century ago; when it was perhaps more like fox-hunting than it is at present. The venerable appearance of the huntsman in his green plush coat - the wildness of the country - the strength of the hounds, and the few scarlet coats that are seen with them, give an appearance different to what we see in other countries. The uniform which the Duke and his friends wear is a blue coat lined with buff. The effect is sombre, if not livery-like, and certainly has not so sporting or so lively an appearance as scarlet. Hunting has been called " the image of war ;" and the simile is in sone measure strengthened by the effect of a large body of men, well mounted, charging rapidly across a country clad in so martial a colour. Add to this, nothing gives so good a finish to a horse and his rider as a red coat, and it is distinguishable at a great distance; with the assistance of good boots and breeches, it looks well to the last, and hounds are certainly fond of the colour.

In one respect, the Duke of Beaufort's hounds stand pre-eminent; and that is, in the persevering manner in which they carry a cold scent over a cold country. Use is said to be "second nature," and 
perhaps it applies in this instance; but I never saw any pack so calculated for the country they have to hunt over. Hounds may be too fond of a scent, but it is a fault of the right side; and " an ounce of hunt is worth a pound of flesh," as the great Mr. Shaw says.

These hounds are well attended. The resident gentlemen of the county are almost all sportsmen ; and strangers come to Woodstock, Chapel House Inn, and Chipping Norton, for the season ; in addition to which, the Duke is seldom without a party of friends in his house. When the place of meeting is within reach of Oxford, numbers of the young men of the University attend, and it is said that such as have not their own horses pay less for those they hire with these hounds than with Sir Thomas Mostyn's-the depth of the country and strength of the fences being taken into account. As far as my observation extends, I never saw them do harm. Some of them ride very well to hounds; and the Tyros fix upon some one for a leader, and follow him as long as they can. Fortunately for them there is only one large brook (the Erenload) in the Duke's country, and that is rather out of their latitude, being on the Gloucestershire side. This brook is to be jumped; but it makes the field very select.

As the Duke hunts the Badminton country, his hounds leave Oxfordshire for about two months in the season, which is unfortunate for those who reside within the limits of the Hunt, though it is doubtful whether (particularly in a short breeding year) the country would stand being hunted all the season. Those sportsmen, however, who are keen, and do not mind riding twenty miles to covert, can always reach other hounds in the Duke's absence.

Some years ago there was an attendant on these hounds, which I never saw on any other, and that was a man on a pony to carry great coats, for which he charged one shilling, and however long the run might be he was certain to crawl up to the end of it.

There are not many hard riders in this Hunt. It is not what is termed a "bruising country." The Duke himself is not a forward rider, though he generally sees the sport, and is a good judge of hounds and hunting. His brother, Lord Edward Somerset, gets well over a country, but Lord Granville Somerset (the Duke's second son) is the best of the family. He rides very light, is well mounted, and can go the pace. One of their best performers, Mr. Holloway, has 
left the country. Mr. Jolnn Codrington goes very well, and is not to be beaten. A bit of a brush sometimes takes place between him and a Mr. Evans, and they decided the point last year (1S21) in a steeplechase of four miles over the country, which was done in the extraordinary short space of thirteen minutes, and won by the former. Mr. Evans is an old Meltonian, and formerly shewed them the way in Leicestershire on his celebrated grey horse; but it is said he never went so well on any other: he has nerve for any fence, but is not a good horseman. Mr. Meyrick is a hard rider, but not a constant attendant. When business is to be done, none of them can beat Mr. Rawlinson: he is acquainted with every gap and weak place in the country, and no man knows better how to ride to hounds. His seat on horseback much resembles that of his brother ( $\mathrm{Mr}$. Lindo), as he is represented in the print shops, and on the snuff-boxes, "going a slapping pace." He has not been without lis imitators; but, as yet, they have failed in accomplishing their wished-for object.

That part of Oxfordshire hunted by Sir Thomas Mostyn is known by the name of the Bicester country. On the western side of it the land is light, resembling the hill part of the county; but on the Buckinghamshire side, there is a fine grazing district, with good-sized fields, a deep soil, and strong fences-not much unlike the better part of Northamptonshire, and good enough for any hounds. The woodlands are very fine, affording plenty of good foxes, and very accessible to horses, though the rides through them are rather deep and sloughy. Those called "the Clayton Woods," and "the Quarters," are too large to be pleasant, but they are a great acquisition to a country, and invaluable to young hounds, as they are full of foxes, and will stand hunting from the first of August to May day. The country around them is very fine, so that sport is ensured by a good fox flying away from them, or from one who may be found on his amusement, or his travels, at some distance from them.

In addition to this country, Sir Thomas has a kennel at Chipping Warden, in Northamptonshire, on the road from Banbury to Daventry, six miles from the former, and ten from the latter place, whence he hunts part of that country rumning up to the Pytchley and the Warwickshire countries. This part of Northamptonshire is 
uncommonly fine to ride orer for those who are not afraid of large fences, but the draw is apt to be uncertain. A blank day has never been an unusual thing here-a circumstance which I never could account for, from the real fox-hunting spirit that pervades the farmer's who inhabit it. It is no uncommon thing to see a hundred of them out in a day ; all anxious for sport ; many of them riding good horses, and selling them for large prices.

Sir Thomas Mostyn, though a young man, is an old master of fox-hounds, haring kept them entirely at his own expense nearly twenty-five years. He took possession of the Bicester country in August, 1800: and previous to that period, he hunted part of Gloncestershire, and part of Oxfordshire, having a kennel at Stowon-the-Wold, in the former county. Few men are better qualified to be at the head of a pack of fox-hounds than Sir Thomas. A single man, possessed of a fine fortune, and at ease in his circumstances, the expense is not an object to him; and his conduct in the field is particularly gentlemanlike-added to which, no man, did his health permit him to enjoy it, is more fond of the sport. His attention to his kemnel is great; and in the field he is a pattern to all masters of fox-hounds. It is much to be lamented that severe fits of the gout prevent his deriving that pleasure from his hounds to which he is entitled; as there are many days in the season on which he cannot go out at all, and on others he is obliged to return home without following them far. This circumstance, however, has not abated his zeal to show sport to others, though he may not have it in his power to partake of it himself.

Sir Thomas Mostyn's hunting establishment is on a very liberal and extensive scale; but his country will not admit of his hunting more than four days a week, and sometimes not so often. His pack is well attended by the resident gentlemen, and there are generally some strangers staying at Bicester, as well as at their friends' houses in the surrounding neighbourhood. When first Sir Thomas hunted the country, he resided at a place called Bainton, four miles from Bicester; but about six years ago, he purchased Swift's House, then a small ale-house, also four miles from Bicester on the Banbury road, which he soon converted into a very comfortable house for himself, and most complete accommodation for his 
hounds, horses, and serrants. The stables are uncommonly good, and built in the form of a quadrangle, with the huntsman's house, kennel, blacksmith's shop, \&c., on the outside; and as he rents a manor surrounding the house, abundantly stocked with all kinds of game, Swift's House may be said to have all the conveniences and comfor'ts which any moderate man may require, and no one lives better than Sir Thomas Mostyn.

Sir Thomas's hounds have had the advantage of three celebrated huntsmen, Shaw, Stephen Goodall, and Tom Wingfield.

Shaw was succeeded by Stephen Goodall, a huntsman of long standing, and great judgment. His education was such as was likely to qualify him for a good huntsman. His earlier days were spent in the service of Mr. Childe, of Kinlet, and Sir Richard Puleston, both good judges, and hunting countries, in which all sorts of difficulties present themselves. Stephen hunted Sir Thomas's hounds nine or ten seasons, and but for his increasing weight, and the usual inconveniences attending approaching age, might have continued to have done so now.

Could Stephen Goodall have hovered over his hounds in a balloon, or been mounted on Pacolet's horse, no man was more able to direct them when at fault; but for several of the last years of his hunting them, he could not ride up to them, though Sir Thomas spared neither expense nor trouble in procuring horses to carry him. The consequence of this was, that when Stephen's assistance was wanting, it was not to be had; and by the time it was to be had, it was too often useless : the scent having died away, or a cast having been made by others, the hounds were in a manner divided between looking for Stephen, and trying for their fox, who no doubt profited by the delay, and was lost.

That weight, when not attended with corpulency, is no general obstacle to riding to hounds, has been proved to demonstration; and, as among a multitude of proofs one does the business, I need only mention Mr. Robert Canning, who, though measuring six feet four inches in height without his shoes, and riding seventeen stone, has, for the last twenty years of his life, on the most moderate calculation, beaten nineteen out of twenty of all the weights, whether light or heavy, that have ridden across a country with him. 
But, as is the case with all short men who alrive at Stephen's size (at least eighteen stone), when the weight lies a good deal about the abdomen, violent exercise of any sort is impracticable. In the first place, it occasions a difficulty of breathing, much increased by going rapidly through the air ; and in the next, an unwieldiness of the person, which destroys all power of, or confidence in, self-exertion, which, in the moment of danger from falls, is the greatest security against injury. Having said this, it is no wonder that Stephen could not ride up to a pack of hounds, which, in my opinion, were in his time the speediest in England.

Any true lover of the sport would ride fifty miles of a morning to see Tom Wingfield hunt these hounds. Tom's education has been complete for the situation he fills, having whipped-in to the late Mr. Meynell, Lords Sefton and Foley, as also to Mr. T. A. Smith, all in the Quorndon country. Considering that he was not educated in woodlands, it is wonderful as well as delightful to see him (as I have seen him) stick to his fox for two hour's in those "little spinnies," as he calls them-the great Clayton Woods-and kill without leaving him for a moment.

In the open country Tom is pre-eminent. A beautiful and determined horseman, he is never out of sight of his hounds, and he can see more with that one eye of his than many would if they had three. When his hounds are at check, he invariably stands still, as coolly as though he were looking at a prospect, and never intrudes his opinion till they appear to ask for it. This is the way to give confidence to hounds; and nine times out of ten, as Tom knows, the instinct of the hound may be backed against the judgment of the man.

Wingtield is a man of few words, but what he says is to the purpose, and he can be a bit of a wag. A friend of mine was riding over Leicestershire with him when he lived with Mr. Smith, and coming to "a rasper," which a third person, who was of the party, did not fancy, Tom turned around and observed, "I think, Sir, that gentleman has no business in our shire."

A man who cannot ride over large fences has no business with Sir Thomas Mostyn's hounds, as the greater part of it is a bruising country, and requires a hunter, and a powerful one, to go across it 
- the quick growing very strong in the fences, and in wet seasons it is deep and heary. He must also be an accomplished fencer, as there is much timber and a great many doubles; neither must he be afraid of water, as there are more brooks in the Bicester country than in any other which I have ever ridden over, and which is evident from the number of bridges on the turnpike roads. The river Cherwell is only to be passed by a bird without swimming it, till you get some distance above Banbury, and even there it is rarely attempted with success. I saw it cleared by Mr. Newnham (late at the head of the IVorcestershire hounds, but for many years an attendant on Sir Thomas's), Mr. Robert Canning, and a Mr. Bawcot, a hard riding farmer in that neighbourhood. I was landed on the bank, but it nearly cost me a good hunter. He fell back into the river, and was carried down the stream for twenty yards, with nothing but his hoofs to be seen before he could turn himself in the water, and it was nearly lialf an hour before he could be got out. As he was a fine brook leaper, I attribute his failure to his seeing Mr. Best's hor'se swimming abont very near to him at the time.

Great part of the Bicester country is very flat, which, in wet seasons, is a great disadvantage to it, as it prevents the land flood from passing off so quickly as it would do if there were a greater fall in the larger rivers. It is often so much under water that hounds cannot run over it at all; and when cleared sufficiently for them, it is very awkward for horses; as when the ditches are full they cannot see them, and many falls are the consequence. On the whole, however, it is a good fox-hunting country, well preserved, and calculated to try the stoutness of hounds and horses, as well as the nerves of those who hunt in it. There is a common field, called "Marsh-Gibbon Field," about three miles across, which, of all open fields I ever rode over, is the most killing for horses, and it generally holds a good scent. If horses are not rrell prepared, and fit to go, they have no business there.

That part of the country called the Brill country is rery severe, and the only one in which I ever saw one man kill two horses in two successive days. On coming to a check the first day, I observed to him that he would kill his horse if he persevered with him, as I saw the distress he was in by a certain stare of his eye which cannot 
be mistaken; and at the time I spoke the mischief no doubt was done. He was a friend of Sir Henry Peyton, and stuck close to him in the run; but at the check I speak of, Sir Henry's horse, as he observed to me at the time, was as comfortable and as much at his ease as the other was beaten and distressed. On the following day, his other horse sank under him on his road home without much apparent distress, and was dead in two hours. To want of condition, or, in the language of the stable, "not being fit to go," is to be attributed the loss of these horses.

Lord Jersey, when at his seat at Middleton Stoney, is within four miles of Sir Thomas Mostyn's kennel, but he does not hunt much in Oxfordshire. His Lordship, like most good judges and old Meltonians, is become fastidious as to hounds, horses, and country; and, unless things go very smoothly indeed, he does not appear happy in the field. Having often seen him as Lord Villiers, and since as Lord Jersey, go brilliantly over Leicestershire, I should be sorry to hear that he slackened his pace, as no man can beat him when he is inclined to ride. He is an elegant horseman, and, when riding to hounds, he goes cheering along as though he were delighted with the sport. If, however, he is fastidious in the choice of his horses, in the purchase of them he has one sine qua non, and that is, power; for he will buy no horse that is not more than a stone above his weight. His Lordship knows how to make a handicap at Newmarket; and is well aware that a man of ten stone weight, on a horse only equal to nine, cannot go so fast over a country as a man of fourteen stone on a horse equal to fifteen. I heard a good anecdote of his Lordship on this subject a short time since. He was trying a horse belonging to a London dealer in the Park. A friend of mine was passing at the moment, and asked him whether he thought he should buy him. "I fear not, Sir," said the dealer, "we don't live by his sort."

Sir Henry Peyton's seat at Tusmore Park is in the centre of Sir Thomas's country, and the Baronet goes as well as ever he did in his life. When riding to hounds, however, he does not show that animation and pleasure that Lord Jersey appears to feel when things go right; but the moment the hounds are away, he presses his hat over his face, and with a look which seems to imply, "Go along, my 
boys-the faster the better" - he is to be stopped by nothing that any other man can gret over, and he is particularly quick at getting out of a crowd. Fence, brook, and timber are all the same to him, and he has a remarkably good eye to hounds. He is also an everyday rider, and certainly one of the pleasantest men in England to ride over a country with; for, so far from having a grain of jealousy about him, he will give a man every assistance in his power, and seems pleased when he sees another going as well as himself. The Oxford men swear by him. He has long been their favourite pilot, though he has landed many of them not exactly in "the haven where they would be." He is very good at a brook, but at times dangerous to follow for those who cannot swim.

In his hunting stable, Sir Henry is well horsed, though his number seldom exceeds five. He is too good a judge to keep more than his country requires; and as he does not go from home to hunt, he seldom gets more than four days in the week, with the exception of now and then a day with the Duke of Grafton at Whistleywood, or one or two other places. His hunters are very perfect, for he will have them so. He is a capital horseman, and, taking him in harness and out, no man can do more with a horse than he can. Sir Henry is also a good judge of the scuvir vivre, and all is right at Tusmore.

Sir Edward Lloyd is a good sportsman, has a good eye to hounds, and few men at his time of day, and of his weight, ride to them so well. His eldest son promised to be a first rate. He is, however, a hard rider, a popular man in the country, and delights in foxhunting.

There are four of the Drakes who attend the Mostyn Hunt, and are uncommonly well mounted. Mr. T. T. Drake resides at Buckland, where Sir Henry Peyton lived previous to his removing to Tusmore. Mr. John Drake is a brilliant performer, and no man can beat him for an hour, best pace, over a strong country. His horses are of the right stamp; and one of them can do anything that is required of a hunter, and he has refused six hundred guineas for him.

Mr. Harrison, of Shelswell, can ride well to hounds, but he has his particular days. When he does "set-to," and things go to please him, he is not to be denied. 
There is a very "promising young one" now at Christ Church, and well bred to go over a country - the eldest son of Lord Forester: He was well entered, when very young, by his father, who kept a pack of harriers for him as soon as he could ride, and in a country (Shropshire) where much is to be learnt.

Sir Thomas Mostyn has no subscription to his hounds, neither has he any uniform for his Hunt, any farther than that those of his friends who like it wear plain silver buttons on their red coats, with the letters M.H. engraved on them.

No part of Leicestershire is finer than is some part of the Chipping Warden country, particularly about Wormleighton, bearing away for Itchington, Ladbroke, Southam, Shugborough, \&c., till it joins the Warwickshire on one side, and the Pytchley on the other; but in some parts of it the fences are almost inipracticable. Three years ago (1819), I saw a fine run over this country. We met at Fenny Compton Wharf, on the road from Banbury to Daventry, and, after drawing for about an hour or more, found very unexpectedly in a small patch of gorse not more than an acre of ground. Perhaps fortunately for myself, or my horse, I did not get a start. I was on the ground at the time fastening up my boot, and before I could mount, some of the quick ones had got two fields off with the hounds. When I came to the fences, they were such as I do not care if I never see again; but when Mr. J. Drake and Sir Henry Peyton first charged them they must have been terrific. Sir Henry, though on old Saladin (a one-eyed horse, for which he gave 450 guineas), was knocked backwards twice, and obliged to decline, and get bled. Mr. Drake was more fortunate, and no one caught him, neither did more than two or three see him until the check at Shugborough, six miles, best pace. Tom Penn, Sir WVatkin Wynn's pad-groom, was out, and saw the place where Sir Henry got his second fall, and he declared the fence was impracticable. From the check at Shugborough we went on fair terms with our fox to Abdy Wood, in the Pytchley country, where of course his life was saved, as the earths were open. The distance, point-blank, was seventeen miles, and the country particularly strong. Towards the end of the run, a $\mathrm{Mr}$. Griffin, a good kind of rough, hard riding farmer, was of great service. He was on a five-year-old horse, got 


\section{OXFORDSHIRE}

by Vivaldi, not quite " up to the trick," but in a fair way to learn it, for he charged everything that came in his way, and for which Sir Edward Lloyd did not fail to cheer him, as he was as good as a pioneer. Mr. Griffin is an old hand at this work, and has sold his hor'ses for good prices. Until I saw this run, I considered the Market Harborough country the strongest that I had ever crossed, but this part of Northámptonshire is more difficult. 


\section{WARWICKSHIRE}

WHEN considered as a hunting country, Warwickshire certainly ranks next to Leicestershire; and a considerable portion of it to the eastward of the river Avon is equally good. Here it is hounded by Northamptonshire; and though, perhaps, taking it throughout, there may be more ploughed land in it than may be met with in that county, yet it is for the most part a pleasanter and a more practicable country to get over, and no man who knows how to ride to hounds, and has a hunter under him, ought often to be stopped in Warwickshire, which cannot be said to be the case in Northamptonshire. The ploughed land in Warwickshire is chiefly of that loamy nature, that, whilst from its general richness it holds a good scent equal to, if not better, than some grass countries, it does not, with a few exceptions, stick and stop horses as colder clay land does. When we consider that the Warwickshire country reaches from Hook Norton in Oxfordshire, to Newnham, the seat of the Earl of Denbigh, within three or four miles of Lutterworth in Leicestershire, a distance of forty miles; and when we look at the magnificent vale it is composed of, the coverts that are interspersed in it, and all other advantages attending it, no unprejudiced person can deny that it is as fine and as fox-hunting a country as a master of hounds can reasonably desire. It not only contains a large space of champaign country, which with a good fox must shew a run, but on the outskirts of it, and which are only made use of for that purpose, there are some of the finest coverts in England for cubhunting, and which are never without foxes. Indeed a blank day in Warwickshire, when fairly hunted, would not happen twice in three years, which can be said of few other countries.

It is a long time since Warwickshire has been without hounds. The first pack that I can recollect in it, when I was a boy, was 
Mr. Ward's, who occasionally hunted some part of the Stratford country, at the same time that he hunted Oxfordshire. His kennel was at a small village, called Newbold, five miles from Shipston-onStour, and six from Stratford. It was on his declining Oxfordshire, and taking to Northamptonshire, in the year 1791, that $\mathrm{Mr}$. Corbet took possession of Warwickshire, and continued to hunt it, with the greatest success, until the year 1809, when he resigned it in favour of Lor Middleton, who gave it up in 1820, in consequence of a fall the preceding season; and it is now (1822) hunted by a subscription pack, of which Mr. Shirley, of Eatington, is at the head.

Although it cannot be said that he hunted Warwickshire for thirty-one years, yet as it was in the year 1778 that he first hunted the Meriden country, together with Staffordshire and Shropshire, Mr. Corbet and his hounds may be said to have been known in Warwickshire for that period of time; and I have reason to believe that he was a master of fox-hounds upwards of forty years, without erer having had a guinea subscribed to them, with the exception of five pounds a-year by each member of the Stratford-hunt Club to reward the earth-stoppers of the country. I recollect hearing him" say he had kept hounds longer at his orn expense than any man had done before him.

Succeeding to a fine estate, Mr. Corbet went abroad after having concluded his education, and returned to his native country a finished gentleman of the. Old School. To the last year of his life, he was remarkable for the neatness of his person and extremely gentlemanlike appearance. His manner's were peculiarly adapted to a man at the head of a pack of fox-hounds, being civil and obliging to the whole field, and particularly so to the farmers, by whom he was so much respected that the destruction of a fox by foul play was never heara of in Warwickshire in his time.

This celebrated fox-hunter, it seems, was first entered to hare; having, when he came of age, been in possession of a lemarkably clever pack of harriers, which, just before he married his first wife, he converted into a pack of fox-hounds; and, commencing with the country about Shrewsbury, then given up by the late Lord Berwick, he crept by degrees, first into the Shiffnal country, previously hunted by the late Sir Edrard Littleton; then to Shenstone, under the 
patronage of Lord Berwick, and so on to Meriden-tincling himself in possession of an extent of country of nearly seventy miles, running parallel with the old Roman road. Some years afterwards, having a son and heir, and a settled estate, his friends advised him to give up his hounds, and his country was divided between the Earl of Craven, Sir Richard Puleston, and Col. Wardle; Mr. Ward occasionally hunting part of Warwickshire. His son, however, dying, and his estate being once more open, he again became a master of hounds, taking possession of Warwickshire, and continuing it till the period alluded to.

Although no man performed the duties of life more correctly than Mr. Corbet, yet he was wrapped up in his hounds. His mind was with them, although corporeally absent, as the following anecdote will prove. He had lost his hounds one day, as also had a friend of mine who was out with them; and as he was riding in search of them, he was passed by Mr. Corbet at a pretty slapping pace, when he exclaimed, "Pray, don't ride over the hounds, you will only spoil your own sport." The hounds were not within five miles of him at the time! It was wonderful, nevertheless, how he would make his appearance at the end of a run, without perhaps ever seeing a hound, as he would not ride over the fences.

In society $\mathrm{Mr}$. Corbet was a most cheerful and entertaining companion, and often said a good thing. I was once present, when an anecdote was told of a gentleman having purchased a pack of fox-hounds; but on their arrival at his kennel his wife went into fits, in which she continued till the hounds were sent back again to their original owner. "If my wife had done so," said Mr. Corbet, "I would never have kissed her again till she took off her night-cap, and cried Tally-ho!"

During many years that Mr. Corbet hunted in Warwickshire, he rented a house within a mile of Stratford-on-Avon, called Clopton House-a substantial old mansion, suitable to his large establishment; but his hounds and horses were kept in the town of Stratford. When the country round Shrewsbury was vacant, which often happened, Mr. Corbet began the season there; but never failed being in Warwickshire by the fifth of November; on which day, if not on a Sunday, his hounds met at some favorite covert. A day or 
two previous to this the Hunt races took place at IVarwickshire, which generally afforded sport. Exclusive of the different stakes, several matches were made by the members of the Hunt; and Mr. Corbet gave a plate to be run for by the farmers, which they were proud to win-not more for the value of the plate, than for the sake of him who gave it.

Although Stratford-on-Avon has been, for many years, the headquarters of the Warwickshire hounds, it is situated quite at the outside, and in the worst part of what is called the Stratford country; and were a person to form an idea of Warwickshire as a hunting country, by travelling through that place on his road from Birmingham to Oxford, he would have no favorable opinion of it as a sportsman. Scarcely anything but a deep-ploughed country and large woodlands are to be seen, and he would little suspect that he was within so short a distance of as fine a grazing district as England can boast of.

This, it must be observed, is all on the other side of the river Avon, and which he would see nothing of. Ploughed and woodland, however, as this part of the country is, it affords excellent sport. It is no unusual thing to find a for within two or three miles of Stratford, and to kill him in the Pytchley country in Northamptonshire-to get to which he must pass through the parishes of Kineton, Geydon, Chesterton, Itchington, Ufton, Ladbrook, Southam, Wormleighton, or Shugborough, \&c.; which are for the most part composed of grass fields of from thirty to one hundred acres each, with practicable fences, and no river to interfere; and fastidious must that man be who can find fault with such a country. When we recollect that it is always well supplied with foxes, and that the Stratford draw in this direction reaches to Ladbrook gorse, within two miles of Southam on the left, and to Wroxton Abbey, within three miles of Banbury on the right, nothing more need be said in its praise. It may not, perhaps, be amiss to mention one circumstance in corroboration of what has been said on this subject. It was usual with Mr. Corbet not to fix one of his prime places on a Saturday: it was the market-clay at Warwick, and he had a consideration for the yeomen and farmers of the county, whose business obliged them to attend. The fixture, on the day I 
allude to, was Farnborough, the seat of Mr. Holbech. There was a large party staying at Stratford at the time; but several of them declined going, saying it was a long way, and a bad place when they got there. I was amongst the number who went, and we killed our fox twelve miles point blank from the place we found him, without meeting with more than one ploughed field, which was just at the last. So much for a bad fixture:

On the western side of Stratford, rerging towards Worcestershire, are Spernal Park and the magnificent woods of the Marquis of Hertford; very serviceable in a country, but only used here in cubhunting, although the former place is sometimes made a fixture, and now and then has afforded a run. On the Shipton or south side are numerous good coverts, and certain finds-such as Alveston pastures, Idlecote, Mr. West's and Mr. Canning's coverts, \&c.; as also Weston Park, near Campden in Gloncestershire, a capital scenting corert, but now made neutral with Col. Berkeley. About six miles to the left of that, close to the four-shire stone on the Worcester and London road, is the well-known IVoolford wood, which has produced so many brilliant runs, and is always honoured with attendance from the neighbouring Hunts, and rery often with some Oxford men, although twenty-eight miles from Oxford. On the left of Shipston-on-Stour, between that place and Banbury, is what is called the Edge-Hill country, consisting of Hook-Norton (now neutral with the Duke of Beaufort), the renowned* Epwell White House, and several other coverts on the hills; when, extending around the outside of Sir Thomas Mostyn's country, and embracing the hanging coverts of Lord Northampton and $\mathrm{Mr}$. Holbech, on the side of them, it descends into that fine grazing district, geographically termed, "the Plain of Warwick."

The name of a woodland country is a damper to many; but the Warwickshire woodlands are such as are seldom, if ever, met with.

\footnotetext{
* In the year 1809 this place afforded a tremendous run with Mr. Corbet's hounds, when the for was killed full twenty miles from the place he was found. It gave birth to a poem by Mr. Edward (ioulburu, called "Epwell Hunt" (somewhat in the style of the "Billesdlon Coplow" poem by Mr. Lowth), in which he gave a most humorous, but faithful description of some of the principal performers of the day.
} 
In Mr. Corbet's time the hounds always went three or four times in the season to Meriden, for the purpose of hunting what was called " the Meriden country," and brilliant sport generally attended them. Although the corerts here are large, they are so peculiarly situated, that it is no uncommon occurrence to see a run of ten or twelve miles an end in this country, and so good are the foxes that they generally skirt the coverts; or if they go into them, they will not turn right or leit; and they are generally easy to get through for horses. The fences here are larger than in the Stratford country, and, from the hedges being often placed on a bank or cop, are not to be taken in stroke, from which circumstance a horse has been styled a good or a bad Meriden horse, in proportion as his temper would accommodate itself to the nature of them. A good creeper here is useful, as indeed he is everywhere else. Meriden is an inn by the roadside, six miles from Warwick, and twelve from Birmingham. Here Mr. Corbet had a kennel; but when Lord Middleton hunted the country, his hounds lay at the beautiful village of Kenilworth.

The Meriden country commences within four miles of Warwick, and, taking Corentry for the centre, extends almost to the town of Birmingham on the left; then, joining Lord Anson's Atherstone country, comes round on the right by Corley, Combe Abbey (Earl of Craven's), Newbold, and Newnham (Earl of Denbigh's), within three miles of Lutterworth in Leicestershire, where leaving Rugby and Dunchurch a short distance on the left, and taking in the coverts of Sir Theophilus Biddulph at Birbury, it proceeds to join the Stratford country in the parishes of Ufton and Long Itchington, and so on to that fine grazing district already described; so that it has more than once happened that a fox found in the Meriden country has led the hounds home to their kennel at Stratford.

The extent of the Warwickshire country exceeds any that I have ever seen, or heard of, and the preservation of it, when $\mathrm{Mr}$. Corbet hunted it, was unequalled. In short, it might have been called a preserve of foxes. Independent of the resident noblemen and gentlemen of fortune, well-wisher's to fox-hunting, the Warwickshire yeomen and farmers are for the most part sportsmen, and numbers of them attend the hounds when within their reach. The Stratford Hunt Club was then held at the White Lion Inn at Stratford-on- 
Avon, and the members of it dined together every other Thursday during the season. It was composed of the principal sporting gentlemen residing in Warwickshire, including several others from the adjoining countries, who made Stratford their head-quarters during the winter. Although the Club only met once a fortnight, there were always some members of it staying at Stratford, for whom dinner was provided in the Club-room, which was always kept for this purpose; and these gentlemen generally partook of Mr. Corbet's hospitality in the course of the week. In honour of the immortal Shakspeare, the room they lived in was called "The Tempest." The walls were decorated with some sporting pictures, and over the fire-place, enclosed in a glass-case, was the head of the famous old fox, which in the year 1794 afforded an extraordinary run before Mr. Corbet's hound̄s, having been found at Wolford Wood, and killed near to Cheltenham, after a run of upwards of twenty miles as the crow would fly. A few lines on the side of the glass-case commemorate the circumstance, stating the names of the chosen few who were in at the death; amongst whom was Mr. Corbet, "who tally-ho'd him a few minutes before he was killed."

Never having been what is called a straightforward rider, Mr. Corbet's name appearing in so enviable a place at the end of this brilliant run, when all but eight out of a field of two hundred horsemen were defeated, has with some been a matter of surprise, and with others has taken away the eredit of the thing; but with those who have witnessed the extraordinary manner in which himself and some others would contrive to keep in what may be called the vake of hounds, without ever taking a fence, and get up to them at last, the surprise will cease : and particularly so, when they consider the country (the Gloucestershire Hills) which this fox went over was a light country; and, mounted as Mr. Corbet always was, on the best of horses, and the fences broken before he got to them, it was by no means improbable but that a horse might live under his light weight during the whole of this tremendous run; whereas he might not have gone half the distance, had he been ridden in the front for the first ten miles. All, however, that at this distance of time we can say on the subject is, to repeat the words of the Bard of 
Epwell, as applied to this distinguished fox-hunter, on the Epwell run-

"How he lived to the end of this terrible day

The muse neither wishes, nor onght she to say:

That he saw it, is clear-What more could old Meynel ?-

And witness'd th' effects of his care in the kennel."

From the great respect and regard that $I$, in common with all who hunted with him, entertained for this veteran sportsman, I could fill a volume in recounting his praise; but as that would be a mere gratification of my own feelings, and uninteresting to the generality of readers, I shall proceed to the description of his hounds and his establishment-only lamenting that time, the destroyer of all earthly pleasures, should have deprived his friends of so kindhearted and so gentlemanlike man, and the sporting world of such a pattern to all masters of fox-hounds, as Mr. Corbet of Sundorn. On his giving up his hounds, a magnificent silver vase was presented to him by the Warwickshire sportsmen, in testimony of their gratitude for the amusement he had afforded them.

Mr. Corbet's hunting establishment was upon a very considerable and a most respectable scale. He had always from sixty to seventy couple of hunting hounds in his kennel, which he divided into a pack of dogs and a pack of bitches. The advantages attending this plan of separating the sexes are supposed to be-first, it prevents quarrelling in the kennel; secondly, it does away with the necessity of spaying the bitches; and, lastly, bitches being generally quicker than dog hounds, it equalizes the speed of the packs. The general opinion of these hounds was, that the bitches were the fastest, but that the dog hounds hunted a lower scent. No man had a better stud of hunters than Mr. Corbet, generally consisting of from sixteen to twenty, and they were horses of the right stamp: they were well bred, with substance. Instead of breeding them-a very precarious mode of obtaining hunters-he annually purchased three or four yearling colts from his tenants or neighbours, and, by selecting those of power and bone, he seldom failed to keep up his stud, without putting his hand into his pocket for them, which he must have done deeply in those days-nothing in the shape of a hunter being to be purchased in his neighbourhood under from one or two hundred 
guineas. Shropshire horses, however, have deservedly borne a good name. The blood of Old Snap, Regulus, Revenge, Tommy, Minister, \&c., is scarcely extinct, and their places have been supplied by some excellent stallions, such as Sultan, Transit, and others equally good; and to this day the dealers keep a sharp look out for Shropshire horses. For the first five or six seasons that I hunted with Mr. Corbet's hounds, Will Barrow, his huntsman, rode two strapping chestnut horses, purchased in the way I have described. One was got by Revenge, and the other by Tommy. They were equal to about four stone more than Will's weight, and being perfect fencers, flying and standing, it is needless to say, that, with such a horseman on their backs, they were not easily stopped. His other horses were also of the first class.

Will Barrow was as fine a horseman as ever rode over a country, which gave him an advantage over his hounds, as his eye was never off them in chase. He knew Warwickshire as well as he did the parish he was born in; and let his hounds go whither they would, or as fast as they would, they could not be long out of his sight. Will, however, was not a good tempered man; and I always thought that it, in some degree, depended upon whether he was in a humour to kill his fox, that his hounds were to have blood or not. He could not bear to be interfered with by any one in his casts; and a word, even from his master, at a critical moment would sour his temper for the day. On the other hand, when things went to please himwhen the fox put his head towards a good country, and his favorite pack (the bitches) was shaking off the crowd and getting upon good terms with him, Barrow was then a good huntsman. He rode so well that he was able to give his hounds immediate assistance; and as he was at all times regardless of fences, his casts were quick and decisive. In dog language, IVill Barrow was never excelled. His view-halloo was the best and most melodious I ever heard;

(What so grateful to the ear,

As the voice that speaks to cheer?)

and to see him and hear him by the side of the bitches, cheering them with his halloo (which defies the pen), and " have at him, my lasses," pleased me more than anything that I have ever seen or heard in 
that way; and if anything could make a man forget that he had a neck to break, a horse to kill, or a wife and family to provide for, it would have been riding alongside this gallant fellow at such a moment.

The uniform politeness of Mr. Corbet formed a striking contrast to the occasional moroseness of his huntsman. IVere a man seen by the former in the midst of his hounds at a most trying moment, "Pray, Sir, hold hard, you will spoil your own sport," was all the rebuke he would receive from him; whereas, "Hold hard, Sir, G-d d-n it, where the hell are you going?" might have been repeated more than once by the latter. I recollect our being alongside each other at the end of a capital run, when a $\mathrm{Mr}_{\mathrm{r}}$. (brother to a Suffolk Baronet) was riding much too close to their sterns, regardless of everything that Will said to stop him. It was his first appearance in the country, and Will did not know him; but at last we saw him rolling over and over in a tremendous fall. "There, thank God," said Barrow, "we have done with you!" He was, however, mistaken; for we had not gone two fields before he was in his old place again-"The devil's in that fellow surely!" said Will in despair.

Warwickshire never knew happier days than during the period of Mr. Corbet's hunting it. The farmers had plenty of money, and so had their landlords; and the greatest good fellowship and sociability prevailed throughout the country. Every man who was a sportsman, and had a good house in it, made a party for some of his brother-sportsmen, on the day preceding a neighbouring fixture: and I recollect on one occasion tiurning out every morning for a week together among eight red and two black coats from under one man's roof. At these times, however, horses and servants were of course at the neighbouring inns and stables, with which the country abounds.

The price of horses in Mr. Corbet's Hunt was only exceeded by that given in the Melton Hunt, and in some instances was nearly as great. From two to five hundred guineas were frequently, and in one instance seven hundred and fifty were paid for a hunter, then ten years old. This was the celebrated horse, called "Confidence," the property of that well-known, thorough-bred sportsman, Mr. 
Lockley; and the purchaser was Mr. Richard Best, also well known in the sporting world, and a member of the Stratford Hunt. Mr. Lockley haring had this magnificent horse since he was four years old, and having ridden him several seasons in Leicestershire, his fame as a hunter was well established; but the immediate cause of Mr. Best's purchasing him at the price stated, was his carrying $\mathrm{Mr}$. Lockley in a superior style, over a most trying country, for an hour and twenty minutes, and taking a large timber fence at the end of it, when the jump was out of all the other horses. On Mr. Best coming up, he asked Mr. Lockley if he would sell his horse; and on the price being fixed, the bargain was closed on the same evening.

This sum being somewhat above a Warwickshire price, it may be supposed that Mr. Best upon Confidence was in some measure an object of attraction, and he was expected to "out-Herod Herod." A decoy was laid for him one day, by getting Will Barrow on one of his great jumping horses, as the hounds were drawing over the country, to lead him in conversation into the corner of a field, out of which there was no way but over a very high rail, and a tremendous ditch on the other side. On Will's clearing it, there was a cry of "now, Mr. Best." Mr. Best, however, followed ; and came at least a yard further into the next field than the horse that went before him. What man, however, who had ever ridden him could fail to put confidence in Confidence, as there was nothing that any other horse could do in the field to which he was not equal, for a finer animal was never formed by nature. He had every appearance of being a thorough-bred horse, with the powers of a cart-horse and the docility of a lap-dog, and a model of his shoulders and hind legs should have been preserved as a master-piece of nature's work in that way.

When on the subject of horses, it may not be uninteresting to hear a little of the history of one of the most enterprising and spirited horse-dealers that England ever gave birth to, in the person of Mr. Richard Bradley, who resided near Stratford-on-Avon during great part of Mr. Corbet's and for several years of Lord Middleton's hunting IVarwickshire. The reputation of Mr. Bradley, as a judge of a hunter and a brilliant rider over a country, reached the ears of George the Fourth, then Prince Regent, who, on his road from Ragley, called at his house, and waited nearly an hour 
for the purpose of seeing him; but he could not be found, though not far from home at the time, and so missed the intended honour. Exclusive of his fine judgment of a hunter, and his excellence in riding him, he had a way of insinuating a customer into a purchase which it was more than difficult to withstand. His flow of language was particularly good; and he wanted nothing but education, and the models of the great pleaders of antiquity, to have fitted him for the Bar or the Senate. Indeed, on one occasion, he was told by a certain Baronet well known on the road, that during the time he had had the honour of sitting in the British Parliament, he had never heard any one talk half so much to the purpose as himself.

In Warwickshire's best day-when MIr. Corbet hunted it-it was not unusual for Bradley to have sixty or seventy first-rate hunters in his stables at one time, and he had, generally, three or four out with the hounds on the same day. He rode admirably to hounds himself, and he had a lad called "Harry" in his service, whose hand on a horse was so fine, and his nerve so good, that he could make a raw horse into a hunter in three or four of his lessons with hounds. It was sometimes, however, laughable to see the different figure that some of these newly-wrought hunters, which had carried Harry so well one day, made on the next, when they lost the assistance of his directing finger, and found the no favorable addition of four or five stone on their backs with a clumsy rider. All that could be said on that subject was, that Mr. Bradley sold the horse, but not the rider.

There was another horse-dealer within a morning's ride of Stratford, who was a conspicuous character in his way. His name was Stroud, and he lived at a small village called South Newington, on the road from Chipping Norton to Banbury. He was allowed to be a superior judge of horses to carry high weights, for which he gave large prices; but he never suffered them to be ridden with hounds, on the principle, that, exclusive of the danger attending it, flesh corers many faults. Strond was supposed to have been of Egyptian descent, which the cast of his countenance bespoke. He was, however, a fair dealer, and bought a good sort of horses. From his vicinity to Oxford, he had caught hold of some scraps of Latin. On showing a horse one day to an Oxonian, who objected to his 
size, the old man observed, that, "to be sure, he is a little horse to look at, but he is what you Oxford gentlemen calls multum in pavo."

Whoever has been at school has heard of the Trojan war, and whoever has hunted in Warwickshire has heard of "the blood of the Trojans," which was a standing toast in that country when Mr. Corbet hunted it, and was always drunk after "The King" in the Club-room at Stratford. The hero from whom these modern sons of Ilion were descended was one of the best fox-hounds that ever challenged on a fox, and whose blood has circulated through most of the first kennels in the United Kingdom. He was bred by Mr. Corbet, and got by Lord Spencer's Trueboy out of a bitch called Tidings, purchased by Mr. C. at Tattersall's.

Trojan was entered in 1782, and hunted nine seasons. He would never look at a hare; and would speak only to a fox, a marten cat, or a pheasant. In his day, however, pheasants in Warwickshire were not much thicker than foxes, so that this propensity was of little consequence, for in chase he was as perfect as his nature could make him. With the nose of a blood-hound, his pace was a killing one; and, as a proof of his powers in chase, Mr. Corbet has often been heard to say, that he was the only hound he ever had who could leap Chillington Park wall after a fox.

It never having happened to me to see so striking an instance of the superiority of one hound over the rest of the pack, I shall devote a few lines to this interesting anecdote, and relate it, as I had it, from one of the best sportsmen that ever rode over a country, who was an eye-witness to the fact.

It appears that Mr. Corbet's hounds found a very dark-coloured fox in Chillington Park in Staffordshire, the seat of Mr. Giffard, which had beaten them twice. The third time they found him, Trojan leaped the park-wall after him; but in consequence of the rest of the pack not being able to follow him, old Cæsar, as this gallant fox was called, beat them again. The following season, Trojan found this fox again nearly in the same place, and leaped the wall close at his brush; but from the cause before mentioned, although he afforded a good run after the other hounds got round to him, he beat them once more! In short, in spite of old Trojan, 
"Cæsar's fortune" attended him to the last, as he was never killed by hounds, neither was it ever known in what way he ended his life.

It is scarcely necessary to observe, that most of Mr. Corbet's best bitches were put to this wonderful hound; and he was the sire of Traitor, Tyrant, Torment, Turpin, and Tarquin, all as fine hounds as ever went into a field, and which hunted in the same pack with their sire, when that pack was sold, in 1790-Mr. Corbet reserving old Trojan to himself.

The purchaser of this celebrated pack was Sir Richard Puleston, of Emral, son-in-law to Mr. Corbet, who sold them some time afterwards to the late Duke of Bedford for a large price; but their blood, so much honored by their original master, has been carefully preserved to this day by Sir Richard in the numerous hounds he has bred from his favorite stud-hound Dromo.

A hound called Champion was also much distinguished in Mr. Corbet's pack when he hunted Warwickshire the second time, and was for some years put to his best bitches, whose produce were equal to any hounds in the kingdom.

It is natural to pursue a favorite system too far; and so it proved in this instance; for, by too strict an adherence to the "blood of the Trojans," Mr. Corbet was at one time supposed to have injured his pack, as it was observed by those who constantly hunted with him, that the Trojan sort had degenerated. Though remarkable for stoutness, they had lost their dash. They would be seen meuseing a hedge, or creeping under the bars of a gate, when the rest of the pack would be topping both the one and the other. This, however, was not unobserved by Mr. Corbet; and, some years before he gave them up, the defect was in great measure remedied by judicious crosses from other kennels, but chiefly by a large draft of young hounds which he had from Sir Richard Puleston, whom he (Mr. Corbet) was often heard to declare he could never equal in breeding hounds. This candid submission to his superior judgment in breeding hounds, from so old and experienced a sportsman as Mr. Corbet, justifies the high compliment paid to Sir Richard, many years since, by the late Mr. Meynell, that he considered him "the best (gentleman) kennel-huntsman in England." 
I have little more to say respecting Mr. Corbet's pack, than that when Lord Middleton purchased them they were in high reputation, as having had a succession of almost unequalled sport, and given unbounded satisfaction to the country they hunted. The speed of $\mathrm{Mr}$. Corbet's hounds was generally too great for nine horses out of ten that followed them, with a good fox and a good scent; and such were their powers of hunting, that even in their woodland country they would always be backed at even against their fox, and at one time a good deal of money was won upon them at this game.

A curious circumstance once occurred with this pack, though not without a parallel, as a similar one with the Brighton harriers was recently recorded: they ran a cur-dog an hour, best pace, and killed him! There was nothing, however, discreditable to them in this, as they were halloo'd away, and cheered on to their game, which of course, was mistaken for a fox, and we must acknowledge the cur made a good fight for his life.

As a master of hounds-a natural accompaniment to the situation - Mr. Corbet's temper was often put to the test; but a harsh or ungentleman-like expression was never heard to escape him. So far from putting himself out of temper on every little accident or irregularity that might occur, he may be said almost to have fallen into the opposite extreme; and powerful examples of the command he exercised over himself will be found in the following anecdotes.

During the latter days of his favorite old Champion, when his powers were on the decline, and he could not run up with the pack, he accidentally got under the horse's feet of a hard-riding friend of mine, and was laid for dead on the ground. Unable to wound the feelings of any man, who, he was aware, would lament the accident equally with himself, all that Mr. Corbet said on the occasion, as he galloped by him, without turning his head, was, "killed the best hound in my pack, that's all!" I once saw another hound of his ridden over, and killed on the spot, but he did not see it. All the notice he took of this was, to address several of his friends as he rode by them with these words: "they've killed me a favorite hound, Sir ; you don't happen to know who did it, do you?" One very laughable scene I was also present at. A gentleman, no great proficient in the art, was caught by him in the act of hunting his 
hounds, not knowing he was so near to him! "Thank ye, Sir," said Mr. Corbet, "but my hounds will do that quite as well without you."

There is an old adage, and a very true one- "the less said is the soonest mended:" and I recollect an instance of its being rery happily exemplified by Mr. Corbet. At a time that a certain Noble Earl was making an attempt to give a check to fox-hunting by actions at law, not only against Tom Oldaker, huntsman to the Berkeley hounds, and his whipper-in, but against his own brother, Mr. Corbet received a letter from a Warwickshire farmer, who had conceived himself injured by some servants wantonly riding over his wheat, when that article bore a great price, on returning with their masters' hacks from covert. The purport of the letter was merely to tell him that he hoped it would not happen again, giving him to understand, with an allusion to what had passed in the Courts of Law, that he had the power to prevent his hounds coming on his land. Mr. Corbet brought this letter in his pocket the next time he dined at the Club, and after reading it to the members, said, "Now, Gentlemen, you shall hear my answer, which I bope you will approve of. It is, that I have written into Shropshire to order my keeper to send Mr. —— two brace of pheasants and a brace of hares, which I think is the hest answer I can give to this letter." It is scarcely necessary to add, that he heard no more from the farmer, than usual kind inquiries after his health, and thanks to him for his handsome present of game. Thirty years' experience as a master of fox-hounds was not lost upon him here; for by replying to this letter he might have embarked in a wide and troubled sea.

As a master of fox-hounds, Mr. Corbet did everything to ensure the preservation of his country. Exclusive of his civility to the farmers in the field, he took care to satisfy the complaints of their wires at home for the loss they might sustain in their poultry ; for every Sunday morning, on his road to church, he called at his kennel and inquired what bills had been sent for damage done by foxes, and, if any, he signed an order for their being paid. His earthstopping was also upon a rery liberal scale, and in one instance is worthy of being recorded. The celebrated and well-known Woolford Wood had been for some time infested with fox-catchers, who took 
them alive, and sent them to distant parts for sale. By way of putting a stop to this destructive traffic, Mr. Corbet entered into an engagement with these men (three in number), to give them $£ 40$ per annum on their promise to discontinue it; and which sum they received every Christmas Day during the remainder of the period of his and also of Lord Middleton's hunting the country; and to the credit of the men it should be said they adhered to the faith of their engagement.

There was another way in which Mr. Corbet gave great satisfaction, and that was by the very gentlemanlike attention he paid to the country, by a wide and timely notice of his fixtures, which were frequently made for three weeks in advance, and advertised in the Birmingham and Warwick papers, which had a great circulation through the country, besides being posted in the different inns in the neighbourhood. In addition to this, he was most punctual to his place and hour of meeting; and, what is of more consequence than may be immediately suspected, he always began his draw near to the place he met at. Trotting away three or four miles to a distant covert may be of no consequence to gentlemen who have perhaps two horses out at one time, and half-a-dozen more in their stables, but is thought much of by those whose stud is small and is called upon often. As a further proof that he lost no opportunity of contributing to the amusement of Warwickshire sportsmen, he fought a main of cocks for several year's at Stratford-on-Avon in the month of March, which was attended by many of the first cockers in England.

In short, whatever could be achieved by one man, by the means of a bountiful fortune, two capital packs of fox-hounds, conciliatory manners, and truly gentlemanlike demeanour, in addition to an enthusiastic devotion to the cause of fox-hunting, was brought to perfection by Mr. Corbet during the time he hunted Warwickshire, and for which his name will ever be remembered with gratitude by that large and respectable county. Indeed, this was amply testified by the regret manifested on his relinquishing it, as well as by the very handsome complimentary tribute paid to him by the Warwickshire sportsmen. It will be long before his name will be forgotten in the sporting world; and in private life it may be said of him, as 
was said of a celebrated ancient, "that he was one of the besthumored, best-natured, and the best-bred gentlemen in the world."

I feel as though I have said enough of Mr. Corbet; but, as the Poet says,

He who excels in what we prize

Appears a hero in our eyes-

even trifles become interesting which relate to so sporting a character. The two following anecdotes, therefore, whilst they may amuse your readers, will shew how strong was "the ruling passion" in the breast of this veteran sportsman :-

At a short distance from Sundorn Castle is a hill called "Hamon Hill," a beautiful feature in the country, and on the summit of which are the ruins of an Abbey and a tower, on which a flag was kept flying when $\mathrm{Mr}$. Corbet was at home. A party from Sundorn were once viewing this Abbey, amongst whom was Mr. Bennet, the Member for Shrewsbury; and who was giving an interesting dissertation on the various architectural arches from the round Saxon to the pointed Gothic. Mr. Corbet, whose politeness induced him to listen attentively - though perhaps impatiently-to all that had been said, was just beginning to shew that Mr. Bennet's information had not been lost upon him, by observing, "that peaked arch, did you say, Mr. Bennet!" when, suddenly, two fox-hound puppies, which were at walk in the neighbourhood, came gambolling across the court, upon which he turned to Mr. Robert Canning, who was present, and pointing at the puppies-his face brightening with increased animation-observed, "two clever young hounds, eh! Mr. Canning; something in our line!" And thus ended his dissertation on the beauties and orders of architecture.

The other anecdote is equally characteristic, though of a more ludicrous nature. The late Earl of Aylesford was no sportsman; but as a well-wisher to fox-hunting, and out of compliment to $\mathrm{Mr}$. Corbet, he would sometimes makes his appearance in the field when the hounds were drawing his coverts at Packington. On one of these occasions his Lordship had posted himself just behind Mr. Corbet in a very dirty ride in a covert. A hound spoke. "Hark!" said Lord Aylesford. "A puppy, my Lord," said Mr. C. Another 
hound spoke. "Hark! again," said the Earl. "Puppy," said Mr. C., softly. At last old Trojan challenged on him: "Trojan, by G-d!" said Mr. Corbet; "a fox for a hundred!" when clapping spurs to his horse, with one of his cheering halloos, he suddenly disappeared in the covert, leaving the noble Earl not only enveloped in astonishment, but covered with such an "explosion of mud," that his situation could only be compared to that of Dr. Slop when "beluted and transubstantiated" by Obadiah on the coach-horse.

An excellent print of Mr. Corbet, by Mr. Weaver of Shrewsbury, was published some years since by subscription, and is to be found in almost ever'y sportsman's house in Warwickshire, Shropshire, and the adjoining counties. He is mounted on a favorite grey horse, which he purchased of the Rev. Mr. Biggs; and is represented in the act of capping his hounds to a scent in a covert, having just unkennelled their fox. He is accompanied by Will Barrow, also on one of his favorite horses, and some hounds of the old Trojan sort; and the likenesses of all which-particularly of Mr. C.-are well preserved. It is much to be lamented, that no able artist had taken a sketch of him in one of his very happiest moments-in the midst of his hounds, when worrying their fox after a good run. He was then seen to most advantage-

"High waving the brusl,, with pleasure half mad;

Roaring out, Hoicks, have at 'em, we've killed him, my lad!

In a state of delight far exceeding all bounds-

See the veteran Squire in the midst of his hounds."

A picture, however, whatever may be its merits, must be a bad substitute for such an original. Such a man never should have died! As an example to sportsmen-as an example to gentlemenas an example to all men-nature for once should have gone out of her way: John Corbet should have been immortal! Death should have had no dominion over him-a whoo-whoop should never have been heard over his grave!

In all hunting countries there is to be found what may be called "a character," a constant attendant on the pack that hunts it; one who, in fox-hunting lingo, may be said to take a line of his own, and who says to the rest of the world-" go you your way, and I will go mine." Of this genus was the late Walter Stubbs, Esq., of 
Beckbury, Salop, but for many years resident at Stratford-on-Avon, where as a man he enjoyed the esteem of his friends, and as a sportsman was much in the confidence of Mr. Corbet.

It has been very justly remarked, that whaterer we enter into, whether it be pleasure or business, we should do so with spirit; and thus it was with Mr. Stubbs: for if erer a man could be said to be enthusiastically deroted to fox-hunting, it was he. Indeed it was facetiously hinted, in the Epwell poem, that hunting six days in the week was not sufficient for this insatiable Nimrod, but that once in his life he cried "who-whoop" on a Sunday-

With his hat in the air, peeping out for a gate,

Neither looking, nor riding, by any means straight;

Mr. Stubbs-a crack rider, no doubt, in his time-

Who hunting on Sundays did ne'er deen a crime.

Agreeably to the Italian proverb, "Se non " revo i ben' trovato""If it is not true, it is a rery good story ;" and you shall have it as related to me.

Mr. Stubbs, when resident in Shropshire, which was very near to the church, had a fox in his keeping, which he intended turning out before his hounds on a Monday morning. On the Sunday preceding, having lain in his bed, resting from the fatigues of the week, till the good people had assembled at their prayer's, his serrant came to inform him that his fox had escaped. "Has he, by Jove!" said Mr. Stubbs. "Saddle the bay horse in an instant, and I will be after him." So jumping out of bed, and forgetting the day of the week, he soon unkennelled the pack, and laid them on the scent of the fox. Puggy having lingered about the buildings which were close to the church, the hounds remained giving their tongues for some minutes, in seeming opposition to the parson in his pulpit; and it is said that each cried "Amen," at the end of a twenty minutes' burst-Mr. Stubbs having killed his fox, as the parson concluded his sermon.

Innumerable are the ludicrous anecdotes in existence of this veteran sportsman and truly singular character; one of which, as he was used to relate it himself, I shall venture to mention. He had a peculiar practice of keeping one eye shut, but which, on any occcasion of surprise or alarm, as invariably opened. Having made 
a bet in the ring at Newmarket, and lost it, he was suddenly accosted by the winner, and asked for the money, which had the usual effect on the optic. On the Greek looking into his face, and observing his perfect vision, he apologized for his mistake, and rode away, observing, that "the gentleman he had betted with was a one-eyed one."

Mr. Stubbs having been a great frequenter of race-courses, his time, with the help of such other diversions as that season affordsalmost all of which he partook of-was tolerably well occupied in the summer; but in a long frost in the winter, he may be said to have laboured heavily under that tadium vite which has been supposed so particularly to attach itself to us " unlearned gentlemen on a rainy day." During this time, he exhibited a most voracious appetite for novels, many volumes of which he would devour in a day, and would occasionally be seen returning them, by baskets full, to the two circulating libraries in the town. He was often heard to lament that there was not an Act of Parliament to enable all Sundays in the winter to fall together in a frost, which, he said, would strengthen the spirit of devotion by their repetition, without interfering with fox-hunting when the weather was open. After a good day's sport, he always took some tea, and went to bed as soon as he got home, and towards nine or ten o'clock he would get up and enjoy the society of his family. His method of travelling was equally singular. He would go almost incredible distances in a day, in his gig, with relays of horses on the road-setting off at two o'clock in the morning, and his refreshment nothing but tea and cold meat on the journey.

Whatever may have been his other recreations, Mr. Stubbs might be said to have lived for fox-hunting. The pleasure he took in it was derived from the purest source-from the real love of finding, hunting, and killing a fox; from the hound that spoke to him on the drag, to the worrying him in the next country but one; whither, sooner or later, he was certain to be, let the distance be ever so great, provided his horse could carry him so far, though, perhaps, without having seen a hound from one end of the run to the other. The animating description, however, he would give of such a chase, which he had seen but "in his mind's eye," was highly amusing to 
those who heard it. As far as concerned himself, all this was but a secondary consideration with Mr. Stubbs. His object was, that sport should be afforded, and that a fox should be killed. Let those ride who liked it, he had a pace of his own, beyond which, not a view, not a dying fox, not old Trojan at his brush, would ever induce him to go. His horses seemed to know this pace as well as he himself did, and were as little anxious to exceed it; for it was a nice gentlemanlike canter of about nine miles in the hour. His aversion to fences was equally remarkable : they appeared to grow as he looked at them, and he would often see a ditch when others saw none.

The pace Mr. Stubbs rode over a country after hounds, at last became proverbial. I remember being once too late at covert, and the hounds had gone away with their fox. Neeting a groom returning with his master's hack, I asked him whether they had gone away quickly? "No, Sir," said the man : "about MIr. Stubbs' pace." Strange, however, as it may appear, Mr. Stubbs has, a hundred times, been known to continue this pace for twenty miles on-end over a country, and all the way from home, without, perhaps, having ever seen a hound in chase; but from his knowledge of the country he was sure to arrive soon after the sport was concluded. The day never appeared too long for him; for he would always recommend drawing for a fresh fox when it was far advancedfrequently reminding his brother-sportsmen that there was a moon which would serve to kill him by.

At the festive board Mr. Stubbs was little more than a spectator, being remarkable for the temperance of his habits; but his conversation was highly amusing. He abounded in anecdote, was a great observer of mankind, and his remarks upon the follies and indiscretions of those twenty years younger than himself were irresistibly diverting. He was a very honorable man; and, what in my opinion entitled him to no small respect, he was a warm friend to fox-hunting, and an enemy to no man!

Mr. Corbet had also a very peculiar way of crossing a country, and, as far as related to fences, much resembled Mr. Stubbs. Although he would not leap, he would gallop as fast as anybody, and shewed no small share of nerve, as well as hand, in going the 
splitting pace he did along stony and sloughy lanes-a service of more danger than riding straight over the fences. He disdained having a pad-boy to help him; but from the respect in which he was held, every one was anxious to afford him assistance. He had, indeed, a laughable way of helping himself to it in the following manner: on coming to a fence he did not like the look of, and seeing any one he knew going at it, he would exclaim, "Thank ye, Sir, I am very much obliged to you; you'll just catch my horse!" This just catching his horse, just lost his friend the run, if it were a good one; but few could refuse the boon when asked for by him. The last thing that Mr. Corbet could have been accused of was being selfish in the field-for no man was ever more anxious to shew sport to his friends, even if he could not enjoy it himself; and when his hounds were well settled to their fox, and things looked well, he would cry out, "Now, gentleman, ride and catch 'em if you can."

Having mentioned two of the principal characters in this once celebrated Hunt that could not ride, your reader's will think it time I should speak of those who could.

Whatever may be the art we attempt, our merit in excelling in it is proportionate to the difficulties we may have to contend with, as he who might make a good arithmetician might cut a very bad figure in fluxions. In riding at a rapid pace over a deep and strongly enclosed country weight must be allowed to be the greatest obstacle that presents itself; therefore he who outstrips his competitors, with such fearful odds against him, is most entitled to the prize. I shall therefore first introduce the name of Mr. Robert Canning.

It was said of Caligula, that he was sent by Heaven to shew what mischief the worst man in the world, with the greatest means, could accomplish-an awkward experiment, we must allow. It was said of the late Duke of Bedford, that he was sent by Heaven to exhibit a contrasted lesson to mankind, and to prove what good could be done by a man well disposed to do it, when fortune had placed the means in his hands. Of Mr. Robert Canning it may be asserted, that among other excellent qualifications, he was sent amongst us to shew what that fine animal the horse can do. When we reflect for a moment on the subject-when we think that a man, measuring six feet four inches in height, and weighing, with his saddle, serenteen 
stone-that such a man, for so many years of his life, should have performed such wonders in the field, we almost feel inclined to believe that he must have had the assistance of some supernatural power. The power, however, which he has availed himself of was derived from the rare faculties he possesses-faculties seldom united in one man :-viz. a quick eye, a clear head, a fine hand, extreme coolness, and undaunted resolution. That a man of his height and weight should have, what is called, a neat seat on his horse is not to be expected; but Mr. Canning looks to advantage when mounted. The evenness of his hand is much in his favor: himself and his horses always appear upon the best terms with each other; although it must be admitted he has sometimes demanded more than ordinary sacrifices from them.

No man that ever yet was born could have beaten Mr. Canning over Warwickshire, for a whole season, during the time he may be said to have been in his prime. All surmountable obstacles he was more than a match for; and from his geographical knowledge of the country, he always knew how to avoid those which were not so. He frequently made his appearance in Leicestershire, where he was always seen in the front rank.

To prove how his fame as a rider had extended to distant parts, I must relate the following anecdote:-An honorable and reverend gentleman - a very old Meltonian, and a very good judge-came one year into Warwickshire, as he was heard to declare, for two distinct purposes: one to see Mr. Corbet's hounds, and the other to see Mr. Robert Canning ride. When he got back into Leicestershire, he expressed himself as follows: "The morning," said he, "was unfavorable, and the scent so bad that we could not get on with our fox, and I saw nothing remarkable in Mr. Canning. At two o'clock, we found a fresh one: the day altered, and the scent was good. The hounds went at their very best pace; when $1[\%$. Canning came out of the crowd, like a bee out of her hive, and beat every man that was out." Longinus himself could not have improved upon this!!

When I assert, that there was no man in Warwickshire who could beat Mr. Canning in the field, I do not mean to say that there may not have been some light-weights who could get as near to 
hounds as himself for three or four miles, when things went smooth and well; but when difficulties arose, horses became distressed, and judgment was called into action, he was the man to look to. What is not always the case with men that are called hard rider's, all sorts of fences came alike to $M r$. Canning; and those who have seen the brooks and gates which he has ridden over in a run, have been almost inclined to believe that he had borrowed Pegasus for the day.

Mr. Canning's stud generally consisted of five or six hunter's, but he seldom had more than one out at a time, and never appeared to recollect that he rode seventeen stone. He was generally very fortunate is not materially injuring them, and, all things considered, escaped pretty well himself, although he has had some hard blows. His horses, generally speaking, lasted several years, and he seldom sold them, unless he was tempted with large prices. He rode one horse, which he called Favorite, for eight seasons in succession; but the best hunter he ever had was a stallion, called Knowsley, which he purchased from Mr. Boycott, and which he hunted in the winter, and bred from in the summer, producing some very useful stock in the country. This horse was not quite thorough-bred, though he appeared to have a very small blot on his escutcheon; and when the country was not too deep, and with Mr. Canning on his back, he proved himself to be one of the most brilliant and perfect hunters that ever went into the field. Mr. C. lost his start one day with this horse in Leicestershire, in a very quick thing of forty minutes, and recovered it in a wonderful manner, getting quite into a front place, and maintaining it to the end of the run. He had another very wonderful hunter he called Conjurer. He was a vulgar-looking horse, with extremely fine points about him, and could go an extraordinary pace, and leap any thing.

Having ventured to presume that this gallant horseman was born to display the powers of the horse, I take leave to introduce one more instance of his prowess. Towards the conclusion of Lord Middleton's hunting Warwickshire, Mr. Canning got slack, and his stud fell off. The hounds meeting near to him one day, he went to see them find, on a little four-year-old mare that he had bred, equal to about ten stone on the road, and which had never seen hounds 
before. Strange to say, he rode this little animal a very sharp burst of nearly half an hour, with his legs almost touching the ground; and just before the fox was killed, he rode her over a good brook and a new oaken stile. Mr. Lucy gare him eighty guineas for the mare a few days afterwards, in consequence of her (or rather his) wonderful performance. It is in allusion to such feats as this that Mr. Canning is thus mentioned in the Epwell Poem :-

\footnotetext{
"On his five-year-old horse, though of course in the front, Robert Canning comes next-the crack man of this HuntLet him ride what he will, whether hunter or hack,

Sure, by some means or other, to be with the pack :

At the end of a day almost always alone,

" And scarce ever behind, though he weighs sixteen stone."
}

Notwithstanding the high repute this gentleman attained as a rider, no man was more free from jealousy; and so far from throwing any impediment in the way of a brother sportsman in the chase, he would give him every assistance in his power. He has always been heard to say, that fox-hunting was a social amusement, and that a liberal mind would not enjoy it the less from its being shared with others; but, on the contrary, the pleasure must be increased by being mutual.

A short time before Lord Middleton declined Warwickshire, Mr . Canning quitted it, having built a mansion-house on his estate in Gloncestershire, where he now resides; and where the same directing eye that piloted him so well over a country has assisted him in planning one of the best-constructed houses and offices for the residence of a country gentleman that could be formed with hands. With the exception of his race-horses, his stud is reduced to one hunter, on which he sometimes makes his appearance with Colonel Berkeley's hounds; and when things go to please him, he is still awk ward to follow, and difficult to beat.

This gentleman is the second son of the ancient and honorable house of Foxcote, in Warwickshire, where his elder brother

* It is singular that the elder Mr. Canning, who has also been deroted to fox-hunting, and a wonderful performer for his weight, should reside at $F_{0} x$ cote, and that the name of Mr. Robert Canning's house in Warwickshire should have been Hounds-hill. 
resides. I am not aware that he claims kindred with a Right Honorable Secretary of the same name, but each, we must allow, is a prime minister in his way.

One of the hardest riders which IVarwickshire has had to boast of is Mr. Edward Gale Morant, who resided for many year's at Upton House, near Edge Hill, one of the seats of the Earl of Jersey, and where he kept a clever pack of harriers, to amuse himself with on the intermediate days. Mr. Morant is an old Meltonian, and one of the heroes of the Billesdon Coplow. I cannot call him a fine horseman, but as a determined rider over a country he has few equals; and no man in England would beat him for fifteen minutes when hounds run very hard, or for fifteen hours if his hor'ses could carry him so long, as he has strength for any exertion, and nerve for any fence. It is, however, "the pace that kills," and this Mr. Morant has too often proved; for so briskly does he put them along, that he never had but one hunter that could carry him through a run of an hour. This was a thick, little, hard-pulling chestnut-horse got by No Pretender, shewing a great deal of good breeding, and such was his stoutness that it was difficult sometimes even for $\mathrm{Mr}$. Morant to stop him. In the real sense of the words, he was no pretender, for he would go long after nature said "enough." Mr. Morant, however, is of all others the man to ride a hol'se in distress; for towards the end of a run it always appeared a matter of perfect indifference to him whether his horse cleared his fences or not, so that by some means or other he could get into the next field. Falls seemed but a minor consideration: his object was to put his horse at the fence, leaving it to chance, or fortune, whether he got safe over it or not. When hounds went their very best pace, then Mr. Morant was in his element. Had he been less severe on his horse, he would have seen more sport; but the cream of the thing was what he wished to gather, and as long as it lasted he had it in perfection. His pleasure, however, was generally short-lived, for no horse that ever was foaled could sustain his pace long.

It was sometimes diverting to see Mr. Morant in distress; and on one occasion in particular he afforded considerable amusement to a large portion of the field. It was in Mr. Corbet's time, and we had had a capital run of an hour and ten minutes, and killed. After 
worrying our fox, we proceeded homewards, when, turning the corner of a large quickset hedge, we came suddenly upon Mr. Morant. He was mounted on his famous chesnut horse, a terrible example of disaster and defeat. He had lost his hat, and his face was much scratched and bloody. Poor Splogio's tongue (for that was the name of the No Pretender) was out of his mouth, his head hung down, and he had none of that fiery temper with which he had left his stable in the morning. Although made the subject of much merriment, particularly to $\mathrm{Mr}$. Corbet, Mr. Morant exclaimed, "upon my word, a very pretty run. Where did you kill him? I wish I could have been with you, but I don't know how it is, my little horse did not like it to-day : perhaps I hurried him too much. It was a very pretty thing." The ardour of the rider was too much for the powers of his horse, and he verified the old saying, that the most haste does not always make the most speed.

One of the characteristics of fox-hunting is that it begets a contempt of danger; and no one ever appeared less afraid of breaking his neck than Mr. Morant. Without this enviable qualification, it is useless to think of contending for the honours of the field. In one instance Mr. Morant proved himself almost superior to the influence of fear, or, in more sporting language, a game one. He got a fall one day into a road, and alighted on his head on a heap of stones. Though alarmingly hurt, and obliged to quit the field, yet, to the surprise of every one, he was at the covert side the next day as if nothing had happened. On his friends asking him how he was, he told them that he had some awkward sensations, to be sure-such as dizziness of sight, shivering, and a feel as if cold water was running down his back (all by the way symptoms of a slight concussion of the brain), and that they wanted to bleed and physic him, but he thought a bottle of claret over night and a good run with hounds in the morning would do him more good, so he was come to try the experiment. Now, although this may be a had way of providing against the consequences of a bad fall, yet we cannot but admire the manly spirit that prompts a man to adopt it, as it would lead him, if occasion required it, with the same coolness to a doubleshotted battery.

It may not be amiss here to observe, as a hint to hard riders, that 
I attribute many falls which Mr. Morant got to his not riding in spurs. When horses come to be crammed at such places as he was in the habit of cramming them, and perhaps blown at the time, the assistance of spurs is most useful, to keep up the stimulus, and prevent their slackening their pace when they come to the fence, by which much of the impetus that would have carried them over is lost, and a fall is too often the consequence.

Mr. Morant has left Warwickshire, and now resides in the New Forest. It is also said he has declined hunting, which all those who have not must lament. By his good humour and high spirits, he was a great promoter of mirth in the field, and a gallant riaer over the country; but only fit to follow fox-hounds on a good scenting day. Could he have persuaded himself to have gone "Mr. Stubbs' pace," he would have shewn more sport than he did with his harriers, but with them he always rode among the leading hounds.

Another celebrated character in our sporting catalogue is Mr. John Hawkes, who resided many years at Snitterfield in Warwickshire, but who has lately been living in Worcestershire, and only occasionally appearing in the former country. Mr. Hawkes is also a very old Meltonian, having been a great deal in Leicestershire in the late Mr. Meynell's time, and distinguished by the friendship and confidence of that renowned sportsman. Mr. Hawkes has not only been a brilliant rider over a country, but was at one time supposed to be one of the best gentlemen-jockeys of his day. "He was not only," to use the words of Buckle, "clever in the saddle, but right in the attics," his judgment in a race being particularly good; and had he been a jockey by profession, and three stone lighter, he would have ridden many a winner of the Derby. Mir. Hawkes was born to ride, nature having cast him in one of her favorite moulds; and I have heard that when in the army in early life he was considered a model for a light dragoon.

If Leicestershire does not spoil a man for most other countries, it certainly makes him fastidious; and Mr. Hawkes would have been better satisfied with Warwickshire if he had never hunted in the former county. It was not every day's sport that would please him there, though, perhaps, he may have been heard to find fault with a run in Warwickshire, which he would have been very well 
satisfied with had it been in Leicestershire. His best day in Leicestershire was gone by before I knew him, having never hunter in it in Mr. Meynell's time; but by the way in which I have seen him ride over Warwickshire, particularly on a horse called "the Printer," I am convinced he has been a match for any man. Having been upon the turf for many years of his life, and a considerable breeder, he generally rode well-bred horses, and of a good stamp for business. He purchased Williamson's Ditto for a large price, after he won the Leger, as a stallion.

A very old member of the Stratford Hunt, and one of the most respectable personages in the county of Warwick, is Sir Gray Skipwith, who, though the father of fifteen children, still rides to hounds with the ardour of his youthful days, and is a subscriber to the pack that now hunts this fine country. Sir Gray was never what is called a bruising ricter; that is to say, he is not one of those who will go with a fall lather than not go at all ; but he may be said to ride, as he lives, quite like a gentleman, and is what is termed a very pretty rider to hounds. Being a light weight, he has always ridden the right sort of horse-well-bred, near to the ground, and with sufficient substance. Sir Gray is a true friend to fox-hunting, and just the kind of man that should be found in every other parish throughout England, as nothing can go wrong in a country where gentlemen of his weight and influence reside.

Mr. Reginald Winniatt is well entitled to notice among the hard riders of Mr. Corbet's and Lord Middleton's days in Warwickshire. He is a very powerful horseman, with rare nerve; but, from want of the finger, got a great many falls in his noviciate, and was some time before he completed his education. He had a wonderful mare on which he often distinguished himself, and to which, perhaps, he is indebted for his celebrity. She was not quite 15 hands, but long and wide, and possessed every good quality for a hunter. After riding her several seasons, he sold her to $\mathrm{Mr}$. Walsh Porter for 200 guineas, who also at the same time gave Sir Gray Skipwith that sum for much such another animal. These two mares were the extent of Mr. Porter's stud; but one or other of them was always ready for him, and few men in Warwickshire went out oftener, or got better to hounds, than Mr. Porter. Mr. Winniatt purchased his 
old mare again after she had done her work, and sold two hunters out of her, by Fyldener, to Colonel Berrington for 500 guineas.

Although it was before my time that he hunted regularly in Warwickshire, yet having seen him out in many other countries, I cannot pass over Mr. Boycott. This gentleman resides in Shropshire. It has been said of him, that as a coachman he can drive, and as a horseman he can ride anything, and I believe it is truly said; and, had he been cast in the lot of those who are obliged to work for their bread, he would have made the best rough-rider in England. As there are some who nerer have a goose on their pond, so Mr. Boycott never had a bad horse in his stable; but I will do him the justice to say, that he can do more with a bad horse than half the world can with a good one; and a lesson or two from him will complete the education of a hunter. He is also a first-rate judge of the animal, and was at one time in the habit of selling his hor'ses for large prices.

As a coachman, Mr. Boycott is well known on the road, and when punishment is wanting, he can administer it with effect. If he takes hold of them, they must go; and he has been heard to say that three legs are sufficient for a coach horse. At one time of his life he would buy those which no one else could drive, and generally got the better of them at last.

In early life Mr. Boycott was a soldier-having had a troop in Sir Watkin Wynn's Fencible Cavalry, which saw so much service in the Irish Rebellion. Here he was shot in the body, and the ball was never extracted. He suffered much for two years afterwards, but he has felt no inconvenience from it since, excepting now and then when he has been thrown out in a run; but his friends never remember it to have affected him when he could take the lead and licep it. When he arrived in England, after his wound, a brother fox-hunter facetiously observed, that he was come over with a bullet-in; but many thought it was no subject for a joke, as he had a very narrow escape for his life. Had he been killed, we should have lost a gallant sportsman, and his friends would have missed many a hearty laugh; for, though no one can do anything quite so well as himself, he is a great promoter of mirth in society, and a very good fellow to boot. 


\section{SURREY}

THE most disagreeable circumstance attending the Surrey Hills is the flints, which in most places exceed in size and quantity those met with in any other countries. They cut both hounds and horses. the latter being frequently spoiled by them. It not unfrequently happens that they divide the tendon of a horse's leg, so that on his rider dismounting, he finds his toe turning upwards! He is of course ever after useless. This accounts for no large prices being given for hunters in Surrey-about 200 guineas being the top of the tree. Were I to hunt constantly in it, I should prefer stallions or mares, as they would be of some use after such an accident had happened to them.

There is, however, a chain of woodlands through all that part called "the Hills," too inviting for a fox to quit for a country of which he can have little knowledge, and where he would not be likely to be very well received.

The hounds at the time I am writing (1823) are under the management of Mr. Haigh, who resides at Furze Down near Streatham. He has been a sportsman, and report says a good one, for many years.

In all hunting countries there is a particular character to be found which attracts the notice of strangers, and this is the case in Surrey. I allude to the "veteran" Cochran, who, having passed the grand climacteric, had this epithet applied to him two winters ago, in an account of a run with Lord Derby's stag-hounds, wherein he had distinguished himself.

Mr. Cochran is a very wonderful man. He is supposed to be upwards of seventy years of age, and though time has "silvered o'er his locks," he is still fresh and vigorous, possessing extraordinary 
nerve for the many summers that have rolled over his head. He is in a large way of business in London, and has a house close to Croydon. What is also most extraordinary, he never hunted till he was fifty; but when on his favorite old King Bladud horse, which he has ridden seven seasons, I am told no man in Surrey can beat him, nor will any fence stop him. He sticks to the old costume of the cap, straight.cut coat, and the leathers, and looks like anything but a quick one.

The stag-hounds are $\mathrm{Mr}$. Cochran's favorite pack, as the following anecdote will shew:-In one of his rooms he has got the head of a deer stuffed, supposed to be in the act of looking over some park paling, which, for effect, is also introduced in the room. When old King Bladud has run his mortal race, his head in the opposite corner will complete the amusing scene.

"Hector is dead, and Ilion is no more!"

There is an anecdote or two of this gentleman which should not be lost to posterity. Getting a bad fall one day, he was laid out for dead on a hurdle, and a surgeon immediately sent for. "Where shall I find him?" said the doctor. "In such a field," said the messenger, "on a hurdle." The doctor found the field and the hurdle, but the "veteran," by the aid of a little cognac from his side-pocket, had re-mounted his horse, and was gone to the hounds again.

There was another sample of the old costume in the field, who attracted my notice; and that was Mr. Percivall, father to Veterinarysurgeon Percivall, of the Royal Regiment of Artillery, author of "Lectures on the Veterinary Art."

There is one member of the Surrey Hunt who deserves a place here as a character which all true sportsmen must admire; and that is Mr. Hobson. A Jolliffe is known by his hat; but in the winter, no man can tell Mr. Hobson by his coat; for, though he never turns it, he changes it as often as Harlequin in a pantomime; for he hunts with three packs of hounds, and wears "the livery" of each, never missing a day. This, however, is not the most extraordinary part of the story. His house is sitnated at Stamford Hill, five miles north of London, whither he never fails to return every night, afterhunting, over London-bridge, though certain to be in Surrey again 
the next morning if there is any hunting to be had. He is a very heavy man, and past the prime of life, but has the character of being an excellent sportsman, and one of long standing in this country, having, it is said, been at the first turning out of deer before Lord Derby's hounds, twenty-seven years ago. His horses lie at Croydon; and, judging by one or two that I have seen, I may perhaps be allowed to say that, for once, "Hobson's choice " is a good one.

Mr. Hobson always comes in his carriage to Croydon, where he generally dines after the sport of the day, and then gets into it again, ready dressed for the drawing-room. Were it not for this economy of personal exertion, he could not go through the fatigue, as he never quits hounds till he either hears the who whoop, or till the last glimmering of hope has fled. This may be called an humble imitation of the method which the Earl of Darlington (now Marquis of Cleveland) adopted when he hunted his own hounds six days in the week. His Lordship had a change of clothes kept well aired at all the principal inns within his Hunt, to the nearest of which he always repaired after his sport was over; and putting himself into a chaise and four, ready dressed for the evening, a small field-piece at the lodge of his park announced his approach to the Castle, and by the time he arrived dinner (if ready) was upon the table.

There was a Captain Harrey also out with these hounds, who must not be overlooked; but I understand he is chiefly a staghunter. He left one arm at Waterloo; but with the other he makes a good fight over a country, and has got two very superior hunters.

A Mr. Dyer is also a conspicuous character in this Hunt. He has a good stud of horses, and gives the best prices of any man in it.

There was one other character out with these hounds which I must not pass over, as, perhaps, I may never see such another. His name is Holt. He appeared to have arrived at the age of man ; but there was no appearance of "labour or sorrow." He looked still sound and heart-whole, and as if every muscle in his body were as tough as whipeord; and was, I hear, a very handsome fellow in his 
time. The moment a hound challenged on scent, his pulse quickened, his eye sparkled, and I was certain he had been a sportsman in his time; and I afterwards learned that he had formerly kept hounds. He now keeps a mad-house ; and looks as if he had just broke loose from one himself. Reader, mark his dress, and I think you will agree with me! He had a light pepper-and-salt coat, over the collar of which hung his venerable tresses, which, in the language of the stable, wanted trimming. He wore white jean trowsers, which, with apparent difficulty, were pushed down into his boots, and these were gartered above his knees with brown leather straps and buckles. Fortunately for decency, he had breeches under them; for, as he went over or through everything, they were soon made an example of. All that we can say to this is, that there is no accounting for tastes; but, as sportsmen, we must all admire that which brings a man a hunting at all at an age when half the world are not even fit to talk about it. All wine, however, we are told, does not grow sour with age, neither does every man; and it was a pleasure to grow old at Lacedæmon.

The Union is a very old-established subscription pack of foxhounds in the county of Surrey, and were for many years under the management of Mr. Bolton, of Gibbins Court, near Leatherhead, whose son now holds that honorable post. Their kennel is at Fetcham, one mile from Leatherhead on the Guildford road, and contains about fifty couples of hunting hounds. Their country on the right hand of this road is tolerably good; but on the left, hilly and flinty. Their fields are not large-seldom exceeding fifty or sixty persons; but they are, for the most part, of that description of men which one is in the habit of seeing by a covert's side in better sporting countries. They are well mounted, well appointed, and look like gentlemen.

Of the Union hounds I cannot at present say so much as I wish, having been only out with them a few times. Like many other packs from the same cause, they have suffered of late years from want of a good huntsman-so particularly necessary in such a country as Surrey-and were getting somewhat into disrepute. This defect, however, was remedied when the Worcestershire hounds were given up, by Mr. Bolton hiring Christopher Atkins, who hunted 
that pack for three seasons after he left Sir Bellingham Graham, and who, no doubt, will soon restore the Union to their former celebrity. He only came to them in the month of June last; but all those who know anything of hunting are aware how much may be done with hounds by what is called "summer work," and two good months' cub-hunting in the autumn.

As every situation in life serves for formation of character, so the biography of a good huntsman is as interesting to a sportsman as that of Sir Isaac Newton to a philosopher. When a great Personage introduced a celebrated sportsman some years since on the racecourse at Bibury, in my hearing, to the late Lord (then General) Lake, he added these words to the introduction :- "Two such great men in their way as $\mathrm{Mr}$. _ _ and General Lake should be known to each other." A little sketch, then, of Christopher Atkins, whom I have known for many year's, may not be unamusing.

Kitt (for that is the name by which he is best known amongst $u s$ ) first started in life-and no bad start either-with riding exercise in Lord Strathmore's racing stables; and, when that Nobleman died, was transferred to Sir Bellingham Graham in the same capacity. Sir Bellingham was also at that time making his debrit in the sporting world with a pack of harriers, to which Kitt was appointed whipper-in. At this period the greatest intimacy subsisted between Sir Godfrey Webster and Sir Bellingham. The harriers were taken into Sussex, where the woods of Battle Abbey resounded to their cry. Hares, however, were thought to be too humble game, and a stag was sometimes turned out for the day's diversion.

Soon after this Sir Bellingham took to the Badsworth hounds in the Ferrybridge country, which he kept at his own expense for three years, and to which Kitt was second whipper-in-Jack being first, who, as well as Kitt, remained with Sir Bellingham till he took the Quorn country, when the former went as huntsman to the Badsworth, and the latter to the Worcestershire. From the Worcestershire-with which pack he gave unbounded satisfactionKitt came to the Union. Kitt only weighs nine stone. He is a particularly good horseman, and, when with Sir Bellingham, had generally the office of making his young horses into hunters, and he was ( $I$ think) nine year's in his service. I once saw his nerve put 
to the test, when Sir Bellingham had the Atherstone country. He was upon a mare that Sir Bellingham had bred, and which, until she was seven or cight years old, had prored very unwilling to make a hunter, and had given him a great many falls. He was, however, determined to get the better of her, declaring she was "sure to make a good one some day." The hounds got into Annesley Deer Park, and Sir Bellingham and Kitt came up to the pales (which were very high) at the same moment. "Now, Kitt," says Sir Bellingham, "either you or I must get to them. Come! you talk a great deal about your mare-let us see what she can do." Kitt immediately put the mare at the pales, and cleared them. Sir Bellingham cheered him when over, and immediately followed.

During my visit to Surrey, I hunted five times with Colonel Jolliffe's hounds, but was unfortunate in not being out on their good days. The first time I saw them, I missed a pretty half hour, owing to my horse being turned back at the turnpike; and the second day I met them in a country not very propitious to sport. Neither the Colonel nor Mr. William Jolliffe was out, and the hounds had had a hard week of it; so Roffey (the huntsman), casting his eye around us, trotted us through two or three small coverts in the neighbourhood, where no fox was at home, and landed us comfortably in Bansted Park for the day-a covert of about one thousand acres, very difficult to get away from, and which should be put in the Litany as one of those evils from which we sportsmen pray to be delivered. I met them twice at Walton Heath, but did not get a gallop; and afterwards at their kennel, when I saw them race a fox up wind and burst him in less than twenty minutes; and this was nearly all I did see, excepting a most complete pack of fox-hounds, by far the best in Surrey.

Colonel Jolliffe was kind enough to tell me that I should see his hounds in the vale, as they could not shew themselves on the hills, in which I agreed with him. We fixed a day, and I met them at Povey Cross, twenty-seven miles from London on the Brighton road. The following note, which I found on my table two days afterwards, will best explain the sport of the day. It is from an excellent sportsman, and said to be the best performer in the Hunt:- 


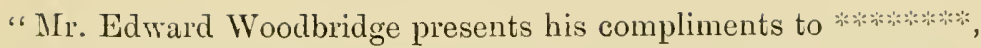
and begs his acceptance of the enclosed FInE Brush, the fruits of a fox well retrieved, and handsomely run in to. Mr. IV. regrets much that opportunities that may occur this season of seeing Colonel Jolliffe's hounds hunt and chase a fox; and possibly of being better pleased with the country than was likely he might have been with the first part of it.

"Charlwood Park, Feb. 5th, 1824."

To this I returned the following answer:-

"SIR-I beg you will accept my thanks for the honour you have done me in sending me the brush of so gallant a fox as yours proved himself on Wednesday, when he faced a country, after the rattling you gare him in those strong woodlands before I left you. I much regret that I missed so good a finish; but thinking-as he twice appeared inclined to go away, and turned again-that he would hang in those coverts till he was killed; and having been unfortunately spoiled for such a wretched country as we were then in, I turned my hor'se's head towards his stable as soon as I could see which way to steer for it. I conclude, that in this respect others were of my opinion, as only eight persons were at the covert's side when the hounds met-an unusually small field, I should imagine, with a pack so well attended as Mr. Jolliffe's, and on so fine a hunting morning. As a sportsman, however, I should have recollected, that the worst countries generally produce the best foxes.

"I have the honour to be," \&c.

Except Sussex, I never saw, heard of, or was in, a rougher country than Surrey. Not a ride was cut through the coverts, and the lanes surrounding them were belly deep in many places. Notwithstanding this, runs are sometimes had in these parts; and which is rare, on the day alluded to, a keeper said there was a brace of foxes in a certain pitch of gorse, "and it was so." On the Wednesday following, we met at Povey Cross. I breakfasted at Mr. Jolliffe's, and was much pleased with his stables. They contain thirty stalls and boxes, with a veranda extending all around 
them, in which horses can be exercised in tempestuous weather. The kennel, which is a very good one, and abundantly supplied with running water, is within two hundred yards of the stables, and close to the huntsman's house, on the Brighton road-side.

It is well known in the sporting world that Colonel Jolliffe has been master of fox-hounds upwards of twenty years, for more than ten of which he hunted them himself. Never having seen him in that capacity, I can only speak from hearsay; but I understand from those who have, that he was esteemed a very skilful huntsman, but not without a fault. His fault, however, was on the right side with fox-hounds-that of being given to make his casts rather too quick over a light scenting country. He however, like Shaw in Leicestershire, would recover his fox by a chefd-'auvre worth all the oldfashioned casts at the moment, and by which he gained much credit in the field. He has a most melodious pipe, with a very sportsmanlike appearance ; and, having so large a property in the country, is the man of all others who should hunt it. In addition to this, he has always been extremely popular in the field, and looks like an English gentleman. He has for some years resigned his post to his servant Roffey, who was educated under him as whipper-in; and who may be called a superior huntsman, both in kennel and in the field.

When I meet with a character in my travels, I cannot pass him over; and of this genus I must class Mr. Roffey. As I have before observed, every situation in life serves to form one, and a huntsman, above all, cannot hide his talent in a napkin : his calling will not suffer him to do so. "Every block, however, will not make a Mercury," nor will every fellow with a wide throat and a good voice make a huntsman. Nature is too sparing of her gifts for this; but we may all say with David, "He made us, and not we ourselves."

Roffey has lived with Mr. Jolliffe upwards of twenty years, and has been a good and faithful servant. Taking the liberty of calling one day to see his kennel, I will do him the justice to say I never saw hounds looking cleaner or in better condition than his were; and their sport this season has been brilliant. As the fixtures for this pack are given out in the name of " the Merstham Hounds," I 
conclude there is some subscription towards them; but from whom, or to what amount, I did not make it my business to inquire. All that I can add is, that, to please my eye, they are very complete indeed, and from the pains that have been taken with them they ought to be so.

Unless a man be an enthusiast in the sport, he never makes a good huntsman ; but this is one of Roffey's perfections. Not content with the fine season's sport his hounds have had, he sometimes sticks an additional feather in their caps. A very good sportsmana constant attendant on his hounds-overheard him one day describing a run to a gentleman from London, who had been lamenting that he was not out to see it. He not only went over all the country the fox had taken, but all that had been drawn over in the morning, making pretty nearly a tithe of the county of Surrey. "Why, Roffey," said the person who heard him, "how could you cram that gentleman so about the run on Wednesday?"- "God help him, Sir!" replied Roffey, "I thought I might as well tell the gentleman that as anything else." The last time I saw Roffey, I was very much pleased with the manner in which he accosted me, as I passed his door on my hack. "Oh, Sir!" said he, "you should have been with us on Saturday: we had an hour and twenty minutes without a cast, and killed him!!"

Roffey is a man of much humour, and when he speaks of me he always calls me "the bookman." The Colonel told me, he came up to him one day, and informed him "the bookman "was out. He was, however, very civil to me, and very obliging in answering any questions I asked him. I call him a very good one orer a countrythough he must ride nearly fifteen stone, and one of the best to make his way through a strong covert that I ever met with in my life. Trees of twenty years' growth have no chance with him at all. His general appearance, also, is in his favour. With a good badger-pie complexion, he has a keen eye in his head, strongly expressive of a mind only waiting to be cultivated.

I must confess that nothing pleases me more than the genuine, unsophisticated remarks of persons of this description-the result of practical observation alone, where Nature has been the schoolmaster, and where books and the dreams of the Schools have formed 
no part of the lesson. Thus, I am told, some of Roffey's answers and remarks are uncommonly good. Being sent one day with his hounds into the wildest and most remote parts of Surrey, where the Colonel took good care not to go himself, he asked him, when he returned, how he liked the country? "Why, Sir," said Roffey, "they just knows when it's day-light, and that's ail." Now had Aristotle been asked to define the first link in the chain between barbarian ignorance and a faint dawn of knowledge, could he have done it better?

I must now return to the hounds. As the Poet says-

"Nnmber and rhyme, and that harmonious sound

Which never does the ear with harshness wound, Are necessary, though lut vulgar arts :"

and there is a sort of prosoly to be observed even in a kennel. Names which caress the ear, and words of emphatic meaning, should be chosen in the first place; and, in the next, the cadence and quantity of them should be considered. A spondee, for instance, as Trojan; a trochee, as Stormer; or a dactyle, as Lucifer, can only be allowed with propriety. I was told that Colonel Jolliffe was particular, and happy, in his choice of his hounds' names; and on looking at his list, I think them very good, with the exception of Bclinda, which will not do at all. Thalia or Granicus would sound very well for hounds' names if the $i$ could be pronounced short instead of long. Mr. Chute has a bitch called Penelly, which is still worse. We might as well call one Aurora.

The Colonel had a famous hound in his kennel, from which he has bred much, called Chattercr.* This name is new to me; but there is no objection to it, provided the hound do not sympathize with the meaning of it. The Colonel seems also partial to the names of towns and cities. He has Appleby, Coventry, Lancaster, Lough-

* I observed two remarkably clever hounds, Conqueror and Corridor (second season), by him out of Belinda-one of the best-bred bitches in England. Chatterer was by MIr. Leigh's Chanticleer out of Dainty; Chanticleer, by Lord Vernon's Burster out of Careless ; Dainty, by Mr. Corbet's Fearnought out of Mr. Jolliffe's Damsel ; Fearnought, by Lord Fitzwilliam's Admiral out of Sir Richard Pnleston's Famous; Famous, by Sir Richard's Dromo out of his Fashion. In the entry of puppies this season, I observed two couple and a half by Chatterer. 
borough. I wonder he has not a Petersfield." It would sound well in a halloo, and if I were one of his constituents I should esteem it an honour.

In Colonel Jolliffe's kemnel is much of the best blood in England ; and it will be observed that he has not spared his trouble to procure it. I will first notice some of his favorite sire hounds, and then the bitches he has bred from.

Colonel J. seems to have sent his bitches much from home, and Nanager appears now to be the parent blood of his own kennel. He was got by his Mercury out of Lord Vernon's Flourish; Mercury, by Lord Sefton's Mariner out of Tilter; Mariner, by his Tantrum out of Milliner; Tilter, by Mr. Bowes's Jingler out of Jollity; Jingler, by his Jovial out of Mr. Paulet's Graceful.

Manager is the sire of Wonderful, Mountebank, Belinda, Barbara, and Manchester, from all of which, except Wonderful, Colonel J. has bred with success. He also bred two couple and a half of very clever hounds by Artifice out of Selima, now third season: Artifice, by Mr. Leigh's Artful out of his Fashion; Selima, by Mr. Jolliffe's Flasher out of his Stately, by Ostler out of Songstress; Songstress, by the famous Berkeley Chaunter.

In a bitch called Rhapsody is some of the best old blood. She is by Mr. Newham's Hymen (who was by the Duke of Rutland's Jupiter) out of Mr. Newham's Relish; Relish, by Lord Althorp's Roderick, who was out of Sir Thomas Mostyn's Leopardess; Leopardess was by Lucifer out of Lady, who was by Lord Lonsdale's Grasper out of Whimsey; Lucifer, by Mr. Meynell's Sultan, by his Stormer out of his Harmless. Rhapsody is the dam of Mr. Jolliffe's Regency.

Nectarine is the dam of three couple and a balf of hounds now in the kennel. She is by Mr. Newnham's Juba, by Sir T. Mostyn's Juba ; grandsire, New Forest Justice out of Sir T. Mostyn's Witchcraft ; grandam, Mr. Jolliffe's Damsel. The dam of Nectarine, Mr. Newnham's Nightshade, by Lord Vernon's Ferryman; Ferryman by his Rallywood; Rallywood by Lord Sefton's Ranter out of Modish.

Belinda is by Manager (as above), out of Bashful ; Bashful by

* The Colonel's own borough. 
Colonel Jolliffe's Hazard out of his Bedlam ; Hazard by Mr. Bowes's Hubert out of the Duke of Rutland's Graceful.

Normandy is by Mountebank out of Nectarine; Mountebank, own brother to Manchester, by Manager out of Bashful (as above). Manchester is the sire of Masculine and Mutiny out of Nectarine.

The pedigree of the following bitch contains some famous old blood :-Beautiful (1822), by Pertinax out of Barbara; Pertinax, by Mr. Newnham's Pillager out of his Norah; Pillager, by Mr. Hanbury's Pillager out of Mr. Ward's Spinster; Spinster, by Mr. Ward's Jason out of his Songstress; Mr. Hanbury's Fillager, by the Herefordshire Pillager out of Mr. Russel's Prudence, who was by Mr. Leech's Prompter out of his Jewel; the Herefordshire Pillager, by the Herefordshire Dreadnought out of Dimity; Dreadnought by Delver; Delver by Mr. Ward's Statesman out of Prince of Wales's Dimple.

Norah, by Sir T. Mostyn's Norman, who was by Meynell's Sultan out of Sir T. Mostyn's Nosegay, who was by Meynell's Conqueror out of Lord Spencer's Rosy ; Rosy by Forester, by Grandison out of Symmetry, who was out of the Duke of Rutland's Symphony; Grandison, by Meynell's Gusman.

Barbara, by Manager out of Bashful (as above).

There is a particularly clever bitch in this pack, now nine years old, called Fantasy. She is by Mr. Leigh's Artful out of his Fashion. There is also a remarkably neat bitch, called Faculty out of Fantasy, by Dexterous. The blood of Lord Fitzwilliam's, Mr. Chute's, Duke of Richmond's, and the Cheshire (from Coroner and Conquest) kennels, will be found in this pack.

The kennel does not consist of more than thirty-five couples of hunting hounds, but from attention to legs and feet, and from the power they are bred with, they are said to be generally up to the mark, even in that distressing country. 


\section{SUSSEX}

Having a great desire to see Colonel Wyndham's hounds, I took up my quarters at Brighton on the 23rd of February, and on the 24th went to Newtimber House, the fixture for the day, six miles from Brighton on the London road.

The signal for meeting in our grandfathers' time was when "the light morning star, day's harbinger, came dancing from the east, and fled at the approach of Aurora." Colonel Wyndham's fixture was for eleven ; and about twenty minutes before our grandfathers' dinner hour the hounds arrived, and by the time they were in their second bottle we found our fox. They came up at a brisk trot, and appeared by the horses as if they had not let the grass grow under their feet in their road from the kennel-the distance from which was about nine miles. They retired into a small field by the side of the road, whilst Colonel Wyndham changed his horse, and then proceeded to draw. The Colonel was mounted on a very clever Octavius mare, and his two whippers-in rode thorough-bred ones: in short, all looked well-bred together. There was a large field out, upwards of two hundred horsemen being present.

From the great reputation this pack had acquired-from the pace they carry a scent over a light country, and the great pains that have been taken in breeding them-I was very anxious to have a sight of them. They seemed formed for speed, not deficient in power, and abounding in good form and symmetry, though not exceeding (generally) twenty-two inches in height; they are very handy in coming to horn, or halloo. I never saw this excelled. These hounds also appear to be equally as good in covert as out of it. There was one hound which instantly caught my eye as above their standard, and on asking the whipper-in his name, he told me it was Conqueror. I afterwards found it was no misnomer, for when 
he had killed his fox, he carried home his head as a trophy, in spite of all attempts to make him drop it. I afterwards saw a brother to him (Caliban), a very fine hound, but I understood not quite so true on his line.

It has not always been supposed that gentlemen huntsmen are the best. Perhaps it may be on the principle, that those are not fit to command who have not been accustomed to obey. Having heard much of Colonel Wyndham's performance, I was anxious to witness it, so followed him, in drawing, through many rough coverts. I was much pleased with the quiet manner of himself and his men, and his hounds were particularly steady, and drew as if they meant to find. Unfortunately, however, they drew a long time blank; and, what was still more unfortunate, when we did find, only seven of eight out of this large field got away with the hounds; and, from the severity of the pace, and the extreme depth of the countrysome of it approaching to bog-catching them was out of the question. They, however, caught their fox at the end of an hour and twenty minutes, just as he had reached an earth, and was on the point of creeping up the bank to enter it, when he fell back among the pack and was killed.

On the following day (the 26th), I met the East Sussex Subscription Pack at Clayton Cross, also six miles from Brighton on the other London road, and, after drawing blank the side of some hills (over which the Brighton shepherd would have beaten all the horses in the field), we descended into the vale, to the adjoining coverts to those which we had drawn the day before with Colonel Wyndham. This vale forms part of the Weald of Sussex-a country much resembling parts of Shropshire, with the exception of its being much worse farmed, draining being miserably neglected. It is true that the nature of this land, being a loamy clay on the surface, with inferior strata of strong brick earth, is friendly to retention of water, yet I perceived that where nature pointed out the remedy no advantage was taken.

We continued drawing blank through this ungentlemanlike country till three o'clock, when, being in a strange land, and evening approaching, I turned my face homewards. As I was crawling up a sheep track on the opposite hills, in a direction for Brighton, I 
saw them find-not a fox, but I afterwards heard-two brace of foxes. Having a bird's-eye view, I could perceive that this variety of scents made a little confusion at first, but I soon saw the pack go away on good terms with one fox, accompanied by about five of the field. The rest had previously determined upon the line they were to take, or rather, in the language of O'Kelly, determined to be "nowhere." Some went in exactly an opposite direction to the hounds; others made the best of their way to the turnpike road, and stood still; whilst the few that set out on fair terms with the pack were, by some disaster or other, soon defeated, and one farmer alone, on a little hollow-backed mare, was the only man who saw him killed, at the end of an hour and thirty-five minutes over that severe country.

It is said of Chatsworth, the magnificent seat of the Duke of Devonshire, that to see it to advantage the traveller should approach it from the north, and not from the south, or, from similar scenes, its effect may be diminished. For the same reason I should have seen the East Sussex pack before I saw Colonel Wyndham's, and I should have liked it better. There were, as is the case in most packs, some very clever hounds among them-hounds of much power and calculated for a rough country; and there were also several plain and misshapen ones. On this day, however, the old adage of "handsome is that handsome does" might be applied well to them. They found their foxes when there were any to be found, and killed the one they settled to in a gallant manner. In drawing, they were certainly unsteady; but they are a young pack, of only three year's' standing, and perfection in hounds is allowed to be a plant of very slow growth.

The kennel of the East Sussex is at Ringmer, three miles from Lewes on the Battel road, and the hounds are under the management of one of their contributory masters-Colonel Cator, of the artillery. Lord Gage is one of their subscribers, and a pretty regular attendant. The huntsman wants a lesson from Colonel Wyndham in his dog language. The Colonel uses it sparingly, but when he does speak to them he is good. The other is very lavish of his lingo, but it was Hebrew to me. His halloo-away is a complete view-halloo. 
On the following Wednesday Colonel Wyndham's hounds met at Torrington Wood, where we found our fox the first day I was out, but on this day we drew it blank. The weather, indeed, was dreadful-nothing but thunder and lightning being wanting to complete the war of elements. A shower of snow overtaking us in our draw, just as we had got upon the hills, sent us home with nothing but a good appetite for dinner. Friday was Washington Common, between Steyning and Petworth, about seventeen miles from Brighton, in a country capable of being made a tolerable hunting country; but, like all those which have not been regularly hunted, the find was uncertain, and we had the pleasure of another blank, though we drew several miles down the Wealds of Sussex.

There is a country in Bœotia, which they call Hyetus, supposed to be the dirtiest in the world. This I have never seen; but I was bred up in a dirty one, and more than once, when a boy, was nearly smothered on my pony, in a lane called "the Devil's Gallery." I thought I had seen some dirt about the Clayton Woods in Oxfordshire, and the Grafton Woods in Worcestershire, but when I got into the lanes of the Wealds of Sussex and some part of Surrey, I found it was all to come. However, it is the best extreme of the two, and of two evils we must always choose the least. The country we drew over on this day would, no doubt, have held a scent, and by no means an impracticable one to cross-bearing in mind that what will stop horses will also generally stop hounds.

On the following day (Saturday) we met at the Burrell Arms, between Horsham and Worthing, close to West Grinstead Park, the seat of Mr. Burrell, Member for the county, and also about eighteen miles from Brighton. We drew some very fine gorse in the plantations in the park, but no fox was at home. We continued drawing over a good deal of country-the prospect beginning to lour -when we had a beautiful find in a beautiful patch of gorse. Perceiving they were determined to have him out or taste him, he went gallantly away across a good rasping brook in the meadows below, and I thought we were in for a clipper. I presently found, however, that it would not do; for as soon as the hounds got upon the plough, their heads were up, and nothing but feeling for it (which they did to perfection) could enable them to get on at all. Here the country 
alone was in fault. We had a good fox, and a good pack of hounds behind him, but a country that marred both; for, in consequence of there being no room between the coverts, the one ran short, and the others were never out of difficulties. This enabled our fox to stand a two hour's' run, and to save his life at last; whereas, had it been a good grass country, they would have tasted him in half the time. If we had found where we first met in the morning, we should have had a much better chance of sport.

Whether it was a judgment on me for laughing at others I know not, but in the course of this run I got one of the worst falls I ever had in my life at a gap. The mare I was riding fell with me as if she had been shot, and then struck me in three places on the head and face. Having once ruptured the temporal artery by an accident, I thought I had done so again from the quantity of blood that flowed; but this did not prove to be the case. A farmer remained with me till the bleeding abated, and then, from his knowledge of the country, and having a short running fox, I got in a line with them in a turnpike road, just in time to see the hounds going their very best pace over some meadows, which confirmed the opinion I had before formed as to the fate of their for, had grass, instead of plough and woodlands, been the order of the day. He was also, I understand, indebted for his life, towards the finish, to all being pounded in some gentleman's park, having been viewed but a short time before.

Not being able to ride off a trot, I can give but a lame account of this run from the time I got my fall. I thought Colonel Wyndham rode very well to his hounds, and his cheering halloo to them in chase would make an old man's heart feel glad. There was a Major Keen, of the 7th Hussars, on a very clever horse, and I saw him much inclined to get forward. This was, however, that kind of a run in which no man could distinguish himself, owing to the short and frequent turns. I had noticed the Major's horse on the first day I was out with these hounds, and I have since heard that he is of Irish blood. He is exactly the horse for Leicestershire.

I cannot conclude my observations on this day without expressing my gratitude to the farmer who assisted me in my misfortunes; neither can I forget the pressing invitation Mr. Burrell gave me to West Grinstead Park. I was, however, no figure for a drawing- 
room, so made the best of my way to my hack, and after ten days' repose was able to shew again. Mr. Burrell rode Vagabond, Brother to Wanderer, and a charming hunter he appears to be.

I have reason to believe the county of Sussex produces the only instance in the sporting world of two brothers, each keeping a pack of fox-hounds; but so it is. Colonel Henry Wyndham hunts the western side of the county.

Colonel Wyndham has two kennels - one at his own house, from which he hunts his Chichester country; and the other at Finden, three miles from Worthing on the Horsham road. The latter was built for the hounds which hunted this country when Mr. Newnham had the management of them. They are both very good and healthy.

It may be expected that I say something of the condition of Colonel Wyndham's hounds. On the first day that I saw them, they looked a little the worse, as all hounds do, for the preceding week's sport, which had been very severe; but they were even in their flesh, and not lighter than they should be for a flying country, which they so often hunt in, and where wind and speed are everything. On the last day I was with then I thought there was a beautiful pack out, and having had an easier week, they looked very bright and well.

The origin of this kennel I found to be as follows:-The Earl of Egremont bred them, with the assistance of a Yorkshireman by the name of Luke, now dead, but whose memory still lives in Sussex, and whose word (as it ought to have been) was gospel on anything relating to hounds. The Noble Eari, getting slack, made a present of them to the late Duke of Richmond, and the Dul:e gave them to the King. Old Luke, however-a good judge-kept some of the best blood, until, as he expressed himself, "his young master's would want them;" from which is descended the pack I hunted with, which I understand is of ten years' growth. In the Chichester country, I hear, they have a superabundance of foxes, and hunt very late in consequence.

I liked the appearance of Colonel Wyndham's first whipper-in. His name is Robert Bartlett; and though with a strong cross of the harrier in him, I thought he knew well what he was about in the 
field. The second-a young one-will some day or other turn up a trump-nature not having forgotten to put some brains in his head.

I was not fortunate enough to see Colonel Wyndham's hounds to advantage-that is, when they find their fox in the open, and run him, up wind, over that trying country. I am assured that the pace on such occasions exceeds anything that I have experienced. I can easily conceive this; for, whether on the old gieen sward, or the heath with which these hills are covered, there must be a high scent; and the circumstance of hounds being always able to beat horses among hills must make it appear even faster than it really is.

Colonel Wyndham's favorite sire hound is Labourer. He was bred by Mr. Powlett, and got by his Limner out of his Pigeon. $\mathrm{He}$ is the sire of several first-rate hounds; and what is most extraordinary, not one of his puppies has ever died of the distemper. A hound called Lashwood, got by him, appeared quite perfect, and the Colonel has bred a good deal by him. He is the sire of a very beautiful bitch (first year) called Scicnce, ont of a bitch called Tempest, now, I believe, with the Warwickshire. I asked the Colonel if he had ever bred from a hound called Blunder, which I particularly noticed the last day; when he told me he was going to do so, but did not like his colour. He is by Mr. Tom Smith's Barbarous. Nothing in nature is more beautiful than her colours; but there is an old saying, that " a good horse is never of a bad colour;" and why should not this apply to a hound? What is called the red-pie, howerer, is very unsightly in a hound, and, unfortunately, that is Blunder's colour; but, from his fine form and fox-hound-like appearance, I should be induced to cross him with such a rich-coloured bitch as Venomous (if she is open), who is also in every respect a fox-hound.

I saw a very fine sportsman with these hounds, whom I must not pass over. His name is Mr. Bigland Newnham, residing at Chichester, and who hunted this country many years in old Luke's time. His opinion is considered to be quite orthodox.

On quitting Sussex I passed through Petworth, with the hopes of seeing Colonel Henry Wyndham's hounds; but they had been out on the day I arrived in the neighbourhood; and understanding that their next fixture was in a very woodland country, and at a distance, 
I deferred this pleasure to another opportunity. I was informed by a very good sportsman, at whose house I took up my quarters, that they are more powerful than his elder brother's, and more calculated for a rough country. I hear Colonel Henry is a very bruising rider, and being a light weight, and well mounted, is difficult to follow, and hard to beat. His house and kennel are at Slade-land, in the parish of Carford, about four miles from Petworth.

In the intermediate days with Colonel Wyndham, I attended the Brookside Harriers, under the management of Mr. Harrison Carr. There was a constant attendant on these hounds in the person of a Reverend Doctor of Divinity, whose venerable presence adds much to the respectability of their field. The Doctor is not one of those gloomy sectaries who think that man is only sent into this world to mortify himself into condition for the next. His reading has informed him, that "Christianity forbids no reasonable indulgencesno innocent relaxations." - (Bishop Porteus.) If life be the gift of Heaven, it must be religion to enjoy it; and, as has been so beautifully told us, " the mind goes a great way towards praise and thanksgiving when filled with gladness; for such a disposition consecrates every field and wood, and turns a morning ride into a morning sacrifice." Milton makes even the devil pleased with the beauties of nature!

By common analogy, the decline of life is associated with the dreary scenes of winter. No wonder then that nothing should be more delightful than a green old age; and I confess I was not a little pleased with the appearance of Dr. Hooker. Cicero says of Catiline, that he lived with the old gravely, and with the young pleasantly; and this would apply to the Doctor. There is a natural gaiety about him which is rare, but most agreeable, at his period of life, and still more so when fighting against infirmity and pain. Though only a water-drinker, he is a martyr to the gout; but, when lifted on his horse, he can ride him well, and even the young ones cannot beat him over the Brighton Hills.

In conversation with Dr. H., to whom I was introduced, I observed, that he reminded me of the late (Honorable) Sam Ongley, whom I had seen riding so hard with the Oakley hounds, though severely afflicted with the gout; when the Doctor told me, 
he was a very intimate friend of his, and that he had educated his nephews-pointing to Lord Ongley and his brother then in the field.

"Quem Jupiter odit, pædagogum facit," is a very ancient proverb, but here is an exception to the rule. Neither gods nor men could pass such a sentence on the Doctor, for I was assured by a friend there was not a blot in his escutcheon. It appears, however, that he takes a few young men of fashion under his roof, whom, if they will not be made scholars, lie is certain to make gentlemen. It amused me much to hear, that, when applied to by parents to receive their sons, he always reminds them that he is a sportsman; and why should he not be? Agesilaus being asked what was most proper for boys to learn, answered, "what they ought to do when they became men." Now, as nine ont of ten of that class of young men the Doctor is likely to have the handling of are almost sure to be sportsmen, a lesson now and then from the Doctor on so classical a subject as hunting would no doubt be of service to them. A gentleman should know something of everything; and we must all remember the rebuke the young Roman nobleman received from the Oracle of his country for being ignorant of one of its commonest laws. The nobleman, says Cicero, set to work in earnest, and became a better lawyer than the Oracle.

A hunting parson, and a parson who hunts, should not be confounded together; they are as different as Paley's drunkard and the man who may sometimes be drunk. The following is a good anecdote on this subject. The circumstance that gave rise to it occurred to a brother of my own, also of the sacerdotal order, and who can ride well to hounds. Trotting over one day to call on a brother clergyman, mounted on a clever grey horse, and rather good about the boots and breeches, he saw his friend walking at some distance in his grounds, accompanied by another person. On cantering up to him, he found it was his diocesan. After looking him over for a minute or two, the Bishop observed_- "__ you put me in mind of a brother prelate of mine, who met one of his clergy in the road, not very canonically dressed (I don't allude to you, added his Lordship), but mounted on a very fine black horse; on which he patted him on the neck, and said, "You are a noble animal, and I wish your master was as clerically dressed as you are." His Lordship 
continued the joke by a second assurance that he did not allude to my brother, and asked him to return with him to his palace to dinner. He thanked him, but told him he was afraid even to dine with a Bishop on a Saturday.

Bishops, however, are men. A few years since I passed two days in the same house with one of them, and, owing to a sporting man or two besides myself being of the party, we talked so much about hunting, that his Lordship was heard to declare, that he really believed, if he had remained a little longer at —-, he should have become a fox-hunter, though he had never worn a pair of boots in his life.

The best anecdote of a Bishop and hunting is yet to come. It is well known, that (though before I was born) a certain highbred dignitary of the Church kept a pack of fox-hounds, and was one of the best sportsmen of his day. When, however, the mitre adorned his brow, the hounds were transferred to his noble brother, who continued them in great style, but the Bishop did not attend them. Taking a ride, however, one day in a country in which he thought it not unlikely he might see something of them, he met the fox. The hounds were at fault; when, putting his finger under his wig, his Lordship gave one of his beautiful view-halloos. "Hark, halloo!" said one of the field. The huntsman listened, and the halloo was repeated. "That will do," said he, knowing his old master's voice; "that's Gospel, by G-dl!"

I seem to forget that I am writing a history of a hunting country. There was a Doctor of another description in Sussex-a saviour of bodies, and not of souls-who took my fancy much as a sportsman of the Old School. His name is Hodson, and he resides at Lewes. Though a disciple of Esculapius, he is much more partial to the rural gods, and is a pretty constant attendant on the East.Sussex hounds, generally contriving that his patients shall be convalescent on hunting days. He has got two useful nags, if they vere in condition; but despite of this, they are doomed to carry himself- - no feather weight-pretty often, and a friend now and then into the bargain. He had them both out one day, and I could not help smiling at the pad-boy on the second horse-a good welter weight of about fifteen stone! 



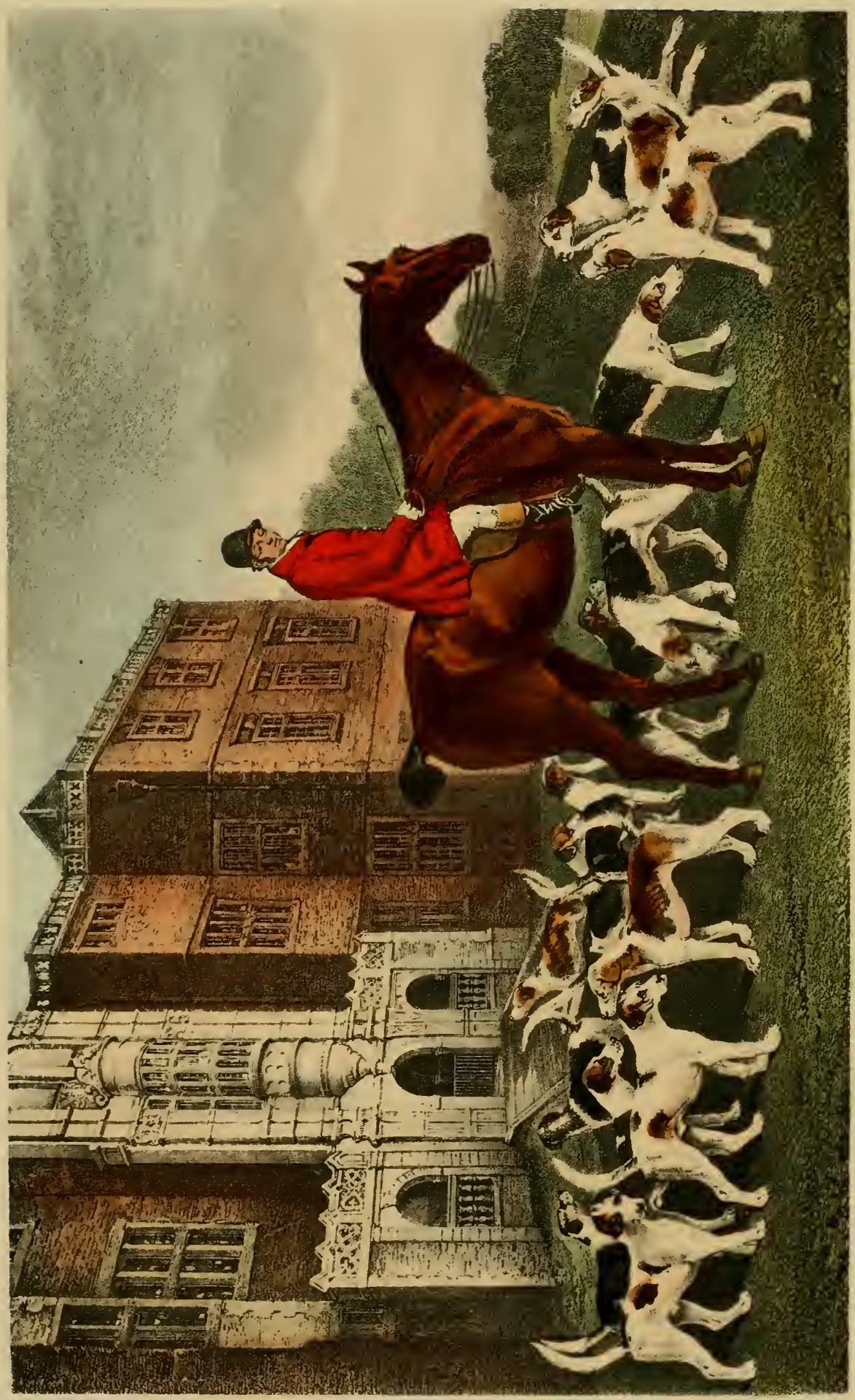




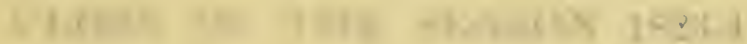

01

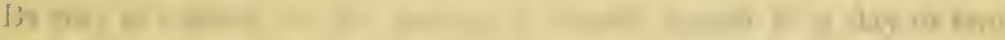
wish by

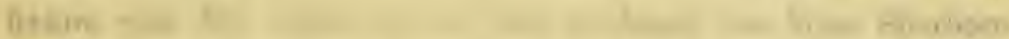

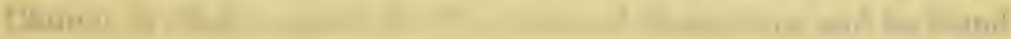

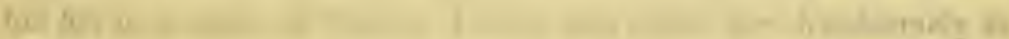
Tandly -

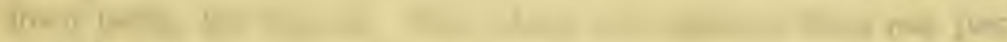

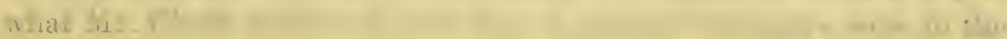

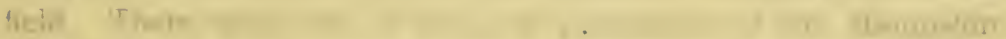
Wunk- L

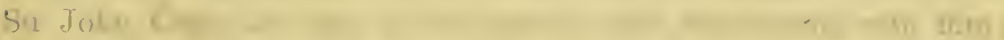

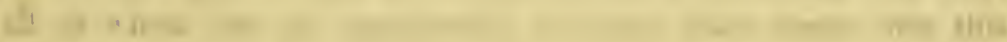
hamerat.

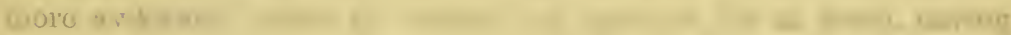

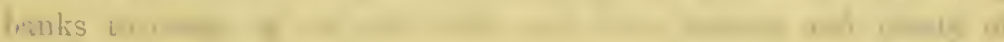
them

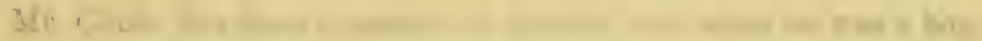

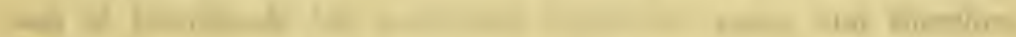

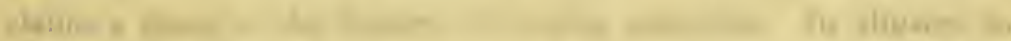

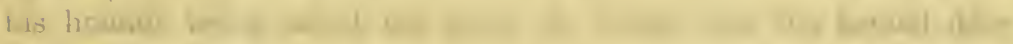

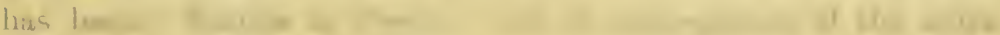

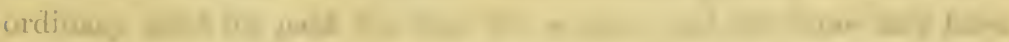

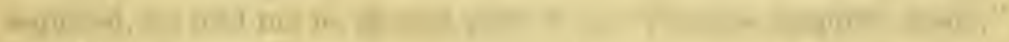

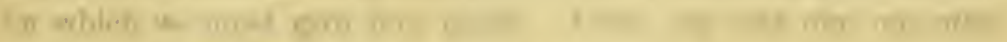
any, but si bet

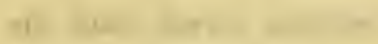

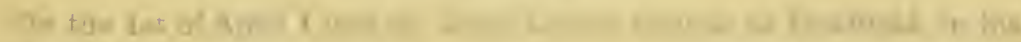

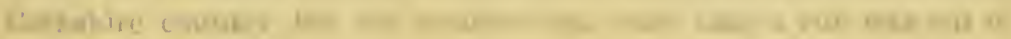

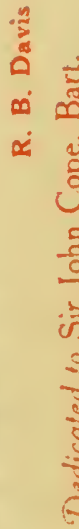

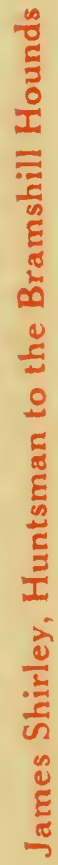




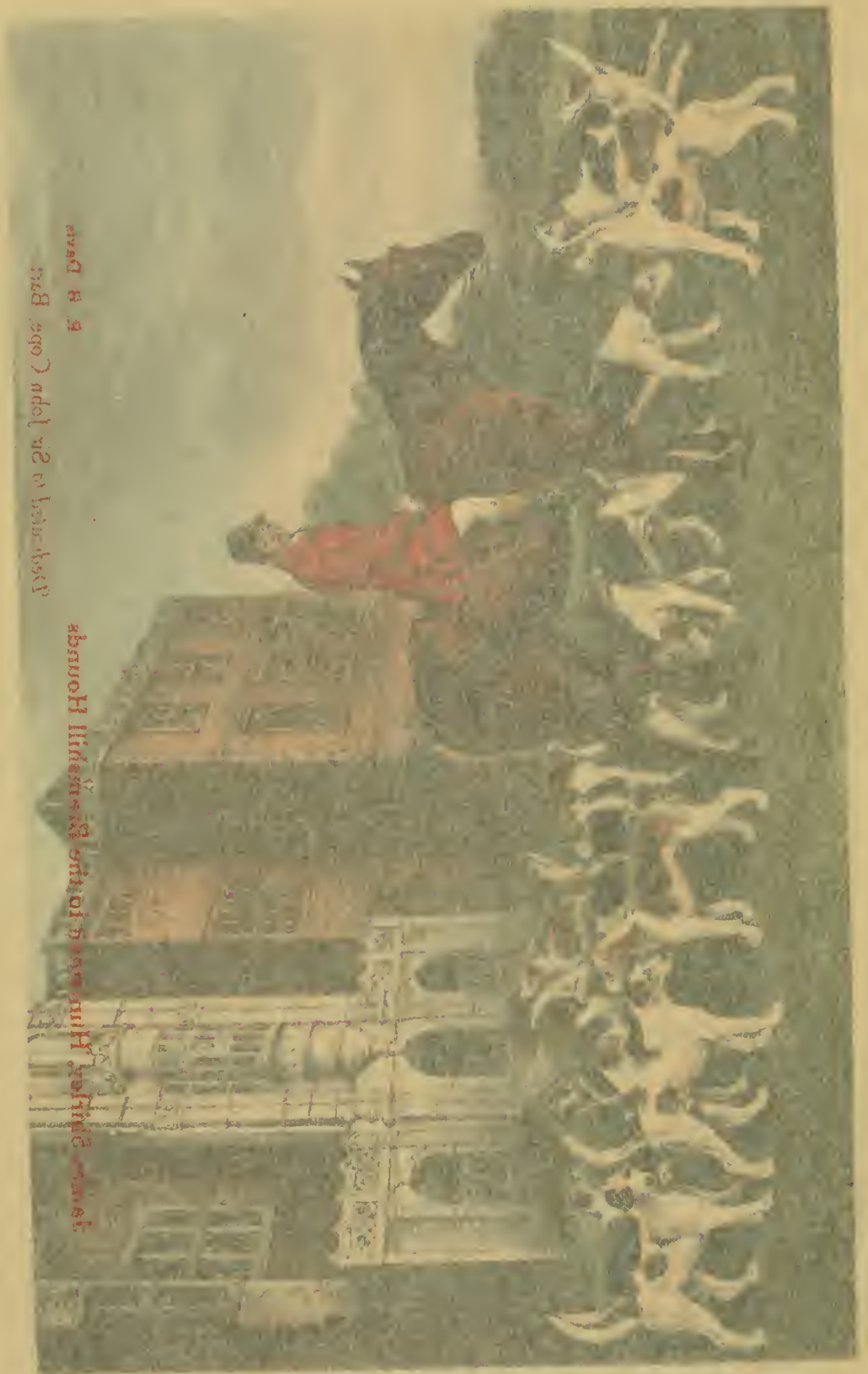




\section{CLOSE OF 'THE SEASON 1823-4}

MR. CHUTE'S-SIR JOHN COPE'S-AND MIR. WARD'S HOUNDS.

Br way of a finish to the season, I treated myself to a day or two with Mr. Chute's, Sir John Cope's, and Mr. Ward's hounds. The fixture with Mr. Chute, on the 31st of March, was West Sherborn Church, in what is called the Woodlands of Hampshire, and he found his fox in a corner of Pamber Forest, and killed him handsomely at Lord Bolton's-eight miles as the crow flies-so beaten that he laid down before the hounds. This sharp and decisive thing was just what Mr. Chute wished on this day, as several strangers were in the field. There were two of the best performers of the Hampshire Hunt-Mr. Gage, brother to Lord G., and Mr. Knight-as well as Sir John Cope, and one of his bruisers (Mr. Simmonds) with him; all of whom had an opportunity of trying their nerve over this strongly enclosed country. Mr. Gage told me he never rode over more awkward fences for horses not quite au fait at them, having banks to creep up on, with wide and deep ditches, and plenty of them.

Mr. Chute has been a master of hounds ever since he was a boy, and of for-hounds for more than thirty-two years, and therefore claims a place in the history of hunting countries. In allusion to his hounds being small, but good, the motto over his kennel door has been "Multum in Purvo;" but in consequence of the extraordinary sport his pack has had this season, and the fame they have acquired, he told me he should alter it to "Viresque acquirit eundo," for which we must give him credit. I was out with him one other day, but we had not scent enough to hunt.

SIR JOHN COPE'S HOUNDS.

Or the 1st of April I met Sir John Cope's hounds at Bradfield, in his Berkshire country, but the weather was such that a run was out of 
the question. We found a fox in a fine piece of gorse; but before he could get out of it he died. There had been a fall of snow a short time before, which had pressed down the gorse on the meuses, so that he was as it were stopped in-there being nothing else to prevent him going away if he could have once got to the outside of it. This cause was evident by the long time the hounds were in coming to the horn after the fox had been chopped. We soon found again, but all to no purpose, as we had not an atom of scent to serve us over that ploughed country.

I knew Sir John when he had a house for several seasons at Bicester, hunting with Sir Thomas Mostyn, when he rode very hard. Some time since, he had the misfortune to break his thigh as he was riding about his own grounds, and was attacked by typhus fever afterwards, which he says has done his nerve no good. His hounds are much admired for shape and make, very quick, and said to be particularly powerful in covert, where no fox can stand them long. He divides his kennel, and it was the dog pack on the day I was out with him. An old friend of mine, a very good judge, who has been hunting with them this season, told me their kennel management must be superior: "for," said he, "they always look well, and no hounds in England work so hard, or travel further, and often through a dirty country, for Sir John will have a day's sport if possible." My friend added, that one day this season, after a capital run, and the hounds twenty miles from home, Sir John went and found another fox, and killed him, after a run of one hour and three quarters, when the hounds had nearly as far to go home. He declared he should have been ashamed to have asked any man to have drawn for a second fox after the run they had had with the first. This, however, not only shews power, but condition.

A curious circumstance occurred with these hounds this spring. A vixen fox was tally-ho'd away, with a cub in her mouth, which she carried for a considerable distance, and saved.-Another of the evils of spring hunting also occurred about the same time. A dog fox was run to ground and dug for. In doing this, a vixen with seven cubs was stopped in, and all perished together. Let this be a caution to all masters of hounds how they break ground for a fox! I know not which I detest most-to see a yelping cur in the shape of a 


\section{MR. W'ARD'S HOUNDS}

terrier, in the midst of a fine pack of fox-hounds; or a hunted fox dug to, unless it be in a common drain or a rabbit spout, for which purpose there is always a cur dog at hand.

\section{MR. WARD'S HOUNDS.}

Os the day after I was out with Sir John, I met Mr. Ward's hounds within a mile of Newbury. It is just twenty years last December since I hunted with him, when, if I had not made a memorandum of the sport, it was well impressed on my memory, as it cost me a pretty good hunter. It stands thus in my book :-

"Friday, December 30, 1803, met Mr. Ward at Winnick Warren (Northamptonshire). Ran a fox to ground, bolted him, and killed him. Found again, five minutes before twelve, near the same place, and killed him when attempting to reach the earths at Thorncomb in Leicestershire, after a run of one hour and three-quarters, with only two trifling checks, and which was declared by Mr. Ward and Lord Spencer to be the quickest run fur the time ever seen in Northamptonshire. A large field was out, and among the few who saw him killed were, Lords Spencer and Althorp, Mr. Elwes, Mr. Buller, Rev. Mr. Barnard, \&c. Mr. Ward came up about twenty minutes after we had killed the fox. Bob Forfeit, the huntsman, got a bad fall at a brook. Horses-Caravan and Snuff-box."

In May, 1805, the following note appears at the bottom of this memorandum :-

"Snuff-box never recovered this day. A humour settled in his thigh, and after a great discharge, thought it was well. Turned out for the summer, but worse than ever when he came into work again. Sent him up to Mr. Field, who fired him, but all to no purpose, and sold him at Tattersall's for $26 l . "$

On the day I have previously alluded to (the $2 d$ inst), I was disappointed in not seeing $M r$. Ward in the field. It was a very inclement morning, and no doubt he was prevented by weather. His hounds, however, were a matter of considerable interest to me, as a pack bred by one of the oldest and most celebrated sportsmen of the last century-a sportsman of the Old School, but who has had the opportunity of judging of all the advantages and disadvantages of the New-one, whose judgment has been acknowledged 
in, and whose breed of hounds has mingled with, all the best kennels in England-who, as a convivial companion, or a real specimen of old English blood, has seldom been equalled, and never excelled-whose name in the sporting world will live, till "time shall throw a dart at death."

From what I had heard of Mr. Ward's hounds, I was prepared to find them larger than they are. I had heard them compared to mastiffs fit to guard a tanner's yard; to calves two months old; to poneys fit to carry children over a country; but I found them, with few exceptions, little larger than many packs I have hunted with; and, if fed to run, they would appear but little above the Duke of Beaufort's standard. Such hounds as Solomon, Somerset, General, and two or three others, are certainly rarely to be met with, and from their uncommon height-at least twenty-seven inches-are eye-sores to the rest of the pack with those who insist on seeing hounds sizeable; but the generality of the bitches are above all praise-combining great power with the symmetry and high breeding of a fox-hound. For my own part, I am partial to full-sized fox-hounds; and for nineteen countries out of twenty they are the best. A little hound will go well in some countries : a large hound, if fed to go, will go well in all.

On conversing with a gentleman who was out, on the appearance of Mr. Ward's hounds, he told me there was one called Sovereign, for which Mr. IV. has often declared he would not take 150 guineas: he was a light-coloured hound, with a spot on his side. Observing, very soon afterwards, a yellow-pied hound answering this description, very near to the huntsman, in the covert, I asked him whether it were not Sovereign? when he told me it was; and the words had scarcely dropped from his lips, when putting his nose to the ground on a bare pad-way, and throwing his tongue to a scent, Sovereign ran up to his fox, and found him in less than a minute, and never quitted him till he was killed, at the end of two hours' cold hunting. Well may Mr. Ward be proud of such a hound as Sovereign! I understand he is got by his famous Centinel, with some of his old Statesman blood in him, with a cross from Sir Thomas Mostyn's Lady. Mr. Harvey Combe, and his huntsman Henry Oldaker, were out, and were much pleased with 



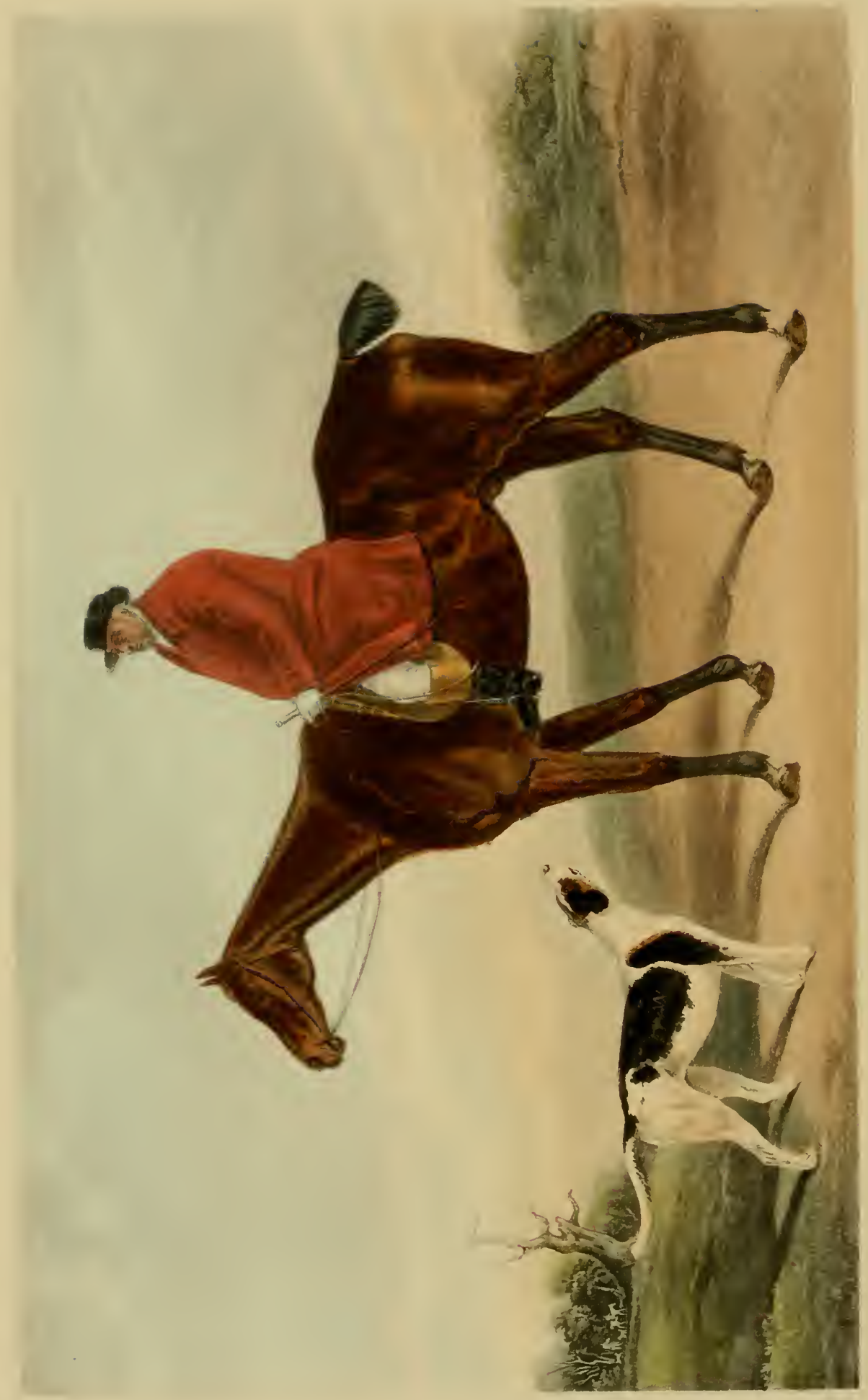




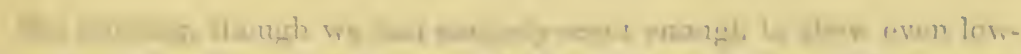

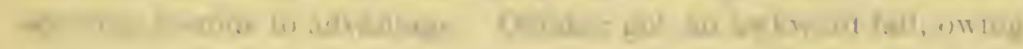
L on of of the / /

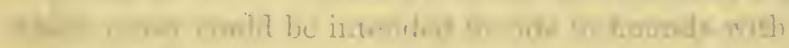

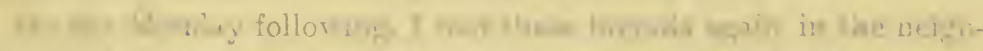

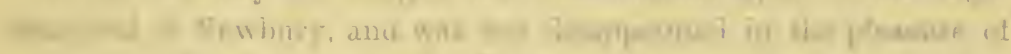

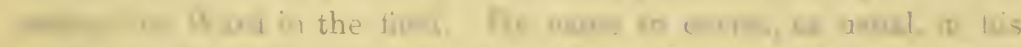

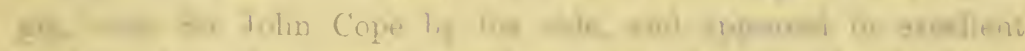
I

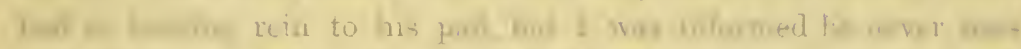

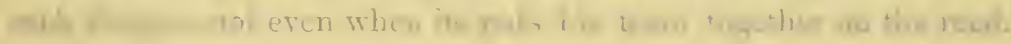

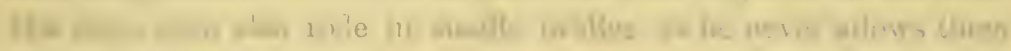
$14+2=0$ low

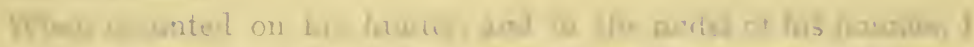

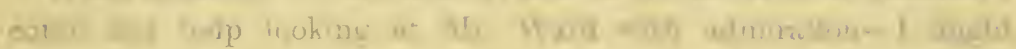

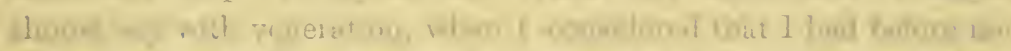

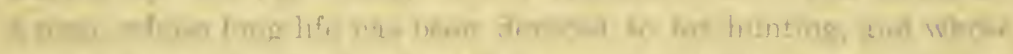

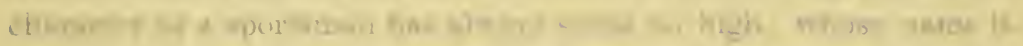

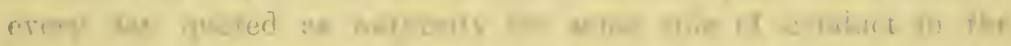

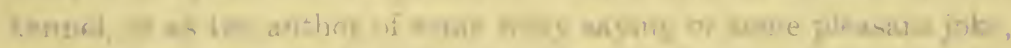

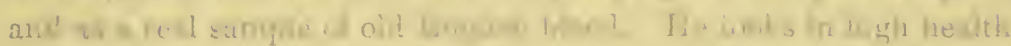

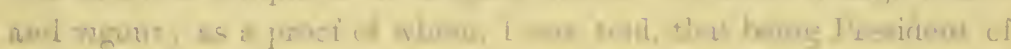

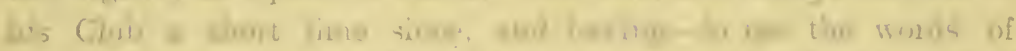

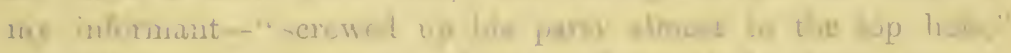

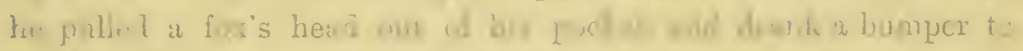
Fos-binting.

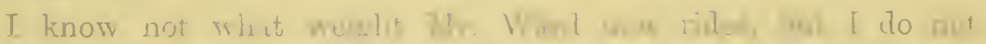

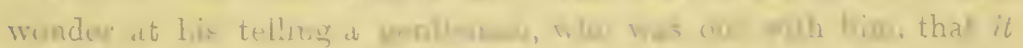

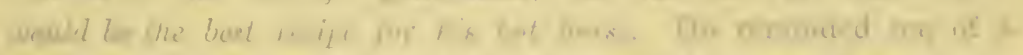

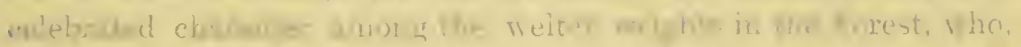

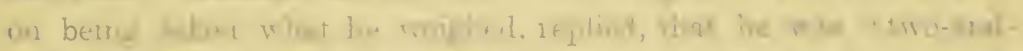

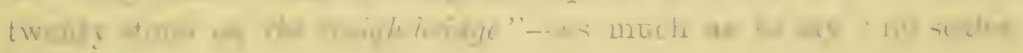
will bist nes"

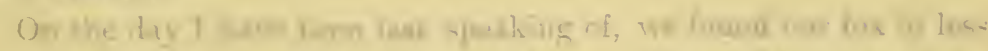

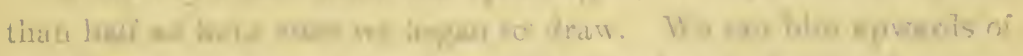

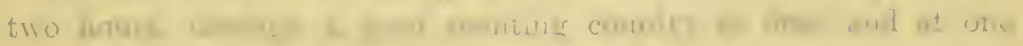

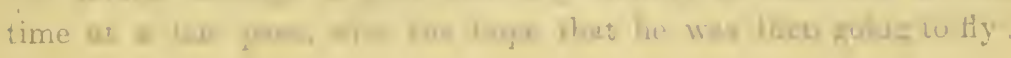


:

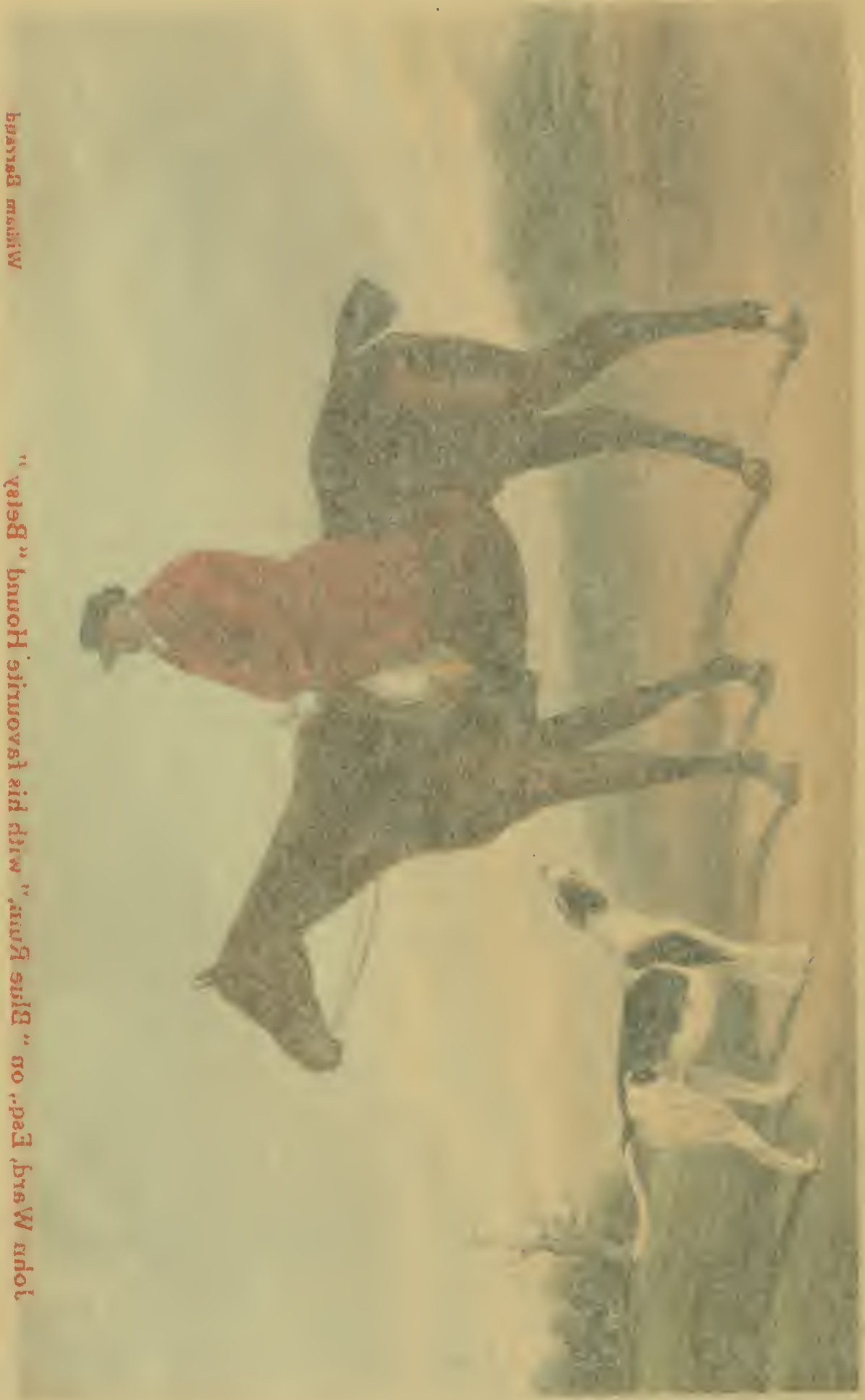




\section{MR. WARD'S HOUNDS}

the hunting, though we had scarcely scent enough to shew even lowscenting hounds to advantage. Oldaker got an awkward fall, owing to riding in one of those felo-de-se instruments, a gag-rein bridle, which never could be intended to ride to hounds with.

On the Monday following, I met these hounds again in the neighbourhood of Newbury, and was not disappointed in the pleasure of seeing Mr. Ward in the field. He came to covert, as usual, in his gig, with Sir John Cope by his side, and appeared in excellent health. As a dragsman, I could not help observing that his horse had no bearing rein to his pad, but I was informed he never uses such things - not even when he puts his team together on the road. His three men also rode in snaffle bridles, as he never allows them to use any other.

When mounted on lis hunter, and in the midst of his hounds, I could not help looking at $\mathrm{Mr}$. Ward with admiration-I might almost say with veneration, when I considered that I had before me a man, whose long life has been devoted to fox-hunting, and whose character as a sportsman has always stood so high; whose name is every day quoted as authority for some rule of conduct in the kennel, or as the author of some witty saying or some pleasant joke, and as a real sample of old English blood. He looks in high health and vigour; as a proof of which, I was told, that being President of his Club a short time since, and having-to use the words of my informant-" screwed up his party almost to the top hole," he pulled a fox's head out of his pocket, and drank a bumper to Fox-hunting.

I know not what weight Mr. Ward now rides, but I do not wonder at his telling a gentleman, who was out with him, that it would be the best recipe for his hot horse. He reminded me of a celebrated character among the welter weights in the Forest, who, on being asked what he weighed, replied, that he was "two-andtwenty stone on the weigh-bridge" - as much as to say " no scales ivill hold me."

On the day I have been last speaking of, we found our fox in less than half an hour after we began to draw. We ran him upwards of two hours, through a good scenting country at first; and at one time at a fair pace, with the hope that he was then going to fly; 
but being a good fox, and not scent enough to press him, he put his face towards home again, and we lost him not more than two miles from the place where we found.

I have before ventured to remark, that it seldom happens that hounds are equally good in covert, and out-that "scoring to cry," as we call it, and which is so useful in the one case, being apt to make them wild in the other. Mr. Ward's hounds, from their steadiness, might be compared to highly-broke pointers; and for this reason, perhaps, might appear slacker in covert than some I have lately hunted with. When out of covert, however, every nose is to the ground, and those who are admirers of cold hunting will here see it to perfection. William Knivert has hunted these hounds for many seasons, but of course I am unable to say much about him. I saw him more than once make his casts in the face of a strong wind, but no doubt he had his reasons for doing so, which I was not arvare of.

On neither of the days I was out with Mr. Ward had we a scent sufficient to enable me to see what pace his hounds can go; but were they fed lighter, "* no doubt they would be fast enough for the horses that follow them. When, however, we consider Mr. Ward's great weight, we cannot wonder at his, in some measure, regulating his pace accordingly-bearing in mind also, that in great part of his country nose is as much wanting as pace. His servants' horses are useful-looking animals, but perhaps it would be dangerous to go too far into their pedigrees. To all admirers of good hunting, and of the fine form of a fox-hound, Mr. Ward's hounds will always afford a treat; and if the eating of the pudding be any proof of its goodness, or the blood of foxes beneficial to fox-hounds, these ought to be

* On looking at Mr. Ward's pack, any one who is a judge will perceive, that, from the style of hound, they shew flesh more than lighter ones would do, but yet it is evident that they are fed higher than is necessary for their country. The Duke of Grafton's hounds are fed full as high, bat they have a different country to deal with. I heard a good anecdote on feeding hounds, which was told of an old gentleman who kept a pack of harriers not an hundred miles from Nowbury. Just before he went out one morning, he asked his huntsman if the hounds had been fed? "Fed, Sir!" said the huntsman: "you would not feed them now, would you?"-_"Oh, yes," said the owner: "give then some breakfast, John! How would you like to go a hunting all day without your breakfast?" The old gentleman was, no doubt, fond of hunting. 


\section{MIR. WARD'S HOUNDS}

good, as, by the huntsman's account, they have tasted forty-seven brace this season! Their kennel is at Hungerford, where Mr. Ward resides in the hunting season, and which is in the centre of the Craven Hunt.

In a subsequent letter, Nimrod says-When I last saw Mr. Ward's hounds the elements were in arms against them. Determined, however, to see them under more favorable auspices, I fixed on November as most likely to afford them, and arrived at Hungerford on the 20th of the month. He then proceeds :-

The Craven country has been hunted by $\mathrm{Mr}$. Ward for eleven seasons, with a subscripton of about $1000 \mathrm{l}$. per annum to his hounds. This sum must leave a large balance to be paid by himself, as he always hunts four, and sometimes five days a week, and has from seventeen to twenty horses for himself and his men.

Mr. Ward may very justly be called the father of fox-hunting, having been a master of fox-hounds fifty-four years-namely, twentytwo in Oxfordshire and Warwickshire, thirteen in Northamptonshire, six in the New Forest, and eleven in Berkshire.

It has generally been supposed that when Mr. Ward was in Oxfordshire, his hounds were at the highest pitch of perfection; and by some it has been asserted that when he gave up that country he gave up a throne. In Northamptonshire, however, his hounds had a fine opportunity of distinguishing themselves, and afforded some capital sport. One run, in particular, will never be forgotten in that country. They found their fox at Marston Wood, and killed him at Skeffington in Leicestershire-a point-blank distance of eighteen miles, but at least doubled by the acute angles the fox made in his course. That fine sportsman, General Harry Warde, was one who saw it, and has marked it accurately on the map: but Mr. Ward was (fortunately for his horse) absent at a sale of hounds.

When Mr. Ward was in Oxfordshire, his pack afforded one very remarkable day's sport. They found their fox at Ardley Thorns near Bicester, and killed him beyond Chipping Norton, after having gone through no less than thirty-two parishes in the run. The hounds and horses remained at Chapel House for the night, where rather a ludicrous occurrence took place: Mr. Ward gave orders 
that a messenger should be despatched to Chipping Norton for some bread for the hounds; but just as he was on the point of setting off, Bob Forfeit came to inform him there was no need of bread, as one of the Oxford gentlemen's horses was dead, and another would die before he was got cold.

It is not to be supposed that in the space of half a century, favored even as he has been, that Mr. Ward's hunting establishment has been free from evils incident to all human institutions; and in his kennel and in his stable he has more than once risen like a phonix from its ashes. Twice he has been visited by madness; and in one year he lost forty-five couples of hounds by that dreadful malady, and thirteen horses by the glanders. He was once reduced to one hound bitch, called Festive, which was got by Jason, a brother to the New Forest Justice. Once also he sold his pack to Lord Althorp for 1000 guineas, reserving two couples of bitches to himself. Those, however, who can remember Mr. Ward's hounds twenty years ago can plainly perceive that it has not been in the power of money, madness, or even grim Death himself, to annihilate his favorite sort; for his present kennel of hounds, with very few exceptions, are exactly in his own mould.

Mr. Ward's hounds are now hunted by William Neverd, who has been in his service about seventeen years. He lived several years with Colonel Cook, who once hunted part of the Staffordshire country, and who also had the Hambledon hounds for three seasons. He is assisted by two whippers-in, one of whom, Will Hedden, has been with Mr. Ward eleven years. From some cause or other, his voice sounds as if it were cracked, and falls on the ear in several distinct tones. His rate to hounds, however, is a very good one, and he knows what he is about.

Previous to his whipping-in to $\mathrm{Mr}$. Ward, Hedden lived under Filer, who hunted the Craven hounds when under the management of Mr. Dundas, the Member for Berkshire; and who ended his days in the service of the Marchioness of Salisbury. He has been heard to say that he never liked fox-hunting; but having been bred up with hounds, he should not leave them. Thus is the proverb verified, "Train up a child in the way he should go, and when he is old he will not depart from it." 


\section{MR. WARD'S HOUNDS}

Monday, the 21st of November (1824) was the first day of my seeing Mr. Ward's hounds this season. We met at Wooday, the seat of Mr. Sloper, about six miles from Hungerford, and drew some fine gorse coverts in the neighbourhood, which ought to have held foxes; but the night had been tempestuous, and they were not at home. We found late in the day, but without a particle of scent, and the weather drove the hounds home. I considered this part of the country capable of shewing a run.

On the 23rd we met at Hunt's Green, to the left of the road from Hungerford to Newbury. We hunted a fox four hours, but had not a scent to get up to him. A celebrated sportsman of old standing in the Craven country pronounced this to be one of the finest day's sport he had ever seen; but in this I could not agree with him. It is true we had a deal of fine hunting, and great display of nose; but fine hunting alone does not constitute a fine day's sport. Trotting after a fox for four hours, and not killing him afterwards, cannot be satisfactory, even to the master of the hounds, and it will never satisfy his field.

On the 25th we drew Penwood, and found immediately. This I pronounce to have been a good day's sport, though we did not kill our fox. We ran him for at least four hours with never more than half scent, and he only saved his life at last by a trick. This was a hard day's work for hounds and horses, as the country (some part of it very favorable to hounds) was severe, and the pace at times good.

On the 26th, we met at. Stype-the crack covert in the Hunt. We dragged up to our fox, and had a beautiful find. He left the coverts gallantly, and we should have had a run, but, as Mr. Ward justly remarked, he never saw so scentless a day.

On the 29th we met at Woolley Park, the fine seat of Mrs. Wroughton, the best preserver of foxes in the country-a most tempestuous day, and nothing could have been done but by a miracle.

December 1st, place of "meeting five miles on the Marlborough road. Found and ran sharply through the Forest, where the scent was good; but when he faced the enclosures, he bade us "good bye."

I never hunted in the New Forest; but have an abhorrence of all 
others. There is no enjoyment of hounds-the chief object being to prevent being knocked on the head. One gentleman (Mr. Gifford) had a narrow escape for his life in this short burst. His horse ran under a tree with him, and literally tore his coat off his back.

December 2nd, met at Ramsbury, three miles from Hungerford. The weather we had defies the pen. Having had a hard fall the day before, I had taken some medicine, and could not stand it, so went home; but Mr. Ward was out in it all, and I should think he might have watered his horse out of his boots when he got home. Had I been the master of the hounds, they should not have hunted this day, but waited for the next, which was a capital scenting day, and afforded some good runs. Mr. Chute's hounds had a brilliant thing that morning of fifty minutes, and killed. Mr. Ward's hounds changed foxes three times, and consequently had no sport; but it was said to be a very severe day for hounds and horses, the country being knee deep.

December 4th, snow on the ground. A good fox and a good scent: and had it not been for his being headed when crossing the canal, we should have had a tickler. The hounds well deserved their fox this day; and he only lived by reaching the worst scenting covert in the country, stained with another scent.

Here then is a fortnight's hunting with, I was going to say, the best pack of hounds in England. "How is all this to be accounted for?" says one. My answer is, that it was the worst fortnight for scent in the memory of the oldest sportsman present, and the Craven country of all others requires a good one. It is a cold hollow country, almost all ploughed, distressing to horses, and cheerless to hounds.

The Craven country, however, is not without its charms. It is generally full of foxes; and, to use the language of the huntsman, it is one of the most "friendly countries" in England. I was certainly surprised to see the fine fields of turnips ridden over and over again as they were without one murmur being heard; and as to wheat, the farmers themselves lead the way. It is, moreover, said to be the best six-o'clock-country of them all. Its extent is stated to be about thirty miles by thirty; if so, there is plenty of it. It is bounded on one side by Mr. Chute, on one by Sir John Cope, on one 
by Mr. Codrington, and on the other by the Old Berkeley. The forest of Marlborough is too small for cub-hunting ; but the Collainborn woods, the property of the Marquis of Ailesbury, are everything that can be wished for. They consist of two thousand acres of solid covert, holding a capital scent, and with rides of two miles in length in every direction. Lord Bruce, the eldest son of the Marquis-now at Oxford-enters well to the sport; and it is whispered that one day or other we may see him at the head of fox-hounds.

Independent of scent, I take the Craven country to be a very difficult one for hounds to kill a strong fox. In the first place, it is a chain of coverts-very full of earths, so that foxes are continually behind them. That constant change of scent also from covert to the open is baffling to hounds, and no one knows the evils of ploughed countries but those who are doomed to hunt them.

$A s$ is always the case-for "vain his attempt who strives to please ye all "--there are various opinions expressed by various persons on the merits and character of Mr. Ward's hounds. Some assert that they are too big for the country; some say they are too fond of a scent; some that they don't run up to their dying fox as they should do; some say they are fed too high; whilst others assert that they are the best hounds in England. IVe will now examine a little into these several opinions.

With respect to the first, I have reason to believe that Mr. WVard himself considers that a smaller hound would be better suited to the Craven country. We must here, however, recollect whose hounds they are. They are the hounds of Mr. Ward, who has always been conspicuous for a large sort of hound, and, though perfection is within no man's reach, a sort unvivalled by any! It is hardly to be expected then that, in the wane of his sporting career, he should alter the style of hound which he has so long been breeding, and which he has bred so well.

As to hounds being too fond of a scent, this is a charge of rather a posing nature. The first question that might be asked would be, "Can hounds rum without a scent?" My answer is, Mr. Ward's will not certainly go a yard without it. Give them a country that will hold a scent, and I will answer for their taking it with them, and at a pace quite sufficient for horses and their riders. I believe 
no one who knows anything of hunting will dispute the fact, that the difference of speed, and eren of goodness, between one pack of hounds and another, is light in the scale when opposed to the more weighty difference of a good scenting country and a bad one.

With respect to their not running up to their dying fox, I cannot say I witnessed a greater degree of sinking than $I$ have seen in all other hounds, when draggled through a country in such weather as we have lately had, for several hours after their game, withont a scent to enable them to get up to it. We all know that to kill a good fox, hounds must chase as well as hunt; but without scent there can be no chase.

In my experience with hounds, I have heard a greater difference of opinion on feeding than any other point. Some say hounds should be above their work; others feed them to be under their work: but I should imagine the happy medium consists in their being up to their work, and no more. When I saw Mr. IVard's hounds at the end of last hunting season, I certainly thought them higher than they should be at that time of the year, but this is not the case now. On the morning we met at Penwood, I thought I never saw so fine a pack of hounds by a covert's side in my life, or, with one or two exceptions, more fit to go over a strong country, and if the scent had been a little better, I think most of the field would have been quite satisfied with the pace. Their hunting their fox, with the head they carried, over such great variety of country on this day, was the admiration of every one who saw them.

With respect to feeding, it must not be forgotten that Mr. WVard's are very square-built hounds, with more than ordinary muscle in their backs and bodies, which makes them appear fed higher than they really are.

I have been generally accustomed to full-sized fox-hounds, and therefore see nothing very extraordinary in the height of Mr. Ward's hounds. As far as my eye could direct me, it does not exceed twenty-three for dog, and twenty-one for bitch-hounds; and, taking the kennel throughout, they are very even in size. Draft Solyman (bred by Mr. Smith out of a bitch of Mr. Ward's), Slyboots, Mimic, and one or two other dog-hounds, and Cherry, Plaything, Bantling, 


\section{MR. WARD'S HOUNDS}

Baby, Placid, and Stella,* among the bitches, and they would be more perfect to the eye; but who would draft such hounds as some of these are for such a gratification?

In answer to those who say that Mr. Ward's are the best hounds in England, I have only to remark, that when we recollect by whom they have been bred, they liave a right to be so; and but for the fatal accidents which befel them, and the no less fatal change of country, I have no doubt but they would long ere this have been entitled to that honorable appellation; but England is a wide space, and "the best in England" a boastful and indefinite term. This, however, I will pronounce of them-that if brought to Messrs. Tattersall's hammer to-morrou', they would feteh more money than ever hounds sold for yet.

I have no hesitation in saying, that Sorereign is, without exception, for nose and chase, the best and surest hound $J$ ever saw in a field. From first to last he is always in the front; and if hounds were to bring a scent out of covert twenty times a day, I would bet an even wager that he would be one of the first five couples. $\mathrm{He}$ has also another striking good quality. If he comes out of covert with other hounds, feeling for the scent, and does not find it, he gets back again directly to the line, and by his peculiar tongue (a short chop) brings the rest back to him. He is a grandson of Mr. Ward's celebrated Selim, and is the sire of his Abraham, a young hound of great promise.

A great many hounds in $\mathrm{Mr}$. Ward's kennel are singularly and rather unfortunately marked, being what is called " half-faced : " but when we are told that this comes from his celebrated Statesman, no more can be said. Nearly thirty couples of these hounds are also stained with the blood of the New Forest Justice. Guardian is by Aimwell out of Mr. Smith's Brilliant-Aimwell by a Son of Justice. There are three Brothers by Guardian of this year's entry-viz. Downright, Dragon, and Dryden-not to be excelled. A bitch called Festive, almost the only open bitch remaining of the last pack, Mr. Ward lost by madness, was also got by Jason, a Brother to

* Stella is a particularly handsome bitch, and, if my memory serres me, of the Bertram blood. 


\section{NIMROD'S HUN'TING 'TOUR}

Justice, and from whom he may be said almost to have laid the foundation of his present pack.

I was in the kennel one morning, when a couple of puppies not eight months old were brought in. They were walked by a gentleman of the name of Ashe, residing near Chippenham, and he had done ample justice to them: but he was obliged to send them in, as they took to ramble-the bitch having once found her way to Bath. I never saw two such fine puppies in my life! They are got by Mr. Ward's Rustic (who was by the Duke of Beaufort's Ragland) out of his Comfort.

Huntsmen, as far as their calling goes, are public men, and of course their talent in that calling is often canvassed; and my ears were not shut to remarks on William Neverd. On all hands it was admitted that he was a trusty and faithful servant, but by some said to be slack in shewing sport. Much, however, is to be said for a huntsman in the Craven country. The land is cold; it is stained with sheep (the worst stain of any), which are driven long distances to fold; the earths are numerous; and the fox is as often behind him as before him.

Were I to pass my judgment on William Neverd, I should say he has one fault, but that has nothing to do with slackness. In my opinion, he takes hold of his hounds too soon when at fault; and when he has taken hold of them, he does not make his first cast quick enough. The peculiar tact of Mr. Ward's hounds is hunting: undoubtedly, then, they should be suffered to feel for the chase where they have first lost it before a word is said to them. They should then be cast, and if they don't hit it, they should be brought back as quick as possible to the line, with a whipper-in behind them. There will then be time for Neverd's knowing cast, if the natural one do not succeed.

It may be presumptuous in me to dictate to Mr. Ward's huntsman ; but I think Neverd is also a little slow in holding on his hounds over sheep-stained ground. Hounds so disciplined as Mr. Ward's are of all others the hounds that will bear lifting; and eight times in ten they must have it to kill a good fox over that country.

I saw no deficiency in Neverd's getting to his hounds. On the day we met at Penwood, and ran our fox four hours, we had at one 


\section{MR. WARD'S HOUNDS}

time a very brushing and awkward country to get across, but I never saw him turn his head. He was, however, on a magnificent hunter, called Blue-ruin, for which Mr. T. Smith offered a large price; and he has three other able horses for his own riding.

Mr. Ward seldom misses a day being in the kennel, but he has a good servant here in Neverd. They very seldom lose hounds in the distemper. They find good keep the best preventive; and nothing answers better than dry barley meal, with a little oatmeal and good rich broth. Neverd has a hound called Plaintiff now in his kemel, which was seized with the distemper after he was entered, and never stood up for three weeks. He took no medicine except a little cream of tartar: but was drenched with bullock's-cheek broth, and kept very warm, till at last he was perfectly recorered.

The discipline in Mr. Ward's kennel is very good, but I saw no appearance of the whip. I witnessed one instance of it which I could scarcely have believed to have been feasible. When the hounds were on one side of the yard, Neverd went to the other, and called out Bitches! when every bitch-hound came forward, and every dog-hound stood still. This is very useful on occasions. In the field also Mr. Ward is a strict disciplinarian. He will have no scoring to cry-no flying from a scent; and those which do so are down in his black book.

Talking of books, Mr. Ward adopts one very good system. The kennel book is brought to him every night, in which the draft for the next day's hunting is entered. If any casualties or accidents occur, they are entered opposite their names after hunting, so that he always knows how to make his future drafts. The hounds entered in the book for the day's sport always appear before his window as they start for covert in the morning, and no alteration is ever made in them.

I was more than once asked what I thought of the speed of Mr. Ward's hounds? My opinion is, that the speed of the hody of fox-hounds of a certain size is much alike-the pace depending on the head the scent enables them to carry; for which reason all hounds go faster over grass countries. From want of scent, however, I had few opportunities of seeing the speed of this pack. When they ran through the forest with their heads up, the pace was 
quite enough for the horses; and I never heard that Mr. T. Smith complained of any wart of speed in those hounds he took from Mr. Ward into Lincolnshire. The lot consisted of fifteen couples of hunting hounds, two couples of puppies fit to enter, and five couples of sucking whelps.

Mr. Ward's hounds are proverbially steady in drawing, and every tongue is a fox. There are generally six or seven couples of young hounds out every day. Had the best judge in the world been out on Penwood day, he could have found no fault. We ran over great variety of ground with a very indifferent scent, and the working of the hounds to catch it was extremely beautiful. Sovereign, Minor, and Posum, particularly distinguished themselves.

One thing struck me in the Craven country, that I did not see the same faces (at least not more than a score of them) by the covert's side on each day of hunting. The field generally consisted of about sixty, but on one side of the country I saw men whom I never met on the other. One gentleman, however, never failed being at his post, and that was the Rev. Fulwar Fowle. This gentleman resides in the village of Kentbury, about four miles from Hungerford, of which place he is Rector; and proved himself so good a subject, and such a useful member of society, that in the time of our troubles, when fox-hunting, as well as every other valuable institution in the country, was in danger, he stepped manfully forth, and was invested by his Sovereign with martial as well as clerical authority-having the command of a corps of Berks yeomanry. On being reviewed by the King (George III.) when on duty at Windsor, his Majesty was pleased to observe, that Colonel Fowle was not only one of his best cavalry officers, but one of the best preachers, one of the best shots, and one of the best riders to hounds in his dominions. Who would not be proud of such a compliment from such a man!

From the following anecdote of the Rev. Colonel, we may very fairly conclude that he would not have disgraced the martial order had he met with the enemy in the gate :-He got a fall one day into a brook, by which he knocked out three of his teeth, and broke one of his legs. He was carried home and put to bed; but having a party that evening in his house, he had a glass of wine brought to him, and drank all their good healths and success to fox-lunting! 


\section{MR. WARD'S HOUNDS}

The following circumstance, also for the honour of fox-hunting, ought not to be lost to the sporting world.-A medical gentleman, by the name of Hemsted, residing near Newbury, ordered his gardener to set a trap for some vermin that infested his garden. As ill luck would have it, a fox was found in it in the morning with his leg broken. On being taken to the doctor, he exclaimed, "why did you not call me up in the night, that I might have set the leg?" He did set the leg however, and the fox is quite recovered, and Mr. Ward told me he expected him at the kennel every day for the purpose of being turned out upon some earths.

I saw a great many good horses in the Craven Hunt, and some looking pretty fit to go. Amongst them was one prodigy; and it is "fronti mulla ficles" with her. This was a little black mare, not fourteen hands high, got by a cart horse out of a thorough-bred mare, the property of Mr. John Sloper, of Woodhay, who has ridden her nine seasons. His weight on her back is about eleven stone; but no fence is too high or too wide for her, neither is any day too hard for her. She has great length of frame on a very large set of limbs ; and, in the language of the huntsman who was describing the action of his favorite old mare, she "goes like oil."

Among the horses I met with in this country I recognized an old acquaintance in Mr. Wroughton's Doctor, once the property of Sir Bellingham Graham, and ridden by his servants. This was one of the most restive horses that ever went into a field, and it is not long since that I was speaking to Christopher Atkins (who now hunts the Union hounds) of the trouble he had in making him into a hunter; but when once made he was a good one. An old woman might ride him now. Mr. Wroughton is always well mounted, and gets well to hounds; and I was sorry to hear that he lost three very valuable hunters some time since by some bad management in his stable.

There were two other friends of $\mathrm{Mr}$. Ward on a visit to him when I was at Hungerford-one of them a sportsman of very fair promise, and well known in the grass countries. His name is Lambert-a "Man of Kent." He is a particularly good horseman.

It is not my practice to introduce the ladies, but I must take 
leave to make mention of one here. A few years back, when the country was so depressed, and rents came in so slowly, Mr. Ward told his Lady he feared he must give up his hounds. "Oh, no!" said she, " don't do so, the times perhaps may mend." Going shortly afterwards to his banker's, he found the sum of a thousand pounds placed to his credit by a "Friend to fox-hunting." This friend to fox-hunting was Mrs. Ward, and the sum was paid out of her private purse. Hear this, ye married ladies, and do not forget the moral! If you wish to retain the affections of your husbands, encourage, but do not thwart his favorite pursuits. Your beauty may fade in his eye; your charms may pall upon the sense; but such conduct as this can only be forgotten in the grave.

Mr. Ward resides in the town of Hungerford, in the Manor-house, which is his own. Behind it are the garden, stables, kennel, excellent airing yard, land grass land sufficient for a few cows. Few men live better than Mr. Ward does at his seat in Kent; and at Hungerford he most hospitably entertains his friends with good old English fare, well adapted to fox-hunters. Where he is, however, we are sure of a feast, for mirth and good humour give a seasoning to everything; and during my stay at Hungerford I spent many pleasant evenings in the old Manor-house-he having told me beforehand that he would "take care my waistcoat did not run in."

I rejoice to say that this veteran sportsman continues heart-whole and well. His appetite is good; and, from his fine constitution and roomy frame, many winters will yet roll over his head-and I wish from my soul they may. "It is not," says Cicero, " in the first act of the drama that a good player is applauded; but it is the concluding scenes that the warmth of our feeling, as it were, breaks forth into a blaze." I scorn to flatter him, for "praise undeserved is satire in disguise;" but we are all indebted to Mr. Ward: we are indebted to him for the honour he has done to fox-hunting: we are indebted to him for the pains he has taken in breeding the English fox-hound: we are indebted to him for all the mirth, the pleasantries, and good fellowship he has given birth to: and, above all, we are indebted to him for preserving the character of the old English 


\section{MR. WARD'S HOUNDS}

gentleman. The French petit maitre, the foreign hussar, the frittering dandy, may be grafted on the stock, but they will not flourish, for the soil is not genial to their growth. I'll fill my glass then as full as I can, and drink "success to John Ward and his hounds." *

* The chorus to a song written on Mr. W.'s hounds. 


\section{DORSE'T AND DEVON}

On my way to Blandford races in September, I passed by Mr. Farquharson's kennel, and treated myself with a peep at his hounds, which were at exercise in the park; of course I saw them to disadvantage, but they appeared very much like going fast; and, considering they were just returned from cub-hunting in a woodland country, their condition was bright and healthy. Their huntsman, J. Jennings, has hunted them a great many seasons, and has the reputation of being a good sportsman. On my asking him to shew me some of his sire hounds, he observed that they sent most of their bitches from home; and, among other kennels, mentioned that of Sir John Cope. "If you breed from him," said I, "your foxes must take care of themselves in covert."- " VVe have a young hound here," said Jennings, "got by Sir John's Drunkard. I never saw such a dcvil in covcrt in my life: he has nearly stripped himself naked already in cub hunting."

One rather curious circumstance arose out of our conversation in the kennel. On Jennings remarking that he believed Mr. Ward's hounds were very full of bone, I described the sort of hound he bred, only on a still larger scale, and pointed to a hound called Guardsman. "That is odd enough," said Jennings, "for that hound and his brother Ganymede were got by our German, who was by Mr. Ward's Gaffer." He told me they had put some bitches to Guardsman.

I never was in Dorsetshire before, but, from what I saw of it from the road side, I should imagine Mr. Farquharson's home country to be far from a good one, but he has a great extent of what is good in the Vale of Blackmoor.

Mr. Farquharson's hounds seldom hunt less than five days in the week, which the country will well afford; and I was told he had 


\section{DORSE'T AND DEVON}

twenty good hunters in his stable-so that he may be said to be horsed equal to his work-being a horse for every day in the week for himself and men to begin with. Jennings rode a favorite old horse on the race-course, which, if my memory serves me, had carried him fifteen seasons, but was to be provided for after the present cub-hunting was over. $\mathrm{He}$ is a well-bred light-bodied horse on a large set of limbs, which accounts for his lasting so long.

Devonshire is certainly the worst hunting country I ever was in ; yet, strange to say, there are more hounds kept in it than in any other three counties in England. Independent of the established packs of stag and fox-hounds (of which there are one of the former, and four of the latter), nearly half the resident gentlemen, and the greater part of the yeomanry, keep what they call " a cry of dogs;" and a friend of mine, who resides among them, told me he had hunted with seventy-two packs!

A new pack of fox-hounds has lately been added to the list, kept by Sir Arthur Chichester, of Youlston near Barnstaple, and are hunted by John Horlock, whom I knew when he hunted Lord Glammis' stag-hounds in the lower part of Hertfordshire. Before he lived with his Lordship, he hunted a pack of subscription foxhounds in Cambridgeshire; and as, when we come to impressions, contrast is everything, I should much like to know what he thinks of the Devonshire dingles, and those killing hills which abound in his new country, after the flats of Cambridgeshire. He has made his debut, however, at the Chulmleigh Club, but the weather must have been much against him.

Sir Arthur, I understand, commenced operations last season, and finished with lamentable diminution of hounds and horses; but from what I saw of his country, it never could be intended for foxhounds. "Over the mountains, and over the moors," is a pretty commencement to a love song, and the words sound well to music; but it is a sorry recommendation to a hunting country.

I 'must here introduce one gentleman, who resides in Sir Arthur's country, as an example to all sportsmen. His name is Incledon, and he resides at Yeotown near Barnstaple. He is both a stag and a fox hunter, and the best preserver of the best sort of game in the country. He himself told me that he was then feeding no less than 
five brace of foxes which used his own earths; and that he trimmed at his own expense no less than ten miles of rides through his own coverts. From others I learnt that he had almost the greatest extent of highly-dressed pleasure grounds of any man in the county, and that on hunting days the gates are all thrown open, and he is one of the first to gallop over them when the chase leads that way. A sportsman might almost be pardoned for exclaiming "what reward shall be given unto thee!"

A great portion of English clergymen are sportsmen, but in Devonshire they may be almost said to abound; and it is well for them that they have so many opportunities of entering into sports of the field, as from the miserable state of the roads they would otherwise derive but little pleasure or benefit from horse exercise.* Add to this, as the poet says,-

\footnotetext{
"To spring a covey, or unearth a fox, In reverend sportsmen is right orthodox."
}

The Rev. Dr. Troyte, of Huntsham near Tiverton, keeps a pack of fox-hounds, as his brother and father have done before him for the last fifty years. His health being but indifferent, the fixtures were chiefly regulated by it, and the establishment was not a large one, so that, being pressed for time, I did not make any effort to see it.

My visit to Devonshire unfortunately happening at the time when we were visited with what almost appeared to threaten a second deluge-added to the sickness of almost all my friend's horses and my own-I was unable to see half the lions. There was one pack of fox-hounds which I wished particularly to see, and it was my intention to have done so; and those were the hounds of the Hon. Newton Fellowes, whose house was not more than twenty miles distant from where I was staying. Though slightly known to $\mathrm{Mr}$. Fellowes, by meeting him occasionally by the covert's side, a very

* In my travels through life, I have heard some sneers against " huntingparsons;" but my idea is this:-A hunting parson makes friends: a shooting parson makes enemies. A clerical friend of mine being disappointed at the death of a relation, said he should give up hunting and sell his horses. "Do no such thing," said a certain noble relation, very high in the sporting world; "stick to the brush, and it will get you a living." And so it did. 


\section{DORSE'T AND DEVON}

intimate friend of his was on a visit to my friend, and was kind enough to offer to take me to Eggesford to see all that was to be seen. What was a sufficient inducement to me, I was told by several sportsmen in that country that I should see a very clever pack of hounds in Mr. Fellowes's kennel. The day before I was obliged to return home, therefore, we were booted and spurred for the occasion, but the weather forbade us stepping beyond the threshold of the door. Mr. Fellowes is also well known in the sporting world as the owner of Escape, and also as a very extensive breeder of thorough-bred horses.

Some excellent stories are told of Stephen, Mr. Fellowes's huntsman, who has lived about thirty years in the family, and therefore, in some degree, a privileged man. It seems, however, that he has done credit to his master's good keep, and some of it, "as the sparks fly upwards," has found its way into his nose. On a friend of Mr. Fellowes's giving him a hint of its rubicund appearance, he gave the following ingenious reason for the possession of it-namely, that he "caught it by riding after his master over the cold moors."- " How happens it," said my informant, "that your master has escaped the same fate?" - "Why, Sir," said Stephen, "master" is able to drink his bottle of Port after his dinner, which will keep the crimson frostwork out of any man's nose."

Another good thing is attributed to Stephen. Taking his hounds to covert one molning, he was joined by a farmer who was notorious for a good tap of cider. "Well," said Stephen in his hearing, "I never will eat no more of those red herrings for my breakfast, for they do make me so dry." Here we must admit Stephen hit his fox cleverly; but knowing nothing of his performance as a huntsman, of course I have nothing to say on that subject. For the same reason, I must be equally silent on his master, who, I understand, takes an active part in the field. His halloo, I am told-particularly his "cover-hoik," when hounds are drawing-is remarkably melodious and good, and his kennel discipline quite of the Spartan order. I heard a great deal of a hound of his called Minstrel, and having reason to conclude he was a model of what a fox-hound should be, I hope he has preserved his blood in his kennel.

I must not, however, dismiss Stephen, without mentioning one 
circumstance well worth recording. In the year $1816 \mathrm{Mr}$. Fellowes's hounds were running their fox with a very high scent over Mr. Buller's park at New-place near King's-nympton, when he crossed the Southmolton road. Stephen-then riding nearly seventeen stone-charged the fence at the end of the park; but when his horse got upon the bank (the fence being a double one), he found, that instead of "going in and out clever," if once he got in he should never come out, as the drop into the road was tremendous, and it was newly covered with fresh-broken stone. Dreadnought,* however, was not to be daunted ; but Stephen exclaimed, "no go!" so catching hold of a large bough of a tree (a smull one would have availed him but little), which fortunately hung over his head, he suffered his horse to leap from under him, and so preserved his life.

The following Poem, describing a run with Mr. Fellowes's hounds, was given to me during my stay in Devonshire, and I present it as a "tale well told." The verse is smooth and melodious-the events faithfully described-the language correct and sporting, and quite in the epic style.

\section{A DAY WITH THE EGGESFORD(1) HOUNDS.}

LoNG had the stiff'ning frost display'd its force, And check'd the sport of man, of hound, of horse ;

The boist'rous east-wind long with chilling blast

In icy bands had tied the waters fast;

And Winter, from his cavern in the north,

In hoary majesty had issued forth ;

Asserted over nature's face his right,

And clad the regions in a robe of white:

Stout Dawson (2) even stood aghast, and cried,

"Gude faith! it ne'er was caulder on Tweed-side!"

At length th' advancing season of the year

Brought warmer weather and a softer air;

And Spring's mild breezes, whisp'ring through the woods,

Bade roll the rivers, and nnchain'd the floods.

Rejoiced the Squire of Fggesford's (3) wide domain!

Rejoiced both he and all his hunter train!

* The horse he rode.

1 The seat of the Hon. Newton Fellowes, near Chulmleigh, Devon.

2 A Scotch Bailiff, remarkable for his portly person.

3 The Hon. Newton Fellowes. 


\section{DORSE'T AND DEVON}

Sore had they griered that so much time was lost, Nay sometimes wish'd the devil had the frost;

But now their hearts are light, their hopes are high, And expectation sparkles in each eye.

'Tis fixed at Levesclen (1), on tlie ensuing morn, Betimes to rouse a fox with hound and horn : Th' neighb'ring sportsmen summoned to the place Bestride their steed , each anxious for the chase; And, ere th' appointed hour, upon the ground In deep array a motley group is found.

At ten the Eggesford cavalcade draws nearHorses, and hounds, and huntsmen, all appear. And first the Squire himself rides v'er the plain, Guiding old Mufti (2) with an easy reiu : Mufti, with arching neck and glancing eyes, Seems in his master's thoughts to sympathize; And, proudly looking ronnd, appears to say, "Some here shan't see too much of me to-day!" The hounds, low crouching, follow close behind, In compass small, at Mufti's feet confin'd :

No thoughtless pupry straggles from the pack, Each dreads the well-known whipcord o'er his back. Next Stowell (3) comes, than whom no other wight In field sports seems to take so much delight; While Fuss (t) gay-prancing owns his happier fate, Than when condemn'd to bear the huntsman's weight. There, on his chesnut, rides the Parson Clay (5)-

From home he comes this morning all the way; But should the day prove long, and good the sport, To Eggesford House at night will he resort : Full well the stables there does Captain (6) know, And to his (proper) stall without a guide can go.

Next come two brothers-one of Bow the Priest (7), A Lawyer 't' other (8), - so he says at leastBut, spite of what he says, 'tis my belief He likes a fox-chase better than a brief.

1 Lewesden, a favorite covert in the neighbourhood of Chulmleigh.

2 Mufti, an invaluable hunter, by Mufti, bred by the Duke of Bedford-one that was never known to flag with the severest runuing even in this impracticable country.

3 Willoughby Stowell, Esq., of West Anstey-a thorough-bred sportsman.

4 For the performances of Fuss, vide Racing Calendar.

5 The Rev. B. Clay, of Worlington, in this county.

6 Captain, a chesnut hunter, well known in the Chulmleigh Hunt.

7, S The Rev. Bonchier Marshall and his brother J. M. 
See, at a cautious distance from the rest, Curvets the royal Czar (1), by Stephen (2) prestStephen, whose modest blnsh outvies the rose, Or like a delicate red-cabbage glows, And crimsons chiefly on his bottle nose! Last of the train comes on the whipper-in, John Noble, mounted upon Harlequin. The rest, a mingled crew, remain around, Waiting in silence for the joyous sound Of "Covert, hark! Hark into covert!" In Dashes at once the pack, through thick and thin, 'Till the close brake, completely threaded through, Presents a moving surface to the view.

One dog at first proclaims the scent is found"Hark, hark to Cardigan! To him er'ry hound!" On stirrup rais'd, "Look sharp!" the master cries, "For Cardigan's a dog that never lies!"

Next Butcher's deep-mouth'd thunder swells the gale,

And Darling's triple yelp confirms the tale;

Whilst chiming in, each hound so mute before, Joins in the crash that makes the welkin roar. But "Hark! a 'Tally-ho!' from yonder side: I saw him through the bushes softly glide," Says John; "and see, Sir, there the hedge he broke, Close to the corner, just before I spoke!"

Pours forth th' impetuous pack with merry noise:

The master cheers them with his mellow voice;

Whilst Stephen's notes, hoarse braying through the horn, Swell the fnll gale that rising greets the morn.

Old $K-r s-e(3)$ knows the line the fox must take, So straight he gallops to a distant brake :

There may he wait in vain till close of day, For reynard's gone directly t'other way.

And first to Chubhouse earths he speeds his course, But, prest too hard, is driven thence by force: His wiles are baffled, and he finds at length That he must now depend upon his strength. Bending his white-tipt brash, his point he makes For Broadwood Kelly-next for Colstone Brakes.

1 Czar Peter, by Sir Peter Teazle out of Xenia. He beat Prospero and Witchcraft over the B. C. at Nowmarket.

2 An excellent huntsman, and most devoted admirer of the genuine Nantz.

3 This was a favorite practice with the old gentleman, and by it he lost many an excellent day's sport. He is no longer living, but in his lengthened and well-spent life " he gathered golden opinions from all sorts of men." 


\section{DORSE'T AND DEVON}

A quickset hedge here intercepts the view; The rapid hounds, too eager to pursue, O'errun the scent, and dashing heedless on Come to a fault at last near Broadwood town. Stephen, the while his master makes a cast, Tries up the lane, to see if there he past, When "Blowsy hits it-13lowsy's got the scent! Hark, hark to Blowsy !-that's the way he went!" Now the full pack deep op'ning once again Rush headlong on, and madly scour the plain : The horsemen follow at the stretch. "Now where, Where are the tail-hounds now?" demands the Squire :

"See every dog that came with me from home

Within the compass of my dining room!"

Now on our left the gate a man uulocks-

"Vour zarvant, Zur."- "Well, have you seen the fox?"

"Zeed un? Yeaz, fath (1), us zeed nn t'other night:

He put old Deame in a cruul viight (2),

Her thort (3) her geeze"-The Squire his chatt'ring stops,

With "Stephen, lay your whip about his chops :

I wish I had some pudding, or a bung,

Or anything, to stop that blockhead's tongue!

Seen him last night, you stupid fool!-and yet

I might have known what answer I should get."

Hodge sneaked away. Each urges on his horse,

Until a set of bars arrests their course :

Out comes the saw (4), down goes the upper bar, And Stephen first rides over npon Czar:

The Squire goes next : then, seated upon Panl, A neighbouring Parson (5) leaps, and gets a fallFor, catching 'tween two bars with both his toes, Paul blunders, and comes down upon his nose :

Up spring again directly man and horse,

Rejoiced to find themselves no whit the worse;

And, joining partnership, once more proceed,

To follow those before them, at full speed.

Next Bouchier Marshall, on his gallant grey,

Rides at the leap and bears a bar away,

Then forward springs amain, whilst those behind

Vote him their thanks for his assistance kind.

1 Anglicé-seen him?' yes, faith.

2 Anglicé-Dame in a cruel fright.

3 Anglicé-thought.

4 "Discretion is the better part of valour."

5 The author here records his own mishap; he seems to have been more at bome on Pegasus than on Paul. 
Now Bondleigh parish hears the uproar wild: Out rushes every woman, every child, Whilst pigs, geese, turkeys, women, children, vie In a shrill scream that almost rends the sky.

Reckless the hounds dash on-their game's afore ! The earths at Bondleigh Wood, well known of yore, He tries; but vain his hopes of shelter thereGabriel and Marksman thunder at his rear : He takes the water next with desperate bound, Swims fearless through, and gains the further groundA moment pauses-shakes his fur-clad sides, Then hastens to the copse with lengthen'd strides, And breath recovers-leaving for a space His followers, fretting at their dire disgrace : But short his triumph-short-lived every dream Of safety proves, for, dashing at the stream, The Squire and Mufti stagger boldly through : Then Cottleswood soon hears the wild halloo; Whilst Boniface takes up the scent, and deep His gallant chiding echoes up the steep.

Splashing and splasht, the rest, no matter how, Contrive to stem Taw's (1) muddy wave, and now Hounds, horses, and their riders see once more In safety landed on the other shore:

One luckless wight(2), as up the bank he goes, Falls back, and plunges in o'er ears and noseThe suff'rer's name it lists me not declare, Perhaps it was myself, perhaps some other there. And now again their speed outstrips the wind, And soon the Ashridge Oaks are left behind. For Milsum Castle next their course was bent. Poor Reynard! now thy strength is almost spent, To Brushford Wood rush on with all thy speed, And gain the sheltering earths-great is thy need! But ah! in vain each quiv'ring nerve he strainsIn vain he presses over Milsum plains!

At each step falt'ring, faint he staggers on, And every hope of safety now is gone;

For near and nearer still, with eager cry, His rav'nous foes their untired sinews ply; And whilst their flagging game they swift pursue, In speed each strives the other to outdo.

1. The river Taw, running under Chulmleigh, empties itself into the sea below Barnstaple.

2 J. M. W-llc-be, Esq. 


\section{DORSE'T AND DEVON}

At length tall Trunnion, with resistless launch, Ontstrips the rest, and fastens on his haunch With savage fury! Now thy wretched wife May well bewail her spouse bcreft of life; And, growling mournfully, each long-tailed son Lament his father's race untimely run, For forty mouths at least, with piercing fangs, Drink thy heart's blood, aud revel in thy pangs.

'Tis o'er! and Stephen winds thy death-note.shrill, Which quick returus again from Brushford Hill And Milsum Castle Wood, re-echoed back.

Now homewards slowly plod the weary pack, Whilst the keen sportsmen, riding o'er the plain, In eager converse kill their fox again!

I am now about to impose upon myself a task which I shall have some difficulty in performing-namely, an attempt to describe a system of hunting pursued by that well-known sportsman $\mathrm{Mr}$. Templer, of Stover House, near Chudleigh.

Mr. Templer's hounds are professedly fox-hounds, inasmuch as they hunt and run nothing but fox; yet they are not all thoroughbred fox-hounds, nor indeed would it be possible, without travelling to all the kennels in England, to get fox-hounds of his size-not exceeding nineteen inches. The most extraordinary part of this establishment is, that in their own country this pack is never suffered to taste the blood of a fox, if by hard riding or by any other fair means it be possible to prevent it. The following is the system pursued:-The hounds generally meet at a covert, with the intention of finding a wild fox. If they do find him, he must look sharp for his life, for they are capital hunters, and very quick. If he sinks before them, some of the field-among whom are two or three particularly au fait at this work-get forward and pick him up by his brush. The hounds, partly from their being in the habit of being stopped by a rate, with a fox in view, and partly from their not possessing that power which larger hounds would have, are more easily stopped on these occasions than might at first be imagined; and a great many foxes are picked up unhurt before them. In case the coverts they draw prove blank, a fox in a bag is always in attendance, and is turned down before them in view.

On Monday, the 27th of September, I was out with Mr. Templer's 
hounds. The place of meeting was Chudleigh rocks-about a mile from Chudleigh-the scenery of which was romantic and beautiful, and they would answer all the purposes of the Tarpeian rock. There was no fox there; but we had a beautiful find in an adjoining covert, and ran our fox, with only half a scent, to ground. We then turned out a brace of bag-men, and took them both unhurt before the pack. In consideration of the time of the year, the heat of the day, and a bad scent-in addition to Mr. Templer having met with an accident which rendered it very painful to him to ride-the foxes turned ont were not of a flying sort, so that the chases were short, though sufficient to show the nature of the system, which to me was quite unique.

I should have been in Devonshire one year sooner to have seen this system to perfection, the present being a young pack, just formed; and though, as might be expected, not quite so perfect in their discipline as the old one which Mr. Templer sold last year, yet their performance was very much to their credit. The foxes were turned out not twenty yards from them, but they scarcely stirred until Mr. Templer gave the word of command; or until he "bade them to the chase," which was by the last of three signals. In the old pack there was one hound that never looked at the fox, but always kept his eye on Mr. Templer, and when the last signal was given, he was off.

The most curious part of Mr. Templer's establishment is his method of keeping his foxes. He has nearly thirty brace of cubs and old ones, many of the latter of which he has had for some time; and, strange to say, there is one, called "The Bold Dragoon," which has been hunted six-and-thirty times-often affording most excellent runs! What is also most extraordinary, when he comes home at night, after the sport of the day, he never goes into his kennel without taking his supper with him, which always awaits his arrival. It consists of half a rabbit and some kennel meat, without flesh; or, in default of the rabbit, a small portion of flesh. The Bold Dragoon is a strong dark-colored fox of the greyhound kind, and does not appear to have lost any of his natural character.

Mr. Templer's old foxes are kept in two large yards, in which their kennels-the same as we use for pointers-are placed; and 


\section{DORSE'T AND DEVON}

thiey are confined by collars and chains, the latter six feet long. The chains of some of them are affixed to swivels fastened on the tops of the kennels; so that by describing a circle of about eighteen feet, they keep themselves in tolerable wind. He has one fox at his kennel so tame that he wags his brush as a spaniel wags his tail when any one he knows approaches him; and he has also one jackal in his possession, which of course he does not hunt.

Some thorough-bred fox-hunters may say there is too much of the bag about Mr. Templer's hunting. This we must all admit; but in such a country as Devonshire, exceptions to rules and customs may be allowed; and to ensure sport by any means is the grand object. If a covert prove blank in many countries, it is nearly as good as a middling chase to trot away for two or three miles over hedge and ditch, and try another; but to be trotting up and down the Devonshire lanes for half the day would be anything but agreeable. Mr. Templer's field, then, is never disappointed, a brace of foxes being always at hand; and what is of no small advantage in his case, he can generally pick his country for his day's sport.

To shew that Mr. Templer's hounds can kill foxes when suffered to do so, it may not be amiss to mention, that whilst they were at Northmolton, for the purpose of hunting alternate days with Mr. Fellowes's or Sir Arthur Chichester's hounds, at the Chulmleigh Club, they killed three brace of foxes in four days.

The Chulmleigh Club is a rery old-established meeting, and attended by most of the principal gentlemen of the county. As a proof of the force of local customs, plum-pudding and tongue (eaten together) form a standing dish.

IIr. Templer rides hard, and had six very clever horses for his own riding-four of which he bred by Czar Peter and Colossus, horses in Mr. Fellowes's stud. On the day I was out, he rode a very fine Colossus mare, equal to fourteen stone, and which ought to be in a better country.

There is one gentleman who is a constant attendant on Mr. Templer's hounds, a very fine horseman over a country, and, report says, quite the clipper of the west. This is the Rev. Henry Taylor. There is another gentleman of the same cloth-the Rev. John 


\section{NIMROD'S HUN'TING 'TOUR}

Russell (but much better known by the name of " Jack Russell ") who, though he resides about thirty miles from him, hunts a good deal with Mr. Templer, and who also stands high among the Devonshire bruisers. This gentleman finds hunting so conducive to his health, that with stag-hounds, fox-hounds, harriers, and otterhounds, he contrives to enjoy it all the year round. The lastmentioned pack are kept by himself; and he has killed the almost incredible number of twenty-five otters in the last two summers, for which he should receive the thanks of the fish! Each of these gentlemen spent the evening with us at Mr. Templer's, and added much to its conviviality and pleasure.

Having passed the night under the hospitable roof of $\mathrm{Mr}$. Templer, on the next morning we inspected all the lions. The stable, kennel, and fox-yards of course were not forgotten; but what most particularly attracted my notice, as something I had never met with before, was the school in which Mr. Templer perfects the education of his hunters, and which I strongly recommend to all those who have large studs of horses. The following is the plan :-

A piece of ground, about twenty feet diameter, is railed around, and within the rails are a single and a double leaping bar. Without the rails-where of course a larger circle is described-are a large double fence (two rails and two ditches), and a drain cut to imitate a brook. In the centre a stage is erected, on which the groom stands, holding the rope which is attached to the horse in the school, and he goes around as if in a lunge. Mr. Templer was kind enough to send three of his hunters into the school, and I was much gratified by the sight. They appeared to be quite at home, taking the fences as they presented themselves with the greatest judgment. One of them in particular-Moscow, by Czar Peter-gave us a specimen of the superior use some horses can make of their corporal powers, in comparison with others who appear. equally capable. When he came to the single bar, which was higher than most gates, he seemed to play with it; and it was quite a matter of indifference to him whether he went close up to it, or whether he sprang two or three yards before he came to it, as he was certain to leap a foot higher than the bar. If a horse could play these harlequin tricks 
at the end of an hour (best pace) with hounds, how much more delightful would hunting be !

To one so deroted to hounds, horses, and everything relating to hunting as myself, a visit to Mr. Templer's could not fail being a treat; and when I quitted his house, I easily accounted for the very flattering character I had heard of him in the country. I have good reason to think he is a first-rate sportsman; and had it been his lot to have been at the head of a regular pack of fox-hounds in a good country, he would doubtless have distinguished himself as a huntsman, for his method with his hounds is remarkably good.

Sportsmen are apt to look at a country with merely a sportsman's eye, as a friend of mine did on his road to Doncaster. "What a beautiful country!" said one of his fellow.travellers. "Aye," said he, "tis a pretty country enough, but how the devil do they ride over it?" This I confess is my own case, having but little taste for the picturesque. The North of Devon, then, has no charms for me, who spend half my life in the saddle. The roads, with the exception of a few of the principal ones, are execrably bad: you cannot break out of them for more than one mile in twenty; and if there be a pretty prospect on one side or the other, you cannot see it for the hedges. Some parts of the country are extremely rough and dreary; and an epitome may be found of it in a provincial saying-that "the devil caught cold at Chagford, and died at East Looe." As, however, it generally happens in most rough countries, a great deal of hospitality and good fellowship prevails in the county of Devon; but it is the only one in which I have heard a pack of hounds called "a cry of dogs," or a cow called a bullock.

During my visit to Devonshire I could not live in the society I was in without hearing some anecdotes worth remembering. The late Colonel Kelly, of Kelly in the county of Devon, though a determined sportsman, must have been an odd fish. Being invited one day to dine at the house of a lady of high fashion in the county, he sate for a long time in her presence without saying a word, and then addressed her thus :- "Pray, Madam," said he, in the punctilious language of the Old School, "did your Ladyship ever tail-pipe a grey-hound?"- "I know not what you mean," said her Ladyship. "Why, Madam," observed the Colonel, "'tis the finest diversion in 
nature: Tom Sowden * and I once tail-piped a greyhound at Jack Land's † door (there being no steps,) and he made but one jump to the bridge, as God's my judge" (the usual way of the Colonel clenching all his stories). Those who know where the bridge is situated must agree with me in thinking that the Colonel could jump a bit also. I am told, however, that his anecdotes were generally good, and the merit of them much enhanced by the very peculiar mode of utterance with which he delivered them.

A clergyman residing in Devonshire, having another living in Nottinghamshire, went a short time since to visit it. As is customary on such occasions, his old bailiff, or farming man, wrote to inform him how things were going on in his absence, and concluded his epistle with these words :- " Betty Hony was married a Monday-Time she was. The old sow have a farrowed nine." Now whether among the figures of speech, or the rules of writing, this may be termed a climax, I leave others to determine; but there is a unity of thought and a closeness of expression about it which savour strongly of the concise.

* Thomas Sowden, Esq., of Whitstone near Exeter, a gentleman of considerable fortune and eccentric habits, who keeps a small pack of harriers.

$\dagger$ Landlord of the London Inn, Exeter. 


\section{HAMPSHIRE}

THE H. H. OR HAMPSHIRE, AND THE HAMBLEDON HOUNDS.

I Never hunt in Hampshire when I can help it-that is to say, when I can hunt in a better country; but there is an instinct that takes a man to hounds when they meet within reach of his stable, which it is quite impossible to resist. I have known what it is to repose upon a bed of roses; and, like most of my kind, I have languished upon a bed of thorns; but to ride a good hunter over a bed of flints is a misery which was reserved for me till I came to reside in Hampshire.

Bad as this country, however, is, and little as I have hunted in it, I have experienced a great deal of pleasure from the very masterly manner in which Mr. Villebois hunts it-it being quite impossible for any establishment to be better conducted than his; and the only alloy that attends it, is the painful recollection, that so fine a kennel of hounds, so able a huntsman, such clever whippers-in, such a liberal master, and so good a judge, should not all be transplanted into a better country. Here, however, are they fixed; and fortunate is it for the Hampshire sportsmen that they have them; and I have good reason for knowing that they are not unmindful of their treasure.

Although Mr. Villebois has no subscription to his hounds-not even an earth stopped for him-they are better known by the name of the H. H., or Hampshire Hunt, which is a title of old standing in this county. Their kennel is at Harmsford, four miles from Alresford on the Basingstoke side of the town, and close to the mansion in which Mr. Villebois resides, and where he rents a farm of five hundred acres. He also occupies a still larger farm of his own in the neighbourhood of Popham Lane-so that he cannot be said to be in want of rural occupations. The kennel was built by 
himself, has every convenience for so large an establishment, and is particularly healthy and clean. He has also another kennel at Hursley, four miles from Winchester, from which he hunts his Forest country, and whence he gets his cub-hunting. Foster, the huntsman, resides in a comfortable house about a quarter of a mile from the kennel, where his own five horses stand, as also eight others for the use of the two whippers-in-those ridden by Mr. Villebois being kept.at the mansion-house.

Mr. Villebois lays claim to the honorable appellation of an old master of fox-hounds-having been now twenty-three years in the service. His debut is said to be this: when he resided at Preston Candover, he was master of a pack of harriers; and having found a fox with them in a country not hunted by fox-hounds, he had a capital run, and killed. In commemoration of this, he has an excellent picture (by Marshall) in his dining-room, in which he is represented in the act of dismounting his horse for the purpose of cutting off the brush. This is supposed to have spoiled him for cutting off the scut; and, aspiring to higher honours, he succeeded Mr. Paulet in the management of the Hampshire hounds. These he continued to keep, wlth the subscription, for a period of three years, when he purchased the pack from the Club, and has ever since hunted the country at his own expense.

It may not be too much to assert that nothing in the shape of a country Club can be more respectable than that of the H.H. Having more than once had the honour of dining with them, I can speak to the fact, that not only are their dinners served up in a style almost amounting to elegance, but there exists among the members, in their social hours, exactly that proper portion of jollity and good fellowship, which upon such occasions ought to exist among foxhunters of the present day.

At the head of the list of the Hampshire Hunt stood his late Najesty's name (George IV.), for many years previous to his accession to the throne; and to this are they indebted for the plume of feathers which adorns their uniform button. This honour was conferred upon them when his Majesty resided at Kempshut, within the limits of the Hunt; and, as himself a master of fox-hounds, his patronage was aptly bestowed. The morning uniform is a plain 
scarlet coat, and the evening costume consists of a blue coat, with white kersymere waistcoat, having the gilt button, with the letters H. H. under the plume, handsomely embossed on its surface.

The father of the H. H. is that well-known sportsman Mr. Græme, who resides in the neighbourhood of Alresford; and with whom fox-hounds and the other good things of this world have agreed so well, that he is said to look as young as he did twenty years ago, and is one of the few men who ride hard and well at his time of life.

Mr. Villebois' kennel consists of seventy couples of hunting hounds; and his usual entry is from twenty-two to twenty-four couples. He divides them into two packs-one called the large, and the other the small pack - the average height of the first being from twenty-two inches and a half to twenty-four and a half, and of the other from twenty to twenty-two; and this division of the kennel makes them very even to the eye. As may be supposed, there are rather more bitches than dog-hounds in the small pack, though there are nine or ten couples of the latter.

An unparalleled instance occurred two years back of Mr. Villebois taking out a pack for the day's hunting all got by one hound out of four bitches. The name of the sire was Pontiff, and the bitches were Vengeance, Thoughtless, Notable, and Milliner-the two last now running with the pack. There are no less than nine couples of hunting hounds now in the kennel out of the first-named bitch got by Pontiff; some five, some forr, some three, and some two-yearold hunters, but all distinguished by their tanned heads, and all good of their kind. One of them-Patriot-can do anything that is required of him; and what is also singular, there are four couples of one-year hunters got by Patriot out of a bitch called Lady-a descendant (by Lashwood) of Sir Thomas Mostyn's Lady. Patriot is not only a brilliant chase-hound, but his nose is particularly good; and I saw him make a most beautiful turn a short time since on the heel of the whole pack-going away singly to his fox. He is a great favorite of Foster, who sometimes violates the prosody of the kennel, and calls him by the familiar name of $P$ at. His sister Penitent is equally good, and if possible a harder-working hound than himself.

Patriot, I perceive, will be a favorite stud-hound in Mr. Villebois' 
kennel. He has already distinguished himself as the sire of Voucher and Vestal (the one in the large, the other in the small pack), twoyear-old hunters, and as good as they can be; and also of two young hounds, called Lunatic and Labourer (out of Lady), that might be shown against anything of their age. In all, he is the sire of seven couples and a half. Norval, also by Pontiff out of Notable, will be favorite blood.

Exclusive of the nine couples of hunting hounds by Pontiff out of Vengeance, there are two couples more out of her by Telamonone of which, a hound called Vexer (his first year), has been pronounced by a judge to be "the finest young hound in England." Lady also is the dam of Stormer, Symphony, and Sailor, by Mr. Osbaldeston's Sailor-all particularly clever. Vengeance died when in whelp to Mr. Chute's Larkspur, and Pontiff died of old age at Sir Thomas Winnington's in Worcestershire.

When I first put my eye upon Lady, and asked Foster her name, I well remember his answer. "When Mr. Ward saw that bitch," said he, "he observed that nineteen stone could not often see where she went." She is in the small pack-and so are all her produce, except Labourer, but quite at the top of their mark; and when I saw her, singly in the kennel, I was amazed at her power, as also at the ground she stood upon.

There are three bitches in Mr. Villebois' kennel which must not be passed over-namely, Priestess, Nadcap, and Jewel. The two first are by Pontiff out of Vengeance; and Jewel is by Foreman (sire of Lady) out of Jezebel. Jewel is the dam of Juryman and Jovial, two uncommonly fine hounds; also of Jolly, and two couples and a half of young ones of great promise. Jewel has got a bone in the mouth of her stomach, which she cannot get rid of, and which prevents her hunting; but from her blood and shape she is invaluable in the stud. Priestess breeds so hard they are afraid to trust her; and she has only produced one bitch, called Rattle, by Mr. Nicholl's Rattler. A bitch called Columbine, by Mr. Osbaldeston's Chorister, and another called Artful, out of Mr. Villebois' celebrated Active (one of the quickest bitches I ever rode after, and now in the pack), may be? șhewn as patterns of Hampshire hounds. 
Before I hunted a month in Hampshire, I pronounced it to be the most difficult country to kill a good fox in that I ever had seen, and my opinion is in nowise changed. By the time Christmas is past, if the weather be open, more than half of it is ploughed; and from the constant changing from pretty good to very bad land, hounds are always uncertain of their scent, and consequently afraid to hold on. To this must be added the number of small as well as large coverts which abound in it, where foxes are always making work, and have the advantage. Exclusive of these, the large hedgerows he meets with enable him to turn back, unperceived, upon the hounds, and consequently to gain time.

I have said enough to prove the difficulty of killing a good Hampshire fox, but I have not done. It may be safely asserted, that Mr. Villebois' hounds in chase are two-thirds of their time either in covert or on ploughed land, which generally carries; and although there are fences in his country, yet there are no brooks, nor anything sufficiently strong to keep back the body of the horses, so that hounds are always more or less pressed upon when at fault. The foxes also seldom run straight, so that all the field get up sooner or later; and some of them accidentally find themselves before the hounds, when they had good reason to think they were behind them.

Mr. Villebois then has these evils to provide for:-In the first place, he must sacrifice anything to nose, for your stiff-necked ones will never do in Hampshire. He must have legs and feet of the very best form, or they will not stand the flints. He must have speed, or his hounds could not get away from the horses. He must have power, particularly in the loins, or they would not only not get up the hills quick enough for their foxes, but they would not be able to carry the weight that sticks to their feet over these greasy fallows. They must have high form and symmetry, or they would not do what is required of them; neither would they do for Mr. Villebois.

It will readily appear that $\mathrm{Mr}$. Villebois is very strong in his own blood; and, with the exception of a few Fitzwilliam bitches, and now and then a cross from his neighbours, he is not much indebted to distant kennels. The character of his hounds is very strongly 


\section{NIMROD'S HUNTING 'TOUR}

marked. They are particularly deep in their fore-quarters; short and straight in their legs; a little arched in their backs; very clear in their throats; heads well set on; rich in their colours; and, being lightly fed, have a very airy appearance. From the number he enters-never less than twenty-two couples-be is able to keep up that strength in his kennel which the severity of his country and four and sometimes five days' hunting a week require. I asked him one day how many of his hounds he thought were on an average cut by flints after a hard run, when he told me at least one half.

Foster, the huntsman, was brought up under that renowned old sportsman, Mr. Smith, of Sholebrook Lodge in Northamptonshire, who farmed the Duke of Grafton's hounds, and rode after him as pad groom when in his eighty-ninth year! John Claydon then hunted them, and was succeeded by Tom Rose, the present huntsman. Foster then lived ten years with Lord Southampton, whence he went to Lord Foley; and it was with his Lordship's pack, as first whipper-in, that I first knew him, and where he greatly distinguished himself both as a sportsman and a rider. He has been nine years with Mr. Villebois' hounds, with which he has given the greatest satisfaction to the country and to his master.

Having seen most of the best packs of hounds this country has produced for these last twenty years, it may not be presuming to say that I have seen many of the best huntsmen of that period; but I do not imagine that any of them could have excelled Foster, with his present experience, as a woodland huntsman. $\mathrm{He}$ has an excellent eye as well as ear to his hounds; is very quick and clever in his casts; and his language to hounds is delightfully sporting and good. He is now only in his 40 th year.

Foster, however, has one great advantage with Mr. Villebois-he is uncommonly well assisted. I am no man for a pun; and still more ignorant of the lingo called "slang;" but I must be allowed to say, that his first whipper-in is quite " a top Sawyer"." His second whipper-in, John Jennings, is very good; and on my asking Foster whether he were any relation to Ben Jennings, who hunts Mr. Farquharson's hounds, he told me he was not. "He is the first of his family, Sir," said he, "that ever was in our line."

* His name is Sawyer; and the Hampshire people called him Mr. Shawyer. 


\section{HAMPSHIRE}

Sallust says of kings, that " neither armies nor gold can preserve them upon their thrones-they must reign in the affection of their people:" and this partly applies to the masters of fox-hounds, who are little kings in their way. Mr. Villebois is very popular in Hampshire-as the abundance of foxes and the respect shewn to him will amply testify. His deportment in the field is extremely gentlemanlike; at the same time that there is a firmness of character about him which never fails to add authority to command-the consequence of which is, that I never saw less mischief done to hounds than his generally experience. Like many other masters of hounds, Mr. Villebois was never a forward rider; but, from his knowledge of the comntry, and being well mounted, he is seldom wide of his hounds; and he is an excellent judge of hunting, and everything belonging to that noble science. He has two brothers very well known in the sporting world-one of them (Mr. Henry Villebois) as a first-rate coachman, and the other (Mr. Frederick Villebois, who resides in the Craven country) as an excellent sportsman and a very good rider to hounds. I have more than once chosen the latter for my pilot in strange and awkward countries, and never repented of my choice.

Despite of the country, I have received a great deal of pleasure in hunting with Mr. Villebois' hounds. From Alpha to Omega there is-if I may be allowed the expression-a propriety attending the establishment, as well as a correctness of conduct in everything relating to it, which are highly gratifying to a sportsman's eye, and which cannot be too closely imitated. The civility and respectful behaviour of the servants are beyond all praise; and whether it be by the command of their master, or whether it be from their own sense of propriety, I will not take upon myself to determine, but an oath or a coarse expression of any sort in the field is never heard to escape them under the most trying circumstances that may occur.

Mr. Villebois' country is of very considerable extent; and so it ought to be for four regularly advertised fixtures every week, and very often a bye-day on the Friday. It commences at a village called Crundell, to the right of the road from Odiham to Farnham, and reaches to Southampton in one direction, and to Romsey in another. 
It is also of considerable width. Almost the whole of it comes under the denomination of a woodland country, though much of it has a very fox-hunting appearance; and were it not for the flints it would rank high among the provincials. In point of fence it is not difficult to get across, as there are no brooks, and the ditches are for the most part dry; but notwithstanding this, it is one in which no man can be sure of being with hounds. This is, first, owing to the frequency of the coverts, in which hounds are hidden from his view; and, secondly, to the almost constant occurrence of those very wide hedge-rows, which nothing in the shape of a horse can pass but by pulling up into a walk and boring through. Here much time is lost; and in two instances I have been stuck fast in the middle of them, unable for some minutes to get forward or backward. A gateleaper is essential, as in many places the hedges are only cut once in nine years for the fuel, so that they are impenetrable to a horse.

It is true that a considerable part of Mr. Villebois' country is pretty clear of flints. It is also true that less injury by cutting and wounding is done to horses that are hunted in it than might be imagined, though fatal cases do occur.

There is one part of riding over Hampshire, however, very injurious to horses, and from which I have witnessed several bad accidents in the little $I$ have hunted in it-and that is, leaping into the roads covered with broken flints. At these fences, where the drop is considerable, every man who has a regard for his horse, and has good use of his own legs, should dismount; for though the injury to the internal part of the foot may not immediately appear, danger of ruining him for ever is always at hand.

A particular sort of hor'se, as well as hound, is adapted to Hampshire. He should be well bred, on account of the hills; short in his legs; quick and handy to turn ; a good upright leaper; and not long in the pasterns on account of the flints. The hair on his heels should be encouraged to grow ; he should be drawn fine in his body, and set on the muzzle the night before hunting.

There is one part of Mr. Villebois' country, which, when looked at by a sportsman, he regrets is not of greater extent, and that is called the "Hartley country." It is composed of large grass fields with strong fences, and holds a good scent. 


\section{HAMPSHIRE}

Wishing to see the whole of Mr. Villebois' country, I sent my horses to Alresford, which is the head-quarters of the Hunt, and arrived there on the 21st of December (1824), which is called the shortest day; but it was long enough for us, for it rained the whole morning, and we drew blank. Considering the weather, however, I was very fortunate-having seen one beautiful burst of forty minutes, and two fine runs (one two hours and twenty-seven minutes, and the other one hour and thirty-seven minutes-killing both foxes), in seven days' hunting. I missed one very fine run of an hour and forty minutes (and killed), by going to London; and these hounds had the best run of the year the day after I returned home. It was upwards of fourteen miles in a straight direction, and over so severe a country that there were several bad falls, and it was for some time doubtful whether or not the Coroner would not have been in requisition. Mr. William Heysham rode at a stile, which his horse refused. On turning him at it again, he saw the cause of his refusal: Mr. Hugo Mildmay was lying on the ground on the other side of it covered with dirt, with his head under his shoulder apparently dead; and an hour intervened before animation was restored. The fox on this day was so pressed that he ran into a dwelling-house, and secreted himself in the pantry among the bacon. Foster said it was one of the severest and most brilliant day's sport he had ever seen with hounds. This run was with the small pack.

Not having hunted last season in Hampshire, I missed some of $\mathrm{Mr}$. Villebois' field. Amongst them I looked in vain for Mr. John Willan, who was one of their best performers, but who, with his family, has left this part of the world. Captain Price (son of that well-known sportsman Mr. Barry Price) has also taken up his quarters in Sir Thomas Mostyn's country, where I hear he is considered a teazer when things go straight. Mr. Charles Beaufoy and Mr. Thompson are gone on a tour to the Continent. Surely there can be nothing to be seen there equal to Dick Foster and MIr. Villebois' fox-hounds ! and a writ of ne exeat regno should be served upon such men in October. It is gratifying, however, to see the rising generation of young men of fortune in this country entering so well to the sport. The Messrs. Knight, of Chawton Park, all ride hard; and from what 


\section{NIMROD'S HUN'TING 'TOUR}

I have seen of the elder brother, I am of opinion that he would make a first-rate performer with one or two year's' experience in Leicestershire. The two Captains Greenwood come under the denomination of elegant horsemen over a country, and I have good reasons for thinking they would go well anywhere. Mr. Scott and Mr. Baring, jun. promise well; and Mr. Frederick Heysham has not been to Oxford for nothing; and if degrees were taken in a riding school, I think he would be a first-class man. $\mathrm{He}$ is, at present, rather too fond of hounds; but this is a fault on the right side with a young one, and will in time correct itself. I never saw him ride anywhere but in Hampshire, therefore cannot say how he performs in deep and strong countries; but I think, when on his chesnut horse, he is rather quicker in getting to his hounds than any one I have seen in Hampshire, and has no objection to a new-painted gate at any time of the day. Mr. George Butler stands high among the Hampshire riders, having served a five year's' apprenticeship at Melton. The Hon. William Gage, Mr. George Delme, and Mr. Meares, ride very well to hounds.

There is one gentleman whom I must not pass over-not only as an old member of the Hunt, and a brother-in-law to Mr. Villebois, but as a most useful member of the commonwealth, in everything relating to fox-hunting, and keeping things straight and well in a country-and this is Major Barrett, late of the 11th Light Dragoons, now residing in the neighbourhood of Alresford. The Major, like many of the rest of us, is not so quick as he was ten years ago; but the turn-out of himself and his horse is "quite the thing." Talking of a neat turn-out, however, I must not omit one member of this Hunt who has so long been conspicuous in this difficult art-I mean Mr. David Murray. When I first knew Mr. Murray he was a member of Christchurch College, Oxford, and rode a horse, if possible, neater than himself. I allude to the well-known Zigzag, afterwards purchased by Lord Plymouth at a large price: he was a complete pattern of a Leicestershire hunter for a certain weight.

Among those who seldom miss a day's hunting with Mr. Villebois are Mr. Smythers and Mr. Wilkinson. The former is a most respectable yeomen and farmer, who resides at Bramdean, and who is as good a sportsman and as good a judge of hunting as the county 


\section{HAMPSHIRE}

of Hants can boast of. The latter is the well-known Mr. Wilkinson -well-known, because he kept an inn for many years on the great Western road. Having taken good care of number one, he some time since retired from business, and resides in a good house of his own in the town of Alresford, where he keeps his two hunters and his gig, and is, if we may judge by appearance, one of the happiest men in Hampshire.

I never met Mr. Villebois' hounds but once without Mr. Wilkinson being with them, so enthusiastically fond is he of the sport; neither did I ever see-nor do I expect I shall ever see-a fox found by this pack without having a halloo from him in some part of the run. Upon the balance, perhaps, more harm than good may arise from it, but he cannot help it, and nothing but the pace stops him. Notwithstanding this, Mr. Wilkinson is a useful man in the country. He has a smile for every one, is very civil and obliging, and promotes peace and good humour wherever he goes.

Previous to my residing in Hampshire I do not recollect having met with a regular working dragsman by the covert's side. A coachman by the name of Wyse, however, who was a great many years on the old Southampton Union, and feathered his nest so comfortably on, what we call on the road, " a twenty-four-mile bit of ground, with fourteen good coaches a week, and only one home," that he has for a long time kept his one or two hunters, and enjoyed himself as a man ought to do who has the means in his power.* He has now left the coach, and retired on the fruits of his industry. I met him several times with the Hambledon hounds, and could not help smiling to see him double-thonging his horse when he charged a large fence (which by the way he does gallantly for a man of his weight and the cattle he rides), as if he had him at the wheel of the old coach, with six in and twelve out, and ten minutes behind time.

During the time my horses were at Alresford I had the pleasure of spending a week with Mr. Smith, who has the management of the Hambledon hounds. He resides at Hill-place, three miles from Droxford on the road to Romsey - in the house which Sir Bellingham

* Mr. Wyse arrived at Popham-lane in the morning, and had to wait till evening for his down-coach, which enabled bim to hunt whenever the hounds met in that quarter. 


\section{NIMROD'S HUN'IING 'TOUR}

Graham and Mr. Osbaldeston occupied when they hunted the Hambledon country. There are stables for twenty-one horses; and the kennel, built by Sir Bellingham under the superintendence and direction of Mr. Nicoll, is a very comfortable one for a small establishment, and agrees well with hounds. The roof is thatched, which is considered an advantage in keeping hounds warm in severe weather.

The Hambledon country is decidedly the best in Hampshire. It is a better country for hounds, has more of grass, and less of flints, than those hunted by Mr. Villebois, or the late Mr. Chute, and has altogether a more fox-hunting appearance. That part of it in the neighbourhood of Waltham Chase, Durley, Rowheig, Twyford Park, \&c. is capable of showing very good sport indeed.

There are several good sportsmen and hard riders in the Hambledon Hunt; and amongst the subscribers are three naval officersAdmiral Colpoys, Sir William Hoste, and Captain Collier, all very fond of the sport. I do not recollect ever meeting a sportsman belonging to this noble profession who did not ride hard. A sailor is used to smile at danger, and thinks nothing of being capsized upon dry land. Sir William Hoste has been in Leicestershire, and can shew them how to ride as well as to fight, and we must also allow that "fas est ab hoste doceri."

There are two other gentlemen of this Hunt-Major Ridge and Captain Close-who, though they spent all their younger days in India, took care not to leave behind them their passion for foxhunting, but have verified the words of the Poet who says,

"Coelum, nod animam, mutant, qui trans mare currunt."

On hearing an excellent view-halloo one day from the former gentleman, Mr. Nunes, who was five years master of the Hambledon hounds, exclaimed, "Could you not swear he was got by a foxhunter!" The Major's father once hunted the Hambledon country.

One very killing pack might be drafted from the Hambledon kennel, and there is a good parent stock. Such hounds as Lexicon and Pallafox, by Colonel Wyndham's Labourer; Tracer, by Lord Middleton's Traitor; and Foreman, of the Richmond blood; with such bitches as Dairymaid, bred by Mr. Saville; Bridesmaid, bred 
by Lord Middleton; Wanton, Woodbine, and Jordan; with two very fine young bitches, Margaret and Mischief, by Mr. Ward's Maniac; will not fail to produce all that is wanting in the field; but when we try to be perfect, we should carry perfection in our eye, and Jordan is as near the mark as possible for Hampshire hounds. She is by the Duke of Rutland's Rummager out of his Joyous.

The Hambledon Hunt are not quite unmindful of the ladies; as there are races in April, on Soberton Down, and a ball and supper at Hambledon in the evening. A cup is given for the farmers' horses, and a sweepstakes for those belonging to gentlemen who hunt in Hampshire or Sussex, carrying twelve stone each, two-mile heats.

Every one sonth of London who moves in the sporting world has heard of Captain Bridges, who has long been conspicuous for daring feats of horsemanship and coachmanship. The Captain is the son of the late General Bridges, and resides at the Hermitage, situated in a beautiful part of the county of Hants.

The following anecdote of the Captain is truly characteristic of an Englishman. Being out one day with the fox-hounds, he saw two gentlemen parleying with a farmer in a gateway, who refused to let them pass through it. The Captain rode up to them, and asked what was the matter. "Why," said one of the gentlemen, "this farmer says he will murder the first man who attempts to go into his field."-." Does he?" said the Captain; "then here goes, life for life;" and immediately charged him. The fellow aimed a desperate blow at his head with a very heavy stick, which, in spite of the velvet cap, would have felled him to the ground, if he had not had the good fortune to have avoided it; when, taking to his heels, the coward fled, with the Captain after him, and absolutely crept into a large covered drain to avoid him. "Who-whoop!" said the Captain; "I've run him to ground, by G-d!"-Among his other accomplishments, he has the credit of riding a race so well, that, when I once went to ride against him, I found he was more the favorite than his horse. "The Captain wins for a pound," said a farmer in my hearing, as I first entered the course. Inowing there was a large field against him, I naturally asked the farmer if he knew anything of the horse the Captain was going to ride? "N ot 
I," said the farmer; "but the Captain wins, and no one else, for a pound."

Were it necessary to shew the Captain's devotion to hunting, the following fact would be sufficient. The last time I saw him out, he told me that he was severely attacked by gout at three o'clock that morning; but, determined to hunt, he had taken two strong calomel pills, sixty drops of colchicum, on the top of which he put a glass of hot gin and water on his road to covert, "to keep things in their places."

Although Captain Bridges resides at the Hermitage, he does not live the life of a hermit, being what the world calls, " a jolly good fellow; " and I have reason to believe that in these shady groves the nightingale oftener hears the Captain than the Captain hears the nightingale. Captain Bridges is all fun and good humour, and strongly reminds me of the lines of the Poet-

"And sure there seem of human kind

Some born to shun the common strife;

Some for amusive tasks designed,

To sooth the various ills of life." 


\section{A TOUR IN 18:5,}

EMBRACING ACCOUNTS OF THE HOUNDS OF

$\begin{array}{ll}\text { Sir Thomas Mostri, } & \text { Colonel Berkeley, } \\ \text { The Old Berkeley, } & \text { Lord Anson, } \\ \text { Duhe of Grafton, } & \text { The Quors, } \\ \text { Duke of Beaufort, } & \text { Duke of Rutland, } \\ \text { The Warwichshire, } & \text { Mr. Nicoll. }\end{array}$

WEARIED with the rattling of flints and the cracking of wattled fences, I sent my horses to Oxford on the last day of January, and followed them the next evening. The Duke of Beaufort's hounds were out of the country; but finding Sir Thomas Mostyn's fixture was Croton Town, twenty miles from Oxford, I ordered a hunter to be led thither in the morning.

On arriving at the fixture, I found that I was once more in the land of sporting, as barouches-and-four, gigs, tired hacks, and clever-looking hunters, seemed to form a phalanx in the road. In short, at least three hundred sportsmen were assembled, and the sight was to me more than beautiful.

In Aynhoe Park, the seat of Mr. Cartwright, we found a fox, but which, like most other animals who "fare sumptuously every day," was very unwilling to quit his comfortable abode, and hung about this noble domain for at least an hour, when he got away whilst we were at check in the village, and went over that fine vale in a line for Banbury, but there was no scent to hunt him. We afterwards went very quickly off with our second fox for about twelve mintutes, when coming to some poor ploughed land all was over for the day.

Four years have passed over my head since I last saw Sir Thomas Mostyn's hounds, and they struck me as being very much 


\section{NIMROD'S HUN'TING 'TOUR}

improved. They are more powerful and better hunters; and I have no hesitation in saying, that they are exactly in the form in which they ought to be for the very severe country and the very gallant foxes they have to contend with. Their condition, also, I consider perfect.

There is one circumstance worthy of notice in Sir Thomas Mostyn's country, evidently flattering to the establishment, and that is, the steadiness with which so many of his field-not residents in Oxfordshire--adhere to his country. Colonel Broadhead is, I should think, of more than twenty years' standing, and many others nearly approaching that period. Amongst the residents also we see the same faces; and, what is agreeable to every welldisposed mind, faces but little marked by the killing hand of time. I was most happy to see Sir Henry Peyton, the Messrs. Drake, Mr. G. Lloyd, Lord Jersey, Mr. Pierrepoint, Mr. Jones, cum multis aliis too numerous to mention, all looking and going as well as when I saw them last. Sir Edward Lloyd, still well disposed to go, got disabled by a fall on the second day of his hunting, and could not come again ; but his eldest son, Mr. Mostyn Lloyd, is become quite a leading man over this difficult country. When speaking of nerve, however, we must not forget Mr. Peyton (Sir Henry's son), who has made such a capital start, and who, when a little more perfected by experience, will, by every one's account of him, make as good a performer as his father. The endowments of nature, however, like the gifts of fortune, are often hereditary; and this is only what might have been expected.

There is no small alloy in the present history of Oxfordshire; and that is, the continued indisposition of Sir Thomas Mostyn, who has been confined all this season by the gout, and consequently not able to see his hounds even one day in the field. It is natural enough to hear Tom Wingfield (his huntsman) say, he thinks it would do him good if he would only "come out and see 'em find;" but a man in health cannot dictate to a man in pain.

On the following morning I met these hounds again at Gallows Bridge, eight miles from Bicester on the Aylesbury road.. This fixture is generally voted a bad one, and therefore seldom fashionably attended. It is true there is an awkward association in the name; 



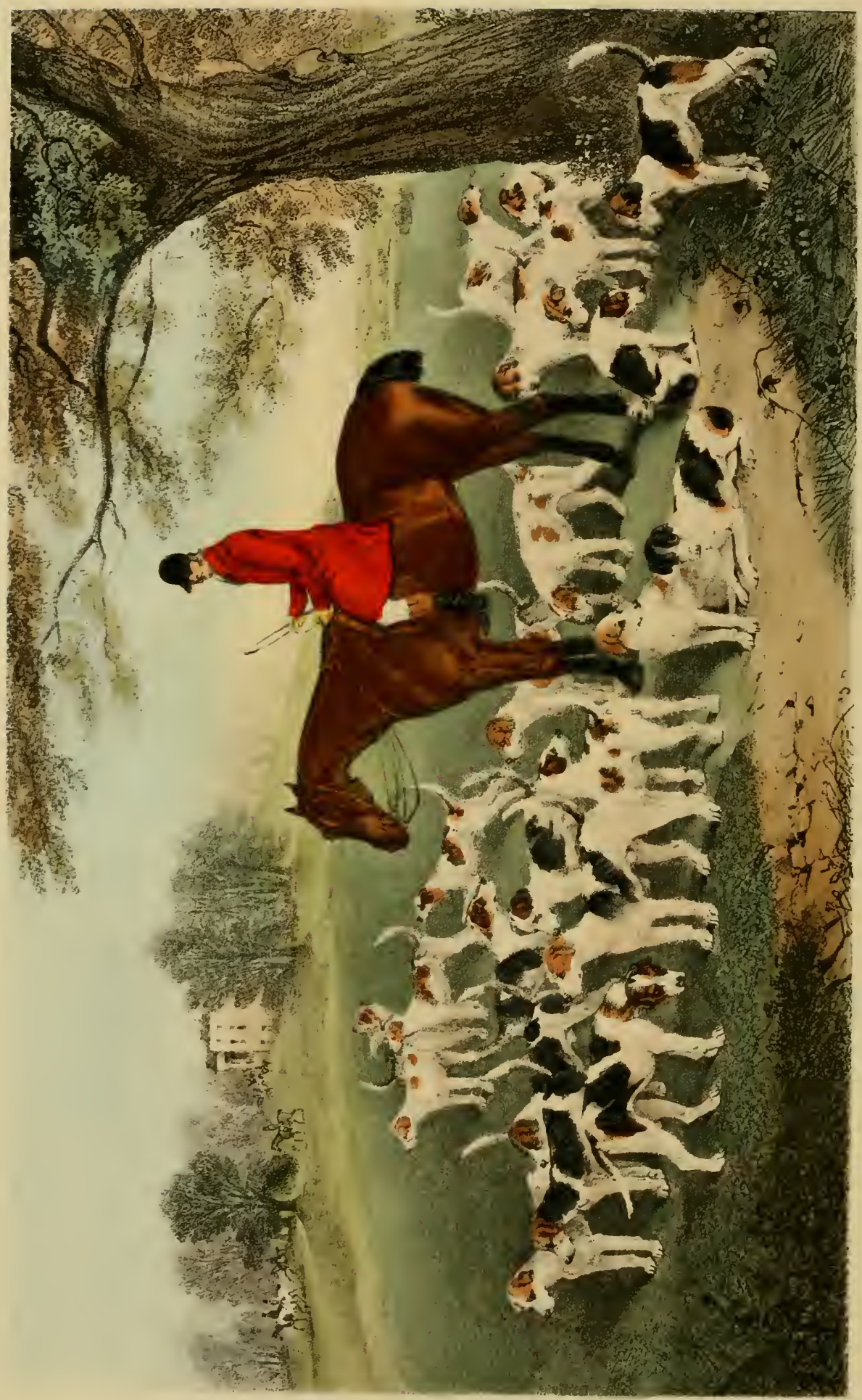




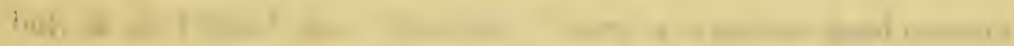

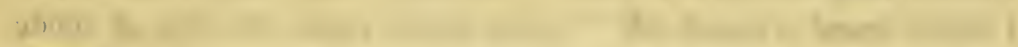

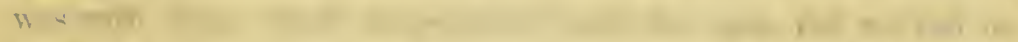

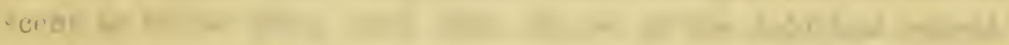

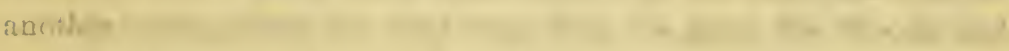

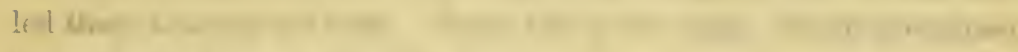

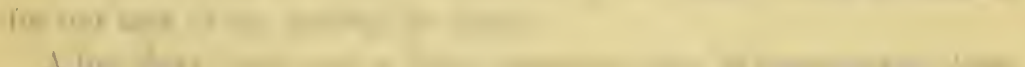

$1 \lim 31+212$ me fine

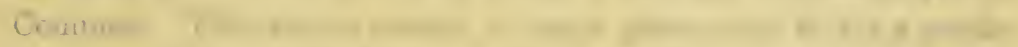

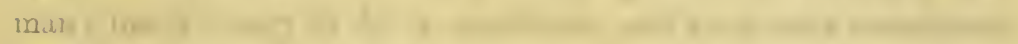

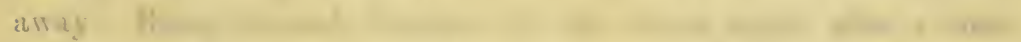

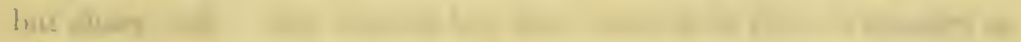

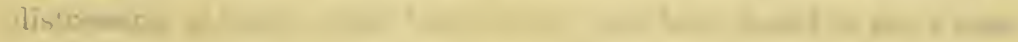

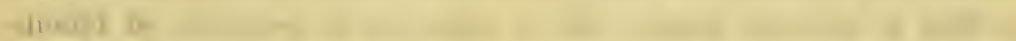

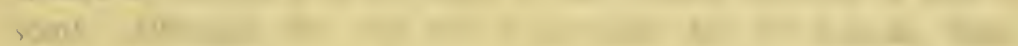
rith ar at

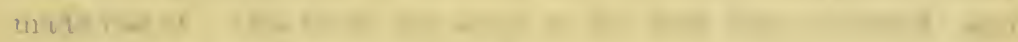

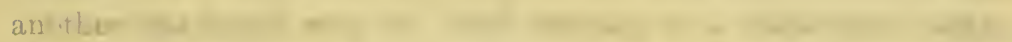
Whe $+2=0$

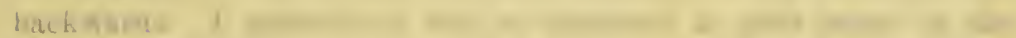
I) ike of 0 iat

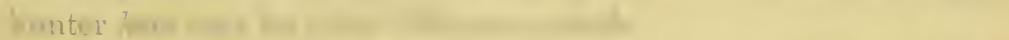

$\stackrel{\infty}{\infty}$ $\infty$

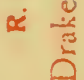
产 동 $\stackrel{0}{\approx}$

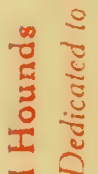
है $\infty$ (1) Or. Sian. I + [rintions a

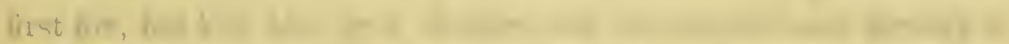

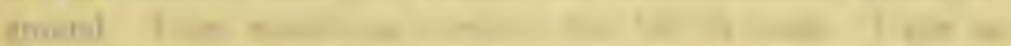

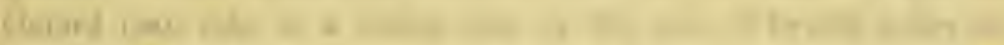

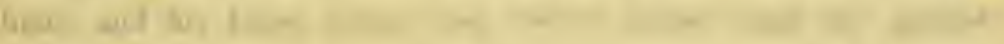

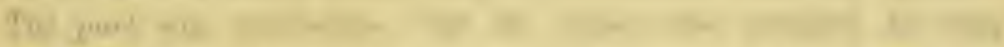

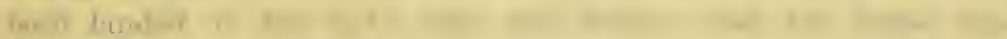

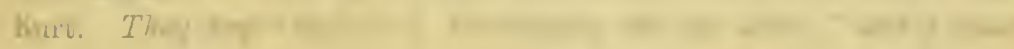
t... so so

I sav arm

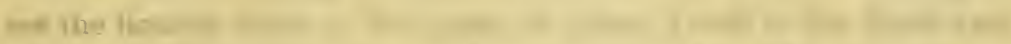

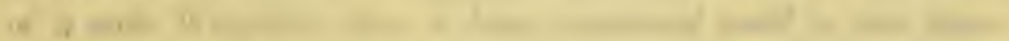

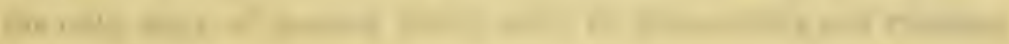




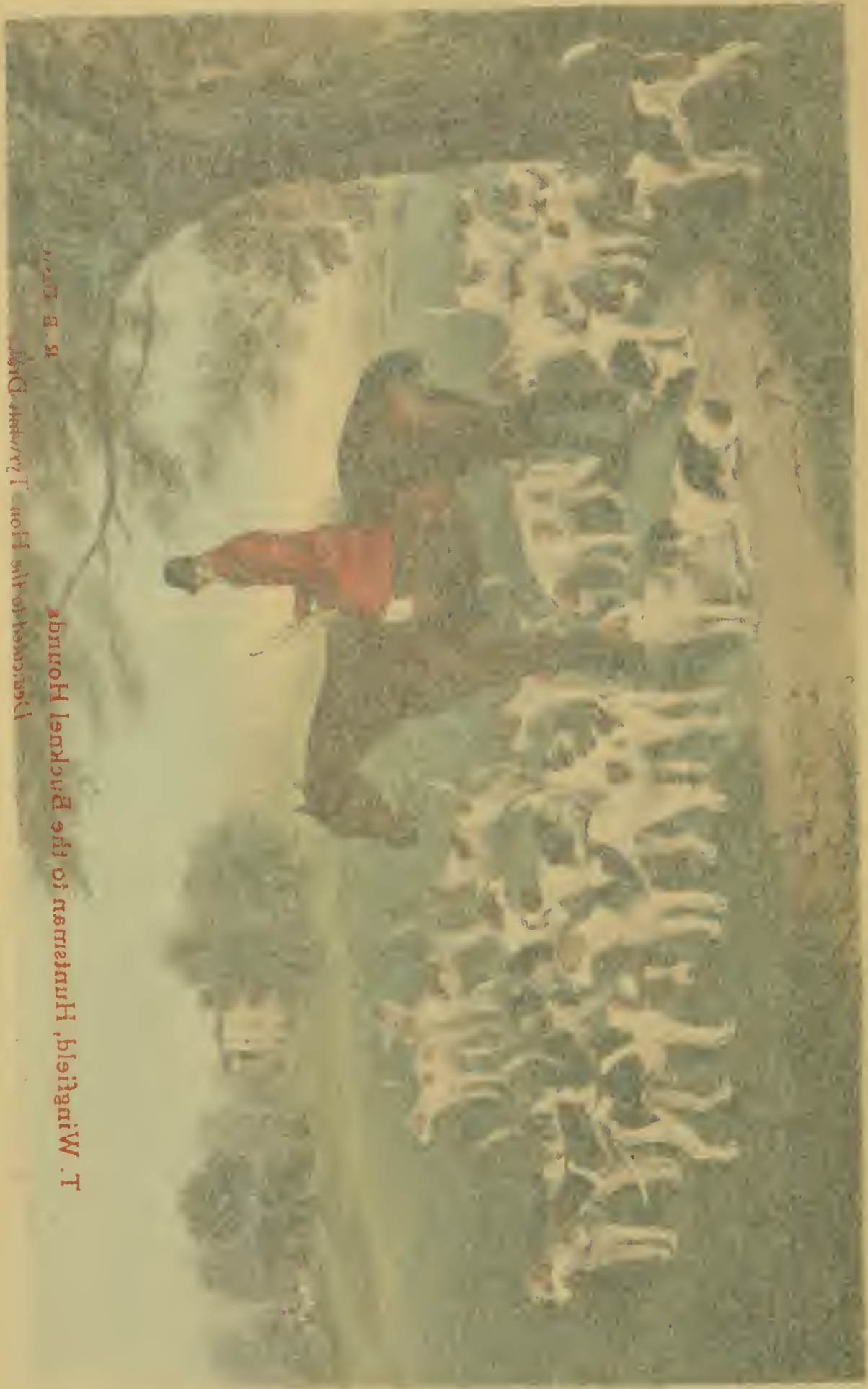




\section{SIR THOMAS MOSTYN}

but, as an Oxford man observed, "there is a gallows good comutry about it, and the foxes never hang." We found a brace whilst I was with them, which immediately faced the open, but we had no scent to follow them; and, after almost all the field had retired, another most gallant fox went away from the great See Woods, and led them a dance till dark. Snow fell in the night, which accounted for our lack of the needful for blood.

A few days' frost and a little excursion into Worcestershire kept me from hounds till the 11th, when I met Sir Thomas at Horton Common. This also is termed a rough place-not fit for a gentleman; but it is very fit for a sportsman, and a fox went immectiately away. Being pressed, however, he got home again, after a short but sharp ring. Our second fox went over Brill Hill-a country so distressing to horses that Lord Jersey has been heard to say a man should be mounted on an eagle to see hounds run over it with a scent. Although this was not a favorable day for hounds, there were strong symptoms of distress, and the lancet was pretty freely made use of. One horse lay down in the field, but recovered; and another was found with his head sticking in a black-thorn hedge, like a pheasant in a bush, neither disposed to get forwards nor backwards. I understood this is esteemed a good horse in the Duke of Beaufort's country; but a good hunter there and a good hunter here may be quite different animals.

On Saturday the 12th I turned out with Sir Thomas again at Frinkford Bridge. We had twenty-five minutes rery quick with our first fox, but lost him by a change, and our second went directly to ground. I saw something, however, that left its mark. I saw an Oxford man ride at a strong stile at the rate of twenty miles an hour, and his horse never rose twelve inches from the ground! The purl was tremendous: but the object was attained, for they both landed on the right side, and neither man nor horse was hurt. They say "there's a Providence sits up aloft;" and it must be so!

I saw another thing worthy of record on this day. Wishing to see the hounds draw a fine piece of gorse, I rode to the lower end of it with Wingfield, when a fence presented itself in our linethe only ways of passing which were by dismounting and creeping 
through a hole, or by leaping a very high timber fence. The creep was quite out of the question, as the ground was boggy, and the boots would have been "done for the day;" so three Oxford men (one of whom I understood to be a Lancashire Hornby) charged the timber one after the other. It consisted of four oaken rails, as strong as the ribs of a ship, and the taking off none of the best. "I am ten years too old for this in cold blood," said I, so went quietly round to the upper side of the covert. Notwithstanding all this nerve in "larking," with which no doubt Oxford as usual abounds, I did not see many of the young ones what I call quick and decisive in getting to their hounds-no George Foresters or young Peytons amongst them at present I fear. Lord Dorchester is very hard, and will be a workman in time, as he is strong on his horse, and afraid of nothing.

Were I to see a man, and be told he was the son of an Archbishop, I should look at him as I should look at any other man; but anything got by old Tom Oldaker must demand superior respect from me. Knowing, that one son of his hunted, and the other whipped-in the Old Berkeley hounds, I took the first opportunity of seeing them, which was on the 16th of February, at Lew Heath, three miles from Witney, in their new country, lately hunted by $\mathrm{Mr}$. Codrington. The blood of old Tom did honour to him on this dayfor never was there a finer finish to a morning's diversion; and, I am bold enough to say a finish which but few would have accomplished; for, after running our fox ten miles over a country with only a ticklish scent, Henry and Robert Oldaker killed him in seventeen hundred acres of wood-being part of Whichwood Forestwhere he stood for upwards of two hours before their hounds! By what I could learn from many who were present, there is no similar instance to this upon record, all other hounds having been stopped before, or as soon as they got into this large forest. To the credit of the Old Berkeley hounds it should be added, that they never quitted their fox for a moment, turning as short after him as harriers upon a trail; and the perseverance and activity of the men were the admiration of every one. A harder day than this for hounds and the servants cannot well be imagined.

I must hark back to the Barley-mow near Brackley in North- 
amptonshire, where I met Sir Thomas Mostyn's hounds on the 17th of February. We had ten minutes as quick as lightning, when our fox got into a drain; but, being bolted, he gave us a very pretty forty minutes, which must have cost him his life, had not by some accident Mr. Pierrepoint's earths at Imley been open, into which he was seen to crawl just before the hounds. In the course of this run Sir H. Peyton, on Lepidus, and Mr. Beecher leaped Stead Park wall, five feet four inches high, as measured by Mr. Beecher.

On Friday the 18th, I met the Duke of Grafton's hounds at Billesdon-park. We drew all the coverts there, as well as Whistley Wood, (the latter I never saw drawn blank before,) without finding a fox, and at two o'clock we went home. It was the dog pack on this day, and I found them exactly the same stamp of hound as when I saw them last-full of power, of fine symmetry, and high in condition, but quite free from unnecessary weight or lumber. I saw also little alteration in that father of huntsmen, old Tom Rose. His white locks to be sure formed a striking contrast with his black velvet cap; but they are still more at variance with anything like a white feather in the tail, for he rides to his hounds at seventy-five with all the courage and animation of youth. On the preceding Wednesday this pack had a very fine run.

On Monday the 21st, I met the Old Berkeley hounds at Cold Harbour, ten miles from Farringdon on the Malmesbury road.

The country about Cold Harbour is very fine, being chiefly grass, and nothing appears wanting to afford sport but a better show of coverts. This is, therefore, called an uncertain draw; and on this day we travelled over a large space of country very tempting to the eye, and did not find till quite late in the day, at the great Coxwell woods, within two miles of Farringdon, which are never without foxes. We soon whipped off-partly on account of the advanced hour of the day, and partly because this place was fixed on for the following Wednesday's draw.

On Tuesday the 22nd these hounds met at Ashdown Park, which they draw upon sufferance from Lord Craven and Mr. Ward. Here was almost the largest field I ever saw in my life in any country but Leicestershire. This was partly to be accounted for, by a wish to see what might be called a new pack of hounds, and partly owing to 


\section{NIMROD'S HUN'TING TOUR}

the fixture being within reach of Mr. Ward's and Sir John Cope's Hunts, as also of the Oxford sportsmen. No' small share of science was present.

We found our fox immediately, and he afforded us a capital run. After taking a turn or two in what is called "the Kennel Wood," he broke at the upper end of it over the Downs, pointing for Celbourn Chase Woods. Being headed, which caused a trifling check, he turned to the left by Baydon village, along the ridge of the woodlands to Ringwood; across the inclosures to Mimbury Banks; over the earths by Mimbury House for White Hill; and was killed at Soleby farm, in the parish of Chilton, about three miles from Hungerford, and twelve from the place where he was found.

The hounds having slipped away over the Downs with their fox when they first found him, several of the horses were overmarked in their pace to catch them, which accounted for the many falls I saw as soon as we entered the enclosures, although the fences were quite easy. The finish also was extremely pretty, having run from șcent to view-killing in an open field. A curious and somewhat amusing scene at this time presented itself. Two farmers, anxious for the honours of the day, rode into the midst of the pack, quite regardless of the hounds, and began to contend for the brush. Mr. Combe followed them, and I thought another brush, if not another whowhoop, would have been the consequence. Although no great difficulties presented themselves, this day's sport was highly creditable to the Oldakers and their hounds, and a great treat to those who saw it.

On the following day we met at Uffingdon Wood, a beautiful place for a find. Above it is a range of downs, and below it is as fine a vale as can be found in Leicestershire or in any other country. Over this vale our fox took, and we killed him after a bad beginning, but an excellent finish-in all thirty-seven minutes. Uffingdon Wood can never be without foxes so long as a farmer and his wife by the name of Spackman are in existence-for they feed them as they would part of the stock on their farm. The worthy dame was this day in great alarm lest we should kill her vixen fox, as she called it, which I fear we were guilty of doing; but there is no help for such things in the middle of the month of February. 
There was a person riding well to the hounds during this run, who is deserving of notice, not only in honour of himself, but of the horse he rode. His name is Bob Westall, many years huntsman to the Highworth Harriers; and his horse, or rather galloway, was purchased out of the Wantage coach in the year 1805-now twenty years ago! Such is the natural goodness of this well-shaped little animal-who is quite a Harlequin at his fences-that condition has always been considered a superfluous appendage, and he has been taken to the field in almost a state of nature. All the preparation he had for a day's hunting for several years was a blast from Bob's horn, which brought him to the gate to be saddled. He is one of Nature's prodigies; and she has not been very unkind to Bob, for he has got some brains in his head, and knows well how to get to hounds.

Having never seen it when Mr. Codrington hunted it, I was quite unconscious that I was living within fifty miles of so fine a country as the one I have been speaking of. Consisting chiefly of dairy farms, there is a very large proportion of grass, of course favourable to scent; and though the ground is apt to be deep, yet the fences are practicable, and there is nothing to prevent a good hunter being with hounds. Some parts of it resemble Leicestershire: there is the large grass field, the strong ox fence, the bridle road, the guide post, the windmill, and here and there a good rasping brook. One brook was pointed out to me, over which Mr. Barry Price once shewed the whole field "the trick" upon his famous horse Monarchy, though then riding eighteen stone.

The Old Berkeley country exceeds all others with which I am acquainted in extent. It begius at Scratch Wood, seven miles from. London, and extends without any interruption to Cirencester in Gloucestershire, upwards of eighty miles.

The subscription to the Old Berkeley hounds does not exceed 700l. per annum-the remainder being made up by Mr. Harvey Combe and Mr. Marjoribanks. Mr. Tilbury finds six hunters and a hack for the Oldaker's for a given annual sum; but they are never short of a horse, as Mr. Combe has always a good stud.

Having seen Mr. Combe three days in the field, and spent three 
evenings with him in society, I may be allowed to pass some opinion on him as a sportsman, a companion, and a gentleman.

For the first of the honourable qualifications, nature has endowed $\mathrm{Mr}$. Combe with one very great requisite for excellence, and that is, an activity of mind and body which appear to have no bounds. Of a robust frame, composed chiefly of muscle, he is quite in the form for hard work, and no exercise fatigues him. He is said to travel more miles after his hounds than any other man in England, Mr. Osbaldeston excepted; and either before or after hunting mile-stones are no object with him. When by night, he of course travels in his carriage; but at other times he is remarkable for getting across a country in his gig, in which he performs great distances in a short space of time, by availing himself of relays of horses. Over a country also, $\mathrm{Mr}$. Combe is always in his place, and is allowed to be a good judge of hunting, which indeed his experience in, and his devotion to, the sport cannot fail to have made him. In the field he is like most other masters of hounds-in high good humour when things go prosperously; that is to say, when he finds a fox, has a good scent, and kills after a good r'un; and he bears adversity full as well as the rest of them. Both himself and Mr. Marjoribanks are, I understand, very popular in their new country, and doubtless will continue to be so. They are kind and obliging to everybody; and, as managers of fox-hounds, one very good quality attends them, they have pretty good accounts at their bankers!

$\mathrm{Mr}$. Combe is as straight-forward in the evening as he is in the morning; he is one of the best companions I ever sat down with in my life, full of animation and anecdote, and certainly not belonging to that class of beings, who, old Horace tells us, are only sent into this world to consume the fruits thereof; for he is a most active member of society in every sense of the word.

There is no peculiar distinctive character in the Old Berkeley pack, which no doubt is to be attributed to Tom Oldaker not having bred hounds for many year's past, but trusted to drafts to keep up his kennel. His son, however, is pursuing a different plan: he will soon find the benefit of it; and doubtless some excellent milk-walks will he found in the fine dairy districts of Berkshire and Wiltshire. Mr. Combe has lately added to his kennel by purchasing Sir Jacob 


\section{SIR THOMAS MOSTYN}

Astley's hounds-there being no room in Norfolk for foxes and pheasants, consequently no need of fox-hounds!

The Old Berkeley hounds, however, have one characteristic, and that by no means to be despised: they are very steady from riot, very true to the line, and, with a scent, pretty sure of their fox. Although I think Bob Oldaker is himself as good as one and a half of many whippers-in I have seen, yet the other half would not be amiss - not merely for the look of the thing (although fox-hounds certainly do not look complete without two whippers-in)-but because one whipper-in ought always to be with the huntsman to turn his pack to him when at fault, whilst the other is bringing up the tail-hounds. I saw no fault with the condition of the Old Berkeley hounds, taking into consideration the great extent of country they travel over, the frequent change of kennel, and the very wet weather they had so long been exposed to.

On Thursday the 24th, I took my leave of Mr. Combe, and met Sir Thomas Mostyn's hounds at Stratton Ardley in the Bicester country. We did not find till we got to Gravenhill, where a dodging fox kept us a full hour in the covert, and then got to ground in a stone quarry, before he had run three fields. We found again, and had two of the sharpest bursts of the year. At the end of the second, seven of us leaped Lord Jersey's park-wall *-Mr. Henry Kingscote going first upon "the Baby"-only serenteen hands high. I looked with admiration at the pack of hounds Tom Wingfield brought to covert on this day, nor shall I very soon forget the pace they went, or the quickness with which they turned to their fox. At one period it was evident that two bitches had the speed of the whole pack.

The Duke of Beaufort's hounds being now returned from their home country, I met them on the 25th at Heythorpe, which is the usual place of their meeting on the first day. It is well chosen for a show-day, as foxes seldom quit the park, and the rides in and about it are very pleasant. Contrary to custom, however, on this day two foxes went away, but we did nothing worth

* Different accounts having been given of the height of this wall, I wrote to Mr. Deakins of Bicester for the particulars. His answer is-"The Earl of Jersey's park wall, on the Oxford road, is nearly seven feet high; it is mortar in the middle and the top, and is what is called a fast wall. The Kidlington side (where we leaped it) is about five feet and a half high." 
speaking of. The great treat of the day was a sight of this celebrated pack, whose fame has long since reached every corner of the sporting world.

Experience is a great teacher: it is a professor that neither reasons nor debates, but carries conviction and proof, which no one but a madman can dispute. In the Duke of Beaufort's kennel, then, we have it in full force and virtue; and the benefit of Philip Payne's experience-the result of twenty-three years-exhibits itself to the admiration of every one; as he is allowed, on all hands, to have more skill in the breeding hounds than any other huntsman of his day. Those who have observed him would almost imagine that he were (what Mr. Beckford, perhaps justly, says a huntsman has no occasion to be) a man of letters and a philosopher; for more years than he has spent in it have failed making others (and men of talent too) proficient in his art; and he may certainly be said to have reached perfection. One would almost imagine that he had looked into books, and found, that although the arts of man vary in every age and in every nation, the arts of animals are different. They claim neither invention nor improvement; but, like the bee, they have their art by inspiration. They have the same talents and the same qualities, but differ in the manner of possessing them; and Providence seems to have advanced to the very verge of possibility in the extent of the instinct they possess.

Philip Payne, however, I have reason to believe, owes his honours to Heaven and to himself; and his observation alone has taught him, that for excellence in animals we have only to breed from those which shew the peculiar qualities we require; and which, when combined with strength, activity, and symmetry-which we call beauty-produce the perfect hound. On this principle then, Philip has travelled much abroad for his blood, and the crosses he has made have done infinite credit to his judgment. He has much of very indifferent country to hunt over; and the pace his hounds run over it, and the head they carry, plainly indicate that he has at last acquired what he sought for.

It is said of Time that he is the only winged personage that cannot fly backwards, and that his speed is but hurrying us to the grave. It is to be wished, however, for the sake of the breed of fox-hounds, 
that for once he could be persuaded to retrace his flight, and make Philip "young and lusty as an eagle." There are, unfortunately for him, other duties in a huntsman, which it is to be lamented that he is scarcely able to perform. An epicure cannot judge of a cook by the palate of another; neither can a musician give an opinion of a concert unless he hears the music. We can neither taste, hear, feel, nor see by proxy; neither can a huntsman tell what his hounds have been doing unless he has been within sight of them himself. Thus the painter in Sir Philip Sydney went into the hottest of the battle to enable him to paint it correctly.

It will of course be anticipated that Philip cannot ride up to his hounds, and therefore cannot do justice to what is otherwise so complete. This I am given to understand is unfortunately the case ; and although Philip did some clever things this season, yet some discontent, as may be expected, has been expressed on the subject. Those gentlemen who keep hunters on each side of his Grace's country have not too much hunting for their trouble; and when they do get it they are unwilling to throw a chance away. It is indeed to be lamented that so fine a pack of hounds should not have every advantage that can be given them, but the question is, what is to be done? for although he is supposed to have saved some money, yet so deservedly respected is Philip by all who have hunted with him, no one would wish to see him displaced, if they thought he would be a sufferer by it. Sportsmen have ever shewn a kind feeling towards sportsmen, whatever may be the grade between them ; and nothing but a Stoic could have sung-

\footnotetext{
"Life's but a feast, and when we die, Horace would say if he were byFriend, thou hast eat and drunk enough, 'Tis time now to be marching off. Thou, like a well-fed guest, depart With cheerful look, and ease at heart; Bid all your friends good night, and say, You've done the bus'ness of the day."
}

There is nothing more striking in the Duke of Beaufort's hounds than the brilliancy of their condition. This is in great part to be attributed to Philip Payne's good feeding, although the general cleanliness of the country they have to travel over has no small share in it; and it 


\section{NIMROD'S HUN'TING TOUR}

is an amazing set off to the appearance of them. One week's travelling through the dirty lanes of Leicestershire, or a good day's sport in the Widmerpool country, would take off much of the polish, and some of the beauty. It is not a little singular, that the names of the two favourite studhounds in this celebrated pack should be Wellington and Waterloo! and their blood is much in request.

On Friday the 25th, met the Duke at Sarsgrove, three miles from Chipping Norton on the Stowe Road-reckoned a good fixture, but a bad place to get away from with hounds. This being the Duke's first appearance at a good covert-added to its not being a hunting day with the Warwickshire-a very large field were assembled. Our fox took, what might have been supposed to have been, the most favourable country for a scent-running over some low meadow's by the side of a brook; but we had scarcely enough to keep us out of a trot. Since I have been a sportsman, however, I never saw hounds so ridden over, and pressed upon as they were on this day; and even the Duke's temper would not have stood it much longer. Being on a white horse, and therefore conspicuous, I pulled up into a walk, and saw them get up to their fox by the assistance of a halloo, and kill him after a pretty little ring.

We found another fox on this day, which having but three legs, we killed in half a mile, and here our sport ended.

"You have a new performer in Oxfordshire since I was here last," said I one day to Sir Henry Peyton_-"Mr. Webb."_-"Very good indeed," replied this candid and first-rate judge; "he rides straight and well to hounds." Mr. Webb resided till lately in Hertfordshire, and was a member of the Old Berkeley Hunt, but now lives at Kiddington House. Mr. Webb also knows how to live, as well as to ride, to which I can bear ample testimony; and he must be considered no small acquisition to that part of the country.

Monday the 28th, met the Warwickshire at Idlecote, three miles from Shipston-upon-Stour. This has always been esteemed a good fixture, and I have seen many pretty things from it. It is, however, too near the Braills Hills to be certain of sport; and on this day our fox seemed to seek the very worst part of the country, which got me into a scrape with some of Sir Thomas Mostyn's 


\section{DUKE OF BEAUFOR'T}

men for telling them it was a good place, and thereby inducing them to come. We did nothing.

Finding myself so young and vigorous, from seven days' foxhunting out of eight, and full two hundred miles of road work, I went twenty miles on this evening to dine at Leamington with Sir Loftus Otway, uncle to Mr. Otway Cave, of Stanford Hall in Leicestershire, who has a good stud of hunters at Leicester in the winter, and rides well over a country. When I entered his room, and saw six or eight gentlemen dressed in scarlet coats, and black waistcoats,* I fancied myself gone back to those days of Elysium when Mr. Corbet hunted the Warwickshire country. There is, however, it appears, a club formed at Leamington, composed of hunting men, at the last assembly of which no less than six-andtwenty sat down to dinner at Copps' hotel arrayed in this sporting garb. Leamington, we must recollect, is very well situated for hounds; it commands all the best part of Warwickshire, a great many of Lord Anson's, a few of Sir Thomas Mostyn's, and one or two of Mr. Musters' fixtures.

On Friday the 4th of March, I met the Duke of Beaufort's hounds at Lyddell Farm, three miles from Woodstock. Owing to the miscarriage of a letter, I had no horse at the covert, so was only a looker-on. I saw, however, something that surprised me; I saw the hounds go away with their fox from a beautiful bit of gorse, and every man had a fair start. I saw about a dozen men riding well with the hounds, and "all the rest," as Colonel O'Kelly said, "nowhere." Until they came to the brook (which I saw Captain Evans and Mr. Webb charge side by side), there was not a fence to stop a woman on a pony ; yet, strange to say, the field were dispersed in all directions. I saw one man in scarlet turn away to the left, when the hounds were going to the right, and gallop along a newlystoned road. When I heard the clattering of his horse, I exclaimed, "Surely you must be an apprentice to M'Adam!" The fox was soon lost, and the sport over for the day.

On Saturday the 5th, I met the Warwickshire at Whichford Wood, five miles from Shipston on the road to Stratford-on-Avon. We

\footnotetext{
* The uniform of Mr. Corbet's Hunt.
} 
did nothing with our first fox, but had a sharp thing with our second, and lost him from want of the needful. We went at a quick pace up one of those hills with which this part of the country abounds; and when they came to the top, the hounds threw up, upon the line from want of wind, and the fox went on and beat them.

After hunting this day, I proceeded into Warwickshire for a week, and took up my quarters at Alscot Park, the fine seat of Mr. West.

On Tuesday the 8th, we met at Alveston pastures, two miles from Stratford-on-Avon, but had nothing worth speaking of ; and on Thursday, at Wolford Wood, with about the same success. On Friday, however, there was a fine day's sport with the Duke of Beaufort, from Sanford.

This fox was found at Ilbury gorse, and, crossing the Deddington road, went close to Adderbury town-thirty-five minutes, very fast, to the first short check; and then forty minutes more at a quick hunting pace, when a longer check ensued. The hounds, however, hunted up to him to within a mile and a half of Wroxton Abbey (Lord Guildford's), when they set to, and ran into him at a small gorse just outside the park-in all, one hour and forty minutes.

The country this fox ran over, and particularly in the neighbourhood of Banbury, was heavy, and the fences very strong. Sanford, however, is the best appointment the Duke has in Oxfordshire, because it affords a chance of the hounds running over this fine vale, which is worth a week over many parts of the Duke's bills.

Had this run been a little more straight, very few would have seen it; and it was a most creditable day to the hounds. Some of the Mostyn men were out, and Mr. Mostyn Lloyd and the elder Mr. Kingcote went well; as also Messrs. Holloway, Webb, Molony, and some others of the Duke's. Sir Henry Peyton's mare was ill, and did not go three fields; and Mr. Foley's horse dropped down dead at the end of the first quarter of an hour, having broken a bloodvessel. An Oxford man, whose name I could not learn, charged most gallantly in this run, on one of Sadler's horses, and exhibited some excellent bull-finching. Philip Payne came up at the finish, and shed tears of joy at the excellence displayed by his pack.

On Saturday the 12th, I met Colonel Berkeley's hounds 
Foxcote. Four seasons had passed away since I saw them last, but found them very much in their usual form-very business-like looking animals, and (considering I had so lately seen the Duke of Beaufort's) appearing in very fair condition. We had no sport on this day, but in the course of the season this pack have had more than their share; and a day or two before I met them, they had done what is worthy of record-they divided, and each lot killed their fox at the end of ten miles. I have also been informed that they had several good runs in the dry weather; and on April 25th, (their last day) they ran a fox two hours, and killed.

The Colonel not being "before time" - as we call it on the roadI had a good opportunity of looking over his pack. On my observing a hound called Selim, I said to a friend who stood near me, that I was certain he was of Mr. Ward's sort. "No, he is not," said one of the whippers-in; "he was bred by Lord Darlington."-" Yes, he is," said the other, "he is got by Mr. Ward's Sentinel." The huntsman, William Lepper-late head whipper-in to Sir Thomas Mostyn-was absent from illness; and one of the whippers-in had liked to have been absent also, as he had a very narrow escape for his life, and all from want of the finger. He put his horse gallantly enough at a strong rail with a ditch on the other side, and, instead of letting him take his own way, he gave him what is called "a lift" with the curb bridle, which very nearly lifted his rider into the realms above. The horse got entangled in the rail, threw him over his head, and then leaped upon him-avoiding him as much as lay in his power. One of his feet, however, struck him on the head, and the blood flowed copiously. I immediately got to him, and examined the place, but finding the eut in an oblique direction, I assured him he had nothing to fear; so he mounted his horse, and went on. Very few whippers-in are qualified by nature or art to ride in curb bridles.

On Sunday the 13th, I bade adieu to Alscot, and went to Mr. John Lucy's to dinner, where I was asked to meet two or three sporting friends, and to be near the Warwickshire on Monday. I had, however, had enough of the Warwickshire, being convineed that from some cause-bad meal, I presume-they were incapable of shewing anything worth putting myself to inconvenience for, so sent 
my hunters straight on the road for their place of destination. It so happened, however, that they had a pretty thing of twenty-five minutes, but without catching their fox.

The Varwickshire hounds had, last season, a glorious succession of sport; but to any one who knows what hounds should be, it is obvious that, in the condition they have lately been, such another series of sport was not upon the cards-even with Jack Wood to hunt them; and I very much admire Wood's method with his hounds. Like Harlequin's snuff, however-collected by a pinch out of every man's box - the Warwickshire are of all sorts and sizes, and a very coarse lot to look at; but they are particularly handy and steady, and, when going at a certain pace, stoop well to their game; but further this deponent sayeth not. No animal can do what we require him to do, unless he be in a condition to do it. The Warwickshire hounds have also laboured under another disadvantage. They have not been able, until last year, to spare any of their own bitches to breed from, so have been entirely at the mercy of other kennels. In every other respect, they may be said to have had more than their share of advantages, Mr. Shirley having done the thing with a very liberal hand.

It has hitherto been my intention to continue my account of this country (Warwickshire), as a hunting country, from the time of Mr. Corbet's relinquishing it to the end of Lord Middleton's reign; but there are so many circumstances to be alluded to, which I could not touch upon with pleasure, that I had better perhaps not allude to them at all. In some respects Lord Middleton was everything that could be wished for at the head of a pack of fox-hounds-he was rich, munificent, and even profuse in his expenses attending them, and he was by some allowed to be a sportsman : in others, he was ill calculated for the post. He came, it is true, after " a well-graced actor;" but, instead of being greeted by the country and hailed with applause, there was a something about him that threw a mist over the land, which not the bright effulgence of his gold could dispel ; and $I$ have heard of more fun and merriment at a Welch funeral than I ever saw by a covert's side in Warwickshire in his Lordship's time. There is only one way of hunting a country; and that was not the way Lord Middleton chose! 


\section{THE WARWICKSHIRE}

During my visit to Mr. John Lucy, one circumstance was mentioned as connected with Lord Middleton, which may be properly introduced; and that was, what is called "the Ditchley run," in the year 1816, in which Mr. John Lucy himself performed so conspicuous a part. The following is about the pith of the story.

We found a fox early in the day, and ran him very sharply for about a quarter of an hour. We found again, and the history of this run is curious. Our fox picked the severest country he could find; and after rumning some miles over a deep and strong vale, he faced the Oxfordshire hills, and got to ground at Ditchley-ten miles from Oxford, and upwards of seventeen from where he was foundthe hounds having only had two momentary checks. The most extraordinary part of this story is yet to come: there were at least one hundred and fifty persons present when the fox was found; and among them a sprinkling of Meltonians. Every man got a fair start; but, strange to say, Mr. John Lucy was the only man who went with the hounds to the end. The two next best were Lord Molyneux, upon Oxford, and the late Sir Charles Mordaunt, on a horse he had just given four hundred and fifty guineas for, but he died the next day. Not one of Lord Middleton's men-capitally mounted as they generally were-could ever get within reach of their hounds, and they were left in the Duke of Beaufort's kennel for the night.

The pace Lord Middleton's hounds went through the whole of this run (the severity of the country being also taken into consideration) exceeds anything that I had before seen or hear'd of, or that I have ever seen since; and which only hounds in the very best condition could have shewn. During the run it hailed and rained, with a cutting north-east wind.

As Mr. John Lucy has cut so conspicuous a figure in this part of my story, it may not be amiss to say he is the younger and only brother of George Lucy, of Charlecote in the county of Warwick, and M.P. for Fowey, lineally descended from the well-known Sir Thomas Lucy, to whom we are indebted for the treasure of Shakspeare's plays; and by whom the noble mansion of Charlecote was built in the first year of Elizabeth. This family boasts of great antiquity-going regularly back to William De Lucy, a Knight in 
the reign of Henry the Third, whose family were entrusted with high and important offices; and still further back to Walter, son of Thurstane De Charlecote, to whom the village of Charlecote was granted by Henry De Montford, and the grant confirmed by the First Henry. A gentleman by the name of Knightley was of our party at Mr. Lucy's on that day, whose family have been also long seated in this fine county. The name of the mansion-house is Offchurch, so called from having been the residence of King Offa; but the Knightleys have possessed the estate since the time of Harry the Eighth. Mr. Knightley has not long left the University of Oxford, where he acquired a taste for fox-hunting, which, it is to be hoped, will only leave him with his last breath.

When speaking of pedigrees-not of horses, but of men, which is something unusual for me-we should not overlook the late master of the Warwickshire, Mr. Shirley of Eatington, whose family possessed that lordship before the Norman Conquest. When speaking of Eatington, Dugdale * observes, that it is " the only place in this county that glories in an uninterrupted succession of its owners for so long a tract of time." High breeding, however, generally tells, whether in a master of fox-hounds or over the Beacon, and Mr. Shirley does eredit to his ancestry. He has given the most universal satisfaction during the time he has kept the hounds, which has been acknowledged in a manner most gratifying to his feelings; and his motive for relinquishing them-which I had from his own lips-is creảitable to his feelings as a man. "We cannot do everything," said he: "I am building a house on my property in Ireland, where I mean to reside part of the year, and the hounds would be much in my way."

As is frequently the case, there was no little difficulty in procuring a substitute for Mr. Shirley in the management of the Warwickshire hounds. Mr. Payne, of Selby in Northamptonshire, first offered himself; and his terms were very handsome. He asked for no subscription, and moreover agreed to bring twenty-five couples of hounds with him to the kennel, and to leave them behind him if he quitted the country. This offer, however, was refused; and, as far 


\section{THE WARWICKSHIRE}

as I could learn, the following were among the reasons given for the refusal. It was about this time reported that $\mathrm{Mr}$. Musters was likely to give up Northamptonshire; in which case Mr. Payne declared it to be his intention to keep fox-hounds at Selby. He would therefore only engage to hunt Warwickshire until his own country might become vacant.

Mr. Robert Fellowes, of Talton, (a very excellent sportsman,) offered to take the Warwickshire country, with a subscription of 2400l. per annum, 2000l. of which was almost instantly subscribed; but here an objection arose. It was insisted upon by the subscribers, that Mr. Fellowes should continue the use of the Butlers' Marson kennel, which he positively refused to do. In the first place, it was seven miles from his own house-a circumstance which would render it impossible for him to do justice to the subscribers by paying that attention to the hounds which it was his wish to do; and in the next, he knew from his own observation, and from what Wood had told him, that it was in many respects a very bad situation for hounds.

Wood, I was informed, gave notice to quit as soon as he heard Mr. Fellowes was not to have the management of the Warwickshire hounds. It appears, however, that he is hired to Mr. Hay as kennel huntsman-having, as report speaks, signified his intention of not hunting hounds again. Although a beautiful horseman, with almost the best hand on his horse I ever saw, he has had a great many falls ; and, according to his old fellow-servant Waddington's account of him, has broken a leg, a thigh, and his collar-bone in the service. It is also reported that Wood has had some money left him, and is in very comfortable circumstances, which all sportsmen will rejoice at.

From Mr. Lucy's I proceeded by invitation from Mr. Edmund Peel to spend a day or two at his house, for the purpose of seeing Lord Anson's hounds, which met the next morning at his door.

Lord Anson's Atherstone country is very well known to me. I hunted in it in Mr. Adderley's time ; I hunted in it in Lord Vernon's time, as also with Sir Bellingham Graham; and I now pronounce it, with the acquisition which Lord Anson has received to it, to bebarring the Duke of Rutland's and the Quorn-the best country I 
ever rode over. It all holds a good scent; is easy and gentlemanlike to get across; and the Leicestershire part of it is very fine indeed.

I am making myself an old sportsman when I talk of hunting in the Atherstone country with Mr. Adderley and Lord Vernon, as it is full twenty years ago. There was, however, a good deal of fun going on in those days, and some very hard riding. There were-I shall call them by their proper names-(Propria quæ maribus tribuuntur mascula dicas; ut sunt Divorum), or at least by the names by which they were then best known; there were, I say-Billy Breton-The. (Theophilus) Levet, Tom Boultbee, Ned Croxall (now going), and his father (a gallant old sportsman), Sambrook Anson, Ned Monday, Flozer of Hints, and several others whom I cannot now call to mind-all hard and good riders to hounds-not forgetting little Burton, the tanner of Nuneaton (on his pony), better known by the name of the Paroquet, who proved himself once or twice such a teaser to Tom Smith over Leicestershire. "Damn that fellow," said he one day when he was following him close at his heels, "but now I will stop him;" so charging a most tremendous timber fence, he would in all probability have made his words good, had not his horse broken the top rail, and the Paroquet flew over.

Amongst those I have mentioned, Levet, Boultbee, and Flozer rode very heavy, but all particularly good horsemen; and it would have taken one of our very first-rate ones to have beaten Levet upon Banker, or Boultbee on anything in his stable. The last mentioned sportsman is brother to Mr. Charles Boultbee, the best screw-driver * in England.

I never saw harder riding in my life than on one day when Lord Vernon hunted the Atherstone country, and the hounds met at Bosworth. There were a good many Quornites in the field; and as his Lordship's colour was orange, and the other red, the esprit de corps was aroused up, and the struggle between them was tremendous. My Lord Foley was then going well in Leicestershire, and I shall never forget seeing him charge a very bad place, into a

* This is somewhat technical, and wants an explanation. A lame or very bad horse is called "a screw." I really bolieve Mr. C. B. is the best man in England on a horse of that description. 


\section{LORD ANSON}

road, without ever stopping to look at it, although he saw several hard riders turn away from it. It was a very great drop, from a high fence into a green lane, full of very deep ruts-partly overgrown with gorse, but he landed well, and went on.

A great deal of amusement was afforded in these days by my old friend Billy Breton. He resided at Oldbury, the seat of Mr. Oakover, of coaching celebrity, where he had a few good hunters in his stable, and what we call "a fair sort of a scratch team " on the road. The most amusing part, however, of my old friend (in whose house I spent many a happy day) was, the active part he took with Mr. Adderley's hounds-carrying a horn to his saddle, and displaying no small share of science in the field. I shall never forget his giving Sam Lawley, Lord Vernon's huntsman, the different blasts on the horn for his future instruction and improvement.

Mr. Adderley always put me in mind of Mr. Allworthy. He was, like him, one of the most amiable and mild-mannered Christians that ever lived in the world, but no more fit to be a master of foxhounds than he was fit to be a bishop-not indeed that he would not have made an excellent bishop, for he spoke ill of no man, and did by his neighbour what he wished his neighbour should do by him; and therein, I believe, consists the whole moral law. The following anecdote is quite in character with what I have said of this excellent old gentleman :-

Before that celebrated huntsman Mr. Shaw went to live with Sir Thomas Mostyn, and not long after he had left the Earl of Moira, he heard that a $\mathrm{Mr}$. Adderley (not knowing anything about him) was in want of a huntsman for his fox-hounds. Shaw was hired by proxy for the purpose, and arrived at his house on a Sunday evening. At nine o'clock the bell rang for prayers. Shaw went into chapel, and behaved with great propriety; but the next morning he was nowhere to be found. Now whether it was that there was no allowance for praying in his wages, or whether, as is the case with many, Shaw might have been of opinion that " prayers are but words, and words but wind," I will not take upon myself to determine; but so it was-he had packed up his saddle-bags, and returned to the place from which he came. Mr. Adderley himself related this anecdote to me-humorously adding, that although he supposed he had lost a 


\section{NIMROD'S HUN'TING 'TOUR}

very first-rate huntsman, yet he was not at all surprised at his sudden departure, as he had lived long enough with my Lord Moira to know how to take French leave.

I am always anxious to relate anything that redounds to the credit of a sportsman, and therefore, take this opportunity of mentioning one of the many liberal acts of my Lord Middleton when he hunted the Warwickshire country. Shaw then resided at Stratford-on-Avon, where, from the fruits of his savings in the various fine situations he had held, he had a very comfortable house, and two good hunters in his stable. If, however, at any time, his work was too much for his horses, he had nothing to do but to send word to his Lordship's groom at night, and there was always one at the covert's side for him in the morning. As a proof of his good sense, I never heard Shaw make but one remark during the many times I saw him in the field with Lord Middleton's hounds. "That's all flash," said he aloud, one day when he saw the hounds set to run without, as he thought, knowing why; and he was right.

Before I quit the pleasing recollections of what happened in the days I have been speaking of, it may not be amiss to observe, that Lord Vernon hunted this country in very excellent style, and had usually his share of sport. Sam Lawley was his huntsman; and Harry Jackson-afterwards many years huntsman to Lord Middleton -was his head whipper-in. As a proof, however, of the effective manner in which his Lordship mounted his servants with his hounds, I should mention that Mr. Levet offered him nine hundred guineas for the three Sam Lawley rode-namely, John o'Gaunt, Hercules, and another. Sam Lawley has retired from the sporting world, having a large farm under his late noble master.

On Friday Lord Anson's hounds met at Mr. Edmund Peel's door. Mr. Peel is a very hard rider; and, according to Robert Thurlow's account of him, possesses one very desirable property. "He rides as near to hounds," says Robert, "as any man need do, but never rides over them. If every gentleman," continued Robert, "was to ride like Mr. Peel, hounds would not so often lose their foxes, and we should have much better sport." Robert having lived some year's as whipper-in with Mr. T. Smith in Leicestershire and 


\section{I.ORD ANSON}

Lincolnshire, must be a pretty good judge of what riding over hounds produces.

Robert was one of the two unfortunate servants of Lord Anson who came in contact with each other two years ago at Lichfield when clearing the course at the Anson Hunt races; by which dreadful occurrence his leg was broken, the same leg which was broken in two places the year before in a fall with Lord Anson's hounds. When he lived with Mr. Smith, he not only whipped-in his hounds in the winter, but occupied several posts of honour in the summer; and among which-though I forget the rest-were cook and boatswain on board his yacht at Southampton. This universality of talent reminds me of the old miser Elwes' celebrated servant, who was his butler, coachman, gardener, huntsman, groom, and valet, and, according to his unreasonable master's account of him, "a d-d idle rascal " into the bargain.

March winds and a hot sun are great adversaries to fox-hunting; and during the three days I hunted with Lord Anson's hounds they operated most strongly against us. The consequence was I did not see one run worth describing. The first day we had the bitch pack -with the addition of two couple of dog-hounds, I suppose to make up the number, as that is the time of the year when the former often fall short. Their condition ras good, and, taking into consideration the fine season's sport they had had, did much credit to their kennel-huntsman, Waddington. The second day we met at the Seal Woods, and-what I nerer saw before-drew them blank. Went on to Gobsall, the splendid seat of Lord Howe, where we found, but conld do nothing from want of scent. On this day we had the dog pack, which to look at-being particularly level and even as to size and power, and rery full of the latter for their inches-pleased me best; but, as generally happens, the bitches have had the most sport. Lord Molyneux was out on this day on Oxford, the horse he rode in the famous Ditchley run in the year 1816. The old horse was very fresh on his legs; but, what is extraordinary, has lost all his mane.

When I first knew Lord Anson in the field, I thought, with many others no doubt, that he went a hunting merely because other people went a hunting, little suspecting that he ever would have filled the 
situation he now does-a master of fox-hounds, hunting them himself; and thus-I write perhaps as an enthusiast-being an honour to his country. At the time I am speaking of, he was a very indifferent horseman, displaying but a very small share of nerve; but we must never judge from first appearances, and we should never judge rashly. There is a certain string, which, when properly struck, the human heart seldom fails to accord to, and this was the case here. Lord Anson was fond of hounds: his fondness for hounds has, much to his credit, made him a sportsman; his fondness for hounds has made him one of the best and hardest riders of the present day.

From the little we had to do during the three days I was out with Lord Anson's hounds, it would be presumptuous in me to offer an opinion on the merits of his Lordship as a huntsman. As nothing, however, is so valueless as indiscriminate praise, I may be allowed to say that I thought he made too free a use of his horn in covert when his hounds were drawing. In the first place it is not necessary, as hounds will come over to their huntsman as he turns in his corert without it; and in the next place, the too frequent sound of it makes them somewhat regardless of it at other times when they should fly to it quickly ; and this effect was visible more than once when I was with them in getting them away from covert.

A covert called Debdell, in the Dunchurch country, the property of Sir Theophilus Biddulph, has shewn Lord Anson two very fine runs this season-one of which I heard a correct account of from two gentlemen who were present, and a most magnificent thing it must have been. By way of shewing the fascinating powers of foxhunting, and dangers incurred in the pursuit of it, by those who are really fond of it, I will relate the following anecdote:-A gentleman by the name of Henry Kingscote was out with Lord Anson's hounds on this day. When his horse left his stable in the morning, he had but one eye, the other useful but delicate organ having failed him two years before. It so happened, however, that there was some little inflammation in the remaining one, which the excitement of carrying sixteen stone in the way Mr. Henry Kingscote rides, and at the pace these hounds ran, did not fail to increase; the con. sequence of which, was, that this only eye soon became opake. Mr. Kingseote was apprised of this by the good old horse-so contrary 


\section{LORD ANSON}

to his usual practice-giving him a fall at about every third fence. It soon, however, was evident that he could only distinguish upright objects; the consequence was, that whenever the ditch was on his side of the fence, he was as certain to be down; but gates, stiles, and fences with ditches on the other side, he was able to take to the last; and, strange to say, that although he had eleven bad falls, Mr. Fingscote got to the 'end of this terrible rum' before the hounds had worricd their fox! Lord Anson told me that he was lucky enough to change his horse in the middle of it; but declared it to be his opinion that no one horse could have carried a man with the hounds to the end of it.

It is not to be marvelled at that so much respect is paid to blood by all breeders of animals, when we see it distinguish itself so conspicuously in men; where we generally find the old proverb verified, that "like begets like." I shall never forget being in the company of that facetious old sportsman, the late Mr. Leech, of Carden in Cheshire (who hunted that country so many years, and whose society was so delightful to every one), when it was observed to him, that the son of an old and very convivial friend of his was filling a bumper every time the bottle passed him. "Why," said Mr. Leech, "I don't wonder at that; for, got by old . . . . . . out of a sister to . . . . the lad must drinki." This anecdote somewhat applies to the gentleman I have been speaking of. He is the son of the late Mr. Thomas Kingscote (brother to the Colonel of that name of sporting celebrity, and founder of the Kingscote Racing Club), and his mother is a sister of Sir Henry Peyton. Both himself and his brother-who is in the Life Guards-are six feet three inches high, of peculiarly fine form, and most straight-forward riders to hounds.

I met Lord Anson again the next morning at Coome Abbey, the seat of the Earl of Craven. Lord Craven, we know, is a good friend to fox-hunting; and the objection to Coome Woodlands used to be the frequent change of foxes; but on this day we drew it blank; and the only sign of a fox in the neighbouring coverts was a stale scent which the hounds spoke to for about two hundred yards.

On the 22nd met the Quorn hounds at Oadby toll-bar, five miles from Leicester on the Market Harborough road. The last time I 


\section{8}

\section{NIMROD'S HUN'TING 'TOUR}

saw Mr. Osbaldeston in the field, I saw him under very different circumstances. I saw him on the ground with his leg broken, the bone protruding through the skin, with his boot full of blood, and with every prospect of immediate amputation being necessary. He bore it like a man; but one remarkable expression escaped him. "I am so unlucky," said he (having only just then recovered from another bad fall-and to the regimen he had been undergoing in consequence of it, was he, perhaps, indebted for the preservation of his limb), that I think I shall give up hunting." I thought the same at the moment; for to say the truth, when Mr. Lucas, Veterinary Surgeon, put his whip into the boot, and it came out bloody, my heart sickened at the scene; and I said to myself" this will be my case next." Fortunately, however, for humanity, like the woman in travail, who says in her haste, "all men are liars," these impressions soon wear away; and Mr. Osbaldeston now hunts his own hounds six days a week!

There was a very large field on this day, and rather a novel scene presented itself. Glen Gorse, a very thick covert, was the first place drawn, and it was surrounded by at least a hundred foot people, assembled there, as they said, from the neighbouring villages, for the purpose of finding the for, and to be paid for their trouble by a collection from the field. When they came to me for my shilling, I told them I never would bestow one upon such purposes. Fox-hunting, said I, has already lost much of its native wildness; but if this is to be the case-if men, not hounds, are to find our foxes--we must soon leave them to men to kill, for hounds would be useless, as every covert in the country would be surrounded by foot people, and every chance of a fox getting away would be lost. I believe this farce originated in some foot people getting into this very thick gorse the last time the hounds drew it, and being the means of pushing the fox out, for which they received a reward, and of course they speculated on a similar adventure.

After a good deal of badgering, our fox broke gallantly. As I tally-ho'd him away two fields from the gorse, of course I got a fair start; but having been so long in the provincials I was only half awake, and instead of going away as about a dozen of the leading men did, with only six couples of leading hounds, I pulled to my 


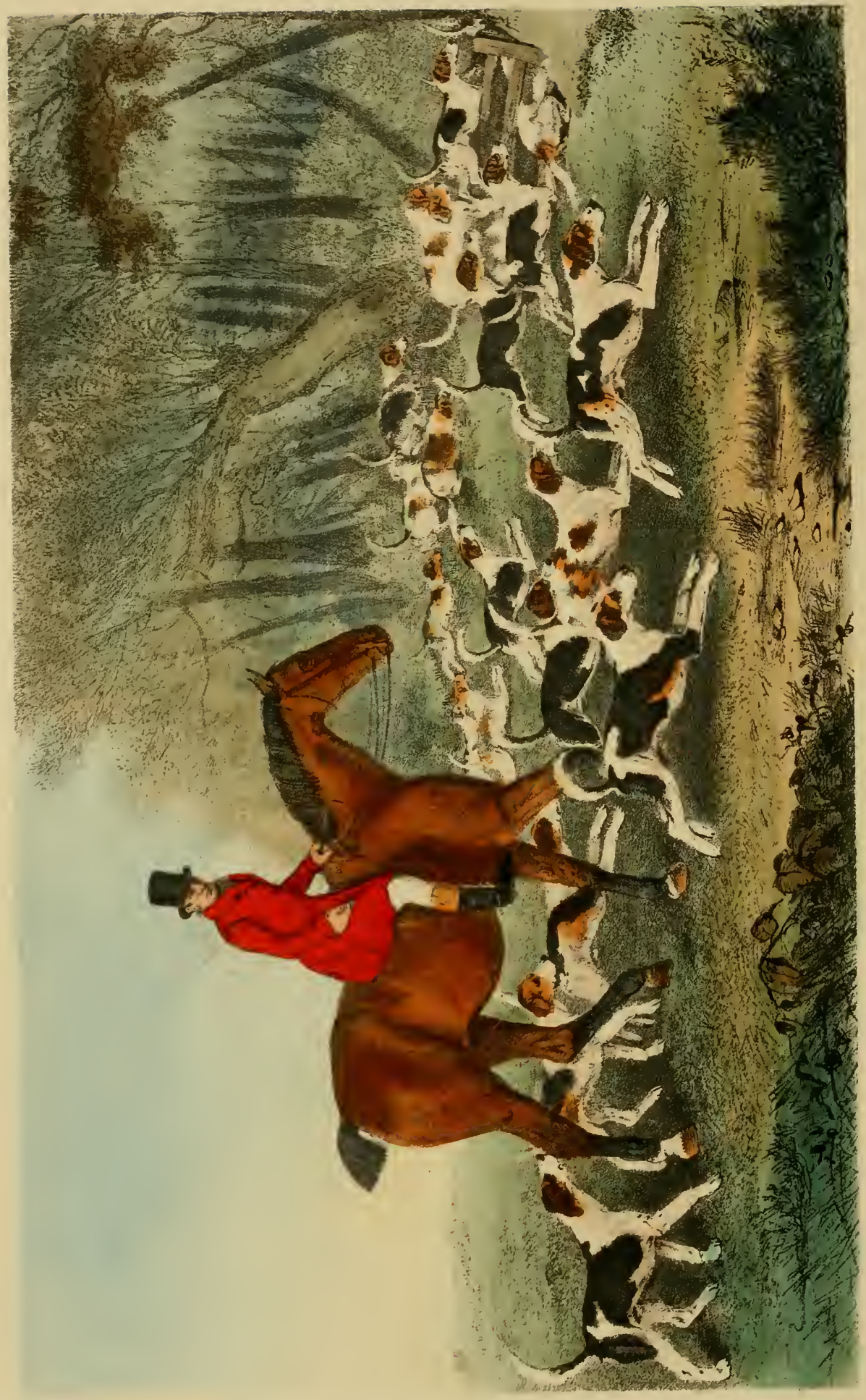




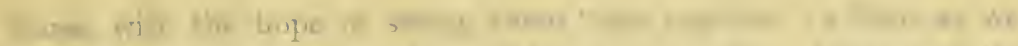

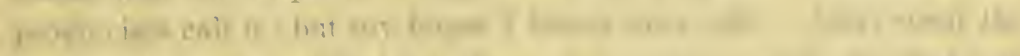

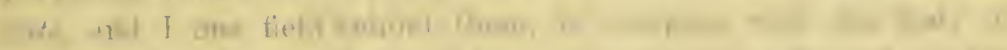

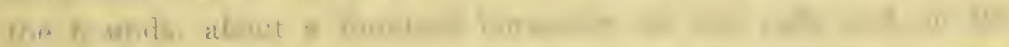

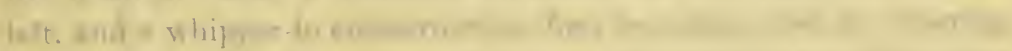

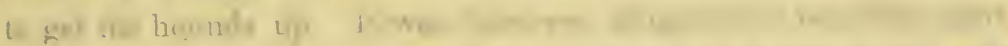

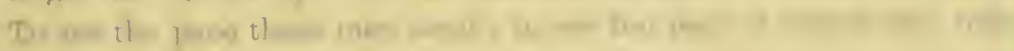

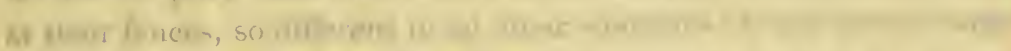

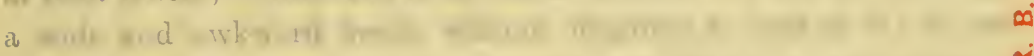
shes $t$, we

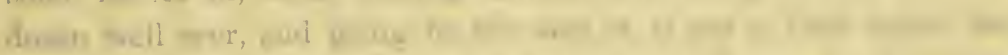

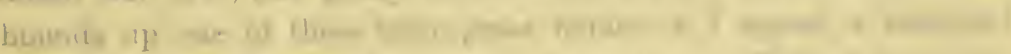

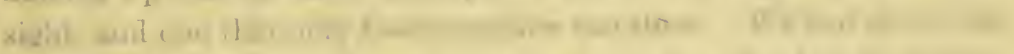

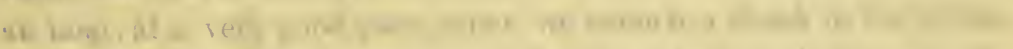

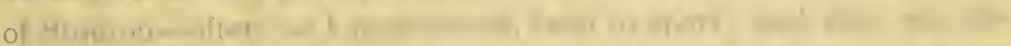

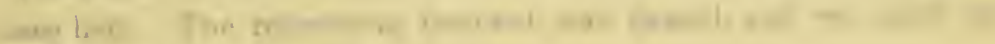
$64 \times m+10+1=$

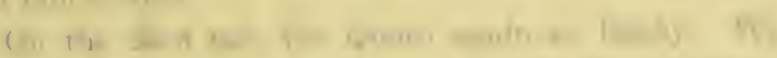
lom ty

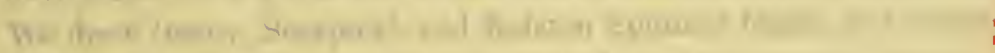

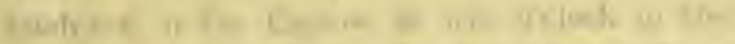

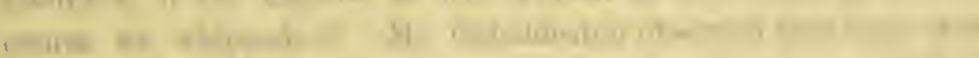

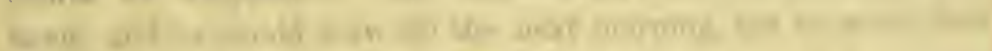

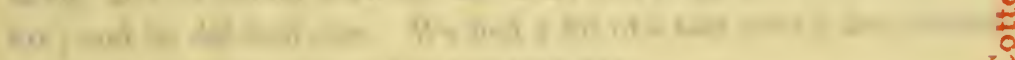

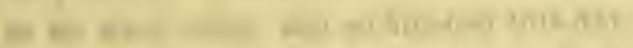

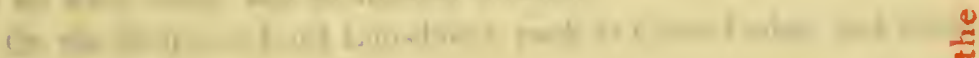
in $1+n=n-n$

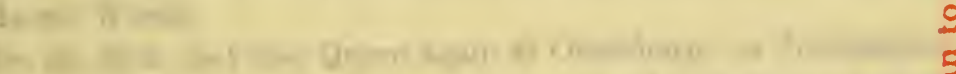

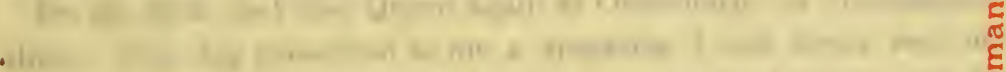
1.

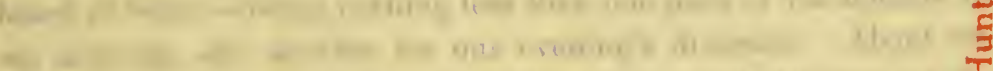

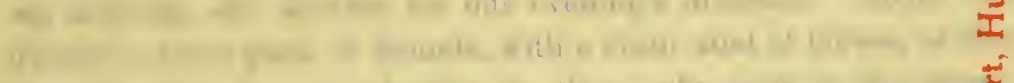

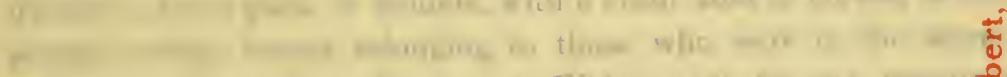
-

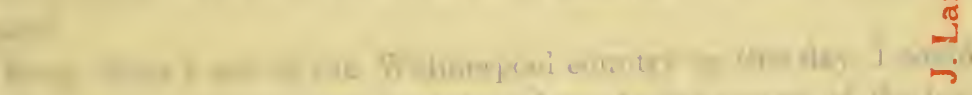

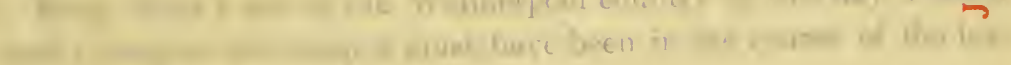




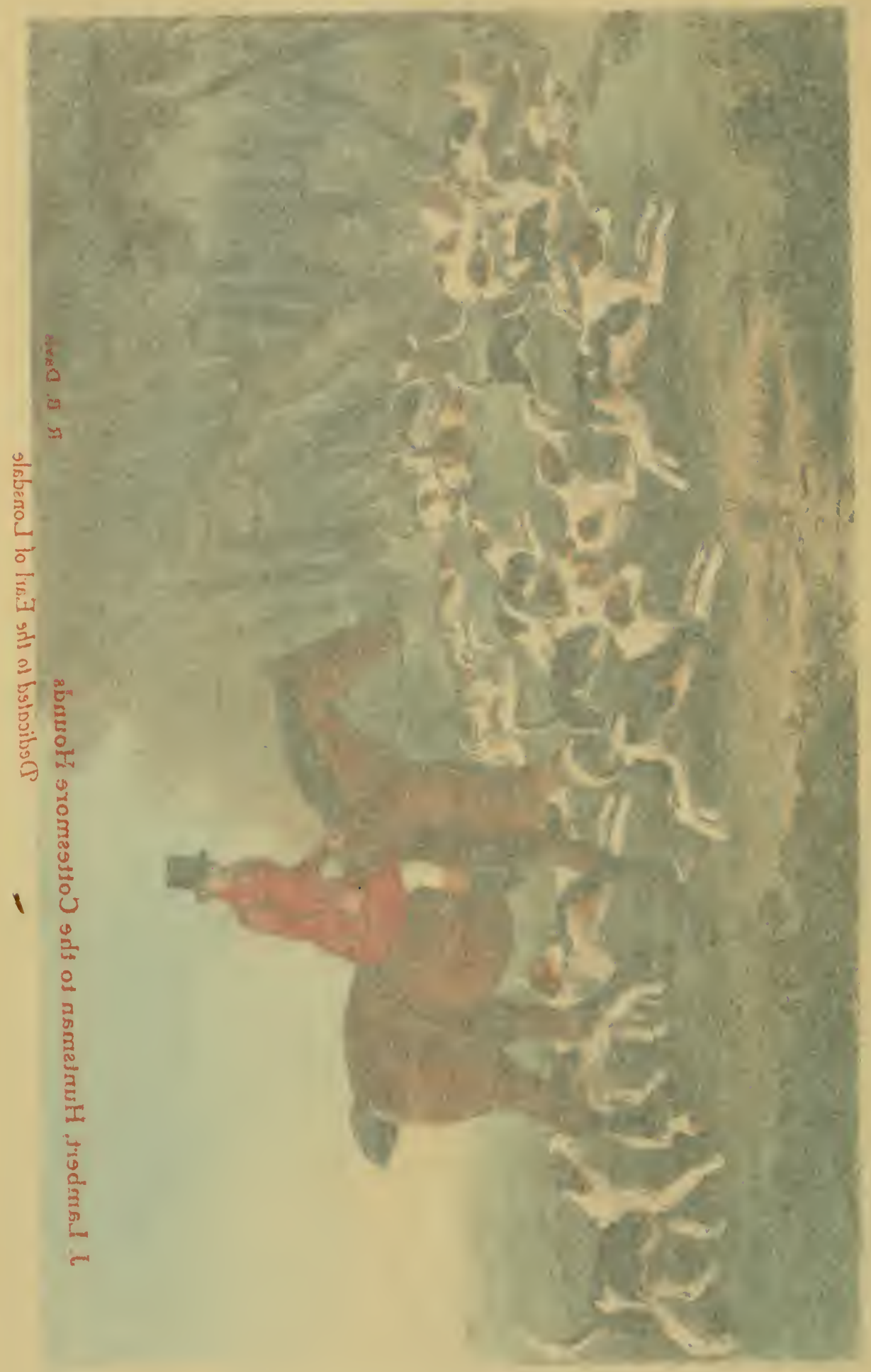




\section{THE QUORN}

horse, with the hope of seeing them "get together" a Iittle, as we provincials call it; but my hopes I found were vain. Away went the clite, and I one field behind them, in company with the body of the hounds, about a hundred horsemen on the right and on the left, and a whipper-in endeavouring, first by rating, then by cheering, to get his hounds up. It was, however, altogether a beautiful sight. To see the pace these men went; to see the pace at which they rode at their fences, so different to all other countries; to see them charge a wide and awkward brook without deigning to look at it; to see some horses in, some turning around, not liking it, and about a dozen well over, and going by the side of, if not a little before, the hounds up one of these large grass fields-is, I repeat, a beautiful sight, and one that only Leicestershire can shew. We had about half an hour, at a very good pace, when we came to a check in the village of Stouton-often, as I understood, fatal to sport; and such was the case here. The redeeming moment was passed, and we could not hit him further.

On the 23rd met the Quorn again at Beeby. We had liked to have found-not a fox, but a rara avis in this country - a blank day. We drew Beeby, Scraptorf, and Rolston Spinnies blank, and found a bitch-fox in the Coplow at five o'clock in the evening, when of course we whipped-off. Mr. Osbaldeston observed that there was a moon, and he would draw till the next morning, but he would find a fox; and he did find one. We had a bit of a lark over a fine country as we went home, and so finished this day.

On the 24th met Lord Lonsdale's pack at Coles Lodge, and found in Lawn Woods.

On the 25th met the Quorn again at Owelthorpe in Nottinghamshire. This day presented to me a spectacle I had never seen nor heard of before-being nothing less than one pack of fox-hounds for our morning, and another for our evening's diversion. About two o'clock a clean pack of hounds, with a clean stud of horses, as also several second horses belonging to those who were in the secret, were turned out from the inn at Widmerpool for our evening's sport!

From what I saw of the Vidmerpool country on this day, I could easily imagine how deep it must have been in the course of the last 
winter. The Bicester country was never known to be so tender as it was in the month of February last, and I hope I may never see it so again. Draining, however, appear's almost entirely neglected there, whereas that is not the case in Leicestershire; and I have heard Mr. Lockley say that it does not require a horse to be so good by a stone to carry his rider over the greater part of that country now, as it did when he first rode over it, when much of it was neither drained nor inclosed. The Widmerpool country, I have heard him say, was all open in his younger days.

I was asked by several why I had not come to Melton sooner in the season, and before the dry weather set in? My answer to this was obvious. "A man," said I, "with five hunters and a hack, makes a very respectable appearance in the Provincials, but he has no business in Leicestershire. He would be more than half his time kicking his heels in the town where he was quartered, whilst his friends were enjoying themselves in the field."

Exclusive of work for horses, when hounds are rumning, there is another way of making use of horse-flesh in Leicestershire; and that is, in coming home from hunting, or what in the language of the day is called "larking." One of the party holds up his hat, which is a signal for the start, and putting their horses' heads in a direction for Melton, away they go, and stop at nothing till they get there.

One of the leading men on these occasions is Mr. Maher-a brilliant performer with hounds; but without hounds in Leicestershire, few men have a chance with him, from his perfect knowledge of the country. On the Widmerpool day, he led about a dozen of them a dance of upwards of nine miles over a beautiful country, when at last the party was reduced to three-himself, Captain Standon, and another, each riding one of his horses; and I was told they rode the distance in little more than half an hour. This is all very well for Mr. Maher, with fourteen or fifteen horses in his stables, but it accounts for one or two of my friends having almost as large a stud at Melton, and only two horses fit to ride.

A certain noble Earl-long since bid adieu to Leicestershire, but who could almost say with Catullus, "Gymnasii fui flos, et decus olci"- has often been heard to declare that hounds sometimes are a 


\section{DUKE OF RU'TLAND}

great bore; * and so they certainly are to your very hard riding men, for they cannot always get from under their horses' feet. Mr. Maher, upon Potash, would always ensure sport; and only let him get clear away from the crowd, it must be a very good one that can catch him.

On the 26th met the Duke of Rutland's hounds at Stubton, the seat of Sir George Hearn, to the right of the road between Grantham and Newark. I found them-as I expected to find them-very clean in their skins; but I was more particularly struck with the fine length of their frames, and the strongly marked and uniform character of the pack. All this, however, is to be accounted for: For one mile that these hounds travel, $\mathrm{Mr}$. Osbaldeston's travel six, and the Duke generally breeds from thirty to forty couples of whelps every year; so that if twenty couples of them stand, he can always pick and choose.

We found a vixen fox heavy at Stubton, which luckily got to ground in good time; and found again in about an hour afterwards in a beautiful gorse covert by the side of a hanging hill. The fox went away quickly over a very fine vale for about two miles, when a fallow field stopped us. He then turned again for the hill, and we did nothing worth speaking of afterwards.

I was told the day before by a hard-riding Meltonian, that I must screw up my nerves if I went into the Stubton country; and I think I never did see one so strongly fenced. If I could have made use of the pencil, I would have brought away a sketch of one of them. It was a blackthorn hedge about eight inches higher than the top of my hat as I stood on the ground, with grower's in it as thick as a man's thigh, plashed at the top, and with a wide ditch on one side. On remarking to $\mathrm{Mr}$. Robert Grosvenor that it was a stiff country, he observed that it was so to be sure: "but," added he, "a man has nothing to do but to throw his heart over" and follow it." This is all very well, thought $I$, but it is not every heart that will leap so high even when its owner gives the word: " a man cannot add a cubit to his stature."

* It is a well-known fact, that a season or two back two very hard-riding Meltonians, at the end of a very sharp burst, went half a mile neck and neck over the country beyond where the hounds had killed their fox. 
It would be more than presumptuous in me to offer any further opinion of the Duke of Rutland's hounds from merely what I saw of them on this day, and also on the morning after Croxton Park races, when nine hundred people were supposed to be out, and hunting was of course only a secondary consideration. I liked Goosey's (the huntsman) manner with his hounds very much indeed, particularly his getting them away from covert. The Rufus-headed whipper also took my fancy--not for his likeness to the Belvidere Apollo, but for a something about him that looked very much like a hard riding whipper-in to a good pack of fox-hounds; and he seemed to know his business well. The Duke's hounds hunt only four days a week.

On the 27th Captain Ross, Mr. Grant, Mr. Douglas, and myself rode over to Quorndon, at which place the hounds are kept, and Mr. Osbaldeston resides. It is fourteen miles distant from Melton by the bridle, and eighteen by the carriage road.

The situation of Quorndon Hall, speaking geographically, always struck me as being very ill-chosen, as it is so distant from the best part of the country, and consequently causes so much travelling for hounds-worse for them in Leicestershire than in most other counties that I have been in. Its nearness to the high hills of Charnwood Forest likewise would almost make a stranger believe it was situated in any but a good hunting country; and from the populousness of the surrounding neighbourhood it would give him more the idea of the residence of a great stocking manufacturer than that of a master of a pack of fox-hounds. Here, however, it is situated, and here it is likely to remain; and it having been once the residence of the great Meynell, it ought to be sacred even from the consuming hand of Time.

We found Mr. Osbaldeston in the kennel, accompanied by Sir Harry Goodricke and Mr. Coke. After looking at the old hounds, we proceeded to view the young ones; and here I am bound to say I never saw so fine an entry, consisting of no less than thirty-four couples!

On few occasions-not even in a ball-room-is the word " beauty" more often made use of than in a kennel of highly-bred fox-hounds; nor, indeed, is it often more appropriately applied. To imagine that 



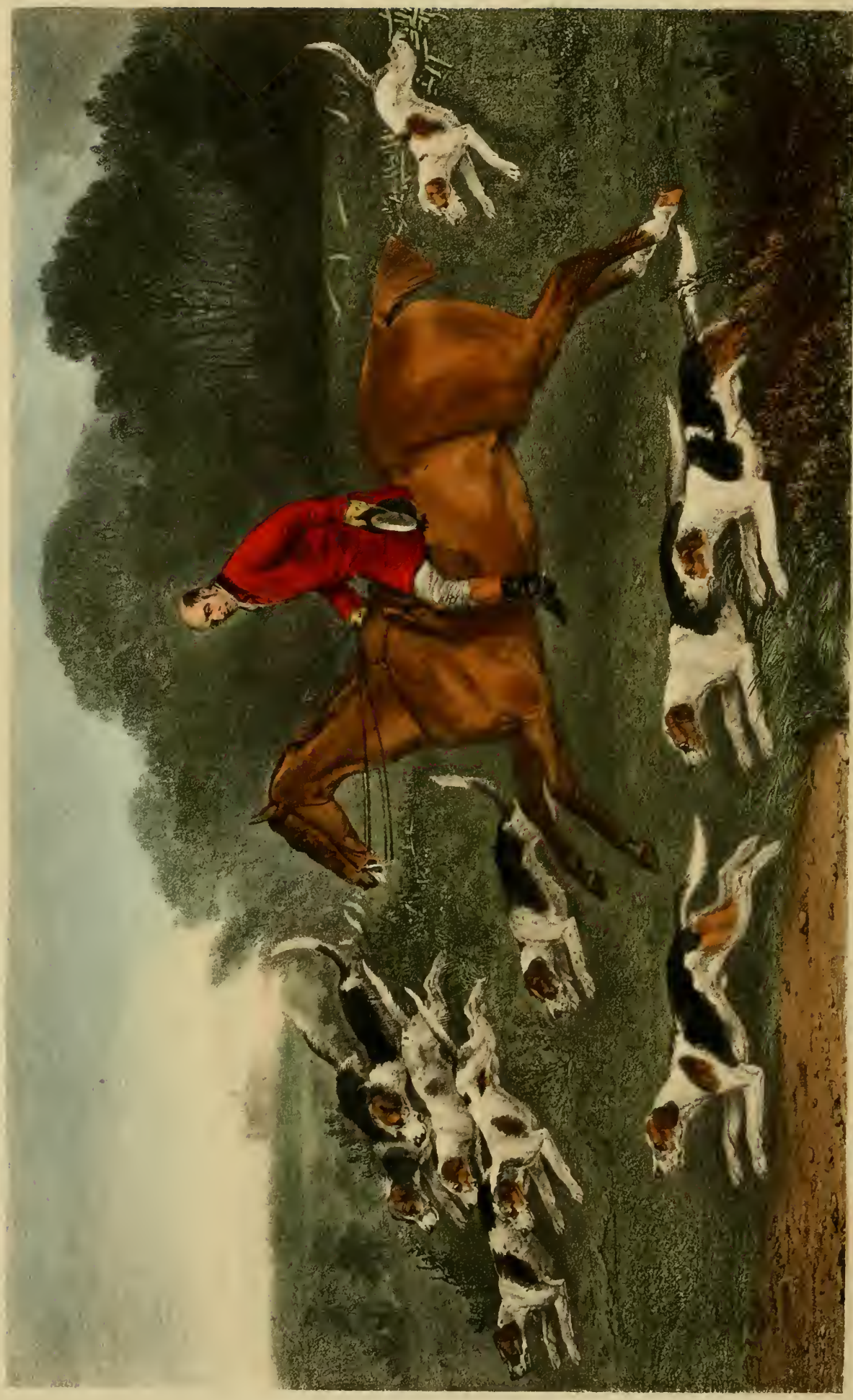




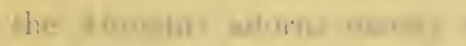

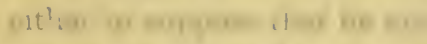

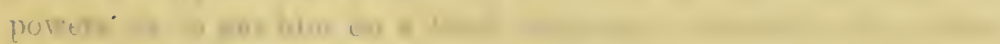

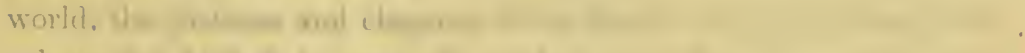

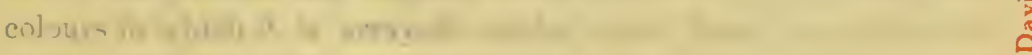

requil

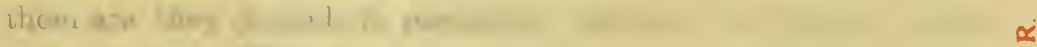

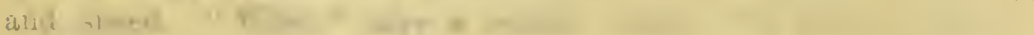

nect-

were arizom

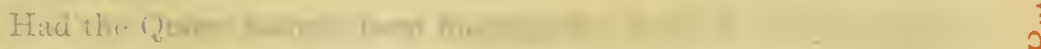

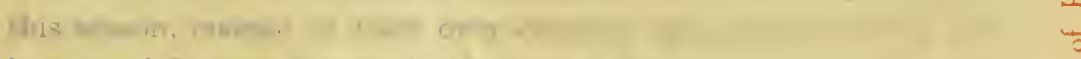

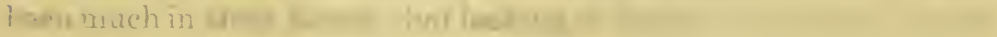

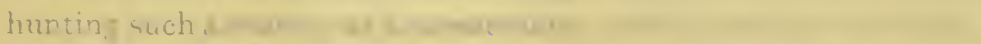

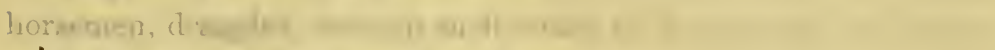

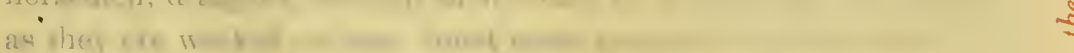

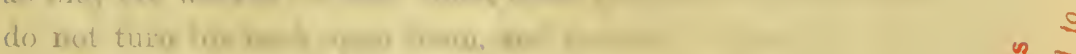

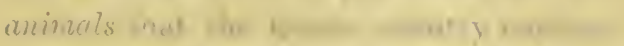

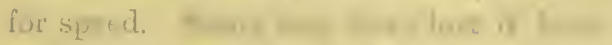

otheis, 111 mont when mat

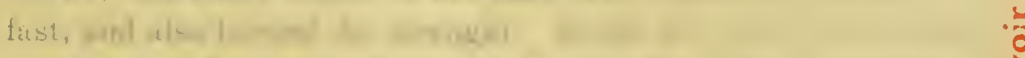

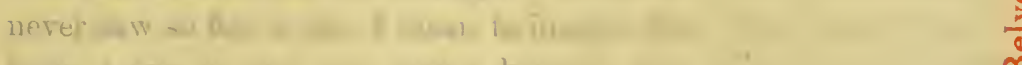

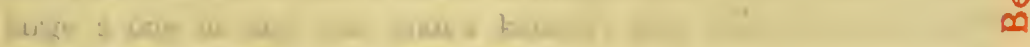

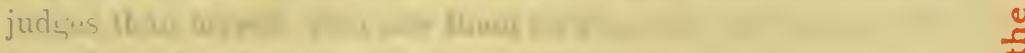

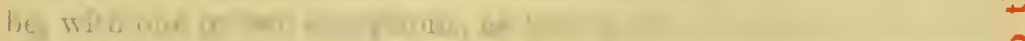

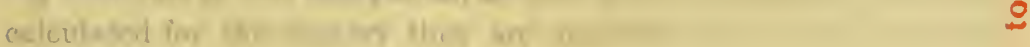

(t) or e liset-1

When in - hask ou 11

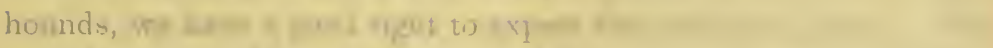

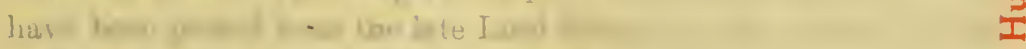

:

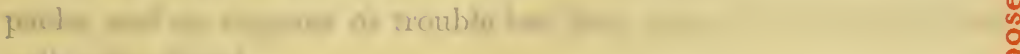

mith wh.

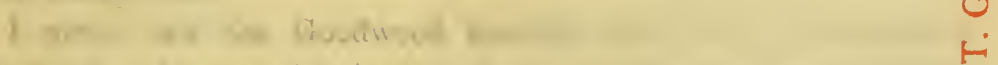

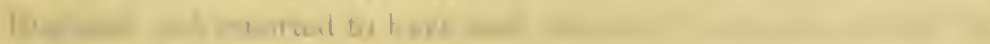

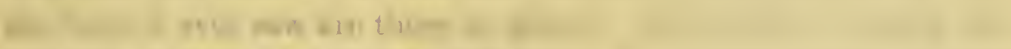

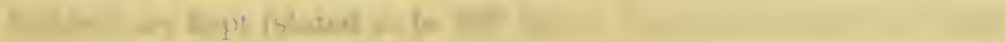




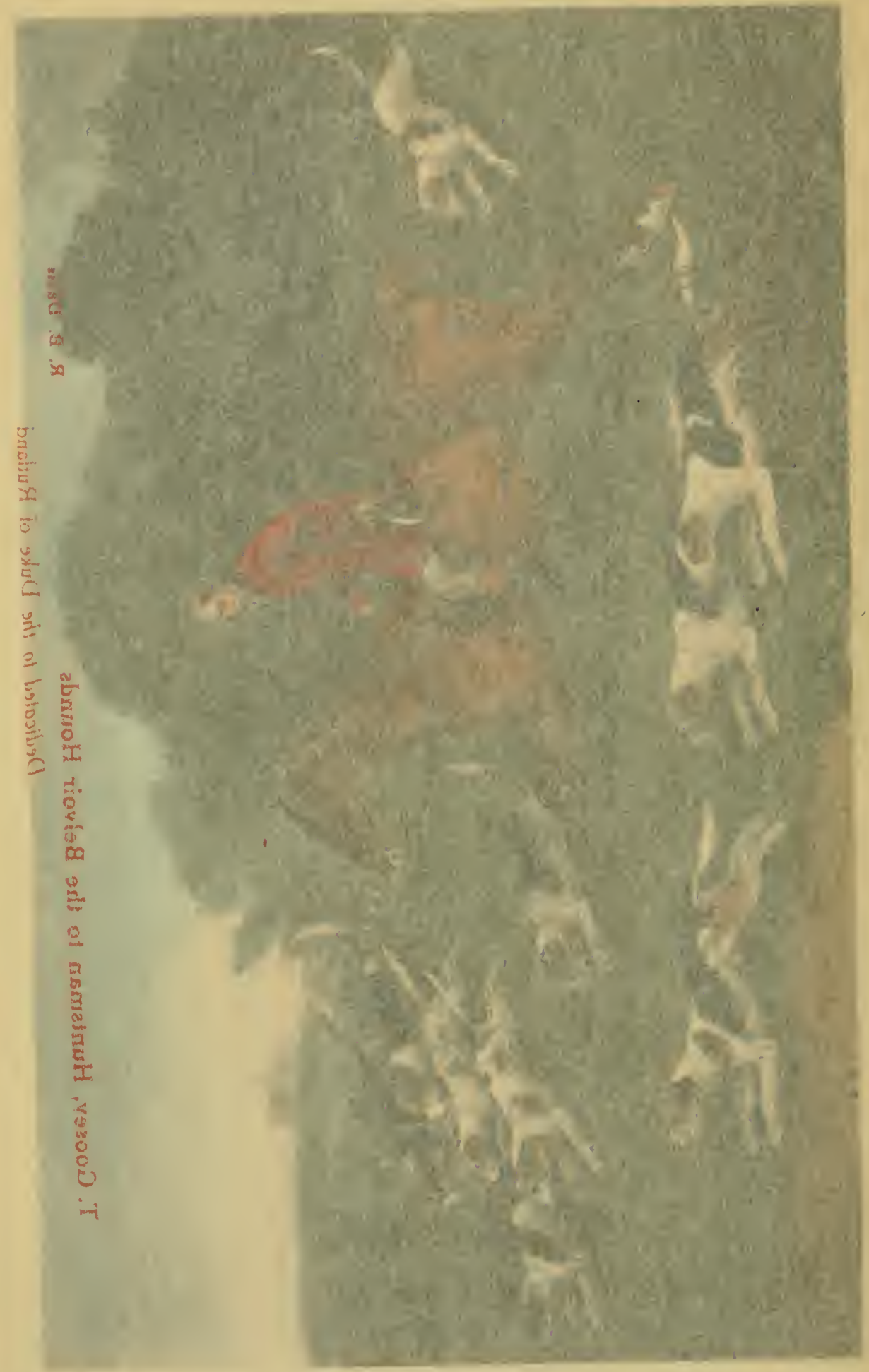




\section{TIIE QUORN}

the Almighty adorns merely for the sake of ornament, would be either to suppose that he anused himself with an ostentation of his powers, or to put him on a level with man; whereas in the animal world, the justness and elegance of the figure-to say nothing of the colours in which it is arrayed-confer upon them the qualities we require, and are necessary to the very ends of their creation; for to them are they (hounds in particular) indebted for strength, agility, and speed. "What," says a certain writer, "is beauty, but a necessary result of the aptitude of forms to the offices for which they were designed ?"

Had the Quorn hounds been hunting the Duke of Beaufort's hills this season, instead of their own country, appearances would have been much in their favour; but looking at them as a kennel of hounds, hunting such a country as Leicestershire, ridden after by such fields of horsemen, draggled through such roads as they travel, and worked as they are worked-a man must come prepared to find fault, if he do not turn his back upon them, and exclaim, "these are the sort of animals that the Quorn country requires!" All of them are made for speed. Some may have lost it from one cause, and some from others; but every hound in the pack was formed by nature to go fast, and also formed for: strength. As for the entry, when I say I never saw so fine a one, I mean to imply-first, that I never saw so large a one in any one man's kennel; and secondly, that better judges than myself, who saw them on that day, pronounced them to be, with one or two exceptions, as level a lot of hounds, and as well calculated for the country they are intended for, as were ever seen in one kennel.

When we look a little back to the parent stock of the Quorn hounds, we have a good right to expect that which is clever. They have been picked from the late Lord Monson's (the celebrated black and $\tan$ sort), the old Pytchley, and Lord Vernon's well-known packs, and no expense or trouble has been spared in crossing them with other blood.

I never saw the Goodwood kennels-said to be the finest in England, and reported to have cost nineteen thousand pounds-but the finest I ever saw are those at Quorn. The stable in which the hunters are kept (stated to be 300 feet in length) has stalls for thirty 


\section{NIMROD'S HUN'TING 'TOUR}

horses, all standing in a row. When I cast my eye up it, I could not help fancying myself looking at King Solomon's stud, having never seen so many horses in one stable before; but in compliment to the groom, I must say it bore no resemblance to that of Augeas, for it was remarkably clean and sweet. A well-polished watering bridle, neatly folded up, hung on the right side of each horse, and there is a patent lamp between every fourth stall. Among the stud were several very clever hunters; and I recognised Cervantes, the horse which occasioned the sad accident to his master by not clearing his fence; but I understand experience has since made him perfect. In a box in the yard we were treated with a sight of Mr. Osbaldeston's favourite horse, which he told me he thought was the best hunter he ever threw his leg over in his life.

Fox-hunting, to a man who is thoroughly fond of the sport, scarcely admits of bounds; and $\mathrm{Mr}$. Osbaldeston alone would bear me out in my assertion. He hunts his own pack six days in the week, always rides his hack to covert, and is always the last to say " enough." Lord Darlington is the only gentleman huntsman that ever did this before, and it must require something more than common excitement to induce any man to do it-particularly in so difficult a country as Leicestershire, and where the fixtures lie so wide. At all events he must be a well-bred one, or he would not come again so quick.

Assiduity and zeal are the first requisites in every situation which man attempts to fill; and for these I am sure I may give Mr. Osbaldeston his full measure of credit. Of his merits as a huntsman I scarcely feel myself qualified to speak, having been so unfortunate in the weather during my visit to his country. In my experience with hounds, however, I have always found a huntsman's fame to rise and fall with his sport, which is by no means a fair way of judging him, as that depends on circumstances he cannot control. So it is, however, on most other occasions. The good opinion of the multitude is capricious; it can only be kept up by tribute, for they are apt to forget past services. Had Cæsar lost the battle of Pharsalia, he would have been but little better than Cataline-at all events it would not have been written "Omnia Cesar erat." 


\section{'THE QUORN}

Though I cannot say much from my own observation, I may be allowed to repeat what I have heard. The season before last, Mr. Osbaldeston's hounds had as brilliant a succession of sport as any hounds could shew; and this year (generally an unfavourable one) they have had about their share. Up to the time I was with them, they had killed their fifty brace of foses ; though this is not much to boast of in a country so preserved as Leicestershire, with six days a week, and in such an open season. His hounds stand pressing uncommonly well, and are very obedient to command.

Whether gentle or simple, I have never yet seen the man in the shape of a huntsman to a pack of fox-hounds who could always comply with the apostolic precept-be courteous; and in a Leicestershire field he ought to be nothing less than a Job. I cannot, however, say I witnessed anything more than proper authority in the gentleman I am speaking of, though once or twice put to the test; at the same time it cannot be said of him, as was asserted of Sir Edward Littleton's buntsman, "that he was never heard either to laugh or to swear."

It may be easily imagined that the very severe fall and its consequences could not fail to leave its impression; and MIr. Osbaldeston does not ride quite so hard as he did before his accident. It is not that he is afraid of fences; but he seems in constant dread of being ridden over when in a crowd; which is indeed the most dangerous part of the business in his fast country. Many a good man, however, after what he suffered, never would have come to the post again at all; and too much praise cannot be bestowed upon him for the very spirited manner in which he hunts the finest country in the world!

Masters of fox-hounds are, in great measure, public characters, and as such only do I myself feel anthorised to speak of them. I may, however, perhaps be allowed to say, that in society Mr. Osbaldeston is affable and communicative, perfectly free from the absurdity of affectation, and just what an English country gentleman should be. He resides at Ibbertson Hall, between York and Scarborough, where he has very fine estates; and though the name of Osbaldeston is one of which most men might be proud, yet being, I suppose, deemed awkward to halloo to, he is better known among 


\section{NIMROD'S HUN'TING 'TOUR}

his Leicestershire friends by the familiar appellation of "the Squire."

On the 28th met the Quorn at Thrussington, and found in Cussingdon Gorse ; but the sun was so overpowering and the ground so dry that we could do nothing, although we had a beautiful find.

On the 29th, as is always the custom on the day before Croxton Park races, the Quorn hounds met at Kettleby, where at least three hundred horses were assembled, with a pretty sprinkling of Ladies. The field, however, was not so large as on some former anniversaries, in consequence of the Duke's hounds meeting within easy reach of Melton. We found in Wartnaby Gorse, and killed in Melton Spinney, after forty-five minutes-called very good for the time of year. Had it not been for one check the field would have been very select indeed; and-to say nothing of the pleasant time spent at Melion, for which I am so much indebted to my friendsthe gallop over this fine country amply repaid me for the many miles I had travelled for it. The hounds did their work to admiration.

The fox we killed this day was one that had given the Duke two or three good runs, and I am sorry to say was a vixen. A fresh pack of hounds and a fresh stud of horses again awaited our arrival at Widmerpool Inn for this afternoon's diversion; but owing to the warmth of the day, and the pace we had gone, few felt disposed to go to them, and I, among many, went home. As Mr. Osbaldeston, however, was on his road thither with his hounds, the Duke's pack crossed him with their third fox; and, what is singular, they also had a capital day's sport-even to the tiring of almost all the horses.

I might as well attempt a history of the Punic wars, as to describe all the changes and revolutions which have taken place in Leicestershire since I first hunted in it; but as far as regards the hounds, Lord Foley took them from Lord Sefton (who succeeded Mr. Meynell), and kept them two years. Mr. Smith became master of them in the summer of 1810 , and Mr. Osbaldeston took them from him in September 1817, and kept them till the middle of the season of 1821 ; when Sir Bellingham Graham entered upon the country, and hunted it the remainder of that and the whole of the following 
season, when Mr. Osbaldeston again took possession of it in the summer of 1823 , and has hunted it to the present time. Mr. Smith and Sir Bellingham Graham hunted their hounds themselves; but during the first time Mr. Osbaldeston was master of them, they were hunted by that celebrated performer, Tom Sebright, who now lives with Lord Fitzwilliam. At present Mr. Osbaldeston hunts them himself.

There is one part of hunting in Leicestershire which is very striking to a stranger-and that is, the assembling of the field at the covert's side. Like radii verging to the centre, they are seen coming in all directions to the place appointed; and many of them mounted on what in some countries would be considered very good hunter's. Unless, however, the horses used for this purpose were good, they could not do what is required of them, as the pace is generally quick. When I see them coming, splashed up to their necks, I often think of our Immortal Bard. When welcoming the messenger from the battle of Holmedon, King Henry exclaims-

\footnotetext{
"Here is a dear and true-industrious friend, Sir Walter Blunt, new lighted from his horse, Stained with the variations of each soil."
}

The grand sight, however, in a Leicestershire field is the start; and here it is that what is called "a workman" distinguishes himself; for, as Dean Swift says, "it is as hard to get rid of numbers as of hell. Whoever has an ambition to be heard in a crowd," continues this facetious writer, when "speaking of public spokesmen, " must press, and squeeze, and thrust, and climb * with indefatigable pains till he has exalted himself above them;" and so it is with a man who means to see a Leicestershire r'un. No small danger is here to be encountered; for if he fall, he is almost certain to be ridden over, and some luck must attend him if he be not seriously hurt. In the mêlée there are always some who have not the best hands on their horses, and therefore cannot always stop when they wish, however well inclined to do so.

Cato talks of charming dislocated bones by repeating mystical

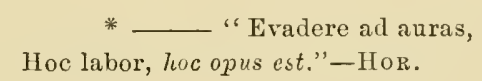


words. If this renowned sage had lived in the present day, he would have had plenty of custom among the hard-riding Meltonians, as broken arms and collar-bones are accidents of frequent occurrence. On meeting my old friend Captain Stuart (brother to Sir Simeon) the other day, with his arm in a sling, I asked him how it happened. "I got a fall," said he, " and seventeen men rode over me, and broke my arm in two places!" That capital sportsman Mr. George Marriott, the draper, whom I have known and admired as a firstrate judge ever since I first hunted in Leicestershire, was walking about with his arm disabled-having dislocated his shoulder, and otherwise injured the limb.

When on the subject of falls, I may be allowed to mention the universal regret expressed at Melton for the serious injury that befell Mr. Ralph Lambton, when riding after his own hounds. Mr. T. A. Smith also had a very severe fall this winter, which was thus described to me, in a letter from a master of fox-hounds:- "Tom Smith has had a terrible fall, by which he received a blow on his head that half finished him; but he is now better, and at it again." It is asserted, that from the many impracticable places this gallant rider attempts, on horses not always with the jump left in them, he gets from sixty to a hundred falls every year with hounds. Courage is not only to be seen on the rampart, on the deck, or in the ranks, but is a very necessary ingredient in a man who rides hard over Leicestershire.

When on the subject of nerve, and to show that the old adage of "like master like man" is sometimes verified, I will relate the following anecdote.-When Jack Shirley was whipper-in to Mr. Smith, he was riding an old horse called Gadsby (not much the better for having been many years ridden by his master) over one of the worst fields in Leicestershire for a blown horse-between Tilton and Somerby-abounding] with large ant-hills and deep-holding furrows. The old horse was going along at a good slapping pace, with his head quite loose, and down hill at the time, whilst Jack was in the act of putting a lash to his whip, having a large open clasp knife between his teeth at the time!

We might be almost put to it to find a better proof of nerve than what I have just related; but the following is not an every-day 



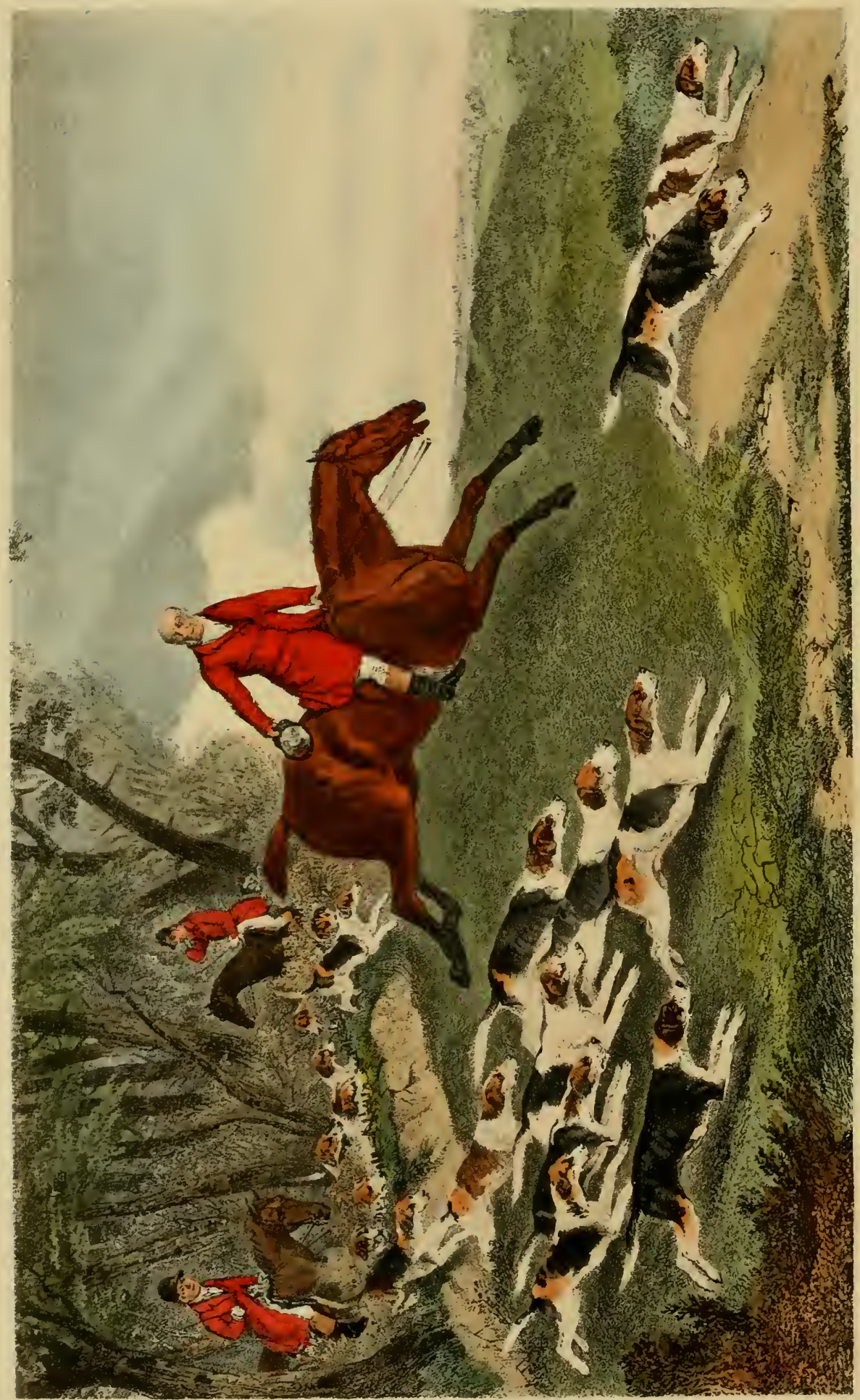




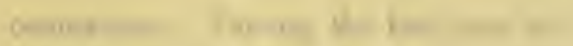

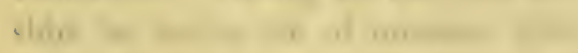

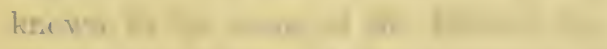

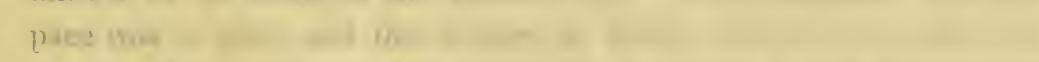

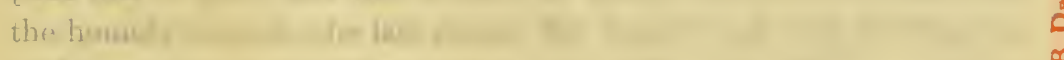

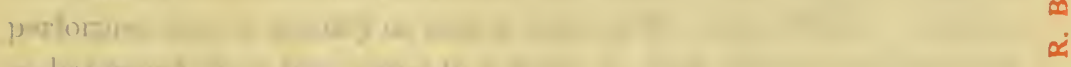

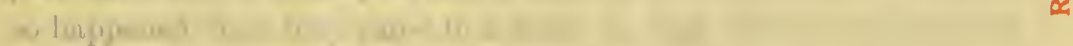

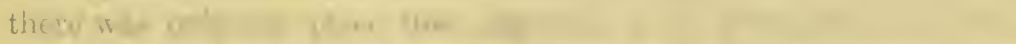

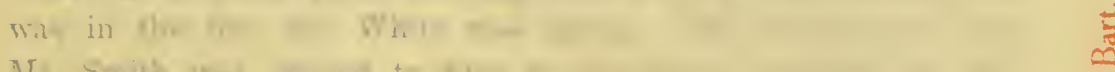

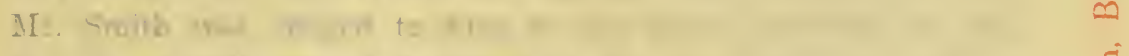

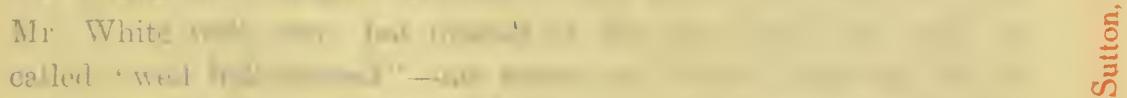

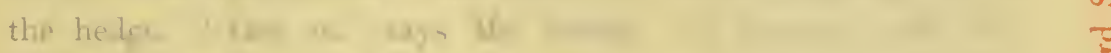

Whine, "I wo che the ate

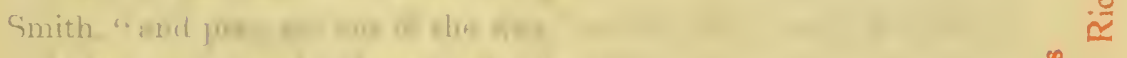

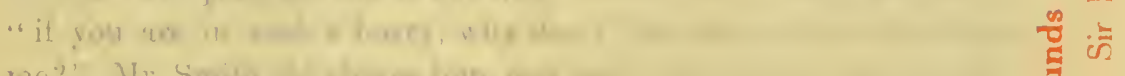

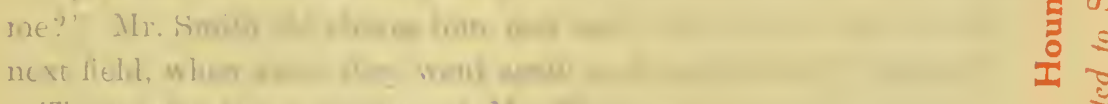

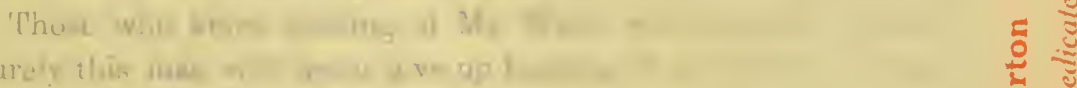

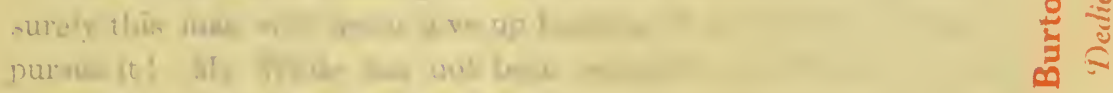

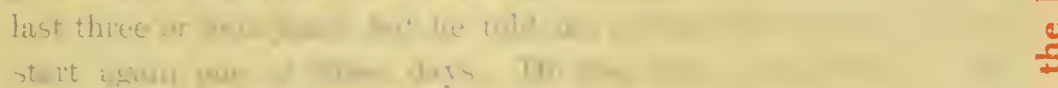

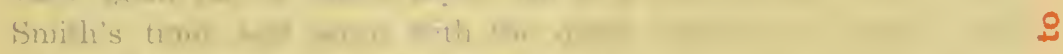

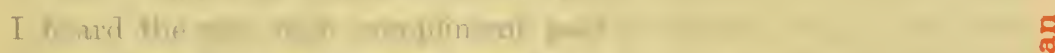

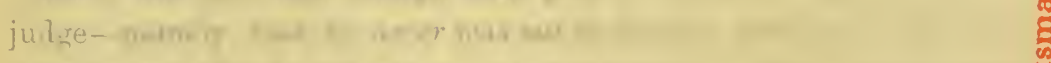

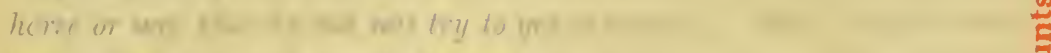

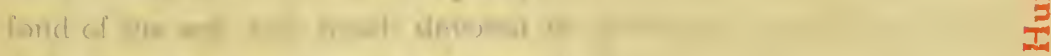

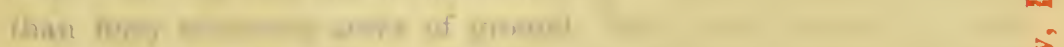

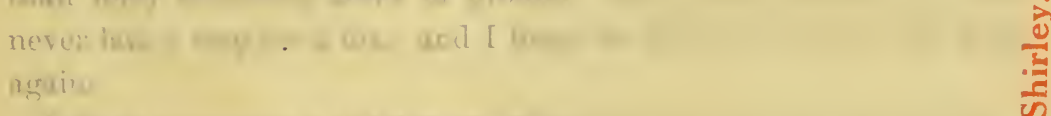

I. What

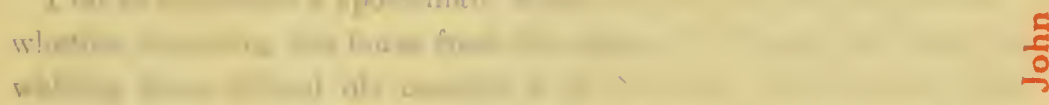

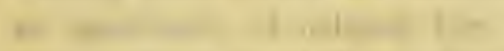

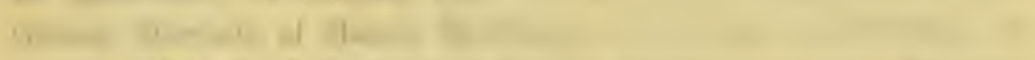

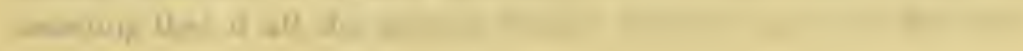




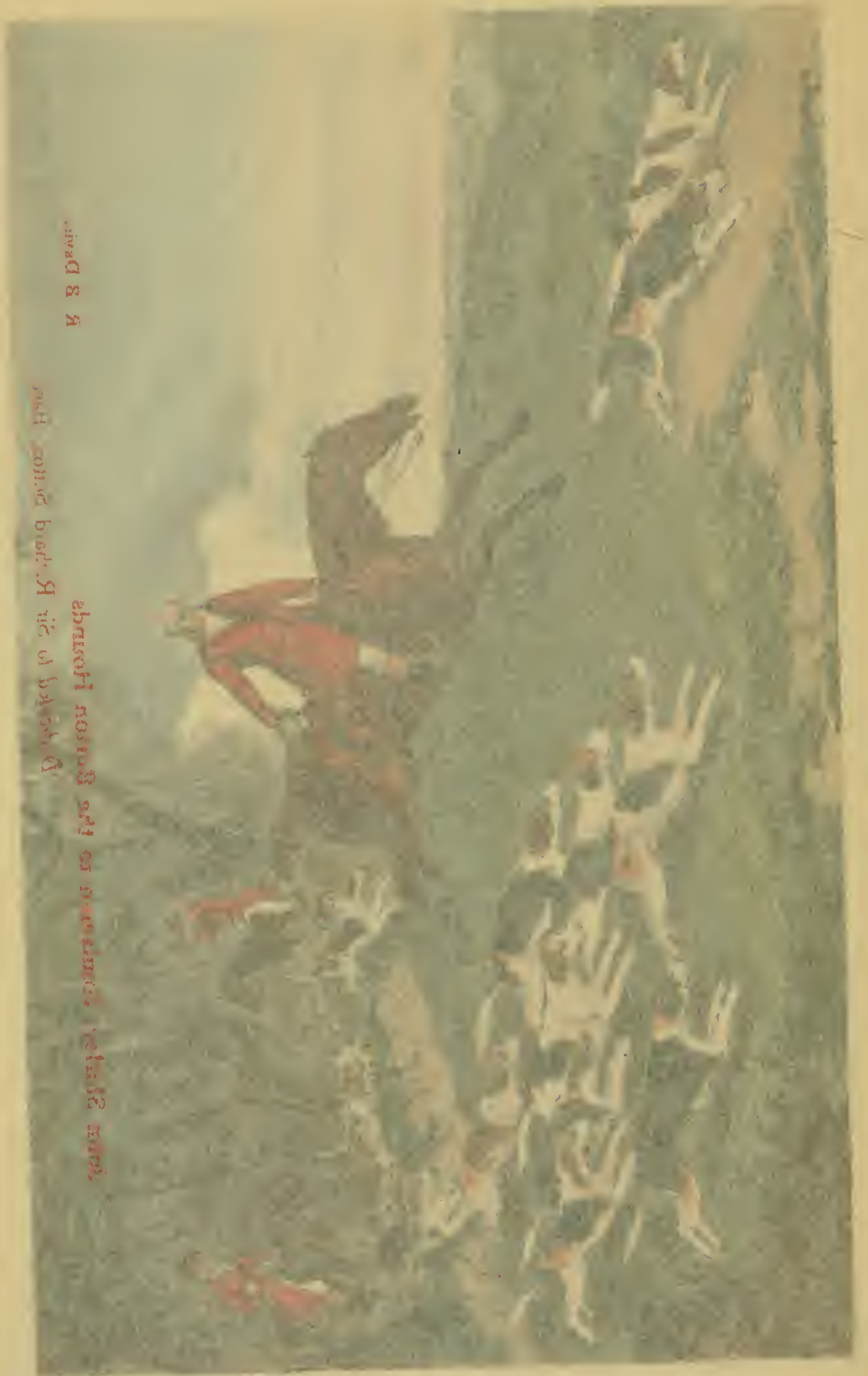


occurrence. During the last year that Mr. Smith hunted Leicestershire he had a run of nineteen miles, point blank, which is well known by the name of the Belroir day. It so happened that the pace was so good and the country so severe, that no one was with the hounds towards the last except Mr. Smith, and that well-known performer over a country or over a course, Mr. John White. It also so happened that they came to a fence so high and so strong that there was only one place that appeared at all practicable, and this was in the line Mr. White was taking. The consequence was, Mr. Smith was obliged to turn to this place, expecting to find Mr. White well over"; but instead of this, he found him what is called "well bull-finched" -his horse and himself sticking fast in the hedge. "Get on," says Mr. Smith. "I camnot," said Mr. White, "I am fast."- "Ram the spurs into him," exclaimed Mr. Smith, "and pray get out of the way." - "D-n it," said Mr. White, " if you are in such a hurry, why don't you ride at me, and charge me?" Mr. Smith did charge him, and sent him and his horse into the next field, when away they went again as if nothing had happened!

Those who know nothing of Mr. White will naturally exclaimsurely this man will never give up hunting if he has the means to pursue it! Mr. White has not been regularly at Melton for these last three or four years, but he told me a short time since he should start again one of these days. He was three years there in Mr. Smith's time, and seven with the other masters of hounds; and I heard the very high compliment paid to him by a very excellent judge-namely, that he never was out in his life, whether he liked his horse or not, that he did not try to get to hounds. He is become very fond of the sod, and much devoted to shooting-preserving no less than forty thousand acres of ground; but I will answer for it he never laid a trap for a fox; and I hope we shall see him in the field again.

I do so reverence a sportsman, whatever may be his cast in lifewhether mounting his horse from the steps of his mansion-house, or walking from behind his counter to go to covert-that I never miss an opportunity of noticing him. Of the latter description is Mr. George Marriott, of Melton Mowbray, and I have no hesitation in asserting that if all the ground George Marriott has travelled over 
with hounds were to be measured by the yard, it would be found to exceed the circumference of the globe at least twice over. When I first knew Leicestershire, twenty-two years ago, he was reckoned an experienced sportsman, and supposed to know the country better than any other man in it; and he himself informed me that he has hunted altogether thirty-seven years--viz. with the late Mr. Meynell, with the present Lord Lonsdale when he was Sir William Lowther, with Lord George Cavendish, with Sir Carnaby Haggerston, who hunted the Duke of Rutland's country during his Grace's minority ; and, as I can myself answer for his having been a constant attendant upon the various masters of the hounds since Lord Sefton's time, he may, without presumption, be entitled to the honourable appellation of Sportsman. He has always been a steady and good rider to hounds, though weighing at least sixteen stone and measuring six feet two inches high, and I never before recollect hearing of his meeting with any serious accident.

Mr. John Fryatt, formerly groom to Mr. Brommell, but of late years landlord of the George Hotel at Melton Mowbray, is entitled to the thanks of the sporting world for the various horses he has introduced into Leicestershire, by which the breed of hunters has been very much benefited.

The town of Melton Mowbray is very finely situated. It is embosomed in a rich vale, with the river Stour flowing by the side of it; and has a very handsome church, the tower of which is often a grateful sight to a returning sportsman on a beaten horse. The roads about Melton are uncommonly good-particularly that to Leicester, from which it is distant fifteen miles.

But what would Melton be were it not for the noble sport of foxhunting? Something perhaps what Cheltenham would be without its springs; though springs alone would be no great recommendation to Melton, as the visitors to that place drink something better than water. The money, however, spent in this town alone by strangers, who resort to it for the purpose of hunting, cannot be computed at less than twenty thousand pounds per annum, as there are generally from two hundred and fifty to three hundred horses quartered in its stables. Leicester, Grantham, Nottingham, and the neighbouring towns, also turn out their share of sportsmen. 
The grand feature at Melton Mowbray is the Old Club, which has been established about thirty-two years, and owes its birth to the following circumstance. Those distinguished sportsmen Lords Forester and Delamere (then Messrs. Forester and Cholmondeley) had been living for some year's at Loughborough, for the purpose of hunting with Mr. Meynell, and removed thence into Melton, where they took a house, and were joined by the late Mr. Smith Owen, of Condover Hall in Shropshire. As this house, now known by the name of the Old Club-house, only contains four best bed-rooms, its members are restricted to that number; but the following sportsmen have, at different periods, composed it:-the Hon. George Germain (now Lord Sackville), Lords Alvanley and Brudenell, the Hon. Joshua Vanneck (now Lord Huntingfield), the Hon. Berkeley Craven, the late Sir Robert Leighton, the late Mr. Meyler, Messis. Brommell, Vansittart, Thomas Assheton Smith, Lindo, Langston, Maxse, Maher, Moore, and Sir James Musgrave.

There is something highly respectable in everything connected with the Melton Old Club. Not only is some of the best society in England to be met with in their circle, but the members have been remarkable for living together on terms of the strictest harmony and friendship; and a sort of veneration has been paid by them to the recollection of the former members, as the following anecdote will prove. Not only is the same plate now in use which was purchased when the Club was established, but even trifles are regarded with a scrupulous observance. A small print of the late Samuel Chifney, on Baronet, was placed against the wall by the present Lord Sackville, then Mr. Germain-(so distinguished as a most excellent sportsman, as well as a rider over a country or over a race-course-in the latter accomplishment, perhaps, scarcely excelled by any gentleman jockey) —and although since it was first affixed the room has undergone more than one papering and repairing, yet the same print, in the same frame, and on the same nail, still hangs in the same place.

\footnotetext{
"The rivets were not found that joined us first, That do not reach us yet:-we were so mixed, We were one mass, we conld not give or take But from the same, for he was I; I, he."
} 
There are none of the "certamina divitiarum," no ostentatious display at the table of the Old Club, but everything as good as a first-rate man-cook can produce, and the wine of the best quality. Sir James Musgrave was absent, performing the duties of his shrievalty for the county of Gloncester, whilst I was at Melton; but the well-known good fellowship of Mr. Maxse, and the neverfailing agreeableness of Mr. Moore (son to the late Archbishop of Canterbury-nine years a member of this Club, and whose absence this Club would not easily forget), give everything a relish.

On one of the evenings which I spent at the Old Club, I had the pleasure of meeting that paragon of sportsmen, Mr. John Musters. I also met that Ajax of the high weights-Mr. Thomas Edge, of Strelley Hall near Nottingham-who, when riding the enormous weight of twenty stone, was not to be beaten by any man in England for twenty minutes in a quick thing over Leicestershire; and who is moreover-not always the case with very hard riders - a very excellent sportsman.

Were this gentleman's name Blunt instead of Edge, I should still have pronounced that edge to be keen which would take any man into a Leicestershire field, determined to go with such fearful odds against him ; and nothing but the very best of horse flesh could have enabled him to enjoy even his short-lived pleasure. His two famous horses, Remus and Banker, I well remember by the extraordinary circumstance of his refusing my Lord Middleton's offer for them of two thousand two hundred guineas; returning for answer-in words that ought to be emblazoned on his tomb when he is no morethat he liked his horses better than his Lordship's money. He had another very remarkable hunter called Gayman, which, wonderful to relate, he rode every Monday that hounds hunted in Leicestershire for nine seasons in succession.

A singular aneedote respecting this horse was related to me by Mr. Edge himself. He had him one day by the covert's side in Leicestershire, purposing to ride him for the day, when Mr. Compton, of the Manor House near Lyndhurst, who had two horses of his own in the field at the time, went up to him and offered him fifty guineas to ride Gayman the first fox-taking all chances of a run or no runwhich offer Mr. Edge refused. Mr. John Edge, brother to this 


\section{LEICESTERSHIRE}

gentleman, and a still heavier man, has gone quite as well over a country.

Among the high weights in Leicestershire, Mr. Maxse is quite a front-rank man, and is remarkably well mounted for that country, his horses having a great deal of power, upon short legs, with a good allowance of blood. Strange to say, he also has one horse called Cognac, which has carried him nine seasons, and is still very fresh and well. A finer animal in the shape of a horse was never formed.

Mr. Maxse's weight is sixteen stone; but his seat on his saddle is much in his favour. He sits well down on his fork, elose behind his horse's shoulders, and has a fine bridle hand. He has also an excellent method of putting his horse at his fences, and as a proof of its good effect, he himself informed me that he went through one whole season, and up to Christmas in the next, without having a fall.

Sir Harry Goodricke's stud, consisting of fourteen, was just what I expected to see in a hard-riding man's stable, who never misses a day with hounds, who rides nearly fourteen stone, and stands six feet high. Sir Harry is a sportsman. His father was one before him; and though but a tyro in those days, I remember being out with a pack of fox-hounds of which he had, in part, the management. His confederate was the well-known Colonel Wardle, a very keen sportsman and a very hard rider. I do not speak from my own knowledge of the fact, not having seen enough of him to form so decided an opinion; but I speak from what I heard from all quarters at Melton, that Sir Harry Goodricke is not only as fine a horseman over a country as can be put on a saddle, but that riding is only a secondary accomplishment with him. He is allowed to be an admirable judge of hunting, devotedly attached to the sport; and by his early promise, we may venture to pronounce that a sportsman he will continue to the end of his life.

Mr. Holyoake is a decided adrocate for thorough-bred horses, declaring, from his own experience, that nothing short of full blood can carry him at the pace he wishes to go over Leicestershire. Mr. Holyoake doubtless finds no small difficulty in procuring thoroughbred horses to carry his weight (fourteen stone), but he still per- 


\section{NIMROD'S HUN'TING 'TOUR}

severes in the attempt. He is a very brave man over a country, and has hitherto escaped pretty well-taking the thorough-bred ones into account; but last year he got a very rough fall over timber, which laid him on his back for a month. This happened in consequence of some nervly-made ground giving way with him as he rode quickly at the fence. The horse fell upon him, and hurt him very much, to the no small discomfiture of his brother sportsmen, for he is very popular at Melton. His horses were in very high condition, and it is supposed that he has got one of the very best hunting grooms in England.

The more I see of Leicestershire, and the more I look at it with a sportsman's eye, the less I am surprised that it has ever been considered the Montpelier of hunting countries, and that it is resorted to by persons from all parts of the kingdom. As I was riding to covert to meet Lord Lonsdale's hounds at Coles Lodge, Sir James Musgrave was kind enough to shew me the brilliant run Mr. Osbaldeston's hounds had the season before last from the Coplow to Ranksborough; and I really think that if an artist were to paint a panorama, and make fox-hunting the subject of it, his imagination could not furnish him with a finer prospect for his pencil. I should not think there was a field in the run less than forty acres, and many more than a hundred, with that beautiful variety of ground which sets off hounds to such advantage, and which (though severe for horses) gives such a commanding view to those who are following them.

The ox-fence, peculiar to this part of the kingdom, is considered to be the most formidable; and from the description I shall give of it, my readers must be aware that it is sometimes a stopper, not only to the ox, but to the high-bred hunter, with ever so good a man upon his back. When bullocks, however, get fresh in condition, and the gad-fly gets about them, it requires a strong fence to prevent their breaking their pasture, as they will run almost anywhere to avoid them. The ox-fence is formed thus: First, there is a wide ditch; secondly, a strong black-thorn hedge, which in that rich country generally grows luxuriantly; and about two yards beyond the hedge is a strong single rail about four feet high. Now from whichever side this fence is approached, the exertion to clear it must be considerable. If we approach it from the inner or ditch 


\section{LEICESTERSHIRE}

side, we have not only the ditch and hedge to clear, but the rail also, which is generally strong enough to throw all but the heary weights down, if their horses do not clear it; and if they do, it takes something out of them, which is not very easily replaced in a very quick thing. If the fence be approached from the rail side, the $f y$ is also tremendous; and if, after clearing all, the horse alight in the furrow instead of on the top of the land, the drop is most distressing to him.

In the very strongly-fenced parts of Leicestershire, Rutlandshire, and Northamptonshire, it is often impossible to go at all except where timber is to be found; and, fortunately for those who hunt in them, it is generally to be met with, and particularly in the corners of the fields adjoining either hovels, sheep pens, or gates; and there it is sometimes to be met with single, and unaccompanied even by a ditch-though always awfully strong. The gates are also very strong, and frequently difficult to get at, on account of sloughs or other awkward ground in the approach to them.

There is one kind of fence peculiar, for the most part, to those celebrated countries. This consists in the common thorn fence, with a yawning ditch on one side; but the hedge is not only strongly plashed at the top, but made to lean towards the ficld whereon it grows. This occasions a great space of ground to be covered by a horse that clears all when he takes it from the hedge side; and if he do not clear it, a fall must be the consequence. I do not think "cloubles" are so frequent here as in some other countries I have hunted in; but now and then we meet with a fence of this description;--first, there is a ditch, then a rail, then another ditch, and then another rail. Now as it is obvious there is no landing for a horse on the middle of this fence but on the first rail or in the second ditch, it must be taken at a fly, and it generally extends over a great space of ground. A friend of mine was out one day this season with Lord Lonsdale's hounds, and saw a gallant performance at one of these fences by Mr. T. Smith. My friend happened to be in a situation to view the fox whilst the hounds were at fault, and consequently awaited their coming with the scent. He had been previously amusing himself with looking at this stopper, as he supposed it to be, and was meditating within himself whether it 
were practicable or not, and whether any one would attempt to ride at it. Mr. Smith came up with the hounds, and, without appearing to look at it, put his horse's head straight for it, and cleared it all. Lord Plymouth followed him, and by breaking the second rail, enabled my friend to follow him.

Lord Plymouth is a Nobleman very highly entitled to the respect of the sporting world, not solely in consideration of his ardent attachment to fox-hunting as far as regards himself-so strongly evinced by his foregoing the comforts of his two splendid mansions, and contenting himself with a humble cottage in Leicestershire for five months in the year-but also in commemoration of his very handsome conduct in promoting the sport of the country; for he not only pays the rents of several coverts, but continued to do so during the scasons he was absent from the country on account of ill health. His Lordship's stud is as good as money can procure, and he is a very hard rider.

There is one circumstance, however, in favour of fences in Leicestershire and most other grass countries, and that is, they are planted on the ground, and not on cops or banks; for if they were, they would be quite impracticable from the angle horses would have to make to clear them. The footing also is much more secure when the fence is on the ground.

The brooks in Leicestershire and in the Duke of Rutland's country make their appearance pretty often; and the betting is, that one man in ten is in, instead of over, those which are of any size. The two most formidable are the Smite and the Wissendine, which are very often all but overflowed, and then mischief is sure to be the consequence. There are narrow places in all these brooks, but when hounds are running hard there is no time allowed for looking for them, and all chances must be taken.

A very excellent map was published in 1823 by $\mathrm{Mr}$. T. Combe of Leicester, in which all the coverts belonging to the different hunts are laid down with great accuracy; and which is most useful to those who resort to the several towns for the purpose of hunting in this fine country.

The subscription to the Quorn hounds is 2200l. per annum, and about 700l. per annum is paid for the rent of coverts. All this is 


\section{LEICES'TERSHIRE}

managed by the very kind and gratuitous exertions of that good old sportsman, Mr. Cradock, of Sanford near Loughborough, who, accompanied by Dick Burton, goes around the country as soon as hunting is at an end, pays the rents of the coverts, and inquires into the state of the foxes, litter's of cubs, \&c. Having had the pleasure of meeting Mr. Cradock one evening at the Old Club, he was kind enough to infor'm me in what manner the artificial coverts are made.

"A piece of dry land," said he, "lying well to the sun, and from two to three acres in extent, should be fixed upon. Here some very strong black-thorns are stuck into the ground, and plashed and laid down within about two feet of the surface. In a very short time, if the land is strong, the thorns will be almost hidden by grass and weeds, and the foxes will make their runs and kennels under them. In a covert of this description," adcled he, "which I made on my own land, the thorns were hidden in little more than two months." These coverts, it must be obvious, are difficult for hounds to draw, and in other respects very inferior to those which are natural.

As a small token of regard for the services Mr. Cradock has rendered to the Quorn country, the members of the Old Club, joined by one or two of their friends, presented him with an elegant snuff box of one hundred guineas value, and the Earl of Plymouth sent him a most beautiful and massive silver cup. It is somewhat singular that very few of the Leicestershire resiclent gentlemen ever go out with hounds; so that it may be truly said that almost all the money expended in the county on matters of this description is imported from foreign parts.

There is a very celebrated character in the limits of the Quorn hunt, a most respectable yeoman and farmer, by the name of Oldacre, residing between Leicester and Melton, and to whom also a cup has been presented for his services in the country, and most particularly so for his skill in the formation of gorse coverts-in which it is said he has no equal. The famous John Ball covert was made by him, as was also Walton Holt; and by the skill he exercises in cleaning and preparing the ground, and drilling the seed, his coverts always hold foxes the second year.

The most favourite coverts in the Quorn Hunt are Shankton Holt, Billesdon Coplow, Seggs-hills, Cream and Glen Gorses, Barkby and 


\section{NIIROD'S HUN'TING 'TOUR}

Walton Holts-the latter made by Lord Plymouth in the very finest part of the country, but unfortunately not always a sure find; and Munday's Gorse, so called from the name of its owner, a real well-wisher to fox-hunting. Mr. Munday-to his honour be it told, as he never hunts-made a covert of twelve acres at his own expense in the Seggs-hills country, which always holds foxes. Melton Spinney, though only four miles from Melton, is in the Duke of Rutland's draw.

Leicestershire, desirable as it is, has two great disadvantages ; first, the crowd in the field; and secondly, it spoils a man for any other country, on which account no poor man should ever go near it. On the other hand its advantiges are innumerable. It is the only country in the world that appears to have been intended for foxhunting, and where fox-hunting can be seen in all its glory. The flower of our English youth also (of those at least worth looking at) have always been to be seen there, and a winter in Leicestershire has ever been found to be, to those who are entitled to it, the passepartout that leads to the best society in the world.

It is said of History, that it affords entertainment and instruction by delineating the manners and customs of countries, and that its merit consists in the justice and liveliness of the picture it represents, as well as the peculiarities which distinguish national characters. At Melton Mowbray, as may be supposed, are persons from all parts of His Majesty's dominions, and Ireland and Scotland furnish their share. The house occupied by Mr. Smith Barry and Mr. O'Neil, and that inhabited by Captain Ross and the two Messi's. Grant, stood exactly opposite to each other in one of the principal streets, and, from the unbounded hospitality which was displayed in them, they might almost have been mistaken for the signs of the Shamrock and the Thistle. Here, then, the peculiarities and idioms of countries were apparent:- in the one was to be heard proposals for a match, of heats between rival hunters, with " a twelve-feet draina five-feet wall-and a barred gate," in the course ; and in the other Mr. Francis Grant would be heard finding his fox in a whin. In one respect, however, there was neither difference nor distinctionin the good fellowship that prevailed, in the excellence of their French cooks, or in the streams of claret that flowed round their 


\section{LEICES'TERSHIRE}

well-polished mahogany. Mr. Francis Grant does not return to Melton, which I was very sorry to learn. I was in hopes once more to have listened to the lively sallies of this fine young Scotchman, which reminded me of the wild landscapes of his parent country; who, "all air, and disdaining the bars and ties of mortal mould," as the Edinburgh Review says of the poet Shelley, is about to settle in his native land; where, like his countryman Burns, he will " sit on the fields of her battles, wander on the banks of her rivers, and muse by the stately towers and venerable ruins, once the abode of her heroes."

On one of the evenings which I had the pleasure of passing, if I may be allowed to call it so, at the sign of the Thistle, I had the gratification of meeting with that excellent sportsman, the Earl of Kintore, than whom I know no man so rapturously fond of foxhunting.

The name of Captain Ross has been so often before the public in his various pigeon-shooting matches, that nothing is wanting to establish him as a first-rate shot. I saw him hit a black wafer fixed on the back of a common card at fourteen yards several times; but, strange to say, he only missed the card twice, at this distance, ont of three hundred shots-hitting the wafer one hundred and fifty-five times! Calling on Captain Ross one morning, I found him practising at fourteen yards. He then presented his pistol out of his drawingroom window, and said, "Now you shall see me take the head off the figure on Smith Barry's house." This was a small gilt figure of Hope, about five inches in length, placed between the windows, to shew that the house was insured at the Hope Insurance Office. He lodged the ball in the left breast! "That will not do," said he, "I must have the head off." - "Is it not dangerous?" said I; " there is Smith Barry and a friend sitting close by."- " Oh no," replied he, "I have perfect confidence in my pistol." He fired again, and shot off the head. The distance across the street was certainly not less than fifteen yards; but the space from Madan Hope to the chairs on which Mr. Smith Barry and his friend was sitting, did not exceed three. They shewed no symptoms of alarm on ascertaining, as they arose to the window, whence the shot proceeded, but on the contrary they took their seats again quietly after the first fire. 
Perhaps the following may be termed a chef-d'cuvre. He had made a match to kill with pistol and ball twenty swallows on the wing in one day, and he won his match!

Now, most fortunately for society, Captain Ross is a particularly fine-tempered young man; for, at the customary duelling distance, he must be nothing less than a second Marcellus." "Where would you like to have it, Sir," he might say; "would somewhere about the fifth button suit you?" + As for myself, that I should ever fight a duel with Captain Ross is almost as unlikely as the coming of the second Shiloh; but if I were (which God forbid!), I should act thus: I should toss up for first fire; and if I lost it, I should know how to act, and be prepared for the worst. I should send for an undertaker, give directions for my funeral, fix upon the spot for my bones to repose in, and, in humble imitation of the immortal Virgil, I would write my own epitaph for my tomb:

To Captain Ross I lost the toss,

So here interred I lie;

Reader, take care, of him beware-

If he shoots first you die.

There was a gentleman at Melton, of whose performance over a country I heard a great deal when in Surrey, but I had never seen him in the field-I mean Captain Standon of the Guards. His stud was in Dublin, where he is at present quartered; but I saw him go very well one day with his own spurs and another man's horse (Mr. Maher's), and I understand he has been shewing the Irishmen in their own country how to leap walls and swim rivers-though one attempt at the Liffey nearly cost him his life.

I was glad to see Sir Watkin Williams Wynn once more in Leicestershire. Like another Demosthenes, he shews us at once, that, where Nature gives the bias, all difficulties are to be overcome; and that eighteen stone, at the age of fifty, is no obstacle to going a good pace over a country after fox-hounds. Sir Watkin is a good horseman, and has one property which cannot be too closely imitated by all heavy weights, as indeed by light ones also: I have seen a

* Marcellus always killed his man.

† "Pray now, how would you receive the Gentleman's shot?"-Sir Lucius O'Trigger. 
great deal of him in the field, but never sau him quarrelling, and very seldom interfering, with his horse. He is also always well mounted for his welter weight, and his horses are generally in condition, though he has lost his factotum in his hunting stable-Tom Pennwho rode after him for so many years over the country, and whose judgment in hunters was considered superior. Tom was killed by a fall from his horse in hunting; and his successor dropped dead from his, this season, in Leicestershire ; but such accidents are inseparable from liumanity.

Speaking of pad-boys, as they are termed-which was the original office of Tom Penn-a good "second-horse-man" (now so called) is most essential to a Leicestershire sportsman-a second horse being quite indispensable if he wish to be on a par with his neighbours. He should not only be a good rider and a light weight, but he should have an eye to a country, and be some judge of hunting, to enable him to know which way hounds are likely to turn; to observe when they are sinking in their pace, and likely to come to a check, that he may be able to bring his horse fresh and well up to his master. Having gotten on the horse that has been relieved by the exchange, there is some art also required in getting him round again, by picking the best and soundest ground, weakest fences, \&c., and taking the most judicious line for the point the fox may be making.

\section{A FORTNIGHT IN THE NEW FOREST IN APRIL.}

Iт may create a smile when we think, that not having the honour of being an Archbishop, a Bishop, an Earl, or a Baron, had I been born in the reigns of a Henry, a Richard, or a John, I should not have been allowed to hunt in a King's forest; but living under the milder sceptre of George the Fourth, I am at liberty to hunt where I list. With this privilege then, I promised myself a pleasure $I$ had never enjoyed-a fortnight's hunting in the New Forest in April. On the 10th of the month I arrived at Beechwood, the seat of Sir Hussey Vivian, by dinner, and took up my abode under his hospitable roof during my visit to the Forest.

Although I had never been in "The Forest," as it is called-all others being considered quite infra dig. to this-yet having lived a 
great deal with a friend,* who took much delight in talking of it, and who, but from ill health, would never have forsaken it, I fancied myself all but at home. I had listened with so much pleasure to the many entertaining stories he had related of what had happened there in Mr. Ward's, as well as in Mr. Nicoll's time, (and I believe in no country under the sun has the "Coffee-house," as it is called, or perhaps, more properly speaking, the Converzatione by the covert's side, been equal to this), that the names of John Ward, Sam Nicoll, Charles Mitchell, Billy Butler, Jemmy Gilbert, $\uparrow$ Harbin, Nunes, not forgetting old Woods, and half a score others, were quite familiar to my ear; and I had only to lament that any one of those whose presence had so much contributed to the morning, as well as evening, amusement of the April month, was absent when I was in the Forest.

The present master of the New Forest hounds, Mr. Nicoll, succeeded the great John Ward, and has now hunted the country nine seasons, with a subscription of about twelve hundred pounds per annum. The country not requiring a strong pack, the kennel is not large-consisting generally of forty couples of hunting hounds ; about one half of which are bred by himself, and the other half by the Duke of Beaufort, whose young drafts Mr. Nicoll has been so fortunate as to get for some years past.

My visit to Sir Hussey extended to the twentieth of April, during which time I hunted four times with Mr. Nicoll; but the same cause (the dry weather) which operated against sport in the country I had just quitted, was in full force here--not a drop of rain having fallen for many weeks. Added to this, there was one other bar, not only to sport, but to all chance of sport, and that was a lamentable scarcity of foxes.

* Mr. Chudleigh Haynes. One little anecdote, as a sample of this gentleman's talent for quick and sarcastic reply, may not be unamusing to your readers. Dining one day in a large party, where the almost exploded fashion of drinking toasts was adhered to, he was, in his turn, called upon to give one. Having observed that almost all those already drunk had been the healths of different Noblemen, he told the President he supposed he must give him a Lord. "But you have drank them all," said he, "have you not?"-_"Not quite, neither," added he; "I think I can find one."-" Who is he?" said the President, expecting something ludicrous was coming. "Why, I'll give you Lord have mercy upon us!" said Mr. Haynes.

$\dagger$ Mr. Gilbert's father once hunted the Forest. 
I saw one very pretty thing with Mr. Nicoll's pack, running him to ground in twenty-five minutes. The pace was quick enough to shew hounds to advantage, and also to shew what following them in the New Forest is. The first part was over the open, and the latter among trees and bushes, where the quick turning and flying to scent and cry was beautiful to those who could see it. I also saw a great deal of excellent slow hunting on days in which hounds could have hunted nowhere else; but in all rough ground like the Forest, there is what is called "a side scent," from the game so often touching with his sides as well as with his pads, and which is very favourable to hounds. This description of sport, however, is beautiful to behold, and in some measure suitable to mid-day hunting in the month of April, when the sun is often hot and oppressive.

Mr. Nicoll hunts his own hounds, assisted by two whippers-in, all very well mounted. Indeed, I do not know when I have seen a more useful stud of hunters than Mr. Nicoll's; and Sir Bellingham Graham-who was then staying with him-offered him a large sum for one of them. His weight is a welter, but he rides hard and well across the Forest; and, save and except he has to skirt a bog, or is well planted in the middle of one, he is never away from his hounds. One of his whippers-in, Joe, took my fancy much, a good roughlooking fellow, borm in the Forest, and about as hard as one of its native oaks. His language to his hounds is somewhat unique-all in the monosyllable, whose "breath is short and strong;" and his cheer, when drawing, was compared by a wag to a man in an emetic with the dose not quite strong enough for him. Notwithstanding this, Joe is a clever fellow in his way, and a useful industrious servant.

Mr. Nicoll is but a young master of fox-hounds, and consequently a young huntsman; but he is a man of quick parts, and soon made himself perfect in the science. He has, however, taken no small pains to become so, devoting great part of his time to his kennel; and I scarcely know where he pleased me most-there, or in the field. He is an excellent feeder, and looks to essential points, in shape and make. $\mathrm{He}$ is not like some masters of hounds, all for legs and feet, nearly regardless of other form, but has an eye to points for speed and lasting. His style of hound struck me as being 
particularly good, and I might almost add that when we hare seen a few of his kennel we have seen them all.

Mr. Nicoll looks like a true-born Englishman, who is not ashamed of his country - which is more than we can say of all we meet.

As a master of fox-hounds I saw nothing in the least magisterial or imperious in Mr. Nicoll in the field; on the contrary, he was polite and obliging to all. But where is the gold without alloy? or where is the man without a fault? As well might we expect to see the sun without light, or a mortal putting on immortality! As a companion, Mr. Nicoll is a man of great readiness of wit, and a happy quickness in reply. One proof of the latter being as good as a hundred, I take the liberty of giving the following. A well-mounted man had one day been pressing so closely on his hounds, that nothing but a Job could stand it any longer, and Mr. Nicoll bestowed upon him a few hearty damns. The offender rode up to him, and said, "Upon my word, Mr. Nicoll, I don't understand this, Sir! I did not come out to be damn'd!"- "Then go home and be damn'd!" replied Mr. Nicoll.

On my arrival at Sir Hussey Vivian's, I had the pleasure of finding Sir Francis Burdett an inmate of his house. Sir Francis, like myself, had never seen any hunting in the Forest, so had sent some horses to Lyndhurst for the purpose. Like myself also, he had just arrived from Leicestershire, which had made the scene more interesting by the contrast between the two countries, each so celebrated in its way. Sir Francis, however, unfortunately went home the day before we had the quick thing I have spoken of, which on all accounts was to be lamented.

As a public character and a statesman, Sir Francis Burdett is known to almost all mankind, and I think I may say he is to all mankind a friend. It is not for me, however, to eulogise him here, but as a sportsman I may speak of him, and also as the sportsman's friend.

Sir Francis resides at Kirby Hall, a curious old family mansion house, three miles from Melton Mowbray on the road to Leicester, the park wall of which-apparently of great antiquity-runs parallel with the road; and all the lordship of Great Dolby-a capital country to ride over-belongs to him. At Kirby are very excellent stables 
not long since built by the Baronet, and in which he has a good stud of hunters-seldom sticking at price.

No man rides harder over a country than Sir Francis Burdett; and $I$ think I can exemplify this in a few words. When dining one day in a large party at Melton, I heard the following question asked by a gentleman, who has been at the top of the tree in that country for eleven successive seasons.--" Has any man," said he, "seen Sir Francis Burdett refuse a fence which any other man rode at or over?" The answer was in the negative. Another question was put-" Have we not all of us seen Sir Francis Burdett frequently ride at fences which other hard-riding men have refused?" The answer was in the affirmative.

Sir Francis Burdett took his departure from Beechrood-having previously inspected Mr. Nicoll's kennel-very much pleased with all he had seen; but it was evident he would have liked the hunting better if there had been some good ox-fences in the Forest, and a rasping brook about every half hour-for he appeared quite delighted when, on one occasion, we had a few leaps to encounter. Sir Francis, however, laughs at danger, and is an enthusiast in everything he undertakes.

The New Forest is a very awkward country to get across, and one in which, in my opinion, there is no great enjoyment of hounds when they go the pace. Fences are generally to be managed, but bogs are more difficult and awkward obstacles, and their surface is so treacherous that the most experienced forester-Mr. Harbin himself -cannot always distinguish them-they absolutely require wings : and as heart of oak is rather harder than men's skulls, another difficulty presents itself in the rooded parts-a tree is to be encountered at about every fourth stride of the horse. Horses that are used to all this soon become wonderfully handy; but taking it altogether the Forest is a distressing country to them, although they get a few chances in their favour by foxes running short, which, from the nature of the country, they must often do.

There was one person in the Forest of whom, having heard so much, I was particularly anxious to see, and that was Mr. Harbin. This gentleman resides in the Forest, and, like the oaks that orershadow it, he has not been stinted in his growth. His weight on 
his horse must be upwards of twenty stone, but his seat on his saddle surprised me much. He stood up in his stirrups, in his thin jockey boots, as his horse galloped along, and displayed all the activity of a ten-stone man. He is also allowed to be an excellent sportsman, and knows every track in the Forest.

I have a singular circumstance to relate of Mr. Harbin, which I heard from his own mouth. On my speaking to him in praise of his chestnut horse-for a finer animal eyes never beheld-he told me that he was glandered for four seasons, but it made no difference in his work, and he is now quite well. Another of his hunters was also in the same situation, but he fell a victim to the disease.

Mr. Nicoll's hounds only hunt three times a week-so on one of the intermediate days Sir Hussey Vivian conducted Sir Francis Burdett and myself through a considerable part of the Forest, and shewed us some of the principal lions; but it was the wrong time of the year for this. To see the New Forest to advantage, its beauties should be clothed in the shade of summer or the tint of autumn, for scenes wholly desert have only charms for few.

It is not always that we find the hero and the sportsman united in the same person; but Sir Hussey Vivian is a thorough sportsman. $\mathrm{He}$ is not only a very good shot-very celebrated for his greyhounds, of which he had at least ten brace when I was at Beechwood-but he is also a good judge of, particularly attached and an excellent friend to fox-hunting. Every well-wisher to fox-hunting must read with pleasure Sir Hussey Vivian's speech, a short time since, on the order of the day for the third reading of the proposed Game Bill. "I own," said the gallant General, "I am proud of sporting; and the greatest Commander the world ever had has declared, that he found the men who followed the hounds brave and valiant soldiers."

There is an admirable sentence in Holy Writ, which kindly informs us that pride was not made for man. I know of no one who bears his honours-so thick upon him-with so much meekness as Sir Hussey Vivian, though we might almost say that Fortune hung upon his sword. It is impossible to flatter such a man; but we may safely apply to him the words of the Poet :-

\footnotetext{
"Nor did thy battles make thee proud or high; Thy conquest raised the state, not thee : Thou overcam'st thyself in every victory."
} 
Exclusively of the honours bestowed on him by his Sovereign, Sir Hussey has some private, though not less signal, trophies of his well-earned fame. His own regiment, the 7th Light Dragoons, gave him an elegant vase, which looked very handsome on his dinner table; but, what is still more to his honour, the 18th Light Dragoons, on being reduced-in gratitude for the victories* he had led them to-presented him with a silver trumpet purchased by the non-commissioned officers and soldiers out of their share $t$ of horses captured from the enemy, and which trumpet was to have remained in the regiment for cicr! The officers of his own regiment also honoured him with an elegant sword, which, with the trumpet-in compliment to the donors-is suspended over the fire-place in this gallant soldier's dining room. I am a poor poet, but yet I must be allowed to say,

Well may this trumpet sound the note of Fame,

And Echo, from the woods, return a hero's name.

Sir Hussey Vivian's father was on a visit to him when I was in the Forest, and is an example to all men of the good effects of a country life and country sports. Mr. Vivian resides at Trewan in Cornwall, where he has kept hounds for a great number of years (hunting fox after Christmas), and where he fulfils some of the most important offices of a country gentleman. Although nearly arrived at "the age of man," Mr. Vivian is young in constitution, and as firm and strong a horseman as I ever met with.

On the second day of my hunting with Mr. Nicoll, I had the pleasure of seeing the well-known Mr. Butler. Although we had never met, we had heard and read of each other; and, as some one observes, "where there is a sympathy of thought and sentiments, noble souls make acquaintance at first sight " - a slight introduction put us completely at our ease. Mr. Butler informed me that the

* On the eve of the battle of Tonlouse, Sir Hussey took a most important post with the 18th Light Dragoons, but received a severe wound.

$\dagger$ There is nothing new under the suu. The scholar will go back to the golden shield in the Temple of Jupiter, on which the lines, thus Englished, were engraved:-

"' Th' Athenians, Argives, and Ionians tamed, Tanagras' sons this golden bowl have placed A sacred gift-of all their spoils the tenthFor vict'ry with their friends the Spartans gained." 
last was the fortieth month of April in succession that he had spent in the Forest; but gave it as his opinion, that should he live to see forty years more, fox-hunting in the Forest would only be talked of as having once been.

The colour of his coat being different, trumpets and swords would not be in keeping with $\mathrm{Mr}$. Butler, but he also has been honoured with the notice of his Sovereign. When George IV.- then Prince of Wales-hunted in Dorsetshire, where Mr. Butler resides, he was extremely pleased with his society, and bestowed upon him several slight marks of his attention. Every one, indeed, must be pleased with Mr. Butler. There is about him a simplicity of manner, added to a quaintness of expression, very rarely met with in these sophisticated days; to which an additional zest is given by a powerful Dorsetshire dialect. As a sportsman, a companion, and a worthy and excellent man, however, Mr. Butler ranks with any one; and his name is as well known in the Western hemisphere of the Sporting World as Russell's wagons are on the Western road.

I own I am partial to English customs and manners in their native garb, and only fear that in another century, among the higher orders at least, the remembrance of them only will be left. That they remain at present in full force and virtue among Dorsetshire yeomen, the following anecdote told by Mr. Butler will amply prove; and I wish I could relate it to my readers as well as he related it to me. $\mathrm{Mr}$. Butler informed me, he was lately invited to the house of a person of this description, who gave a dinner to about a dozen friends. "My host," said Mr. B., "weighed upwards of twenty stone, and sate behind a rump of beef weighing fifty-two pounds. Being a bachelor, a friend of his weighing nearly as much sate at the bottom of the table behind a loin of veal weighing thirty pounds, and there was a ham in the middle weighing twenty-seven pounds. When these were removed, the maid in waiting placed six plum puddings, in six different dishes, on the table, when her master called out to her-' that will do, Sally: don't put any more puddings down till I tell you !' ",

When speaking of Dorsetshire, and lest another opportunity should not present itself, permit me to mention a circumstance that occurred there in the course of last season, which, in the eyes of 
sportsmen, reflects immortal honour on the county. A farmer in Mr. Farquharson's Hunt was accused of killing a fox. He was not allowed to dine at the farmer's' ordinary at his market town, until he had proved, by an affidavit to that effeet, that he was not guilty of the act he was charged with!!

As may be expected, the gentleman I have been speaking ofbeing quite an original-does not only afford amusement to his friends, but is now and then himself the subject of a harmless joke. On the last day of my visit to Sir Hussey, he had a large party to dinner, amongst whom was Mr. Butler; and by accident he was placed opposite an excellent painting of a fox by Barenger. It so happened that Mr. Butler never saw this fox till he had taken his glass of port wine after his cheese, when he suddenly exclaimed"What a beautiful picture of a fox!"- "Ah, Billy,"* said an old friend of his who sate opposite to him, "how well your nose must have been down $t$ this last hour, that you never saw that fox before!" Sir Hussey lives well.

It is now, however, time to finish my Tour; but I cannot conclude it without offering my best acknowledgments for the kind and friendly reception I have met in the Sporting World, as well as for the assistance I have received from those to whom I applied for information.

* Among his friends Mr. Butler is better known as "Billy Butler."

$\uparrow$ Technical-for hounds stooping well to their work. 




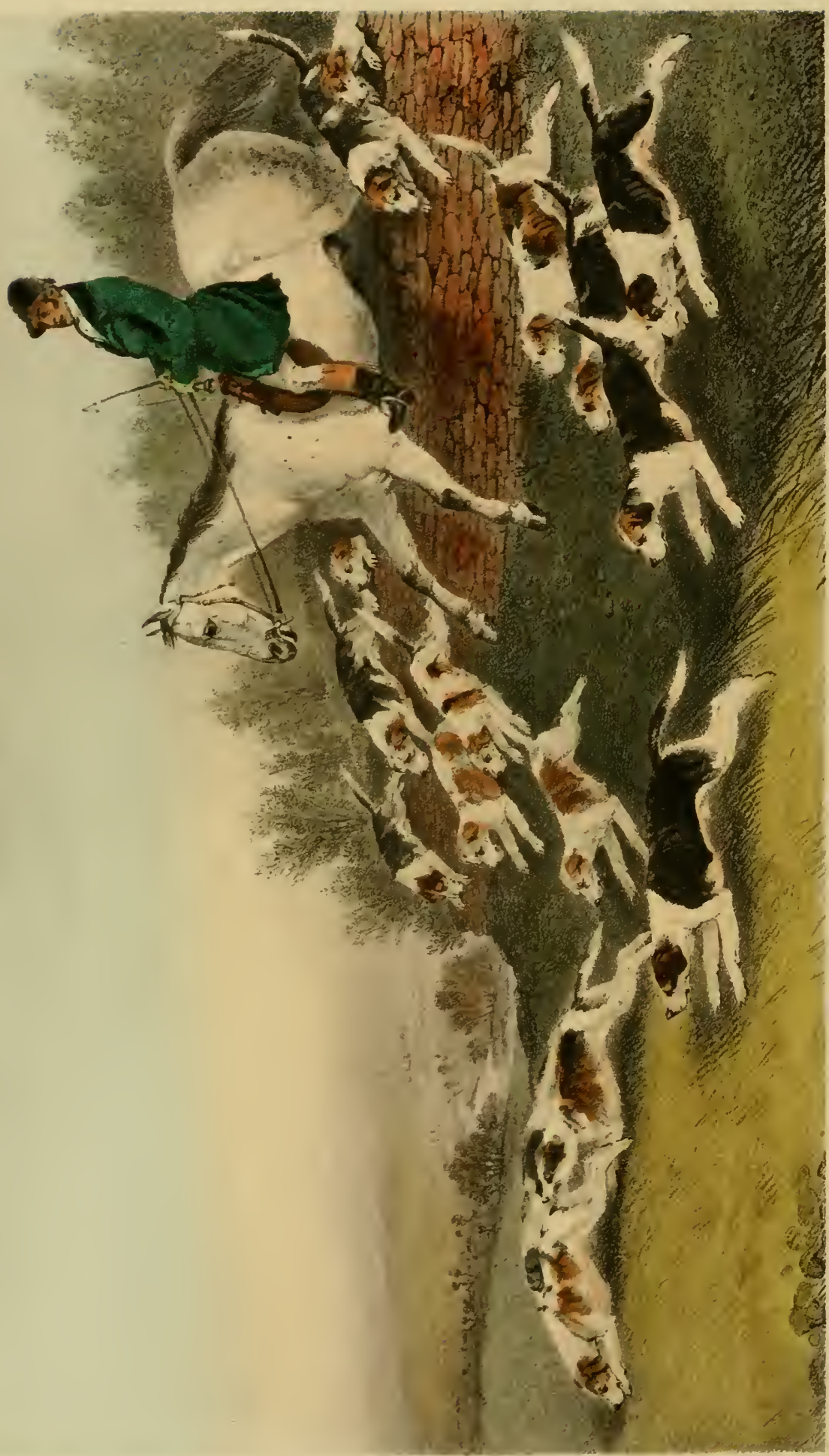


This Cheshire, wyom.

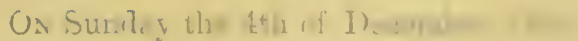
the inclem in state of the war. Fritay, whey 1 wout the d ane This is the place to sou thie all and they come ous of theit i...

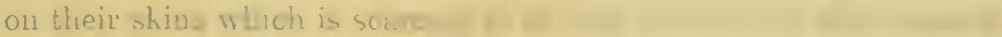

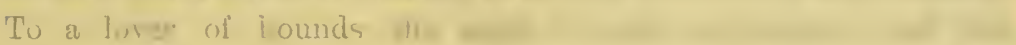
venewule thougli sportus in in

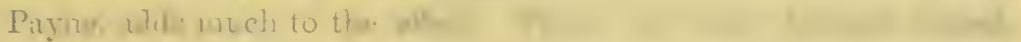

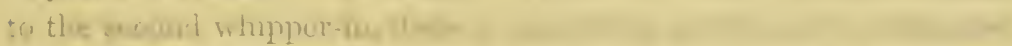

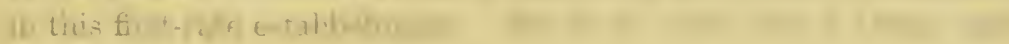

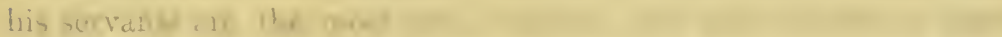

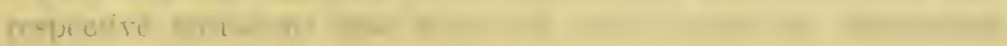

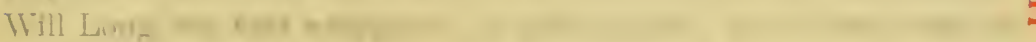

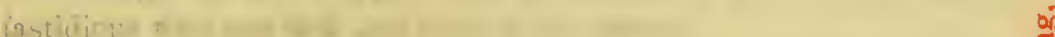
Hel. faroune the

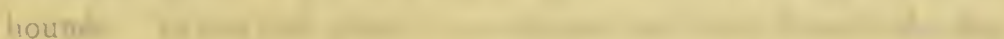

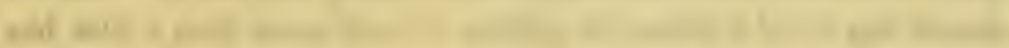




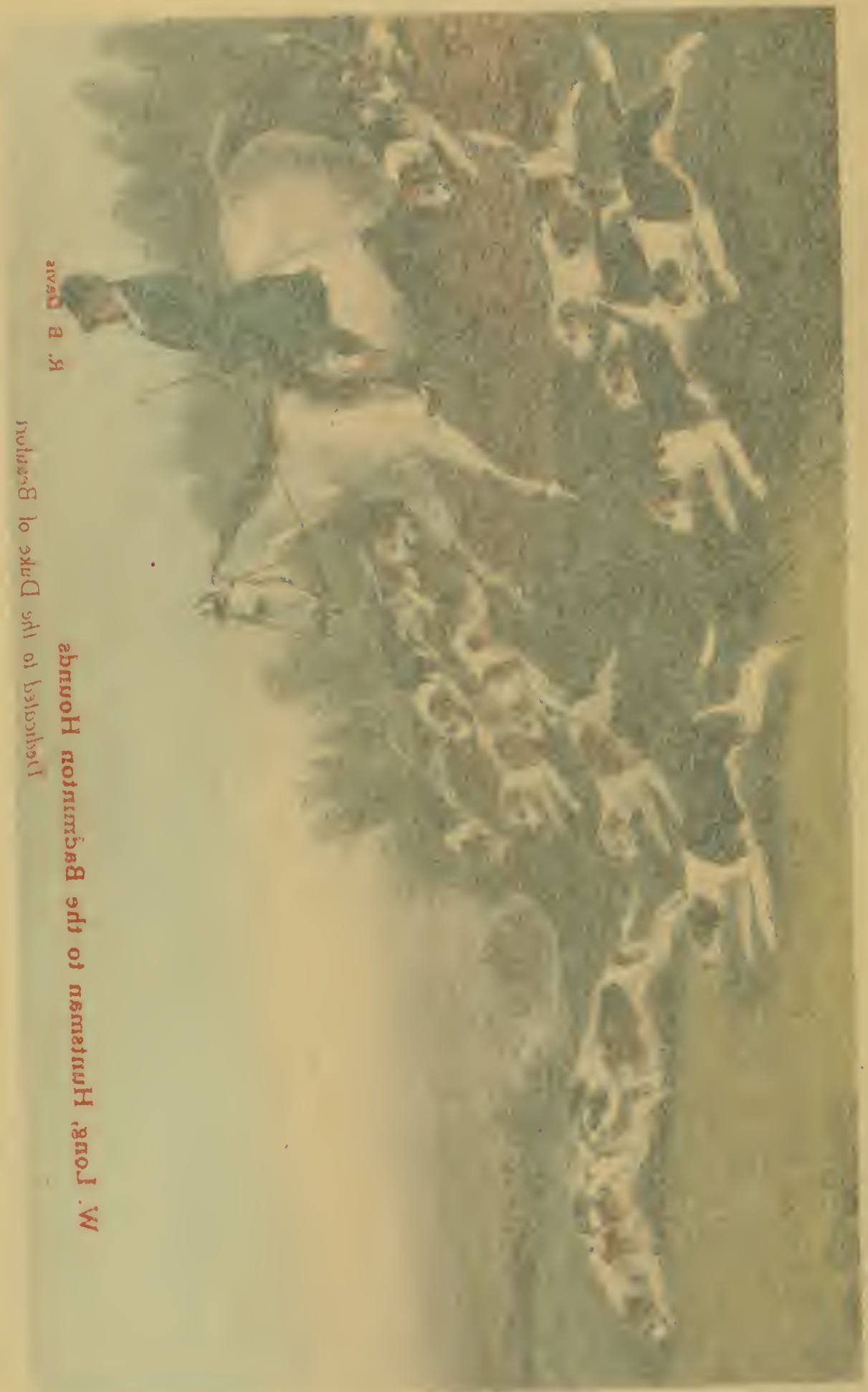




\section{NIMROD'S SECOND 'TOUR,}

EMBRACING ACCOUNTS OF

The Warwickshire Hounds, under Mr. Hay, Mr. Boycott's,

The Shropshire, under Sir Beliningham Graham, The Cheshire, under Sir Henre Mainwaring, Sir Richard Puleston's, The Northamptonshize, under Mr. Musters.

$U_{x}$ Sunday the 4th of December 1825 I reached Oxford, but, from the inclement state of the weather, had no hunting till the following Friday, when I met the Duke of Beaufort's hounds at Heythorpe. This is the place to see this distinguished pack. It is their home; and they come out of their kennel with a sort of lap-dog brightness on their skins which is scarcely to be met with in any other hounds. To a lover of hounds the sight is quite enchanting; and the venerable though sporting appearance of their huntsman, Philip Payne, adds much to the effect. From his Grace himself, indeed, to the second whipper-in, there is something particularly in character in this first-rate establishment. The Duke looks like a Duke; and his servants are the most civil, cleanly, and well-ordered, in their lespective situations that have ever come under my observation. IVill Long, the first whipper-in, is quite perfect; and a man must be fastidious who can find any fault in the second.

Heythorpe-as I suppose, from being a large domain-is not a favourite fixture, but I consider it by no means a bad place to see hounds. In the first place it is a certain find every hour in the day, and with a good scent there is nothing to enable a fox to put hounds at defiance: if he flies, he has some distance to go before he can 
hide his head again, and a fine country, in some directions, before him. To this is to be added, there are several parts of the Heythorpe grounds very favourable for seeing hounds hunt; and this day we had a great treat in riding on one side of a glen which skirts the park, whilst the hounds were running their fox on the other, with the whole pack in view. I was particularly struck with the number of clever horses I saw at Heythorpe, though the field was not a large one.

I thence proceeded into Warwickshire, and again took up my abode at Alscot Park, the seat of Mr. West, which was my head-quarters during my stay in that county.

On the 10th I met the Warwickshire hounds at Compton Verney, the seat of Lord Willoughby-esteemed one of their best fixtures. We found instantly, and ran him more than half an hour, with only one trifling check. Two peculiarities attended this burst. The pace the hounds went at was tremendous, but from the short and curling manner in which the fox ran-almost equal to that of a hare on her foil-it was most difficult to keep with them. The hardest riders were baffled, and it more than once happened that the last became first, and the first nearly last. There was, however, what the Irishmen call some "wicked riding" on this day-at least every other fence being timber, with a good yawning Squire-trap on one side or the other. In spite of the useful practice of tying on the hat, two men were going well bare-headed, viz. Mr. Meyrick (who always goes well), and an Irish gentleman named Lee, who was staying at Leamington. I saw Mr. Lee charging some very rough places, in a line of his own, apparently quite regardless of consequences.* $\mathrm{He}$ rode a good sort of Irish horse, that should not have been allowed

\footnotetext{
* Nothing short of the ardour of the chase would induce a man to be torn, as it were, throngh a strong black-thorn fence at the rate of twelve miles an hour, without anything to protect his head and face. Consequences, however, are out of sight in these happy moments, when things are going well and the music tingling in the ear. The following is no bad exemplar: One day last season, Bob Oldaker, whipper-in to the Old Berkeley fox-hounds, was riding at a fence, determined to catch his hounds. "Take care what you are at, Bob!" said a gentleman to him, "there is a hell of a place on the other side.""Thank ye, Sir," replied Bob; "but a ditch or a coal-pit is all one to me;" and he never turned his head.
} 
to have crossed the Channel again, which I understand he has since done. I was much pleased with his manner of taking his fences. Hewent close up to them before he sprang, and did them in a very masterly manner.

Could it have been possible to have been an ubiquitary, I should have been with the Warwickshire, as well as with the Duke's hounds, on the preceding day: it was a bye-day, and only a few people were out, but it shewed an excellent run. They found their fox in Oakley Wood, and ran him for fifty-five minutes, tip-top pace, over the finest part of the country, and killed.

On Thursday the 15th' met the Warwickshire at Ufton Wood. The covert being central, we had a very large field; but, what is rare, we drew it blank. We found again in Itchington Heath, which never fails, and killed without much sport. He was so pressed by the pace whilst he was on foot, that when he got into Chesterton Wood, he was afraid to leave it again, and thus lost his life in covert. We had what Mr. Hay calls his small pack on this day-chiefly bitches, and those hounds which he brought into Varwickshireand I never saw lounds run closer together than in this short but decisive burst.

Ufton Wood is peculiarly situated. In some directions, a fox can lead you over as fine a country as England can shew, and in others about the worst. This shews the necessity of the field leaving open that side of the covert from which it is desirable that a fox should break.

There was to me, and indeed it must have been to every one, a very agreeable sight on this day in the field. This was Mrs. Shakerley (the Lady of Mr. Shakerley, jun., of Somerford Hall, Cheshire), upon her beautiful, I might almost say superb, horse The Golden Ball. Mis. Shakerley is a French lady of high birth, and certainly the most graceful horse-woman I ever saw upon a horse: the Lady Eveline herself, on her white palfrey, could not have excelled her. Her hand, as well as her seat, is quite perfect, and I understand she has gone very well once or twice in Leicestershire. There was a Foreign Nobleman also in the field on this day who attracted my notice, and who, I thought, sat with much grace upon his horse. This was the Marquis Herrera, an American 


\section{NIMROD'S HUN'TING 'TOUR}

Spaniard, from Cuba, and heir to 30,000l. per annum. He was on a visit to Mr. Shakerley, and, having no establishment in England, contented himself with going out with the hounds on a Leamington hack, which he rode gallantly for two days, charging no less than six gates in the time.

On Saturday the 17th met the Warwickshire at Walton Wood, the seat of Sir John Mordaunt, when a fine day's sport was shewn. There was a burning scent; and with our first fox the hounds ran away from every one for twenty minutes - the field being obliged to go around to a bridge over a flooded river. We found again about two o'clock, and, after three attempts to go away, he put bis head straight for the Edge Hills-going over a very fine country of about ten miles extent. When the hounds got to the Hill-as is too often the case-they got upon a fresh fox; and having of course beaten the horses over this very severe ground, it was impossible to stop them, and away they went. Mr. Hay followed the line of them till it got quite dark, when, not knowing the country, he was obliged to give up the pursuit; and though Will Boxall, the whipper-in, succeeded in getting hold of some of them, a part of the pack were out all night.

It so happened, from the several baftling attempts which this fox made to break from Bowshot Wood-the corert in which he was found-that very few got well away with the hounds. All the Warwickshire old hands were to a man thrown out, and some of them (amongst whom was myself) never knew which way the hounds were gone until all chance of catching them was at an end. Vexatious as this was, it was useless to repine; but it proves what I have before said, viz. that it is better to go through a corert after hounds at certain times, than to keep outside it with the hope of a good start, which hope may never be realized.

It was very generally admitted, even by those who went well themselves, that Mr. Francis Holland, Mr. Patrick (a gentleman farmer from Worcestershire) on his famous little mare, Mr. Cockbill, jun., and $\mathrm{Mr}$. Dews, had the best of this run-Mr. Holland and Mr. Patrick, perhaps, having the cream of it. Mr. Meyrick went gallantly on his farourite old hor'se Jack, but having over-marked him a little in crossing a deep wheat-field, he rather declined at the 
last. The horses, however, were all so distressed, that, when ascending the Hill, not one of them would face a small fence until a little puff was afforded them, when Mr. Cockbill got over it. Mr. Wyatt, Mrr. H. Campbell, Mr. Fellowes, and Mr. Sheldon, the flower of the Warwickshire riders, were all unfortunate in not getting away.

The next morning (Sunday) I accompanied Mr. Hay to the kennel, to learn the state of affairs, and we found that all the hounds but one had arrived. I had never seen this kennel before. Barring its situation (at Butler's Marson, about a mile on the right of the road from Warwick to Banbury, and about ten miles from the former place)-too much in the dirt-it is quite sufficient for the purpose, and the stables very good indeed. In the latter were twenty-three hunters for Mr. Hay and his two men, and I consider them very well adapted for the purpose. There did not appear to be one lowbred horse among them; several of them quite thorough-bred; and, I might almost say, all possessing bone and substance, without which they are of no use in Warwickshire. They are in the liands of an excellent groom, . . Morris, whom I remember when in the service of Mr. Lechmere Charlton and Mr. Hornyold.

I was glad to see Jack Wood (the kennel huntsman) looking in good health; but I did not like him so well in his white jean coat, and on his fect, as I did last year in the bit of pink and the black cap on the old white mare. There, he was quite at home, one of the neatest handlers of a nag that I ever came alongside of in the field, and, in all respects, clever. In his present situation, however, he is well placed; and I considered Mr. Hay's hounds very fit to go.

I very much like the appearance of Mr. Hay's first whipper-in, IVill Boxall. He abounds in zeal, without which nothing can be done well. To a question I put to him as we rode along with the hounds, he made me an answer which stamped him for a good one. "You must have been tired last night, blundering so many hours in the dark, were you not, Will?" said I._-"Why, no, Sir," replied Will, "I was not; I was so afeard about the hounds never coming home." Thus Shakspeare says,

"To business that we love we rise betime, And go to it with delight." 
On the next day (Monday the 19th) I met the Warwickshire at Stoneleigh Abbey, that princely seat of Mr. Chandos Leigh; but the day and our sport were both so bad that I have nothing to say. I have one remark, however, to make respecting the country I was in. Warwickshire is not-neither do I suppose it will ever be-what Warwickshire was. Berricot Wood, the best part of this clraw, is now given to Lord Anson. Frankton Wood, the very best covert in those woodlands, is now drawn by Lord Anson. Ditto, Dubdell, a gorse on Sir Theophilus Biddulph's property, whence his Lordship has had such fine sport these two last seasons. It may be said they cannot be given to a better man-which I readily agree to; but what is become of the Meriden country-the finest woodland country in the world - the country that, when Mr. Corbet hunted Warwickshire, produced such sport-such real sport to real lovers of foxhunting? I answer, it is gone! The Warwickshire woodlands are now termed the "Kenilworth country," which may be said to be a bad exchange.

The following is the history of Mr. Hay, as far as I have any right to inquire into it. His residence is Dunse Castle, in the neighbourhood of Berwick-upon-Tweed; and he commenced his sporting career by hunting the Holderness country. He then took to the Woore country (comprising part of Staffordshire, Cheshire, and Shropshire)-formerly hunted by Sir Thomas Mostyn-where he continued three seasons, and thence he came into Warwickshire. That he is a sportsman no one can for a moment doubt. $\mathrm{He}$ rides very well up to his hounds, and his language-particularly his cheer in chase-is both enlivening and correct.

In society, the manners of Mr. Hay are particularly mild and agreeable, but his conduct with his hounds is firm. Having, at the commencement of the season, lost the chance of some runs by the over-eagerness of his field, he adopted the best method of preventing a recurrence of the disappointment. He addressed his brother sportsmen in a short but pithy speech, when on the point of finding his fox, and begged to explain to them the literal acceptation of those two little monosyllables, "HOLD HARD!" One word to the wise has ever been esteemed sufficient; and two in this instance had a most happy effect; for no field has been better kept than Warwickshire since that hour, and much to its credit be it told. 
Where is the man who has not pressed upon hounds in his time; and where is the man who, in the ecstasy of the sport, may not do it again?

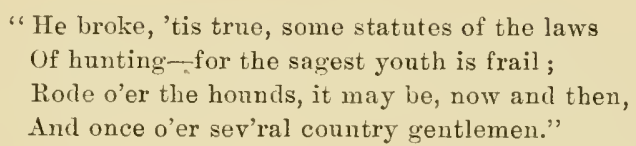

Brron's Don Juan.

But it is almost always to his own cost. Where is there a more pleasing sight than to see a huntsman go forth with his pack, and make his cast unmolested by the crowd? It is here that hunting is displayed! On the other hand, what can be less pleasing to a true sportsman, than to see hounds working-and working perhaps in vain-in the midst of the horses, with their huntsmen dissatisfied and grumbling, with a good fox, and a fine country before them?

Mr. Hay's kennel is divided into two packs-a large and a small one. The former is chiefly composed of the hounds handed over to him, with the country, by Mr. Shirley; and the latter comprises those which he brought with him from Staffordshire. The large one comes under the denomination of a fine slapping lot of hounds, which ought to kill their fox in any country and upon any day; whilst the small pack goes one point beyond this. These hounds give one the idea, that, with a good scent and in a fine country, they could burst, and run in to, the best fox that ever wore a brush in less than half an hour-so smart and quick are they in their nature. On the morning on which they brought their fox from Itchington Heath to Chesterton IVood (where they killed), I thought I never saw hounds get more quickly out of covert and settle better to the scent -running it as true and as close as if they had all been in couples; or, in borrowed but better language than my own,

"like the hor'ses of the sun, all abreast."

Puggy would have told us this, if he could have spoken on the occasion; for in these few fields he was so blown that he lay down in the covert, and would not face the country again. This is as it should be. All hounds will hunt; but, as Mr. Beckford so justly observes, "'tis the dash of the fox-hound that distinguishes him."

Unhappy must that man be who is not satisfied with the manner in which Warwickshire is now hunted! There is a good pack of 
hounds; a sportsman at the head of them-a man full of zeal and activity, who values neither labour nor expense, and I heartily wish him success.

After hunting I dined at Leamington with Sir Loftus Otway. We had a large party of sporting men, and amongst them, Mr. Meyrick, Mr. Buck, and Colonel Robins of the 7th Hussars, who had all been out that morning with Lord Anson at Newnham, the seat of the Earl of Denbigh. A fox was found in the gorse, which afforded a capital run of one hour and fifteen minutes, though the finish was wanting. I was glad the two last-named gentlemen were out, as they were new to the country; and they were also fortunate to see Mr. Hay's fine run on the preceding Saturday.

In honour of the day, and the sport it afforded, Sir Loftus proposed "the health of Lord Anson." It was drunk with enthusiasm. "What a gallant fellow over a country!" said one. "What a trump!" said another. "What a huntsman he will make in a few years!" said a third. "By the Lord," said I, "if the name of Anson had not been immortalized before, this man would do the business!"

Since I first knew Warwickshire, a great addition has been made to it in the town of Leamington. It now contains several resident sportsmen, who live very sociably together, and entertain their friends in the most hospitable manner. Amongst them is a gentleman by the name of Moray, from the county of Perth, a Major in the Dragoon service. The Major is a bruising rider, and by far the best mounted man I saw in Warwickshire. In addition to the excellent stamp of his horses, their condition is quite perfect. In short I have no scruple in saying, that I never saw, four times in my life, six horses in any one man's possession in such a fit state to go as his are. They are full of flesh of the right sort, and their muscles quite luxuriant. I say this with increased satisfaction, because these horses, instead of being turned out in the summer, travelled eight hundred miles on the turnpike road, and were kept on hard meat. The Major assured me he never had them in such tune before, either with respect to their legs and feet, or their bodies. "I may blow them," said he, "but I cannot tire them."

On the second of January (1826) I got upon the Hibernia at Oxford on my road to Shrewsbury Hunt. The Gentlemen of the Hunt not 
assembling until the third, I stopped short at Shiffnal, and hunted with Mr. Boycott's hounds on that day, which met within four miles of the place.

The following is all I know of Mr. Boycott's present establishment. On Sir Bellingham Graham giving up what is called the Shiffnal country last season, Mr. Boycott took to it with a subscription, and he keeps the hounds at Rudge, his seat on the Bridgenorth side of the country, and hunts three days a week. His pack was purchased from a gentleman by the name of Nunn, in the neighbourhood of Colchester in Essex, and to which he has added some drafts from one or two other kennels. He hunts them himself, assisted by Lord Middleton's late celebrated whipper-in, Zac, and Skinner, late whipper-in to Mr. Hay in the Woore country.

Our place of meeting was in the Bridgenorth country, whence, after drawing blank one or two small coverts, we proceeded to Apley Castle, the magnificent seat of Mr. Whitmore, M.P. for Bridgenorth, whose extensive woods we drew without a touch. Mr. Whitmore relinquished fox-hunting, of which he was once such an admirer; but his younger brother still sticks to the brush; and I hope, for the honour of Shropshire, we shall never be without a descendant of "the mighty Belesme" in the field. We got on the stale scent of a fox afterwards-just enough to tantalize us-and thus ended the draw.

I was given to understand that the hounds Mr. Boycott had out of Essex brought with them a very good character for hunting, but not much else. They are very uneven to the eye, and their condition was wretched. In short they were all but diseased. The mnevenness to the eye cannot, of course, be remedied in this short time; but I must give Mr. Boycott and Zac great credit for bringing them to covert in the clean and wholesome state in which I saw them on this day; and considering the season, I understand they have had quite their share of sport.

After this day's hunting (if such it could be called) Mr. Boycott drove me in his gig to Shrewsbury, whither he was going to attend the Hunt Meeting, and I on a visit to my old friend Sir Bellingham Graham. Sir B. resides in a very commodious house within a mile 
and a half of Shrewsbury-the property of Mr. Loxdale, Town Clerk of Shrewsbury; but I found him not in the most comfortable sitnation I ever saw him in. He was sitting, half asleep, by his fire side, having for the first time in his life entirely lost his hounds, and missed one of the finest runs they had had for some time. The fact was, they had slipped away down wind at a ripping pace, and taking a most severe country, all against the collar, his chance of catching them was at an end; so he came home.

Wednesday the 4th, Sir Bellingham's hounds met at the Fox on the Ellesmere road, four miles from Shrewsbury. The morning was awkward, and the fallows hard, but we had a sharp thing for about twenty-five minutes, and lost by an untoward check. On this day I was much struck with the workmanship of a youth about fourteen years old, apparently the son of a Shropshire yeoman. It was somewhat singular, that, on inquiring his name from Mr. Evered Feilding, I was informed that he was the nephew of a Mr. Stephen Matthews, a respectable Shropshire yeoman, then close by my side. Mr. Matthews himself is capital over a country; and I ventured to tell him his nephew would make quite a first-rate performer. He put his mare at her fences in a most workmanlike manner, and displayed a method of handling her very rare at his time of life. Knowing where I could have placed her, I asked him if he would sell his little mare; when he shook his head, and said, "No, never."

On the 5th, Sir Bellingham met at Sundorn, the seat of the late Mr. Corbet. We found immediately, and went very sharply away to Haman Hill, where, under the shelf of the precipice, the pack divided, and, unseen by every one but the first whipper-in, all but six couples and a half went away to Attingham (Lord Berwick's) with a fresh fox. Strange to say, we ran the hunted fox for more than an hour with these six couples and a half through a long chain of coverts, and there is no doubt but we should have killed him, had we not again changed. The scent was a burning one; and by not having the body of the hounds, the lovers of fox-hunting lost a great treat, for it was an excellent morning for hearing them, and the deep notes of the dog pack-which we had on this day-would have made the welkin ring. 
Sir Bellingham and myself dined at Sundorn Castle on this day with Mrs. Corbet (widow of that justly-esteemed sportsman), who now, with her four sons and one danghter, resides in the house, and where the former munificence of the establishment seems by no means diminished. Some alterations have certainly taken place, produced by the sweeping hand of Time. Instead of sixty couples of the blood of the Trojans, with Will Barrow at their head, the kennel contains a small pack of harriers, kept by the present Mr. Corbet-and Will Barrow is dead.

Every sportsman will like to hear what was the finish of the noted Will Barrow, whose halloo so often thrilled through my soul. He descended in the scale, and, from a huntsman to fox-hounds, became huntsman to the present Mr. Corbet's harriers; and an excellent one he was supposed to be. In following them one day last year, his horse fell with him, and in three weeks he was in his grave. Ye fates, how cruel! Will Barrow (as he lived so well with them) should have died with fox-hounds, and the brush of his last fox should have waved among his funeral plumes:

"For could we choose the time, and choose aright,

'Tis best to die, our honour at the height."

The most extraordinary part of Will Barrow's history is yet to come. In boxes in which he kept his clothes, in old stockings, and in all sorts of odd places, was property to the amount of fourteen hundred pounds found at his decease, besides suits of clothes-many of them never put on-sufficient for a parish!! It appears that he had not taken any steps to increase his property by placing his money at interest; neither had he any wish to settle himself in a farm, or any other respectable situation in life; but seemed to think his favourite saddle-room and the servants' hall at Sundorn quite good enough for him. His bones repose in the churchyard at Uffington, about a mile from Sundorn, and on the headstone of his tomb are the following lines:-

Of this world's pleasure I have had my share, For few the sorrows I was doom'd to bear : How oft I have enjoyed the noble chase Of hounds and foxes, each striving for the race!

But the knell of Death calls me away; So, sportsmen, farewell !-I must obey. 


\section{NIMROD'S HUN'TING TOUR}

The pen of Nimrod cannot fail in being somewhat lavish of its praise of so sporting a county as Shropshire, and therefore his readers must make all due allowances. In the first place, there may be seen in it-all on the same day-four packs of fox-hounds:-viz. Sir B. Graham's, Sir Richard Puleston's, Mr. Boycott's, and Mr. Wickstead's. In the next, there are two Hunt weeks in the year at Shrewsbury-attended by almost all the gentlemen of rank and property in that and the neighbouring counties-each week also affording a splendid ball and supper for the ladies. The Old Hunt meets in November, and several pleasant days have I passed at it. The Young One (as some call it) was only established five years since; but its ball is considered the best, being the more select of the two. The uniform of the members is also a set-off to a ballroom, being a scarlet coat, buff waistcoat and breeches, with gilt knee buckles, and handsome uniform buttons to all. The champagne also travels at a merry pace in the supper room, which is not the case among the "old ones." In short, the tout ensemble is quite imposing for the country.

On Saturday the 7th, we met at Acton Reynald, the seat of Mr. Andrew Corbet, only son of Sir Andrew ; but owing to not being able to keep our foxes above-ground, we had no sport worth detailing. I mounted Mr. Mytton on this day (who had no horses at Shrewsbury), and never saw any mare for five days afterwards; but this is a trifle among old friends, and she was very well taken care of at Halston.

I have often seen hounds fed, but never in a more masterly way than that which Will Staples, Sir Bellingham's first whipper-in, adopts, and which I will endeavour to explain. He throws open the door of the feeding-house, and stands at a certain distance from it himself. He draws a certain number of hounds, calling them by their names. He then turns his back upon the open door-way, and walks up and down the troughs, ordering lack such hounds as he thinks have fed sufficiently. During this time not a hound stirs beyond the sill of the open door. One remarkable instance of discipline presented itself on this day. Vulcan-the crowning ornament of the dog-pack-was standing near the door waiting for his name to be called. I happened to mention it, though rather in an under-tone; when in he came-licked Sir Bellingham's hand- 
but though his head was close to the trough, and the grateful viands smoking under his nose, he never attempted to eat; but on his master saying to him, "Go back, Vulcan, you have no business here!" he immediately retreated, and mixed with the hungry crowd. No whip was necessary to keep the hounds out of the feeding-house ; and a gentle stroke of the thong - with very few exceptions-turned such away from the troughs which refused to leave them on their names being called.

The kennel which now contains Sir Bellingham Graham's hounds was built the year before last, by subscription, on a very liberal scale, on ground purchased for the purpose, and reflects much credit on Shropshire. It is capable of holding one hundred couples of hounds, with every requisite convenience, and is situated within a mile of Shrewsbury on the road to Whitchurch and Newport. Many of the hounds were last year affected by kennel lameness, owing to the dampness of the walls; but this Sir Bellingham has effectually put a stop to, by having a stove in each of the lodging-houses Although the use of the stoves has not restored such hounds as were previously affected, yet Sir Bellingham informed me that it has completely prevented the progress of the disease ; and so convinced is he of the benefit derived from warmth in a kennel, that, after this season, he intends having one large fire-place at the back of his present kennel, with flues to convey warm air into the difierent apartments. As it is at present, it is curious to see how the hounds enjoy the heat of the fire. They get around the stove as soon as they come in; and instead of seeing a damp steam, arising from their wet skins, hanging over them for some time, they are dry and comfortable in the space of a quarter of an hour. The temperature is of course, after a certain time, reduced; but it is amusing to see how the hounds sit about the stove, nodding their heads in a dose, as much as to say, "How comfortable we are!"

The stables adjoining the kennel are built on the same liberal scale, and contain stalls for twenty horses and six loose boxes. The joint expense of the stables, saddle-room, and kennel, exceeded the sum of fifteen hundred pounds.

Monday the 9th.-Thermometer at 28. Nothing for it again but the kennel, and grumbling. 


\section{NIMROD'S HUN'NING 'TOUR}

Tuesday the 10th.--Sir Bellingham and myself went to Halston to spend the day with Mr. Mytton. After luncheon we turned out into the preserves, where the pheasants were as thick as sparrows at a barn door, and the hares running about like rabbits. The team consisted (not of highly-broke pointers, but) of four keepers and three stable boys, who kept singing out, as the pheasants got up, "Cock-hen-cock-hen-cock-hen." Pheasants and hares in abundance were of course slaughtered on this afternoon, but don't let us call this sporting.

Our party at Halston consisted of Sir Edward Smythe, Mr. Williams (son of the General), Sir Bellingham, and myself, and as three of the five were old masters of fox-hounds, our evening was rather a larking one. After a hot supper (obsolete almost everywhere but at Halston), we took a walk-not into the groves of Academus, but into the ale and wine cellars, with a cigar in our cheek just to keep out the cold. In the first, we saw hogsheads of ale * standing like soldiers in close column; and in the other, in bottle and in wood, wine enough for a Roman Emperor.

On the following morning just as we were sitting down to breakfast, Mr. Mytton requested me to accompany him to the stables to see his Oaks filly. His dress at the time (which, considering the thermometer was four degrees below freezing, with snow on the ground, was rather airy than otherwise) consisted of his shirt, slippers, and dressing-gown. We walked to the stable in which the filly was, when Mr. Mytton approached her, and after jumping on her back, and playing two or three other harlequin tricks, he laid himself down at full length under her belly, with his naked head towards her heels-playing with her tail, tickling her about the legs, \&c. "I cannot stand this," said I, and bolted out of the stable, though earnestly entreated by my friend to stop, as he had not half done.

After breakfast, we all adjourned to the stables, and looked over the hunting and racing studs. The latter consisted of twenty-two. Longwaist was looking quite fresh and well; but I saved my breath

* Mr. Mytton makes his own malt, and the rords, "John Mytton, licensed malster," are painted in large letters over his malt-house door. How fortunate it is that there is no license required to drink! 



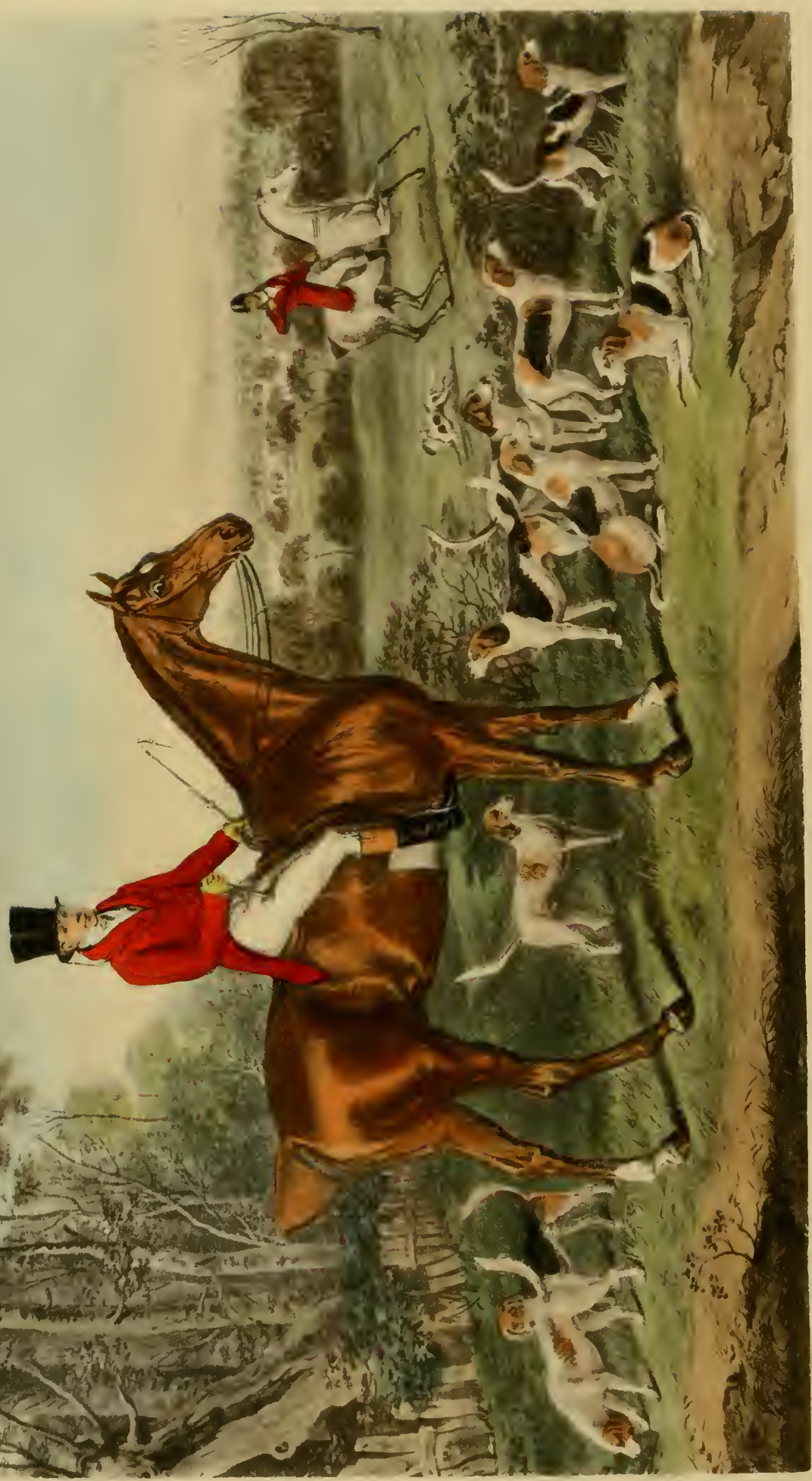




\section{(4) $13030 \times 43183$}

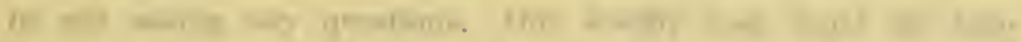

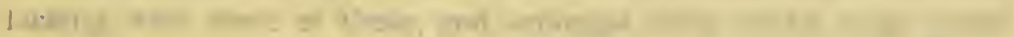

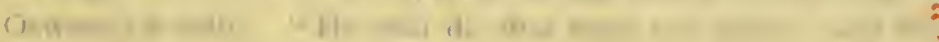

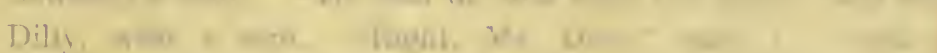

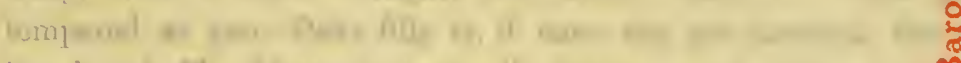

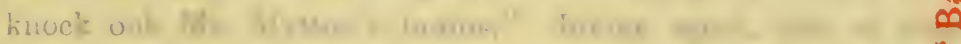

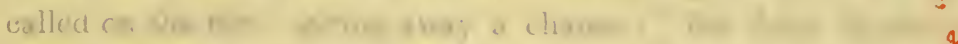

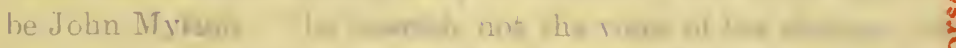

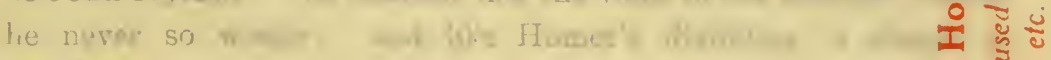
wiselitef.

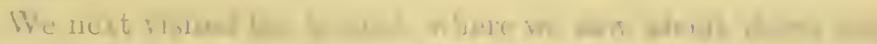

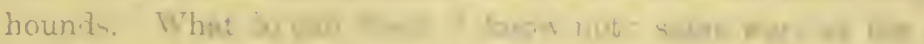

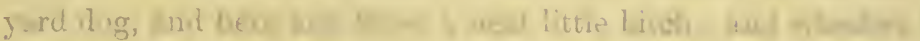

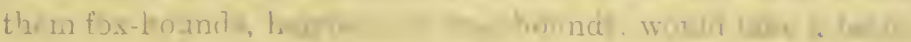

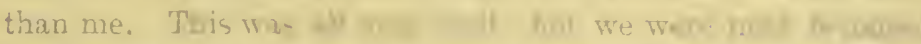

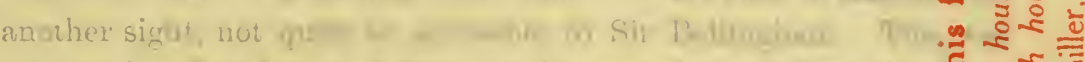

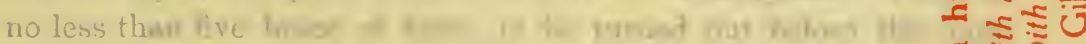
diserint payt: fier y

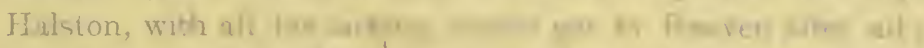

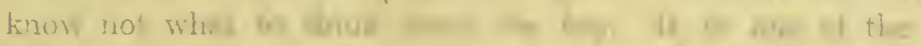

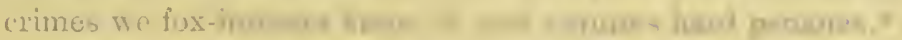

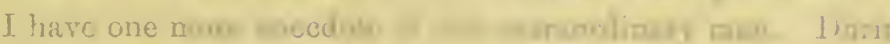

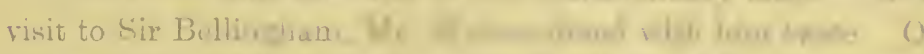

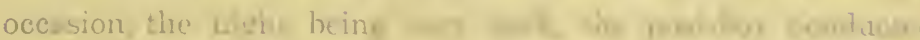

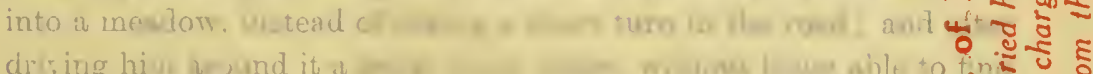

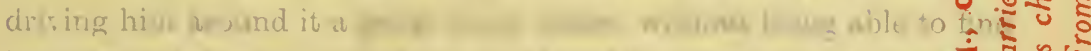

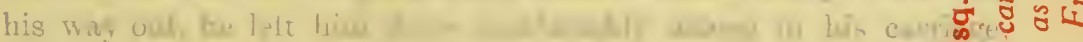
whilst he cruc bach $x$ ํํㄹ กั.

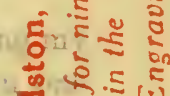
दू จำ

* wesn ftwin rew.

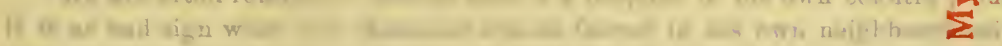

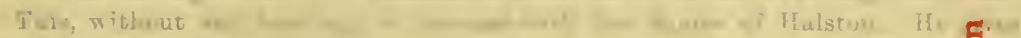

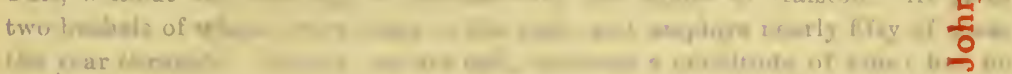
Ilas cue ather whe 6 i 


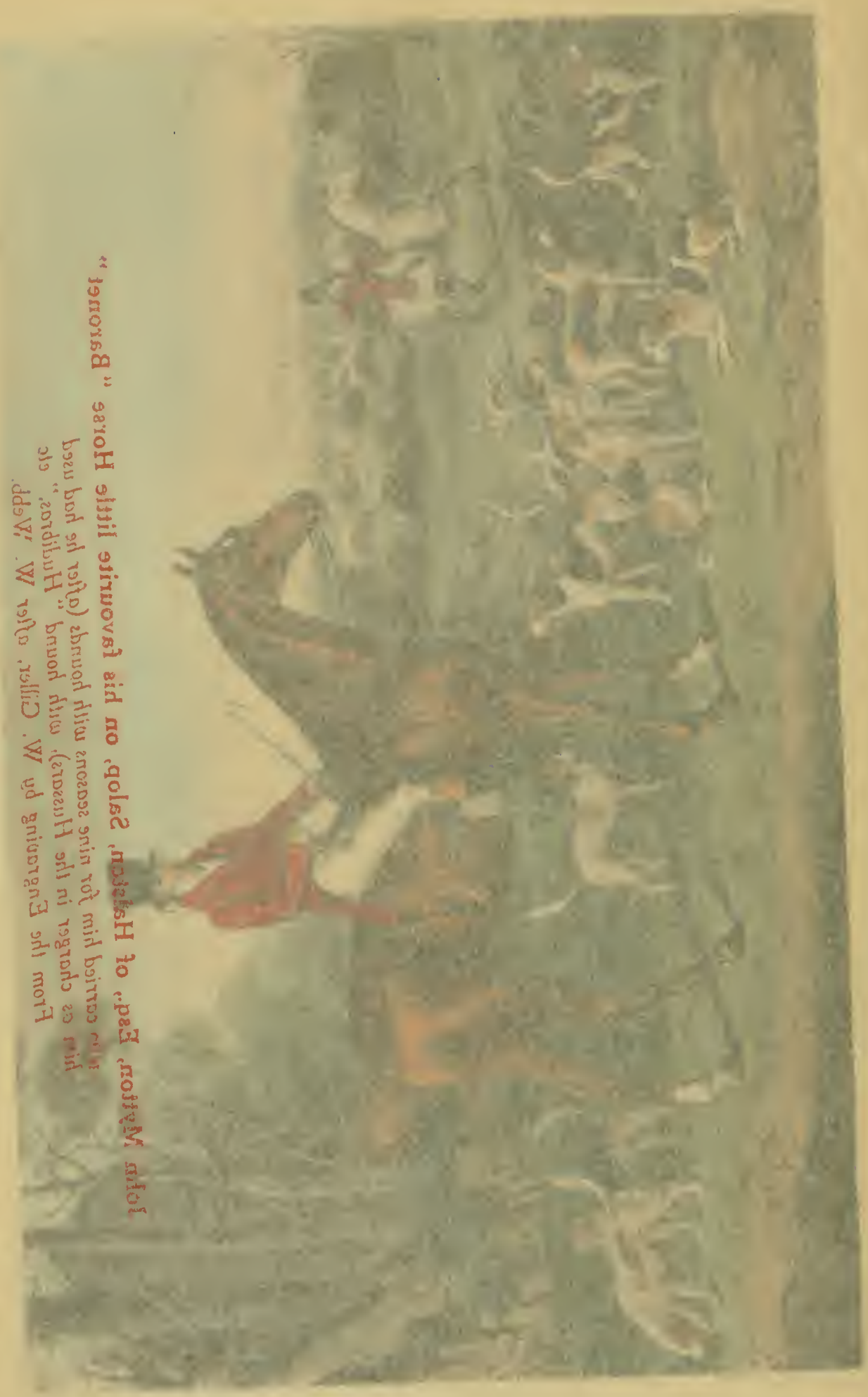


by not asking any questions. Our worthy host could not help larking with some of these, and, amongst other tricks, crept under Oswestry's belly. "He will do that once too often," said William Dilly, with a sigh. "Right, Mrr. Dilly," said I; " and goodtempered as your Oaks filly is, if once she get alarmed, she will knock out Mr. Mytton's brains." Joking apart, this is what is called on the turf "giving away a chance ;" but John Mytton will be John Mytton: " he heareth not the voice of the charmer, charm he never so wisely;" and, like Homer's divinities, is always in mischief.

We next visited the kennel, where we saw about thirty couples of bounds. What to call them I know not: some were as big as my yard dog, and here and there a neat little bitch; and whether to call them fox-hounds, harriers, or stag-hounds, would take a better judge than me. This was all very well; but we were next favoured with another sight, not quite so agreeable to Sir Bellingham. This was no less than five brace of foxes, to be turned out before this nondescript pack. But for this, I should say that the Squire of Halston, with all his larking, would get to Heaven after all ; but I know not what to think about the bag. It is one of the worst crimes we fox-hunters know of, and requires hard penance.*

I have one more anecdote of this extraordinary man. During my visit to Sir Bellingham, Mr. Mytton dined with him twice. On one occasion, the night being very dark, the post-boy conducted him into a meadow, instead of taking a short turn in the road; and after driving him around it a great many times, without being able to find his way out, he left him there comfortably asleep in his carriage, whilst he came back to Sir Bellingham's for a lanthorn. As the

* We are often reminded that no man is a prophet in his own country; but it is no bad sign when his character stands fairest in his own neighbourhood. This, without any humbug, is the case with the Squire of Halston. He gives two bushels of wheat erery week to the poor, and employs nearly fifty of them the year through. Charity, we are told, covereth a multitude of sins; but he has one other saving clause : he is no hypocrite! It can never be said of him when he is gone, that-

"So smooth he daubed his vice with show of virtue,

That his apparent guilt omitted,

He lived from all attainder of suspect." 
household were all gone to rest, the Squire of Halston must have had a good many turns round the meadow; but, fortunately for the post-boy, he never awoke, neither was he at all aware of what had happened.

To be serious.- What would become of Shrewsbury and Oswestry races-what would become of half a dozen other country races, were it not for John Mytton? What would become of the poor about Halston? What would his friends do for a lark? All these questions I am not going to answer; but this I will say, that one of these days he must stop short. Indeed, what with falls from horses-run-away gigs-upsets in carriages-swimming his horse over the Severn*-tumbling into the Severn-to say nothing of twelve paces-being hugged to death by the bear, or his brains kicked out by the Oaks filly-it is next to a miracle that he is now alive. I am sorry to say, I am almost old enough to be his father; nevertheless, unless he minds what he is at, I must see him out. If I do (as I have written my own), I will also write his epitaph. It shall be plain and simple; no weeping over the urn-not a word about the disconsolate widow-no cherubims-nothing typicalnothing to hint as to whither his soul is gone-no humbug, but merely a record of the melancholy truth :-

\footnotetext{
Here lies John Mytton; his short career is past,

The pace was quick, $\dagger$ and therefore could not last.

From end to end he went on errant burst,

Determined to be nowhere, or be first.

No marble monument proclaims his fate-

No pompous emblems of funereal state;

But let this simple tablet say,

That, upon a much-lamented day,

There went to gronnd beneath this mould'ring sod

"An honest man-the noblest work of God."
}

On Wednesday the 11th Sir Bellingham and myself took leave of Halston, and went to Emral to spend a day with Sir Richard Puleston, one of the staunchest fox-hunters this country ever saw-

* The year before last, Mr. Mytton swam his horse over the Severn, though he himself cannot swim; and a short time since he fell into one of the deepest parts of that river out of a ferry-boat, and was only saved by a friend catching him by one of his legs as he was in the act of getting under the boat.

$\dagger \mathrm{Nil}$ violentum est perpetunu. 
having kept fox-hounds upwards of thirty years, and now just as keen as ever for the sport. We looked over his kennel and stables before dinner, and spent a very pleasant evening after.

I must now restrain my pen, for I have a serious subject before me, no less than an humble attempt to describe one of the most celebrated sportsmen of modern days-Sir Bellingham Graham. We historians are said to be either libellers or panegyrists. I must endeavour to be neither the one nor the other; but to praise a man for what is deserving of praise is only a tribute due to him.

The first time Sir Bellingham Graham appeared as a master of fox-hounds was in the year 1815, when he succeeded Mr. Musters in the Badsworth country, which he hunted two seasons. He then took possession of the Atherstone country (now Lord Anson's) on its being vacated by $\mathrm{Mr}$. Osbaldeston, when that gentleman first went to Quorn, and he hunted it three seasons. In 1820 he succeeded that gallant sportsman, Sir Charles Knightley, in Northamptonshire (the Pytchley); and in December, 1821, on Mr. Osbaldeston's declining Leicestershire, Sir Bellingham took to it, and hunted it the remainder of that and the next season. In 1823 he hunted the country Mr. Boycott now has. In 1824 he hunted Mr. Boycott's country and the Shropshire: and since the end of that season he has had Shropshire alone.

The following is a little history of Sir Bellingham Graham's kennel. Upon his leaving the Pytchley country, where he was succeeded by Mr. Musters, his hounds were divided between them, by drawing alternate couples. On his going to Quorn, he purchased from $\mathrm{Mr}$. Osbaldeston, together with the house and eighteen horses, all that gentleman's hounds, excepting twenty-five couples which he reserved for himself. On the other hand, when Mr. Osbaldeston took to Leicestershire again-on Sir Bellingham's resigning it-Sir Bellingham reserved the same number of hounds (only twenty-five couples), which Mr. Osbaldeston afterwards purchased of him for eleven hundred pounds. Here, then, have we run this sporting Baronet to ground, for we have him (and, if I know the man, we had better kill him at once than leave him there) without a hound in his kennel. A lucky card, however, turned up. MIr. Osbaldeston found himself in possession of so large a body of hounds, that 
he selected about twenty couples, which, from age and other causes, he did not wish to keep; and in the ensuing spring Sir Bellingham purchased them. Thus then did he lay the foundation of his present pack: thus is the blood of Abelard, Charon, Marmion, and Orpheus, still to be found in his kennel.

In 1818 Sir Bellingham purchased Mr. Newnham's pack, on that gentleman's resigning Worcestershire, which contained much good blood, and he has had Lord Lonsdale's drafts for some years. In short, he seldom refuses any drafts that are offered him, in hopes of picking up something good. When I was with him, Mr. Boyeott sent him a draft he had had from the Badsworth, from his (Sir B.'s) old whipper-in, Jack Richards-which, he said, were so wild that he was afraid to take them out. Cottager, however, appears a valuable hound, and two or three neat bitches will come in well with Sir Bellingham's bitch pack: but, in the words of an old whipper-in to the Old Berkeley, some of them would "run anything from a hearwig to a hellephant."

There is one part of Sir Bellingham Graham's history, as a public character, which is eminently entitled to notice; and that is, the very liberal hand with which he has conducted every establishment that he has undertaken the management of. Passing over what may be called his minor countries, but countries in which he has left his mark, let us look at him when he took to Leicestershire. On learning that this fine country was vacant, and it was desirable that he should hunt it-he had just entered upon the Hambledon country in Hampshire, under an engagement for three years, and had taken a house in it for twelve-how did he act on this occasion? Why, without a moment's hesitation he resolved to take Leicestershire, purchase Mr. Osbaldeston's house, hounds, and horses, and leave a part of his own pack, with his first whipper-in, to fulfil his engagement with Hampshire. He came forward in this instance without one guinea being guaranteed to him either for hounds or coverts; but Fortune favoured him in one respect: Mrr. Osbaldeston took Hampshire off his hands, and Mr. John Walker succeeded to it the following year.

Of the feeling towards Sir Bellingham Graham as a sportsman, the best test is to be found in the amount of the subscription raised 


\section{SHROPSHIRE}

for him during the two years he was in Leicestershire, which much exceeded that of any previous or subsequent period. For the first year, it amounted (for hounds and coverts) to the large sum of 3,160l. And here I must be permitted to mention the liberal and straightforward conduct of Sir Francis Burdett, which was related to me by a member of the Melton Old Club, and therefore I can vouch for the truth of it. My friend was endeavouring to start the subscription for Sir Bellingham, and paid Sir Francis the well-merited compliment of soliciting his name at the head of the subscribers. "What sum shall I write?" said my friend. "Put me down for three hundred pounds," said Sir Francis ; " and if that is not sufficient I am good for two more." There was no occasion, however, to tax his liberality so far.

Sir Bellingham Graham was very fortunate in being able to requite all this kindness of his friends by the sport he shewed them when he hunted Leicestershire. I was told last year at Melton, by one of his many admirers there, that the second season his old pack (which hunted twice a week) killed every fox they found in the first six weeks.

I asked Sir Bellingham why he quitted Leicestershire-certainly the first hunting country in the known world, and where he had an establishment so suited to it. His answer did him honour. His returns to his tenants, during those disastrous years were, he said, so great, that he could not have continued in it with justice to those who were dependent on him. With such a subscription as his, however, that it should have cost him any serious sum, is the best proof of the magnificent way in which he hunted it.

Of Sir Bellingham Graham, as a horseman and a performer over a country, I need say but little. The Earl of Darlington, in his Field Book for 1810, in which he enters the proceedings of every day's hunting, thus mentions Sir Bellingham as a youngster: "Sir Bellingham Graham was out on this day, and rode conspicuously and well." Now, many a young man has ridden conspicuously; but his Lordship's addition of the word "well" cannot be lost upon us. Every man who has seen Sir Bellingham can bear record, that he ranks among the very best heavy weights England has ever produced. NIuch as I myself have admired his powerful, 
quick, and determined manner of getting across a country, I will quote nothing from my own observation, but will repeat-sufficient for my purpose-what was told me last winter at Melton by several of the leading characters there ; namely, that (almost incredible as it may appear) there was not one single instance of his not being well with his hounds during the two seasons he hunted Leicestershire-the more remarkable as the country was not only new to him, but, in the first year, mole than usually deep, and his weight sixteen stone. In the celebrated run from Glen Gorse to Stanton, he particularly distinguished himself. He took the lead; and though two of the best light-weights in England-Mr. William Coke and Mr. George Anson-started within half a field of him, they could never catch him till all was over.

As is the case with most hard-riding men, Sir Bellingham Graham has had some severe falls, but on two occasions he very narrowly escaped destruction. The following rare instance of his pluch, however, should not be lost to the sporting world. He was killing his fox at the end of a sharp thing, when an ox-fence presented itself. Three first-rate performers were going in the same line, but they would not have it. Sir Bellingham never turned his horse, and cleared all but the rail on the opposite side, which probably his weight would have broken; but unfortunately his horse alighted on one of the posts, and was turned over on his rider's chest. Strange as it may appear, Sir Bellingham re-mounted his horse, and rode on: but he had not proceeded many yards when he was observed by Sir Harry Goodricke to be in the act of falling to the ground, but which he was fortunate enough to prevent. From that period-about twelve o'clock at noon till nine o'clock the next night - Sir Bellingham never knew what had happened to him; and as he lay under the hay-stack-whither his friends removed him at the time of the accident-every moment was expected to be his last. The pith of the story, however, is yet to come. He was bled three times the first day, and confined to his bed five. On the seventh, to the utter surprise, and indeed annoyance, of his friends, he was seen in his carriage at Scraptoff, merely, as he said, "to see his hounds throw off." The carriage not being able to get up to the spinney, Sir Bellingham mounted a quiet old horse (placed there, no 
donbt, for the purpose), muftled up in a rough great coat and a shawl, and looked on. The fox was found; and, unfortunately for Sir Bellingham, took a short ring, but returned, and his hounds came to a check close to where he was sitting upon his horse. Will Beck (the huntsman pro tempore) not being up with his hounds, the Baronet cast them, and recovered his fox. In three fields they checked again, and Beck made a slow but by no means a brilliant cast. Sir Bellingham saw all this from the hill; and, no longer a looker-on, he cantered down to his pack, and hit off his fox again. Things still went on but awkwardly. Another error was observed; when Sir Bellingham-annoyed that a large field should be disappointed of their sport when there was a possibility of having ittaking a horn from a whipper-in (for he could not speak to them), got to work again. The hounds mended their pace : down went the shawl in the middle of a field. They improved upon it : down went the rough great coat in another field. He then stuck to his hounds in a long hunting run of an hour and a half over a very stronglyfenced country, and had gotten his fox dead beat before him, when he was halloo'ed away by one of his own men to a fresh fox under the Newton Hills.

Now what was to be done? The excitement that had carried him thus far was gone, and it was all but who-whoop. With every appearance of exhaustion, and a face as pale as if he were dead, he sat himself down on a bank, and faintly exclaimed, "How I am to get home Heaven only knows!" I am sorry to say that this gallant sportsman had nearly as bad a fall as this last season in Shropshire; and I am still more sorry to add that he feels the effects of each of them to this day.

When speaking of Sir Bellingham Graham as a huntsman-now of some years' standing-I shall again confine myself to the echo of the public voice, as comparisons are odious. $\mathrm{He}$ is universally allowed to be quite at the top of his profession, and "an artist" of more than common fame. One advantage has always attended him: he has ridden the best of horses, which, with his method of piloting them, has enabled him nevor to be long without an eye upon his hounds. Were I to be asked whether any amendment could be made in him, I should say that he is a little too quiet when drawing, 
and he must sometimes draw over his game. This, however, is but a feather in the scale, when set against his fine judgment, quick eye, and his promptness in assisting his hounds in difficulties, and in chase.

Sir Bellingham Graham's judgment in horseflesh is supreme. I have heard several Melton men say that, though the stables at Quorn have often been filled with good horses, they never contained so many good great horses as in Sir Bellingham's time. His present stud is a very superb one. Out of the twenty-six hunters for himself and his men, there is only one-and Jack, the second whipper-in, says of her that, "though she is but a little one, she is a sweet one" - that is not well up to 13 and 14 stone, and he has ten prime ones for his own riding. Besides these, he sold two whilst I was with him, one to Lord Howe for 200, and the other, a whipper-in's horse, to Mr. Mytton, for 250 guineas, who told me he would not take 700 guineas for him from any man.

Before I quit Sir Bellingham's stable, I must mention one circumstance. In the London season last year, a country-looking fellow called on the Baronet, and asked him whether he would sell two of his horses. He said he would; that they were down at Norton Conyers (his seat in Yorkshire), and the price one thousand guineas. The countryman purchased them, and they have never been heard of since. Some time afterwards the countryman came again, and asked the price of Bee's-wax. "Five hundred guineas," said Sir Bellingham. "As I have been a good customer," said the countryman, "I hope you will take pounds." The Baronet's answer was laconic-“I'll see you d--d first."

I must here notice John Pulfrey, the Baronet's groom, who has been fourteen years in his service. The way in which his horses have lived under sixteen stone will save me the trouble of saying anything more than that Sir Bellingham is going to put him into one of the best farms on his estate.

Having mentioned Pulfrey, it is but right I should mention two other most essential characters in this establishment-viz. the two whippers-in, Will Staples and Jack Wrigglesworth. Will is the son of Old Tom Staples, late huntsman to Lord Middleton, and once kemnel-huntsman to Sir Bellingham. He has lived with his present 


\section{SHROPSHIRE}

master ever since he was breeched, beginning by riding his second horse. I have said enough of him; and nothing that I or any other man can say can make him much better than he is. Jack is quite above mediocrity. Indeed, I call him a very useful good whipper-in — still improving, and a very good horseman. He formerly lived with Sir Mark Sykes, but has been in his present place five years.

Although Sir Bellingham is so well manned in his kennel, he does not trust the summer-work (so essential) of the hounds to any one but himself; so that, as soon as the London season is over, and he has taken a cruise or two in his friend Mr. Maxse's yacht, he gets to business again. He himself does not feed his hounds; giving as a reason, that, as his kennel is two miles and a half from his house, he could not always do so, and to have their condition right they ought always to be fed by one man. His system is to feed light; but his meat is as strong as it can be made.

We have not very many instances of men really devoted to fox-hunting continuing long on the turf, though they may mix the pursuits a little in early life. This was the case with Sir Bellingham Graham. He had a few race-horses for three or four years, and made a very good finish, by winning the St. Leger with Duchess, 12 to 1 against her; beating Dr. Syntax for the Cup at Richmond; and selling her for two thousand guineas.

The axiom in breeding, that "like begets like," is, as I have before said, faithfully displayed in the human as well as in the brute race. Though the Poet says

"Who, from the morning's brightest ray,
Can promise what will be the day?"

yet I venture to predict, that Sir Bellingham Graham's two sons will one day or other shine in the field. The eldest will doubtless make a sportsman; but the second-surnamed Godfrey, after his godfather, Sir Godfrey Webster, a great ally of Sir Bellingham in early days-is already nothing less than an artist, though only eleven years of age. When at home for the holidays, I never saw such "a ramming, jamming, cramming cove" of his tender years before. No Shropshire fence will turn him now ; and, in the joy of 


\section{NIMROD'S HUN'TING 'TOUR}

his heart, he rode up to his father one day, and exclaimed, "Papa! I have been before Nrmrod the whole run."

Joking apart, Godfrey Graham is a wonderful performer; and I think I may venture to call him "a promising young one." It happened one day, that Mr. Henry Montague (a noted bruiser) and myself got into a gentleman's pleasure-grounds, the only way out of which was to drop down a sunk fence into a rocky hollow road. We both dismounted; and as I turned round to pull my mare down, I perceived her shoes were much higher than my head. Our friend Godfrey was close at our biush; and, strange to say! he rode down this place, and thought it nothing. The only way to account for it is, that the old mare he was on has been fourteen years in his father's stable, and I suppose she let herself down the wall like a cat out of a cupboard.

It was said of the famous Duke of Cumberland that out of his boots he was an excellent fellow, but in them he was a devil. As the Duke was a soldier, this of course alluded to him when on and off duty. Sir Bellingham forms something like a parallel here. Up to the moment of his getting upon his hunter, and taking hold of his hounds, he is one of the best-humoured men in England; but further this deponent sayeth not. I will not pronounce of him, what a friend of mine used to say of a certain Noble Lord in that situation -namely, that he loolis as if he would bite you; but there are times when it is well not to go too near him. This doubtless arises from two causes: first, his extreme anxiety to shew sport; and secondly, a consciousness of a superiority of judgment, which cannot well brook being interfered with. Sir Bellingham also is an exception to one general rule: he is less polite to his friends in the society of the ladies (the bitch-pack), than he is in that of the gentlemen (the dog-pack); but this must be attributed to the same cause. Spots there are on the sun, and nothing which our eyes are permitted to behold is perfect; but take Sir Bellingham Graham as an English gentleman - as a friend and a companion-in the words of a Member of the Meiton Old Club, as " a downright, straightforward, honest, good fellow" - and though last, not least, as a master of fox-hounds and a sportsman-we may say of him, as has been said of many, that we shall not often "look upon his like again." 


\section{SHROPSHIRE}

On the 12th of January Sir Bellingham and myself returned to Kingsland (Sir B.'s house), and the next day I arrived at home, where I remained till "symptoms of a thaw and visions of coming sport began to dance before my eyes." I then took my departure for London on my return to Shropshire, arriving at Sir Bellingham's on the evening of the 25th. The Monday's fixture was Nescliffe, half way between Shrewsbury and Oswestry on the great Irish road, whither my host conveyed me in his drag.

I must just turn out of the road for one minute here. In most other countries, if a man wishes to anticipate his friend's performance for the day, the question he would ask would be-what horse do you ride? Not so, however, in Shropshire. There are two or three of my friends in that sporting and most hospitable county, to whom the most likely question whereby to elicit the truth would be-not, what horse do you ride to-day? - but, what have you had to drink? The fact is, the fences come very quick in Shropshire, and a little jumping-powder is often found useful; so, going into the publichouse at Nescliffe, by way of a beginning, I put the following question to the landlord: "How much brandy has Mr. Mytton had this morning?"- " None, Sir," was the reply. "I cannot swallow that," said I._-"It is true, I assure you,", said Boniface. "What else has he had, then?" I resumed. "Some egged ale, Sir."-" Ah!" said I, "some of your Shropshire Squires, like many others, want a little egging on now and then."

The following anecdote will shew what a poor chance some men have when quite sober against others a little primed. I remember Lord Forester, being on a visit at Wynnstay some years back, when a friend of his was very much badgered by a certain Welch Squirenow no more-to run him a race over the country for one hundred guineas a side. Observing him always to decline the challenge, his Lordship thus addressed his friend:- "Why, B-, I have seen you ride very decently across Leicestershire; why don't you tackle this Welch Squire? The next time he offers it, take the bet, and I will stand half of it." B-, who was a cautious one, thus replied:- "Why, if I could be sure he would come out sober, I would take his bet to-morrow; but $d-n$ the fellow, he will come out half drunk, and beat me." 
One other anecdote passed across my mind here, when speaking of asking a man the question of "what horse do you ride?" The facetious Mr. Edward Goulburn-now exercising his talent at the Bar-formerly hunted in Warwickshire; and seeing a Worcestershire Squire laughing violently, he went up to him and said, "Quid rides?" ("what do you laugh at?") My friend, not much of a linguist, replied, "My Magog horse." This liberty with the Latin language was, I think, never excelled but once. An Oxonian was being examined a few years since for his degree, when the following passage presented itself:-Loquebantur Apostoli miracula DeiAnglice, " the Apostles set forth the miracles of God." The young one, however, rendered it thus: Apostoli, "Oh ye Apostles"loquebantur, "look about you "-niracula " here's a miracle "-Dei, "by God." This, however, was a lucky hit; for the examining master shut the book, and exclaimed, "By $\mathrm{G}-\mathrm{d}$, you are a miracle, and you shall have your degree."

We had a beautiful find on Nescliffe Hill, and a very sharp twenty-five minutes with the bitch-pack-to ground. It was near, however, being a day of sorrow. That good sportsman and true friend to fox-hunting, Mr. Lloyd of Aston, got a most severe fall, and very narrowly escaped being killed. To use his own words, he was going "at the rate of forty miles an hour to the tune of the Ladies," when, in some very deep ground, his mare fell with him, and all but broke his neck. When I saw him picked up, his face was as black as his hat, and from the discoloration that afterwards appeared on the vertebræ of the neck, it was evident that it was a " near go."

Tuesday, went to meet Sir Richard Puleston's hounds at Petton, about half way between Shrewsbury and Ellesmere, and one of his best fixtures; but the frost had made its appearance again, and we could not throw off, which disappointed me much, as I was anxious to see my old friend's pack once again in the field.

On Wednesday Sir Bellingham sent the dog pack to Hardwicke, Lord Hill's seat, to shew them to Sir Richard Puleston, and we followed them in the drag-frost harder and harder, and neither of us very lively on the road. 
Lord Hill has not long completed Hardwicke; but he has made an excellent house of it, and turned his sword into a ploughshare. In the dining-room is an excellent likeness of the Great Captain of the age, and also a full-length portrait of Lord Hill, by Sir William Beechey. The latter is not wanting in resemblance, but there is an air of fierceness in the countenance that does not belong to the original. If the words of the Poet can be applied to any one, to Lord Hill are they certainly due :-

\footnotetext{
"In war, he's savage as the chafed tiger : In peace, as gentle as th' unweaned lamb!"
}

The frost continuing, Sir Bellingham and myself proceeded on the following Monday to Acton Reynald, the seat of Mr. Andrew Corbet, only son of my old friend Sir Andrew. There was a large party in the house for a battue in the woods the next day, but I preferred going with the Cheshire hounds, which met at Shavington, the seat of that hearty old buck-that real specimen of an Irish noblemanmy Lord Kilmorey, who turned out a small regiment of sportsmen from under his most hospitable roof.

This was my first appearance with the Cheshire hounds. We found immediately, and lost a bad fox at the end of an hour and twenty minutes-partly owing to there being two scents at first, and the hounds not getting well together. Having only one horse out, and having to return to Acton Reynald to dinner-a distance of nearly twenty miles-I did not wait for the second fox, neither did more than a dozen out of a very large field. He shewed them, however, a most beautiful forty-five minutes, running in to him in the open, to the great satisfaction of those who saw the thing. An unfortunate circumstance, however, occurred. In crossing a large sheet of water, where the ice was only partly thawed, two couples of hounds got under it and were drowned; and I was sorry to hear Sir Harry Mainwaring say they were all very useful ones to the pack.

February the 1st, Sir Bellingham's hounds met at Acton Reynald. We had forty minutes, and ran to ground. We had some beautiful hunting over a moor, and the scent was capital in covert. It was also a particularly good day for hearing hounds; and the music of 
the dog-pack in Shawbury Wood, when close to their fox, was quite enchanting. I said to myself-

\author{
"Never did I hear \\ Such gallant chiding; for, besides the groves, \\ The skies, the fountains, every region near \\ Seem all one mutual cry; I never heard \\ So musical a discord, such sweet thunder."
}

On Friday the 3rd met the Shropshire fox-hounds at Boreaton, the seat of Mr. Hunt. Plenty of pheasants, but no fox. Drew on to Leighton Shelf, and found at least a leash. This is a most picturesque covert-overhanging the banks of the Severn, the property of Mr. Lloyd of Dongey, and extremely ornamental to his new house, but the most infernal place for hounds I ever came across. A bad fox may beat the best pack in England in an hour; and it went to my heart to see Sir Bellingham galloping that fine horse Treacle up and down its deep rides, without, apparently, the smallest chance of sport.

After hunting on this day, Sir Bellingham and myself dined at Acton Burnell, which was the fixture for the next morning. This is the fine seat of my very old friend Sir Edward Smythe, who hunted Shropshire six seasons. Sir Edward is the representative of a very ancient Roman Catholic family, and, whether on a Friday or a Monday, whether in Lent or out of Lent, a more jovial fellow is not to be found in His Majesty's dominions. Though this worthy Baronet has plenty of game, he is a strict preserver of foxes, and generally finds a good one.

The day I am speaking of did not prove an exception. We found in the park; and, after upwards of two hours through a deep and distressing country, lost him by a halloo from a keeper, who thought he had marked him to ground. At the second check, I heard Sir Bellingham say we had been running him an hour and ten minutesquite enough for the country we went over.

I witnessed in this run what I never witnessed before, namely, three gentlemen riding at gates, and-without their horses fallingtumbling over their heads. The trio was composed of Mr. Byrne, a friend of Sir Edward Smythe's, but a native of the Sister Kingdom; Mr. Rock, a very thrusting young one; and Mr. Mytton! Mr. 
Byrne, I was told, was determined never to be so served again, as he went to a brook, and wetted the knees of his breeches, to enable him to stick to his saddle. I never heard of this experiment before; but, as far as I am a judge, there is only one other step to be taken with the breeches!

I never hear of a man falling from his horse without thinking of Sir Bellingham Graham's definition of a loose seat. He calls it " a wash-ball seat"- - the analogy (and a most happy one it is) being taken from a wash-ball slipping about in a basin. I also admire his idea of a gull-a man who believes everything he hears, and who, consequently, is often imposed upon. When speaking of such a one, a few days back, he observed, "Oh, that fellow will swallow any. thing ; he don't require a balling iron.'

Monday the 6th, met at Arcall Mill, and had a beautiful find in a gorse-covert-rather a rare thing in Shropshire. The day was extremely stormy, and we could do nothing with our first fox. A curious circumstance occurred with the second. The pack slipped away with him, down wind, out of a large covert, unseen or unheard by any one of a numerous field, excepting Sir Rowland Hill and Mr. Owen (heir-apparent to Woodhouse), who had all the fun to themselves, and ran in to him in twenty-five minutes. So much for woodland hunting in a very tempestuous day! It was curious to see the field scattered in all directions, but none of them able to get a glimpse of the pack.

The fixture for the 8th was the Twemlows-the crack covert in the Shropshire Hunt. Twice was it fixed upon during my visit to Sir Bellingham, and as often were we booked under the mahogany of that good sportsman, Mr. John Crewe, for the purpose of being near it, as also of seeing Mr. Vickstead's hounds, but were each time stopped by the frost. On the 7th, however, we took up our abode at Prees Hall, the seat of Sir Robert Hill, which is within two miles of the covert. Anticipation is seldom confirmed, and we had a very bad day's sport.

Independently of the pleasant party we met at Sir Robert Hill's, I experienced a great treat in meeting with an old schoolfellow, of whom I had for some time lost sight, but who has been more than twenty years Vicar of the parish of Prees. His Reverence had been 
doing the honours of Sir Rowland Hill's tithe-day, but came to us in the evening, and amused us much.

The Vicar of Prees is what I call a good old-fashioned clergyman. He is-as I hope all Rugby men are-quite above the vulgar association of groans and tears with piety and devotion, and is not yet stricken with the new light. "Gravity," says Lord Shaftesbury, "is the essence of imposture;" and who would envy the character Cæsar gives of Cassius?

"He loves no play,

As thou dost, Antony; he hears no music;

Seldom he smiles, and smiles in such a sort,

As if he mock'd himself, and scorn'd his spirit

That could be mov'd at anything."

The Vicar of Prees is no humbug. He sings a hunting song to his parishioners, tells them a good story at his tithe feast, and gives them the best his house affords. His invitation to Sir Bellingham and myself for the next time the hounds came to the Twemlows was rather unique. "My claret," said he, "is of the finest vintage; and if you will drink enough of it, it will make your eyes look like boiled gooseberries."

The Vicar of Prees has a great mind to be a sportsman. Like the Abbot of old,

"He gives not of the text a pullet hen,

That saith that hunters be not holy men:"

so he accompanied us the next morning to the covert's side; and could we have persuaded him to have left his spencer behind him, his appearance would have been far from amiss.

My greatest amusement was yet to come. The next morning before we went a hunting, I accompanied the Vicar to see his stud, and I will exhibit them to the reader as they were exhibited to me:"Here," said the Vicar, " is the mare I am going to ride. There is the pony that beat all Sir Bellingham Graham's hunt-but mind ye, not with me upon him. There is the finest pair of coach-horses in all England-only one has lost an eye, and the other is broken-winded; and there is the colt that is to win the King's Hundred." Now the four-ycar-old colt bred by himself, which was to win the King's Hundred, proved to be a threc-ycar-old filly; and if ever she wins a Maiden Plate, I will engage to eat her, plate and all! 
We were to have met the Vicar again at Sir Robert Hill's on Wednesday, but were obliged to return to Kingsland for Tharsday's hunting at Condover. We had a beautiful thing on this day of fortyfive minutes-with the ladies - till we came to the Severn, when all our fun was over. The hounds crossed, and killed their fox in gallant style. This was the best part of Shropshire I ever rode over : the fields were of fair size, the ground sound, and the fences such as required a hunter to get well over.

I had the pleasure on this day of seeing Mr. Henry Lyster's performance on his famous mare The Doe. The Doe is very small, but very strong, and was purchased from Mr. Mytton for eighty-five guineas-having carried his whipper-in. For the weight she can carry, I think she is not to be beaten, and Mr. Lyster was certainly first man on this day. Mr. Mytton and Mr. Rock went gallantly; but Sir Bellingham Graham surprised us all. He was on a horse always considered slow; but so determined was his rider to be with them, that, though he got a bad start, he soon got among the first flight. I could judge of his pace, being myself on a fast one; for though I got out of the covert not a hundred yards behind him, I never could catch him till I found him in a ditch at the end of the burst.

On the 10th, business called me home, and afterwards to the "little city." On Tuesday the 21st I started again for Shrewsbury, arrived at Mr. Mytton's by breakfast on the 2nd, and found my horses all well. My groom told me it were well I was arrived, as he thought " the Squire would have been a top of some of 'em before another day was over." To say the truth I fully expected it.

The fixture for the day was Mr. Mytton's house, whither Sir Bellingham had arrived the day before to be ready for business. We had a beautiful find in a large piece of gorse, and a good fox went away; but the day precladed a chance of sport, as it was extremely stormy without an atom of scent. We did not find again.

The next day the Shropshire hounds met at Pitchford Park, seven miles on the other side of Shrewsbury, but as I had no horses in that part of the country, I did not meet them. Mr. Mytton went, and saw a fine run of one hour and twenty minutes.

Exclusive of this, I missed another fine run with the Shropshire 


\section{2}

\section{NIMROD'S HUN'TING 'TOUR}

hounds, which by all accounts was a tickler; but I much admired the modest, though sportsmanlike, description given of it by the master of the pack, in a letter to myself :-_ I am sorry," said the Baronet, " you were obliged to go yesterday, as I trust we are getting into a vein of sport. The first half hour to-day a most awful pace, from Babbins wood, over a very fair but deep country; and I shall curtail what I could make into a long rigmarole account, by stating that at the end of one hour and forty minutes I had in my hand the finest bit of (what some people call) vermin I ever touched in my life. We killed him between Chirk Castle and Llangollen; and the connoisseurs were good enough to say the gentlemen (the dog pack) did their business meritoriously." This sporting Baronet's modesty did not end here. He said he was never so ridden away from in his life as he was (as indeed were all the field) on this day by $\mathrm{Mr}$. Mytton, on his Hit-or-Miss mare; and I understand that Will Staples could scarcely go the pace with her.

On the 24th met Sir Richard Puleston's hounds at Penley Green and drew what are called "the Duke's Woods" - the property of the late Duke of Bridgewater. The late Lord Bridgewater behaved in a very liberal manner to Sir Richard, by having excellent rides made through these extensive coverts, which make them very useful to hounds; but as far as sport or pleasure is concerned, they are but ill calculated to afford much of either.

It is necessary I should say something more of Sir Bellingham Graham's kennel, which generally contains from fifty to sixty couples of hunting hounds. His dog pack comes under the denomination of a grand pack of hounds; in stature quite equal to Mr. Ward's, though a lighter sort of hound. They are very close hunters, extremely patient with a baffling scent, and their pace something approaching to awful. They are larger, however, by the admission of their owner, than is desirable in so close a country as Shropshire. The bitch pack-the Ladies-are Sir Bellingham's favourites, and in my humble opinion perfect. The dash of the fox-hound is conspicuous here; and to see these bitches pushing to their game is to me one of the finest sights this world can afford. Their form is particularly elegant; and though they don't say so much about it as the dog-pack, they are not deficient in tongue. So fond is Sir Bellingham (always 
the case with fox-hunters) of "the Ladies," that I heard him say, if he hunted only three days a-week, he would never take a dog-hound into the field. With two such whippers-in behind them as Will Staples and Jack Wrigglesworth, and mounted as they are, Sir Bellingham Graham's hounds cannot fail of being handy; and their condition is powerful and even.

- In the dog pack Vulcan is the crowning ornament. Indeed I think it is not in nature to form a more perfect animal of his species, and he does not belie his looks. He is by Sir Bellingham's Vanquisher (by Mr. Osbaldeston's Vanquisher) out of his Joyful. The following also are very clever: Twister, by his Tapster out of his Abigail; Jericho, by his Aimwell out of his Jubilee; Vaulter, by his Render out of his Vanity-the latter, the right style of hound for Shropshire.

Amongst the bitches Brimstone stands first: she is by Marmion out of his Jezebel. Patience, by his Abelard out of Purity-full of the old Pytchley blood; Famous (well named), by Lord Lonsdale's Reveller out of Sir B.'s Factious; Juliet, Jingle, Jollity, and Jealousy, by Mr. Osbaldeston's Piper out of Lord Lonsdale's Joyful; and Purity and Parasol, both from Mr. Ward, are also very clever.

Now for a word or two about the country. Were it not for a few "ifs," Shropshire would rank rather high among the provincials. In the first place, it is able to stand four days a-week, and the coverts are very well stocked with foxes. It also, on the whole, holds a fair scent, but a very great part of it is not only wet, but boggy. It is also extremely deficient in gorse corerts, and it is-a great drawback to sport, and very annoying to a huntsman and his hounds-the most hollow country I ever hunted in. In the course of this season, Sir Bellingham ran thirteen out of fifteen of his foxes to ground, which I never heard of any hounds doing before. Such earths as are not used for breeding should be dug out, and iron grates should be placed on the mouths of drains which are able to admit a fox. The first of these remedies, however, will not always succeed, as, from the loose nature of the soil in many parts, fresh spouts and earths would be made in each succeeding year.

As a country to ride over, as far as leaping is concerned, 
Shropshire is an easy one-that is to say, the part comprising the Shropshire Hunt. Although the fences come quick, yet there is nothing to stop a hard-riding man on a good hunter, and timber need but rarely be taken. The common Shropshire fence-say nineteen out of twenty-is a small live or dead hedge, not bound, placed on a small bank, with one ditch, and that not generally a large one. These fences, however, stop horses in their pace, for they must be taken quietly. Were a man to attempt to clear bank and all at one fly, he would not go long; but he is generally safe over them if he have a hand on his horse, and will allow him to "foot well" before he springs. In some countries the common Shropshire fence would be considered little more than a gap. Strong places, however, do every now and then occur, and-what makes small fences large ones-the horses are almost always going in deep ground. Horses, indeed, that can go well over Shropshire can go well over most other countries.

There is, however, one part of riding over Shropshire which requires a goad man and a good horse, and even these will not always do. I allude to the black boggy drains, which abound in the low meadows, and which will not admit of a horse approaching their banks near enough to be certain of clearing them. If he do clear them, the exertion is a severe one, and an over-reach or a lost shoe is too often the consequence.

That Sir Bellingham Graham should like Shropshire as a hunting country, cannot for a moment be imagined. He lit the candle at the wrong end for this. Had he begun with Shropshire, and proceeded to Leicestershire, the case would have been altered; but few people like to go back in the world. The way, however, in which he has hunted it-with an establishment very nearly equal to Leicestershire-entitles him to the greatest credit; but though he does not like the country, I have heard him many times declare that he likes the people, and here is the spur to his exertions.

When Sir Bellingham Graham asserts that he "likes the people" in Shropshire, we may naturally conclude he chiefly alludes to those of his own rank in life with whom he every day associates. I think, however, I may take upon myself to say, he goes one step further than this, and includes in his panegyric the yeomen and 


\section{SHROPSHIRE}

farmers who reside within the limits of his hunt; and well he may. I have ridden over the majority of our English counties, but never did I meet such hospitable and jovial fellows as the Shropshire and Staffordshire farmers." With them, "What will you drink?" is the next question to "How do you do?" and, now and then, "What will you drink?" comes first. Some of them, however, as Sir Bellingham says, are "zealous dogs," particularly after a certain hour of the day.

The Baronet told me a good anecdote of one of those Shropshire farmers. He was about as big as any two moderately sized men, and was sitting on his horse in a covert, whilst the hounds were running their fox very hard below him. "Now they are a physicking on him," said he to Sir Bellingham, as he rode by, his countenance sparkling with delight.

On the 25th Mr. Mytton turned out a brace of bagmen before his nondescript pack. I have before said, that a mere detailer of facts is only fit to give evidence on a trial, and therefore I shall dilate as I go on.

On the evening before, as we were sitting over our wine, the butler announced that Mr. Tinkler the stud groom was in waiting. "Send him up," said Mr. Mytton, and Mr. Tinkler appeared.

Tinkler-" What horses will be wanted to-morrow, Sir?"

Mr. Mytton-" All."

Tinkler- "No, Sir, not all surely!"

Mr. Mytton - "Every one."

Tinkler-" Not the little grey horse, Sir! His back gets very narrow."

Mr. Mytton- "So much the better. I hate a fat horse."

Tinkler-" Not the brown horse you had from Sir Bellingham; his legs begin to get very round."

Mr. Mytton- "That is the very reason why I will ride him, as it will make them fine."

* The hospitality of Staffordshire quite equals Shropshire. I remember on one occasion, when Mr. Mytton hunted that country, that a regular dinner was provided fur the field. There was white soup, patties, side dishes, \&c. \&c. I also well remember how small the fences appeared when we were running our afternoon fox. 
Tinkler-" Not the Hit-or-Miss mare; you will want her for the Cheshire."

'Mr. Mytton- "It will put her in wind."

Remonstrance was in vain. Every horse was saddled, and the Squire, his three whippers, with Tom Whitehouse (his jockey), were all mounted on the best horses in the stud.

I cannot describe our arrival at the covert; I cannot speak of the hound that "spoke to him in the gorse;" I cannot even attempt to describe the crash when he broke from the covert; but-from the inside of a wicker basket with a lid to it (oh! how tame, how languidly does my pen move over my paper as I write it!) away sneaked as fine a fox as ever wore a brush, and certainly afforded us a very fine run of an hour, when he fell a victim to the pack, which, I must say, hunted him well.

Nothing is to be done in Shropshire without a luncheon; but on this day we had two-first, at the inn at Ellesmere, after our run; and secondly at the house of a very respectable yeoman by the name of Wynne (of Cricketh) where the second fox was in waiting. The second luncheon, however, saved this fox's life; for after the usual law was given him, and I was in the act of mounting my horse, Mr. Wynne came out to me and said, the Squire proposed one other bumper toast, which he hoped I would return and drink. The hounds were then laid on; but though they were sober, the faculty of smell had deserted them, and they never touched upon their game. The exertions of their huntsman (the Squire himself), however, were great. Mounted upon Magnet, with his horn in his mouth, and at three parts speed, he made his casts with the rapidity of a Shaw; but one peculiarity attended them. If the fence into one field was larger than that into another, that field was preferrednot as most likely to hit off his fox, but as most likely to floor some of his field, who, with his three whippers-in and Tom Whitehouse, were hard at his brush. As the pace was quick, and the country heavy, I was beginning to calculate upon how long the nags would live without a check, when an accident occurred that put a stop to all. A hare got up in view, which every hound followed into Sir Edward Kynaston's plantations, and thus ended the morning's sport. We had a party to dinner, and the evening's cast was by no means slow. 
Of the crack man among the Shropshire riders, Mr. Lyster of Rowton Castle, I have already spoken, and his brother John is hard and determined, but not so much at ease on his horse, or so quick. I do not include Mr. George Forester among the Shropshire sportsmen, or of course he would have a front place; but he is at work in better countries; as also is Mr. Biddulf of Chirk Castie, a very good young one, who hunts with Lord Anson. Mr. Henry Fielding likewise can only be called a visitor; but, when out, he goes well. Mr. Lloyd of Aston is very difficult to beat over Shropshire. He knows the country perfectly, and goes at a good pace over it. Mr. Henry Montague, of the Guards, was on a visit to $\mathrm{Mr}$. Lloyd of Dongey when I was in the country, and having heard a good deal of him as a workman, I was pleased with the opportunity of seeing him. He is a powerful horseman, with fine hand and nerve, and I know no man whom I would sooner mount upon a young horsethat is to say, if he were a pretty good one; if not, he would be in but bad hands, as his pace is quick. Mr. Henry Lloyd, brother to Mr. Lloyd of Dongey, is a very fair performer. He puts his horses well at their fences, and is by no means afraid of them. There are two professional gentlemen in Shrewsbury, who will charge as large a fence as most people. One is Counsellor Slaney, and the other Mr. Wynne, a surgeon in great practice. These are two useful men in the field; for in case of an accident, if the Doctor cannot save you, the lawyer may make your will. Mr. Wynne is esteemed an excellent judge of horses, and has bred and sold some good ones. He rides hard and heavy, therefore the secret-good or bad-soon comes out. He is, however, a great lover of hunting, and for that and other reasons very much respected in Shropshire. Mr. Smythe Owen is a pretty, gentlemanlike rider, and his horses are of a good stamp, and generally fit to go.

Among the young ones, Mr. John Hill (brother to Sir Rowland) stands first and first; and, if he had a good stable of horses, would shew most of them the trick. He is, however, well bred to ride. His father could ride well, and was as good a sportsman as ever got upon a horse-add to which, he is a grandson of the old Sir John, who was game to the backbone. MIr. Rock I have before spoken of as a thrusting young one; and the heir-apparent to Woodhouse 


\section{NIMROD'S HUN'TING TOUR}

(Mr. Owen) and Mr. Kynaston (son of Sir Edward) trained on very much whilst I was in the country. Let them look to Will Staples; they cannot study a better master.

Of Mr. Mytton, as a rider, I need not say much, for he is as well known as the horse at Charing-cross. Strength will be served : and few men make more of a hunter than he does over a strong and deep country. As a proof of this, his horses scarcely ever stop with him, though he is not particular as to his ground or pace; and as to fences, there are times when the larger they are the better he likes them. The time of the day, however, does not operate only upon him. My old friend, Sir Edward Smythe, is a much better man after luncheon than he is before; and I know no one who does more credit to a little jumping powder than he does. I have seen the time when I would back him to leap five-barred gates with any man in England.

Although not exactly connected with Shropshire, yet as a rider very well known in that part of the country, I cannot pass over a very old friend of mine, because $I$ think he excels in the art I have been speaking of. When I first knew him his name was Lloyd Kenyon, first cousin to $\mathrm{Mr}$. Kenyon of Pradoe; then, by an acquisition of fortune, it was Lloyd Lloyd; and now, by another turn of the wheel, it is Lloyd Williams.

This gentleman resides at Penylan, on the banks of the river Britain, and within easy reach of Sir Richard Puleston's and Sir Watkin's hounds, and he can occasionally reach the Cheshire; but he has been, for several seasons, an attendant on Sir Thomas Mostyn's hounds in Oxfordshire. I do not mean to say that my friend was ever a Tom Smith, or a Holyoake; but this I will say of him (and he has always kept a good place with hounds), that what he does he does well. He has a particularly neat seat; his horse is always well saddled and bridled; and from the sole of his boot to the crown of his hat he is dressed like a sportsman and a gentleman.

There is another gentleman in this part of the world worthy of notice. His name is Newton of Pickhill Hall, near Wrexham. Though a great weight, he makes a capital fight over a country; but I remember him at Oxford, where he took a very fair degree with 
the two packs of hounds which hunt that country. Sir Bellingham Graham has now given up the country, and for the future it is to be under the management of Mr. Smythe Owen of Condover, with the subscription now given (and as much more as can be had); and the hounds were purchased from Sir Bellingham for six hundred guineas. The servants also remain with the hounds; and a certain number of their horses were purchased from Sir Bellingham to carry them. This sporting Baronet retires from public life, and is gone to his seat in Yorkshire, whither the wishes of all good sportsmen will attend him. One of the first acts that he performed on his arrival at home was to subscribe one hundred pounds per annum to the York and Ainsty fox-hounds.

On the 26th of February, Mr. Mytton and myself went to Marbury, the seat of Mr. Domville Poole, situated in the best part of the Cheshire country, and where we were within easy reach of the Cheshire hounds on the next morning. The day, however, blasted all our hopes; and after a handsome find in one gorse, and chopping a piebald fox in another, we were glad to get back to the fire-side at Marbury. The next day, however, made ample amends.

Our place of meeting was Shavington, the seat of Lord Kilmorey, and we found immediately in some beautiful briar, lying in the plantation. We ran this fox forty-seven minutes at a very good pace, but we lost him by an unlucky accident. Some idea, however, may be formed of the pace and the severity of the country, by the following fact. At the second check, Mr. John Hill (brother to Sir Rowland) and myself counted the field, when there were only eighteen out of at least one hundred and sixty horsemen who started; neither did any more appear until we gave up the chase and turned back to them.

For our second fox we went to Combermere, the seat of my Lord Combermere, and found in the same small plantation which produced the fox that showed the beautiful forty-five minutes on the last day but one that I was out with the Cheshire hounds, but which fox never lived to return. We ran him nine minutes at a racing pace, and turned him up in view. I expected to have seen him diseased, but he appeared quite clean. Without suffering the hounds to worry 
him, we returned to the park, to another fox which had been seen there, and he went away in view.

Nothing short of Leicestershire, or some other very crack country, could have shown a prettier thing than we had with this our third fox; and at the end of about forty minutes we turned him up alsoa singular circumstance occurring at the finish. Not two minutes before he died, and in full view of those who were close with the hounds, this fox leaped a five-barred gate without touching it (as a greyhound would leap it), as much as to say, "this is my last effort for my life !",

It has so happened, that previous to this season I never hunted with the Cheshire hounds. As a pack, their reputation has not been great, but considerable allowance must be granted them. Their late manager, a most excellent sportsman of the Old School, became, in the language of the day, slow, and they were hunted by a man sadly below the mark. Were I to hazard an opinion, I should say, they never were so good as they now are, under the management of Sir Harry Mainwaring, and hunted by Will Head, formerly in the service of Sir Bellingham Graham, and three years head whipper-in to the Cheshire. To the eye, they come more under the denomination of a useful than a handsome pack of hounds, though certainly by no means wanting in the common requisites of foxhounds. On the first day I was out with them, I considered them unhandy; but it was rather a wild morning, and two scents a-foot. This also should be said, Will Head has only hunted them three seasons, and Rome was not built in a day.

I considered the condition of the Cheshire hounds particularly good. Indeed, I must go so far as to pass over all other packs save his Grace of Beaufort's, which I had seen up to that period, and give the preference to them in this respect. The brightness of their skins, and their general healthy and even state, are worthy of all the praise I can bestow; and the more credit is due to Will for this, having three kennels to boil in-some of them none of the best, and consequently a deal of travelling-to say nothing of being often obliged to feed at irregular hours.

One other fact I must also speak to. With the exception of one mistake, no hounds in any country could have done their work in a 



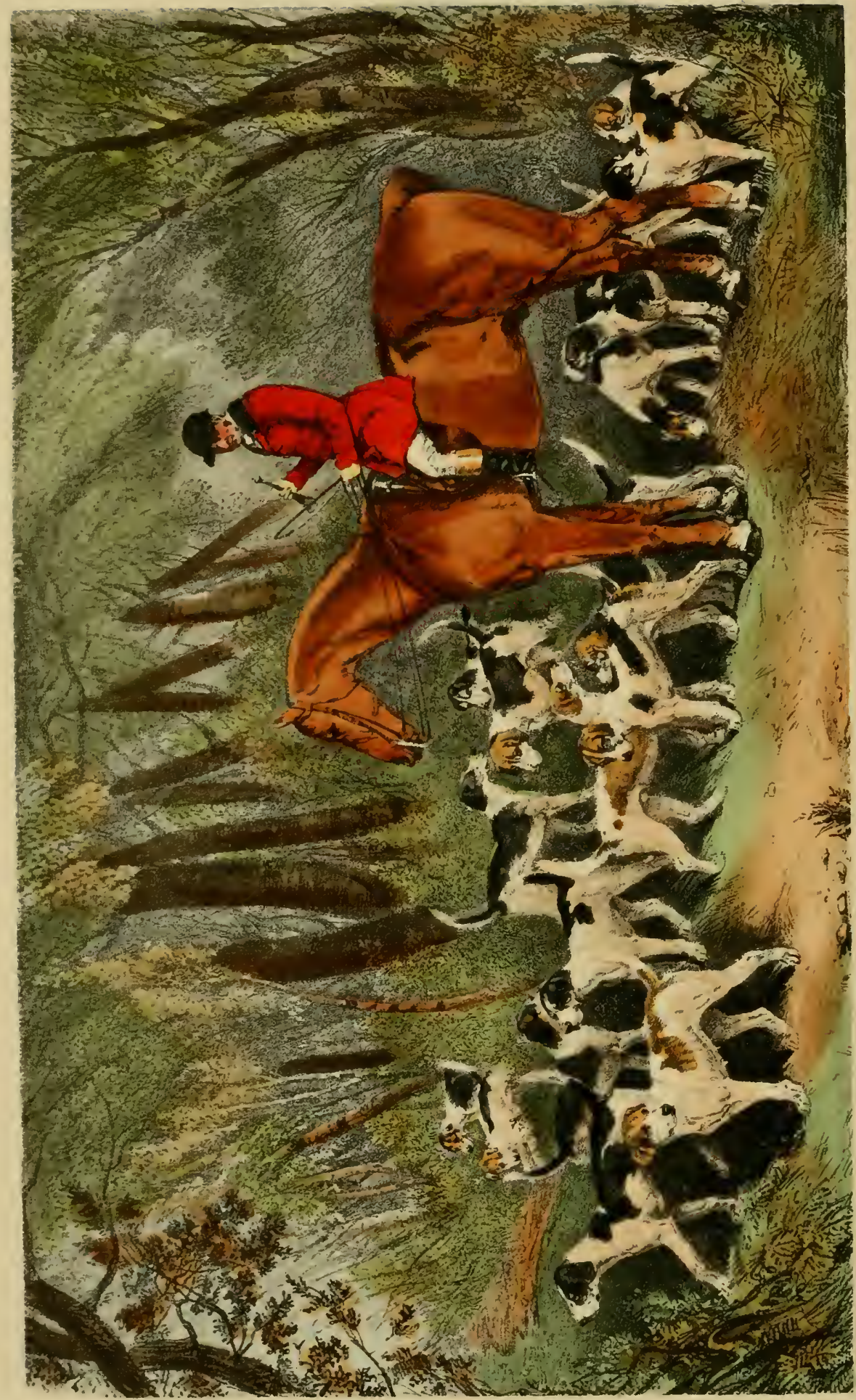




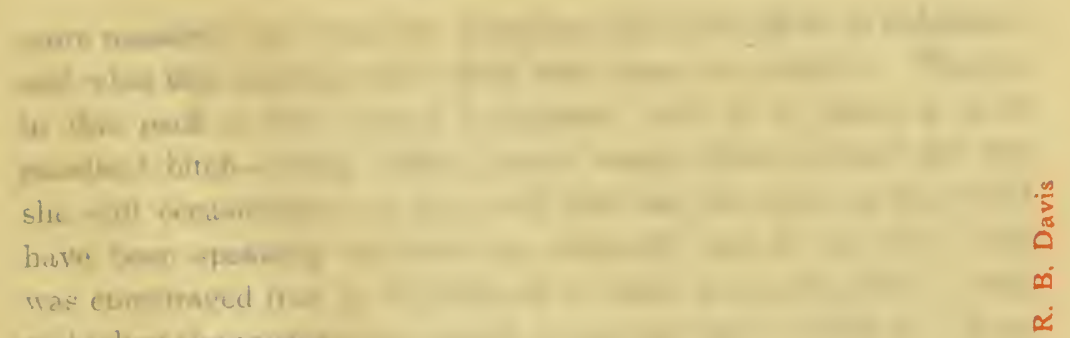

ant silier the moxt

with sommen 1

trait: we lowg on

dang'ruven whe whers

bet in the contracida

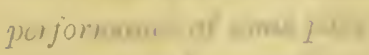

I uberivel of thrie

over this part al Che the

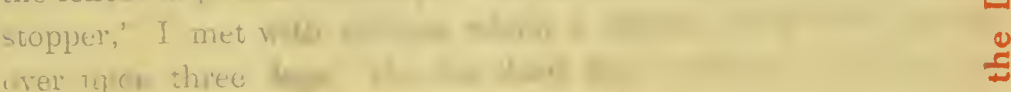

spinion of them, w. mant th

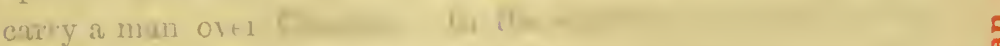

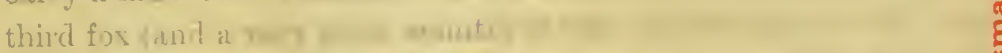

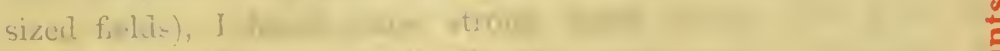
ditches; bit ly di, 1, th

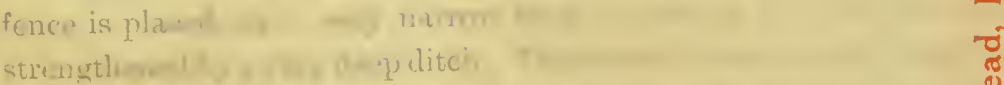

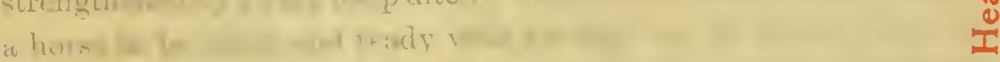

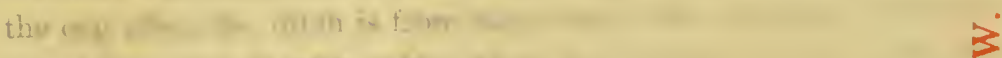
to

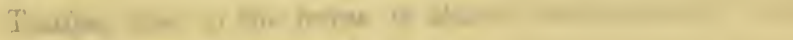

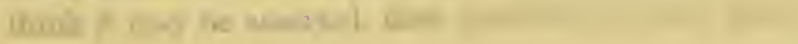




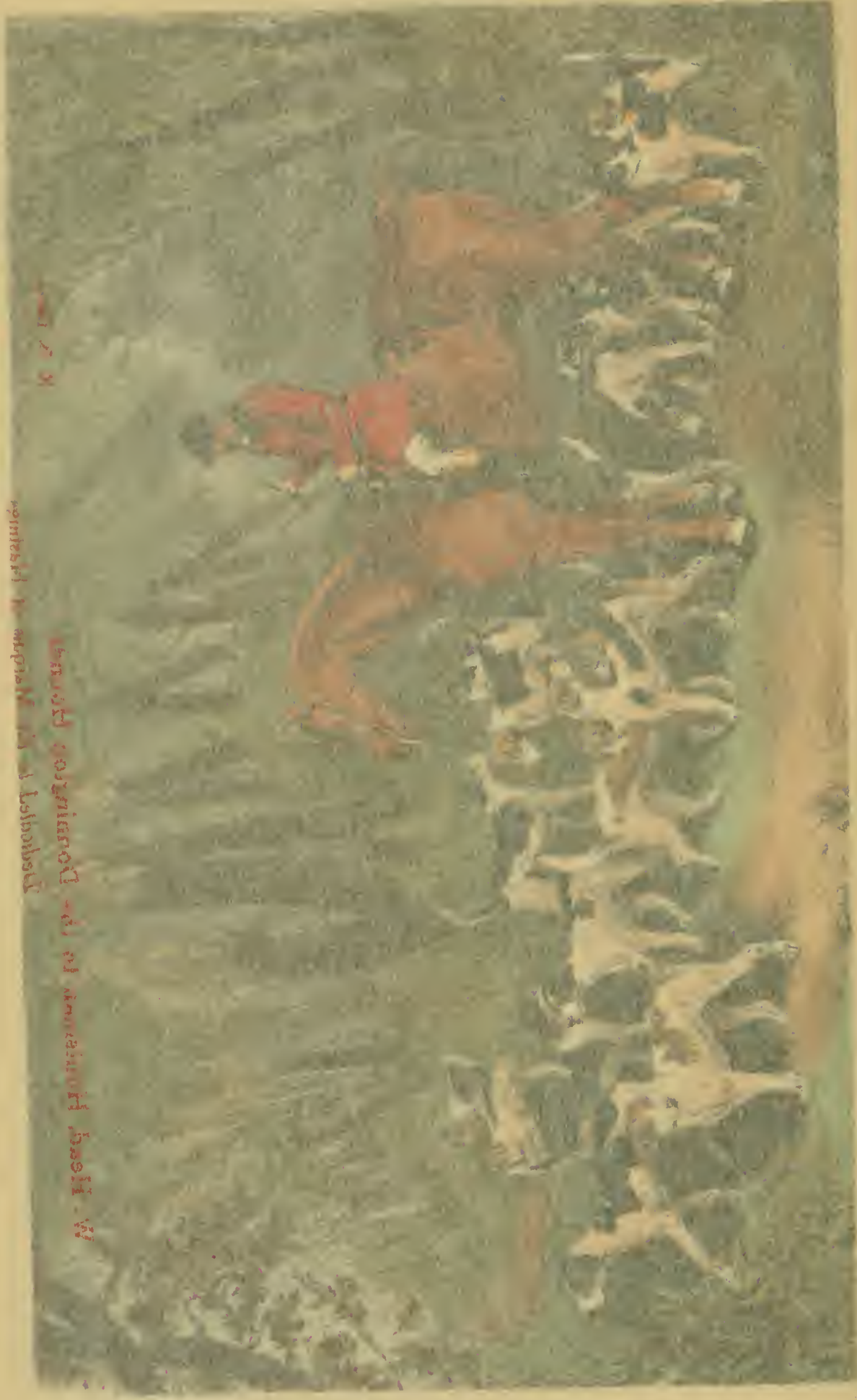




\section{CHESHIRE}

more masterly way than the Cheshire did on the 28th of February; and what this mistake was I shall take leave to mention. There is in this pack a bitch called Lightsome, who is at times a most excellent bitch-doing, indeed, what many others cannot do-but she will occasionally run hare, and this was the case on the day I have been speaking of, when she evidently lost us our fox. She was encouraged (not by Will Head) to hare for more than a mile, and when the mistake was found, it was too late to rectify it. Now, with submission I say it, this is the hound of all others I would draft; for being so good on some occasions makes her more dangerous on others, and if not more harm than good arise from her in the course of a season, she ensures one thing--discredit to the performance of some particular days.

I observed one thing extremely baffling to hounds when running over this part of Cheshire; and that was the number of hares (at least one to an acre) which were continually getting up as we were in chase. Exclusive of the view, there is a strong scent from a hare at this season of the year ; and, doubtless, they save many a fox's life, and destroy many a fine run. As to riot in general, I considered the Cheshire hounds about as free from it as the majority of packs one hunts with.

On the two first days I hunted with the Cheshire hounds, I held the fences in perfect contempt. So far from seeing anything like "a stopper," I met with nothing which a hunter could not have got over upon three legs. On the third day, however, I altered my opinion of them, and was convinced that it requires a hunter to carry a man over Cheshire. In the country over which we ran our third fox (and a very good country it was-chiefly grass, with largesized fields), I found some strong quick fences, with good wide ditches; but this is not all. In the greater part of Cheshire, the fence is placed on a very narrow bank, or cop as it is termed, and strengthened by a very deep ditch. This kind of fence not only requires a horse to be quick and ready with his legs-as he must spring from the cop when the ditch is from him-but it also requires a horseman to get him over it with safety when he becomes a little distressed. Temper also in the horse is almost indispensable here; and I really think it may be asserted, that, provided he have speed, a hunter that 
can go well over Cheshire can go well over almost every other country.

There are several good riders in the Cheshire Hunt; but the crack man of the field, and of whom most has been said, is $\mathrm{Mr}$. James Tomkinson. Mr. Tomkinson has not only been, for many years, a very first rate performer in Cheshire; but, whenever he attempted it, could always go the pace in Leicestershire, and has ridden the best of horses. His brother, the Major, is said to be equally good, though not so well horsed.

There are several more fast men over a country in the Cheshire hunt: mine host, Mr. Domville Poole, very good indeed; as also Sir Richard Brooke, Colonel Brooke, Mr. Clegg, Mr. Ford, \&c. Lord Delamere also, not only as a sportsman, but as a first-flight man for so many years in Leicestershire, must not be forgotten; and I was glad to see him once more in the field. Though his pace is not quite what it was, he is, I am told, still always in a good place.

There is one peculiarity attends the members of the Cheshire Hunt -almost all of them ride in leather breeches. That they are well adapted to the saddle, and for riding long distances on the road, no one will doubt; but in all other countries they are accounted dead slow in the field. Were any other man but Mr. William Coke (who is alway clad in leather) to be seen in them in Leicestershire, some remarks would be made; but as his fault is being too fast for hounds, he gets off cheap. That they are the best protection against thorns, every one must admit; and I was told in Cheshire that the general objection to them for hunting-that is, being cold when wet-is obviated by the use of flannel drawers. Fashion, however, "bear's sovereign sway" in all such important matters; and, in most countries, "going the pace" in leather breeches is considered an impossibility. If accompanied by a straight-cut coat, the point is at once decided.

On the two days I have been speaking of there was some sharp riding with the Cheshire hounds. Mr. Mytton was on his Hit-orMiss mare, for the honour of Shropshire, and the esprit de corps was all alive. With the first fox from Shavington, Major Tomkinson, on his grey horse, had the best of the burst, with his brother "Jemmy," as he is called, and Mr. Mytton hard at his brush. With the second 
the major made an unlucky turn, and his brother, Mr. Mytton, Mr. Domville Poole, and Mr. John Hill (brother to Sir Rowland) were the leading men. Will Head also rode very near to his hounds.

From what I have heard of the Cheshire country, nothing can be better conducted, or made more agreeable to the manager of the pack than all pecuniary concerns. The subscription-2,000l. per annum-is paid to the appointed dày, and there are no less than fifty gorse coverts in the Hunt. One kennel is upon Delamere Forest, another at Wrenbury on the Shropshire side the country, and the other at Peover, near Knutsford, the seat of Sir Harry Mainwaring.

Sir Harry Mainwaring has had the management of the Cheshire hounds for the last six seasons, and has given universal satisfaction. Well, indeed, he may; for he is not only a most zealous sportsman, but one of the best-tempered men in the world. Although it was not in my power to accept of his very kind invitation to Peover, I had the pleasure of spending two days with him at Mr. Domville Poole's, and found him an unaffected country gentleman and a very agreeable companion.

I considered Sir Harry's men very efficiently mounted; and a bay mare of Will Head's of a stamp quite superior. The stud was also in uncommonly good condition, nuder the care of Charles Davis.

Will Head commenced his career with the Duke of Rutland's hounds. In 1817, he went to the Badsworth, and whipped-in to them one season; next, to Mrr. Osbaldeston, two seasons; and then to Sir Bellingham Graham, for one-during the time he hunted Northamptonshire. From him he went to the Cheshire hounds, with which he began as whipper-in, but which he has now hunted two seasons, giving great satisfaction. He is very zealous to kill his fox; rides well up to his hounds; has a nice cheering halloo, though perhaps a little too-free with it at times. Of his two whippers-in I can say but little, as I did not see them in difficulties sufficient to try them.

I was born and bred within a gun's shot of Cheshire, and it is natural to conclude that the first fox-hounds I ever hunted with 
were kept in that county. The owner of them was the late William Leech, Esq., of Carden, one of the finest places in Cheshire.

Mr. Leech was one of those characters of which the breed is nearly lost, and which, when gone, will never be again seen in this country-the plain, unadulterated English country gentleman, who, possessing full ten thousand a year, never left his seat, except he was called to his county town, or went to visit his friends. Being a single man, he did not even keep a carriage of any sort till far advanced in years; but the whole pleasure of his life was centred in the enjoyment of field sports in the morning, and the society of his friends at night. In the present times, however, he would be considered deal slow. He dined at three o'clock if by himself, or if he had only a few of his intimate friends in his house ; and, strange to say, though he kept fox-hounds, and hunted them himself for a long series of years-possessing also abilities quite above the common standard-he knew very little about fox-hunting.

Cicero says of Antony, that "he had a witty mirth which could be acquired by no art;" and the compliment might have been as justly paid to Mr. Leech. His company was sought after more than that of any other man in his neighbourhood; and so original was his wit, and so happily was it applied, that he might have been termed the very life and soul of every party he was in. Although naturally abstemious, yet in a party he never failed to sacrifice most freely to the god of wine, and his wit and good humour seemed to increase with every glass he drank. The signal of enough-and he generally went the length of his tether-was an attempt to sing the first verse of a song, beginning with

"Women and wine the heart delight."

I wish I could recollect a twentieth part of the smart repartees and witty sayings of Mr. Leech; but in the interval of time they are lost. One of his bottle-companions of the sacerdotal order asked him to go to church and hear him preach. He afterwards wished to know what he thought of his sermon. "Why," replied Mr. Leech, "I like you better in bottle than in wood." He was very intimate with Sir Richard Puleston; and as Sir Richard sometimes borrowed his hounds, when he was himself without any in his 


\section{CHESHIRE}

kennel, and always sent them home in better tune than he received them, he generally called him "my huntsman Dick." Riding over to Emral one day, soon after Sir Richard had been having a fall of timber, which opened to the view his parish church, Mr. Leech remarked, that he could not think what had made his huntsman so well behaved lately, but, said he, "I've found it out; he does now sometimes get a sight of the church." Though never profane, Mr. Leech would have his joke. He was once asked if he ever went to church? "Oh yes," answered he, "but I am no church glutton."

Inberiting a sound constitution, rising early in the morning, pursuing the sports of the field, and generally of temperate habits, $\mathrm{Mr}$. Leech lived to (I think) the age of eighty-six; and as a proof that the charms of conversation and the pleasures of a social glass lived as long as he did, it is only necessary to observe, that, the year before he died, he sat down to dinner with a friend of his at Chester at one o'clock in the afternoon, and at two o'clock the next morning he got into his carriage to go home.

Mr. Leech is gone; and with him is gone his sort of English gentleman. He spent his money in the country from which he received it; he kept a most hospitable house; was a sincere friend and a most entertaining companion; and for these reasons, he never spole ill of any man: he was ever in good humour; and in all his jokes he never forgot the wholesome lesson of the Satirist-

\footnotetext{
"Who, for the poor renown of being smart, Would leave a sting within a brother's heart?"
}

The Cheshire farmers are good preservers of foxes, and a blank in their gorse coverts is a rarity.

On Wednesday the 1st of March, Mr. Mytton and myself took leave of Mr. Domville Poole, and met Sir Richard Puleston's hounds at the kennel. Our first fox did nothing for us, but we had a beautiful forty-five minutes with our second, and killed in good style. Since I have known what hunting is, I never saw hounds go faster over a ploughed country than they did on this day, and he must have been a good fox to have stood so long. Many years have passed over my head since I hunted with these hounds, and I was 
struck, not only with the increased pace of the pack, but of those who followed them. There was no stopping to look what was on the other side, as in days of yore, in this country; but away went three or four young Eytons, a young Kynaston, a young Owen, and a nephew of mine, with the Squire of Halston and two or three more older hands, at the rate of twenty miles an hour. Well was it for the hounds that there was a good scent, or some of them must have been killed, as giving them time to get together formed no part of the system of this day; and Sir Richard's "hold hard," though sung out most andibly on the occasion, and sufticient to have halted a charge of cavalry, had no more effect than a summer's shower upon a rock of adamant. "Go it, my tulip," was the order of the day with these aspiring young Nimrods, and very merrily they did go.

Sir Richard Puleston is a very old master of fox-hounds, having kept them almost thirty-five years. Although chiefly confined to his home country, he has at different times had the Shropshire, the Shiffnal, and Lord Anson's countries, in each of which I hunted with him, and though never what would now be called a hard rider, he has always been esteemed a good judge of hunting and an excellent breeder of hounds. Sir Richard also may almost be said to have set the example of gentlemen hunting their own houndsan example which has been perhaps too generally followed, as not always leading to the best results.

As a huntsman to a pack of fox-hounds-since the days of Flying Ben and the Blue Horse*-Sir Richard Puleston has laboured under some disadvantage, in not riding very near to his hounds-a disadvantage not generally considered so important as it really is. Of his judgment in the field, however, I have ever thought highly, and his voice and manner in drawing his coverts were always musical and good; but for many years past he has had a huntsman to assist him.

Sir Richard's present pack is young, but in themselves highly creditable to his judgment as a breeder. They want nothing but some good efficient men about them, who will be as quick as themselves, to make them into a very clever pack. Ned Bates is getting

* Two celebrated hunters of Sir Richard's, the latter of which hunted till past twenty years of age-refusing to be put to any other easier work. 


\section{SIR RICHARD PULESTON}

heavy; his voice is cracked-but, like Falstaff, not with singing anthems-and his day is gone by; and his second whipper-in is too young to be of much assistance to him, but that is a fault which may mend itself. He is well bred, being got by Old Ned out of a neighbouring dairy-maid-by no means a bad cross for hounds.

Sir Richard Puleston's country comprises part of Shropshire, Denbighshire, and Flintshire-his house being situated in the latter county. Were it not for the River Dee, which meanders through the best part of the grazing district, it would be a very pretty one indeed. The fences are easy, the coverts not generally large; and he shewed me a list of no less than eighteen new gorse coverts which his friends have made for him; but he has at present no subscription to his hounds.

Sir Richard Puleston is not only a highly-bred English gentleman, unsophisticated by foreign fopperies; but he is-what is of still more value-a sincere friend. As a companion Sir Richard possesses talent of the first order, and in colloquial wit is seldom excelled. A few of his bons mots are too good to be lost. He was once asked what he thought of the Law and the Prophets? "Why," answered Sir Richard, "I think the Law pockets the Prophets (profits) most damnably." - Some years ago, when Mendoza the boxer was in his glory, Sir Richard was one of a party where the bottle had circulated rather freely, and two Welch Squires were nodding in their chairs, with their heads so close that there was some danger of their coming into contact. "Remove those gentlemen's chairs a little," said one of their friends, "or they will fight in their sleep." - " That would be Men-dozing," exclaimed the Baronet.-A brother sportsman once asked him (alluding to the form of a horse) what he thought of a hollow back? "I like a hollow (halloo) fomward better," replied he.-Another brother sportsman, a master of fox-hounds, once told him he heard his harriers had been running one of his foxes. "Well," said Sir Richard, "you run my game, and why should not I run yours?"-A gentleman in his neighbourhood, whom he knew to be fond of his money, told him he must go to town in the spring, for a polish. "Go to Birmingham," said Sir Richard; "they will do it cheaper for you there." - When speaking of a certain Lady who was in the habit of turning up her eyes towards Heaven one 
moment, and talking rather loosely the next, he observed, in the language of the stud, that "she was got by the Whole Duty of Man out of the Woman of Pleasure."

The following anecdote is too interesting to be omitted. When his present Majesty (George IV.) was Prince of Wales, he paid a visit to the late Sir Robert Leighton, of Loton near Shrewsbury; as also to Lord Forester (then Mr. Forester), who in those days resided at Ross Hall, near the same place; and Sir Richard (then Mr.) Puleston was commanded to meet them.

A wish was expressed by his Majesty to enter the Principality of Wales; but, aware that this could not be done by him as Prince of Wales, unaccompanied by the pomp and pageantry of circumstances, unless in the most private manner, he commanded Sir Richard to conduct him to the nearest part of it, which from his knowledge of the country he was enabled to do. When they approached the spot where a small rivulet divided the marshes of Wales, Sir Richard cantered forward, and, plucking from an oak tree a sprig with some acorns suspended to it, presented it on his knee to his Prince the moment he entered his Principality. The device was extremely appropriate, and his Majesty placed the bough in his hat expressive of the sense he entertained of it; and shortly after, when he was pleased-in the fulfilment, I believe, of an old promise-to present Sir Richard with his Baronetcy, he commanded him to bear, as an additional crest, an oak tree, with golden acorns suspended from one of its boughs.

The Duke of Clarence (his present Majesty) accompanied his Royal Brother on this rural excursion, and was highly gratified with the beauty of the scenery, as well as the novelty of the circumstance. This temporary suspension, indeed, of a life of state could not be without its charms; and I have heard it said the Royal Brothers were in high spirits the rest of the day. On Sir Richard shewing them the situation in which the city of Chester lay, the Duke of Clarence observed, that his old tutor, Dr. Majendie (then Bishop of Chester), lived there, and related some amusing anecdotes of the days in which he was under his care.

I never heard Sir Richard Puleston say anything of this affair, but his conduct on the occasion was quite classical. The British oak is 
a proper type of a British King; for, 'midst storms and tempests the one stands secure, and neither plots nor factions can shake the resting place of the other. But this is not all : in days of yore nothing could be done-no ceremonies at least could be performedwithout having recourse to this monarch of the plain, by some even called "the chosen tree of God." We have read in Virgil, that when his hero Eneas had killed the tyrant Mezentius, and afterwards sacrificed to the god of war, he bared an oak of its leaves, and hanged the gaudy trappings of the dead monster on its naked trunk! It is not in the power of language to say more than this!

On the 10th of March I left home for Pitsford in Northamptonshire, where Mr. Musters resides in the hunting season. His house is situated a little to the right of the road from Northampton to Market Harborough, and within a mile and a half of Brixworth, where the kennel and stables are.

On the day I arrived, Mr. Musters' hounds had met at Kelmarsh, the fine seat of Mr. Hanbury, where I was informed a field of at least two hundred were assembled, and they were very near having a capital run. As it was, they had a pretty little burst at a racing pace, and killed; but one fox went away over a magnificent country, with only about five couples of hounds on the scent-the body of them having gone away with another fox.

To Mr. Musters, as a huntsman, the Sporting World have unhesitatingly assigned the palm of superiority ; and, as far as I am a judge, I fully confirm their verdict. I must say of him, as has been said of another, that (singulus in arte) "none but himself can be his parallel."

Mr. Musters hunted a pack of harriers when a boy. His father kept a pack of fox-hounds for many years; and-independently of the advantages he has had of seeing hounds in all the best countries in England-he has been at the head of a pack of his own for twenty-three seasons.

On the 11th the dog pack met at Mr. Musters's house. In about a mile and a half we arrived at Moulton's gorse, and found directly. An awkward brook immediately at starting, severe ground, and the pace, scattered the field, and made a check at the end of twelve 
minutes by no means amiss. Mr. Musters's second cast was a masterly one, and we ran our fox to ground in about twelve minutes more. We found again in Siwell Wood, and had a fine run of upwards of one hour. The country was between wet and dry, consequently most severe, and there was a good deal of distress among the nags. We had plenty of pace and plenty of hunting; but, in consequence of a long check, only seven saw the finish, which was beautiful. We got him dead beaten-in the midst of the hounds -in a small covert; but by one of those quick turns that foxes make on these occasions, he broke again close to my horse's heels, and got into a main earth in a hedge-row. It was a fine day's sport.

As this was my first appearance in this part of Northamptonshire, I was somewhat anxious to see the country. With our first fox I did not like it. It was almost all plough, in small enclosures, hilly, and altogether provincial. With our second, it was better; a good fox-hunting country, with a good share of grass, but not first-rate. Siwell Wood I consider a beautiful covert.

Monday the 13th met at the village of Great Harrowden, about ten miles from Pitsford, on the great road between Welford and Market Harborough; killed a brace of foxes in the course of the day; had two sharp bursts, and some beautiful hunting with the bitch pack.

15th, met at Fawsley, near Daventry, the seat of Sir Charles Knightley, twenty-two miles from Pitsford. Although no longer a fox-hunter, Sir Charles takes care of the foxes, and we found directly. Having no scent we could do nothing.

On Monday the 20th met at one of their very crack placesMisterton, the seat of Mr. Gough, near Lutterworth. Here are generally to be seen artists from all the neighbouring Hunts, and some splitting work is the consequence, if a good fox is on foot. On this day, however, owing to Lord Anson's fixture being a good one, there were not more than two or three of his men, and very few Quornites, as the Duke of Rutland met at a good place. Mr. Holyoake went well upon old Baronet in spite of his music-and Mr. Osbaldeston was also in the field. Altogether, perhaps a hundred and twenty horsemen-considered a small field for Misterton. 
We had the dog pack on this day, and they looked pretty fit to go. We got upon a newly-disturbed fox, and ran him half an hour, but lost him. It was long enough, however, to shew me a chef-d'cuvve of Mr. Musters. The hounds checked in a spinney, and the scent was back. He appeared to turn almost before his hounds, and got them on the line again in the twinkling of an eye. We lost this fox, and found again at Crick-the very finest part of Northamptonshire -and had a beautiful kill at the end of one hour and sixteen minutes. There was not a good scent, and the hounds were obliged to get their noses down; but, without assistance, I question whether they would have tasted him.

The Crick country is almost all grass, and more strongly fenced than any part of Northamptonshire. Indeed I do not think that I ever saw larger or rougher fences than we had with our first fox; and there were, consequently, a great many falls. One gentleman I was sorry to hear, had his collar-bone broken; and that fine horseman, Mr. Davey, was knocked down three times by the fences in less than as many miles. I considered this a fine day's sport; and every one went home in good spirits and pleased.

On Wednesday the 29th met within a mile of Kettering, and drew the finest woodlands my eyes ever beheld. They are the property of the Duke of Buccleuch; and when I say that they contain avenues to the extent of seventy miles in various directions, I need hardly add they are a treasure to a master of fox-hounds. After running one fox to ground, and seeing some very pretty hunting, myself and several more declined, for the ground was dreadfully hard; but a gallant fox went away to Siwell Wood in the afternoon, and afforded a fine hunting run of about sixteen miles point blank over a very good country.

When I arrived in Northamptonshire hunting was drawing to a close. The harsh winds of March had begun to blow, and a day's sport could never be reckoned upon. Mr. Musters' hounds, however, had had more than their share. Indeed they were allowed by all to have had a capital season, and they may be said to have been fleshed in blood.

Few packs of fox-hounds (or indeed anything else) will bear a microscopic scrutiny. Mr. Musters' certainly will not. The bitches 
are handsome and of a good stamp; but the dog hounds are, many of them, past their prime, and, as a pack, not so sightly as they should be. A liberal draft is wanted, and a larger supply of three and four year old hounds is necessary for the work Mr. Musters gives them.

Of condition I must not say much. The month of March was all against it; but it improved during the time I was with the hounds. It was evident the season's work had been too hard for them, but their huntsman never knows when to say "enough," so fond is he of the sport. I should also observe, that some of Mr. Musters' finest bitches were gone to his seat in Nottinghamshire (where he has excellent walks) to whelp. His first whipper-in I found to be my old acquaintance, Tom Smith, who formerly whipped-in to, and afterwards hunted, Lord Middleton's hounds. Smith is a good sportsman; and no doubt will soon be a very good one under such a master. He greatly prefers Northamptonshire to Warwickshire for hounds. The second whipper-in, Will Derry, is useful and civil, and has been two years with Mr. Musters.

Mr. Musters's kennel and stables are sufficiently good. His horses are of a large stamp, which his strongly fenced country requires.

Of Mr. Musters as a rider little need be said. He has always been considered not only a very elegant horseman, but capital over a country, and he has the eye of a hawk. In his saddle he is fifteen stone; but he maintains, that weight, with horses equal to it, is an advantage in Northamptonshire, and that no light man can go well over it. I know indeed that the Tom Smith has been heard to say, that he goes over Leicestershire, but through Northamptonshirealluding to the strength of the fences.

Among the Northamptonshire riders, Vere Isham (brother to Sir Justinian) stands first, and with a good or bad horse under him he is a very clever fellow. He is not like the parson who could only preach out of his own book; or like many of our fine riders who can go well on fine horses; but Vere Isham-although a grandfathercan ride what others cannot ride; and if he hears of a horse that is to be sold because he will not make a hunter, he generally buys himhaving got a receipt in his stable that will soon make him one. 



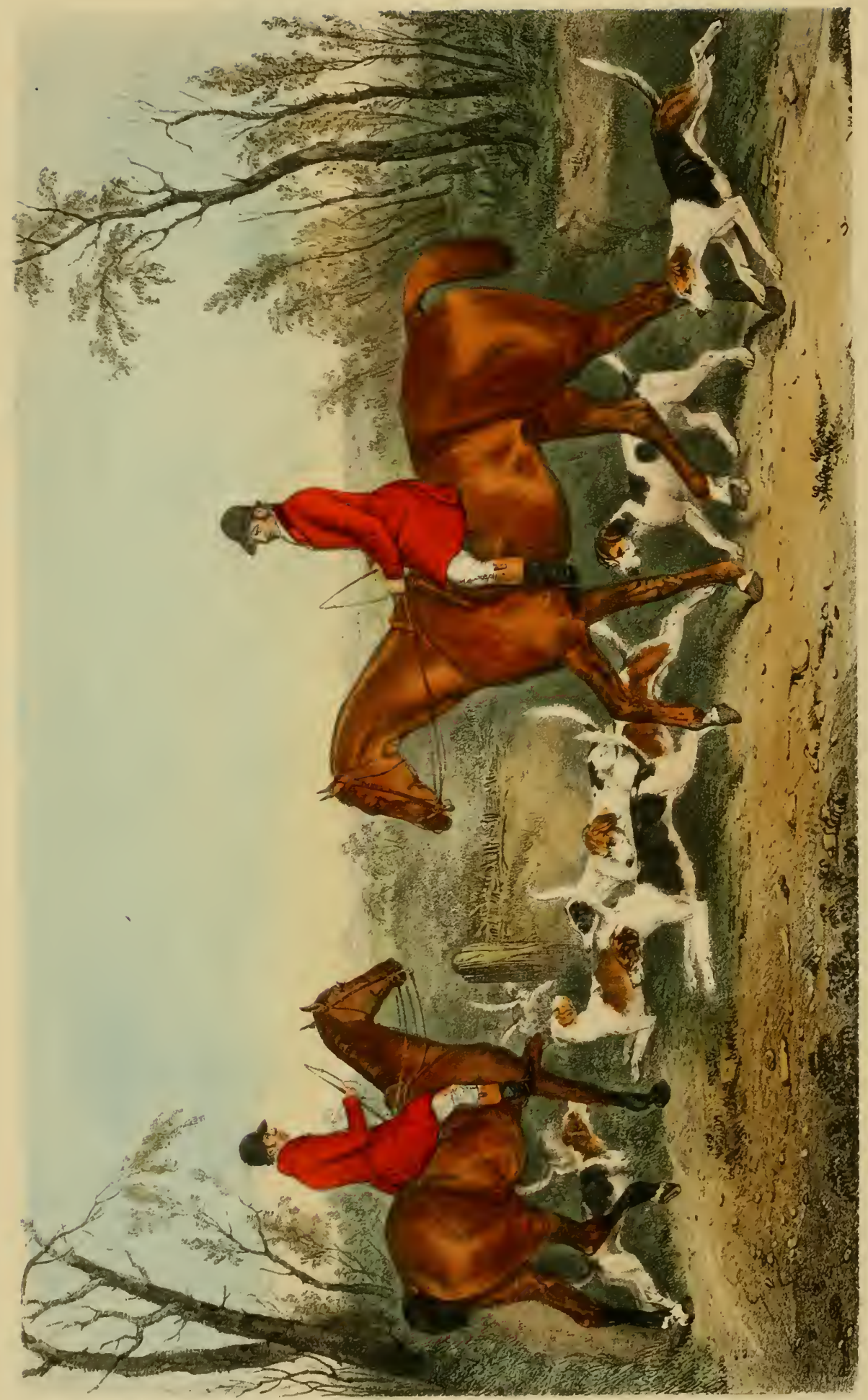




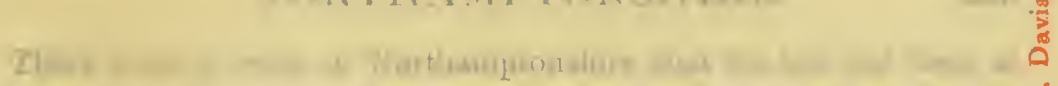

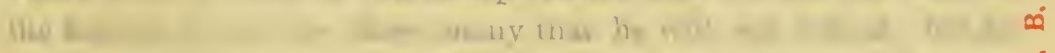

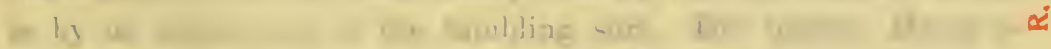

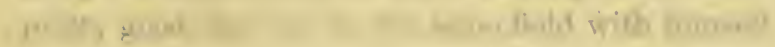

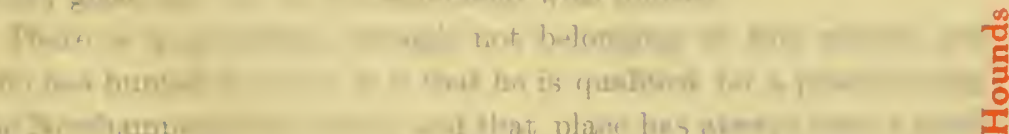

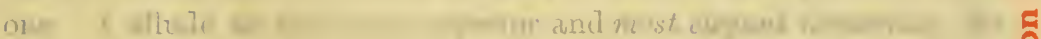

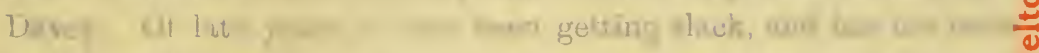

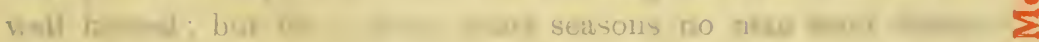

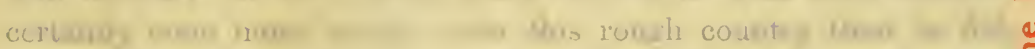

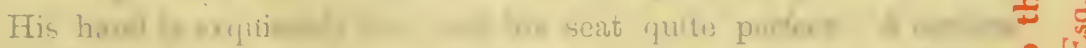

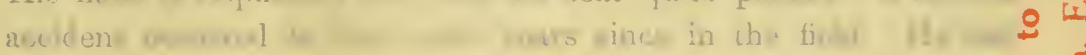

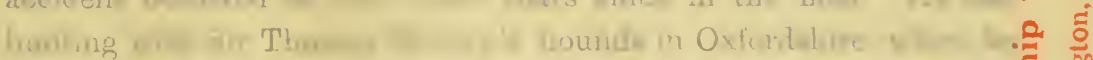

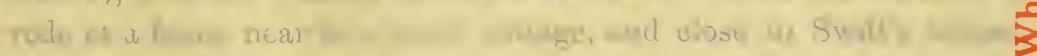

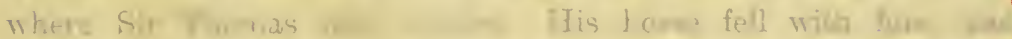

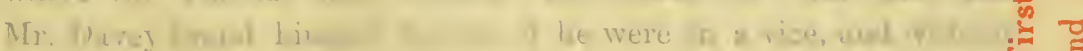

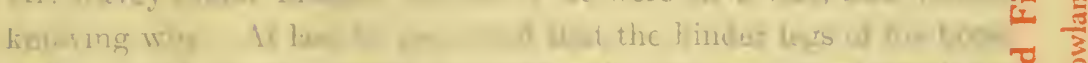

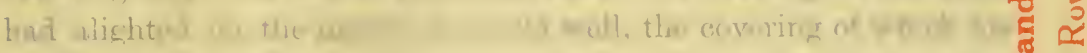

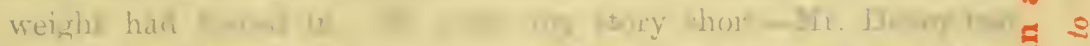

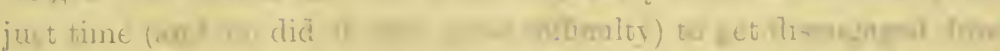

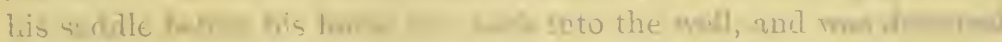

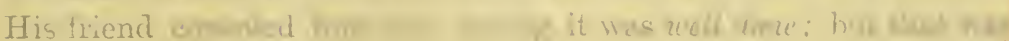

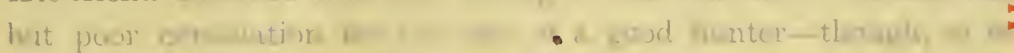

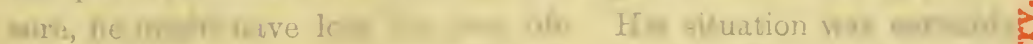

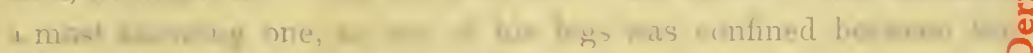

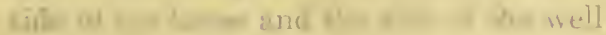

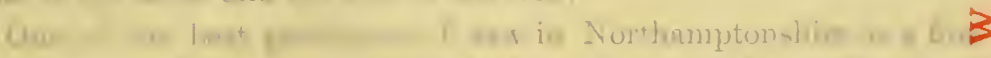

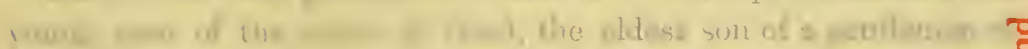

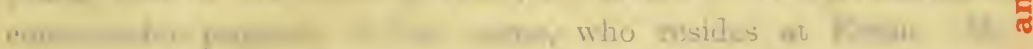

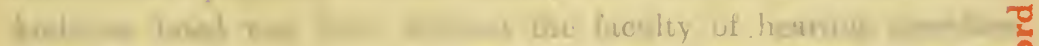
Whatie, in

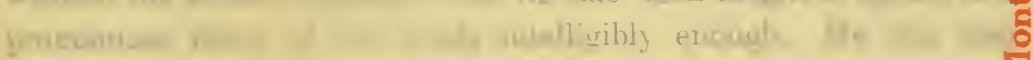
hecri toubtu

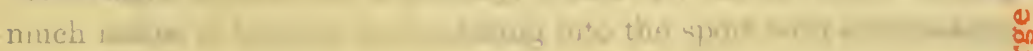
delight

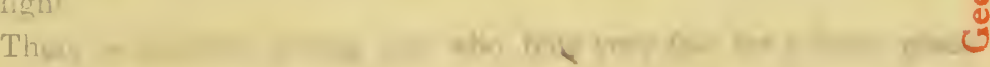




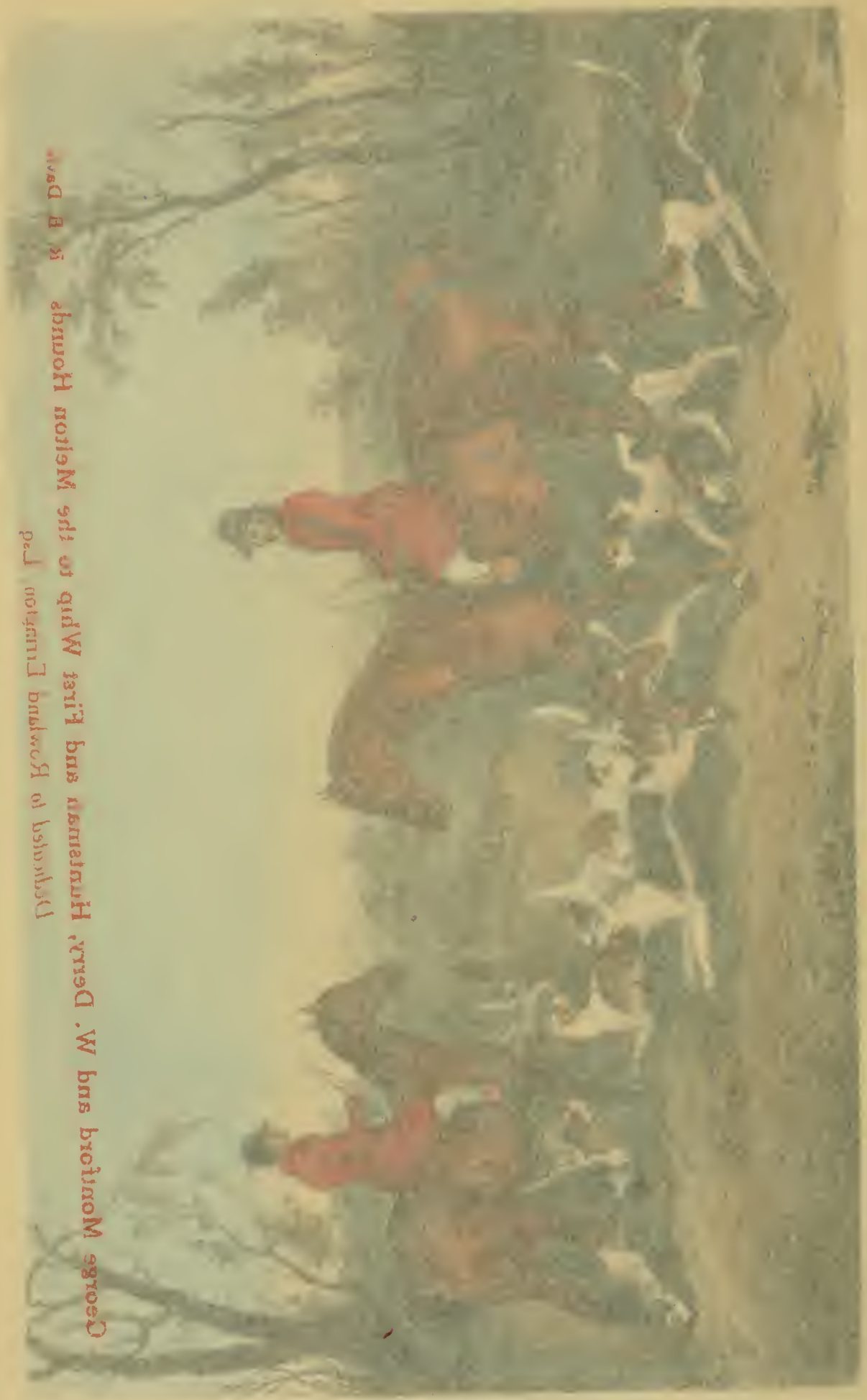


There is not a brook in Northamptonshire that he has not been at the bottom of, nor are there many that he will not ride at; but he is by no means one of the tumbling sort. His brother Harry is pretty good, but not in the same field with himself.

There is a gentleman, though not belonging to this county, yet who has hunted so much in it that he is qualified for a place among the Northamptonshire riders, and that place has always been a good one. I allude to that very superior and most elegant horseman, Mr. Davey. Of late years he has been getting slack, and has not been well horsed; but for a great many seasons no man went bettercertainly none more neatly-over this rough country than he did. His hand is exquisitely fine, and his seat quite perfect. A curious accident occurred to him some years since in the field. He was hunting with Sir Thomas Mostyn's hounds in Oxfordshire, when he rode at a fence near to a small cottage, and close to Swift's house, where Sir Thomas now resides. His horse fell with him, and Mr. Davey found himself fast, as if he were in a vice, and without knowing why. At last he perceived that the hinder legs of his horse had alighted on the mouth of an old well, the covering of which his weight had forced in. To make my story short-Mr. Davey had just time (and he did it with great difficulty) to get disengaged from his saddle before his horse fell back into the well, and was drowned. His friend consoled him with saying it was well done; but that was but poor consolation for the loss of a good hunter-though, to be sure, he might have lost his own life. His situation was certainly a most alarming one, as one of his legs was confined between the side of his horse and the side of the well.

One of the best performers I saw in Northamptonshire is a fine young man of the name of Isted, the eldest son of a gentleman of considerable property of that name, who resides at Ecton. $\mathrm{Mr}$. Ambrose Isted was born without the faculty of hearing, therefore without the power of speech; but he has been taught to speak, and pronounces many of his words intelligibly enough. He has also been taught to ride over a country, which few can do better-taking much notice of hounds, and entering into the sport with enthusiastic delight.

There is another young one who bids very fair for a front place 
with hounds, and that is Mr. Whalley, son of the Rector of Ecton. A Mr. Parsons also, another young one, is a bold horseman, and wants nothing but a few years' experience to ensure him a good place. Mr. Meyrick has been so many seasons in Northamptonshire, that he may be reckoned one of them, and few men are before him in a quick thing.

There is a very sporting draper residing at Northampton by the name of Whitworth; he is a very thrusting rider after hounds.

The Northamptonshire farmers are chiefly men of property-the nature of their occupations require them to be so. They almost all keep hunters, which, if they can't ride themselves, their sons can ride for them. The yeomanry of the country live in great comfort. I called upon one of them-Mr. Potterton of Pitsford-to see his stud. He had three clever hunters in his stable, and some good young stock in his paddock, bred from good blood. This is what we should like to see all England over.

To speak of Mr. Musters as a huntsman, requires the knowledge of a huntsman, but I must make the attempt; therefore as old Corcoran says, when he comes to an awkward fence, "Go along, horse."

Few men, I believe, see less of their hounds in kennel than Mr. Musters does, neither can I call him a good kennel huntsman. I do not think it is his passion. It is in the field he shines; and when I say he is pre-eminent here, I only echo the voice of Fame. In command of hounds, I never saw him excelled, and he certainly handles them with a master's hand. Every art has its terms, and his language in the field is particularly good. He "suits the action to the word, and the word to the action," with the greatest possible effect. From temperament of constitution also he must have been intended for a huntsman, for he is never fatigued, but is always cheery; and as cheerfulness is catching, his field generally seem cheery also. To sum up all-although a gentleman, he is a huntsman. Nature has qualified him for the task. When with his hounds he is in his element, and, without this, it avails nothing; for as Ion says,

"What's the gay Dolphin when he quits the waves, And bounds upon the shore?" 
I now bring my Second Tour to a close, with only a few words.A writer without freedom is a writer without interest; but I hope I have taken no unwarrantable liberty with any man's name. In "this vale of tears," we are entitled to snatch a pleasure where we can find it, provided we rob no one else of the prize, and I would not have it upon such terms. Johnson said of Savage, that "he seldom found a stranger whom he did not leave a friend;" but, not possessing the acquirements of Savage, I am in no wise entitled to such a compliment. Thus much, however, I am enabled to say; that during my late Tour, I received nothing but hospitality and kindness, and every man I met appeared to be my friend. This is the way to pass one's days, for "it makes life's business like a summer's dream." 


\title{
NIMROD'S YORKSHIRE 'TOUR, 1826,
}

\author{
CONTAINING ACCOUNTS OF
}

The Raby Pack, the Lambton, the York and Ainsty, the Hurworth, the Holderness, the Badsworth, ie. \&c.

UNDER THE RESPECTIVE MANAGEMENT OF

The Earl of Darlington, Mr. Ralph Lambton, Mr. Lloyd,

Mr. Matthew Wilkinson,

Mr. Thomas Hodgson, and Lord Hawke:

AND CONCLUDING WITH

A Visit to Leicestershire and the New Forest.

LAst winter Yorkshire was fixed upon, for two reasons : first, it was fresh ground, and therefore likely to produce a good crop; and secondly, because it is decidedly the most sporting part of His Majesty's dominions. One might almost imagine there was something in the physical power of the climate that produced such a host of sportsmen-for every man there is one.

On the 1st of November 1826, I started for the North; halted that day at Birmingham; on the 2nd reached Leeds; and on the 3rd arrived at York at twelve o'clock.

As was natural to suppose, I soon stumbled upon a man I knew. This ended in an invitation to dinner and a very pleasant evening, but not at my friend's house-for when he got home, he found an invitation from Mr. George Swann, and took me under his arm. I am not going to recapitulate the scenes of the evening; but as 
anecdotes form so great a part of my stock in trade, I must bring them to market when opportunities offer, and the present occasion furnishes one. It so happened, that on leaving home, I found myself not quite well, and took the advice of an eminent physician on the road. "There is not much the matter with you," said he; "and if you will only drink three glasses of wine a-day instead of a bottle, which you fox-hunters often do, and take a little of this medicine, you will live to be a hundred."-" Your medicine, Doctor, I will take," said I; "but the other part of the prescription is quite out of the question." However, to the point. On the morning after I dined with Mr. Swann, I met him at the lodging of a mutual friend, where a third person was present, who had dined with us the day before. My prescription was sent to the druggist's, and its contents read over by the party. "Oh," said . . . . . . . ., " it is sure to cure you: there is no finer medicine in the world than cochlearia." Now cochlearia happens to be the Latin for spoonfuls, of which I was to take "duo larga bis die," or two large ones twice a-day.

I was at this time only two days in York, but one of them being Sunday, I had a good opportunity of seeing one of the proudest monuments of human art and human magnificence, York Minster. By way of a comparison between the manners and usages of society in former and present times, I quote the following passage, which I met with in the "Antiquities of Yorkshire." Alluding to the city of York-" Near to the cathedral is the house where the two weekly assemblies are held. These meetings are great helps to strangers, who flock hither in great numbers for the convenience of boarding, which is very cheap, and diet good; for in a week or two's time they may, by using them (and none is excluded either of them for half-a-crown a quarter), be acquainted with all the genteel company, male and female, in the city and adjoining county of York.

In the afternoon, Mr. Swann was kind enough to shew me the York hounds and Mr. Ridsdale's stud. Mr. Ridsdale is an excellent rider to hounds. I saw him out one day on Flaxtonian, and thought he looked like a workman. He has also, I understand, done some good things on the road with his hacks, of which the following may be recorded as one.-He left London on a Monday, and was at 
York on the following Wednesday by four o'clock in the afternoonone hundred and ninety-six miles. The mare rested the next day, and on the Friday he rode her to Newcastle-eighty-two miles; making the average of the days she was at work ninety-two miles. Mr. Ridsdale resides at Murton, three miles from York, where he has built a house, and as complete a range of stables as human ingenuity can effect, or the health and comfort of horses require. He has also some capital paddocks, and is breeding thorough-bred ones on an extensive scale.

As Mr. Ridsdale was in London, we merely walked through his stables and looked at his hunters, which consisted of seven. They were all thorough-bred, and in excellent form to carry his weightabout twelve stone.

Mr. Swann then took me to the kennel of the York and Ainsty fox-hounds, situated a mile from York, and near to Knavesmire, the race-course. As might be expected from the resources of a subscription pack, this kennel has nothing to boast of beyond the necessary conveniences for a small pack of fox-hounds; but it appeared clean and wholesome, and free from epidemic disease. There is one part of it which was new to me; but the plan is a good one, and I found it generally adopted in the kennels in the North: the upper half of all the inner walls are built in open brick work, which gives free circulation of air, and doubtless prevents disease.

In Naylor, the huntsman to the York and Ainsty, I recognised an old acquaintance. I knew him when he whipped-in to Sir Thomas Mostyn in Oxfordshire, but that was in his early days. He has been six years huntsman to the York and Ainsty, in which capacity-as far as relates to the operations in the field-I refrain from speaking of him at present. I never, however, withhold praise where it is justly due, and in kennel superiority Naylor stands high. I considered his hounds looking in splendid condition; and by the great pains I observed he took in feeding them in small lots, it is evident he plumes himself on excelling in this most essential point.

I think the York and Ainsty hounds, as a pack, particularly clever, and possessing, individually, as great a share of beauty as is to be found in most kennels. They have size, power, and size and power without lumber or incumbrance, which, as far as the eye carries us 
in a kennel, is all we can desire to see. I thought Boisterous (by Lord Darlington's Brusher out of their Countess, the old Pytchley sort), Jollity, Pillager, and Charity, among the old hounds, very fine samples; a three-year-old bitch, Pastime, very clever indeed; and the Splendour hounds, out of Countess, Mischief, and Toilet, in very fine form. I also noticed Tuneful, by Lord Lonsdale's Roman out of the Badsworth Tempest-a very promising young one.

The subscription to the York hounds is limited, not exceeding 1300l. per annum, and is chiefly raised by the resident gentlemen of the city of York, although at the commencement of the last season Sir Bellingham Graham became an annual subscriber of one hundred pounds. The management of the establishment is left to a gentleman by the name of Lloyd, who resides at Acomb, two miles from the city, and he has had it six years. He is considered a fair sportsman, and universally commended for his mild and unassuming manners; and there was a time when few men could have beaten him over Yorkshire. He now, however, rides well up to his hounds, although between fifteen and sixteen stone on his horse. Previous to Mr. Lloyd, Mr. Robert Challoner and Mr. J. IV. Clough were at the head of these hounds, during which time they were hunted for one season by Mr. George Treacher.

As far as I can recollect the following is the history of this country. It had once been hunted by Colonel Thornton, of Thornville Royal, and then lay vacant for some time. It was afterwards occasionally occupied by Lord Harewood, Sir Tatton Sykes, Lord Darlington, and also by the late Mr. Lane Fox, of Bramham Park; but the first to establish the York and Ainsty hounds was the Honourable Captain Butler, who started them about ten years ago, and had his kennel at Newmonkton, where he now resides. The country is not only extensive, but wide, which obliges the hounds and horses to lie from home two or three days a fortnight, which is against them : and it is also intermixed with Sir Tatton Sykes's and Lord Harewood's countries, for which reason the York and Ainsty and the latter pack always hunt alternate days.

From what I saw of the York and Ainsty, I considered it favourable to hounds, but unfavourable to horses, on account of the wet, and in many places boggy, state of the land, in addition to its being nine- 
tenths ploughed. In another respect also it is unfavourable to horses : it is so very flat that hounds are lost sight of if suffered to get two fields a-head; so there is no riding to points, as in most other provincial countries. The fences-the common hedge and ditch, not often bound-though they occur frequently, are not difficult; but a brook-jumper is often wanted, as in parts there are many wide drains. Few of the gates in the North are practicable, as they far exceed the usual height. The stiles also, particularly in Durham, were quite new to me. They are formed by two posts, about four feet high, placed in the form of a $\mathrm{V}$, and so narrow that a well-fed Alderman could not, I should imagine, pass through them. Some of the horses of the country, however, will either walk into or jump over them ; but a mistake at them would be awful, as they would be certain to hold them fast. I purpose giving in another place some notice of the men who hunt, and the gentlemen who ride to the hounds.

It was my good fortune, previous to my departure from home, to receive an injunction from Sir Bellingham Graham against going to an inn in Yorkshire whenever the scene of action lay within any feasible distance of either of his houses-Whitwell or Norton Conyers.

Sir Bellingham Graham was at this time residing at Whitwell, where I arrived on Sunday to dinner. His house is situated on the left of the village (all his own), and, during his nine year's' absence from Yorkshire in the service of fox-hunting, was let to tenants, but has lately been painted and furnished by the Baronet, and made in every respect comfortable. It is beautifully situated, twelve miles from York on the Scarborough road, and, standing on an eminence, commands the whole vale between itself and York-at the end of which is distinctly seen the noble Minster.

In the winter months Sir Bellingham's residence is regulated by Lord Darlington's hounds. When they are in the Bedale country, he migrates to Norton Conyers; and when they return to Raby, he returns to Whitwell, where he has Sir Tatton Sykes and the York.

On Wednesday the 8th I made my first appearance with hounds in Yorkshire. Sir Bellingham accompanied me to meet Sir Tatton Sykes' pack at Galley Gap, about four miles from Whitwell, and not so much from the kennel. The place appeared to me more adapted 



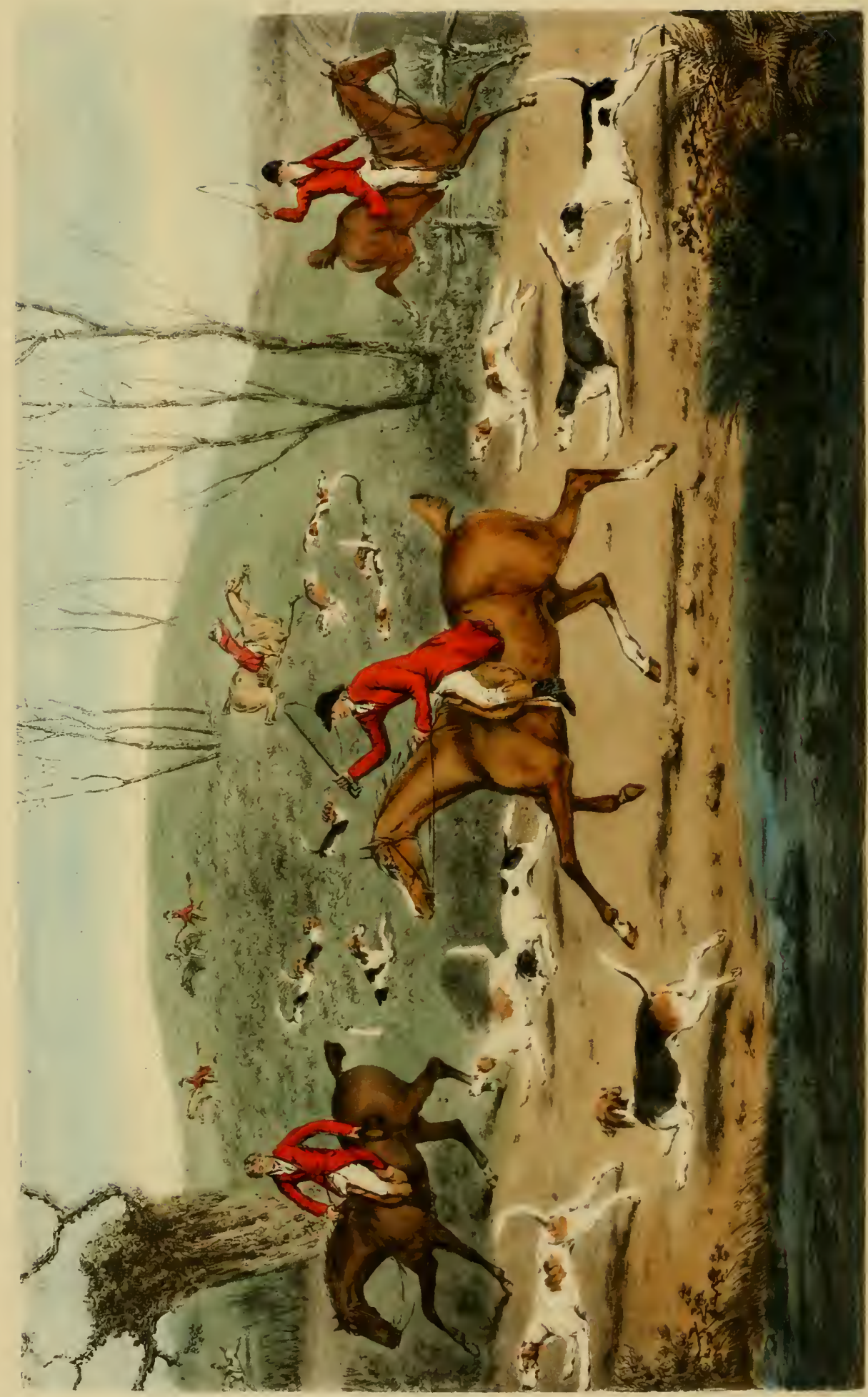




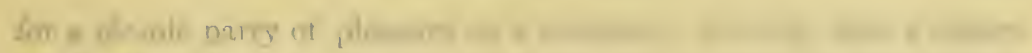

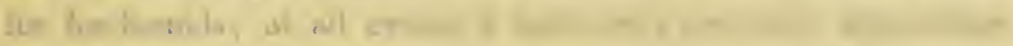

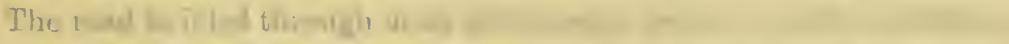

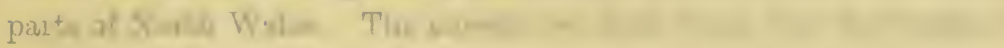

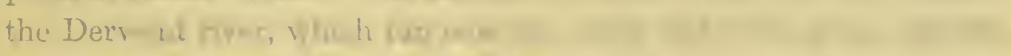

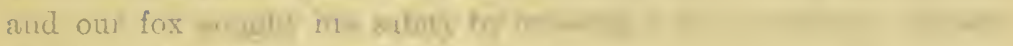

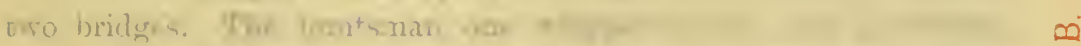

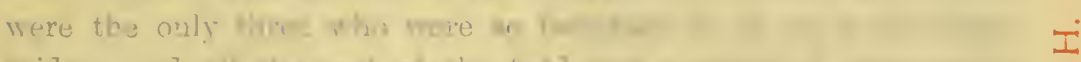

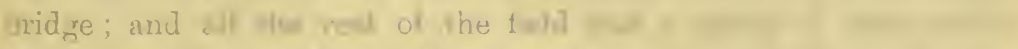

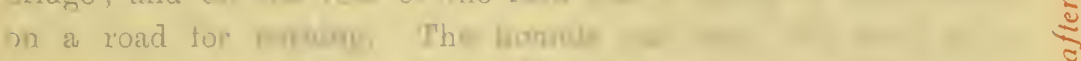

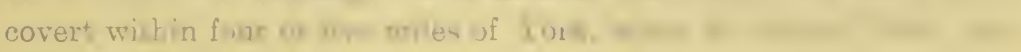
was lust

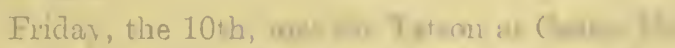

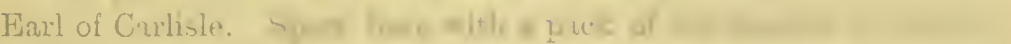

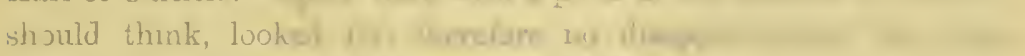
However, we haul o ul

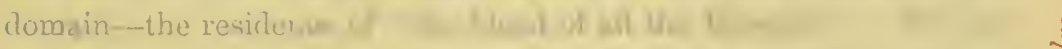

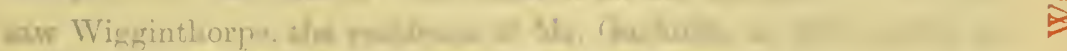

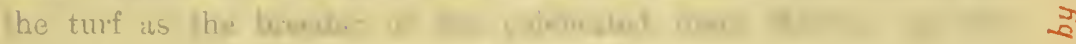

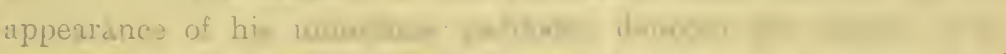

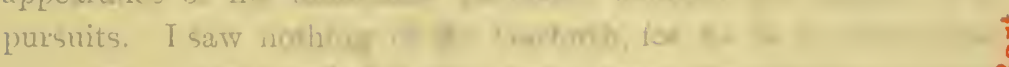

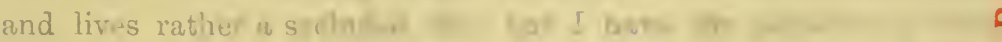

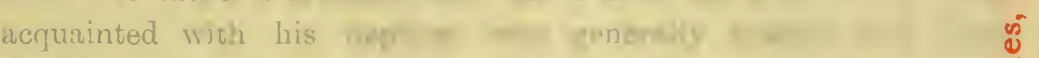

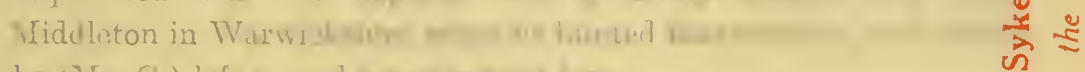

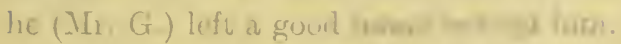

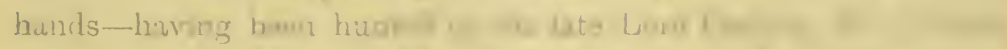

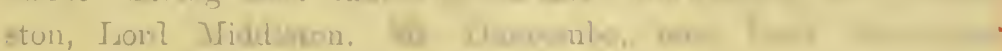

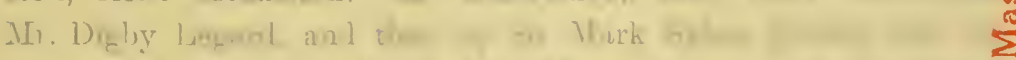

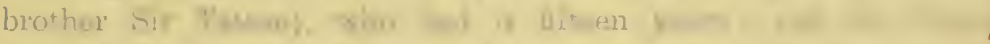

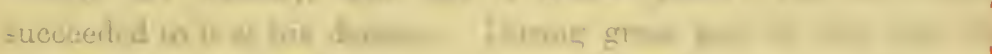

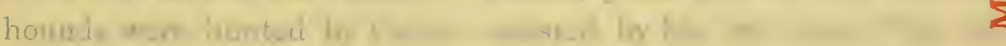

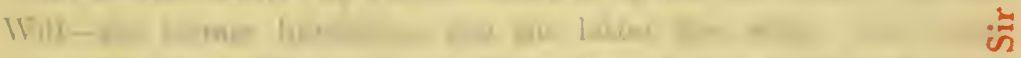

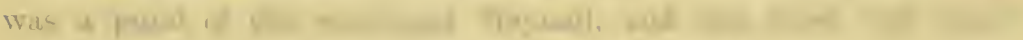

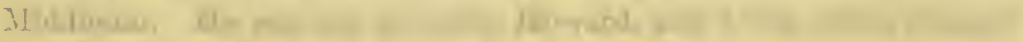

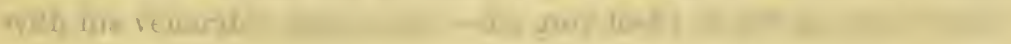

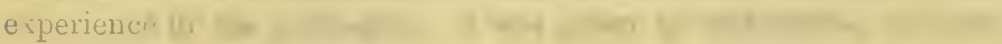




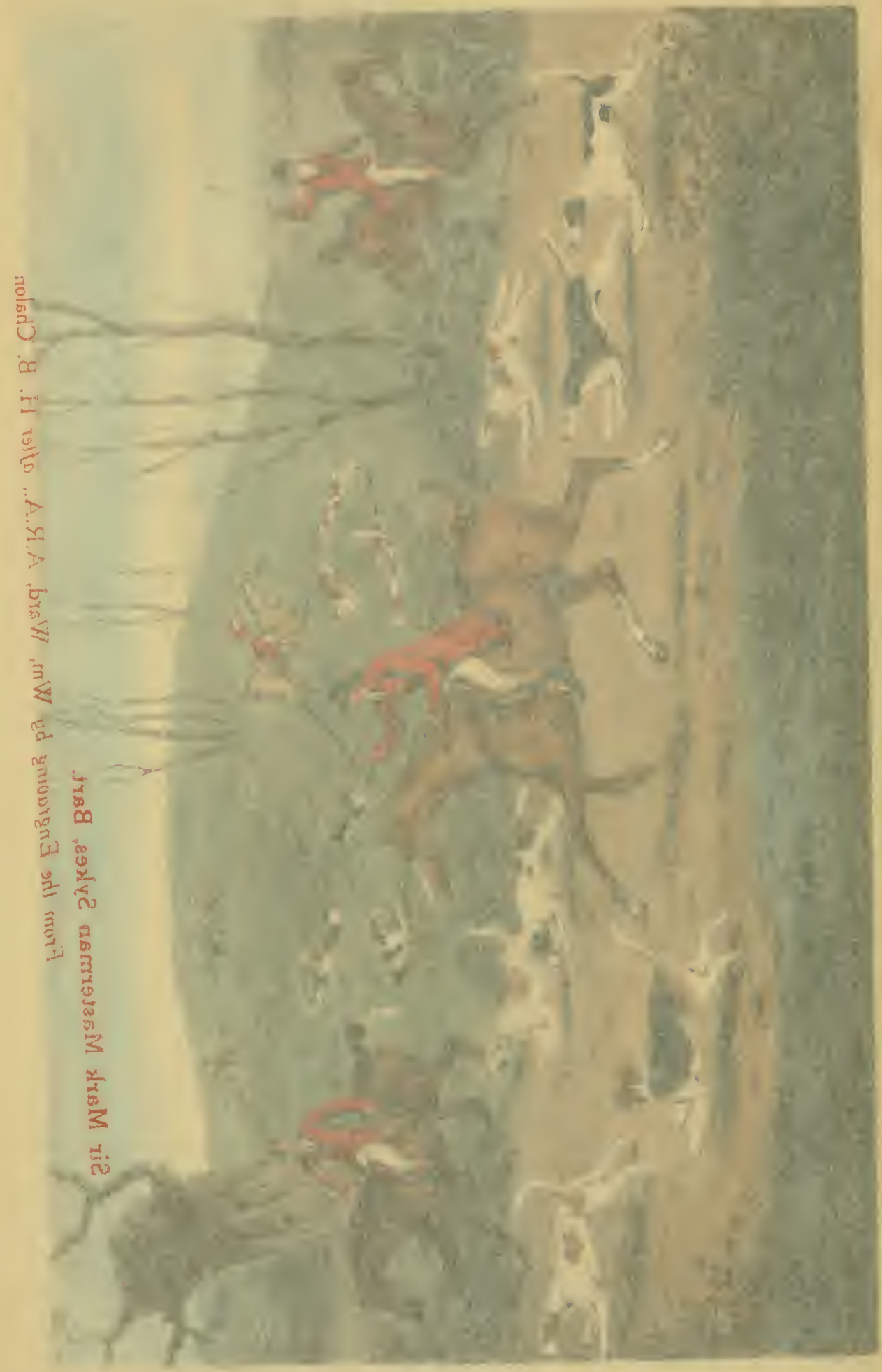


for a pic-nic party of pleasure on a summer's evening than a fixture for fox-hounds; at all events it had a very provincial appearance. The road to it led through most picturesque scenery, much resembling parts of North Wales. The coverts we drew hung over the banks of the Derwent river, which ran over its rocky bed with great rapidity, and our fox sought his safety by crossing it about midway between two bridges. The huntsman, one whipper-in, and one gentleman, were the only three who were so fortunate as to go to the right bridge; and all the rest of the field had a gallop of some miles on a road for nothing. The hounds ran their fox hard to a covert within four or five miles of York, when he turned back and was lost.

Friday, the 10th, met Sir Tatton at Castle Howard, the seat of the Earl of Carlisle. Sport here with a pack of fox-hounds is never, I should think, looked for, therefore no disappointment can arise. However, we had a pleasant morning's ride, and saw the fine domain-the residence of "the blood of all the Howards." IVe also saw Wigginthorpe, the residence of Mr. Garforth, so well known on the turf as the breeder of the celebrated mare Marcia, and the appearance of his numerons paddocks denoted the nature of his pursuits. I saw nothing of Mr. Garforth, for he is no fox-hunter, and lives rather a secluded life; but I have the pleasure of being acquainted with his nephew, who generally resided with Lord Middleton in Warwickshire when he hunted that country, and where he (Mr. G.) left a good name behind him.

The country occupied by Sir Tatton Sykes has been in many hands-having been hunted by the late Lord Carlisle, Mr. Osbaldeston, Lord Middleton, Mr. Duncombe, now Lord Feversham, Mr. Digby Legard, and then by Sir Mark Sykes (jointly with his brother Sir Tatton), who had it fifteen years; and Sir Tatton succeeded to it at his decease. During great part of this time the hounds were hunted by Carter, assisted by his two sons, Tom and Will-the former huntsman, and the latter first whip. Old Carter was a pupil of the renowned Meynell, and also lived with Lord Middleton. He was out at Castle Howard, and I was much pleased with his venerable appearance-his grey locks denoting many years' experience in his profession. I was given to understand, however, 
he was not without his peculiarities and prejudices, one of which was, he never carried a hunting horn.

Previous to last year, Sir Tatton Sykes resided at Westow, about four miles from Whitfield, where he occupied a large farm, and where he had his paddocks for breeding race-horses. He is now removed to the family mansion at Sledmere (no great distance from Malton); but the kennel is where it always has been-at Eddlesthorpe, not far from Westow. Sledmere is fifteen miles from the kennel ; but Sir Tatton, on his thorough-bred hacks, thinks nothing of this, and very frequently rides thither before the hounds leave it on hunting mornings. His hounds hunted four days a-week the season before last, but only, three last. He has no subscription.

Sir Tatton Sykes comes under the denomination of what is called " a character;" and one of his chief characteristics is to be found in his passion for riding a race, his method of travelling across a country, the plainness of his dress, and the outward humility of his demeanour towards all ranks.

A poet calls Humility "that low sweet root from which all heavenly virtues shoot;" but in my opinion, it is not always free from suspicion.

\footnotetext{
"There are some that use

Humility to serve their pride, and seem

Humble upon their way, to be the prouder

At their wish'd journey's end."
}

This, however, I am sure, cannot be applied to Sir Tatton Sykes. It is quite evident to any common observer, that the quiet and unassuming manner in which he carries himself to the world is one of the component parts of his nature; and those who know him can testify that no man is more at variance with affectation or art.

Sir Tatton's method of travelling across country betrays a strength of constitution and hardihood of frame, not only enviable, but characteristic, I believe, of his countrymen. If asked to go a hundred miles to ride a race, he puts a clean shirt in his pocket, his racing jacket under his waistcoat, a pair of over-alls above his leathers, and, jumping upon some thorough-bred tit, arrives there the next day by the time of starting, and, when the race is over, canters his thorough-bred home again. I cannot exactly determine the value Sir Tatton puts upon riding a winning race for a friend; 
but if I am to judge from what escaped him after winning the Bosworth, with Gossoon, at Lichfield, all the pleasures we are taught to anticipate from the realms above fall far short of the mark.

As a gentleman-jockey, Sir Tatton has long been in repute. He is very powerful in the saddle, and never loses his head.

I was very much pleased with Sir Tatton's hounds. They shew a great deal of breeding, are fast, but very close workers, of a most desirable size, and quite the sort of hound for Leicestershire, although there are too many old ones at present in the kennel to suit that country.

Sir Tatton's men are very capitally mounted, chiefly on thoroughbreds, which indeed they ought to be to follow their hounds over the Yorkshire wolds, which generally hold a good scent, and great part of their country is of that description. These wolds are of great extent, enclosed and cultivated after the manner of our Oxfordshire and Gloucestershire hills, and much the same to ride over, but the soil is deeper, and therefore more severe for horses. The fences are chiefly quick, and posts and rails are numerous in some parts.

Sir Tatton's hounds had a very fine run this season from Sir Francis Boynton's coverts ; but I was told it was not so decidedly good as one he had on the 8th November 1823, from Givendale Warren, when, after a run over the wolds of one hour and twenty minutes without a check, the for was killed in the presence of only Tom Carter on his Whitelock mare, and Major Healey on Hardbargain.

Saturday the 11th, met the York and Ainsty at Hulby, eight miles from York in the direction of Boroughbridge. Unfortunately we had no sport. Our first fox was lost by the ignorance of the second whipper-in, who never attempted to turn the hounds, which ran over three fields with their heads up-the fox haring turned short back. He was also ably seconded by a well-mounted gentleman in scarlet, who was of course equally at sea. The hounds being disappointed, and the scent bad, they did not settle again, and we lost him. After chopping another, we found again in Oldwork Wood, but the scent got worse and worse. I viewed the fox across a field about ten minutes after we found, and although the hounds came to halloo immediately, only one of them (Remus) could speak to it. This 


\section{NIMROD'S HUN'IING 'TOUR}

country was close, and some of it loose in the soil, and not looking favourable for scent; but, taken altogether, I did not dislike it; and I thought that part of it which I had ridden across on my road to covert was capable of shewing a fino rum.

Sir Bellingham did not accompany me this day to the York hounds, for two reasons: first, himself and his establishment were on the move to Norton Conyers; and, secondly, he was unwell. On my arival there, I found him in possession of a stud of hunters; and my own horses safely arrived, and most comfortably quartered in one of his five-stall stables.

As may be natural to suppose, the great attractions to my oye in my visit to the North were the Earl of Darlington's and Mr. Ralph Limbton's fox-hounds. The rank of the former-the splendour of his establishment-the character I had heard of him-all had some share in exciting my euriosity; but these were of comparative insignificance to the extraordinary fact of his having hunted his own hounds thirty-six seasons; and not hunting them only, but going through all the drudgery of a huntsman, by constantly drafting and feeding them in the season, and paying the most minute attention to all the operations of the kennel.

Although his inferior in rank, in the same field with his Lordship is a sportsman is that idol of his circle, Mr. Rilph Lambton, who has kept and humted the Lambton hounds thirty-five seasons-his elder brother having kept them seven year's before.

Lord Darlington's hounds met on Monday the 13th at York Gate, on the London and Glasgrow road, three miles from Sir-Bellingham's house. As is always the case when the fixture is so near, we had not a minute to spare, and just got to the place as Lord Darlington drove up in his carriage, with Lady Arabella Vane, his youngest daughter, for whose riding a most splendid horse was in waiting. Lady Arabella was attired in her scarlet habit, and his Lordship in it straight-ent searlet coat, with an embroidered fox on the collar, a hat, and a leather girdle across his shoulder. His two whippers-in were also in hats, and had the embroidered fox on the collar."*

* In the well-known print of the Earl of Darlington und his fox-hounds, his Lordship nppoars in a cap, which hinsolf and his men for many years rodo in, but at present thoy all wear hats. 
Setting aside the attractions I have already enumerated, losing sight of his rank and other adventitious circumstances, I met Lord Darlington greatly prepossessed in his favour. " $I$ have known Lord Darlington," said Sir Bellingham, over our elaret on the evening preceding, "from my earliest years, and have a very great regard for him. There is one thing-his passion for fox-huntingwe must all esteem him for ; and, when we go to visit him, I think you will find him a most excellent companion, and one of the hest bred men in the world."

During Sir Bellingham Graham's absence from Yorkshire, he had not been unmindful of his countrymen, and the foxes on his property had been well preserved. We drew a beautiful whin of his this day (in the North "gorse" is termerl "whin"), of ten acres, just then in its prime. After working at him for thirty-five minutes, a fine young fox was killed; and when the hounds had eaten him, and he had taken them a little turn to recover their wind, his Lordship put them into the whin again. Another fox went gallantly away over a very pretty country; but being so unfortunate as to change in one of Sir Bellingham's woods, where our hunted fox was headed, the fresh fox took a worse line, and went to ground in Tanfield Park. However, we had an hour and five minutes, and marked our fox ; so there was no reason to complain. I made an observation, that I never saw any hounds draw strong gorse as Lord J)arlington's did on this day, and indeed it was the same throughout the season. But it is their trade; they have searcely any other coverts to draw; and they are almost always sure of a fox-a grand security against slack drawing.

When the hounds were first thrown into Sir Jellingham's whin, I observed the Baronet getting rather fidgety at their not finding immediately-it being the first time any covert of his had been tried since his return to Yorkshire; and he afterwards told rne, that, if there had not been a brace of foxes in it, he should have instantly discharged his keepers; but, fortunately for thern, it held a leash.

It is somewhat remarkable that our second fox this day tried the earths under the kennel at Norton Conyers, which earths were constantly used when Sir Bellingham hunted the J3adsworth country, and kept his hounds in it during the summer months. 
On the day I have been speaking of, the hounds crossed the river Ure, in which a gentleman farmer was drowned two years ago whilst hunting with Lord Darlington's hounds, on the same day on which two other sportsmen lost their lives in a similar manner with other packs. The person I am alluding to was mounted on the tallest horse in the field, and was a good swimmer; so it is supposed his head turned giddy, and he fell off his horse, perhaps in a fit. We crossed this river another day when it was neither so deep nor so rapid, but, owing to being obliged to look at the water to avoid the large stones at the bottom of it, it made me very giddy. There are smelts and graylings in this stream, which is a very handsome one, though very injurious, by its extreme rapidity, to the country through which it passes. But Yorkshire is "a land of brooks of water, of fountains, and depths that spring out of valleys and hills;" and, to continue the simile, it might once have been said of it, that it was "a land wherein thou shalt eat bread without scarceness; thou shalt not lack anything in it; a land whose stones are iron, and out of whose hills thou mayest dig brass."

The Saturday previous to my meeting Lord Darlington's hounds at York Gate, rather a singular circumstance occurred. The pack divided, and at the end of half an hour, eleven couples of them ran in to their fox, with only two couple and a half of entered hounds among them, and the remainder of the pack killed theirs.

Wednesday, 15th.-Met Lord Darlington at Tanfield bridge, and had a very hard day for hounds, though never two fields out of covert. I had this day-not much in favour of sport with foxhounds-an opportunity of seeing the magnificent scenery of Hackfall, another pic-nic place, where there is the grandest waterfall in England. The morning was wasted in rattling these coverts, as well as those of Mr. Staveley, of Slemford, and all the field, except Lord Darlington, Sir Bellingham Graham, Hon. Captain Paulet, Mr. Wharton, Colonel Ellice, Mr. Anderson, myself, and the servants, were gone home. At half-past three o'clock, as Lord Darlington was getting his hounds out of covert, Sir Bellingham addressed him thus:- " Well, my Lord, I think it is time to go home, and your road is my road." - "My road," said his Lordship, "is through that wood;" pointing to Heslett Wood, two miles in nearly a 
contrary direction. To Heslett Wood we went, and away went a fox. Hounds never went faster than these did for twenty-five minutes, when they came to the first check. Sir Bellingham had sent his first horse home, and was upon a five-year-old, in little better than dealer's condition, so he prudently pulled up at the check; but as far as he did go he went well. "I shall melt his grease,"* said he to me. "That you certainly will," replied I; for he was then as white as a sheet. To make short of my story, we ran this fox-sometimes chasing, sometimes hunting, as the nature of the soil admitted-for one hour and twenty-two minutes, and the last twenty minutes in the dark, or we should certainly have tasted him. "We want the lamps lit," said I to his Lordship, as he was cramming his mare at a fence without knowing which side the ditch was, and without seeing a gate which I espied in the corner. "I think we do," said this veteran sportsman; but he disdained leaving his line for the gate. I saw the place afterwards, and it was an ugly drop into a turnpike road. Soon after this we stopped the hounds, just as they were getting into Snape Park.

I dined this day at Newton House, situated at the two hundred and twentieth mile-stone on the London and Glasgow road, close to the village of Londonderry, and in that part of the road known by the name of Leeming Lane. When first Lord Darlington inhabited it, it was upon quite a small scale, and abounded with inconveniences, which nothing but fox-hunting could have reconciled a Nobleman with his means to have put up with. In consequence, however, of an accident, occasioned by the falling of a stack of chimneys in a very tempestuous night, about five years back, it was razed to the ground and rebuilt by his Lordship on a very considerable scale. The kennel and stables are close to the house, and the whole is shut out from the road by a very high wall. The house possesses every convenience, as well as comfort, and is the most complete hunting box in England, perhaps in any other country; and here Lord Darlington says he spends the happiest days of the year. The stables and offices for the servants are quite perfect of their kind, as also is the kennel. This place, with a pretty estate

* "A burnt child dreads the fire." This has happened to Sir B. more than once. 
around it, abounding with pheasants and fox coverts, both most strictly preserved by her Ladyship, is the property of the Countess of Darlington.

It is not often that a wrinkle is to be given to masters of foxhounds, but the kennel at Newton House, I think, affords one. There is a passage leading from the feeding to the lodging room which is made to hold water, about six inches deep on the level. This, on hunting days, is filled with broth from the copper, and hounds pass through it in the evening, after they have been fed. The consequence is, they lick their feet dry; and the healing properties of a dog's tongue to a sore are very well established.

Perhaps I cannot do better than here give a brief account of the Earl of Darlington as a sportsman. To the title of sportsman who can have a better claim? It is as legitimate as his Earldom, and we must pay reverence to his name.

I have already said that Lord Darlington has kept fox-hounds, and has hunted them himself, for thirty-six years; and it is positively asserted that, unless prevented by illness-an unusual occurrence with him-or a call of the House of Lords on some important occasion, he has only been absent from them in the field three times in that number of years. Neither does he on this account-fond as he is of racing-ever attend the Newmarket October Meetings. A pleasing recreation, they say, is no task; but if proof were wanting of his extreme attention to his duty, it will be had in the first page of his book, called "Operations of the Raby Pack," published every year, in which it will ibe found that he goes through all the drudgery of cub-hunting-as the old song says"sleep and a downy bed scorning." As a specimen, I will transcribe the two first hunting days of the season before last.

"Wednesday, August 31st.-At seven o'clock, I tried Lady Wood, and only found one fox, and soon lost him. Found again in the whin, ran to the wood, and soon killed a cub bitch fox. Very hot dry morning. Had twelve couples of young hounds, eight couples of the two-year-olds, and ten and a half of the oldest hounds; in all thirty couples and a half. Rode Sir Harry ; Dick, Panegyric; Will, Ravenswood; and George, Bosphorus." Proh pudor! my Lord, to put a whipper-in upon Panegyric in such weather as this! 
“Thursday, September 1st.-At seven o'clock I tried Schoolhouse whin plantation blank; and then Henderson's, where I found a litter of cubs, and again found in Parnaby's, and in the kennel whin, but could not run one yard, nor catch a fox, from the extreme heat and blazing sun. Had fourteen couples and a half of young, sixteen couples and a half of the three, four, and five years old hounds out. Rode Sir Harry; Dick, Swing; Will, Obadiah; and George, Salopian."

In the same style-marking every occurrence of the day-often with much humour, but always with abundance of zeal, does this amusing record proceed, and upon no occasion-no, not after the merriest evening he ever passed-would his Lordship retire to rest until this task were executed. There is a precedent for everything. It was a sacred rule amongst a heathen nation, that they should every evening run over the actions and affairs of the day, and doubtless the practice turned to their account.

Lord Darlington's rank and fortune having placed him on the summit of human life, if money can contribute to the pleasures of the day, that one thing needful can never be wanting. It would not be much then to say of him, that, in point of expense and splendour of establishment in his kennels and stables, he stands first on the roll of masters of fox-hounds, keeping them upon their own resources. I should be inclined to say he did stand first; but perhaps his expenditure may be exceeded by that of the Quorn country.

Everything with Lord Darlington is managed with order and method. He has a weekly state of his coverts regularly brought to him-specifying what had been done to each covert, or the fences round it, and also what is required to be done; and some estimate may be made of the expense he is at in preserving foxes, by the single fact of his paying $340 l$. a-year to his own tenants in the Raby country for rent of coverts north of the river Tees.

Exclusively of advertising his fixtures in the several newspapers, Lord Darlington sends private cards to several of his Hunt, and he always fixes four days a-week, unless when he is obliged to attend the House of Lords, when they are reduced to three. In one respect his hounds have an advantage, and himself must also feel it. 
Both his kennels are in the centre of his Hunts, and therefore they have not long distances to covert.

Lord Darlington's hounds are divided into two packs--one called the young, and the other the old pack, although of course there are some old hounds in the former. His Lordship is fond of large hounds, and he has succeeded in breeding them quite to the top of the standard-bigger, indeed, on his own admission, than his country requires.* Their speed, however, with a scent is quite proportionate to their size, and when brought to hunting, fastidious must be the man who finds fault with them. On this point, then, I think I have said enough; but I am happy to be able to state the candid admission of their noble huntsman, that, to those very eminent breeders of foxhounds, Sir Richard Puleston and Mr. Ward, is he deeply indebted for that-essential to blood-steadiness on the line for which the Raby pack are at present conspicuous.

Pictures cannot be drawn without shades; and truth and impartiality require me to say, that I was given to understand steadiness on the line was not at one time the characteristic of the Raby pack. Their speed was undisputed; but a little more stoop and a little more patience under difficulties were wanting. That they are at this time the speediest hounds in England, it may be hard to determine; but I have heard Sir Bellingham Graham say they are the speediest he ever saw; and during the many times I hunted with them, I witnessed some as fine hunting as hounds can possibly shew.

Having spoken of the high standard of the Raby pack, I must be allowed to state that their size is as little detrimental to their symmetry as can possibly be expected, and they bear evident marks of being bred by a judicious hand. Large animals are never so perfect of their kind as smaller ones, which mainly accounts for the advantage bitches have in this respect over dog hounds; and in horses, where is the pony put into very high condition that we should not call handsome? and how scarce is this quality in a horse seventeen hands high! The Raby pack are not parted for the sex, and the kennel contains between seventy and eighty couples of working hounds.

* In countries so close as Yorkshire, hounds must occasionally meuse, when smaller hounds have the advantage. 
Lord Darlington is assisted in the field by three men-namely, two whippers-in, and the man who rides his Lordship's second horse. Their Christian names are Dick, Will, and George; but I can give the surname of Will only, having known him as Will Price when he lived with Colonel Berkeley. The last time I saw him previous to meeting him in Yorkshire was on the top of a Cheltenham coach, on his road to London-having left Colonel Berkeley's service-to hire himself to Lord Charles Somerset, to take some hounds to the Cape of Good Hope. Will, however, thought better of going among the black boors of that settlement, and went to whip in to Mr. Musters. From Mr. Musters he succeeded to his present place; and I consider him a very able man in the field.

Here Will furnishes me with an anecdote which must not be lost. Previous to his going to Mr. Musters, Will Price was supposed to be a single man, but whilst in Northamptonshire he had an increase to his establishment. This gave rise to the report of his being married; and when his old master the Colonel stumbled upon him, a word or two was exchanged on the subject. "So, Will," said Colonel B., "you are married I find? I should have thought you might have done without a wife."- "Lord bless you, Colonel," replied Will, "I am not married-she's only a woman I've got for the scason."

Saturday the 18th.- The fixture was at Newton House. I was housed there the night before, and Sir Bellingham Graham and his two sons came this day to breakfast, my friend Godfrey on his celebrated pony Barefoot-so named from lis likeness to the no less celebrated race-horse of that name-looking determined to go; and in truth this young Nimrod is very hard to beat. We had two very handsome finds from Lady Darlington's preserves, and one of the two foxes gave us a beantiful gallop of twenty-seven minutes, and a kill; we also killed the second. We had then a pretty twoand-twenty minutes in the evening, from Askew Moor, but whipped off as our fox crossed a river, and it was late. Lady Augusta Milbanke and Lady Arabella Vane (his Lordship's eldest and youngest daughters) were out, and a very numerous field of sportsmen besides. 
With our first fox we had some very severe fencing, and there were two very awkward falls. First, Mr. Fenton, who, although on a very good leaper, was landed on his head, on the headland of a fallow field, in no very enviable manner for a heavy weight like his. The fall, however, was a harmless one; but I attribute the disaster to this cause:- the Goddess of Hunting, like other old maids, is easily affronted, and when she knits her brow is of vindictive temper, sometimes requiring even human sacrifice. Mr. Fenton's costume was ill suited to her court: he was attired in white Russian-duck trowser's and Wellington boots, looking very unlike a fox-hunter in the end of November. As his cloth was black, he ought to have remembered the words of the text- "How camest thou hither not having the wedding garment?"

The other accident was of a more serious nature. The whipperin's (Dick's) horse fell with him at a fence, and came with all his weight on his rider's ribs and breast. He was conveyed home, and every care taken of him; but he was found to be seriously injured.

Sunday the 19th.-As Sir Bellingham and myself passed this day at Newton House, we had an opportunity of seeing some of the operations of the kennel. Contrary to the practice of many gentlemen-huntsmen, Lord Darlington feeds his own hounds, not only on hunting days, but upon all others during the season; and I was much pleased with the very business-like manner in which he set about it. Previous to quitting the house, he put a pair of calashes over his boots, and when he got to the kennel, the feeder presented him with a clean white (I scarcely know what to call it) frock, something like what the better order of butchers wear, which his Lordship put on over his coat. This reached down to his heels, completely preventing his other clothes being soiled; and when he pulled off that and his calashes on leaving the kennel, he was fit to walk into a drawing-room.

His Lordship was minutely particular in feeding the two packs; and, although the day was far from inviting, he walked out each pack for very near an hour, accompanied (with the exception of Sir B. and myself) only by his feeder. Were I to say I never saw a pack of fox-hounds looking better and brighter in their skins than 
Lord Darlington's, I might go a point too far, but their condition was very level, and I never saw a sounder pack of hounds in my life or one more full of bone.

During our walk out with the hounds, Lord Darlington related to us a singular anecdote of the instinct of a fox-hound. In his father's life-time, a hound called Gleaner was sent from Yorkshire to the then Duke of Bolton, of Hackwood Park, near Basingstoke in Hampshire; and in the almost incredible space of sixty hours he was back at his kennel in Yorkshire.

When we had done with the hounds, we devoted an hour to the stables, which, though not equal in space or magnificence to those at Raby, are in every respect sufficient, and hold about thirty hunters, besides coach horses. It is worthy of remark, that with the exception of a pony of the Countess's, I never saw a hack either here or at Raby. Everything goes a hunting, or in harness; but of the stud I shall speak hereafter. Three of the hunters were going off this day to London to the hammer, but we had a saddle put on one of them, and gave him a gallop in the grounds, which ended by Sir Bellingham purchasing him for his own stud. Lord D. made us laugh when he told us he sold that horse solely to oblige the ladies. "A better hunter," said his Lordship, "no man need ride; but he put his foot into a grip one day with my boy, and came down, which the Ladies attributed to his having only one eye."

Speaking of the Ladies, "Pray, my Lord," said I, as we were walking out with the hounds after feeding, " is not your kennel here very near to the house? Does not the savour of the boiler sometimes find its way into the drawing-room?"- "It may," replied his Lordship, "but we are all too well bred for fox-lunting to mind that."-At all events, " a concord of sweet sounds," must often titillate the Ladies' ears.

I cannot here let pass an anecdote of Dick the whipper-in, as it is so truly characteristic of the ruling passion, and also of the attachment men have to hounds when cradled in a kennel. It so happened that we were all-and a pretty large party-seated at the breakfast table, when Lord Darlington made his appearance. Next to the usual inquiries after his Lordship's health, the question was 


\section{NIMROD'S HUN'TING 'TOUR}

asked by two or three at once, "Have you heard how Dick is?""I have been to his bedside," said Lord D. ; " he has bad a restless night, nevertheless I hope he will do well; but he made me smile when he said he had no doubt but he should be able to go out with the hounds on Wednesday! He also inquired after Lightning's eyes, and how Rufus and Mortimer had fed?"

Monday the 20th.-Lord Darlington met at No-man's moor, about five miles from Newton House. Drew several plantations, and Mr. Scroope's whin; plenty of pheasants, but no fox. Found beautifully in Wylde Wood, the property of Mr. Wyvill, Member for York, and had thirty minutes to ground, very straight and very fast till just at the end, when the hounds divided, or we must have tasted him. There was a very large field this day, and amongst them his Grace of Leeds. Lord Darlington rode his famous grey horse Panegyric, purchased some years since of his Grace, and Mr. Milbanke went very well upon a horse once Mr. Maxse's.

As Sir Bellingham and myself were to return to Norton Conyers that afternoon, and we were then nearly twenty miles distant from it, we took leave of his Lordship as he was trying to bolt his fox, and made towards the place where our hacks were planted. On the road we passed through the village of Burniston, and here I saw a sign to a public-house quite new to me. It consisted of portraits at full length and in full costume of the four following personages:-a king, a soldier, a parson, and a farmer; and the house is yclept The Four Alls. Out of the mouth of His Majesty were the words, "I govern all ;" the soldier says, "I fight for all," the parson, "I pray for all," and the farmer finishes with "I pay for all." This reminds me of an inscription over the door of an inn which Lord Darlington informed me he saw at Pisa in Italy, and which he was kind enough to transcribe for me when at Raby. Its ingenuity consists in being written in four different languages, and yet the rhyme and metre so well preserved :-

\footnotetext{
" In questa Casa trouveràte, Tout ce qu'on peut souhaiter, Bonum vinum, pisces, carnes, Coaches, chaises, horses, harness."
}

For the benefit of those who only know one language, the following 
may be quoted as the English version of the entertainment and accommodation thus held out to travellers :-

\author{
In this house a man may find \\ All things suited to his mind : \\ Good wine-fish and flesh in courses, \\ Coaches, chaises, harness, horses.
}

Tuesday, November 21st, met the York and Ainsty at Pilmor, ten miles from Norton Conyers, a common situated between two very large coverts-a wild fox-hunting place, but not a November fixture. In the spring it must often afford runs. On this day our hounds divided and made bad work of it. I got off with the smaller lot; but seeing that nothing could be done, and that the fox was making back for the coverts, I trotted gently on the line. We again found, and had a hunting run through a horrible country composed of fields about two acres each, enclosed with strong black-thorn fences -nice chances for horses' legs! Fortunately for my horse he cast a shoe, and I went home; but rather a singular adventure occurred. I had ridden about two miles in quest of a blacksmith, when I met a person on foot (Mr. Dale of Creakhill). "I think I have got your shoe in my pocket," said he. "Did you not ride over the rails out of Pilmor with Mr. George Swann?" On telling him I did, he informed me my horse pulled off his shoe when he landed on the other side. Had it not come off a fall would have been the result.

On this day several Officers of the Fifth Dragoon Guards (quartered at York) were in the field. Their commanding officer, Colonel Wallace, a very hard rider, was at this time laid up from the effects of a bad fall with Lord Darlington's hounds, which had nearly cost him his life. His foot became fast in his stirrup, and he received several severe kicks from his horse before he could disengage himself from his perilous situation. One of his Captains, the Hon. . . . . . Kennedy, brother to the very sporting Nobleman of that name, is also a bruising rider, and I had seen him and one of the Subalterns (Mr. Brimer) on a visit to Sir Bellingham. $\mathrm{Mr}$. Brimer gave upwards of four hundred guineas for two of Mr. Petre's hunters at his sale, when he gave up the Badsworth hounds. Mr. Goodlake, another Sub of this regiment, and eldest son of the Champion of the Long-tails of that name, was also out 


\section{NIMROD'S HUN'TING TOUR}

this day on a horse he gave Mr. Harvey Combe a longish price for ; and on another day I met $\mathrm{Mr}$. Radcliffe of this regiment in the field, who is a member of Mr. Farquharson's Hunt, and a very pretty performer.

Wednesday, 22nd, met Lord Darlington at Tanfield Bridge, which crosses the river Eure, and had a beautiful find. The fox being asleep on the bank, and jumping up among the hounds, had hard work to get away. However, he only lived half an hour, the pack being close at his brush. This country requires notice. It goes by the name of Piccadilly, with the pleasant addition of Piccadilly with the pavement broken up. For stones, this eclipses all stony or flinty countries I have ever seen, and the worst part of Hampshire is a fool to it. Thank Heaven, however, it is of small extent, as it is surrounded by land of a different description. We found again and again-again and again-in all five foxes; some on Sir Bellingham's, and some on Mr. Staveley's land; but we could do no good, although one took us within half a mile of the town of Ripon.

Thursday, 23rd. Nothing to be done in the hunting way; so I got upon my hack and rode to Ripon, celebrated in the annals of England for its manufactory of spur-rowels; and hence a brave man is called a man of mettle-_" of steel as truc as Ripon rovels !"

Friday, 24th, met Lord Darlington at Butcherhouse Bar, on the great North road. The day was tempestuous, and we were intercepted by snow-storms; so the only thing worth notice was, we found two brace and a half of foxes, and killed a brace. We had ten minutes, I remember, awfully fast from Pickhill whin, one of the finest coverts I ever saw, but too near the rivers Swale and Wisk to produce any certainty of sport; though when hounds do run they must go fast in that country, as the land is rich, with a good deal of grass.

After hunting on this day, Sir Bellingham Graham and myself dined at Thorp Hall, the seat of Mr. Mark Milbanke, M.P. for Camelford.-I have given it as my opinion that the most complete hunting seat I ever saw is Newton House; and I think, if I were asked whether in my walk through life I had seen a more complete residence for a country gentleman of from six to ten thousand a-year than Thorp Hall, I should be inclined to say I had not. In fact, 
the principal drawing-room comes under the head of splendid; but it is the utile dulei, the happy admixture of convenience and comfort throughout the entire of the place, that struck me with admiration. There not only is not a room nor an office wanting, but every room and every office appears to be in its proper place. The stables also are most excellent; and as they remind me of the motto of "good entertainment for man and horse," I am sure it might be displayed on the banners of Thorp, for a more agreeable house no man can enter. You have all the elegances of life, without that overrefinement of them which only operates as their bane. It gives an insipidity to conversation, and may not be inaptly compared to a bad cork in a bottle of good wine. It spoils the flavour of everything.

The Poet says,

\footnotetext{
"'Tis not, indeed, my talent to engage In lofty trifles, or to swell my page With wind and noise ;"
}

and this is very good advice: nevertheless, having been indulged with a licence of now and then reporting some trifling occurrences in private life that meet my eye on my travels, I am induced to notice a singular feature in Mr. Milbanke's establishment: he never owes a bill, neither does he ever dran a cheque. By this he assured me he saves $500 l$. per annum, and I can easily credit the assertion.

Thorp Hall is only three miles from Newton House, consequently the intercourse between the families is almost daily. Mr. Milbanke is a strict preserver of foxes on the whole of his property in Lord Darlington's Hunt-which is very considerable-and yet he has abundance of pheasants. I consider Mr. Milbanke the best mounted man in Lord Darlington's Hunt, his horses being well bred, and more than equal to his weight; and when it came to pace, I thought his horses had the heels of all the rest.

Saturday, the 25th, met Lord Darlington at Exilby, a very short distance from Mr. Milbanke's house. The morning was wild and tempestuous, with frequent snow-storms, and the pack appeared at the covert's side without their huntsman. "He will come yet," said one of the Old School; "worse weather than this has never kept him away from his hounds." The fact was, his Lordship had 
a cold, and was far from well; but the prophetic words were scarcely out of his old friend's lips, than a grey horse was seen in the distance, which we soon perceived was old Panegyric with his master on his back. Nothing occurred worth booking; but we killed one fox in Low Park Wood, and after having tried it blank with one terrier, four foxes were bolted out of one of Mr. Milbanke's drains by another.

Sunday the 26th.-Sir Bellingham and myself quitted Thorp, and returned to Norton Conyers, travelling through deep snow.

Monday the 27 th was a hard frost. The next day a thaw commenced, though not sufficient to admit of hunting; and on Wednesday we were to have hunted with Lord Darlington; but as the fixture was at a distance, and the ground scarcely rideable, we met the Boroughbridge harriers instead. We had no scent, therefore no sport.

On the 30th, Sir Bellingham and myself returned to Thorp Hall, for the purpose of attending the Bedale Club, composed of the Members of the Raby Hunt. The Hon. Colonel Arden was the chairman of the day, and a very pleasant evening was the result. Sir Bellingham was just elected a member, and displayed the embroidered fox on his collar. Was anything wanting to prove Lord Darlington's staunchness to fox-hunting, and all the et-ceteras of it, his constant attendance at this Club every Thursday when his hounds are in the country would go a great way towards it. Some would consider it no small sacrifice to exchange a Nobleman's dinner-room for a half-furnished parlour at the Swan* at Bedale; but where fox-hunting requires it, it ceases to be a sacrifice with such a thorough-bred sportsman as he has shewn himself. It has occasionally happened that engagements have prevented the attendance of any of the members, and which circumstance his Lordship has been aware of: but even this has not prevented his own presence, taking with him some friend or friends that may be in his house.

\footnotetext{
* I mean no disparagement to this house, which is as good as any other to be met with in small towns. Bedale is situated a little to the left of the Great North Road, and not more than half an hour's drive from Newton House, or Thorp.
} 
The Bedale Club has been established six years. They find their own wines, and the funds amount to between four and five hundred pounds.

Friday, December 1st, met Lord Darlington at Bedale town-end. Found in the Rev. John Monson's whin, and had twenty-three minutes, with a kill, very quick indeed. Mr. Milbanke, Mr. George Sergeantson, and Sir Bellingham Graham, were conspicuous in the burst, out of a numerous field, and the fencing was frequent and awkward. Mr. Monson lost his hat, and consequently his place at starting, or no doubt he would have been with them, for he is a very excellent performer. In Lord Darlington's book of last year, his Lordship thus speaks of this gentleman: "I cannot omit to mention that the Rev. John Monson shone as conspicuously this day on his grey mare as in the pulpit, and was alone with the hounds over Ainderby mires at last near Thornhill's willow bed."

On Sunday, December 3rd, I left Northallerton, and proceeded towards Sedgefield, the headquarters of the Lambton Hunt.

Monday, December 4th.-The fixture for Mr. Lambton's hounds was Whitton, a few miles distant from Rushyford, but the turnpike road was as hard as Piccadilly pavement; so I did not send a horse to covert, and began to prepare to retrace my steps to Newton House. About mid-day, however, the wind changed, and symptoms appeared of what is called in Durham "fresh weather," alias rain. So much for the fickleness of English skies, for in three more hours the frost was almost gone!

It is natural to suppose that I was provided with an introduction to Mr. Ralph Lambton, and which he was previously in possession of ; but I did not intend making my appearance at the Club until after the first day's hunting; so, in pleasing anticipation of a good run on the morrow, I sat down to my dinner at six o'clock at Rushyford inn, and in half an hour after the door opened, and in walked three strangers. Two strangers, otherwise attired, might have alarmed my nerves; but the scarlet coats and mud-bespattered boots of these friendly intruders proclaimed them visitors of the right sort; and they came with a message from Mr. Lambton, expressing his regret that I had not been with his hounds in the morning, but hoping to see me at the Club at seven o'clock, their 
hour of dinner. The trio was composed of Mr. William Williamson (brother to Sir Hedwith); Mr. Harland, of Sutton Hall, Yorkshire; and a Derbyshire gentleman by the name of Hurt. They were kind enough also to express their regret that I had lost a great treat on that day; for having gone out at one o'clock into a low country, they had seen a beautiful run of thirty-five minutes, with a kill, and the riding not much amiss. Being on their road to Whitworth, the seat of Mr. Duncombe Shafto, where they were engaged to dinner, they took their leave with the assurance of shewing me a good day's sport on the morrow. This was a promising commencement of my visit to Durham, and a flattering reception in a land of strangers.

When I awoke the next morning, I found the ground so hard that there was no possibility of hunting, so took another nap. My slumbers, however, were light, being disturbed by dreams of frozen oceans, mountains of ice, and all the horrors of the Arctic regions; for I had never before been even thus far North, and I considered this was only the beginning of an inclement season.

The specimen I had in the three members of the Sedgefield Hunt brought me to the resolution of spending a few days at the Club, hunting or no hunting; so despatched my clothes, and followed upon iny hack. Encouraged by the sudden alteration of the weather the day before, I found the servants in their red coats and caps ready for a start, and several gentlemen booted and spurred; but all in vain. There was every appearance of a month's shut-up.

On my arrival at Sedgefield, I lost no time in paying my respects to the master of the hounds, whom I found-sportsman-like-taking up his abode in a small lodging, next door but one to the inn where the Club dined, and where he may be said to be near his work, as the kennel is also adjoining the inn yard. He accosted me with great kindness; assured me he would do all in his power to make my visit agreeable, and to induce me to repeat it another season, whilst he lamented the awkward prospect then before us.

Mr. Lambton's pack being one of very high character, it was natural that I should feel anxious for a sight of them, and in a very short time we were in the kennel. He was also good enough to say, that, although we could not hunt, he would take out the whole 



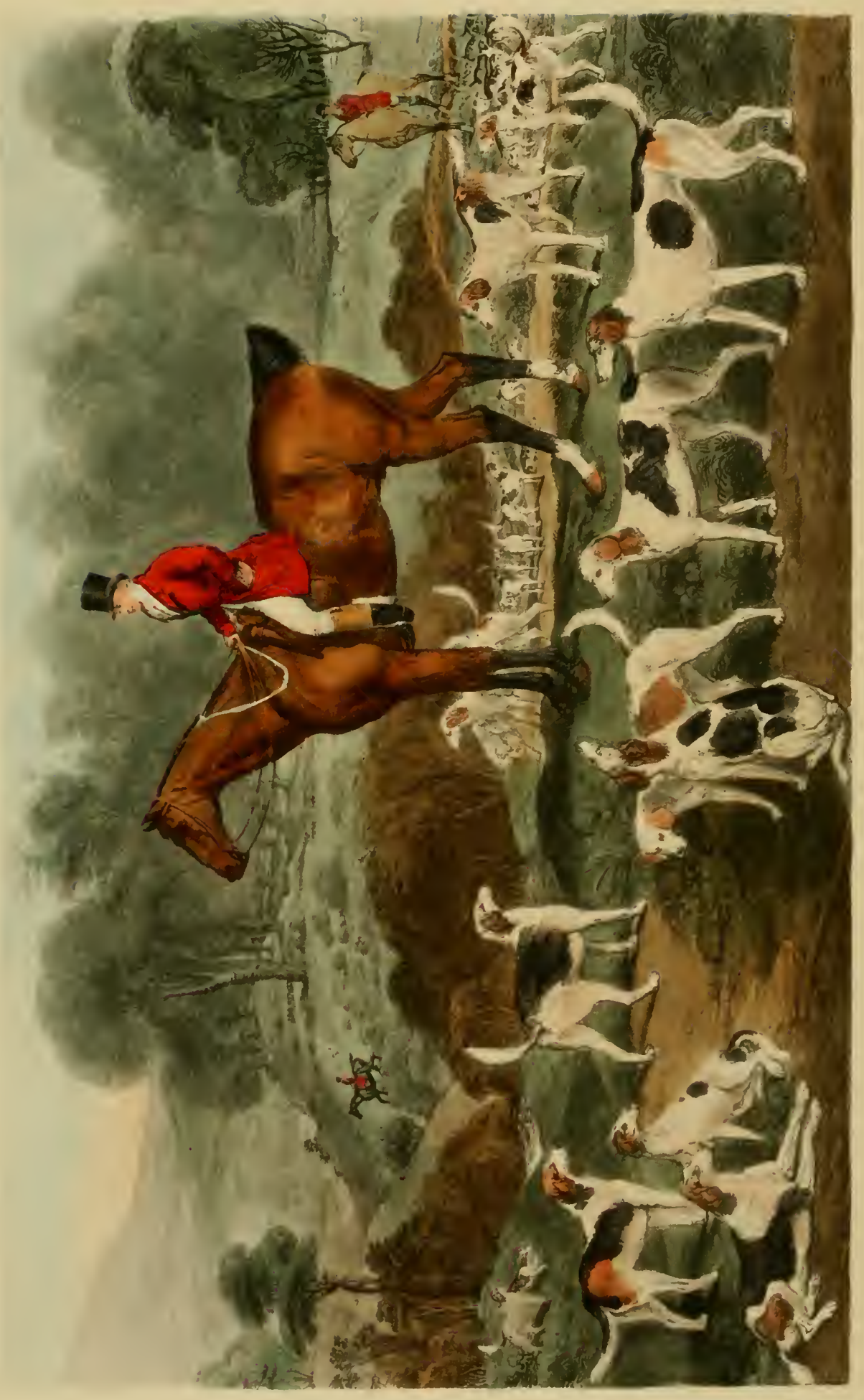




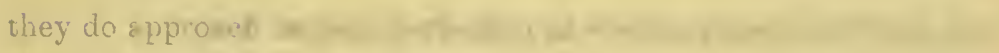

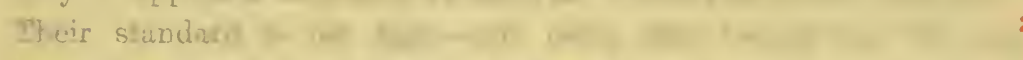

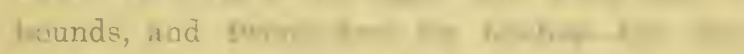

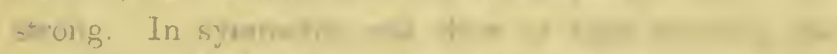

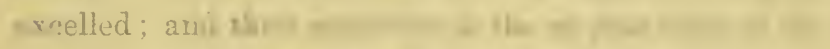

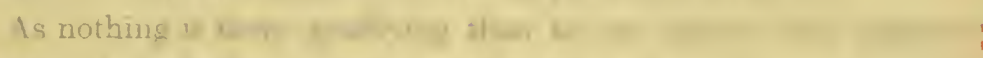

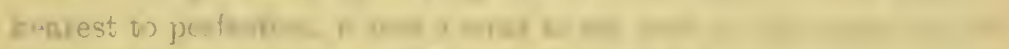

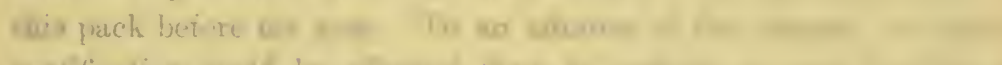

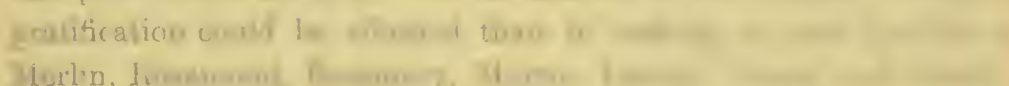

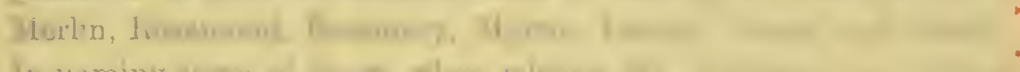

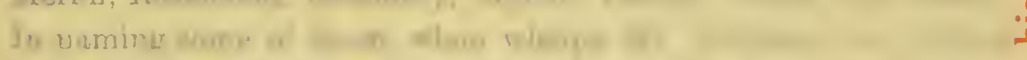

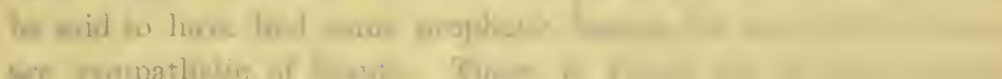

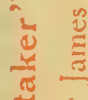

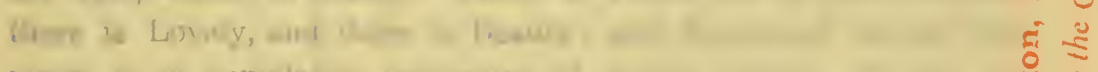

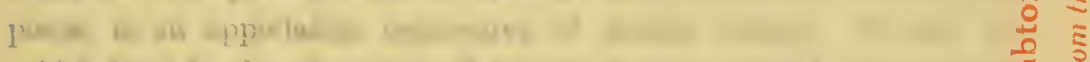

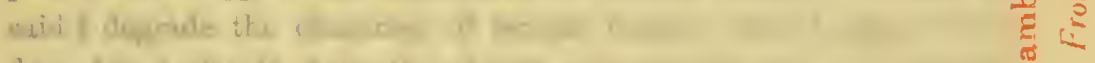

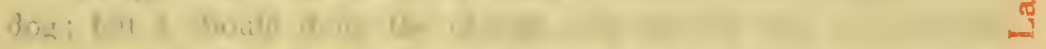

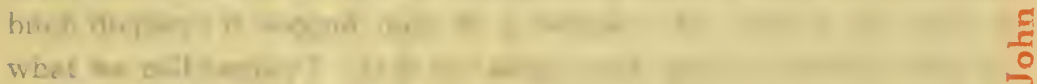

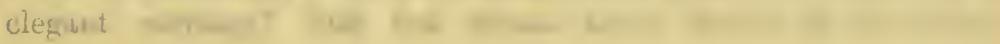




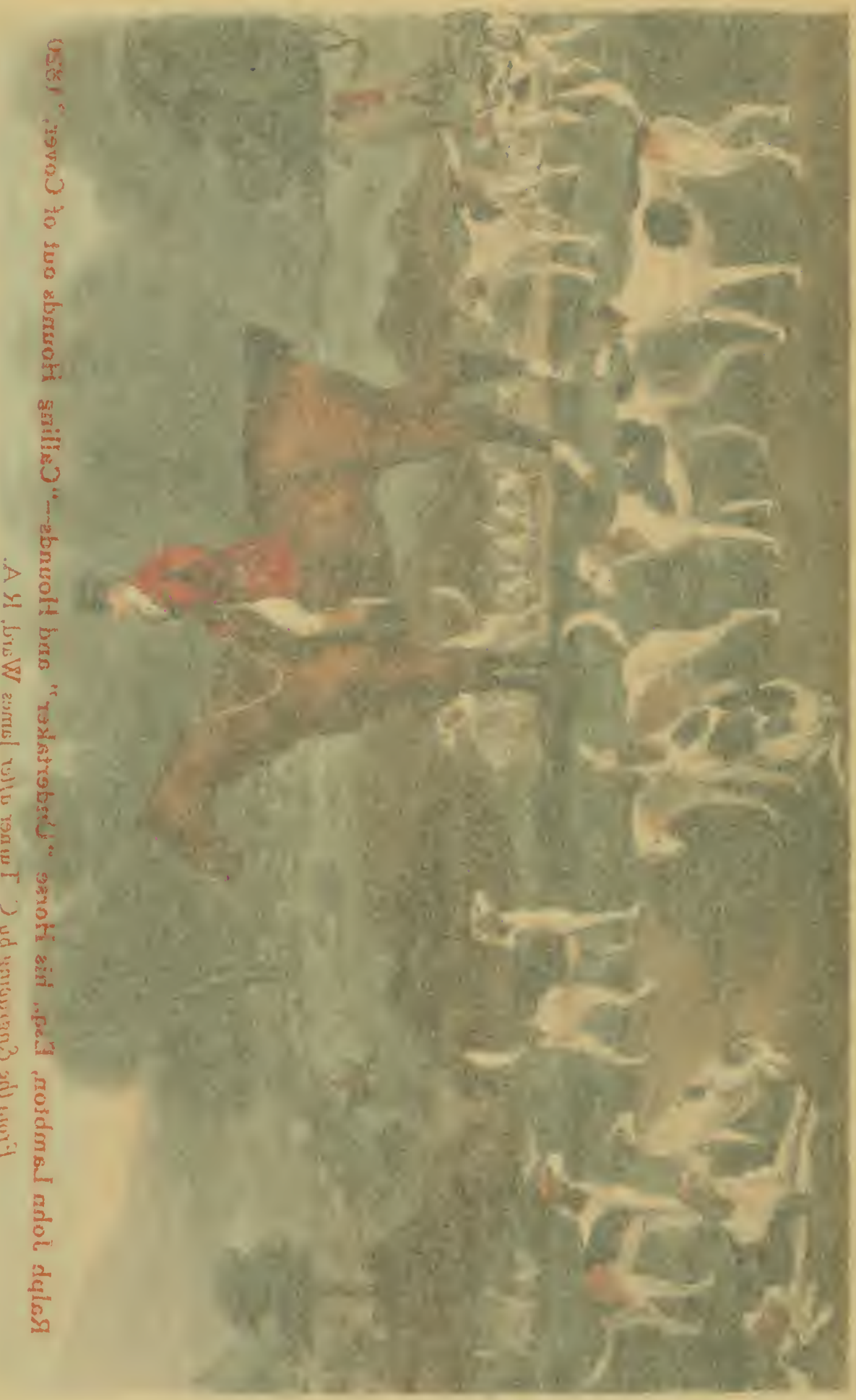


pack for exercise, and shew me some of his best country, of which, as far as my eye could carry me, and looking at it under such inauspicious circumstances, I formed a very favourable opinion.

These hounds have always gone by the name of the Lambton hounds, in consequence, I conclude, of a small subscription, amounting to somewhat about eight hundred pounds, which must go but a little way towards the expenses of so grand an establishment as I am justified in representing this to be. Mr. Lambton's kennel consists of about sixty couples of hounds; a very capital stud of hunters for himself and his men, of whom he has four out every day; and his fixtures are always four, and very often five days a week.

Of Mr. Lambton I shall say nothing at present; but of his pack I am called upon to declare, that although the Poet tells us,-

$$
\text { "so slow }
$$

The growth of what is excellent, so hard T' attain perfection in this nether world;"

they do approach as near perfection as we can expect anything here. Their standard is not high-not more than twenty-four for dog hounds, and twenty-two for bitches-but they are particularly strong. In symmetry and shew of high breeding they cannot be excelled; and their condition is the ne plus ultra of the art.

As nothing is more gratifying than to see objects that approach nearest to perfection, it was a treat to me even to ride upon ice with this pack before my eyes. To an admirer of the animal, no higher gratification could be afforded than in looking at such hounds as Merlin, Rosamond, Rosemary, Myrtle, Lovely, Venus, and Beauty. In naming some of them, when whelps, Mr. Lambton may almost be said to have had some prophetic feeling, for most of the names are sympathetic of beauty. There is Venus the goddess herself, there is Lovely, and there is Beauty; and Rosamond, among the poets, is an appellation expressive of female beauty. It may be said I degrade the character of female beauty when I apply it to a dog; but I should deny the charge, and answer that a fox-hound bitch displays it second only to a woman : for what is the basis of what we call beauty? Is it not shape and spirit, combined with an elegant carriage? Did not Eneas know Venus by her walk? 


\section{2}

\section{NIMROD'S HUN'TING TOUR}

Nothing can be more elegant than the gait of an English fox-hound when cast in a perfect mould.

Mr. Lambton chiefly breeds from his own blood; but where he has gone from home for crosses, he has shewn his judgment in selecting such hounds as the Duke of Beaufort's Lexicon, Lord Middleton's Denmark and Vanguard, Mr. Osbaldeston's Ralleywood and Palafox, the Cheshire Mandate, Lord Lonsdale's Wonder, Lord Darlington's Cruiser, and Mr. Ward's Jasper-the old New Forest blood, that scarcely ever fails.

In our ride this day Mr. Lambton took me to the house of a celebrated old sportsman in this part of the rrorld, and one of that respectable and once happy class of beings called English yeomen. Sir Walter Scott calls them

“England's peculiar and appropriate sons, Known in no other land;"

and John Burrell is as gcod a sample as the Poet could have found. For aught I know he might have had him in his eye when he wrote,

"Each boasts his hearth

And field, as free as the best lord his barony;

Owing subjection to no human vassalage

Save to their king and law ;"

for there was an air of honest independence about John Burrell that made a deep impression upon me: and when he went up to the Hon. Captain Dundas, shook him heartily by the hand, and, "in the full dialect of his nation," asked him how all his friends in Yorkshire were? I thought I saw something like a resurrection of old English manners. There was a warmth of feeling in his address and language so different to the cold-blooded greetings of the present day that was quite to my taste; and I was sorry to hear him decline the honour of dining at the Club, for I am sure I should have had a treat. Independent of waiting till seven o'clock for his dinner, Mr. Burrell told me he was got too old for such company -adding, with a strong emphasis, that he had a great regard for the gentlemen of the Hunt, who had been very kind to him.

Lovers feed upon hopes, and so at times do fox-hunters. We 
returned to Sedgefield, hoping the frost would not last long, but not without some unpleasant forebodings. Our party at the Club, in consequence of the weather, was small, but everything extremely comfortable and correct; and in the secretary (Mr. Benjamin Ord, well known in the school as Ben Ord, and very handy with his fists) I recognized an old Rugbeian, although he quitted half a year after I entered the school.

Wednesday, 6th.-The goddess of the morning appeared in a doubtful garb; not in her saffron-coloured robe-as the poets elegantly describe her-expanding with her rosy fingers the gates of light, and scattering the pearly dew; but with a complexion dark and lowering, suitable to the month of December, and surrounded by a dense fog. In the night there had been what we call in England a black frost; but the wind blew from a more genial point, and hopes were entertained of a change. About twelve o'clock drops fell from the roofs of the houses, and before two it rained.

The disappearance of the frost put us all in high spirits, and the rest of the morning was passed in the kennel, where I had the opportunity of seeing Mr. Lambton's first performance as a huntsman in the act of feeding his hounds. This he did (and he never neglects the duty) with the minutest attention; and his pains are requited, for his condition is perfect. He is here assisted by an excellent feeder, who has been many years in his kennel, and doubtless he contributes his share towards perfection.

In whatever capacity we view him, man is very much the product of his situation; and really, beyond a fox-hound or a boiler, this boiler of carrion does not appear to have a thought. I should have tried to have got a wrinkle from him, but he was so strong of the Durfam that I could scarcely comprehend two words he said. His hounds, however, are not so dull, for he has them in most excellent order: they fly from the troughs at the word of command; and well they may; for when he sings out "Wanton, Wanton! gang along, Wanton!" I am certain he might be heard at the distance of a mile on a still day.

Thursday, 7th.-We might have hunted this day; but as Mr. Lambton's earth-stoppers do not stop from the Newspapers, no 


\section{NIMROD'S HUN'IING 'TOUR}

earths were put to; so Mr. Williamson accompanied me to Rushyford to see my stud, and to help to kill the day. On the road thither, he shewed me something he thought would please. This was a very high timber fence, into the road, just newly covered with broken stones, which Bob, the whipper-in, had ridden over a few days before, merely to turn hounds. From the concussion produced, the horse was unable to keep his legs, and floundered on his head on the ground. Bob, however, stuck to him, hanging at one time only by his spurs; but he never ceased hallooing, "Get away, get away, get away, hounds!" whereas most people would have been thinking of being trepanned. His situation must have been an awful one, or it would have been thought lightly of by Mr. Williamson; for in all my days I never saw-indeed it is impossible to see-a more nerveless rider than the renowned Billy Williamson-I beg pardon, but in the Sedgefield country Mr. Williamson is known by no other name-of whom I must make more honourable mention hereafter.

Friday, 8th.-The Lambton hounds met at Butterwick, three miles from Sedgefield-a long draw, hounds very steady, but no fox. Fancied I was near some great game-preserver; or, what is worse, some vulpecide, and noted the same in my book, but said nothing. We found ourselves at last by the side of a beautiful whin called Greenside, and here we had a beautiful find. We had also something more: we had a good display of a correct ear and attention to hounds in Mr. Beckwith, a sportsman of great note, and also one of the has-beens over a country; but his great weight, added to being the wrong side of fifty, now stops him. This gentleman is likewise dubbed "Billy" among his familiars, and the name of Billy Beckwith is well known in the North. He resides at Trindon House, near Sedgefield, has a good estate in the county of Durham, and is one of the best shots going.

Our Greenside fox gave us a very sharp burst to Lord Howden's plantations, where we changed, and could not do much afterwards. Billy Williamson went, as usual, like a good one upon The Barber, who gave him two falls; but that is a trifle to a man resolved to get to hounds. A Dr. Trotter (M.D.) also, son of that distinguished sportsman, Mr. Trotter of Staindrop, near Raby, went in excellent form on a well-bred grey. We left off this day on the beautiful 
domain of Mr. Burdon, of Castle Eden, who many years represented the county. The scenery is beautiful, but too romantic for foxhunting.

I was much pleased by the sight of John Burrell in the field this morning. His riding days are over, as indeed are those of most other men at his advanced age; but he still likes the smack of the whip. I was happy in having an opportunity of conversing with him, and, as far as my recollection goes, the following is about the substance of our this day's discourse.

Nimrod.-This is a clever pack of hounds, Mr. Burrell.

John Burrell._You never saw such a pack before, and no doubt but you have seen a muckle.

Nimrod.-I have seen another fine pack which you know-Lord Darlington's.

John B.-Oh, he's a fine sportsman! and when he's at Raby I often gang to see him. I am very fond of his Lordship, and his Lordship is very fond of me. And my Lady! eh, what a horsewoman she is! but she don't gang so well as she did: I reckon her Ladyship gets a bit jolly.

Nimrod.--You have a fine country here, Mr. Burrell.

John B.-Aye! the country's well enough; but the parsons suck all the goodness out of it. It all goes to Durham.

Nimrod.-But, Mrr. Burrell, I am sorry to find the Marquis of Londonderry kills your foxes. I fear he will hurt your country worse than the parsons.

John B.-Indeed I am very angry with his Lordship, and I told my Lady so the other day. She can't bear the cry of dogs, she says. Oh fie! her father was as good a sportsman as ever followed a hound. What! Sir Harry Vane Tempest's daughter not bear the cry of dogs! Oh fie! But this comes of all your fine London work. It didn't use to be so. I am very angry at them: I don't think I shall ever gang to dine at Wynyard Park again. The last time I was there, they put me into a room that smoked like a lime-kiln; but I should not have minded that if they didn't kill the foxes.

Style, we are told, is the image of the mind; and here we see it displayed with the freedom and independence of an English yeoman, who, I hope, will never be afraid to speak his sentiments, and boldly 
too, in this land of liberty. Killing foxes, and thereby destroying the sport of a number of gentlemen, who incur great expenses with the expectation of enjoying it, is unworthy of any man aspiring to the character of an English gentleman.

I must not let John Burrell depart just yet. He has long afforded much amusement by that bluntness of expression for which, even in the presence of superiors, the old English character has ever been conspicuous, and I must give my readers one more specimen.

Lord Darlington's dog-language is particularly good. I think he finds his fox in a very superior manner, and some of his cheering halloos quite thrill the soul. In chase, however, he is a little lavish of the word Forward! which once called forth the criticism of his old friend John Burrell. The hounds were one day running very hard, and, it may be, a little too fast for the horses, his Lordship's among the rest. Honest John happened to be close to his Lordship, who was trying to catch them-at the same time singing out, "Forward, forward, forward!"- "What in the name of God! my Lord," exclaimed John, "are you hallooing forward for now surely arn't the dogs ganging a mile before us already?"

On another occasion Lord Darlington made a cast which did not please John. Sure enough the fox had not gone that road; and when, after the failure, his Lordship trotted back with his hounds to the line, John Burrell exclaimed, "That cast, my Lord, was perfectly ridiculous." Lord Darlington smiled; but to the honour of foxhunting be it said, that, had not John Burrell been a sportsman, the joke might not have gone down quite so well, as we must confess the language, though forcible, was homely.

Saturday, Dec. 9th.-The fixture was Bradbury Bridge, about half way between Sedgefield and Rushyford. We had no sport worth speaking of, which I regretted for more reasons than one. A very promising young sportsman, and an elegant horseman, had travelled night and day from Brasenose College, Oxford, to get in time for this fixture. This was Mr. John Shafto, second son of Mr. Duncombe Shafto, of Whitworth. He is one of the steadiest young ones I ever met with; and I pronounce him, even at this time, what an Irishman would term, an illigant rider to hounds.

Monday, 11th.-Met Mr. Lambton's hounds at Grimdon. Found 
in Charlton whin, of eighteen acres, and killed. I know nothing worthy of record on this day, unless it be that Billy Williamson charged an impracticable brook, which The Barber went gallantly at, and, falling backwards, reposed himself in it for about a quarter of an hour; but the next day afforded a day's sport worthy of a place in the annals of fox-hunting, which it gives me unfeigned pleasure to record; for, being obliged to leave the Sedgefield country on the following Thursday, I was afraid I should have quitted it without witnessing a good specimen of what this clever pack of hounds could accomplish.

The hounds met at Long Newton, twelve miles from Sedgefield, where a large field of well-mounted sportsmen were waiting their arrival. Being a favourite fixture, there had been a strong muster of Members on the preceding evening at the Club; and I know not why-for no oracle had been consulted—no favourable omen had appeared-no prophetic dream had been related-but the cheering words "we shall have a run to-morrow," proceeded from the lips of every one. "By the Lord, Nimrod," said Billy Williamson, "but your condition will be tried to-morrow, for we shall find a good fox in a deep country."

The morning was fine; and, as we rode to covert, I thought I saw more than a common degree of cheerfulness expressed in each man's countenance. As for myself-as I often do on this occasion-I felt a buoyancy of heart quite incompressible; and I might well have exclaimed,

"My bosom's lord sits lightly on his throne."

But who will say he does not at times feel some presage of the future? I cannot say so; I had rather yield to the extravagance of the Poet, and declare with him-

" $\mathrm{I}$ know not how it is ;

But a foreboding presses on my heart At times until I sicken.-I have heard, And from men learn'd, that before the tonch (The common coarser touch) of good or ill, That oftentimes a subtler sense informs Some spirits of the approach of "things to be."

I very much liked the country about Long Newton. It was dirty 
and deep, and looked like fox-hunting; the fields were large, with a fair share of grass. Contrary to expectation, we drew some very likely coverts without finding; at last a fox went gallantly away from Foxyhill. The first half hour was an arrant burst. Hounds could not well go faster, and the check was only momentary. One gentleman, a little over anxious, had got too forward on the line, but he was let off better than he would have been in some countries which I know. "Hold hard, Sir," said the Master ; "Venus has it under your horse's feet!"-_" Ah!" said I, "Venus is always kind to fox-hunters;" and away we went again. Wishing to make this part of my story short, at the end of rather better than fifty minutes, our fox crawled, dead beat, into Elstob whin,* where the hounds instantly changed to a fresh one. We ran this fox one hour and three minutes, and killed him in as fine style as ever a fox was killed; and out of upwards of one hundred horsemen who started from the covert's side, only fifteen were able to give any account of either hounds or fox-having been fairly run away from by the pack, and scattered in all directions about the country. As is always the case on these occasions, some ludicrous scenes were presented, and I shall avail myself of my licence to place one or two of them on paper.

The first half hour of this day gave the hounds a good chance to get well away with their fox, which we all know is greatly in favour of a handsome finish. We had a good deal of old grass, with roomy fields; and the fences, though not particularly large, were such as obliged us to take with caution, and of course stopped the speed of the horsemen. On the one side or the other of a great many of them, gorse was planted by the sides of the ditches, which rendered them so blind that we were obliged to walk our horses into the gorse, before they could rise at their leaps. The scent was also good-not perhaps what could be termed a burning one, but such as enabled a pack like this to hold on with their fox, with their heads

\footnotetext{
* Elstob whin afforded a capital day's sport to the Lambton hounds on the 19th of November, 1822. They killed their fox after a run of two hours and thirty-five minutes; when some were planted, many had enough, and none went better than the gallant Captain Healy on a bay mare, who rode best, to the admiration of all who lived with the hounds. This fox ran twenty-five miles of country.
} 
well up and their sterns well down. But to the following circumstance is to be attributed the scattering of the field, and the stoppage of the horses.-The space between all the checks- and there were only four in an hour and fifty minutes, and those very short oneswas very considerable; and the last, which did the greatest mischief, was full six miles, with the hounds going very best pace, and at every yard gaining on their fox. We killed him in a whin; and I shall never forget the pleasure I felt when I heard the pack at bay. "He's gone to ground," said Mr. Harland, who was making his way into the whin with Mr. John Shafto. "Not a bit of it," exclaimed I ; " they have killed him, by G-d !" and, putting my finger" to my ear, halloo'd "who-whoop" till my breath was gone.

If ever the condition of hounds was put to a strong test, and proved to be good, it was in this chase. I had the pleasure of seeing them run into their. fox, and for the last two miles they carried a head such as is seldom surpassed in a ten minutes' burst with a burning scent. Every hound was in his place, and if ever the stale simile of covering them with a sheet might be allowed to be applied, it may not be extravagant to do so here. I said it at the moment, and I repeat it now, that nothing could exceed the stoutness of these hounds on this day; and nothing but the excellence of their condition could have produced such a finish. They had been running over a severe and deep country, with a great deal of plough and a great deal of fencing, for two hours save seven minutes; but their powers were quite undiminished to the last: and I shall never forget the pace they ran, up hill, over a large field, which led to the whin in which they killed.

The latter part of this run was over as distressing a country for horses as I ever witnessed. The fields were large-several of them forty or fifty acres each-and ploughed, or in stubble. In the last half hour we had several of these to traverse obliquely, which greatly distressed the few horses that were then struggling to keep up, and they dropped off apace. My recollection affords me no instance of greater distress than was seen on this memorable day. Some men were leading their horses; others trying to urge them on in a walk; but all would not do: they were obliged to decline-for the fact is, the condition of the hounds was too good for that of the horses. 
It might be invidious in me to state who got to the end of this run, and who did not. The master of the pack, upon Beanstalk, went gallantly to the death, and it would be ungenerous to deny him his place. Ben Ord was also there ; Captain Beville, of the 95th, from Sunderland barracks, kept his place to the end. Billy Williamson went like a good one for the first half hour, when his mare broke down, and we lost him. He will excuse me for expressing a doubt whether, if this had not happened, he would have got to the end of this run. I think it was beyond the period which nature, however good, could resist crying " enough" with his style of riding; for, as a Durham farmer says of him, " Nought but an iron horse can carry him along." There was a gentleman-farmer also on a grey mare that I thought would "call out for mamma," if he continued cramming her along at the pace he was going. I cheered him at the second check, and told him she was a good one; but she was not good enough for this day, and was not to be seen at the end.

There was a hard-riding young one-Mr. Hurt, from Derbyshirewho tried his best to see this fox killed, but all would not do. Although I offered him assistance towards the latter end, I rather enjoyed seeing him reduced to a walk, as he had been very impatient to see, what he called, a run, and seemed rather to doubt whether the country could produce one. If, however, he was not satisfied with this day's sport, I am sure his brown mare was, and I fear she was not worth much afterwards. This is the worst part of the story: such a run as this is certain to produce suffering amongst horseschiefly, however, because people will ride them when they are not fit to go-and I am sorry to say several did not recover the effects of this tickler. Captain Dundas' horse died, which I very much regretted, as he had ridden gallantly through the chase, and several more were at death's door.

I do not recollect that I ever asked for a brush in my life; but on this occasion-so far from home-I wished to possess some attribute of victory; so requested a pad of this gallant fox. I have had it put into a small glass case, with the following inscription on the outside :-

"This fox jumped up on the 12th of December, 1826, in Elstob whin, before Mr. Ralph Lambton's hounds, just on the line of their 
hunted fox, which they had been running hard for fifty minutes, and was then dead beat. He was killed at the end of a splendid chase of one hour-in which the powers and condition of this beautiful pack were displayed to the admiration of the few who lived with them to the last; and which will long be remembered in the county of Durham as a proof of what a victory can be achieved by fox-hounds, with a good fox before them, over the best horses and the best riders in the country."

Some ludicrous scenes occurred in this run; and as, after all, life is but an entertainment, and we all act some part in the play, I am quite certain that Mr. John Davison, of Chester-le-street-one of the best-tempered men in the world, and a member of the Lambton Hunt -will have no objection to being brought on the stage, and add his mite to the amusement of the audience.

It so happened, that on this day Mr. Davison sent to covert a very clever bay horse ; aud, on my making a remark on him to one of his friends, he told me he believed he was for sale, and might be purchased well worth the money. When I saw him again, with Mr. Davison on his back, I liked him better, and asked his price. The answer was, "Two hundred and fifty guineas!" Now, although we are told " money makes the mare to go," it has not always that effect upon a horse; for Mr. Davison came to a standstill, in spite of my more than once calling him, "Come along, two hundred and fifty guineas!" This, however, was nothing, for he had plenty of company ; but I heard afterwards, that about half an hour before the fox was killed the two-hundred-and-fifty-guinea-horse reposed himself on the ground in no very pleasing attitude-his affrighted master standing over him, with his hands clasped, and in an audible voice emphatically exclaiming, "By G-d, he's dead!!" I am happy to say, however, Death did not claim him this time, but only gave $\mathrm{Mr}$. Davison a hint not to bring so nice a horse into the field again, so totally unfit to go through a severe run with hounds; and I hope this hint may not be lost upon others.

Not having been quite up to the mark, I was very much fatigued with this run, and no wonder. We had been galloping over a deep and severe country for two hours all but a few minutes; and I should think we had been over at least two hundred fences. The con- 
sequence was, when I got back to Sedgefield, I went to bed, and here I had an unexpected pleasure. I fell asleep, and dreamed a dream. I saw in my vision - not heaps of gold, not beautiful women, but-Mr. Lambton's hounds running over the country as I had seen them in the morning. I saw Billy Williamson going at a pace that nothing but the blood of Medusa could maintain. I cannot say,

"Methought I heard a voice

Sweet as the shepherd's pipe upon the mountains, When all his little flock's at feed before him ;"

but I could have sworn I heard the whipper-in Bob's "Get away, get away, hounds," quite as plain and in the varmint tone I had heard it in the run. If I could use a pencil, I could sketch Captain Dundas as my fancy painted him-and as he had also been seen in the morning-landing from the top of a steep bank, with his horse on his head, his coat flying up, and his white cords in full view. I'll be bound to say, if any one had been near me, he would have heard me singing out-

$$
\text { "He is off ; no, he's on ; he hangs by the mane." }
$$

I saw Mr. Lambton on Beanstalk, and John Shafto on the little bay horse; but I did not see Mr. Davison's horse on his back, and his master lamenting over him, like Eneas in the storm-("Duplices tendens ad sidera palmas, talia voce refert," by G-d he's dead !). The drowsy god permitted nothing to disturb the pleasant workings of my fancy; so I did not dream of my brother sportsmen in distress, nor of the Derbyshire youth who thought Durham could not shew a run, but whose brown mare thought otherwise; but I was treated with a sight of Rosamond and Rosemary, "the Captain Jewels of the Cankanet," running into their fox, with their sterns down and bristles up, putting me in mind of the dogs of war. What I should have seen next, I know not; for a rap at my door to say it was time to dress myself for dinner awoke me from my sleep, and away went those agreeable ideas which Fancy was at that time entertaining me with, and in half an hour after I was in the Club room.

Pearls in dreams betoken tears, at least so old women have it-

"There is some ill a-brewing towards my rest, For I did dream of money bags to-night." 
However, as my fancy directed me to nothing of the sort, but had merely amused itself with the events of the day, rather might I have exclaimed with the Poet,

"If I may trust the flattering eye of sleep, My dreams presage some joyful news at hand."

And truly this was the case. I passed the evening of this day in a manner I shall not only never forget, but in a manner that more than ever stamped on my mind the solid advantages of fox-hunting. The whole party seemed to possess but one soul. The master of the hounds was transported with delight, pleasure beamed in his eye, and the bottle went round best pace to a very late hour. In short, it was a day of rare festivity, and worth an age of common existence.

When I entered the Club-room at seven o'clock, the whole party, with the exception of Mr. Lambton, were assembled, awaiting the announcement of dinner, and I think I counted sixteen. When he arrived, a most entertaining scene occurred. This was, the excuse each man made for not going to the end of the run; and, if my recollection serves, only five of the party had that pleasure. Their answers to $\mathrm{Mr}$. Lambton, who catechised them separately, gave rise to much merriment; and when $\mathrm{Mr}$. Beckwith told us that he was thrown out in consequence of meeting the fox, a roar of laughter succeeded-that being in the first place a very stale excuse, and in the second, a very bad one for so old and so good a sportsman as the well-known Billy Beckwith. There was only one lost shoc, and that I can vouch for, as having saved the credit of that staunch foxhunter, Mr. Surtees of Mainsforth. This gentleman keeps up the style of old English hospitality and the good customs of our forefather's. He invites Mr. Lambton, his hounds, his servants, his hor'ses, and his friends, with their servants and horses, to his house for one fortnight every season, where he entertains them with everything of the best; and I was very sorry it was not in my power to accept of his kind invitation at the ensuing anniversary of this jovial meeting. Refuse it I could not; for his commands were issued in the Medean style:-_You must come," said he, "I shall take no excuse."

I have not yet done with descanting on the effects of this fine day's 
sport and truly jovial night. There was a young gentleman of the party who had observed a remarkable taciturnity during the whole week. Nay, more than that, he had dozed away his evenings as if careless or unconscious of the passing scene. "He is in love," said I. I was told he was not. "He is plethoric, and should be cupped." -." Not a bit of it," said his friend; " he is as good a fellow as ever cracked a bottle." - " I clo not doubt it," was my reply; "but I should like to hear him throw his tongue a little." The proceedings of this day had the wished-for effect. Like a butterfly in the sunshine, he was all alive; he never once dozed in his chair; he told us several excellent anecdotes, and sang two capital songs.

Although on this evening we dedicated a vigil to the jolly god, drinking is not the characteristic of the Sedgefield Club; for by one of its rules the landlord forfeits a bottle of wine if he neglects to bring in the bill in three hours after dinner is served; and it was only broken through on this occasion, being an extraordinary one.

The undress uniform of the Sedgefield Club is a plain scarlet coat, with collar of the same, and white buttons. The dress uniform is a black coat, black velvet collar, gilt buttons, with a plain raised border, and a fox and the letter L embossed; a white upper waistcoat, with an under-one of scarlet satin, silk, or cloth. The two following rules of this Club are deserving of notice :-

Rule 16. "That any Member breaking a gap into, or riding into, through, or over any covert, after it shall be properly enclosed, be fined one guinea."

Rule 17. "That if, during the continuance of the Sedgefield Meeting, any gentleman of the Lambton Hunt, or any visitor, shall trespass, either by shooting or coursing on any manors or estates in the neighbourhood, without the consent of the proprietors in writing, he shall be fined twenty guineas, upon complaint being made by the proprietors."

There was but one take-off from the pleasure and comfort of the Sedgefield Club, and that was the lateness of the dinner hour (seven o'clock) on non-hunting days. Men who hunt four or five days a week ought to retire early to rest, which is not in their power if they do not get up from the dinner table till near eleven o'clock, which must be the case here. 
Like Lord Darlington, Mr. Lambton is a strong supporter of the Sedgefield Club, as, during the meeting, he never accepts an invitation to dinner from any of the neighbouring gentlemen. Sedgefield is a small town, situate five miles to the right of the great Edinburgh road, distant from Durham eleven, and from Stockton-on-Tees ten miles. It is noted by the celebrated Dr. Askew for the salubrity of its air; the land about it is sound and productive; and I saw a good specimen of modern farming by the Rector of the parish, the Honourable and Reverend the Viscount Barrington.

The Lion of the place is Hardwicke Hall, the seat of Mr. Russell, of sporting celebrity, the park of which adjoins the town. Hardwicke Hall with its domain, however, is only, as I understand, i cottage in a paddock when compared with Mr. Russell's other seat, near Durham, called Brancepeth Castle. Mr. R. was not in the country when I was at Sedgefield.

I must not quit the Sedgefield Club without notice of a song (among several other's) which was sung in most excellent style by our chairman, Mr. Sutton, of Elton near Stockton-on-Tees, on the memorable evening I have been describing. It is called Sir Charles Turner's celebrated hunting song, of "Old Cesar, or sixty years since;" and is somewhat of a parody on the well-known Irish Killruddery Fox-chase, so well described in song, and set to the same music-

Attend jolly sportsmen, I'll sing you a song

Which cannot fail pleasing the old and the young;

I'll sing of a famous old fox and his wiles,

Which led us a chase of at least fifty miles.

I'll tell you a tale of such men and such hounds,

With what courage they'd hie over all sorts of grounds;

See hounds vie with hounds, and how men with men strive,

Old Draper* might rue that he were not alive;

At Hurworth famed village, as soon as 'twas l ght,

We feasted our eyes with a ravishing sight!

Each sportsman had pleasure and joy in his face,

Their horses and hounds were all ripe for the chase.

But first the Commander-in.Chief let me name,

The Lord of Kirkleatham, of true honest fame,

A friend to good men, but profestly a foe

To villains with four legs as well as with two.

* A celebrated old sportsman in the North Riding of York. 
We had not tried long, before Rafter gave mouthEsteem'd by the pack as the standard of truth ; They quickly flew to him, and instant declare That Rafter was right, "for a Fox had been there." And trust me he prored a notorious blade, His name was Old Casar, and plunder his trade. His name-sake, in all the great battles he won, Spilt less blood by gallons than this rogue had done.

Unkenmel'd at Aingholme, he led us a round, In which we might run about four miles of ground; Then back to the earths, but the stoppers took care To baulk lim from making his quarters good there; Disdaining such treatment, he flourished his brush, And seem'd to say-Sportsmen, I care not a rush ; I'll give you a proof of such stoutness and speed,

That old Nimrod himself would have honour'd my breed.

Through Hornby and Smeaton he now bent his way, Resolved to make this a remarkable day ;

He then wheel'd to the left, to the banks of the Tees, But there he could find neither shelter nor ease;

So finding with what sort of hounds he'd to deal, And that his pursuers were true men of steel, He push'd to gain shelter in great Crathorne wood, With the hounds at his brush, and all eager for blood.

Now the field, all alive, how they smoked him along! So joyous the mnsic, each note was a song, And all was good humour, and spirit, and joy, Though strong emulation enliven'd each eye. Next passing by Marton, and Ormsby great hall, He seem'd to say-Little I value you all:

For many a stout horse was now slack'ning his speed, And to see them tail off was diverting indeed.

Then not to be thought a contemptible fox, He dared them to follow o'er Cleveland high rocks. But th' ascent was so steep, and so painfully won, That few gained the top before he was far gone. To Kirkleatham Hall he next bent his career, Hard press'd by the owner to end his life there, Assuring him he and his friends would not fail All possible honours to render his tail. 
Now no one but Turner being left in the field, And finding old Cesar unwilling to yield, At Kilton thonght proper to finish the strife, So called off the pack, to give Casar his life. But Firetail and Bonny-Lass would have a meal, (Whose hearts were of oak, and whose limbs were of steel,) So they soon ran him up to his friend at the mill, Where, triumphant, they seized him and feasted their fill.

Then, just like attraction 'twixt needle aud pole, We were seated that evening at Kirkleatham Hall, Where the bottles of red and the fox-hnnter's bowl Not only enliven'd, but cherished the soul. Oh, long may our host still continue to grace His mansion, the country, and likewise the chase : And as long as Old Time shall be govern'd by clocks, May Turner preside o'er the brush of the fox !

We rarely see or hear a good hunting song; but I think the one I have transcribed a very fair sample, and appeared to me still fairer at the time, from the excellent effect given to it by the animating style in which Mr. Sutton sang it, as well as several others with which he favoured us in the course of this convivial evening.

Everything connected with fox-hunting is conducted upon a very liberal scale by Mr. Lambton. His stud of hunters is not only efficient, but contains several very superior horses for his men, as well as for himself, and the greater part of them are well-bred. Having five out every day, of course he has a large stud; but they were not all at Sedgefield when I was there, as some of them are sent over to his seat at Merton, to be changed for fresh ones, as occasion requires. Being a single man, however, with a good fortune, all these requisites are within this gentleman's reach, and I only do him justice when I say that he does the thing well.

With respect to his hounds, I cannot help once more saying that they are extremely perfect and extremely good. They are beautifully formed, and of a right size for enduring fatigue. There are limits in the operations of nature, as well as in those of art. A long beam breaks by its own weight; neither have large animals often strength in proportion to their size; and of this hint $\mathrm{Mr}$. Lambton availed himself. I have nothing particular to notice in the kennel or stables of Sedgefield. They are quite sufficient for the purpose, and it must 


\section{உ78 NIMROD'S HUN'TING 'TOUR}

be remembered that the hounds and hor'ses are only here at certain periods of the season.

I am unable to say anything respecting Mr. Lambton's home country, not having seen it; but I was given to understand it is bad. By all accounts, it is a more desirable country to have property in than to ride over, as it abounds with an article called "the black diamond," for the large possession of which this family is conspicuous, and consequently it abounds with coal pits." These things do not in the least contribute to the picturesque; but when black is made black and white, it forms a pretty feature in the banker's book.

Had it not been for the long-continued frost, I should have been able to have given a better account of this part of the county of Durham, as I was engaged to have spent some time at Merton, and to have gone thence to Mr. Surtees's hospitable mansion. I was given to understand that I had a double loss here. At the former place I should have seen all the elegances of modern life; at the latter, the old-fashioned hospitality, now become scarce, of the old English country gentleman. This, to its full extent, is rery nearly lost, and all within my recollection. But, as the Poet says,

"The town has tinged the country, and the stain Appears a spot npon a vestal's robe, The worse for what it soils."

I should not think there are many sportsmen who have not seen t he print of Mr. Ralph Lambton and his hounds, from a painting of Ward. He is represented in the act of getting together his hounds in a covert, and is mounted on a farourite hunter, called Undertaker, which he rode several seasons. Although I expected to find a heavier man-Mr. L.'s weight on horseback not exceeding twelve stone-I was struck with the correctness of the portrait as soon as I

* In a cold country like England there is certainly a great advantage in a plentifnl supply of coals, althongh the saring to the consumers is not what might be expected, owing to the profuse expenditure of them in the honses. The grates in Durham are of an immense size, and not only are they filled on all occasions in the winter, but there is always a hoard behind them, ready to supply the place of those which are burning. The first evening that I went into my bedroom at Sedgefield, I asked the chambermaid what joint of meat was going to be roasted at the fire; for there were more coals on it than would be seen in a Hampshire kitchen. 
saw the original-particularly as regards his seat on his saddle. $\mathrm{He}$ is a good horseman and rides well up to his hounds. Undertaker was a most superior hunter. He was got by St. George out of a Trinculo mare, and Mr. L. had also another very clever hunter out of the same mare, got by Atlas. They were both bred by a medical gentleman of the immortal name of Nelson.

Few people follow a pack of fox-hounds regularly for any length of time without meeting with some serious accidents, the marks of which many of them carry to the grave. I am sorry to have to record a most serious one that befell $\mathrm{Mr}$. Lambton three years ago, which very nearly cost him his life. He rode at a fence in chase, and his horse falling, he was pitched upon his head, and taken up lifeless. Paralysis was the consequence of the injury, and for a long time he was considered to be in imminent danger. Having a good constitution he gradually recovered; but most unluckily the year afterwards he got another fall, which was worse in its consequences than the first. He was riding a very old hack from his home kennel to his house at Merton, a distance of about three miles, when he fell with him, and he was again pitched upon his head. I am, however, happy to say that he is now once more in very good health, although at times he suffers from the injuries his frame received, and his head and neck are a little distorted from their natural position; but I have great pleasure in adding, his spirits are as good as ever, and he seemed to stand his work well.

It is said by a writer, whose celebrity perhaps does no great honour to the feelings of human nature, that, let a man die amidst ever so many lamentations and regrets, if he conld rise again from the dead, after a lapse of a few years, his re-appearance on earth would not be found to be productive of unmingled satisfaction among his friends who wept over his closing grave. As this experiment has never been tried, all we can do is, in charity, to doubt the fact: but I think I can assert, that few men in England in private life would have been more sincerely or longer regretted than Mr. Ralph Lambton, had this accident been fatal to him; neither do I think the resurrection of such members of society would ever be deemed unseasonable: for, if weighed in the scale in which I balance the qualities of mankind, he would be found to be thumping 
weight. I was, indeed, given to understand by all who spoke of him, that I should find him everything that a man ought to be; but as Pliny says of a contemporary of his, I found him "superior" to all that was reported of him."* To the ardour of the sportsman, he adds the high polish of a gentlemain; and he has distinguished himself for-perhaps one of our rarest virtues-sincerity in his friendships. In all probability I may never see him again; but I rejoice in the opportunity of declaring that I shall cherish for him the greatest respect. I venerate his judgment as a sportsman; I consider him an honour to fox-hunting; I esteem him as a man; and I hold him up as a pattern of an Enghish gentleman, in the truc acceptation of that word. I can only add in the words of the Bard,

\section{"May he live \\ Longer than I have time to tell his years!"}

It was said of Shakspeare, that he was not to be tried by any code of critic laws; as much as to say, such a genius as his could " rise to faults critics dare not mend." How then can I presume to pass my feeble judgment on Mr. Ralph Lambton as a huntsman to fox-hounds, knowing, as I do, that his pack is one of the very highest character, and that he has always hunted them himself. Wisdom, says the proverb, is the produce of experience; and if such men as himself and Lord Darlington have not learned their trade, this maxim does not hold good, for they have served exactly five apprenticeships to the art. It must also be remembered, that the prowess of a huntsman is not confined to the operations of the field. A skilful General is as great in council as he is in action ; and unless a huntsman be clever in his kennel, he does but half what is required of him. He may have sport, for that is often the consequence of fortuitous circumstances-such as country, \&c.and he may kill his foxes; but he never will have a really good and steady pack of fox-hounds. Combining, however, the duties of the kennel and the field, I am bound to give Mr. Ralph Lambton

* In this able letter of Pliny to Nepos, he mentions the fact of a man travelling from Cadiz to Rome to see the celebrated historian Livy, and, after satisfying his curiosity, returning home. I only speak my feelings when I declare, that from the character I had heard of Mr. Ralph Lambton, I would have followed the example of the enterprising Spaniard. 
the credit of being premier artiste in this line, and in the first class of English huntsmen now going. In some respects he is not exactly a Jack Muster's neither his voice nor his language to his hounds is so good and so cheering; indeed now and then I heard a halloo peculiar to himself; but he is very decisive in his casts, the result of a very quick eye; and his men assist him to admiration, being always in their places. Jack Winter, first whipper-in, and huntsman in his master's absence, is a very good man with hounds, and has been with Mr. Lambton ever since he was a boy; and Bob Fenwick, with his "Get away, get away, hounds!" quite a tip-top hand, and devotedly attached to the sport. There is also a lad, as second whip, an excellent horseman, and will do well by-and-by. Mr. Lambton's man Harry, who rides his second hor'se, is likewise of great use at certain times; so that, in a country where hounds are seldom ont of sight, it would be somewhat odd if they were not tolerably steady.

Foxes are beautifully found by these hounds. Mr. Lambton himself excels here: in drawing up to them he displays a master's hand, and when on foot they are capitally halloo'd away by the men. Previously to this, great order is observed by the field, who, indeed, set an example I wish we could see more generally followed. They all assemble, sportsmanlike, in one spot, and give the fox a chance to $\mathrm{fly}_{\mathrm{y}}$, instead of heading him at all points, the common practice of many countries. Perhaps, this may here proceed from two causes:- first, they have a ligh respect for the commander-inchief ; and secondly, there are a great many sportsmen in this Hunt who really wish to see a run.

Few tempers are proof against riot, whether it proceed from hounds or men, in the act of trying to kill a fox; and although Mr. Lambton's temper at other times is particularly placid, and although I had no opportunity of seeing it tried, yet I was given to understand that he can "serve it out" to them when occasion requires; and upon my word I really think the man who cannot has no business to hunt fox-hounds in these days. He would be something like the Captain of the man of war who made an attempt to command his crew without swearing, and told the sailor to put out the light. Jack did not obey the order; but the moment he heard the 


\section{$\because 8:-\quad$ NIMROD'S HUN'TING 'TOUR}

boatswain call out " $d-n$ your eyes, dowse the glim," the light was out in an instant. Mr. Lambton, however, does not swear, but gives them something a little piquant.

Mr. Lambton rides very clever horses, and gets well over a country, particularly so for his age; for although Time has laid lis hand gently upon him, a few more years will bring him towards the grand climacteric, and this slackens the pace of the best of men.

It has been contended that servants, as huntsmen, must always excel gentlemen hunting their own hounds; but why should this be? If hunting hounds be a science (and who will dispute that point?), why should not the education and theory of the gentleman, when combined with his professional practice, give him the superiority, instead of having a contrary effect? I am here alluding to a comparison that has been drawn between Mr. Musters and Tom Sebright, each very great in the art; but barring kennel management, in which gentlemen huntsmen cannot be expected to equal servants who are hired in great measure for that purpose, and for a great part of their time have little else to do, I confess I can only see one point on which my argument is at all likely to give way. The servant huntsman generally goes through the regular gradations of second and first whipper-in; and although I have heard it asserted that a whipper-in seldom makes a good huntsman, experience gives the lie to that-most of our first-rate huntsmen have served that office: whereas now and then a gentleman puts a horn to his saddle, and assumes the command all at once, which has given to some of them the various titles of professors, heavenborn huntsmen, \&c. Now I conceive Mr. Musters's education has been nearly equal to that of any huntsman alive. His father kept fox-hounds upwards of thirty years, hunting parts of Nottinghamshire and Lincolnshire; and I have been told by those who remembered it well, that, for fourteen or fifteen of those years, (i.e. from the time he could bestride his pony till his father gave up the hounds, ) his son Jack acted as whipper-in whenever occasion required. I have also heard from very good authority, that when Sir Henry Harpur purchased the late Mr. Musters's hounds, and the noted Shaw began to hunt them, he has been heard to declare that he frequently 



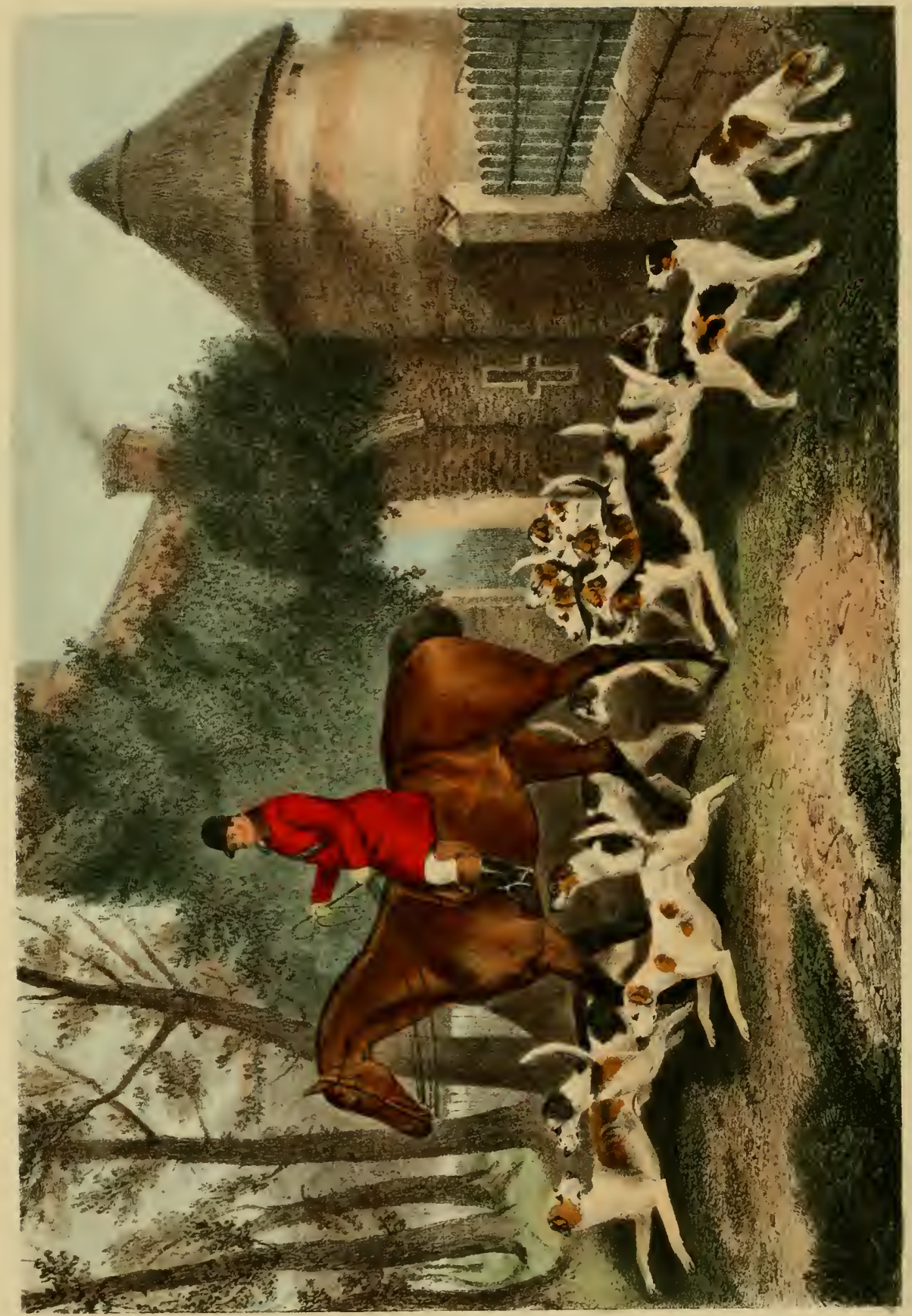




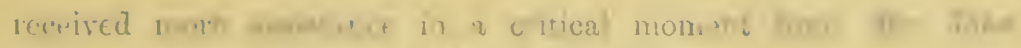

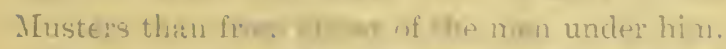

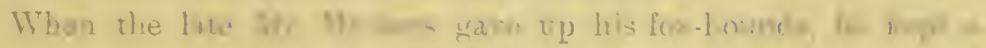

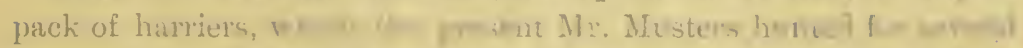

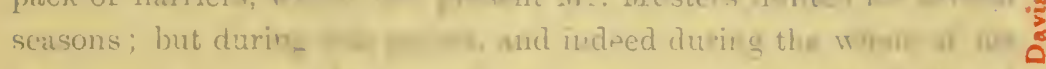

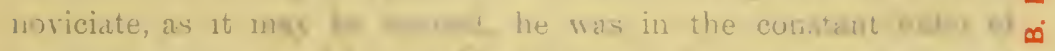

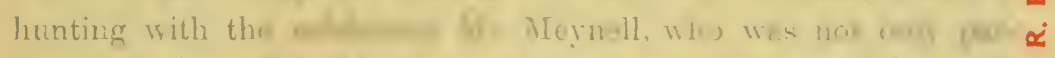

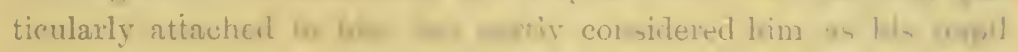
Indeed, almost $\mathrm{cos}$ or whe of the sportins lifo of the "great man in his yst meliag a present to Mr Yunters of ten couples of hi- ymorn I ath as a foundation of hit future 1)icli.

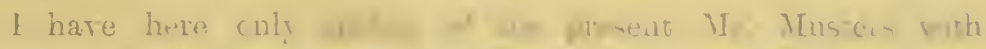

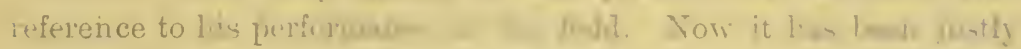

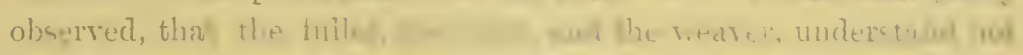

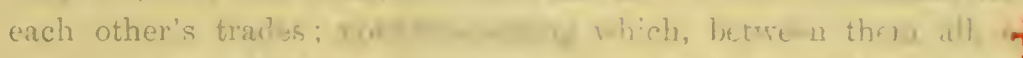

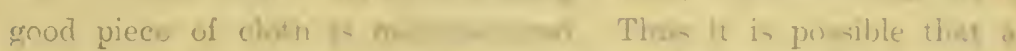

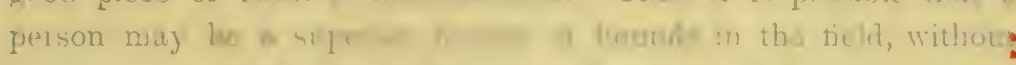

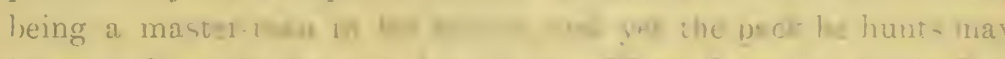

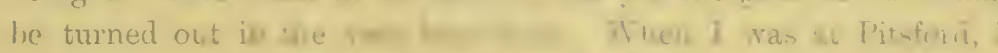

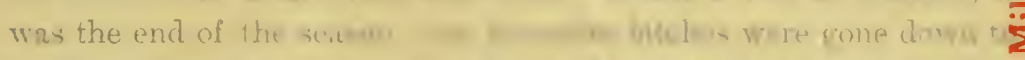

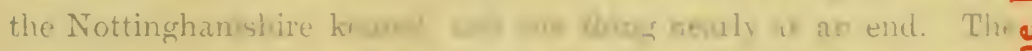
kemnel at Pitsfoul w: which might arroment for u

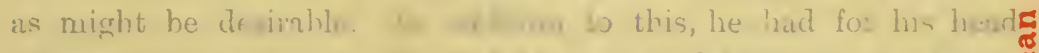

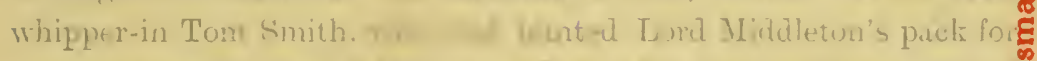

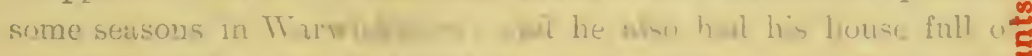

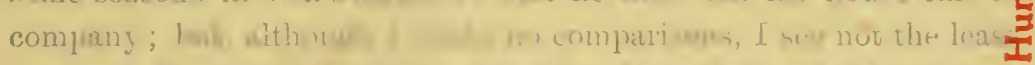

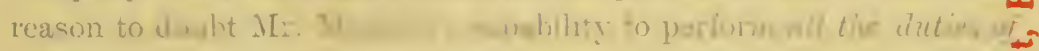

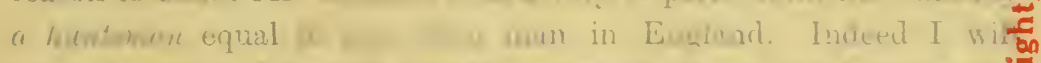

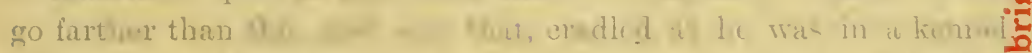

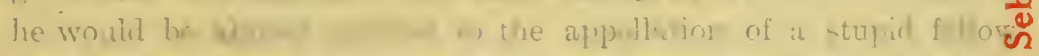

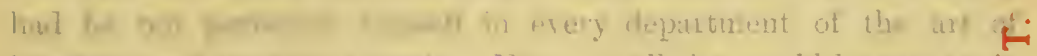

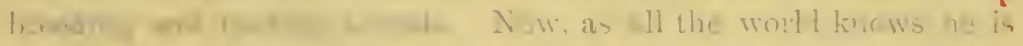

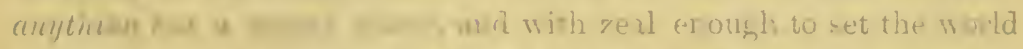

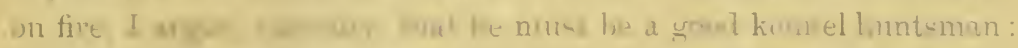

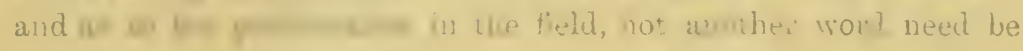




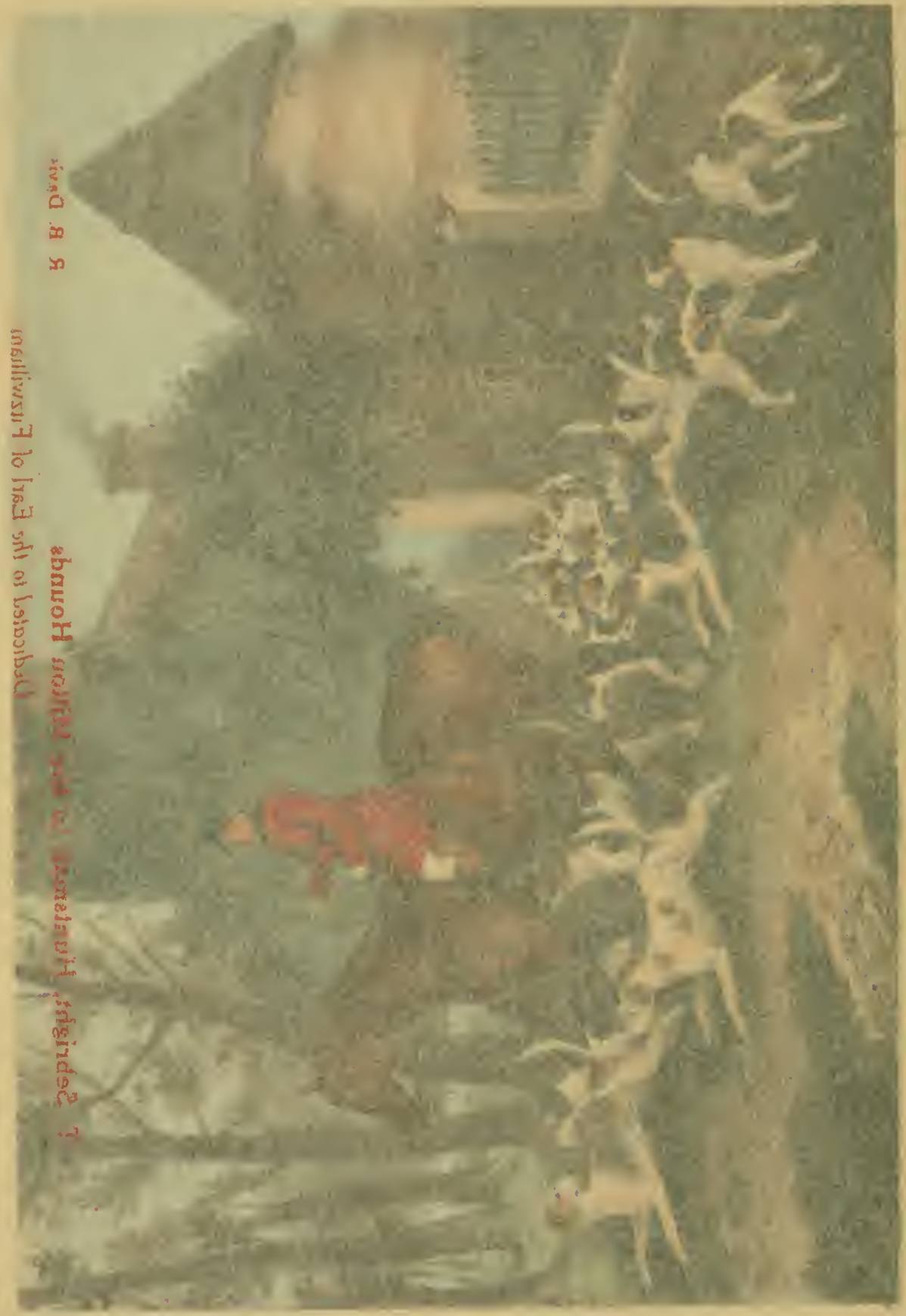


received more assistance in a critical moment from $M T r$. John Musters than from either of the men under him.

When the late Mr. Musters gave up his fox-hounds, he kept a pack of harriers, which the present Mr. Musters hunted for sereral seasons; but during this period, and indeed during the whole of his noviciate, as it may be termed, he was in the constant habit of liunting with the celebrated Mr. Meynell, who was not only particularly attached to him, but partly considered him as his pupil. Indeed, almost one of the last acts of the sporting life of this "great man in his way" was making a present to Mr. Musters of ten couples of his prime old hounds as a foundation of his future pack.

I have here only spoken of the present Mr. Musters with reference to his performance in the field. Now it has been justly observed, that the fuller, the dyer, and the weaver, understand not each other's trades; notwithstanding which, betwreen them all, a good piece of cloth is manufactured. Thus it is possible that a person may be a superior hunter of hounds in the field, without being a master-man in his kennel, and yet the pack he hunts may be turned out in the very best style. When I was at Pitsford, it was the end of the season; the favourite bitches were gone dowu to the Nottinghamshire kennel, and the thing nearly at an end. The kennel at Pitsford was also four miles from Mr. Musters's house, which might account for the master's eje not being orer it so often as might be desirable. In addition to this, he had for his head whipper-in Tom Smith, who had hunted Lord Middleton's pack for some seasons in Warwickshire; and he also had his house full of company; but, although I make no comparisons, I see not the least reason to doubt Mr. Musters's capability to perform all the duties of a Thuntsman equal to any other man in England. Indeed I will go farther than this, and say, that, cradled as he was in a kennel, he would be almost entitled to the appellation of a stupid fellow had he not perfected himself in erery department of the art of breeding and feeding hounds. Now, as all the world knows he is anything but a stupid fellou, and with zeal enough to set the world on fire, I argue, logically, that he must be a good kemnel huntsman : and as to his performance in the field, not another word need be 
said about that. Comparisons, I repeat, are odious: therefore I neither compare him with this man nor with that; but I hope it will not be long before I see the justly-celebrated Tom Sebright-who by all accounts is a charming fellow in the field-partaking of all the animation and keenness of his preceptor', Mr. Musters, with, as I understand, a great share of the "instinctive knowledge of the habits of a fox."

In the life of Somervile, there is a strange expression from the pen of the author-the great Dr. Johnson. "He writes," says he, "very well for a gentleman." Now I own I do not exactly comprehend the Doctor's meaning; for what avails an expensive education unless it sometimes turns to a good account, particularly as relates to the cultivation of the mind? But I once asked a very eminent sportsman what was his opinion of gentlemen huntsmen? and he gave it as follows:- "If gentlemen," said he, "have been amongst hounds from their infancy, and will, when they take the management of them, give up their time and attention to them, the same as a common man who is uneducated, there can be no doubt which of the two will make the best huntsman; but the fact is, most gentlemen who hunt hounds have not been sufficiently amongst them till they arrive at a certain time of life, when other pursuits and avocations present themselves, and then they do not like all the drudgery of the office. For these reasons, and for these alone, we see but few good gentlemen huntsmen."

Were I to be asked my opinion of the Sedgefield country, I should almost be inclined to place it at the head of the provincials. It is tlat; the fields are of a very fair size, a great portion of them between twenty and forty acres, and a good deal of very old sward; it abounds in whin coverts-indeed I saw scarcely anything else; and the fences for the most part are practicable. To South country horses they may be a little awkward, as for the most part they are placed upon banks, and the $\mathrm{V}$ stiles are frequent. It is also considered a good scenting country, as most countries in the neighbourhood of the sea ${ }^{*}$ are; and it must be favourable to hounds, as there are no large coverts in which they can run riot. Thus Mr.

* The sea is not more than ten miles from the kennel at Sedgefield as the crow would fly. 
Lambton's hounds are particularly steady and handy, to a degree not often witnessed.

I consider Durham altogether a very sporting county. The farmers ride good horses, the greater part of which they breed themselves, beginning the cross with the Cleveland-bay mare. There was one part of their rural economy which I particularly admired; and that was, I never saw a real cart-horse in the principality of Durham. They make use of, for all purposes of husbandry, what we call the strong nag horse, so much quicker in his step, and altogether more useful than the heary-legged, slowmoving, cart-horse that we are doomed to employ in the South, and to which I have no hesitation in saying the ruin of many hundred small farmers is to be traced. It may scarcely be believed, but such is the prejudice of carter's and wagoners in my part of the world in favour of these long-tailed, heary-legged brutes, that they will wantonly maltreat a horse of the nag kind if put into their master's stables to work with the other's. I was given to understand, that had I visited Durham some years back, when wheat sold for better prices, I should have seen more well-mounted yeomanry than at the present day, the times having taken the hunting out of some of them.

The eastern side, that is, from the Tees to the Wear, and so on to the sea-shore, is the best part of the Sedgefield country to ride over. Here is a good deal of old grass, the fields from ten to fifty acres in extent; and although the surface of the land appears indifferent, yet being upon a limestone subsoil, with the benefit of a bumid atmosphere from sea breezes, a pretty good scent is often the result. I could perceive there is a large tract of this sort of land, well planted with whin coverts; but the most likely country to ensure a run is the southern side, bounded by the Tees, and extending towards Piercebridge, in Lord Darlington's Hunt. Here, although the inclosures are smaller and the fences stronger, yet the land is greatly superior, and consequently more to be depended upon for a scent. It was this side of the country that afforded us our capital day's sport.

There are sporting peculiarities in almost all counties I have been in. In the one I live in, they call a couple and a half, or three 
hounds, a "harl" of hounds; and in Durham the farmers say, hounds "call" or "give mouth" when they challenge, or throw their tongue to a scent. When analyzed, however, there will appear but little difference in all such terms.

Having mentioned Captain Dundas as one of the conspicuous performers-until the last mile, when nature said "enough" -in our fine run from Foxyhill, and he being also so popular a character in the Sedgefield Hunt, I must devote half a page to his history, and I flatter myself the reader will not consider the time misemployed.

The Honourable George Dundas, brother to the present Noble Lord of that name, resides at Upleatham in Yorkshire, amidst that host of friends which honest John Burrell inquired after so kindly, and represents the Orkneys in our Senate. He belongs to that profession of which England is so proud, and looks as if he had "weathered the storm." On one occasion his own ship was blown up, and he had the ill luck to see three thousand brave fellows blown to atoms in the course of a few months from various other disasters. These things, however, are the fate of war, and are set down to the general account. I regret to say, the Hon. Captain is occasionally a severe sufferer by the gout, and perhaps none the better for foreign climates; but, when tolerably well, no man can enjoy himself more. To the frankness of the sailor he unites the address of the man of fashion and of the world; it is impossible to imagine a more agreeable companion. I must also style himalthough a sailor, and very near-sighted-a capital hand across a country, and very fond of a bit of blood.

Billy Williamson is the most straight-forward rider of this Hunt, and a very popular character wherever he goes. $\mathrm{He}$ is a second Ajax-fearless and intrepid; and being six feet high, with great strength, and in the bloom of manhood, he is just the man to get to hounds over a stiff country, on a good horse. There is, however,

* He once commanded a ninety-gun ship, when she took fire and blew up. He remained on board the last man, when, finding the fire so hot that he could stand it no Ionger, he took his knife out of his pocket, cut off his trowsers, and pulling off his coat, committed himself to the waves, whence he was picked up, unhurt, by his men. 
some truth in what the farmer said about the cast-iron nag. He certainly is too severe upon his horse, and does not pick his ground enough for a man of his weight to live with hounds to the end of a good run. He should recollect he rides fifteen stone, and is what is called long in the leg-though none, perhaps, the worse for that. Billy Williamson is one of the right stamp of young men, and I wish it were possible he could stock half the counties in England with his sort. We are hard to beat now-at least I hope so ; but then we should be invincible.

Mr. Harland of Sutton Hall is a very pretty performer over a country, and had a very neat stud for a man of his light weight. They appeared either quite thorough-bred or within a toucher, and three of the four were purchased of Mr. Ralph Lambton.

On the morning of Wednesday the 13th I quitted Sedgefield, and met Mr. Bowser's harriers about four miles from Rushyford Inn. This gentleman resides at Bishop Auckland, about ten miles to the westward of Sedgefield, and at about equal distances from the Raby and Sedgefield Hunts. He himself was out in a scarlet coat; but his hounds were hunted by an amateur, and what in this part of the world is called a Statesman-Anglicè, a Ycoman. The Statesman here was the well-known Tommy Chapman, whom I afterwards saw with Lord Darlington's hounds. Knowing him to be a sportsman, I tried hard to get a wrinkle or two out of him as to the country, \&c. ; but John Burrell's lingo is plain English to his, and nothing but a glossary could have enabled us to hold sweet converse. It sometimes happens that our Southern Statesmen are difficult to comprehend; but Tommy Chapman would puzzle the Devil himself unless he were bred in Durham.

On this day I recognized in the field the young Oxonian whose horse I had blooded at the end of a fine day's sport with Sir Thomas Mostyn's hounds two years ago, and by which the life of the poor animal was saved. I did not then know his name, but found it to be Gregson, and was informed that he had a pretty property in that part of the world, was likely to make a good sportsman, and was much patronized by Mr. Ralph Lambton.

After my hare-hunting with Mr. Bowser, I had the pleasure of visiting Mr. Duncombe Shafto at Whitworth, where a large party 
had assembled, among whom was Mr. Harland. On the sideboard at Whitworth I saw several racing cups. They were won by a horse called Whitworth, by Agonistes-a very fair racer, and the sire of many capital hunters. Mr. Shafto still breeds thorough-bred ones.

Mr. Thomas Shafto (commonly called Tom Shafto), brother to Mr. Duncombe Shafto, is a very conspicuous character in the Lambton Hunt, and may be truly termed a dear lover of fox-luunting. He has before fallen under my observation as having possessed, as well as having made a hunter of, that very celebrated horse, the original Clipper, on which that fine rider, Mr. Lindo, for so many years starred over Leicestershire. The temper of this horse was very violent, and he gave Mr. Shafto a great many falls before he completed his education. Falls, we know, are awkward things, and not unfrequently do they damp the ardour of young sportsmen, and give them a distaste for the rough, though noble, amusement of fox-hunting; but when I relate an anecdote of Mr. Thomas Shafto, who will assert that, with such men as himself, broken bones or fractured skulls would be even as a feather in the scale against the impassioned delight of this noble science?

Twenty years since, Mr. Thomas Shafto was a Captain in the North York Militia, and quartered in the Sister Kingdom. Having obtained leave of absence, he took his passage in a Liverpool packet, and attempted to cross the Channel on his return to England. The propelling power of steam was then unknown-at least for nautical uses-and, by the violence of adverse winds, the ressel could not keep her course. Being driven near shore, with but little prospect of weathering it, the Captain of the packet thought proper to apprise his passengers of their imminent periladding, indeed, that he had no hopes of saving them from a watery grave!

Captain Shafto was accompanied at this time by one of his brother officers, and both heard the dreadful tidings at the same moment. Captain Johnson fell on his knees, and began to implore the Throne of Grace; and doubtless Captain Shafto did the same as soon as he recovered from his dread surprise. But such is the infirmity of corrupt nature, that mortal man can with difficulty 
renounce the pleasures of this world, or persuade himself he shall find still better in the next; and this must have been the case with Tom Shafto. There cannot be a doubt but on this trying occasion Lord Darlington and his fox-hounds, as well as his friend Ralph Lambton, flitted across his fancy; for in the agony of the moment he did not exclaim, like the jailor in the Bible, "What shall I do to be saved?" but, sitting up in his bed, he heaved a deep sigh, and addressed his brother officer" in the following words:- "I say, Bob, no more Uckenby whin *!!" Surely this was the ruling passion strong in death!

On another occasion, Mr. Thomas Shafto afforded an instance of the prevalence-we might almost call it dominion - of any particular gratification, over thought, word, and deed. He was once present when the oratorical powers of some of our leading Senators became the topic of discourse, and, amongst others, Earl Grey's name was mentioned. "A good speaker," observed Tom; "but he can't ride orer Stanley pastures." At another time, he was asked why he quitted a friend's house when a certain family, just returned from Paris, came to pay him a visit? "I don't like them," said he; "they are half French, half English."

$M r$. Thomas Shafto is a single man, and at present resides with his elder brother at Whitworth. $\mathrm{He}$ is an excellent judge of a horse; a good sportsman, and rider; and, what is more, a very good fellow. To the eye, it must be allowed he has some personal peculiarities - the straight-cut coat; boots and breeches by no means good; a little of his friend Sir Tatton's style about him (by no means a bad one!), and he rides a race nearly as well. There is , not an atom of humbug about him; but if there was, I must esteem him for thinking of fox-hunting in his last moments-at least, in what he had reason to believe would be his last.

On Thursday, 14th of December, I turned my back upon Durham, and went to visit a Shropshire acquaintance, named Flounders, who resides at Yarm. I was, when at his house, within a very easy distance of the far-famed Hurworth hounds, which met the next day at Croft Bridge, on the Great North Road, and which bridge

* A favourite covert in Lord Darlington's Hunt, near Catterick Bridge. 
divides the counties of York and Durham. As it was, I was too late for dinner; but I at one time despaired of getting to my friend at all, and by a circumstance worth naming.

The distance from Darlington (which I passed through) to Yarm is five miles, for which I allowed myself somewhat about half an hour, the road being none of the best, but I did not reach it under an hour. The delay arose from my meeting something, which I could only compare to a moving hell. Excuse my profaneness-if such it can be called-for I cannot find any other simile. This turned out to be a locomotive steam-engine, which, running parallel with and close to the road, so alarmed my hack, that it was in vain that I tried to make him face it. This, however, is not to be wondered at; for a horse is naturally a timid animal, and this machine was enough to alarm the Devil himself, if he had met with it, as my horse did, out of his own country. The night was dark, which increased the terrors of it: and it really was a frightful object. The noise of the wheels-perhaps twenty pairs - the working of the engine, the blazing fires of blue and yellow hues, the hissing of the steam, and the black-faced wretches, with their red lips and white teeth, running to and fro, all conspired to heighten the resemblance, and my astonishment increased the more when I reflected on such a nuisance as this being suffered so close to a turnpike road. The only way in which I got past it at last was to get my horse into a hole, with his tail towards the machine, but I never saw an animal so alarmed.

On Friday morning, Mr. Flounders accompanied me to Croft Bridge to meet the Hurworth hounds, which place was about eight miles from Yarm. Our road led us through the village of Hurworth, within a short distance of the kennel, and we overtook the hounds going to covert. They were accompanied only by Mr. Wilkinson and his whipper-in; and Mr. Flounders took this opportunity of introducing me to Mr. Wilkinson. I found him very much what I expected to find him-a well-fed Englishman, with a back as broad as those of three of our dandies put together; mounted on a finely-shaped chesnut-horse, looking very like a hunter to carry seventeen stone which he had then on his back; with a keen eye in his head, and a very intelligent countenance-strong, to 


\section{IORKSHIRE}

be sure, in the dialect of his country, but looking very much like a sportsman.

There was a very large field of sportsmen assembled on this day -amounting to at least one hundred, which is a very unusual circumstance with this pack. Mr. Lambton's hounds, however, were gone from Sedgefield, and Lord Darlington's were a long way off; so it was supplied by the gentlemen of those Hunts, many of whom had come a long distance for the occasion.

We proceeded to draw Dinsdale IVood, a covert of some size, and situated on a steep hanging bank. Before throwing in his hounds, Mr. Wilkinson did me the honour to ask me to accompany him into the wood, and see him find his fox. This invitation I readily accepted, and so far I was much gratified. He found his fox almost instantly, and in very excellent style. His halloos were very capital, and his ear unusually quick. This was not all. We had a very baffling fox on foot-very unwilling to break-and his turns were short and frequent. The pack and their master, however, were quite a match for him, and for abont five minutes, the scene-witnessed only by ourselves-was enchanting. "Have at him, Music, good bitch!" halloo'd Matty. "By G-d! th' ast better gang away, for thou'lt die if thou don't. Have at him again, Cruiser, old fellow! but thou'lt have his head in thy mouth before neight." * Oh! that I could give his view-halloos on paper! but that can't be done. They were enough to raise a man from the dead!

The bad part of the story is now to come. Sportsman-like, Mr. Wilkinson wished to see his hounds get well away with their fox, and therefore stood still and blew his holn; but he should have ridden on, and blown his hom; for when we got to the top of the covert, not a hound, except the few that were with us, could we get sight of. "I know where they are gone," said Mr. Wilkinson; "you must follow me, for we shall never get over that stell." + I did follow him, and he took me to an awkward ford; but we might just as well have gone around by York. The hounds had a capital run of

* Mr. Wilkinson told me, that last season his hounds ran a fox twelve miles in the dark, and killed him, and Cruiser brought his head home to him at night.

† Anglicè, a brook. 
an hour, and killed their fox, but only in the presence of a chosen few, who were bold enough and fortunate enough to get well over this awkward stell-Billy Williamson, I believe, being the first to charge it. It was deep and rotten, and the change that was effected in the colour of the ci-devant white-cords of those gentlemen who dropped short at it plainly showed what sort of a bottom it had.

Two things were now erident: I was quite sure they were in for a lun, and I was equally sure I should see nothing of it unless let in by some lucky turn. I did not, howerer, quit my pilot; but strange to say, I rode for exactly one hour about fifty yards behind him, without ever hearing the tongue of a hound until within the last ten minutes. When we did get up to them, the thing was over; the who-whoop was only wanting: they had not tasted him, but he was dead beat, and in a few minutes more Matty had him by the brush. It must have been a beautiful rum for those who saw it. The pace was excellent, and the country rery good indeed for the provincials.

I had two reasons why I did not regret this wrong turn, at first starting. First, I and my horse might have been planted in the stell; and secondly it was a great treat to me to see Matty Wilkinson and his chesnut horse get orer, or, I should rather say, creep over, upwards of a hundred fences, in the very masterly manner in which they both performed. He has ridden this horse three seasons without having had a fall from him; and when I saw him creeping over his fences, which appeared nothing to him, whilst my horse was flying over them, and afraid to touch a thorn, I almost envied his great weight. Certain, however, is it, that hunters carrying heary men do walk into their fences in a most enviable manner, although indeed, if they did not walk into them, they could never gallop across a deep country for an hour and a hundred fences into the bargain.

I really was much pleased with the scientific manner in which Mr. Wilkinson and his horse crossed the country in this hour's gallop. We exchanged but few words with each other-with the exception of his telling me he was too heavy for a huntsman, and an occasional lamentation of our ill luck. Matty, however, once addressed his horse, and it had the desired effect. We came to a very awkward fence, a wide ditch from us, and no footing for our 


\section{IORKSHIRE}

horses but among some strong stubs. "Tak time, lad," said Matty. The lad * did take time, and did it like a workman. Towards the end of our gallop we came to another still worse place. It was high and stiff, and near to a tree. Matty rode up to it, and not liking it, stood looking at it. "Shall I try and pull down those strong binders?" said I. "No, no," replied Matty, "we'll gang at it;" and over he went at a good hand gallop. All his fences but this were taken either at a stand or in a walk. In his gallop he stood up in his stirrups, reminding me much of the New Forest Harbin, and I think there is very little difference in the waistbands of their breeches. Cæsar wished Cassius were fatter, but here this wish were vain.

This certainly was a good run, and a good finish. We drew again, and three foxes all broke covert at the same moment; but we did nothing worth speaking of, although they tasted one of them.

After hunting this day I had the pleasure of dining at Hutton Bonville, near Northallerton, the seat of Colonel Tower's. Birds of a feather flock together; and here I was under the roof of a man as fond of hounds and everything belonging to them as myself. His father kept fox-hounds thirty-five years at his own expense; and his lady is the daughter of Mr. Baker, of Ekmore Hall, near Durham, one of the keenest sportsmen of his own or any other man's day. Worse is the luck, he is now past the age of man; but is still to be seen by the covert's side when the place of meeting is near Ekmore; and only three year's ago he rode Jenny Horner at Middleham for the Hunter's' Stakes (gentlemen riders), and won his race in style.

Saturday, 16th.-Having left two horses at Norton Conyers, I met Lord Darlington's hounds on this day at Firby, about three miles from Newton House. It rained very hard when I left Hutton Bonville, and when I got to the place of meeting I found neither great-coat nor mud boots had had the desired effect. I was "spoiled for the day," as the dandies have it. We had no sport in the morning-great part of which was passed by Mr. Milbanke's fire-

* This reminds me of an anecdote of a capital old sportsman-Johnny Wynne of Ryton-in Sir Richard Puleston's conntry. He rode a very good biack horse about fifteen seasons, but he never called him anything but "the colt." 
side, waiting for the rain to abate-but a most agreeable evening at Mr. John Monson's, where Sir Bellingham Graham was staying, and two or three more of Mr. M.'s friends. Amongst them was his brother-in-law, Mr. WVyvill, Member for York, whose manly and independent speeches in Parliament I had often read and admired. There is a vast deal of the native Englishman about this Mr. Wyvill, and a very considerable share of talent; and-what rendered hin in no wise less estimable in my eyes-he has always been a good friend to fox-hounds. He hunted until he turned the scale against twenty-two stone, and that stops all men except old Harbin and John Ward.

Sunday, 17th.-Returned to my old quarters at Norton Conyers, and was happy to hear that Lord Darlington's hounds had had some pretty sport in my absence. I was also glad to find Sir Bellingham in better health, and his stud recovering from some bangs and bruises that horses will get when ridden straight over a close country. I had also the pleasure to hear, on good authority, that the Friday after our capital run, the Lambton hounds had another tickler in their home country, which again produced many alarming symptoms among the horses, and several awkward excuses from their riders.

Monday, 18th.-Lord Darlington's hounds met at Catterick Lime Kilns, sixteen or seventeen miles from Norton Conyers; but Sir Bellingham Graham fought shy. Like all old masters of fox-hounds, the pleasure of hunting with any other man's pack is not sufficient to make him right keen, so I lost the pleasure of his company. IVe found two, if not three, foxes in Tunstall whin, and one went away orer a good country. The Peer, however, was not aware of it, and having the body of the hounds with himself in the whin, Will Price got forward and stopped those that went away. But for this we might have had a run, although there was but a middling scent. I thought this looked like a good country for a good fox. IVe found again, but he ran very short, and, being twenty miles from home, I left about three o'clock.

As one of the field was going to Bedale, and my hack was there, I put myself under his protection, for I was in a strange country. Our road lay through the Duke of Leeds' domain, Hornby Castle, and I was surprised to find such a great extent of grazing land. 
For several miles before we came to the park, we rode across so many large grass fields that I fancied myself going over Leicestershire. The Castle appeared a fine building as we passed within a mile of it, but my attention was arrested by the immense number of bridle gates on this domain, amounting, I was told, to many more than a thousand. These were put up when his Grace kept harriers ; and, with a small field, such as generally atten'd hounds of that description, would almost preclude the necessity of leaping. The Duke was out only twice when I was in the country, and then I thought he seemed more attentive to what his training groom had to say to him than to anything else going on in the field. His Grace, however, is a preserver of foxes, and therefore long may he live!

Tuesday, 19th.-Met the Hurworth at the third mile-stone from Northallerton on the Boroughbridge road. We soon found a fox, and the hounds had a good run, marking him to ground in Lord Darlington's country; but no one saw it after the first three miles, and very few so far, for the pace was tremendous and the fences awful. What floored us all, however, was the river Swale, which the fox crossed, after having previously passed the Wisk, at which Sir Bellingham got a floorer. Some of the horsemen were ferried over the Swale; but as we met Will Price, who was crossing the country in pursuit of one of Lord Darlington's terriers that was lost, and who informed us the hounds were full four miles ahead, running very hard, myself and a great many more did not go into the boat. We knew there was no draw for a second fox, and therefore it appeared useless.

This was decidedly the best scenting day I saw throughout the last season; but I am sorry to add it terminated unfortunately. Mr. Wilkinson violated the rules of fox-hunting, by bolting his fox from, and killing him on, one of Lord Darlington's earths, but a short distance from his kennel door.

This day, after hunting, Sir Bellingham Graham and myself went on a visit to Newton House, where we met several of our sporting friends. We found our noble host a good deal annoyed by the report that had reached him of a fox being bolted and killed from one of his own earths; and, much as I may respect Mr. Wilkinson as a 
sportsman, I must not attempt to justify him here. He has been a master of fox-hounds many years, and we might as well assert that Lord Eldon knew nothing of the laws of his Court, as that Mr. Wilkinson was ignorant of the fox-hunting code. A huntsman has a prescriptive right to hunt his fox into another man's country, and to kill him, if he can, by catching him above ground; but the moment he earths, that moment he is in his castle, and is inviolable. I repeat, that Mr. Wilkinson could not have been ignorant of the rule, and he ought not to have killed this fox. It is a reflection upon him as a sportsman; but I am told he made an acknowledgment of his error, and therefore no more must be thought of it. "To err is human ; to forgive divine."

As we were drinking our wine after dimer, at Newton House, and this subject was in discussion, I embraced the opportunity of ascertaining whether my notions respecting it were correct. I did not appeal to Lord Darlington, although so much the older sportsman of the two, but I addressed myself to Sir Bellingham Graham, as having hunted six or seven different countries, and therefore more competent to decide the question generally. He gave us a clincher. "I was once out," said he, "with Lord Lonsdale in Leicestershire, and we ran a fox into a spout in the Quorn country. He was to be seen, and almost to be touched, but the whipper-in could not bolt him without moving two or three stones. 'Don't touch them,' said Lord L.; and Slack was ordered to take his hounds away." The example of this old and good sportsman is worthy of being imitated.

I was amused with the effect the murder of this fox had upon Dick, Lord Darlington's first whipper-in. It appeared to affect him quite as much as his late bad fall, and, with "a face as long as my arm," he told me he thought it a very ungentecl action.

Wednesday, 20th.-Lord Darlington met at Flyntorf. We drew the famous Uckenby whin blank, and then on to Pepper Hall, the seat of the Hon. Colonel Arden: neither the Colonel nor his foxes were at home; nor indeed could I see any lying for a fox, but there is a tine country here. One of my horses having been taken ill at Northallerton, I quitted about two o'clock, and lost a pretty burst of trventy-five minutes, with a kill. It was late when Lord Darlington 
and his party returned to Newton House, having had a trot of nearly twenty miles in rain and darkness.

Thun'slay, 21st.—Sir Bellingham Graham returned home, but I remained at Newton House, intending to quit the next day for Melton Mowbray. The Glasgow mail would have picked me up at his Lordship's gates at five o'clock in the evening, and I should have been in very good time for the Quorn hounds the next morning, having had the promise of a mount for that day and the next. The coach, however, was full, so that speculation failed.

This was a day of note in the ambals of fox-hunting. It produced that brilliant run with Lord Anson's hounds from Enderby, in Leicestershire, the seat of Mr. Loraine Smith. Young Peyton, as he is called, went to the end of it; but his famous mare Edgecot paid the forfeit of her life; and I believe Mr. Braithwaite likewise saw him killed. Lord Anson was also near doing the same at the expense of two tired and one dead horse; but it was awfully severe. The finish, I am told, was grand, as the death took place in the castle at Ashby de la Zouch, in Derbyshire, fifteen miles point blank from Enderby-best pace all the way. I saw Mr. Loraine Smith in London in the spring, and he told me he had built a triumphal arch on the spot which produced so gallant a fox, and a rum well deserving of a record beyond the day.

There is, generally speaking, something irresistibly amusing in the active workings of immoderate zeal; and particularly so when the object in pursuit is of an agreeable uature, and one with which we ourselves can sympathize. The truth of this will, I think, be exemplified in a short account I am enabled to give of Mr. Matthew Wilkinson, as a master of fox-hounds and a sportsman-in the style and character of the Old School.

Mr. Matthew Wilkinson is the youngest of three brothers, two of whom are now alive and are the representatives of a family long seated in the county of Durham, and possessing property amounting, as I was informed, to somewhat better than 2,000l. per annum in land. To distinguish their Christian names requires a short preface. All who are acquainted with the customs and manners of the northern counties of this Island are aware that in them John is cilled Johnny; William, Willy; Thomas, Tommy; Matthew, Matty; 
and so on, adding the $y$ to the termination of every name that can receive it, and otherwise corrupting it when the $y$ does not sound prettily to the ear. Thus, then, the eldest of these brothers, Thomas, was called Tommy; the second, Lozalure, is dubbed Lozzy, and still farther corrupted by his particulars; and Matthew is known by no other appellation than Matty, or Mattha IVilkinson, maister of and. hoontsman to the Hurworth Hounds. These are what eritics term " the abortions of familiarities;" but it would be useless to adopt any other phraseology; so I shall take the liberty of adhering to the vulgar tongue.

The Huworth Hounds were oliginally harriers, but were promoted to fox-hounds thirty-six years ago, nearly thirty of which they were kept at his sole expense by the eldest brother Tommy, who died about seven years back. Tommy, I was informed, had the advantages of education, was a very superior sportsman, and his view-halloo, which was magnificent, is said to be still echoed in Hutton Ranby Woods. Lozzy comes next in the first page of the Family Bible. He resides at Heigington, not far from Rushyford, but about ten miles from the kennel, and of course contributes to the expense of the hounds. He is very keen; rides any distance to covert-in the old style-on his hunter"; and thinks lightly of twentyfive miles home in the dark after a good run. He also is esteemed a fair sportsman.

Matty, however, is the hero of $m y^{-}$tale; and his character is described in a few words. He boasts of no scholastic education, no collegiate reading; neither does he appear to be much under the discipline of art. But of this he may be proud-he keeps a pack of fox-hounds on perhaps smaller means than almost any other man in England; and he is acknowledged by all to be as good a rough-and-ready sportsman as ever halloo'd to a hound. He is likewise much esteemed anongst his neighbours as a kind-hearted man-a character, indeed, true sportsmen for the most par't lay claim to and maintain.

I did not see the Hurworth kennel; but it is situated at Measham, about five miles from Darlington, and $I$ an told is not badly arranged for convenience and health of hounds. Here Tommy, the whipperin and feeder-one and the same man-with his wife and six 
children, have their dwelling; and by way of preventing riot by night, a small trap-door opens close to Tommy's head when in bed, through which either himself or his wife, whicherer may be awake, can rate the hounds, and put all quiet in an instant. Methinks I hear Lady Londonderry exclaim, "Hearens! how can people bear" to be so near those nasty dogs! What a stench there must be!"Not a bit of it, my Lady! To Tommy and his wife it is all lavender water; and, should the wind set that way, and waft into their chamber a little of the kennel perfume, it would only be to them

" Like the sweet south

That breaks upon a bank of violets, Stealing and giving olour."

In everything relating to the passion for hunting, Mr. Matthew Wilkinson may have his equal, but his superior would be difficult to produce. His attachment to his hounds is almost beyond belief. He has always some of his farourites walking about his house; and to a bitch with whelps he will give as much as she can eat of a good sirloin of beef or leg of mutton from his own table. I had it on unquestionable authority, that, althongh he keeps ten or twelve cows, the whelps in the spring have all the best milk, and nothing but skyblue is allowed for the house! I was also informed, that it has been his practice to keep a tame fox, which would run about the house and buildings for the edification of the puppies as soon as they were able to follow him. He keeps but four hunters for himself and Tommy, and his stable system is this-His horses are nerer physicked, neither are they galloped in their exercise-haring, as he observes, "plenty of galloping when they hunt." In corn, their bellies form the measure.

Death and its terrors kick the beam when put into the scale against Matty Wilkinson's passion for the chase. Although he cannot swim, no, not even a little, he has crossed that rapid and deep river the Tees at least forty times in his life after his hounds, and has had some hair-breadth escapes. Very soon after I was in his country, he was in the greatest danger of being drowned. $\mathrm{He}$ plunged into this stream when swelled with rain, and was unhorsed in the middle of it. Fortunately, catching hold of one of the stirrups, his horse dragged him out, but I believe it was what is 
called " a very near go." When he had run his fox to ground, he coolly laid himself down on his back, and held up his heels to let the water rum out of his boots. I should like to see a picture of him on another occasion similar to this, when he addressed the boys on the bank to ascertain what injury a certain part of his clothes harl met with in the water. I must not write what beauty would blush to read, so dare not repeat the question asked, but it was a most ludicrous one. For the same reason, I must suppress the answer he made his brother Tom, who told him he thought the fox was not gone " "p wind;" but it will not be forgotten in Durham till time shall be no more.

I very much fear this gallant sportsman will one of these days change time for eternity in his attempts to cross this rapid river. Indeed, on his late escape, his brother Lozzy seriously admonished him of the impending danger; but all the notice taken of the salutary hint was, "My life is my own, and I suppose I may do what I like with it!"

A polish weakens the vigour of native powers. Eton and Christchurch might have spoiled Matty Wilkinson, and deprived him of his niche in the Temple of Fame. It is the native simplicity, the original character, that pleases here, as the wilds of the forest are superior to the parterres of the flower garden; and there are on record some most amusing and characteristic anecdotes of this infatuated sportsman. As I have before stated, I cannot relate them all, neither would one or two look well in print.

When Mr. Matthew Wilkinson's eldest brother was on his deathbed, he was asked by a friend for the fixtures for the forthcoming week. His reply was this: "Why, Tommy is very ill, and if Tommy dees we can't hunt till Monday; but, if Tommy don't dee, we shall hunt at . . . . . . on Friday." A brother sportsman died, and left Matty five pounds to purchase a black coat to his memory. Matty purchased a red one, thinking thereby that he had shewn still greater respect to his departed friend.

It is but natural to suppose, that, fond as $\mathrm{Mr}$. Matthew IVilkinson is of hounds, and having but a short kennel of them, he is very much afraid of their being ridden orer, not only in chase, but in drawing over the country. A gentleman was one day very near 
to them.- "Take care of the hounds, Sir," said Matty._"Oh!" replied the gentleman, "my horse never kicks hounds."-_"Perhaps not, Sir," replied Matty in his dry way, "but he may tread on their tails." On another occasion a young and zealous fox-hunter was riding too near his darlings in chase. Matty checked him. He was again on the line. Matty rated him again; and at last insisted upon his riding behind himself. The young one acquiesced, and so went on till towards the end of the run, when Matty's mare began to Hag.-_"Get forward, Sir," said Matty; "ride as hard as you can.""Zounds!" said the young one; "did you not tell me I was to ride behind you?" — "Why yes, I did," said Matty; "but you may gang along now, as mayhap you'll tice my old mare after thee."

Matty once came to a brook-I beg pardon, a stell-which he did not like to ride at, so walked through it, and told his whipper-in (Tommy) to turn the old mare to him. The old mare would not have it; so what was to be done? "Tum thy oun orer, Tommy," said his master, "and then mine will follow."-Tommy's horse got orer; but the old mare would not look at it. What was now to be done? The hounds were running hard. Why, the master jumped upon the man's hor'se and rode away to his hounds, Tommy exclaiming, lond enough to be heard by him, "Dom thee for a .... but that's not fair!"

I have already stated that Mr. Matthew Wilkinson is not much under the discipline of art. He might say with a certain great personage, "By the grace of God, I am what I am;" but from all I had heard of himself and his man, of the rhinoceros breeches and the oil-skin hat, the odd spur, the new-fashioned whip, and other specimens of " $\mathrm{d}-\mathrm{n}$ all dandies school," I was prepared to meet with something still more out of the common way. This, howerer, was not the case. Tommy, with the exception of his topper, was as well rigged as any whipper-in for a rough country need to be; and as for the Squire, although perhaps it might be as well to stop at the letter M, and call him Natty, and not Natty, yet there was nothing extraordinary in his appearance. Some there are who cannot reconcile themselves to the innovations of fashion, and Mr. Matthew Wilkinson appears to be one; but, with reverence be it spoken, he is a good sportsman, and what matters the cut of his coat! 
Where is the tongue-where is the pen-where is the pencil that can describe to the life? It would be a vain attempt to do so here; and my reader's must either journey to Durham, or picture to themselves Mr. Matthew Wilkinson. They will see before them, or they may fancy they see, an English sportsman of the old stamp-keen beyond words ; resolute and daring in his favourite pursuit; and of a frame not of the doubtful gender, but manly and powerful, and formed for hardships-not quite so heavy as the great John Ward, nor with a countenance quite so expressive.

Mr. M. Wilkinson is esteemed a very superior huntsman as far as the working of his hounds is concerned, as also assisting them in recovering a scent. His great weight, however (full seventeen stone), precludes the possibility of his always being in his place; though every one I conversed with agreed, that, from his great knowledge of the country, and of the usual line of his foxes, he creeps up to his hounds, when at fault, much sooner than might be expected. This is the result of a quick eye and a good share of brains, with each of which $\mathrm{Mr}_{\mathrm{r}}$. W. is very well furnished. Of his management in the kennel I can say nothing; nor can I say much of the condition of his pack, any farther than that their elbows were clean, and that is as much as can be generally said of hounds that work as hard as his do; but I thought the hounds themselves did credit to his judgment. They are fine slashing animals, with great power and bone, and are allowed to have as much hunt in them as their owner has zeal; and truly that is in abundance. Tattler, Cruiser, Juggler, and Music would be an ornament to any pack.

I am not well qualified to speak of the Hurworth country. Some of it, I was informed, is very good, as indeed was that part which I rode over from Dinsdale wood; but, generally speaking, it is narrow and limited, and much interrupted by the Tees. The subscription, I understand, amounts only to 175l. per annum, which may perhaps with good management find meal for the hounds, as the pack is small, only consisting of twenty-six couples of hunting hounds, and this year not more than four couples to come in. Days of hunting, Mondays and Fridays.

I have now done with Mr. Matthew Wilkinson and his hounds. Long may he live to enjoy his favourite sport; and, when he is gone, 


\section{YORKSHIRE}

let his memory be cherished for the zeal he has shewn in the noble science of fox-hunting! Keeping a pack of fox-hounds with extended means is a praiseworthy act; but when those means are limited, it becomes doubly so, as many other gratifications must of course give place.

Friday, 22nd, wishing to get home by Christmas-day, I was afraid to try the mail again, so got on the box of some coach that passed the house, and arrived at Leeds at nine o'clock, whence I proceeded by the Express to London.

It was the second of March before I could quit home on my return to the North; and as the Holderness hounds were my next object, I started for Beverley, their head-quarters, at which place I had ordered some horses to meet me.

No sooner arrived at the Tiger Inn, in the neat town of Beverley, than I sent my card to Mr. Hodgson, the Master of the Holderness, who, as he was sitting alone, most kindly acknowledged the receipt of it in person. I found him exactly what I expected, for he had been accurately described to me by Sir Bellingham Graham. "You must go," said he, "and see Tom Hodgson. He is a very old acquaintance of mine; one of the best fellows in the world; a eapital sportsman; in short, he lives for lunting." He was in the prime of life; no dandy; six feet three inches high; and, as Mat Milton says of a light bellied horse, "carrying very little dinner bag."

Tuesday, 6th, a non-hunting day.-Breakfasted with Mr. Hodgson, and spent the morning in looking over hounds and horses. In the evening accompanied Mr. Hodgson to dinner at Swanland, the seat of Mr. Sykes, who, I much regretted to hear, paid the debt of nature about six weeks afterwards. Amongst the company, which was numerous, was a West Riding Baronet, Sir Edward Dodsworth, very fond of fox-hunting, and a staunch advocate for blood to hounds in the morning, and a glass of good Port wine in the evening.

On our return in the evening we found Lord Mountsandford at the Tiger, who was come for a week's hunting with the Holderness. His Lordship was in just the right trim to receive us. He had taken his bottle of Champagne and ditto of Claret; and was in the act of lighting a cigar to top everything up with, when we entered the 


\section{NIMROD'S HUN'TING 'TOLR}

room. We soon followed his example; and a glass of gin punch and an hour's gossip closed the evening of this day.

Lord Mountsandford is a handsome young Irishman, educated entirely in England, and therefore carries no mark of his country on his tongue; but his Lordship possesses the characteristic cheerfulness of his native land, and is what we call "a very good fellow." He resides a great deal in Yorkshire, partly at Mr. Oliver's of Darrington, and partly at Mr. Gascoigne's of Parlington, to both of which gentlemen I believe he is related.

Wednesday, 7th.-Met the Holderness hounds at White-cross, the residence of a very wealthy yeoman by the name of Jackson, who occupies a considerable property of his own, and resides in all the comfort-I had nearly said luxury-of that station in life. Two peculiar features mark the character of Mr. Jackson. First, he takes under his roof, uninvited, any sportsman living at a distance, as also his servant and horses, on the erening before hunting, when the next day's fixture is near his house. Secondly, he gives a public breakfast on the mornings on which the hounds meet at White-cross, which is laid out in the true style of Old English hospitality. No wonder, then, he is so highly esteemed by the gentlemen in his part of the country, that they presented him with a handsome silver cup, on which is an inscription, testifying it to be given to him as "a slight mark of esteem for his universal kindness and unbounded hospitality on all occasions that may occur." On the morning I am speaking of he gave a most excellent breakfast to the field, and I had the honour of wetting my lips in this cup. It was filled with capital cherry-brandy (no bad jumping-powder in this country of drains), which went down the better for looking at the inscription on the outside. Long life to this man, and all of his sort! said I to myself, as I put the massive tankard to my lips.

We had this day twenty minutes over the open, very fast, from Catwick whin, and puggy, thinking it time to shift, got into a drain, from which the hounds drew him, and were rewarded with his blood for this business-like burst. It certainly was very quick-so much so, that Captain Dowbiggin pronounced it the fastest twenty minutes he had ever seen. We then partook of Mr. Bethell's hospitality, who gave us a most excellent luncheon at his handsome seat at Rise, 
and found again in Hattield whin ; dusted him so severely in covert that the puff was out of him ; and we turned him up also in the open, after a ten minutes' race - the hounds never ten yards from his brush.

It always gives me additional pleasure to speak of persons, male or female, who preserve foxes-themselves not partaking of the sport. There is a good deal of merit due to such conduct; for, to say nothing of game preserves and the poultry-yard, it does not, I admit, improve the neat appearance of a gentleman's grounds to have a hundred horsemen gallop across them after a wet night, as was the case at Rise; although no real injury may be ultimately sustained by the land. I have here, however, an anecdote to relate of Mrs. Bethell, the fair partner of the gentleman I lave been speaking of, which every true sportsman must admire her for. On one occasion, the season before last, after a capital run of an hour and a half, Mr. Hodgson marked his fox to ground in Rise Park; bolted him, and killed. Mrs. Bethell said, "Oh, Mr. Hodgson! after such a run as this, the late Mr. Bethell * uould not have killed his fox!"

Thursday, 8th.-The Holderness met at Scorboro, five miles from Beverley. It blew a hurricane, and rained in torrents, but they killed their fox from Elton whin, after thirty-five minutes' slow hunting. I afterwards dined with Mr. Hall of Scorboro, whose son, a rery good performer over a country, I was acquainted with, by having met him at Mr. Osbaldeston's at Quorn. His place-not on a very large scale-is one of the neatest and prettiest I ever met with, quite unique in its way.

Friday, 9th.-Breakfasted at Burton Agnes, the beautiful and justly-celebrated seat of Sir Francis Boynton.

The Baronet and his lady accompanied us to Sir Tatton Sykes's hounds, which met at a covert about five miles distant. It was a fine whin, in a wild country, not far from the sea, but held no fox this day. We afterwards found in Barnston whin, a very large and strong covert, and too large for hounds to press a fox in, as they should do to make him fly his country. A few rides cut through it would be of signal advantage. Barnston whin was formerly within the limits of the Holderness Hunt, but withdrawn in consequence

* A gentleman of this name who ouce hunted the country. 
of some misunderstanding between the proprietor and a quondam master of those hounds. Were this proceeding to become general hunting countries wonld not be long kept entire, and great confusion would be the result.

We had no sport worth speaking of on this day; indecd the scent was very indifferent; but the short run afforded me one anecdote, perhaps worth relating. A fox went away at last from Barnston whin, taking a ring over a nasty wet country. I made the best of my way over it, riding inside the hounds, till we came to something like a poser. It was a deep and boggy drain, with a black and rotten bank to jump upon, and, as the Irishman said, " another river on the other side." It was far from agreeable; and the more we looked, the less we liked it. A pause ensued. "The hounds are turning to us," said I. "That admits of a doubt, Sir," said Mr. Welbourne, a tenant of Sir Francis Boynton; and gallantly charged the fence. As I expected, the bank let his horse in up to his houghs, and when I saw him, hor'se and all, well landed in the second drain, I thought it was my turn to say something; so comforted him by exclaiming, "That, Sir, admits of no doubt." I then put my horse at a fresh place, but that "admitted of no doubt:" headlong we went into the next field, and although little Shamrock did contrive to throw me clear of the water, yet we both got up completely piebald: the white blaze down his face was no longer visible; and when I looked at the cords and the boot-tops, I might have sung with Ovid,-

"Qui color albus erat ; nunc est contrarius albo."

Two more of the field-all I believe who came our line-were also floored at the same fence, and one of them was dragged a hundred yards by his stirrup. His boot came off and released him from his awful situation, or the consequence might have been dreadful.

Of all fences, the most certain floorer is what is called a double, with unsound ground between the two ditches or drains. The impetus from the leap being added to the weight of the horse and his rider, causes of course very considerable pressure from the hoofs; and if the ground is not able to resist it, all spring to encounter the second difficulty is lost, and a fall is the result. 
I had the pleasure of spending the evening of this day at Thorpe, the seat of the Lord Macdonald. It is beautifully situated in a snug vailley on the edge of the wolds, with every convenience for a large family; but his Lordship only resides here during the winter months, having a fine place in Scotland.

In the morning, as we had a long distance to go to meet the Holderness hounds, we were in the breakfast-room betimes, owing to which, in addition to a sharp hoal-frost, we got to Brandsburton Moor about two hours before Mr. Hodgson arrived with his pack, so tender was he of his hounds. This being a favourite fixture, there was a large field-considerably more than a hundred. With the exception of the hounds getting no blood-three foxes going to ground, two of them in rabbit-burrows-this was a good day's sport to hard-riding men, for in each burst the pace was tremendous; and the last was rather more than a burst, for it exceeded forty minutes, taking the puff out of most of the nags, and causing some of them to stand on their heads instead of their legs.

On Sunday afternoon, Mr. Hodgson accompanied me to Bishop Burton, three miles from Beverley, the seat of that very eminent sportsman Mr. IVatt. After an excellent luncheon we looked into the paddocks, where I was in hopes of seeing Manuella; but she was not there, neither were any of his best mares. All the racehorses in work were at Scott's stables at Malton.

Mr. Watt is an admirer of the chase, and generally is seen by the covert's side twice a-week. Although, perhaps, there may be keener sportsmen, there is no man who wishes better to fox-hunting.

Monday, 12th.-.The Holderness hounds met at Elton, about four miles from Beverley, but we could do nothing with hounds on this day. The moment they were thrown into covert I saw it was a hopeless case; for they were rolling and staring about them from want of something better to do. We at last hunted a fox to Bishop Burton, and after losing some time in getting through Mr. Watt's paddocks, we hunted him back to Elton, and killed in the covert he was found in. It was a wretched scenting day; and I well remember that, over a very large ploughed field, only one hound (Render) could speak to him.

The Holderness Club consists of only twenty Members. They 
dine together once a month, and the IVednesday I was at Beverley happened to be a Club day. We had a large muster of Members; the dinner, at the Beverley Arms Inn, was very deserving of praise; the wine, the property of the Club, so-so ; and a ball at the assembly rooms for a finish.

The following would be a very posing question to me:- "Who do you esteem the most zealous fox-hunter-the man fondest of everything relating to hounds and hunting, that you have met with in life?" I think I should reply, either Squire Osbaldeston or Tom Hodgson; for I really think the question rests between those gentlemen. I need not say that it has not been in the power of $\mathrm{Mr}$. Hodgson to hunt hounds six days a-week, as Mr. O. has done; and for the best of all reasons; namely, every one knows he has not had the stuff to do it with; but by my soul I believe, if he could keep his eyes open without sleep, he would be with his hounds by day and by night. No hen appears prouder of her brood than he does of his staunch little pack; and well indeed do they requite his pains. Perhaps no man in England does so much work with so small a kemnel of hounds, for', with only twenty-two couples of old, and nine of young hounds, he hunted three times a-week throughout the whole of last season; and such has been about the state of the case since he has had the Holderness country. With this strength, he killed his thirty brace of foxes last hunting season, which I call great doings.

Encouragement is the soul of enterprise; and although Mr. Hodgson's subscription is not more than $1000 l$. per annum, yet he is supported by the good wishes of all descriptions of persons, and particularly by those of the yeomen and farmers-no bad criterion by-the-bye of doing things right and straightforward between man and man.

Mr. Hodgson, I should imagine, spends more time with his hounds than any gentleman-huntsman in England, and, I may venture to add, or than any other. He attributes, indeed, the extraordinary work they do for him to his walking them out so often on non-hunting days, by which all stiffness of the joints and soreness of the feet are greatly relieved. Dogs, we know, of all descriptions are much given to sleep on a full belly; and on the morrow after a 
hard day's sport, hounds would scarcely quit the benches after feeding were it not for being made to do so. Mr. H. frequently walks out his pack as often as six times a-day, and I was told it was nothing very uncommon to see him doing this by moonlight. Indeed, as far as kennel-work is concerned, Mr. Hodgson is certainly the most painstaking huntsman I ever came across in my life. In the field his skill is also acknowledged ; and there is little doubt but that time and experience will place him in the front rank; - zeal like his will not be denied!

There was one disadvantage as a huntsman to a pack of foxhounds in a deep and high-scenting country, that Mr. Hodgson laboured under when I was at Beverley, which I hear he has this year rectified. His horses, although good fencers, did not possess sufficient speed to place him where he ought always to be when his hounds come to a check. No man can ensure being at all times present with his pack; but the less his eye is off them the better, and he should always be able to break away from the crowd.

In the summer MIr. Hodgson lives with his father, at Sugfield, near Ferrybridge, but of course in the hunting season he takes up his abode at Beverley. Trifles light as air mark the character of a man, and here you see Tom Hodgson in his real form-the true sportsman, giving up everything to fox-hunting. His crib is close to the kemnel and the stables; and, as it has been pronounced by a master of fox-hounds "to be better worth secing than a palace," I cannot do less than describe it. It consists of but two rooms; one for himself, and one for an old woman who waits upon him. The furniture of the master's room consists of a turn-up bedstead, a sofa, half a dozen chairs, and a table; but here he can do what no man can do in a palace. As he lies in his bed, he can open his window, shut his door, stir the fire, and rate his hounds if he hears them quarrelling in their kennel. His walls are ornamented with some excellent prints of sporting characters-himself $i n$ caricaturâ among the rest-and the place is altogether of a piece. We are not all rich enough to purchase the pleasures of Corinth, as an old proverb has it; but the riches of a Caliph could not make this man happier than I have seen him in his crib at Beverley, within hearing of the sweet music of his pack. 
Too nice a taste-in no matter what-is little less than a curse. He who is pleased with nothing short of perfection has less pleasure and less happiness than one who is more moderate in his expectations and desires. When I entered the Holderness kennel, I did not expect to see a complete and perfect pack of hounds, such for obvious reasons being within reach of but few; but I was confident I should see a good style of animal, hounds looking like doing business, and drafted down, as the old man's cats were to those only which would kill mice. No Modishes and Merkins kept, as I have seen them kept, because they were too handsome to hang, and too bad to give away; but almost every hound in Tom Hodgson's kemnel looked, like his master, as if he kneu hou to kill a fox.

There is a hound in the Holderness pack worth his weight in sovereigns-one of the best and closest hunters I ever saw, and he appeared quite without a fault. $\mathrm{He}$ is most appropriately named Pilot, and in truth he is a capital steersman when any diffieulty occurs, at the same time that he runs quite up to the head. He is a three-year-old hunter, and appears in the list as got by Mr. Ward's Palestine out of the Badsworth Harmony-the Duke of Grafton's Roderick blood-and drafted, I believe, for the Badsworth kennel. Another hound of the same year I considered particularly goodviz. Leveller by Lord Lonsdale's Leader out of Lord Yarborough's Merry Lass-his Lordship's old Wildair sort: also Justice (very clever, and a hound of great power), one year younger, by Mr. Osbaldeston's Jasper out of Sir Bellingham Graham's Jealousy : Comrade, same year, a capital sort, but don't exactly remember what.

The Holderness country has been established many years, and is one of very considerable extent. Speaking geographically, it is bounded by the German Ocean, by the river Humber, by Houden, by Pocklington (fourteen miles from York), and Bridlington, on the coast, eighteen miles south of Scarborough-which two latter places may be called its corner points, and about thirty miles apart. From North to South its extent is full forty-five, from East to West thirty-six miles. It is only interrupted by Barnston whin and Burton Agnes, and abounds in corerts and foxes. One half of 
it is composed of that part of Yorkshire called Holderness, and the other half the wolds and low country extending nearly to Houden. The river Hull divides Holderness from the wolds. The air of the former is soft and humid; of the latter such as is generally experienced on situations of a similar altitude.

My opinion of the Holderness country is, that it is a rare one for hounds, but, after much rain, a cruel one for horses; and I must say is too deep to be pleasant. On some days the best hunter in England may be stopped in ten minutes, if ridden at the top of his pace; for in some parts there is no chance to bring him round again by getting on a dry headland or a bit of sound ground. It is sop, sop, all the way, and the dark colour of the soil plainly denotes its quality. As for the drains, it appeared to me as if more has been said about them than is needful; as I don't think they present themselves oftener, or are at all more formidable, than the brooks in parts of Northamptonshire, Warwickshire, Leicestershire, and one or two other Midland counties. I saw but one that appeared impracticable, and that was shewn me on my road to covert. Perhaps I was fortunate; but those we met with in chase, whilst I was in the country, were such as no hor'se fit to be called a hunter ought to be appalled at. The horses of the country make easy work of them, by, where the ground is sound, creeping down the banks on the rising side, and then taking the drains in a stand. Notwithstanding, it requires a good hunter to get well across Holderness, and a man on his back who knows how to ride him. If he is wantonly pressed, he must stop; and there must be times (when hounds run hard) when every advantage must be taken, and ever assistance given him. As for the fences in Holderness, they are the common hedge and ditch, without binders, and therefore only require a steady horse, and a good finger on him, to get over them without much danger of falls, that is to say, when the puff is in. When it is out, a molehill and a mountain are much alike.

The Holderness country has changed masters sereral times within the last ten years. The first of these mentioned to me was Mr. Digby Legard, whose sons are now going well, particularly Mr. George Legard. After he left it, it became vacant for some time, a gentleman by the name of Hill hunting it part of two seasons. 


\section{NIMROD'S HUN'TING 'TOUR}

Mr. Hay (late of the Warwickshire) had it after Mr. Hill, and hunted it a year and a half, declaring it was the best scenting country in all England. Mr. Osbaldeston once had a turn at it, but I believe for not more than half a season. Then came Mr. Hill again, and to him $\mathrm{Mr}$. Hodgson succeeded, this being his fourth season.

The amount of the subscription to Mr. Hodgson was not more than $£ 800$ the first year, but increased afterwards to abont $£ 1,000$. That it will continue to increase, I cannot doubt; for he has shewn excellent sport; and as far as himself is concerned, no man can be more popular or more really deserving of encouragement.

There is one characteristic of the Holderness country which must be highly flattering to the gentleman who hunts it. The farmers are, to a man, not only preservers of foxes, in the common meaning of the phrase, but they go beyond that; for they will not have a fox killed, even with hounds, if they can any how save his life.

I must say a word in favour of Will Danby, Tom Hodgson's first whipper-in. He is quite as much a devotee as his master, and a most obliging, civil fellow; a good and bold horseman; and by no means particular about a fall or two.* He lives, like his master, but a short distance from the kennel, and has, what is called "a very tidy woman" for his wife, and a very pretty litter of cubs. The following anecdote is much to his credit:- "Will," said his master, "I hope next year to raise your wages."-_ "Lord, Sir," replied Will, "I wants no more wages. I am as happy as a man can be; only let me be with the hounds, and I wishes for nothing more." Oh what a lesson does Will Danby give us! What a compliment to Tom Hodgson and fox-hunting.

In consequence of the long-extended drought of the summer before last, the price of hay was exorbitantly high in many parts of the North of England. Singular as it may appear, that consumed by Mr. Hodgson's stud at Beverley was purchased in Smithfield Market, London, and sent down by water to Hull. It was thence

* He got one rattler when I was in the country. I asked him the next day how he was. He replied, he was quite well, only he felt rather queer about the head. 


\section{YORKSHIRE}

conveyed gratis by some sporting farmers to Beverley, and, when lodged in Mr. Hodgson's buildings, cost him only six pounds per load of eighteen hundredweight.

There are a few very hard riders in the Holderness Hunt. The following are very good indeed, and would go well in any country: -the Hon. Alexander Macdonald; the two Messi's. and more especially Mr. George Legard; Mr. James Hall; Mr. W. Barkwith of Hessle; and Mr. John Smith of Hull; also Mr. Watson of Wandby, a gentleman farmer, always well mounted, and as well inclined to go. Report spoke highly of him in other respects, as what the Sporting World calls "a good sort of fellow." There is a Ir. Thompson, also a farmer, residing at Harpham on the wolds, who is a good performer, and also a good sportsman. But what I call the clipper of this Hunt is a farmer of the name of Medford, on his little ewe-necked grey mare. Mr. Medford resides at a place called Carlton in Holderness, and although he is so far north, and in the provincials, I should be inclined to say he was not far from being a match for those crack Leicestershire yeomen, Dick Christian and Mr. Thomlin. I had my eye upon him one day in one of the very fast things we had over Holdemess, when the ground was cruelly deep. He went off at score with the little grey mare; but, as it will happen sometimes, every turn he made was wrong, and from the pace the hounds were going and the state of the country, I despaired of seeing him in his place again. My fears were groundless; he got upon the line; and putting his head as straight as a crow could fly, was soon to be seen cheeking the leading hounds, and going quite at his ease.

There is one gentleman who hunts with these hounds of whom I must make very honourable mention, although I know not exactly whether he can be called one of the Holderness Hunt, as he resides principally with his father, the well-known and highly-respected Major Bower, of Welham, near Malton, a great man among the long tails. I am here alluding to his second son, Mr. John Bower, whom I hesitate not to pronounce as fine a horseman as ever touched a bridle, with undaunted courage, and a capital eye to hounds. Mr. John Bower is very well known in the Burton Hunt, Lincolnshire, where I understand the general opinion is, that he is 


\section{NIMROD'S HUN'IING 'TOUR}

quite a master-man in the field; and, as the best hands generally are, free from either presumption or conceit.

Mr. Alexander Macdonald is one of the quick ones; and as his hor'ses are all thorough-bred, and his nerves thorough good, it will take a very quick man to beat him. But he is good at everything, and is popular everywhere. His brother-in-law, Lord Hopetoun, also goes a great pace for his weight, and has one most extraordinary hunter in his stud. He has all the strength, and indeed some of the appearance, of a waggon horse, but is as fast as the wind, and can jump anything. His Lordship puts him along at a merry pace.

Although the heroes of poetry must be exalted somewhat above the level of ordinary men, yet fault has been found with Virgil, for uniting too many perfections in one man-for then he becomes a prodigy, and all interest ceases. This is the case with his hero Æneas. On every occasion, save his amour with Dido (but what man of gallantry could have done less?), he calls him pious, and makes him appear quite equal with the gods. Let me then beware how I fall into this extreme in describing such a man as Tom Hodgson. True it is, his being a master of fox-hounds, and hunting them himself, goes a great way with me, and I should like to add one feather to his plume; but really that plume is full. All who know him are unanimous in his praise: every one render's him this homely homage-Tom Hodyson is, all over, a man.

Speaking of Æneas, and speaking of piety, why should not my hero be styled pious? Among my fox-hunting friends I know of no one so steady to church as Tom Hodgson: he is really what old Leech would have called a church glutton; for he is not content with morning service on Sundays, but often attends again when the lamps are lit. Now too much of a good thing is worth nothing, and it is possible a man may have too much church. Even devotion itself will now and then require rest; and, as Dean Swift has told us, people will sometimes sleep in their pews while the parson is dreaming in his pulpit. Thus it was with the Master of the Holderness when I was at Beverley. "Do you take Vengeance out to-day?" said I to him on the morning of the Monday we met at Elton. "Why, no," replied he; "I settled that point last night 
in church. I fell asleep in the sermon, and dreamed she was running hare like the d-l."

Dreams are only our waking thonghts, and dreaming of hunting by night is by no means unnatural to one who thinks of little else by day.

In sleep, when fancy is let loose to play, Our dreams repeat the business of the day : The judge in bed will argue fresh his cause, And o'er and o'er again dispense his laws. The jockey dreams he rides a winning race, And gnides his courser with a Chifney's grace. The huntsman draws his coverts o'er again, And finds his fox, coil'd in his well-used den; Enraptur'd thinks he hears the woods resound, And faintly halloos to some fav'rite hound. The poet takes his night.cap for the bay Stript from the brow of Dryden or of Gay.

Thus went Tom Hodgson to his chureh to pray, And well resolv'd his evening prayers to say: Say them he did; but when the learn'd Divine Monnted the pulpic, and began to shine In theologic lore, Tom fell fast asleep, And dreamt his hounds were running hares, or sheep. (Believe, me, Rearler ! this is nothing new, Tom gets many a snooze in this snng pew.) "Get forward, Will," cried he, "and stop those hounds, I hear them running hare like h-ll."_-"Zounds!"

Said his friend; "why, Tom, you have forgot The place you are in! "- (waking) "Oh ! no, I have not," Said Tom; "where dre we now ?......in the Lord's Prayer? (Sleeping) Oh, Will ! that Vengeance always did run hare."

From Beverley I proceeded to York, where I arrived in the night of the 12th of March, and took up my abode at the Black Swan. On the following morning I went to have another look at the York and Ainsty fox-hounds, but have no recollection of the place of meeting, any farther than it was ten miles from York on the Boroughbridge road. I overtook the pack about seven miles on the road, and found they were not accompanied by their huntsman, who was ill. The hounds could not run a yard; so I trotted home, and dined with Mr. George Swann.

Thursday, 15th.-Met York and Ainsty at Nun Appleton village, 


\section{6}

\section{NIMROD'S HLNTING 'TOUR}

ten miles from York. We hunted a fox, that had stolen away from one of Sir IVilliam Milner's coverts, for some distance; but owing to a false halloo, and two or three other awkward circumstances, we conld do nothing with him. Found again on Askham bog, but the day was very stormy, and, we had not any scent. There was a large field out, several of whom belonged to Lord Harewood's Hunt. In the evening of this day I went to Whitwell to dine with Sir Bellingham Graham, and with the intention of hunting the next day with Sir Tatton Sykes, but was disappointed of my horse. Sir Bellingham also moving off to Norton Conyer's as soon as breakfast was over, rather put me to my shifts for something to fill up the morning; so I determined on looking at Castle Howard, the magnificent seat of the Earl of Carlisle, and one of the greatest Lions of Yorkshire. It was formerly a place of great strength, where many battles were fought-particularly in the reign of King Malcolm, of Scotland, who laid waste this part of Yorkshire, and deluged its soil with some of England's best blood.

I was given to understand there are some good riders in the York and Ainsty country, exclusive of those I had the pleasure of being known to. Among them I heard the names of Mr. J. Agar, Mr. J. Clough, and a young one of much promise of the name of Smith, a son of Colonel Smith of Placeville.

Of the huntsman, Naylor, I shall begin with paying him a very handsome compliment. The splendid condition of this pack was not eclipsed by anything of that description which I met with in Yorkshire ; and he has the greater credit here, from the circumstance of his hounds being obliged to sleep out once a-week at least, and sometimes oftener. I shall ever maintain, that, whether in their kennel or in the field, there was a brightness of skin, a liveliness of carriage, an evemness of flesh, and something altogether about the York hounds, which denoted a master-hand at home.

In the field, although I had but small means of judging of him, I do not think highly of Naylor as a huntsman-certainly not so highly as he thinks of himself. I consider Naylor a huntsman of very average capacity, and particularly so for the time he has been with hounds. However, "there is one glory of the sun, another of the moon, and another of the stars; " all men are not equal, and the 
best of us have only as much knowledge as it has pleased our Maker to give us, and no more. Jack Wilson, the head whipper-in, stands with the country, being accounted rather better than common.

Among other qualities, Naylor is considered a wag, and plumes limself upon now and then saying what he considers a good thing. Whilst I was at York, a gentleman rode up to him, and addressed him thus:- "Now, Naylor, you nust mind what you are at to-day: Nrmod will be out, and will have you in black and white." - " Lord bless you, Sir," replied Naylor, "why I have forgotten more than Ninrod will ever know." A sharp rebuke this; and all I have to say is, that I think I have read that Wisdom raunteth not itself, and is not puffed up; but God help the man who knous only what Mr. Naylor has forgotten! However, there is chaff and cockle in the best grain; so enough of this. Naylor is a good and faithful servant, a capital kennel huntsman, and therefore entitled to great praise: but we all pay the price of celebrity, and so must he.

On Friday I returned to York, for the purpose of meeting the York and Ainsty hounds the next morning. I sent a horse to covert, and set out after him; but the day was so tempestuous that I turned back on the road, and the very keenest of the sportsmen were obliged to give it in, and return home, drenched to their very skins. The evening proved fari, and I despatched my horses to Easingwold, on their road to Raby Castle, whither I was under engagement to follow them on the suceeding Tuesday.

Accordingly, on Sunday the 18th, I took leave of York, and went to Norton Conyer's on my road to Raby Castle. I arrived just in pudding time, and was happy to find the worthy Baronet had nearly got the better of his painful complaint, and was recovering the effects of his bad fall.*

On the 19th, I proceeded to Raby Castle, where its Noble owner had arrived only two days before from rather a long visit to London, having been very reluctantly detained by what he most appropriately

* Whilst I was absent from Yorkshire, this sporting Baronet got an awkward floorer with Sir Tatton Sykes's hounds. 'They had been going very best pace for about a quarter of an hour, when his horse wished to decline a very awkward fence. His rider, however, was not to be denied; and the consequence was the fracture of the collar bone and other severe injuries. 
termed the question of the d-d Corn Bill. "Did Lord Darlington change horses here on Sunday?" said I to the landlord of Catterick Bridge inn. On being answered in the affirmative, I inquired after his health. " His Lordship was very well," replied Mr. Fergusson ; " but when he comes down from London, he never looks so well as he does when he goes up; he never looks litie himself till he has had a bit of fox-hunting." - "Aye, aye," said I ; " that is the medicine of life : there is no such balm in Gilead."

It is an eighteen mile stage from Catterick Bridge to Raby, and as part of it is a bye-road, with a great many gates to open, I found that I should do no more than just get in time for dinner; and losing that at Raby is no ordinary joke. One appetite, however, was highly gratified even in the jumbling a hack-chaise. The approach to Raby is a feast to the eye sufficient to satisfy the veriest glutton for the sublime and grand; and when the noble Castle, with its stately towers, emblazoned walls, and deep fosse that surrounds it, retaining all their appearance of antiquity, burst with commanding grandeur upon my view, strange ideas presented themselves to my mind. I could not help fancying that, like the planets, Old Time had become retrograde, and that I was on my road to visit a haughty Baron of the feudal ages some three hundred years back.

The entrance into the Castle is particularly grand, and the imposing effect must make that impression on all strangers which it made upon myself. As I drove through the outer gate, my arrival was announced by a deep-toned bell, rung by a porter who inhabits the lodge, and which always announces the approach of a guest. My carriage proceeded at a rapid rate along the embattled terrace, and taking a fine sweep through the inner gate, where a portcullis is suspended, brought me into a quadrangular court-yard, where I concluded I was to be landed for the day. But it was not so. The large folding doors of the great Gothic saloon opened as I approached them, and I found myself, hack-chaise and all, in this noble room. Here were two or three footmen ready to take my luggage, and the groom of the chamber's to shew me to my apartment.

"You have very little time to dress in, Sir," said the groom of the chambers, as he led me through the turnings and windings of the ante-rooms and passages of this huge building: "his Lordship's 
clocks are fast, and he dines exactly at six."- "In twènty minutes," replied I, "my toilet will be completed; but pray let me ask you one question-you have brought me hither, but how am I to find my way to the drawing-room? I shall make a wrong turn and be lost." The groom smiled, and said he would come and fetch me when I rang my bell.

I found the Marquis * and his family in good health and spirits, a small select party as his guests, and everything as I expected to find it at Raby Castle: but amidst the glitter of affluence which is so conspicuous here, there is nothing to chill into awe those who move in a lower sphere of life. If rank and wealth were his boast, the Marquis of Cleveland-like Nebuchadnezzar the King-could bask in the sunshine on the battlements of his palace, and look down in his prosperity on nine-tenths of the world. But nothing is less like the Noble owner of Raby. No; there is in this favoured son of Fortune-and indeed on all who bear his name-a praiseworthy affability that sets perfectly at their ease all those who are in his presence; and it may be asserted of him, as was said of a great character of antiquity, that "no man can be great with so much ease, none familiar with so much dignity;" and herein consists one of the greatest ornaments to rank.

Private character is not within the pale of my critical synod; but in describing such a top-sawyer as the Marquis of Cleveland has proved himself for so many revolving years, it would be unjust to the cause of fox-hunting were I not to exhibit him in his several characters of an accomplished English gentleman and a first-rate English sportsman. In the one, perhaps, his merit may be but lightly appreciated; for to say he is the best bred man in England would be but saying little. Those who, like himself, are placed in the first class of the community, acquire, as it were naturally, that easy deportment which their situation confers on them, and the savoir vivre and the savoir faire become their second nature. As a British sportsman-taking all things into account-I fearlessly assert, he has not his fellow. Lord Cleveland is a sportsman in the real acceptation of that comprehensive term; not one of your battue

* The Earl of Darlington had just been elevated to the Marquisate of Cleveland. 
gentlemen, crawling out when the day is far spent with umbrellas and goloshes; not a speculative, but a downright practical sportsman of the Old as well as the New School ; not afraid of a shower of rain, but ready to face all winds and all weathers with his hounds in the morning, and as boon a companion over a bottle of wine in the evening as ever Bacchus smiled upon.

When we think of Lord Cleveland's possessions, and the stake he holds in life: when we look, I say, at his rank and station, and then recollect that he has gone through all the labour in the field, and a great part of that in the kennel which is attached to the situation of huntsman to so large a pack of fox-hounds as his own, for "thirtyeight seasons uninterruptedly, and with high reputation to himself and satisfaction to the sportsmen who hunted with him;" * when we consider also the great personal hazard to which he must have of necessity been exposed in this long servitude to his hounds; we can scarcely reconcile ourselves to the fact. But so it is; and although it is aifficult to make parallels of men who shine in the same sphere, I have good reason to believe his Lordship is as scientific in his calling as any other huntsman of his day. To appreciate a man's merits we must look to his works; and I assert, without fear of contradiction, that at the present moment there is as fine and indeed as grand a kennel of fox-hounds at Raby Castle as any reasonable man would either wish for or expect.

True it is, a pleasing' recreation is no task. The ministering passion stirs us up, and excites us to deeds we should otherwise shrink from. Such is the case here. The Marquis of Cleveland is passionately fond of hunting, and everything appertaining to " the noble science;" so that he rarely feels fatigue in the pursuit. Even in his dress, we see how he honours fox-hunting. His straight-cut coat and leathern belt bespeak the huntsman as clearly as Ovid says the air and habit of Germanicus bespoke the orator :-

\footnotetext{
"Ere yet he speaks, the orator is seen In all the elegance of garb and mien!"
}

I was going to observe--Were the Marquis of Cleveland an illiterate man, with only a second-rate understanding, something

* See Colonel Cooke's Observations on Fox-hunting, published 1826. 
about the cut of the Squire Westerns of their day ; had Nature been less sparing of her endowments, all this would be far less remarkable than it now appears; but the contrary is the real fact. His Lordship is not only a man of very considerable natural talent, but of highly cultivated acquirements; an adept in almost all languages; and possesses what, in the lingo of the world, is called as good a head as any man in England or any other country can boast of. He has travelled a great deal, and now spends his summers on the Continent; has a turn for the polite arts, as well as the lesser elegancies of life; and never forgets what he hears or sees. If, then, we combine these several advantages with his great knowledge of the world, we may safely conclude that he has never gone a hunting, like Gallus of old, from the want of something better to amuse himself with. Exclusive of all this, he looks most minutely into his private affairs, and business may be said to be the pastime of his leisure hours.

The month of March, and particularly this advanced period of it, affords but few opportunities of detailing sport with hounds. On Wednesday, 20th, we did nothing worth speaking of with the Raby pack. We were unfortunate in chopping our first fox; and our sport with our second, which we ran for an hour, was destroyed by his being coursed by a dog in the first place, and no scent in the second. His Lordship rode Bergami and Moses this day-both very clever horses, and the former a splendid fencer.

We had a considerable addition to our party this day at the Castle, amongst whom I was happy to find some of my Durham friendsnamely, all the family of the Shaftos, Mr. Harland, \&c.,-and we assembled in the state drawing-room.

No hunting on Thursday, so it was only a day of lounge. I accompanied Mr. Milbanke to the village of Staindrop, which is just without the park wall, and where the horses of all the visitors to Raby stand. As Mr. Milbanke and Lady Augusta always take up their abode at the Castle during the residence of the Marquis in the winter, he has built for himself some excellent stables and coach-houses for his own private use ; but my horses stood at the sign of the Fox and Hounds, kept by the noted Bob Williams, for many years head 
whipper-in to the Raby pack. I believe I have already spoken of this said Bob Williams; first, as having lived with a brother-in-law of mine; and, secondly, as having found out a specific for the cure of all complaints of his fellow servants-both male and female; which specific consisted in a fourth part of a cordial ball dissolved in a pint of hot Welch ale. I must not, however, thus lightly pass over this celebrated whipper-in, but give a little history of his sporting career.

Bob Williams came to the Marquis of Cleveland with a capital lot of hounds, which his Lordship purchased from Sir Richard Puleston in 1806 or 1807; and he arrived with them at Raby on a little mare also purchased from Sir Richard, which went by the name of The Puleston MIare; and which, as well as himself, cut a conspicuous figure in "The Operations of the Raby Pack" for several succeeding seasons. She was got by Young Snap, son of the Old HundredHouse Snap, which I believe Lord Forester allows to have been the best hunting blood England was ever possessed of; and there is no doubting his authority.

In whatever capacity we view them, all men receive a turn and character from the several occupations and professions they have followed in life; and I think I never saw a more complete cut of a whipper-in than my old acquaintance Bob. He was also-which is not always the case-quite as good as he looked to be ; and I really believe, which is a great deal to say, he had but one fault; but this ault was fatal to him in his capacity of head whipper-in to such a pack of hounds as were often entrusted to his care-he would get a drop too much, and the morning and the evening were all the same to him.

Now the fact is, Bob, being a Welchman, never paid divine honours to water; but unfortunately for him, he was brought up in the servants' halls of three great Welch Esquires, where ale was dealt out with a very liberal hand; and we all know what a catching sin it is, and how perfectly irresistible it becomes at last. His late Noble master relinquished his services with the greatest reluctance; but what was to be done? Bob's complaint was incurable; and I much fear, that, like a King of Navarre, he is destined to perish in strong waters. He is much shook; and if he had kept the Saracen's Head, 
instead of the Fox and Hounds, I should have exclaimed on seeing him,

At the Saracen's Head Bob turns in ale and wine, Until his face does represent the sign.

As it is, however, we may read thus :-

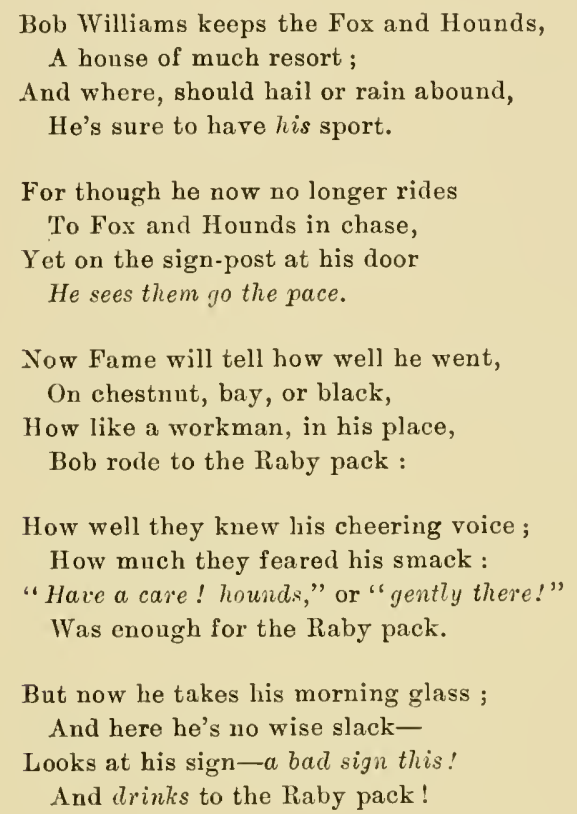

I have before mentioned the two present whippers-in to the Raby hounds: I do not know of two better; and it is delightful to see how devoted they are to the sport. Dick's fondness for his hounds is, I should think, quite unequalled, and the language he uses when speaking of them amused me much. "I like some of your young hounds very much indeed," said I one day to him, "particularly Carmelite and Baby."- " Why, yes, Sir," replied Dick, "I always thought them two very gen-teel hounds." Dick has whipped in to his Noble master about fifteen or sixteen years.

After looking at my horses, I took a survey of Bob Williams's house, and had a little chat with him about old times. "Bob," said I, "we began hunting about the same period of our lives, and have 


\section{NIMROD'S HUN'IING 'TOUR}

been pretty well tumbled about; but I know you have had rather more than your share of hard blows : tell me how you have escaped." — "Why, Sir," replied Bob, "I have been very roughly handled. I have broke three ribs a one side, and two a t'other; both collarbones; one thigh; and been scalped. You remember, Sir Watkin's Valentine?"*_."To be sure," interrupted I ; " as vicious a brute as ever had a saddle on."- " Well, Sir," continued he, " he tumbled me down just as we were coming away with a fox from Marchwiel gorse, and kicked me on the head till the skin hung down all over my eyes and face; and do you know, Siv, (laying an emphasis on those words as if they were intended to convey something more than was expected), when I gets to Wrexham, I faints for loss of blood."-Now after all this, who can wonder that this gallant horseman, and certainly first-rate artist in his line, should like to sit under the shade of his laurels for the rest of his life, and make it a merry one if he cannot make it a long one! Who knows also that he may not have read Tom Moore?

\footnotetext{
"Friend of my soul! this goblet sip,

'T'will chase that pensive tear;

'Tis not so sweet as woman's lip,

But, oh ! 'tis more sincere."
}

Although all conditions of life are equal in the sight of God, "and of a wise man too," says a philosopher; yet there is a wide difference in the treatment of servants by their Lords. Some are peremptory in every command, inexorable to every failing, and use their domestics as brutes; whilst others treat them with great kindness, and for the most part receive kindness in return. In the private relations of life, nothing tells more to a man's credit, or ensures him a better name in the country, than the reputation of being a good master to his servants. When Shakespeare's Lear asks old Kent, Why he wished to be in his service? I think he answers, "Because you have that in your face which I should like to call master." The old boy was no bad judge; for we have heard from very high authority "how good and pleasant a thing it is to live together in unity." In the language of metaphor, it has been compared to the

* Bob Williams commenced as whipper-in to Sir Watkin Williams Wynne, Bart., with whom he I ved several years. 


\section{YORKSHIRE}

precious ointment poured upon the head of Aaron, that ran down to the very skirts of his garment; by which we are to understand, that it extends from the highest to the lowest ranks of life ; and, indeed, without it this world is nothing. I have tried most things; but I am inclined to think that perfect tranquillity of mind is the ne plus ultra here.

The Marquis of Cleveland's servants must have been of old Kent's opinion-that a kind master is a great recommendation ; for many of them are remarkable for their long services. As I am ignorant of a great part of the establishment, I can only speak of a few. Tommy Hodgson I have mentioned as having lived more than half a century in the family; Storey, the butler, as long, having entered it when a boy, and he and his Lord are growing old together. It was to this excellent servant that I before alluded when speaking of the diary of sport kept by the Marquis, and published for a long series of years for his profit. Cicero was not kinder to Tiro than Storey's master is to him; and has honoured him by calling one of his favourite whin coverts after him-namely, Storey's whin. I like to see this: a gentleman should be social in his spirit, unassuming in his manners, and kind to all who approach him.

The coachman bas lived with Lord Cleveland between forty and fifty years, and by the size of his waistcoat I should imagine he has been on pretty good terms with the cook and butler ; Thomas Sayer, who was kennel huntsman, and afterwards porter, the same length of time, and now alive in his retirement; and $\mathrm{Mr}$. Barnes, the house steward, twenty-two years.

Wheatley, his Lordship's private trainer, and cousin to the jockey of that name, has been thirty-five years in his place, and no doubt will complete his half-century, if not called away sooner by One whose commands he must obey even in preference to his present master. In his younger days he used to ride George the Fourth's light weights-Mother Bunch, Mademoiselle, \&c.; as also Lord Cleveland's match with Pedlar against Hippopotamus.

Amidst all the display of wealth and magnificence at Raby Castle and Newton House, there is none of that over-strained and sickly refinement,

$$
\text { "So dull, so vapid, bo genteel ;" }
$$


that I have too often met with in my walks through life; and on the evening previous to hunting days, the groom frequently makes his appearance in Lord Cleveland's drawing-room, to receive his orders from his master's lips. I now want the aid of the pencil; for a Hogarth or a Bunbury would not have desired a better subject for their fancy than Tommy Hodgson would have afforded on these occasions. I will endearour to describe the scene as I witnessed it.

The door opened with an announcement of "Mr. Hodgson, my Lord; " and in walked Tommy Hodgson, presenting a full front to his master. No soldier on parade could present a better; no gatepost was ever straighter ; no Shakspeare's apothecary was leaner; and the succession of lines from the forehead to the chin too plainly shewed that age had traced his cruel way orer Tommy's honest face. Not a word escaped him until the Marquis took his card* out of his pocket, and then the dialogue began. It was a rare specimen of the laconic :-

Is Moses sound?

Yes, my Lord.

I shall ride him.

Yes, my Lord.

Also Bergami.

Yes, my Lord.

Dick, Swing.

Yes, my Lord.

Will, Salopian.

Yes, my Loid.

Lady Cleveland, Raby.

Yes, my Lord.

Edward, The Parson.

Yes, my Lord.

Lady Arabella, The Duchess.

Yes, my Lord.

George, Obadiah.

* List of Hunters, which his Lordship has every day presented to him, noting such horses as are fit for work. 
Yes, my Lord.

That's all!

Yes, my Lord.

[Exit Tommy.

I should here add that all these "Yes-my-Lords" were accompanied with a respectful bob of the head, a partial shutting of the eyes, and the thumbs revolving with the uniform motion of a windmill impelled by the gentle breezes of a spring morning.

Lord Cleveland's complement of hunters is thirty, which, after deducting those for the Ladies' use, leaves about ten for his Lordship, and six a-piece for the two whippers-in. There are, of course, some splendid horses in the stud, and I observed they all possess power much more than equal to the weights they have to carry, which is the grand secret after all in keeping a stable together. Moses (a very fine animal), Bergami, Panegyric, and Sir Hedworth Williamson's mare, appeared the greatest favourites with the Marquis, and they certainly possess an excellent property for: his close country. They are very quiet at their leaps; will poke and creep into them in any way their rider likes; but, when roused, are equal to clearing very great fences.

Raby, Lady Cleveland's favourite horse, must not pass unnoticed. $\mathrm{He}$ is a beautiful animal, fifteen hands three inches high; bright bay, with black legs; and, if he had been bespoken for the purpose he has been put to, could not be more complete. Her Ladyship has ridden him seven seasons, without, I believe, having ever given her a fall; and she rewards him for his care of her by visiting him almost every day in the winter, and giving him some plum bread. Strange to say, he is particularly fond of it, always expressing his delight by a neigh when his fair mistress appears at the door of his box.

The stables at Raby for hunters and coach-horses are on a grand and very extensive scale; and there is a most spacious riding-school attached for exercise in bad weather. There is also a separate yard for race-horses, of which, at the period I am speaking of, there was no great show.

Friday, 23rd.- We found a leash of foxes in Hilton whin, and had a beautiful half-hour with one of them over a very good country, and 


\section{$3 \cdot 8$}

NIMROD'S HUN'TING 'TOUR

quite the ultra pace. Found again : ran into rather a wild country and whipped off, having no scent.

Major St. Paul-brother to the gentleman of that name who formerly was conspicuous in Leicestershire-was out on this day. He rode a clever young horse of his own breeding, and I liked his method of putting him at his fences. "But," said the Marquis, "did you see a gentleman with the hounds this morning by the name of Trotter?" On my answering in the affirmative-" Then," said his Lordship, "you have seen the best horseman I ever saw in my experience in the field. Mr. Trotter has been all his life, not only a most superior rider over a country, but he has ridden with admirable temper and judgment, and never pressed upon hounds." $\mathrm{Mr}$. Trotter must ride at least fifteen stone. He resides at the Deanry, at Staindrop.

Saturday, 24th.-The Raby pack met at Crag Wood, a wild place to look at, but likely to hold a good wild fox. We found immediately, and a beautiful find it was; but our fox was headed by the foot people, and our chance here was lost. TVe found again in Etherley Wood, and lost on the banks of the Wear.-A bad day's sport for the hard riders, but a deal of good hunting.

The turn-out from the Castle this morning was good-in all, I think, nearly twenty red coats and scarlet habits, and the Marchioness was mounted on Raby. Mrs. Wilkinson also joined us at the covert's side, and I had seen this lady once in the field before. Lady Augusta Milbanke rode a thorongh-bred horse, formerly in Mr. Maxse's stable, and one which but few women would have nerve for. He likes to go quick at his fences; but her Ladyship's hand was quite a match for him, and I saw him very well piloted over two or three awkward places. The Marquis rode the bay mare he purchased of Sir Hedworth Williamson, and rode her over a very dangerous place towards the end of the second run. She had to spring at a bank faced with stone, having her footing on large flag-stones in a water-course, which had been rendered slippery by the current. A slip might have been awkward to legs and thighs; but his Lordship will get to his hounds if possible, and that mare is particularly careful and steady.

Billy Williamson was also out this day; and, I am sorry to add, 
met with a serious accident. He rode at a small fence into a road, when his horse fell, and threw him with much violence to the ground. Being close behind him, I was immediately aware that mischief had ensued; for, on his horse and himself recovering their legs, one ran to the left, and the other to the right. There was something very frightful in the motions of Mr. Williamson. He ran wildly down the road, rubbing his head hardly with his hand, for the space of fifty yards, and then fell to the ground. Mr. Harland and myself instantly approached him, when we found all the front teeth of his upper jaw gone, his mouth full of blood, and he complained much of his head. I understand he is all right again now, with a fresh set of ivories; but it is rather a cruel trick for the old Dame to play so goodlooking a young man as he is, and just in the hey-day of youth. I like, however, the way he spoke of the accident afterwards. "I would not," said he, "have taken a thousand pounds for my teeth; but I should not have cared so much for the loss of them, had the accident happened at the finish of a d-d fine run!"

Najor Healey was also out to-day: he is a workman; but on this day he was, like myself, suffering from an injury in his back, and not able to ride over a fence. The IIajor's brother, Captain Healey, goes well, considering he has lost an arm, and his performance did not escape the keen eye of Godfrey Graham. "I say, papa," said he to Sir Bellingham, as he trotted by him on his pony, in the true Harrow-school lingo, "how devilishly that one-armed fellow rides!"

I have stated that the Marchioness of Cleveland was out on this day. She is a most graceful horse-woman; and, when her favourite hunter Brighton, was in his prime, cut a prominent figure in "The Operations of the Raby Pack."

The Ladies Augusta Milbanke and Arabella Vane are constant attendants on the Raby Pack three times a fortnight, which is pretty good work for the softer sex. They have been well entered to hounds from their very infancy; yet it would be difficult to produce two more amiable or accomplished persons. As for Lady Augusta, she is not only a fine rider, but she is nothing less than a sportswoman. She is as attentive to hounds in their work as her noble father himself, and he never enjoyed a fine run more. Then look at the elegant and 
delicate Lady Arabella Vane, of whom it may be said, a hundred years hence,

\author{
"Non illa loco, neque origine gentis \\ Clara, sed arte fuit ; " *
}

and who will say that fox-hunting abates woman's softness?

In the dining-room of Raby Castle is a grand picture of the Feast of Canaan; but I was more pleased with several on sporting subjects. There are three groups of hounds particularly well executed, and a beautiful portrait of the bitch Costive, which may be said to have been the Niobe of the Raby pack. This noted bitch is buried in the pleasure grounds of the Castle, and her cemeter'y is enclosed by a wall.

The picture, by Marshall, of Lord Darlington and his hounds, from which the well-known print is taken, also adorns these walls; and there are portraits of four celebrated hunters and two distinguished race-horses. Amongst the latter are Haphazard, with Pierse the jockey and Sam Wheatley the training groom; and Muley Moloch, with $\mathrm{Mr}$. Hardy Thompson and $\mathrm{Mr}$. Trotter. In short this splendid apartment is quite in character with everything else at Raby.

The kennel at Raby was built by the late Earl of Darlington and the late Duke of Cleveland; fox-hounds were kept in it many years. It is a Gothic ornamented building, conspicuously situated in the park, and possesses every comfort and convenience for the largest establishment of fox-hounds. The Raby hounds are divided into an old and a young pack; and bear evidence of being bred by a judicious hand.

As a horseman Lord Cleveland deserves a word. What most men delight in, that is, a fine-mouthed horse, is far from a treat to him. He rides all his horses with a hard hand, and consequently likes those that will bear against him; and he has a peculiar way of putting them at their fences. I have seen him absolutely make them paw down the hedge before he will let them rise, if there should be a blind and deep ditch on the other side, by which plan he no doubt saves many falls; and he had but one whilst I was in the North. His perfect knowledge of the country also gives him a great advantage in

* Not more conspicuons by her birth than her accomplishments. 


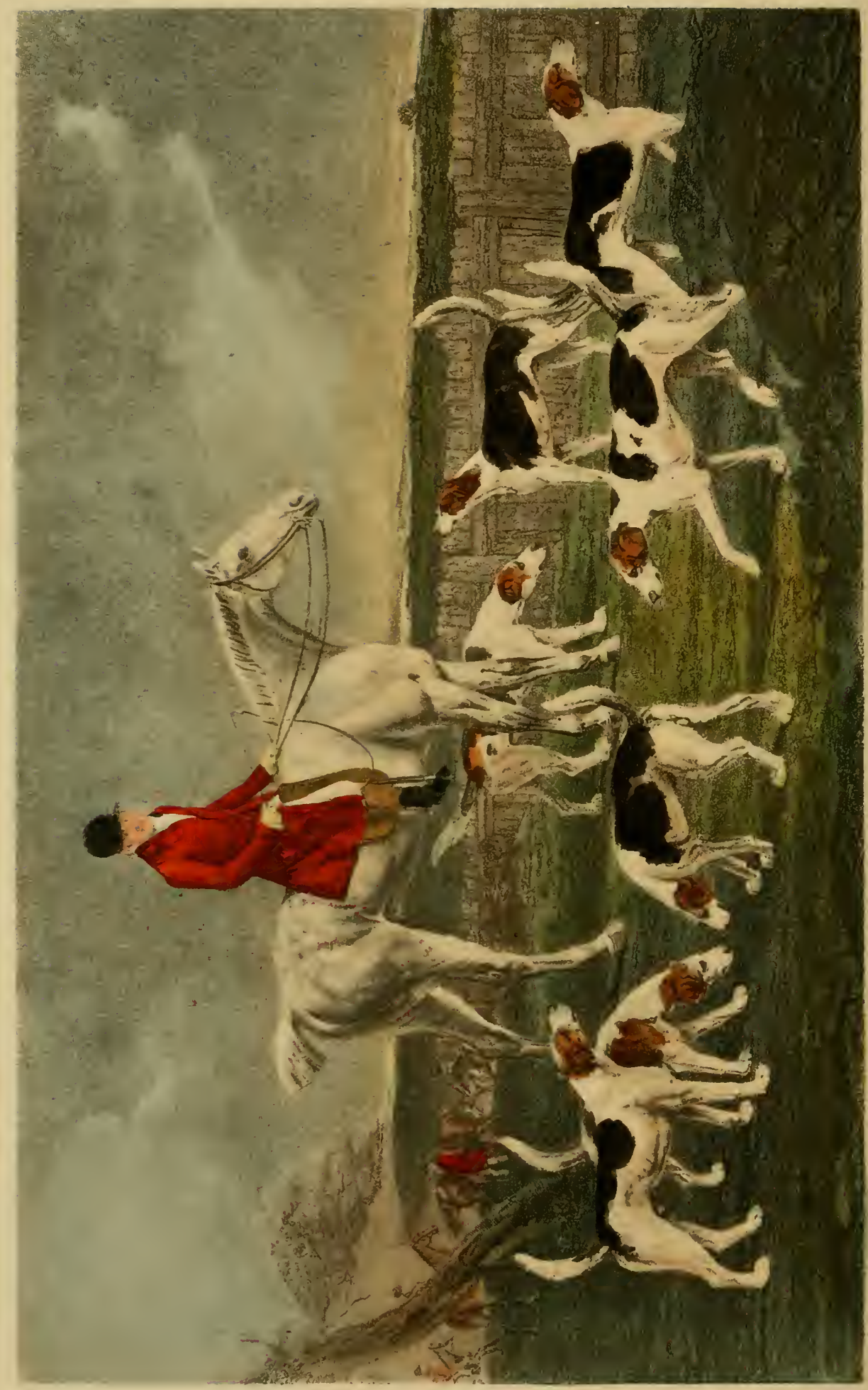




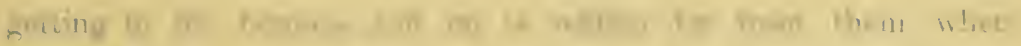
W. utist:-

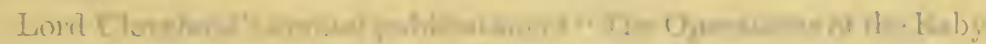

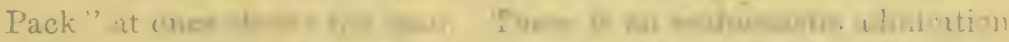

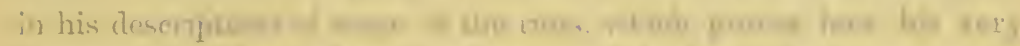

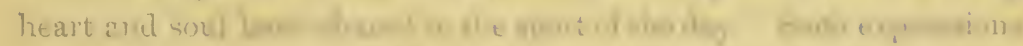

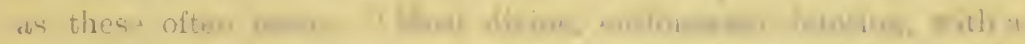

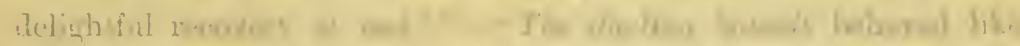

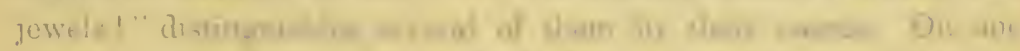

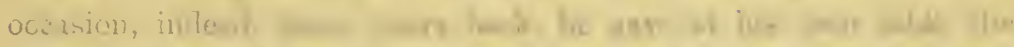

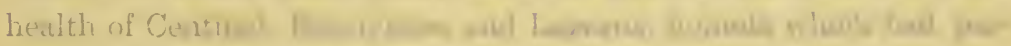

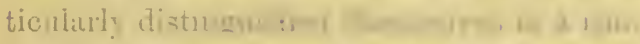

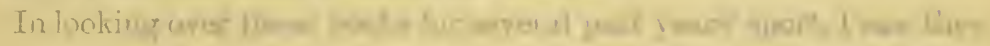

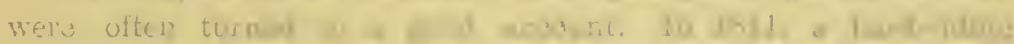

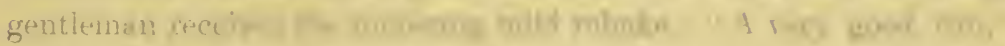

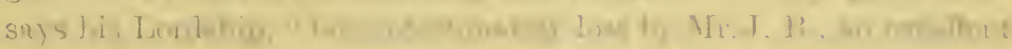

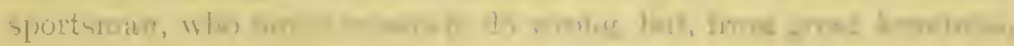
is sonsetmes triff to say to hins.

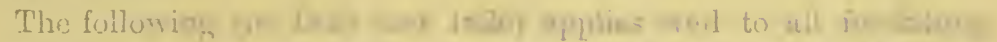

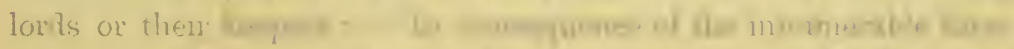

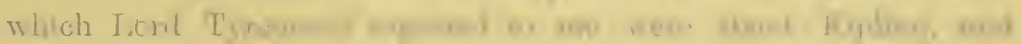

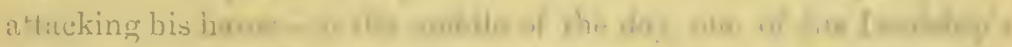

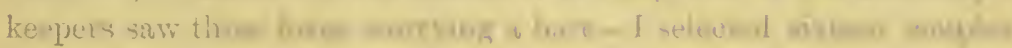

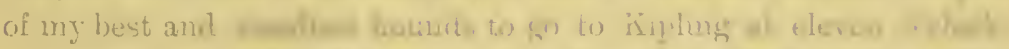

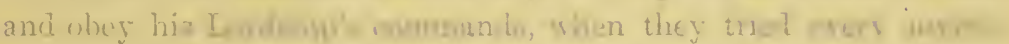

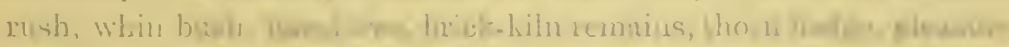

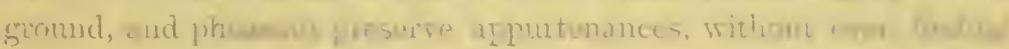

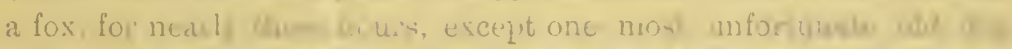

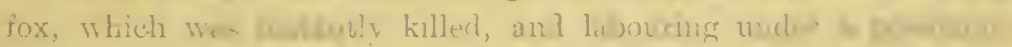

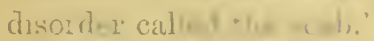

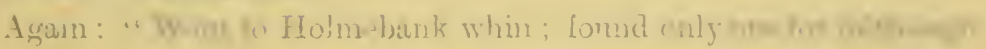

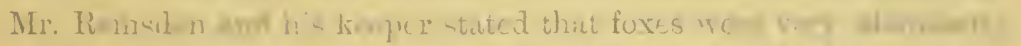

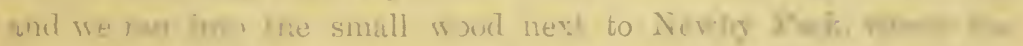

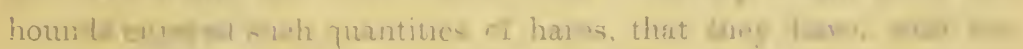

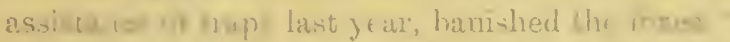

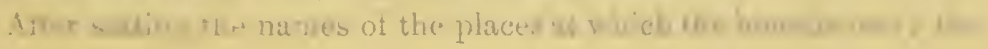




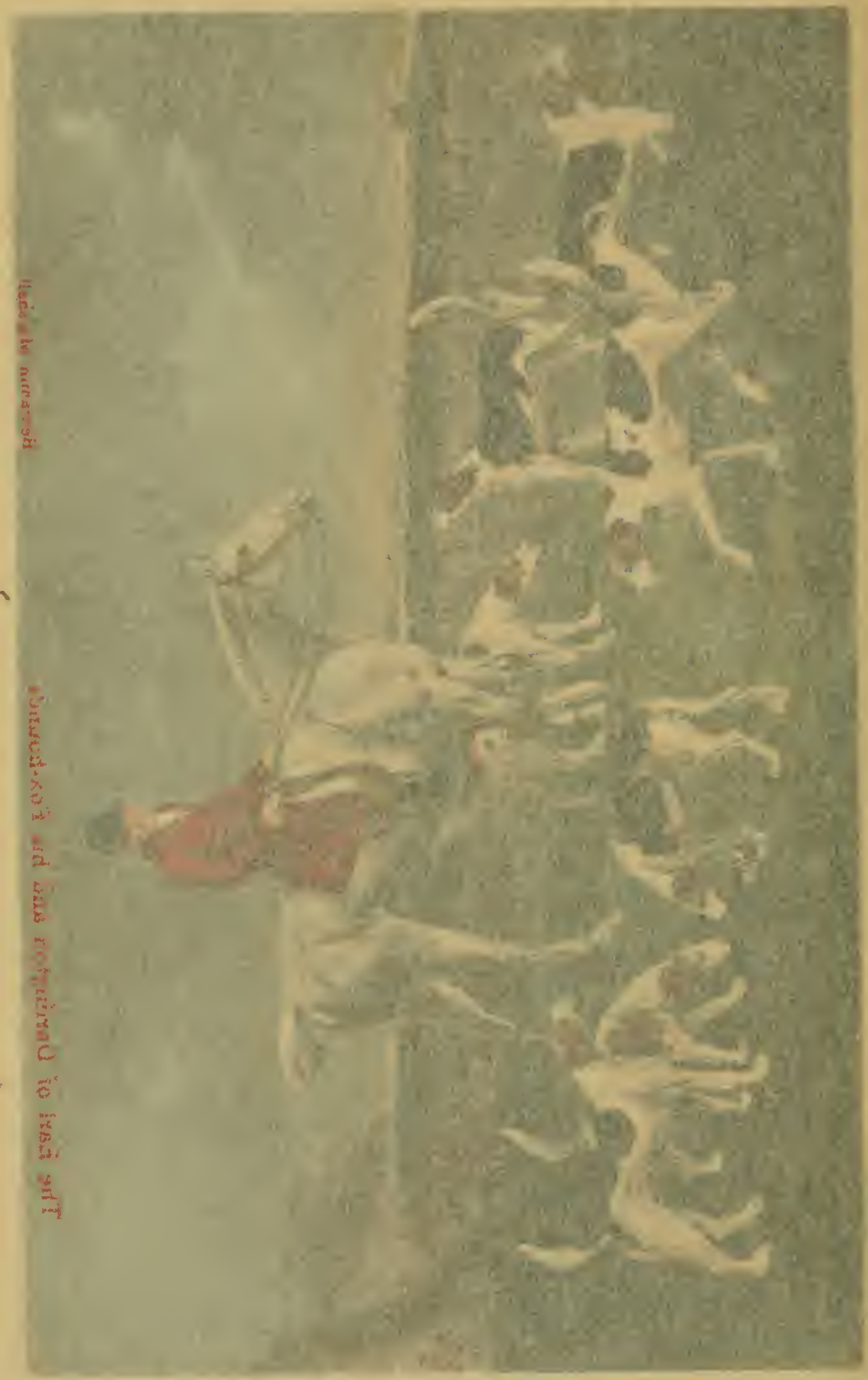


getting to bis hounds, and he is seldom far from them when wanting.

Lord Cleveland's annual publication of "The Operations of the Raby Pack" at once shows the man. There is an enthusiastic admiration in his descriptions of some of the runs, which proves how his very heart and soul have shared in the sport of the day. Such expressions as these often occur-" Most divine, enthusiastic hunting, with a delightful recovery at last!"- " The darling hounds behared like jewels!" distinguishing several of them by their names. On one occasion, indeed, some years back, he gave at his own table the health of Centinel, Bonnyface, and Lazarus, hounds which had particularly distinguished themselves in a run.

In looking over these books for several past years' sport, I saw they were often turned to a good account. In 1811, a hard-riding gentleman receives the following mild rebuke: "A very good run," says his Lordship, " but unfortunately lost by Mr. J. B., an excellent sportsman, who never means to do wrong, but, from great keenness, is sometimes too forward, which, as an old sportsman, I claim a right to say to him."

The following (in 1825 and 1826) applies well to all fox-killing lords or their keeper's:- "In consequence of the innumerable foxes which Lord Tyrconnel reported to me were about Kipling, and attacking his hares - in the middle of the day one of his Lordship's keepers saw three foxes worrying a hare-I selected sixteen couples of my best and steadiest hounds to go to Kipling at eleven o'clock, and obey his Lordship's commands, when they tried every myrtle, rush, whin bush, hazel tree, brick-kiln remains, thorn hedge, pleasure ground, and pheasant preserve appurtenances, without ever finding a fox, for nearly three hours, except one most unfortunate old dog fox, which was instantly killed, and labouring under a poisonous disorder called the scab."

Again : "Went to Holmebank whin ; found only one fox (although Mr. Ramsden and his keeper stated that foxes were very abundant), and we ran into the small wood next to Newby Park, where the hounds enjoyed such quantities of hares, that they have, with the assistance of traps last year, banished the foxes."

After stating the names of the places at which the hounds met; the 


\section{NIMROD'S HUN'TING 'TOUR}

coverts in which foxes have been found; the days on which foxes were either killed or earthed, between the 31st of August, 1825, and the 18th of April, 1826, with a detailed account of each day's sport-this book concludes with a list of the hounds; casualties of the pack; and hounds drafted in kennel: and the following is the result of the season's sport: killed eighty-cight foxes-carthed tuentyone-blank days none!!

There are two or three very clipping riders in the Raby Hunt; and the gentlemen of the black cloth are quite as conspicuous as the pinks. Amongst the former Mr. John Monson is pre-eminent; but Messr's. Newton and Henderson are always in good places. Mr. Milbanke is quite a first-rater, being as quick as any man need to be; and quick must he or any other man be to live with these hounds. Like Bob IVilliams, and a good many more that I could name, he has been rather roughly handled in the field, having been blooded no less than nine times, in consequence of severe falls with hounds. $\mathrm{He}$ is, however, nothing daunted, but will be close to their sterns if possible.

I was also much pleased with the style of riding of Mr. Thomas Maude, of Selaby. Captain Baird I did not see in the field during my stay in the North, but I believe he was unwell. Of that great artist, however, or of Sir Bellingham Graham-who is now a Raby Huntsman-I need say nothing, as I should only waste my words.

Mr. Wharton (the well-known Jerry Wharton) is almost altogether on a visit to Lord Cleveland in the hunting season. He is a good workman, and generally well mounted, having this year a horse Mr. Holyoake offered him 400 guineas for.

Monday, 26th.- The Raby pack met this day at a place with a wild name, and wild also by nature: I think it is called Crain-raw. It is situated on the borders of an open country almost approaching to moors, and affords them some very fine runs with old travelling foxes in the spring. The Marquis promised me a treat this day; but unfortunately our game took the wrong line of country, and we had no great diversion. We found in an unenclosed gorse, but could make nothing of it. We found again, and had a very sharp thing to ground, Lord Cleveland viewing him before his hounds for more than two miles. Bolted him and killed. Did not find again, and drew more country blank this day than I had ever seen with the Raby 
pack. There was a good field, considering the wildness of the place.

Tnesday, 27th.-The fixture Raby, and the turn-out from the Castle was grand - the scarlet habits again mingling with the throng, and the Marchioness on Raby. We found; but our fox taking down wind with very little scent, we could do nothing worth speaking of. Found two more foxes in the morning-chopping one; but in the afternoon we drew one of the fine whins, in the park, when a fox went gallantly away, and gave them a good half hour, very best pace.

There was a fine old sportsman on a visit at Raby Castle on this day, the veteran Colonel O'Callaghan; who, although at a very advanced age, retains all the good humour and gaiety of youth, and was a match at a rubber of shorts for any of them. He resides at Heighington, not far from Raby.

Wednesday, 28th.- - Took leave of Raby, and made the best of my way for Ferrybridge, about eight miles south, where some horses awaited my arrival, and where I intended sojourning a few days to see the Badsworth hounds.

Thursday, 29th.-Met the Badsworth at Hutt Green, about eight miles from Ferrybridge. There had been a ball at York the night before; so that, instead of meeting, as I expected, a large field, with many of whom I should have been acquainted, Jack Richards, the huntsman, was the only man out to whom I could say "how do you do?"

Lord Hawke has had the management of these hounds since Mr. Petre gave them up; and his Lordship, in spite of the ball, which he had attended, was at his post about an hour after the usual time. He very politely informed me that he had enjoyed a good season's sport, and had not been absent from his hounds one day since the hunting season had commenced. This I thought looked very well in a young one.

When I say we found a fox, I have said all. The clerk of the weather was determined we should do nothing; for, what with wind, rain, and snow, a more miserable day no man ever encountered by choice. After drawing Pollington whin, I returned to Ferrybridge, where I was capitally accommodated in every way. 


\section{NIMROD'S HUN'TING 'TOUR}

It would be presumptuous in me to give an opinion of the Badsworth pack after so short an acquaintance, and this with only part of them; but what I saw did not very much captivate my sight. I thought them rather coarse, and wanting that airy form and peculiar scale which characterize the high-bred fox-hound of the present day. Modish and Roman attracted my notice; and on looking at the list I find they have bred from Roman, although they have very little of their own blood on the sire's side. Modish is neat, but of too close a frame to please my eye. I believe she is dam of the York Twister. The pack is small, consisting of only forty couples.

Of their country I can say nothing, for I saw nothing. Jack Richards looked uncommonly well and sportsmanlike, but is a good deal heavier than when I saw him swim the Thame in Staffordshire, when whipping-in to Sir Bellingham Graham, by whom he was brought up; and I used to think him an excellent whipper-in when in his service. Jack Chapel-another of Sir Bellingham's pupilswhips in to Richaris, and a very clever fellow he is; perhaps as fine a horseman as ever sate in a saddle.

Saturday, 31st.--Set out to meet Lord Harewood's hounds, which met twelve miles from Ferrybridge. When I had proceeded about a mile on my road, I found the weather so boisterous that any chance of sport was at an end; and, having sent some horses to Melton Mowbray, turned right about, put myself on the box of the Edinburgh mail, and got to Grantham by dinner. I learnt afterwards that I had acted wisely; for the day, the country, and everything was against sport; and those who reached the covert soon made the best of their way home again.

I was, however, disappointed in not seeing Lord Harewood's hounds. It is an old-established pack, and, of course, there is no want of the means to do the thing well; and money is almost a sine qua non in fox-hunting. A strange circumstance happened last season with these hounds. Their huntsman imprudently capped them into a very rapid mill-stream, and three or four couples were drowned. A young gentleman, named Markham, gallantly plunged in to their assistance, and very narrowly escaped their fate. $\mathrm{He}$ succeeded in saving one of them. 
April 1st.-Arrived at Melton, and had the pleasure of dining at the Old Club. On the 2nd, met Mr. Osbaldeston at Kirby Gatethe Lady pack looking in high beauty, and a thundering large field. Rode Captain Ross's Waterman, brother to Clinker; and, in spite of the Decalogue, could not help wishing he belonged to my stable.

A curious circumstance connects itself with this day's hunting There was a fox which has given these hounds no less than three remarkably sharp bursts from Carberry Hill without their being able to catch him, and he had in consequence obtained the name of the Carberry Hill Fox. What was also extraordinary, he always took the same line towards Orton, and the following are the various periods for which he stood before this celebrated pack: first time, twenty-eight minutes; second time, twenty-five minutes; third time, twenty-three minutes, defeating them on each.* On the day I am speaking of, he did not wait to be found; but we viewed him going gallantly away, and taking his old line-George Marriott close at his brush, with his hat in his hand, hallooing as if the devil was in him; but George Marriott, I suppose, is a privileged man.

As may be expected, all the hard-riding men were on the alert, and hard indeed did those ride who went anywhere near the hounds on this day. The pace was truly awful; but that was not all. If he had picked Leicestershire, this fox could not, I should imagine, have found four or five more distressing fields for the nags than those they had at first to encounter-all against the collar, high ridges with deep furrows, and the latter, between wet and dry, almost enough to pull their legs off. Had it not been for a bit of a check in a road for a minute or two, where several changed their horses for fresh ones, some of the best must have declined; as I heard Lord Alvanley (who went as usual like a good one) say, his horse had just carried him those ten minutes, and that was all he could do. His Lordship, however, jumped on a fresh one at the check, and went on. As Captain Ross's horses had been thrown out of work, in consequence of his having been an invalid, I was only a looker-on; but to any one who had never seen Leicestershire before, this burst would have afforded a very pretty specimen. Sir Belling-

* Mrr. Osbaldeston had another turn at this fox late in the month of April, when he beat him again, after a very severe run over partly the same country. 
ham Graham also declined at the same time with myself, having only taken a peep at them on one of Mr. Maxse's horses, being still unable to ride from the fracture he had received in the North. I finished this day most agreeably under Sir Harry Goodricke's mahogany, where I met several old friends, who, like myself, were partakers of the hospitality and good fare of the truly sporting Baronet.

Tuesday, 3rd.- Met the Quorn hounds at Widmerpool Inn. This was never a favourite fixture with me. The country about Wynnstay gorse is about as bad as anything in the provincials; and it is not only deep, but most disagreeably sticky and holding for horses, of which none but the very best can go there. We drew a good covert, however, on this day, called Par'son's Gorse, and encountered one of the evils attending spring hunting. The pack had passed through without a feather, when unfortunately a farmer espied a fox in one corner of the gorse, and gave the office. It is in vain to attempt to stop fox-hounds with their game in view; and in less than two minutes, a vixen, with six cubs in her, was torn to pieces by the pack. We had a large field; a great deal of hard work for horses, and a beautiful pack of hounds-- dog pack No. 1 .

I was treated this day to a ride on Mr. Maher's Picton, which I call a perfect hunter for the weight he can carry. The free use of his shoulders, in all his paces, is quite above praise. Highly however, as Mr. M. values this first-rate horse, he rode him hack in London in May and June last, and told me he thought it was better for him than doing nothing. Mr. Maher has been a regular Melton man for twenty-two seasons; and his nerve and horsemanship are unrivalled even there. He amused me by saying he had rather ride to and from covert all his life in Leicestershire, than hunt in three parts of the counties of England in which hounds are kept. Met a considerable party at dinner this evening at Sir Harry's.

Wednesday, 4th.-Croxton Park races. All went off very pleasantly and well, with a good display of gentleman-jockeyshipMessirs. White, Kent, Captain F. Berkeley, Lord Wilton, \&c. Returned from the course on Mr. Payne's coach-a beautiful team, and very well handled by Mr. P. ; made one of a very large party at Sir Harry's ; and finished the evening at the Cocking. 
Thursday, 5th.-Met the Duke of Rutland's hounds at Stowe Wood, about twelve miles from Melton, a woodland country, but looking much like the land of fox-hunting:-a very large field, and drew a great tract of country without touching on a fox-partly, perhaps, owing to Lord Lonsdale's hounds having run through several of the eoverts on the preceding day. When we did find, however, we could not get on; for we had two enemies to contend with-a harsh wind and hot sun. The hounds hunted to admiration, and looked in their usual good form; but April hunting is generally a failure.

No sooner is a thorongh-bred hunter seen in Leicestershire than he is sold, if his owner is disposed to part with him. I rode Shamrock at Stowe Wood, and the following morning he became the property of $\mathrm{Mr}$. Middleton Biddulph-at a premium of eourse, as they say on 'Change.

Friday, 6th.-Met Mr. Osbaldeston at Six Hills. Found in Cussington Gorse, the fox taking a beatiful line, as if thinking of Melton Spinney; but there was not an atom of scent. To my surprise we drew Munday's Gorse blank, and a vast deal of country besides, persevering till five o'clock. Amougst a host of sportsmen liom all parts of His Majesty's dominions, was Sir Edward Mostyn, on the Clipper, for which horse he gave six hundred guineas. He is eertainly a very grand animal, although Nature has somewhat defaced her work by griving him white stockings. Went with Mr. Osbaldeston to Quorn, and, although past seven o'elock when we arived there, looked over the young hounds before we fed.

Saturday, 7th.- Met the Quorn hounds at Widmerpool Imn. We were a long time finding a fox this day. At half-past three o'clock, however, Lord Raneliffe's wood at Bumny produced us a good one, and we had half an hour very sharp, but lost him. I rode a eharming horse of Mr. Osbaldeston's, ealled Blucher, and had the pleasure of hearing Mr. Biddulph say he would not take three hundred guineas for little Shamrock, although he ran away twice with him in the run. In the skur'y, that straight-forward one, Captain Frederick Berkeley, got a damper in a brook, but it was a yawner.

Good hounds and sport are not naturally co-existing circumstances. 


\section{:338 NIMROD'S HUN'TING 'TOUR}

Excellent as the Quom packs must be allowed to be, they did not shew much sport last year, with the exception of a few splendid things, particularly one from the Coplow with the bitches, which, I believe, was considered quite the ultra of fox-huuting. They went away close at his brush from this classic ground, taking over the fine lordships of Norton-by-Galby and Oadby, and ran in to him near Wigston, AFTER A BURST OF FORTY-ETGHT MINUTES WITHOUT A check!! There was a trifling pause, I was told, owing to a flock of sheep, but the scent was carried on in a trot, so there was but little relief for the bellows, and only six or seven saw the finish. I need not say these were first-rater's; but, for the honour of that noble animal the horse, I am proud to add, there was one welterweight up at the death-Mr. Maxse, on the Baron.

Such runs as these, in any country, are "like angels" visits, few and far between," but they must be highly gratifying to a master of hounds in Leicestershire; and I can fancy the Squire and Jack Stevens talking over this day's sport on their road home with the pack. "Well, Jack," methinks the Squire to have exclaimed, "thank God we went fast enough for them to-day! There was no occasion to cry Hold hard! no pressing upon the hounds; and I would have bettert a guinea to a shilling on blood after the first ten minutes."

Mr. Oshaldeston's hounds shewed great sport in their new country, Northamptonshire-the natural consequence of having what may be called fair play. I also understand that in his office as huntsman he has been extremely fair towards his foxes, on which subject it would be well if some of his brother huntsmen woukd take a bint. "Murdering foxes," said the great Meynell, "is a most absurd prodigality; for seasoned foxes are as necessary to sport as experienced hounds." That Mr. Osbaldeston's hounds are as good as hounds can be, I think no sportsman who has seen them will deny.

I was delighted to see Lord Alvanley going so brilliantly over Leicestershire, notwithstanding his increased weight, and having been, as we say in the stable, out of regular work for some of the past seasons. His Lordship also, we well know, has been very intimate with "the little hour:s," which the doctors tell us are not 
favourable to the nervons system; but his nerves are equal to the largest fence in Leicestershire, and for pace, he is quite in the first flight.

Lord Alvanley's return to Melton Mowbray has been hailed as a happy omen of perpetuating the renown of reicestershire as a hunting country. Whithersoever he goes, he must act as a magnet; for his presence and conversation may be compared to the Sun's rays, which enliven every hour of the day ; and, as for the night-

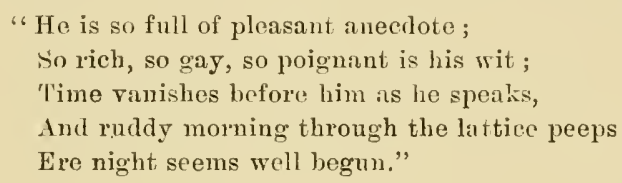

His appearance and costume in the field also amused me much. He wears what may be compared to the Regulation jack-boot of the Royal Horse Guards Blue, the top of which reaches considerably higher than the knee, and doubtless protects him from the thorns and blows he would otherwise receive in cramming through the rough Leicestershire fences, of which he is anything but shy.

On Sunday the 8th, I left Quorn, and proceeded to London on my road home, ordering my groom to make the best of his road to Lyndhurst with my horses, to enable me to top up the season in the Forest.

Having now turned my hack upon Yorkshire, I hegan to ruminate upon what I had seen in it. Its character as a fox-hunting country is comprised in in few words. It is, like all the provincials, too close to enjoy hounds in, and subject to everlasting interruptions from coverts, rivers, canals, and railroads. The plonghed land in some parts may rather be termed rotten than deep-though, generally speaking, this is by no means its character-but in the Bedale country the grass land is particularly sound and dry. The fences, with the exception of the brooks, are such as do not so much put to the test the spring and power of a hunter, as his temper and the ready use of his legs; but the finger of his rider is almost constantly put to the trial. It is a country in which men who ride quickly over it must get falls.

For scent, I should say, Yorkshire is upon the whole favourable, 
and Holderness good to the proverb; but, notwithstanding this, I have reason to think straight-forward runs are scaree articles in this land of sporting. It must, however, be recolleeted, that the majority of the coverts are whin, and ringing runs generally prevail where they abound, which accounts for the ease with which gentlemen now jump upon their second horses in Leicestershire. A fox breaking from a wood has usually time to look about him, steal quietly away, and make his point; but from a gorse eovert he is almost always viewed away, is alarmed, gets blown, and turns short.

As a sporting county, Yorkshire hals no parallel, neitler is it possible it ever can have one. In extent (ninety square miles) it is equal to several of the petty German Principalities; and every man in it-aye, even the Arehbishop himself-is a sportsman. There is not in "boots" at an inn that has not his guinea on the Leger"; and the manufacturer with his apron, who, in other places, knows no more of a horse than a horse knows of him, will take "foive to one" he names the winner. In short, the hor'se is the Yorkshireman's idol; and had Virgil visited its plains previous to writing his first Georgie, he would have assuredly given it the preferenee to Epirtus.

During my visit to Raby, Lord Cleveland told me I missed a treat by not being present at an interview he had with one of his Durham earth-stoppers; but I will answer for it I should not have understood five words he uttered. Language, however, is the dress of thought; and there is something very amusing in the native laconism, as Mr. Pope calls it, of these people, when neatly and aptly applied. The following is no bad specimen. The Marquis was ehanging hor'ses some time sinee at an inn in his neighbourhood, when he expressed a wish that no time should be lost, as he was in a hurry. "Drive my Lord well, lands," said the landlord; "but (by a side wind) mind me-don't oreregy t' pudding." Anglicè, "Don't kill my hor'ses."

The monosyllables cars, yylls, and stells often appeal in Lord Cleveland's book. "What is a stell?" said I one day to a Durham sportsman. "A stell is a beck," he replied. " IVhat is a beck?" added 1. "A beck is a brook," was the answer. "Oh, now I have it," resumed I. 
The character of men's native country is for the most part as strongly impressed upon them as its accent is on their tongue; and such is the case here. The county of York is a proud and bold feature in the map of England, and its inhabitants do not disgrace it. They are good soldiers, keen sportsmen, and in fine manly race, worthy of British soil.

I shall now take leave of the North, by presenting my reader's with a celebrated hunting song, made some year's since on Lord Cleveland's Hunt, when his Lordship had the Badsworth country. Several of the characters mentioned no longer exist, but it was considered a well-drawn picture of the time.

HOWELL WOOD :

OR, “THF HOUNDS OF OLI RABY FOR ME!"

Whilst passing o'er Barnsclale, I happen'd to spy

A fox stealing on, and the hounds in full cry;

'They are Darlington's sure, for his voice I well know,

Crying "Forward! lark forward!" from Skelbrook below.

With my Ballynamonaora,

The lounds of Old Raby for me.

See linchester loads them, whose speed seldom fails, And now let us seo who can tread on their tails;

For, like pigeons in flight, the best hunter would blow,

Should his master attempt to ride ovor them now.

With my, \&c.

From 11 well Wood come, they to Stapleton go, What confusion I sec in the valley below;

My friends in blacli collars nearly beat out of sight,

Aud Badsworth's old heroes in sorrowful plight.

With my, \&c.

"T'is hard to describe all the frolic and $\mathrm{fm}$, Which, of course, must ensue in this eapital run ;

But I quote the old proverb, howe'er trite and lame,

'That "the looker-on sees most by half' of the game."

With my, \&c.

Then, first in the burst, see dashing away, 'Taking all on his stroke, on Ralpho the grey, With persuaders in flank, comes Darlington's Peer, With his chin sticking out, and his eap on one ear.

With $\mathrm{my}$, \&c. 
Never heeding a tumble, a scratch, or a fall, lying close in his quarter, see Scott of Woodhall ! And mind how he cleers them with " Hark to the cry!" Whilst on him the Pcer keeps a pretty sharp eye. With my, \&c.

And next him on Morgan, all rattle and talk, Cramming over the fences comes wild Martin Hawke; But his neck he must break surely sooner or late, As lie'd rather ride oier than open a gate.

With my, \&c.

Theu there's dashing Frank Boyuton, who rides thorough-breds, 'Their carcuses nearly as small as their heads;

But he rides so d-d hard that it makes my heart ache, From fear his loug legs sliould be loft on at stake.

With my, \&c.

Behold Harry Mellish, as wild as the wind, On Lancaster mounted, leaving numbers behind : lint lately return'd from democrat France, Where, forgctting to bet, he's becn learning to dauce. With ny, \&c.

That cagle-eycd sportsman, Charles Branding, behold, lying in a snug place, which needs scarcely be told; But from riding so hard, my friend Charley, forbear, From fear you should tire your thirty pound mare:

With ny, \&c.

And close at his heels, sec Bob Lascelles advauce, Dress'd as gay for the field as if leading the dance, liesolved to ride liard, nor be counted the last, l'retty sure of the speed of his fav'rite Outeast.

With $m y$, dc.

Next mounted on Pancake, see yonder comes Len, $\Lambda$ sportsman I'm sure well descrving my pen ; His looks in high glee, and enjoying the fun, Tho' truly I fear that his cake's over clone.

With my, \&c.

On Methodist percli'd in a very good station, Frank Barlow behold, that firm prop of the nation: But nothing could greater offend the good soul, Than to Coventry sent from the chase and the bowl. With my, \&c. 
'Then those two little fellows, as light as a featlicr, C'liarles Parker and Clowes, come racing together: And riding belind them, see Oliver Dick, With Slap-dash half blown, looking sharp for a nick. With $m y$, \&c.

On Ebony mounted belold my Lord Barnard, To live near the pack now obliged is to struin hard; liut monnting friend Barny on something that's quick, I warrant, my lads, he would sliew you a trick.

Witlı my, \&c.

Then Bland and Iom Gascoigne I spy in the vau, Riding hard as two devils, at catch as catch call, But racing along to try which ean get first,

Alrealy I see both their horses are burst.

With $\mathrm{my}$, \&c.

Then smack at a yawner falls my friend Billy Clongh; He gets up, stares around him, faith ! silly enough; While Pilkington near him, eries, "Pr'ythee get bled!" "Olı no, never mind, sir, I fell un my head."

With my, de.

But where's that hard rider, my friend Colonel Bcll? It the first setting off from the covert he fell.

But I see the old crop, thus the whole chase will carry, In respectable style, the good temper'd Harry.

With my, \&c.

With very small feet sticking fast in the mud, Frank Hawksworth I see on his neat bit of blood; But pull ap, my friend, say you've lost a fore shoe, Fise blecting, $T$ fear, in ust he shortly for you.

With my, \&c.

'To keep their nags fresh for the end of thr day, Sir Edward and Laseelies just eanter away; Not cnjoying the pace our liaby hounds go, But preferring the maxim of rertain and slow.

With my, \&e.

At the top of his speed, sadly beat and forlorn, Behold Captain Horton is stecring for Bain ; For accustom'd at sca both to shift and to tack, He holes by mancuvring to gain the flect pack. With $11 \mathrm{y}$, \&c. 
The two Lees, Harvey Hawke, Frank Soth'ron, and all, Are skirting away for Stapleton Hall;

Whilst far in the rear bchold Overley Cooke, Fndear'ring to scramble o'er Ample's wide brook.

With my, \&c.

Far aloof to the right, and op'ning a gate, There's a sportsman ly system who never rilles straight; Bnt why, my good Godfrey, thus far will you roam, When a pack of fine beagles liunt close to your home?

With my, \&c.

Safe o'er the brook-but where's Captain Dancer? $\mathrm{Oh}$ ! he's stopping to catch Sir Rowland Wim's prancer But what is the use of that, my friend Winn? If on foot you attempt it, you'll sure tumble in. With my, \&c.

On his chestnut nag mounted, and hearing in flank, At a very great distance behold Bacon Frank, So true's the old maxim, we ever now find, That Justire vill always come limping behind. With my, \&e.

See Starkey and Hopwood, so full of their jokes, From Bramliam Moor come, to be quizzing the folks ; And when they return the whole chase they'll explain-'Tho' they saw little of it - to crony Fox Lane. IVith my, \&e.

Lost, spavin'd, and gall'd, but shewing some bloodFor from Coxcomb's poor shoulders it streams in a floodBehold Mr. Hodson, how he fmmes and he frets, While his black lies entangled in eursed sheep nets. With my, \&c.

If his name I pass'd over I fear he rould cavilI just wish to say that I saw Mr. Saville : And with very long coat on (a friend to his tailor), With some more Wakeficld heroes, behold Mr. Nailor. With $m y$, \&c.

A large posse sce in the valley below, Who serve very well just to make up a show ; But broad as the brook is, it made many stop, It's not ev'ry man's good luck to get to the top. With my, se. 
Now all having pass'i, I'll to Ferrybridge go, Each event of the day at the Club I shall know; Where bright bumpers of claret enliven the night, And chase far away hated cury and spite.

With $\mathrm{mr}, \& \mathrm{c}$.

Then forgive me, my friends, if you think me serere;

"Tis but meant as a joke, not intended to sneer :

('ome, T'll give gon a toast, in a bumper of wine,

"Here's success to this Club, and to sport so divine!"

And the hounds of old Raby for me.

I arrived at home on the 10th of April, and left it again on the 15th for the New Forest. I was to have taken up my old quarter's under the hospitable roof of Sir Hussey Vivian ; but he was deprived of the pleasure of receiving a large party of his friends at this time, by being obliged to attend His Majesty in London. I had received many kind invitations from Mr. Nicoll to visit him, and I spent one of the pleasantest weeks of my life under his roof. Here, however, I must pause. Numerous would have been the jokes, countless the anecdotes-for John Ward was with us-that I might have gleaned in those "gay-spent festive nights;" but all must now be silent. The hand of Death has snatched away one who presided at the feast, and the house of feasting has been a house of mourning. In a few months afterwards, the wife of our kind host and the mother of his nine children died in giving birth to a tenth, and Mr. Nicoll lost what nothing can replace.

Impatient, however, as mankind are apt to be under calamitieswhich, after all, are but the condition of their existence-yet contrasts give variety to life. Did we never taste what is bitter, wo should know nothing of the sweets. Where, then, can there be a greater contrast than between the large rich fields of Leicestershire, and the sterile, heath-clad surface of a Hampshire forest? Notwithstanding this, there is something in a forest which calls to mind pastoral and hunting ages long since gone by, but of course congenial to the feelings of a sportsman; and as, according to the doctrine of Aristotle, the love of the beautiful is implanted in us by Nature, every man-sportsnian or no sportsman-must feel instinctive pleasure in such a scene as Monday the 16th of April presented to us at the meeting of Mr. Nicoll's hounds. The 
morning was most propitious; Nature appeared in very gay attire ; and, exclusive of ladies, upwards of three hundred horsemen, from all parts of England, formed the motley group. Amongst these, the following conspicuous characters composed Mr. Nicoll's party: the great John IVard; the no less celebrated John, commonly called Jack Wormald; Mr. Spurrier; Mr. Foljambe, master of the Lincolnshire fox-hounds; Sir Harry Goodricke, and Sir Bellingham Graham. Mr. John Moore, as usual, was also in the neighbourhood (at Mr. Compton's); a considerable party of sporting men at the Inn at Lyndhurst; and Billy Butler, being his forty-second appearance. The Leicestershire dons did not bring their own horses, but were very respectably mounted by Mr. Tilbury, who sent eight hunter's to Lyndhur'st for their use.

To give an account of sport with hounds on this occasion will not do now; but on the first day we were saved from one of the evils attending April fox-hunting, by the keen eye and activity of $\mathrm{Mr}_{\mathrm{r}}$. Foljambe, who jumped off his horse just in time to save a vixen fox which gave suck from falling prey to the pack. After the hounds were taken away by Mr. Nicoll, she was put down, and, although apparently injured by a gripe on her back, she trotted away as if nothing had happened.

April fox-hunting never can be good; but this was a most scentless week, even in the New Forest, where hounds generally catch a scent by some means. To cut the matter short, we had but one pretty rum out of four days' meeting; but we saw a deal of good hunting-picking it out by the inch-and we witnessed great skill in our huntsman. I remember saying to myself, the second day we were out with a very perplexing scent, "IVell, considering our huntsman told us last night, that, to make a huntsman perfect, his lips should be sewed together, I never saw hounds lifted better than these have been this day." To say he lifted them off the ground would be too figurative an expression; but he certainly did it to a charm, and his scream was thrilling and good. However, we might as well say Horace was a stupid fellow, and Demostlienes no spokesman, as to say Mr. Nicoll is not a huntsman; for he is one: but what cannot a master-mind like his accomplish-particularly when direeted principally to one point? 
I have said that Mr. Ward was of our party. I have said enough, then, to show that mirth and good humour were the order of the day. His presence, indeed, always reminds me of Lucian's description of the Elysian fields, where he makes it appear there are two springsthe one of laughter, and the other of joy; and it is almost needless to add, that those who drink of them are filled with mirth and hilarity for the rest of the day. The moral here is delightful to contemplate ; for it is as much as to say, that, unless we bring a kind heart into society, we have no business there. Here Mr. Ward may be almost termed the miracle of his day. Courted as he has been for such a great length of years, we might expect to find him, like a wayward child, wishing to have everything his own way; but it is not so. No; his social capacities seem to expand as his age advances, and, like Saul, to be more glorious in his latter year's.

It would be tantalizing to mention the name of this real old English Gentleman, and not accompany it with an anecdote or two ; so I hope I shall be pardoned for selecting the following.

It is well known that this far-famed sportsman has ever been fond of having his hounds high in flesh, in their work. I partly place it to his having always hunted strong, wet countries, with rough woodlands; but I am not going to argue the merits of the case here. We are all fond of our own systents, and, like Pygmalion the sculptor, never fail to become enamoured of our own creations. Mr. Nicoll, on the other hand, feeds lightly in the spring months, and we well know that hounds which work on light food will look light in warm weather. "There is one advantage," said Mr. Ward, as we were one morning passing away fon hours in the kennel, "in visiting my friend Sam Nicoll. No man need trouble himself to take his razors with him; for only let him lather his face well, and walk down to the kemuel, he might take any one of these hounds by the head and tail, and share himself to perfection with his back bone! These hounds," added he, "look as if they had just landed from Noah's ark."

Anecdote the second may surprise, and for this reason:-I think it is Fielding who has told us, that there is an air of gentility about a real gentleman which dress can neither give nor conceal. Notwithstanding this, Mr. Ward told us, that is short time 


\section{its NIMROD'S HUN'TING TOER}

since he was taken for a butcher! and I will give it in his own words.

"I was driving down the road one day," said he, in his usual facetious style, "when I saw a man I knew bargaining for some fat bullocks. 'Camnot you deal?' said I. 'Why, no, Sir', replied the buyer'; 'the gentleman is too hard with me.'- 'Then let me try and put you together.' So, getting out of my curricle, and handling the beasts, I pronounced them to be worth a certain sum. The buyor doubted it. ' Well, then,' I said, 'here is a butcher coming, we will hear what he has to say.' The butcher looked at the bullocks, and then at me; and after taking a second look, addressed me thus'Why, you are in business, aren't you ?' - ' Not at present,' I replied, pulling a very long face; 'I have been unfortunate.'-_ Worse luck!' said the butcher ; 'for you are a d-d good judge.'."

Now I can only account for this in two ways: either the butcher was a better judge of beef than of a gentleman, which is by no means improbable; or, Mr. Ward having his box coat on, the knight of the cleaver did not see those neat boots and leathers for which his person has ever been so distinguished; neither do I think it possible he could have looked into his face. Mr. Ward, however, would make an excellent master-butcher in one respect; for, having been a very considerable stall-feeder of cattle for a great number of years, and paid much attention to the system, it must be a good judgo that conld get the blind side of him in a deal.

I must now bring my visit to the North to a close. Tet me conclude it, then, with the following remarks :-

In the first place, I have to thank all the Sporting World, and my friends in particular, for the kind dispensation granted me in the free use of their names, as, without this indulgence, my pen would have been cramped, and I should have fluttered like a bird with its wings clipped, unable to soar above the ground. I hope I have taken no unfair advantage of this boasted privilege. I am not aware of having stained my paper with falsehood, neither have I dipped my pen in gall: but if it be said I have written in a spirit of partiality ; if kind feeling and friendship have had too great a share in the chalacters I have drawn, and I have heightened them a little beyond the truth, I am sure of pardon herc. An abler pen than mine would 
have executed the task better; but in one respect 1 am not illqualified for a traveller. I have neither antipathies, nor prejudices to mammers, habits, climate, meat, drink, persons, or things, having long learned to take the world as it comes, making the best of everything. I am now verging on those yeurs in which I am entitled to contirm by practice what was taught me in theory, and I have found most of those lessons good. My experience, however, has given the lic to one. 1 was told,

\footnotetext{
"You'll find the friendship of the world a show :

Mere outward show! 'Tis like the larlot's tears.

The statesman's promisc, or false patriot's zeal . . .

Full of fair seeming, but deInsion all."
}

I cannot suy I have found it so! Rather would I tell the snarling eynic that the world to me has proved a friend, and I am proud to say "I ouve thee much." Were I, however, to allude for a moment to the commendations bestowed upon what little I have written, I should account for them all in the language of Swift. "It is the wise choice of the subject," says he, "that adorns and distinguishes the writer ;" and mine, we know, is a popular one. In the shape of a Tour, however, this is my last attempt; hut it may serve for a model for others to improve upon; and, perhaps, more good than har'm might be the result. Society exists amongst men by a mutual eommunication of their thoughts; and, although I fear I have added little to the stock, their reciprocal commerce is the chief source of knowledge.

To conclude:-I shall never forget the pleasure $I$ derived in the perusal of a passage from the pen of Gibbon, wherein he describes the hour in which he completed that great monument of his fameThe Decline and Fill of the Roman Empire. "It was," says he, "on the day, or rather the night, of the 27 th June, 1787 , between the hours of eleven and twelve, that I wrote the last lines of the last page in a summer-house in my garden. After laying down my pen, 1 took several turns in il covered walk of acacias, which commands a prospect of the country, the lake, and the mountains. The air was temperate, the sky was serene, the silver orb of the moon was reflected on the waters, and all Nature was silent. I will not dissemble the first emotions of joy on the recovery of my freedom, 
and, perhaps, the establishment of my fame. But my pride was soon humbled; and a sober melancholy was spread over my mind by the idea, that I had taken an everlasting leave of an old and agreeable companion; and that, whatsoever might be the future fate of my History, the life of the Historian might be short and preearious!"

On the 22nd of April, I left the Forest, and in the evening of that day arrived at home. Although my pockets were as empty as when they eame from the tailor's, my spirits were good. I dwelt with pleasure on the scenes I had been a witness of, and indulged a hope that I might see something like them again. But this was not all. I echoed the words of an elegant writer, who so happily expresses himself on a similar occasion. "When we travel towards home," says he, "we return, as it were, to the arms of a friend ; and BLEss that GoodNess Which has so ordaINed, that hoMe with vo charus CHARMS US BECAUSE IT IS OUT HOME!!" 


\section{RIDTNG TO HOUNDS}

Venatu invigilant pueri, silvasque fatigant ;

Flectere ludus equos et spicnla tendere cornm.

At, patiens operum parroque assneta, juventus

Aut rastris terram domat, ant quatit oppirla bello.

VIRGII.

Our boys the forest range, and lead the course, Bend the tough bow, and break the prancing horse. Long thirst, long hunger, onr bold youths ean bear. Plongl, fight, or shake embattles towns with war.

PrTr's Translation. 



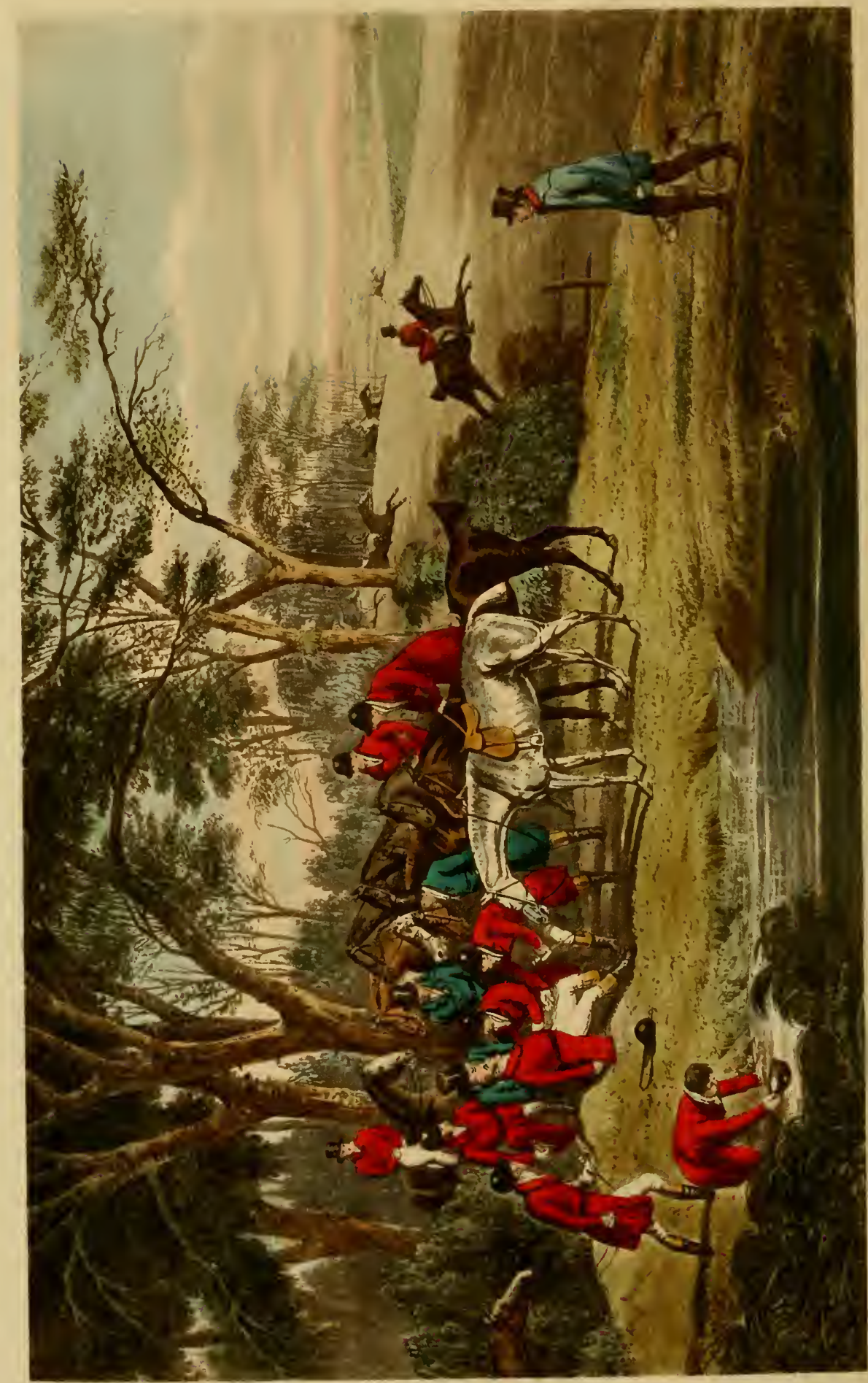




\section{RIDING: T( ) IIOT:}

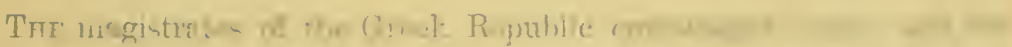

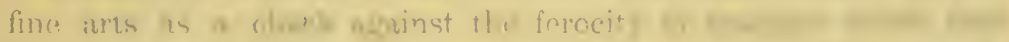

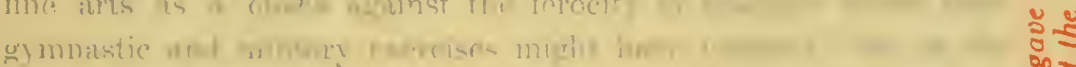

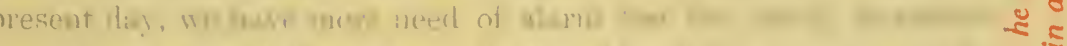

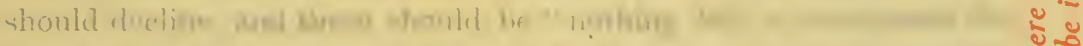

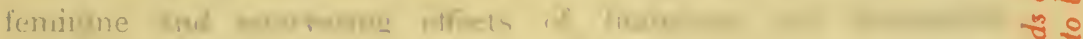

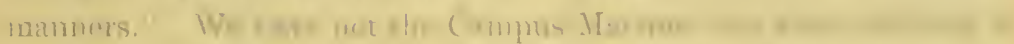

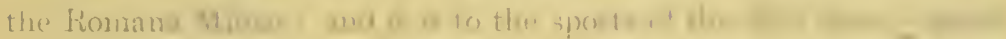

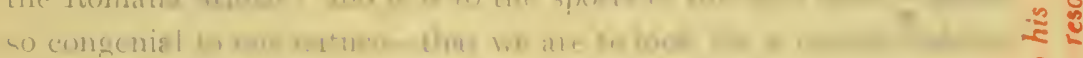

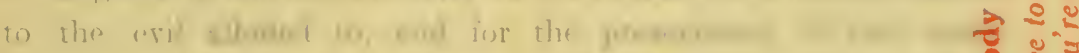

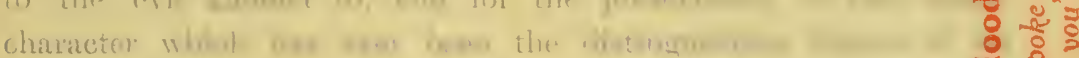

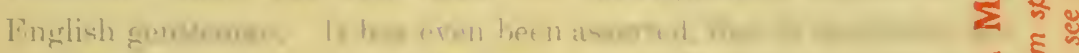

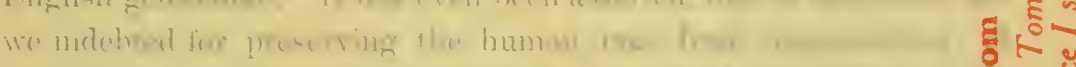
this, kowents, we we ef rtain that Lhe -tomet

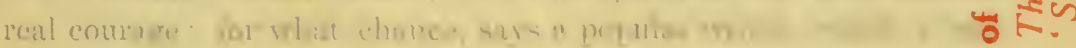

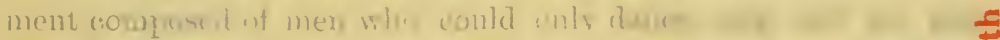

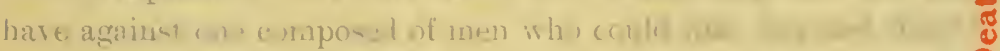

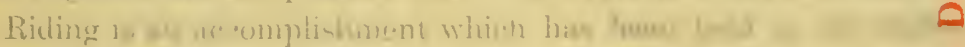

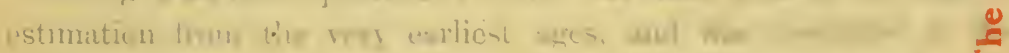

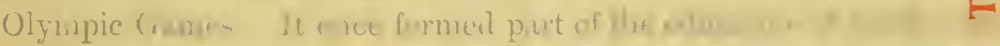

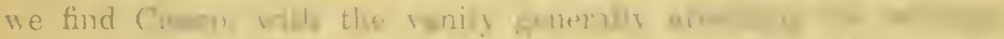

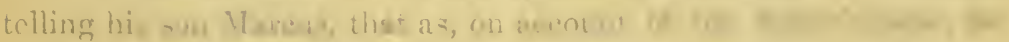

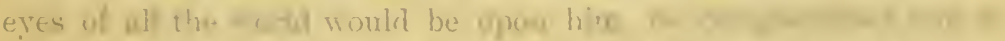

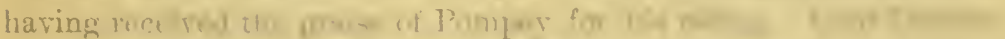

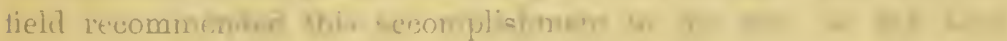

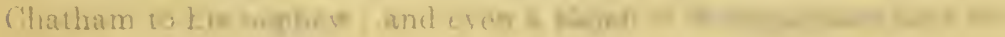




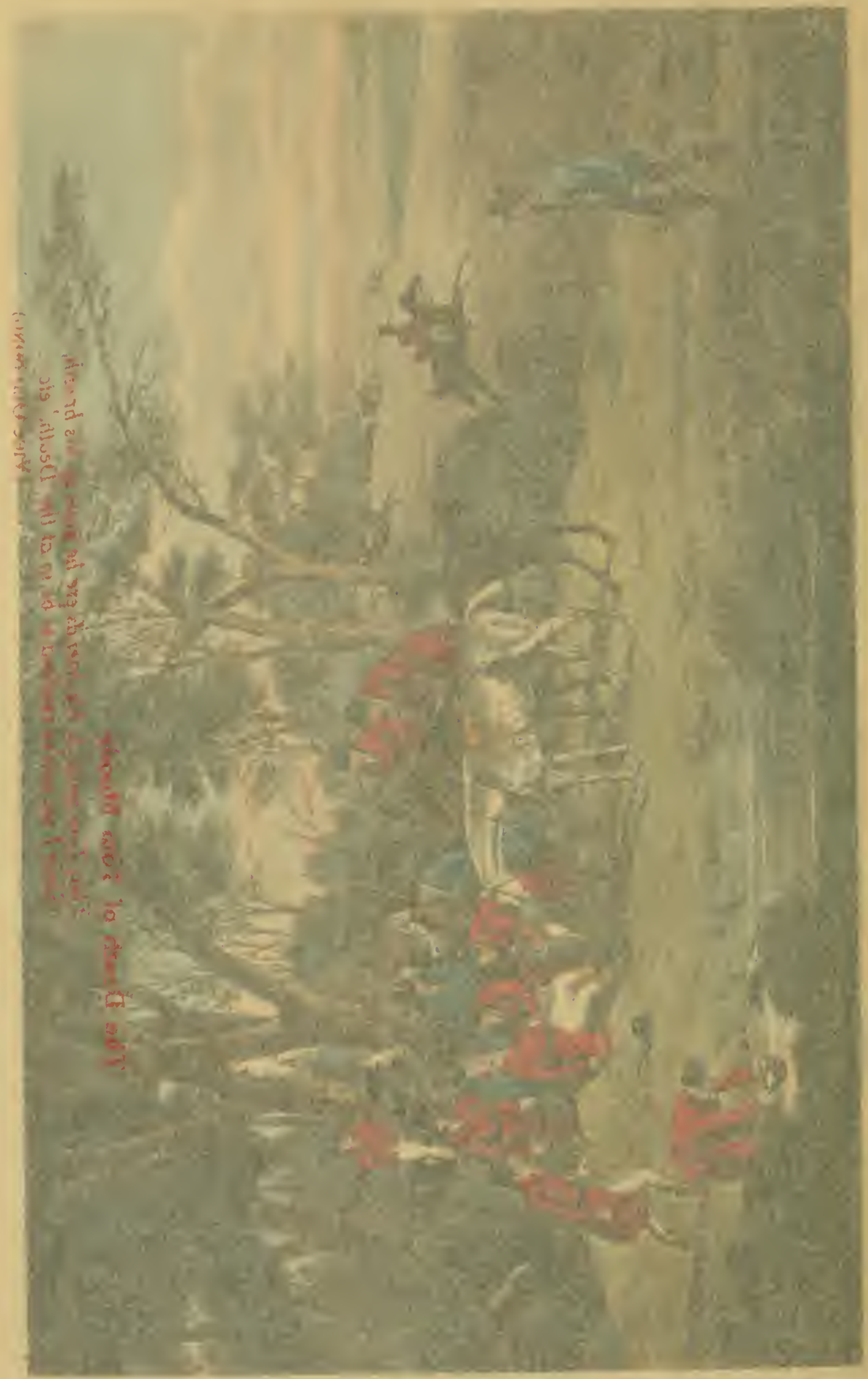




\section{RIDING 'TO HOUNDS}

The magistrates of the Greek Republic encouraged music and the fine arts as a check against the ferocity of manners which their gymnastic and military exercises might have inspired; but, at the present day, we have more need of alarm lest the manly diversions should decline, and there should be " nothing left to counteract the feminine and enervating effects of luxurious and fashionable manners." We have not the Campus Martius-we know nothing of the Romana Militia; and it is to the sports of the field alone-sports so congenial to our nature-that we are to look for a comberbalance to the evil alluded to, and for the preservation of that manly character which has ever been the distinguishing feature of an English gentleman. It has even been asserted, that to sportsmen are we indebted for preserving the human race from degenerating: of this, however, we are certain, that the sports of the field promote real courage; for what chance, says a popular writer, would a regiment composed of men who conld only dance, sing, and act plays, have against one composed of men who could ride, box and shoot!

Riding is an accomplishment which has heen held in the highest estimation from the very earliest ages, and was rewarded at the Olympic Games. It once formed part of the education of youth ; and we find Cicero, with the vanity generally attending his writings, telling his son Marcus, that as, on account of his father's fame, the eyes of all the world would be upon him, he congratulated him on having received the praise of Pompey for his riding. Lord Chesterfield recommended this accomplishment to his son; as did Lord Chatham to his nephew; and even a Rajah of Seringapatam does not 
think it beneath his Imperial dignity. Hamnibal, we are told, was the best horseman of his day. In his dress he differed in nothing from the ordinary men of his time; but in everything that related to his hor'ses and their accoutrements, he was superbly magnificent and fastidiously correct. In battle, he was the first to engage, and the last to retreat.

From the days of the young Ascanius to the present hour, riding to hounds has formed one of the chief amusements of men of all iges, and in all situations in life; and it appears by Tibullus, that there was a "painful pre-eminence" in the field in his time. That riding over a country was in fashion in the Augustan age, we learn from Virgil's * direetions for breeding, where he tells us we should not leap a mare when she is in foal. Ossian compliments the son of 'Tol'an with being first in the chase; and Addison observes, that "some find their account in heading a cry of hounds, as much as others would in the dignity of Lord Chancellor." What figure these ancient Nimrods would have cut by the side of a good Meltonian of the present day, it is not in my power to conjecture. The best Kings and Emperors, however, encouraged all such manly exercises; and Horace wrote his Carmen Seculare in their praise. The pursuits of the ficld in particular, being more or less attended with risk, have a tendency to increase natural courage; and, by rendering men familiar with danger, make them less liable to lose their presence of mind when in it, and less anxious to get out of it. As the foil is the semblance of the naked sword, the chase is the image of war; and after all, "it is the contempt of danger which emnobles the life of a soldier."

Riding to hounds on paper, or over a bottle of wine by a good fire side, is one thing; and riding alongside them for an hour when going their best pace over a strongly-enclosed and deep country is another. Than the one nothing is more easy-gates, stiles, brooks, and fences, we all taken in stroke, and nothing is too high or too wide. Than the other nothing is more difficult-body and mind are both at work, and every now and then the "courage must be screwed up to the 


\section{RIDING 'TO HOUNDS}

sticking place." Like most other thing's, however, there are two ways of doing it-one in comparative safety and supreme enjoyment; the other, like Damocles at the feast, in the midst of pleasure, but in constant apprehension of destruction. All this depends on the goodness of the horse we ride, and our skill in riding him. "Hand without head" will not do, neither will head without hand. Judgment, hore, must be combined with execution.

Independent of the pleasure arising from the chase, I have always considered a covert's side with hounds that are well attended to be one of the most lively scenes in nature. The pride of the morning, the meeting of friends, and the anticipation of diversion, contribute to raise the spirits and expand the soul. In my experience in life, I have found, or heard of, lut ferv friendships formed on the associations of very early years; and for one lasting friendship founded at a school or eollege, I have known a dozen proceeding from fox-hunting; and I have no hesitation in adding, that the best introduction for a young man of fortune and fashion of the present day is to be found at Billesdon Coplow or Oadby toll-bar.

Leicestershire is the place of all other's where riding to hounds is put to the test. The excuses of "I was the wrong side of the covert-I did not get a start, or the hounds slipped away from me," will seldom serve here, as ever'y man can get a fair start if he is awake, and every man has an opportunity of distinguishing himself.

It is a remarkable fact, and a striking proof of the difficulty attend. ing it, that, barring Leicestershire, there are not in other countries mole than half a score men calling themselves sportsmen and well mounted who can ride to hounds-that is to say, who can live with them for an hour over a strong country and at their best pace. There are, however, I will venture to assert, in each of these countries twice that number of men whose nerve is equal to any fence that the others will ride at; yet, from certain causes, they cannot get near hounds. Now, how are we to reconcile this ? Here are two men, with nerve equally good and equally well mounted, get a fair start with hounds: one of them shall never be a field from them, and the other shall be dead beat, or perhaps lost, before lie gets half through the run if it is a good one. Nay, I will go ono step farther 
-the one man shall ride three or four stone heavier than the other! This appears paradoxical, but every day's experience proves it. Let us endeavour to account for it.

If hounds always ran straight over a country, the difficulty of riding to them would be materially lessened. A good horse, with a good hand upon him and boldly ridden, would nineteen times out of twenty carry a man up to them, provided no insurmountable difficulties, such as rivers, intervened: the hand, without much assistance from the head: would then do the business; but the difficulty consists in turning to hounds, and riding inside and not outside of them, and thereby cutting off the angles. Whoever considers the proportion of the diameter to the circumference of a circle will be convineed of the great advantage of riding inside of hounds in their turns, and avoiding angles. Hackney-coachmen in London are well aware of this. For example, let a man get into one of their coaches, and give Jarvey his direction : if his place of destination lies to his right hand, he will observe how immediately he makes his turn down the first street that leads in that direction, and vice versa.-Let us suppose two hackney-coachmen started at the top of the Haymarket, and were ordered to Temple-bar : let one take the first turn to the left, which is Panton-street-cross Leicester-square, along Chandos-street, and get into the Strand down Southampton-street-how much sooner would he be at Temple-bar than the other, should he make the angle of Charing Cross! This exactly applies to riding to hounds. How often have I seen one set of men riding as hard as their horses could carry them and stopping at nothing, but still losing ground, and being beaten; when at the same time, others, better judges, were going by the side of hounds quite at their ease, and merely because they have turned with them, and not after them, by which the angles have been avoided.

There is another point in riding to hounds not sufficiently considered. Every sportsman will know what I mean by the difference between a quick horse and a fast one. Very few countries require fast horses, but all require quick ones; and a quick man upon a quick horse would beat a slow man upon Eclipse. The speed 


\section{RIDING TO H()INDS}

and stride of Hambletonian would be useless in any country, however valuable at Nerrmarket; but it is a quick man upon a quick hor'se that in nineteen countries out of twenty gets best to hounds. By a quiek man, I mean one who has a good eye to the direction his hounds are going in - who tums as his hounds turn-has a good eye to practicable places in his fences, and, when he comes to them, is decisive in his determination to go at them. In many other things besides riding over il country, he who stops to consider is lost; but in this decision is everything. The "non progredi, est regredi," may be particularly applied to riding to hounds. When we stop, they are going; and eatching hounds with a holding scent is what few men and horses are equal to. The celebrated Dick Knight's speech to Lord Spencer, when he hunted his hounds, proved he was of this opinion. He had just ridden over " rusper, which his Lord stopped to look at.- "Come along, my Lord," said Diek; "the more you look, the less you'll like it."

By a quick horse, I mean one that is quick on getting on his speed again after having been stopped at his fences, and is handy in being pulled up or turned. This is the horse that will distinguish himsel in enclosed countries, where hounds seldom rum or men seldom ride straight. It was this wonderful quickness at his fences, independent of his speed, that gave that famous horse "the Clipper" such an advantage over a country when hounds ran hard. Whether the ditch was towards him, or from him, he would not suffer himself to be collected, or pulled together, therefore lost no time in his fences. He was on his speed again, as it were, before other horses had scarcely alighted on the ground. Thus taking all sorts of fences in this rapid way, without suffering himself to be collected, might do very well with Mr. Lindo on his baek, but it is not every man's nerve or finger that it would suit. It enabled him, however, to go a mile and a half over a country on the Clipper, whilst many others were going a mile.

In my experience of men riding to hounds, I have made the following remark - that it is not hecause a man is a good horseman, that he puts his horse well at his fences, and is not afraid of them, that he can live with hounds. On the contrary, I have seen numbers 
answering this description that never could see a run when the pace was quick. The reason of this was-they were not quick. They lost time at their fences, and they would not gallop. I am willing to admit that the act of extending a horse over rough ground, and among grips-particularly if that horse has a long stride and does not pull together-is a greater trial to nerves than the generality of fences; and is attended with more danger. The worst falls are those which happen in the open field when horses are going at nearly the top of their speed; and it requires a finer finger to put a horse along his best pace, over rough ground, than to ride him if he knows his business over the stiffest and most difficult fences. In the one case he sees his own danger; in the other his ricier must see for him, and, by the finger, caution him against it. It is in this way alone that I can account for so many persons that I have known and met with, who, with all the necessary quahifications for riding to hounds, as far as fencing and horsemanship are concerned, yet never see a run at the best pace, because they will not gallop.

There is another description of persons who are generally defeated when business is to be done, and those are your very light weights. In my experience of fox-hunting, I have observed that men above eleven stone for the most part beat men under eleren stone-and for this reason: the very light man says, "anything will carry me; " and if he hears of a slight hit of blood, which no man of any size will buy because he cannot carry weight, he goes and purchases him, calling him " a nice little horse to carry his weight." The consequence of this is, as force must be opposed to force, this nice little horse and his rider are knocked backwards and thrown over by fences, which a heavier man on a heavier horse would break through if he could not clear. I am no advocate for large horses, but they must have substance and weight, or they cannot get through a strong country.

Putting fences out of the question, we may view this matter in another light. IVe know that weight equalizes all horses of all ages and all sizes. If, therefore, a man weighing only ten stone gets horses only fit to carry ten stone, he can go no faster in a deep country than the man who weighs fifteen stone, provided he be 


\section{RIDING 'TO HOUNDS}

mounted on horses equal to carry fifteen stone. This only applies to galloping; but if they come to fencing, the heavy man has it hollow. The heary man says, "I must get horses to carry me"; the very light man says, "those which can carry no one else will do for me" ; and thus he is too often defeated. To this must be added, in favour of the heavy man, that strength in the rider, as well as in the horse, is necessary in getting a horse across a stiff and deep country where the fences are large and frequent.- "The gentleman rode very well," said Buckle the jockey, of a gentleman rider opposed to him in a lace, "but he tired before his horse" ; and this applies to the rery light man over a country.

Riding to hounds, like most other things, has undergone a revolution in the march of time. Some years back, the best man was he, who, after never being near the hounds for nineteen miles (supposing them to run so far), came rip to them at the twentieth, and got the brush, which he carried home in triumph under the front of his bridle. The best man now is he who goes best through the best part of the run, even should he be "dead beat" at the last. As to riding, or asking for the brush, a man would as soon ask for the scalp of the huntsman's head in the regular hunting countries as for the brush of a fox. I once did see, and in one of the crack counties, a man ride over a fence into the middle of hounds as they were in the act of worrying their fox; and on the owner of them asking him why he did so, he replied that he wanted the brush. "You shall have the brush, sir," said the master of the pack, "and let it serve you for the rest of your life. Take off that red coat when you get home, and never come a-hunting again."

There are many men, particularly those whose hunting has been confined to ploughed and light-scenting countries, who can form but a faint idea of the speed of hounds in those countries which are capable of holding what is called a burning, or', more properly, a lasting scent, such as will enable hounds to run straight. The circumstance, however, which I am about to mention, at the same time that it will show the pace which hounds under certain circumstances are able to maintain, will warrant the assertions I have made as to the difficulty of secing a run when the pace is very quick, 
as also the necessity of horses being in the very best tune to attempt it. The instance I now allude to was with the Duke of Rutland's hounds when shaw hunted them. There was, as usual, a large field on the day I speak of ; but, what is very unusual in Leicestershire, the covert in which we found our fox was surrounded by a wall. This wall, in the direction the fox went off, was not to be jumped; but there was a bridle-gate, which the first man who was lucky enough to get through was $M r$. John Storey (better known in the Sporting Work by the name of Jack Storey), on the old racehor'se Cockspinner. Strange as it may appeal, Alr. John Storey, upon Cockspinner, was the only man who saw that run, although it lasted but twenty-two minutes, and there was not a fence to stop any horse deserving the name of a hunter. Seeing $\mathrm{Mr}_{\mathrm{r}}$. Lindo on Petruchio, and Mr. Davy-no better pilots-making for a place in the side wall, which was practicable, I followed them; but in consequence of a rail being on the other side of it, which obliged us to take it at twice, and meeting immediately with another double fence, added to the acute angle we made by going over the side wall, we never could get near the hounds. The hor'se I rode had just been wimning Hunter's' Stakes, and, as before observed, there were no impracticable tences in the way; but I never caught a sight of the pack over that fine country, until just as they were running in to their fox, when I saw them on some rising ground better than a mile ahead. When Shaw eame up, he pulled out his watch, and exclaimed, "Beat two miles in twenty-two minutes, by G-d!'”

This is one among some hundred instances of horses not being able to live with hounds unless they not only start with them; but as the speed of hounds has been ascertained to be superior to that of horses, it is absolutely necessary, to enable them to live with them at their deepest rate, that they should not only not go orel as much ground as they do, but by turuing inside, and not outside them, they should, consequently, go over less.

In some countries, getting well away with hounds is diftienlt and uncertain. Where corerts are large, on windy daỵs it is almost even betting whether a man gets a good start or not. It is true, though singular, that in woodlands, foxes will often run the same 
line of eountry for generations in suceession; but this is not to be depended upon, neither is there much reliunce to be placed upon the wind. I remember telling an old and rery good sportsman one day in Leicestershire, that the wind would most probably take us to his country; when he observed, that by the time 1 had been a fox-hunter as long as he had, I should learn to trust but little to the wind. "A fox," said he, "will make his point in spite of the wind: and it is only when he finds himself pressed that he will eease to face it." This I believe to be the ease; but one observation I have made is, that when a fox starts up wind, and then turns, he seldom faces it again. All they, howerer, who consult the wind, and ride to it, instead of to the hounds, will too often find themselves in a wrong latitude.

It is one of the drawbackis upon the pleasure of fox-hunting, that a man sometimes rides twenty miles to meet hounds, and then loses a fine run by not getting away with them. The rose, however, is never without the thom; and this must sometimes happen in large woodlands, which most commonly produce the best foxes. As foxes grenerally hang a little in large coverts, the hest sportsman is often puzzled how to act. If rumning down wind, it is difficult for hin to hear them. If he follows them up and down a deep eovert often, his horse is half beaten before the run begins. It is necessimy therefore to be wide awake upon these occasions; and I have always thought it to be the safer plan, when a man comes out determined to have a day's sport, to keep as near to hounds in eorert as it is possible-even if he does take something out of his horse in cloing

* I have seen many instances of this at a covert called Alveston Pastures, near Stratford-on-Avon, in Warwickshire, a place which has afiorded several brilliant runs. Unless foxes break for Mr. West's coverts, they almost invariably come away to sir Charles Mordant's woods, beyond which is as fine a comtry as any in England. To aroid sinking the hill, and a rery bad brook, all those who know the cirenmstance are in the habit of going along : road for about a mile, whence they can command the hounds by the time they can settle to their fox. () n a particular day, however, when Lord Middleton hnnted Warwickshire, I remember Colonel Berkeles and his two brothers were oni, when, not knowing of this nick, the $y$ followed the hounds down the mendows, when, contrary to the usual practice, the fox did not cross the brook, but turned short to the left, down a fine rale, for Wellesburn, and the three brothers alone saw the run. This was almost a solitary instance of a fox taking that direction. 
so. By getting well away with them, he has not got to eateh them, which may be still more against him than even going two or three times up and down a deep ride in a eovert. At all events, a sportsman's object is to be with homnds ; and it is better to be with them on a horse half beaten, than to be riding abont the country asking the old question, "Did you see the hounds?" on a fresh one.

The following aneedote is in point. A gentleman of large fortune, well known in Staffordshire, was out with the late Mr. Meynell when he hunted Leicestershire, and in those days was going " with high and vent'rous sail." Coming to a river which had much overflowed its banks, he pulled off his coat and waisteoat, and swam for a considerable distance. The first man who got around by a bridge was Lord Forester, who, getting on the line of them, asked a countryman whether he saw the hounds. "Oh yes," said the fellow, "I seed 'em-but you will never' see 'em no more; they" have been gone this quarter of an hom." " Who was with them?" sitid his Lordship. "No one but the miller," was the reply, "and he was riding most nation hard to be sure." This was Mr. Gin his shirt.

Had hunting and the present spirited manner of riding to hounds heen practised as we practise them in earlier times, I cannot help thinking that they would have formed a fine subject for a pastoral or an epic poem, in the hands of Theocritus or Virgil, when dresser in the lustre of their language, and adorned with their "living" words." Such a poem would have been read with unmingled feelings of dolight. The twang of the horn, the echo of the woods, the ery of the hounds, the cheers of the huntsmen, and the ardour of the riders, would not have been interrupted by the recollections of countries wasted by want, or eities depopulated by the sword. What a contrast would the cheerful and happy scenes of the sportsman present to the blood-stained career of the hero! As Bellona is represented by the poets in language too horrible to read, Diana, though bent on the pleasures of the chase, is painted with all the attractions of her sex, and in the elegant simplicity of nature. The epithets applied to this sporting goddess are said to be the happiest in the Latin language.

Although we have but an imperfect idea of the manner in which 
he ancients hunted their hounds, and got across a country after them, yet we are satisfied that they did both. We are also satisfied that, amongst those who wrote upon domestic economy, there were many good judges of hounds and horses, particularly of the latter. Instead of taking up a Scotch novel, which I could not read, or at fashionable canto which I could not understand, it has been $m y$ practice, when wiling away a tedious hour, to look in the books which I read in my youth. I have been forcibly struck with some passages that I have met with in them relating to the horse, which so exactly accord with my own ideas of what a hunter should be, that I shall take leave to mention them.

Pliny has the following remarkable sentence:- "Equi sine frænis, deformis ipse cursus, rigida cervice, et extento capite, currentium," which we may safely translate thus: horses that go with a stiff neck, and their noses poked out, and not pulling together in their stride, are unfit to carry a gentleman. How to choose a colt for a hunter, we cannot improve upon Virgil's advice. Let him be well hred, says he, and tread well on his pasterns. Of his courage-so essential to a first-rate hunter-he says, he should be the first to lead the way, to dash through the stream, and to trust himself on the unknown bridge. The "primus et ire viam," is all that we conld wish or ask for. Varro says we should choose one that is the first to plunge into a stream without waiting for his companions; and Columella, one which is afraid of nothing; who goes faster than the rest, and particularly, "si fossam sine runctatione transilit." How exactly a brook jumper!

The form of a horse seems to have been well understood by these ancient writers. Virgil and Horace speak of the "ardua cervix," by which, no doubt, they meant to imply carrying the head in a good place. They also speak of the neat head, and Varro recom. mends caput "non magnum," but not a small head, which is certainly. a defect.

The necessary points to carry weight were not overlooked. The broad back and the double chine are mentioned by several of them, as well as the wide chest; but Virgil's "luxuriatque toris, animosum pectus," is exactly expressive of the power and spirit of a fine hunter. The "tori" I take to be the brawny swellings of the 
museles of the breast, which are so apparent in some hor'ses, and which word is applied by the same author to the lion. I have never met with any observations on bone; but in their descriptions of this fine animal they deseend to the most minute points, such as the nostrils, which they tell us should not be narrow, but they do not say they should be wide, which they certainly should not be. They apply the epithet "hilaris" to the temper, which implies everything we could wish-lively, but docile. As to the colour, Virgil is not quite so intelligible. He says bay horses are reckoned stout (honesti), as also greys; but condemns the white. Now as I believe there never was a white foal, it is diffieult to separate the virtues of the one from the other.

In one point of view, our present method of riding to hounds bear's some analogy to ancient times. It is a solt of Saturnalian amusement, in which all ranks and privileges are set aside, and he that bas the best horse and the best nerve takes the precedence for the day. A buteher's boy upon a pony may throw the dirt in the face of the first Duke in the kingdom. This, however, though little thought of, is one of the many advantages arising from it land of liberty.

In proportion to the number of young men of family and fortune that are rising up in the world, will be the proportion of the different oceupations and diversions which their several inclinations will lead them to pursue. Nature, however, has something to do with this; for some bodies are less vigorous than other's, and must be content with diversions of a less fatiguing deseription than hunting, which, when well followed, is the most laborious of all pursuits of the field; and he who pursues it in earnest should be in proportion as strong and as sound as the horse he rides.

It was remarked by a Northamptonshire Baronet, too universally distinguished for his knowledge of hunting, and his determined and desperate manner of riding to hounds, to require any mention of his name-that he considered it part of a man's moral duty to preserve his health for the sake of riding to hounds! That it is part of every man's moral duty to aroid dissipation, and to take care of his constitution, no one will dispute: and that men who are devoted to hunting generally live temperately, those who live with them ean 


\section{RIDING 'TO HOINDS}

best testify. Without temperance, the fatigue of hunting fire ol six days a week would exhaust the strongest constitution. Hard work, or what we call "severe exercise," wears the human frame by attrition; but if that attrition be increased by the excitement of drinking and a quick pulse, the machine will be the sooner worn out. Nevertheless, as strong exercise is a preservative against the penalties of high feeding, he who takes the greater share of the one may indulge with more impunity in the other. The man, however, who wishes to distinguish himself in the field, and to continue to do so for the hest part of his life, must be temperate. The muzzle must now and then be put on limself as well as his horse; but "non miscre rivit qui parce rivit," is a maxim too old and too true to be disputed or doubted.

Few men have tried the effect of hard work more than myself. For several years of my life I have had horses with three different packs of hounds-choosing the best fixtures for the day with each. As may be imagined, I hare had plenty of road-work, besides hunting; and, when the weather has been open, my time may be said to have been almost divided between my saddle and my bed. I never knew what it was to be fatigued provided I lived temperately and went early to rest; and such a life bade defiance to disease. A rery celebrated physician of the last century was in the habit of giving much such a prescription to his patients: "Live," said he, " in a saddle." That riding is the most wholesome of all exercises I have little doubt, for despite of all the vile stuff that finds its road down his throat, who ever heard of a bilious post-boy !

To return to my subject. As

"withont a genius, learning soars in rain,"

so is riding to hounds like the inspiration of the muse. It must in some degree be born with a man, or he will never excel in it. He must possess judgment, temper, coolness, and courage; and even then, though these good properties may receive their birth with himself, yet they must be perfected by practice and observation. A madman or a coward are equally unfit for the business; but under any circumstances, as Humphrey Clinkicr observes, he must serve an apprenticeship to it. As far, howerer, as nature is concerned, the 
form of a man has a good deal to do with it ; for it is impossible that any one with a round thigh and a large calf to his leg can have a perfect seat on his hor'se, and without a good seat he cannot have a good hand.

'The hand on a horse I take to proceed also from other' causes. I conceive it to be intinately comnected with the nervous functions of the digestive organs - and here again is the necessity for temperance and regular living in those who wish to excel in the field more particularly enforced.

The advantages of a fine hand on a horse are, no doubt, of the very highest importance in riding a lace, but not more so than in liding over a country; and if a horse could speak, he would sity, "ride me with a fine hand and an casy bit." A hor'se's eal is said to be in his mouth; and it is from the bit that he receives the wishes and instructions of his rider.

The art of riding has been but little cultivated in this country, nor do I think much benctit would be derived from it if it were. That the ménage was known in the time of Augustus is evident; but that any advantage could be gained by teaching a horse, by severe and painful discipline, to clance a capriolo, or a cornetti, I never could bring myself to imagine, unless the object were to fit him for the stage or the circus. As for the lessons of a riding-master, they may be essential to a good military seat, or to teach an Englishman to ride like a Frenchman; but they never will teach a man how to ride, and make the most of his horse over a country. With the assistance of nature, he must teach himself ; but whether he is to be an apt scholar must clepend on a variety of circumstances.

The many instances of falls which I have seen from the effect of a bad hand are innumerable; but as the head of a horse may also be termed the rudder that steers him, if the helmsman is a bad one, a capsize must often be the consequence. On the other hand, it is not within the power of my pen to describe the benefit of a fine, but firm and steady, hand on the hunter when going at a rapid pacc across a country. TVe all recollect some year's ago, that the late Sam Chifney talked and wrote about a new method of riding the racer with a slack rein; but this was theory, which, even with his fine finger and his superior horsemanship, could not be put into 


\section{RII)ING 'TO HOL NDS}

practice. We also remenber, that a few yeal's back it was considered stylish to ride the hunter with his head quite loose. It is certainly pleasing to see one so perfect as to be capable of being so ridden; but I confess it yet remains for me to see a man keep up with hounds for an hour at their best pace with a slack rein. When they ar'e going witl a bad scent, it is possible, perhaps, to be donc; but even then, if the hor'se, as I before observed, could speak, he would ash for a little assistance where the ground was deep and clistressing.

One of the principal advantages arising from a fine finger on a hunter is in handing him orer his fences so as to prevent a greater exertion of his power's than is neessary to get safely over them. To those horses which carry high weights, this style of riding is most beneficial; and to the practice of it is Mr. Maxse inclebted for the front-rank place he has so long held among the Meltonians.

I well remember the first time that this fine effect of superior hand struck me so forcibly, and that was the first time I ever hunted in Leicestershire, when Lord Forester was in his prime. I had scen him out several times in provincial comntries on his friends' horses when on a visit at their houses, but I had never seen him in Leicestershire. On the day I allude to we had a sharp bur'st of about half an hour. Lord Forester (then Mr. Cecil Forester) was mounted on Bernurdo; and thinking that I could not fix upon a better pilot, I followed him at a humble distance, but sufficiently near to him to remark the superiority of his style of riding, and to account for his being able to make horses lice an hour under his weight, which could not live more than forty minutes under much lighter men. It arose from his very superior manner of landing them over their fences, and husbanding their power's, by preventing them from leaping ligher or further than was absolutely necessary to clear the fences he put them at. The fences we met with were strong; but so easily dick he seem to get over them, that they appeared tritling, until I came to them, when I found them quite large enough to be agreeable.

It was on this celebrated horse (Bernardo) that Lord Forester leaped a brook, when he was said to have cleared the astonishing space of thirty leet. Not having witnessed the leap, I can only 
say, that if any man on any horse conld have done it, it was to have been accomplished by Lord Forester on Bernardo. $\mathrm{He}$ was followed by a hard-riding farmer by the name of Wing; lout it appears that he had not quite so strong a feather in his pinion, as he barely cleared the brook, which was twenty-three feet from bank to bank.

As there are few, if any, instances in the records of sporting of so conspicuous and eminent a character as Lord Forester, and as anything relating to such a character must be entertaining and interesting, I shall devote a few lines on. the subject.

Lord Forester was educated at Westminster, and went thence to Christ Church. Oxford; but having been brought up under the eye of his uncle, so well known as "Old Forester of Villy," and who kept fox-hounds for many years of his life, he may be said to have been well entered to the sport. He shewed, early in life, a remarkably fine eye to the essential points of a hunter; and so much was his judgment looked up to, and so great was his reputation as a rider, that many a man has given him a hundred guineas more for a horse than he wonld have given to any one else, merely because he could say, "I bought him of Forester." It is needless to observe that this predilection was not lost upon so good a judge, and that at one period of his life his hunting was by no means an expensive amusement to him.

Lord Forester-which can be said of ferv other men-was a hard rider for nearly thirty year's of his life; and it was only in consequence of repeated attacks of the gout that he was obliged to resign his place in the field to men younger than himself; but such are the effects of that terrible disease, that few persons are enabled to stand the bangs and bruises that are met with in riding over a country after one or two severe fits of it. Having, however, married the Duke of Rutland's sister, he goes every season to Belroir, appearing at covert when his health will permit him, but giving place to an excellent representative in his eldest son, who bids fair to equal his father in the field, and whom I mentioner in one of my letters on Oxfordshire, as " a very promising young one."

Lord Forester's seat on his hor'se at once denotes the workman, 


\section{RIDING 'TO HOUNDS}

being strong, powerful, and graceful. "A fine man upon a fine horse" has been characterized as one of the best specimens of the plastic art of Him who made them; but unless the man sits gracefully on the hor'se, and handles him well, that fine effect is lost. As the poet says, he should be "incorporate with the brave beast," and such does Lord F. appear to be. His eye to a country is remarkably quick, and his knowledge of Leicestershire has given him no small advantage.

Where a strong competition exists - as in riding to hounds-it is almost requiring too much of human nature to shut out all appearance of jealousy; and some humorous anecdotes are related of Lord Forester in his hard-riding days. One is, that getting first to a gentleman's park, the pales of which were not to be leaped, he espied a small bridle-gate, which he got through before the rest of the field came up, and locking it after him, and putting the key into his pocket, he bade farewell to his brother sportsmen, and of comrse had the rest of the r'un to himself. On another occasion, he is said to have ridden at a fence regardless of the good old caution of looking before we leap, and to have landed in the middle of a very deep pond: on a countryman, who saw him, calling out to some others who were coming in the same direction to warn them of their danger, he stopped him by exclaiming, "Hold your tongue-say nothing-we shall have it full in a minute!"

As I before observed, Lord Forester always shewed a masterjudgment in the points of a hunter; and in consequence of his residing in Shropshire-a county which has so long been celebrated for its breed of horses-he has a good opportunity of mounting himself well. He has always insisted on the necessity of lengthy shoulders, good fetlocks, well-formed hind legs, and open feet; and knowing better than to confound strength with size, his horses seldom exceeded 15 hands 2 inches. On anything relating to a hunter his authority has long been considered classic, and if "Forester said so," it is enough.

There is an old adage, but a very true one, that "when a man's character is established, he may say anything;" and this may in some measure be applied to Lord Forester. Without any ill-natured object, but merely to afford amusement, he will occasionally indulge 
in some freedom of speech; and certainly his Lordship must be allowed to possess a most happy talent of quizzing what, in the phrase of the day, is called " a slow top." * As a sportsman, however, the name of Lord Forester will always stand pre-eminent in the field; and in private life he is a very friendly man, and has ever adhered to those prineiples of honour and integrity which characterize the gentleman.

Lneorporated as it were with the name of "Forester," in the Sporting IVorld, for these last thirty years, has been the name of "Cholmondeley." The strongest friendship has existed between them from very early life, and when we heard of the one, we generally heard of the other ; and it is hard to say which of them has given most iclat to Leicestershire fox-hunting. As a rider to hounds, though a brilliant one, the latter always gave way to the former, who must be considered as the champion of his day; but in elegant manners, and in the accomplishments of a gentleman, he yields to no one. These gallant sportsmen might be classically termed the Castor and Pollux of their day; and had they lived in the time of Hereules, they would have borne away his honour's at the Olympic. As it is, lowever, they have been rewarded by their Sovereign, by being raised to the Patrician order. Whether they would have been so honoured had they not been so conspicuous in the field, it is not in my power to determine; but certain it is, that though Lord Forester nuay sound well enough, Lord Delamere is a bad exchange for Thomas Cholmondeley, Esq., of Vale-Royal, M.P. for the county. The one reminds us of "olden times;" the other is to be heard of nowhere but in the third volume of a four-andsixpenny novel, "by a Lady."

The way to heaven was once so easy, that, if I recollect right, Juvenal makes Atlas complain that his shoulders ached with the load of gods he had to carry; and if this were the case now, he who could beat

* A "slow top" is one who is sc unfortunate as to appear by a covert's sile within twenty miles of Melton Mowbray nuder any of the following circumstances:- "With a frout to his bridle, or with a martingal; on a country-made saddle, with nobs on his stirrups; with a saddle cluth: in a straight-cut coat ; in leather breeches or military spurs. It is deemed impossible that such a man (anl "do the thing." 
every minn in Leicestershire for a season would in time have a snuy herth amongst them. There was, however, says Cicero, rather too elose a resemblinnce between gods and men in those days to please him; and we will not dispute this point. Nevertheless, we may venture to assert, that amongst us sportsmen, "the laurels that Ciesar" won " would be weeds compared with those which we should wreath around his brow.

In what way the sons of Adian were to have passed their lives had not Paradise been too good for them, I leave others to decide; but to me a covert's side in a good country is an Elysium. Solomon satiated himself with women, wine, and palaces, fine horses, gold and silver, good eating, drinking, and music, and then grumbled at them all; but he never tried fox-hunting, or I think he would have been in better humour. It is among the scenes of nature that generous emotions are excited, and like the veteran Cochran, or the great John Ward, if we live amongst them, we shall enjoy them to the last, and leave to others to indulge in softness and effeminacy, which not only deprive them of all fence against discord or age, but leave them with shattered nerves and exhausted senses, and a pampered appetite for what they cannot enjoy. Of such men is these we may justly exclaim, "Non his juventis orta parentibus!"" it is not from such sires that the race of English gentlemen is to be propagated."

In fair play, however, there is one reason why hing Solomon could not have tried fox-hunting, and that is, the company he must have mixed with when riding to hounds; for certainly the best performer we have ever heard of has been one with whom this Royal Israelite could not with propriety have entered the field, after having preached so much against him; and that is, the devil! Reader, be not surprised or alarmed! but ask a Meltonian how such a one, who has been distinguishing himself with hounds gets on, and it is ten to one that he inswers, "Oh, he rides like the devil!" Now as this simile is really become proverbial, it is only fair to conclude that the devil has been a very good performer in his time. As to the colour he rode in, it may be difficult at this moment to determine, but we have the best authority for believing he was never so black as he is painted. In his own country we should imagine he rode in red. 
Though Solomon may never have tried it, hunting has been a favourite sport with kings since the days of the princely Cyrus. Our Second Henry - acknowledged to be one of our greatest kingswas such a determined sportsman that I shall give a little sketch of him in that character in the words of one of his historians.

"He neglected his hands," says this pleasing writer, "never" wearing gloves but in hawking. His clothes were short, calculated for expedition, his boots plain, and his bonnet unadorned. His feet and legs were generally in a bruised and livid state, from the repeated blows of his horses, yet he never sat down unless when unavoidable. His chief amusements were those of the field, which he pursued with immoderate ardour. He was on horseback before the sun was up-often fatigued the most robust sportsman in the chase; and returning sometimes late, sat down to a frugal meal, which was soon despatched, and he was again on his feet till an early hour called him to his couch. Thus, by exercise and abstemiousness, he opposed a disposition to corpulency, which indulgence would soon have rendered troublesome and unwieldy. His hawks were brought from Norway, and some from Wales; but he was particularly curious in his hounds, that they should be fleet, well-tongued, and consonous. His vices were the vices of the man, and his virtues were the virtues of a Prince. He wished to make his people happy by easing their burthens; and mitigated the severity of the forest laws, in the eye of his ruling passion. Notwithstanding this," adds his biographer (but perhaps his subjects were unreasonable), "he was little loved, and died unregretted."

The character I have now transcribed is the character of a man, as well as that of a prince; and we might find some parallels to it in modern days. I have already mentioned the opinion of a sporting Baronet in Northamptonshire, that it was the moral duty of every man to take care of his health for the sake of riding to hounds-an opinion in which I heartily concur; and as to the bruised and livid state of his Majesty's legs, we might also find a comparison here; for it is said of Frederick Berkeley, that at the end of one season in Leicestershire, his body was "black and blue," as it is termed, from the bangs and blows he had encountered in riding to hounds. 


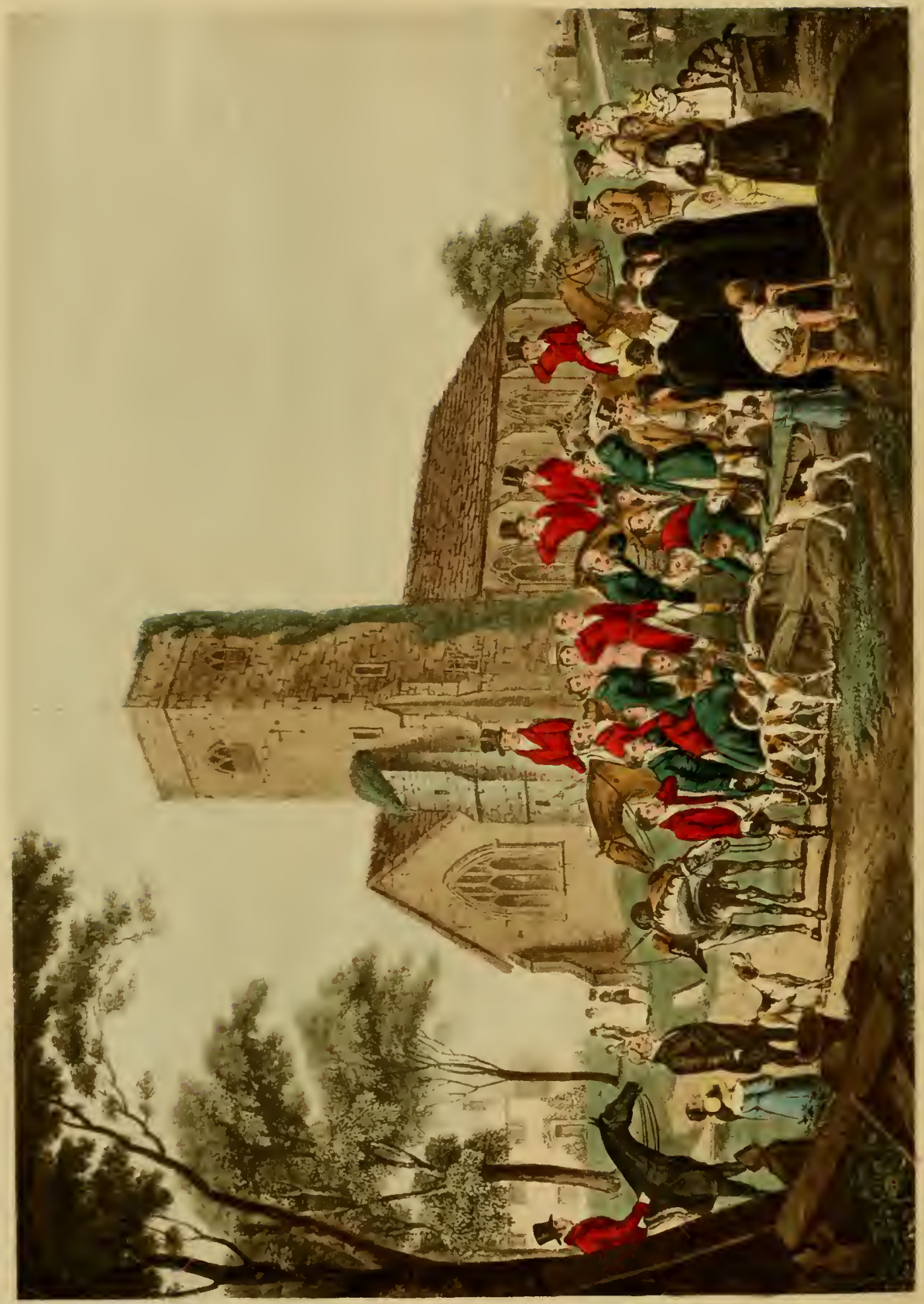




\section{RIIINT, wa hith yk}

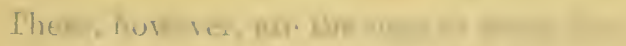

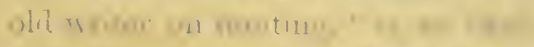

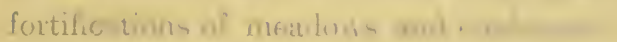

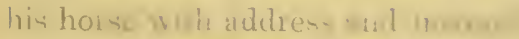

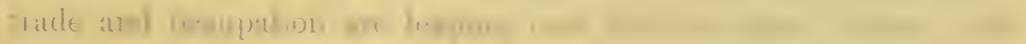

ame walls: [Jubit and espen ..

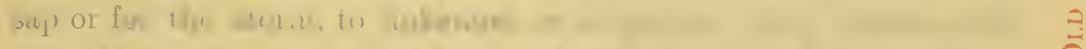

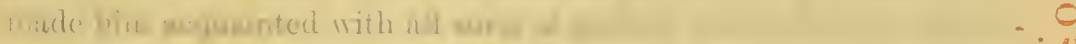

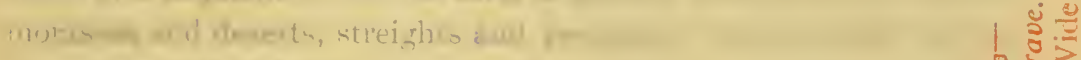

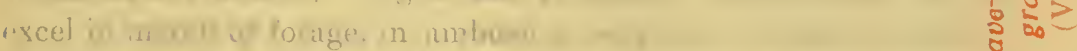

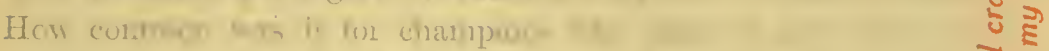

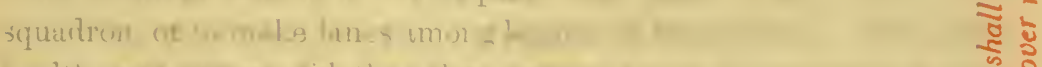

"ealth aud riome dial the y.hen wat the

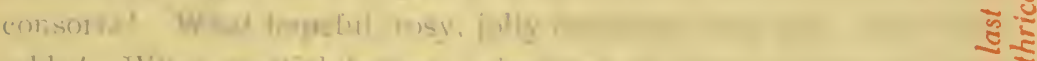

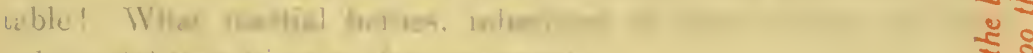

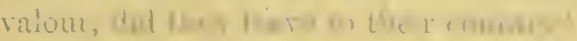

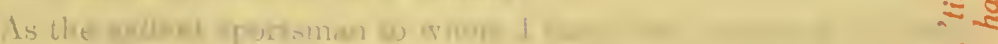

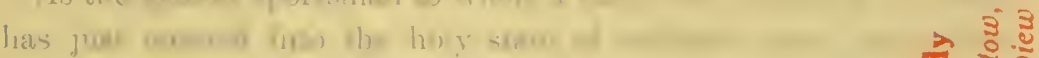

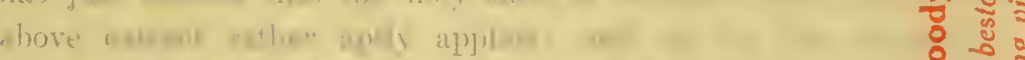

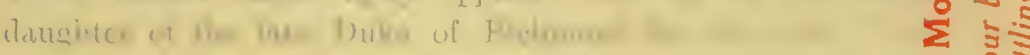

allownd the whene, in the lamen... I

br a raselor or

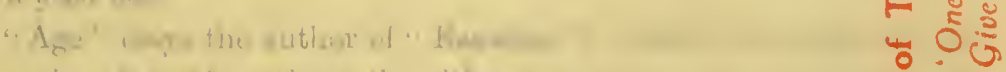

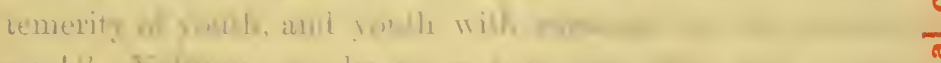

acel" X

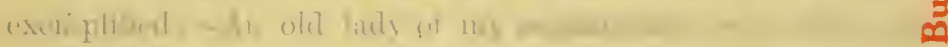

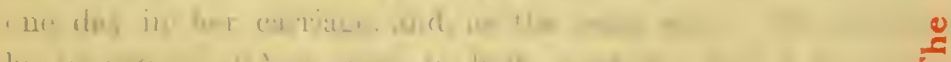

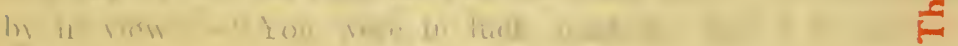

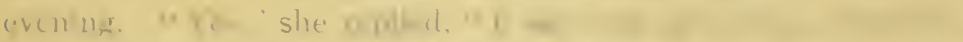

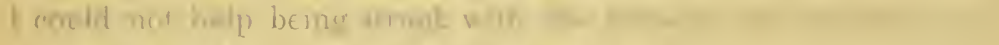

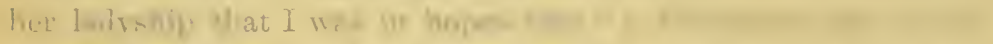

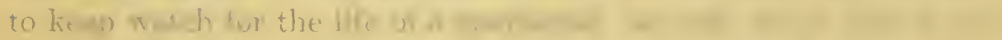

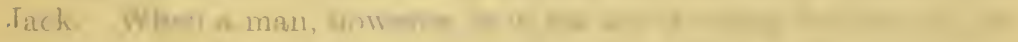

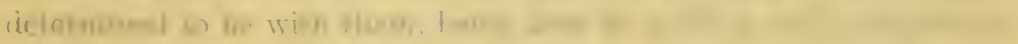

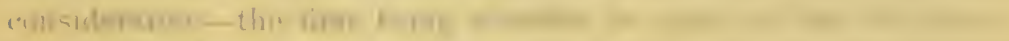

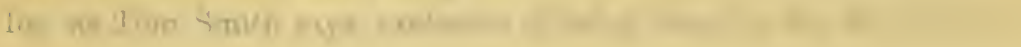




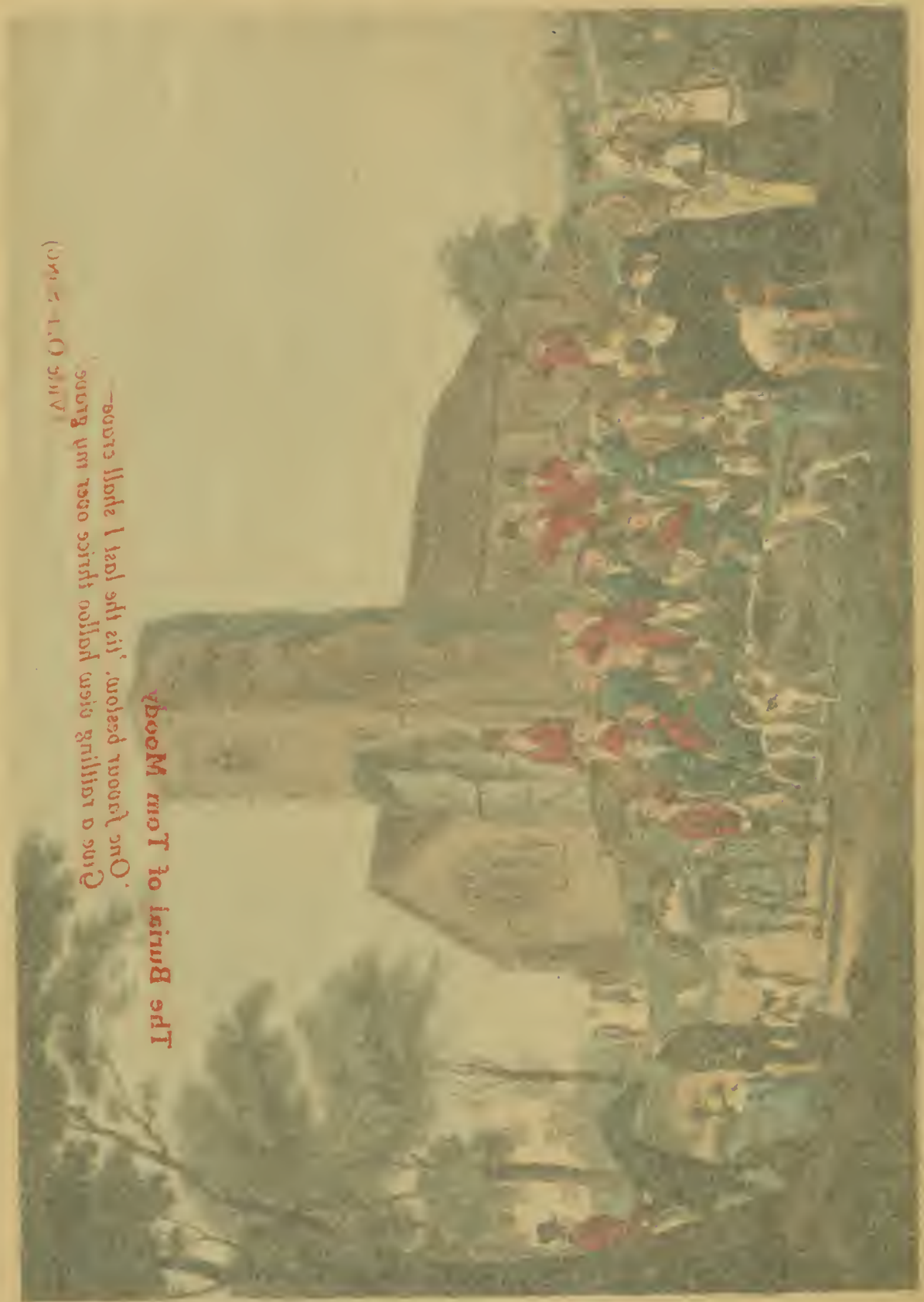




\section{RIDING TO HOLNIOS}

These, howerer, are the men to breed from : "for who," says a very old writer on hunting, "is so likely to gain a rampart, or mount an entrenchment, as he whose long practice hath been scaling the fortifications of meadows and enclosures? who so proper to manage his horse with address and intrepidity in time of action, as he whose trade and occupation are leaping over five-bar gates, hedges, and stone walls? Habit and experience qualify the fox-hunter for the sap or for the storm, to unkennel or to pursue: long eustom hath made him acquainted with all sorts of ground, with hills and valleys, morasses and deserts, streights and precipices; hath enabled him to excel in march or forage, in ambush or surprise, in attack or retreat. How common was it for champions like these to give terror to a squadron, or to make lanes among legions of Frenchmen! With what health and rigour did they then return home to the arms of their consorts! What hopeful, rosy, jolly branches were seen round their table! What martial heroes, inheritor's of their virtues and their valour, did they leave to their country!"

As the gallant sportsman to whom I have now rentured to allude has just entered into the holy state of wedlock, some part of the above extract rather aptly applies: and as he has selected il daughter of the late Duke of Richmond for his wife, I may be allowed to observe, in the language of Nimmod, that the cross must be a yood one.

"Age" (says the author of " Rasselas") "looks with anger on the temerity of youth, and youth with contempt on the scrupulosity of age!" Nothing can be more true than this, and I once saw it exemplified:-An old lady of my acquaintance was taking an airing one day in her carriage, and, as the song says, "the hounds came by in riew." "- You were in luck, madam," said I to her in the evening. "Yes," she replied, "I saw you all during Providcnce." I could not help being struck with the remark, but ventured to tell her ladyship that I was in hopes that " a Providence sat up aloft" to keep watch for the life of a sportsman as well as for that of poor Jack. When a man, however, is in the act of riding to hounds, and determined to be with them, being hurt by a fall is only a secondary consideration-the first being whether he may not lose his horse; for, as Tom Smith says, exclusive of being done for the day, there is 
nothing so low as to be running after one's horse, crying out, "Catch my horse! pray catch my horse!"

When we come to reflect, however, it is astonishing how few persons out of the number that ride orer a country are hurt by falls. A good story is told on this subject of a hard-riding whipper-in, who had had a great many falls in his time, but was never hurt in any of them. One unlucky day, howerer, his horse fell with him, and, rolling him as a cook would a pie-crust, nearly flattemed all the prominences of his body. Getting up, and limping after him, he was heard muttering to himself-" Well, now I be hurt!" There is a picture at Mr. Corbet's, of Sundorn, of the famous Tom Moody, when whipper-in to Mr. Childe. He is represented in the act of falling over some high park palings, and at the same time giving it view-halloo to a fox that was sinking before his hounds. This is the man, who, when he was run to ground himself, was carried to the churchyard by six earth-stoppers, who, by his request, gave three "rattling view-halloos" over his grave.

If I were asked who it was that had shown the greatest contempt for the consequence of a bad fall, that ever came under my observation, I should have no hesitation in saying, it was a gentleman by the name of Stanhope, who was on a visit to Sir Bellingham Graham, when he hunted the Atherstone country. On the Friday his horse fell with him, and hurt his shoulder, but nothing was broken or displaced. The consequence was, he came out on the following Monday with his arm in a sling. We formd a fox in the finest part of Sir Bellingham's Leicestershire country, and killed in fifteen minutes, during which Mr. Stanhope was in a very good place. Having had the pleasure of meeting him a few evenings before at Sir Bellinghan's, Ia asked him if he did not find it rery awkward to ride with only one hand, when he assured me he found little difficulty with the horse he was then riding, as he was so very temperate, and had never given him a fall. "That is dangerous to boast of," said I to him; and here the conversation ended. We found another fox, and had a fine run of an hour and ten minutes, and killed. About the middle of it, we came to a brook, which we all got well over with the exception of Stanhope, who unfortunately pitching on a turn in the hank, and disdaining to look, did not clear 
it, and his horse threw him with great violence on the opposite side. I saw him lying on the ground, apparently as dead as if he had been shot at Waterloo; and it was upwards of five minutes before he showed any signs of returning animation. On getting back to Sir Bellingham's house-having heen blooded at Bosworth-all necessary measures were taken, and the doctor would feign have persuaded Mr. Stanhope that some ribs were broken. He bad a short husky cough, and two or three other directing symptoms which seldom mislead a skilful apothecary; but he resisted all such insinuations, and assured him he should be well in a few days; and the Quorn homnds coming within reach on the following Thursday, he went to meet them, still having his arm in a sling!

In the course of this day's sport, some of the party, among whom was Mr. Stanhope, got into a corner of a field, and were pounded. What is not very usual in this country, one of the hardest riders in England had dismounted, and was trying to pull down the top har of a flight of rails, which dic not otherwise appear practicable. "Let me try," said Mr. Stanhope, "I am on a good one." The sequel was, he rode it it and got a trementous fall. On seeing lim lying on the ground, Sir Bellingham rode up to him, and said, "Now I'll tell you what, Stanhope, you are a good one, but by G-d you shall ride no more to-daly! Go to Leicester and put yourself into you carriage, and get to town as quick as you can, and get cured!" He took his friend's alvice; and when he arrived there, Mr. Heaviside found out that he had two ribs broken, and his breast-bone heaten in!! This, we may also say, is not a bal sort of a man to breed from.

The most difficult part of riding to hounds is "facing a brook;" but before I proceed to say anything on that subject generally, I shall mention one which Mr. Mytton leaped, in cool blood, on his return from hunting with his own hounds in Shropshire. It measured a little more than seren yards in the clear' but the space corered in the leap was nine yards and a quarter, from one hind footstep to the other. Being at his house at the time, I saw it measured the next morning in the presence of several other sporting men. This extraordinary leap, without the presence of hounds, was 
taken by that extraordinary horse Baronet. Some years since Mr. Mytton baeked him to elear nine yards orer hurdles placed at some distanee from eaeh other; but he performed the task so often with him before the appointed time, that he refused it then and lost his master's money.

Baronet is a mean-looking horse, with only one eye ; but Nature has made amends for that, by giving him more than one life, or he would never have survived the last seven years which he has been in Mr. Mytton's possession. He may be said to be as stout as steel; and if there was rank among brutes, this Baronet slsould have been raised to the peerage.

Mr. Mytton has no doubt put the power's of the horse to the test as mueh as any man in England, or in any other eountry; and it is in common answer to the question whether sueh a fence is practicable, that "it would do for Mytton." In Lord Bradford's Park, when he hunted the Shiffnal country, he cleared one of his Lordship's deer-hurdles, upwards of six feet high; and, what is more surprising, he covered the space of eight yards in length at the same time. This was aeeomplished on a horse ealled " The Hero," which he purehased of me for 500 guineas, and was the same that leaped the gate with him in Mr. Jellieo's grounds in Shropshire, the height of which was seven feet. I have possessed better brook-jumpers than "The Hero," as he would always make a triffing stop at them; but he was the highcst leaper I ever was master of in my life.

In my experience of riding to hounds, I have observed that nothing tends so much to make a field select as a good rasping brook. In the first place, many horses will not face it, and in the next, many men will not ride at it; and to be good at water is one of the first and most essential qualifications in each. Even a brookling, with soft banks, and horses a little abroad, often ereates no small confusion among those who are not mounted on hunters.* A fall at a brook is generally an awkward one, both to the rider and to his horse: the latter is very liable to strain himself; and the former, if not hurt, is sure to be spoiled for the day, exelusive of affording some amusement to his friends. When the famons Dick Knight hunted

\footnotetext{
* .II hunters are lorses, but all horses are not hunters.
} 


\section{RIDING 'TO HOUNDS}

Northamptonshire, he rode over a wide and deep brook at the same time that a Reverend Gentlenan was floating down it, having been landed in the middle of it. "The gentleman swims like a cork," said Dick, without ever thinking of assisting him. This tumbling into deep brooks, however, is no joking matter ; for when a man comes to fall backwards with his horse into deep water, and, as it often happens, gets under him, and remains there till his horse recovers his legs, he may be said to be anywhere but in clocer, and many narrow escapes to my knowledge have been encountered.

Several wagers have been made about leaping brooks in cool blood. One was between Lord Alvanley and Mr. Maher, some years since, in Leicestershire, for 100 guineas. It was that each did not ride over a brook that measured six yards in the clear, without disturbing the water. They both cleared it handsomely, but a bit of dirt being thrown back into it by Lord Alvanley's horse, after he had landed, it was of course decided against his Lordship.

Among the accidents that happen from brook-jumping, overreaching horses is the most common. To guard against this, the inside edge of the hinder shoes shoukd be bevilled down with the blacksmith's hammer, so as to make it quite harmless, as the best preventive of orer-reaching.

A horse cannot be called a hunter unless he is a good brookjumper; but to be a very good one is a rave qualification. It is not that almost every horse has not the power of extending himself orer six or seren yards of water; but a great many of them appear to have a more natural dislike to it than to any other species of fence; and to get over a wide brook requires as much resolution in a horse as in his rider; and in no part of riding to hounds does a man distinguish himself more. When I was in the habit of making young horses into hunter's, I found the best effect from the following plan of education:-I used to pitch upon rather a soft meadow, through which ran a small rivulet, or " brookling," as it is termed, with shelving banks on each side, so that there was no possibility of getting a fall by a young one putting his feet into it at taking off. I then accustomed him to go three-parts speed at it, taking it in his stroke, which he generally appenred to do with increased confidence every time he was ridden at it. I never rode hin orer it more than 
three times in one day, taking care that he did not see it till he came close to it. I have frequently seen six or seven yards, from side to side, cleared in this way without apparent difficulty. The advantage of this method is that it gives confidence to a young one, as, from the nature of the ground, a mistake cannot happen: and I have no doubt but that many hor'ses are prevented from ever being good brook-jumpers by getting into brooks before they know how to get over them. I had a rely satisfactory proof of the efficacy of this plan three years ago with a thorough-bred horse just ont of training, and who, when I first had him, stopped and snorted even at a deep cart-rut: after a few of these lessons, he would leap a very fair brook--merely the result of confidence in himself.

Amongst other countries, I hunted one season in Ireland; and there I found out the reason of the horses of that country heing such good drain-leaper's, as they are called, which is to be attributed solely to their education. If an Irishman has got a clever young horse, which he means to make a hunter, he puts a fellow more than half drunk on his back, with a pair of sharp spurs and a cutting whip (Anglice, a hand-whip), and he gallops him at all sorts of fences regardless whether he goes into them or over them-though with the help of the instruments just mentioned, and a good "Horough! by Jasus, the devil a balk you're going to make now!" the latter is generally accomplished. In our own country, however, I am sorry 10 say, a little punishment is wanting to persuade most horses to extend themselves over large brooks; and "the persululers," ats they are termed, as well as a stroke or two of the whip down the shoulders, are of the greatest nse. It should here be observed, that though the spurs should be applied when in the act of charging a brook, the rider's knees should be straightened hefore he comes to the bank, or, in case of a refusal, a ducling must be the consequence.

Most people know what a number of brooks there are in the Quorn and Belvoir countries; and most sportsmen have heard what a rare hand Tom Smith is at getting over them. The Styx itself wonkl scarcely stop him when a fox is sinking. This is to be attributed to his resolute way of riding to homds, hy which his horses know it is in vain to refuse whatever he may put them at. 


\section{RIDING 'TO HOINISS}

What I have now said, was strongly exemplified when he hunted the Quorn hounds. He was galloping at three-parts speed down one of those large fields in the Harborough country, in the act of bringing his hounds to a scent, and was looking back to see if they were coming: in the middle of this field, and exactly in the course in which his horse was going, was a pond of water, into which he leaped, thinking it useless to refuse, and of course not knowing that he was not intended to do so. This horse would, no doubt, have jumped into the Thames or the Serern.

Milton gives reason to brutes; and undoubtedly some hunters that have been ridden many seasons in enclosed countries, and are of docile tempers, nearly bear him out in his hypothesis-for it is wonderful with what care and caution many of them avoid danger, and at the same time ease themselves of labour in a r'un, by taking every adrantage of picking their ground. A horse of this description can scarcely be made to go on the top of a deep-plonghed land, as he knows he shall tread much more firmly in the furrow ; and he will make many attempts to get on head-lands and other sound ground. I once saw a particular instance of sagacity in a luunter of my own, which I shall never forget: I was riding him at a small fence in Northamptonshire, having my eye intent on the hounds, and did not see a row of live stakes, the remains of another fonce which had been ent up, as is common in that country, and on which he would have alighted; but he stopped short, and refused it. Whether this was ol was not reason, I leave others to determine; hut it was something "sui grneris," which saved me a good hol'se, and I am satisfied.

Having mentioned what I lave found to be the best method of getting horses orer brooks, 1 now come to point out the best way of getting them out of them, when they are so unfortunate as to get in ; and which is always a troublesome and often a difficult task. TWhen a horse of my own was pulled out of the river Cherwell, the cheek of the snaffle bit was forced through his under jaw, so that he conld only eat bruised corn for the rest of the season. This was from want of better management. Two seasons back I got a horse into a brook in Staffordshire, the bottom of which was so bad that he was unable to keep on his feet. His head was the only part above 
water, and one more struggle would have drowned him. By the direction, however, of some old sportsmen who were present, a quantity of stirrup-leathers were buckled together, one of which was secured around his neck, and he was pulled out by his head, and thus his life was preserved.

In leaping a wide brook, a borse must spring a certain height, or the joint weight of himself and his rider would bring him too soon to the ground. The momentum, however, has a good deal to do with it; for which reason a man should always ride at a brook at a quick pace, holding his horse fast by the head, sticking the needles well into his sides, and never letting him see it till he comes to it.

Standing leapers-that is, horses which will only leap standingare now almost exploded, and are very unfit for brook-jumping. It must, indeed, require no small degree of nerve to ride one of this description over a good deep brook with hollow banks. Some years since $\mathrm{Mr}$. Robert Camning bought a very magnificent horse, called Parnassus, from the Earl of Stamford, who, though he leaped a fence or two flying on the day he bought him, would always stand at them afterwards-probably to be aceounted for by his not liking seventeen stone on his back; and also, perhaps, the result of a little of that reasoning faculty which the poet I alluded to has allowed to these noble animals. It was astonishing, however, what brooks Mr. Canning could get this hor'se over; but the world is not peopled with such rider's as hin, and standing jumpers are, generally speaking, bad articles for fox-hunters.

There is one method of riding to hounds most essential to getting across enclosed countries, which the Melton men call "screwing." This consists in forcing a horse through rough places, without suffering him to jump-at least not more than sufficient to clear the ditch, if there be one. Two things are requisite here-a fine hand in the rider, and a disregard of being pricked in the horse. It is on the latter account that thoroughbred horses so often fail in making good hunters, as not one in twenty will bear pressing against strong thorns, in consequence of their skins being so thin. With men in the habit of riding to hounds, being thrown off a horse, unless the horse fall, is the last thing they dream of; but I was never so near it in my life as I was the other day, in trying to screw 


\section{RIIING 'TO HOLNDS}

at thorough-bred one through a thick place ont of a covert in Surrey. He took a sudden spring in the air from the place where he stood, trying to clear the highest twig in the fence; and being very powerful in his hips, the lash of his hind legs all but unhorsed me. It accounted for my having seen him throw a groom over his head a few days before at two trifling fences in succession.

Without screwing and creeping, however, no man can be sure of gretting over all kinds of countries. The former is most particularly useful in Leicestershire, Northamptonshire, and Wartwickshire, where the quick is not plashed down; and creeping is a sine qua non in Staffordshire, Shropshire, Cheshire, and all those countries where the herlge is put on the bank or cop. Were horses to take these fences flying, it is next to impossible that they could live very long with hounds. Creeping adds also rery much to the safety of the rider; for if a horse take time to get on the bank, and will stick his hinder feet firmly into it before he springs, he will have it in his power to clear a ditch, however broad; and I understand this is the way in which the Essex hunters are trained to get across that deeply-ditched country.

It may be said, that when a horse is creeping, hounds are getting away from him. This, I admit, would be the case were he to creep at all sorts of fences; but it is only at such as are not to be leaped flying, without distress to himself and danger to his rider, that such a method of fencing is to be recommended. It must be recollected, that when a horse is creeping, he is getting a puff at the same time, which will enable his rider to take a liberty with him, which he could not otherwise have done, by putting him along. merrily over the next field.

When horses are perfect at their business, and time will allow, they cannot be ridden too slow at most sorts of fences, as the shock to the frame in alighting on the ground must be, in great measure, proportioned to the velocity with which they go at them. There is, however, a just mean to be observed, and a good deal of judgment to be used at some fences. For instance, when riding at stiles, little more is to be done than giving a hunter to understand that he is to go at them, and if "the puff" is not out of him, and he is a good timber leaper, they are nearly as safe as any other stiff fences that a 
man rides at-provided, I should observe, there are no awkward foot-bridges or planks on either side of them. At gates is different methor of riding is necessary : a hor'se should always be put briskly at a gate, for two reasons-one, because it distinguishes between riding at it with the intention of leaping it, and going up to it to open it ; and the other, because, if he do not clear it, he is more likely to break it. I remember seeing a celebrated hard rider, who hunts his own hounds, have a fall over one gate and break two more in the course of the same rum, and I was convinced that all the mistakes were to be attributed to the quiet manner in which he rode at them. His horse did not appear to be satisfied whether he were to go at them or not, till he came close to them, and then he could not command them with more than fourteen stone on his back. When riding at park paling, or any other fence that is not familiar to hin, and therefore in some degree appalling, a eonsiderable share of resolution should be displayed by the rider to induce his hor'se to face it. He should take fast hold of his head, ramming his spurs well into him, at the same time giving him a strolie or two down the shoulder's with his whip, as much as to say, "it is no use to refuse."

I an an adrocate for riding lather fast at most timber fences, as being less dangerous to the rider in case of a fall. As to myself, I have, of course, had many falls over timber, but I never had a hor'se fall on me, which I attribute to generally riding briskly at it. In doing so, if a holse hit it so as to bring him down, his rider gets what is called "a purl," but nine times out of ten he is thrown clear of his hor'se. On the other hand, when riding slow at it, if the hor'se is suffered to stop and half refuse it (if I may be allowed such an expression), the odds are much in favour of his quietly landing his rider on the other side, and then quietly falling upon him and perhaps giving him his quietus for ever.

Taking the aggregate of countries, I will be bold to assert, that one half the accidents in riding to hounds are to be attributed to some awkwardness in the rider; and in some particular ones which I could name, it is next to miraculous that they do not more frequently occur. A short time since I heard that a well-known owner of in horse-repository in the metropolis had had a dreadful fall over a stile 
with the Hatfield hounds, and there was little hope of his recovery. "My life for it," said I, "that was some awkward trick or other !" Upon inquiry, I found it was occasioned thus:-Forgetting old Dick Knight's advice to My Lord Spencer, he rode up to the stile to see how he liked it, and in the act of "claning" to peep at the other side of it, his spurs ran into his horse: the horse marle a spring, chuched his rider over the stile, and then tumbled on the top of him.

Now had this good eitizen lost his life by this pantominic exhibition, and 1 had been the foreman of his inquest, do not for a moment imagine that to either horses, hounds, or hunting, should this melancholy catastrophe have been attributed. No; there should have been no "Aceidental Death" -no deodand on the horse-for" I should have depicted it as one of the elearest and best-defined cascis of "felo de se." Had he ridden his horse lilie a workman at the stile, all, no doubt, would have been well, and he might have anused himself with looking at it some other time.

My experience has taught me that many falls over timber arise from horses not having a catch to their shoes. I have for many vear's insisted on the necessity of the outer heel of the fore, als well as the hinder, shoes being turned up for hunter's that are to be ridden over a country; for if a hor'se stops at a fence of this description, and his legs all get together under his fore parts, his power of springing from the ground is destroyed. As to the injury which many people apprehend from the fore feet not having in this case an equal bearing on the ground, I confess I wats never able to trace any to this cause, with horses that have been properly shod in other respects; for during the winter months, when either on the road or in the field, the "turned-up " heel, as it is called, will always sufficiently indent the ground to produce an equal bearing to the foot. With respect to the danger of a horse over-reaching, and catching the heel of the fore shoe in the inner edge of the hinder one, it is entirely to be obviated by having that edge bevilled down, and made hlunt, as I have before directed. Without this precaution, accidents of this nature have occurred; and in a particular instance in Surrey; a few year's ago, the shoes were obliged to be taken off the hor'se of a gentleman's huntsman, by a blaclismith, before he could be released from his perilous situation. Fortunately; his rider escaped injury; but such falls must 
be doubly hazardous, from the suddenness with which the animal must come down.

The advantage of what is called "a catch" to the outside heel is very great in riding at timber, and most particularly so at stiles on greasy foot-paths-sometimes rendered doubly so by a frosty morning succeeded by a mid-day sun. Horses will often make a pause at common stiles; but if there happen to be a foot-bridge on either side of them, they are still more apt to do so, and, for the reasons I have before given, falls are too often the consequence.

Putting leaping out of the question, with some horses a catch to all the four shoes is of great advantage in galloping across a wet country. None but those who, like myself, have been accustomed to ride all sorts of hor'ses with hounds, know what difference there is in the firmness with which some of them take hold of the ground, in all their paces, when compared with others. Some have what grooms call "a slathering way of going," which is tiresome to themselves, as well as most unpleasant to their rider; and to them such a catch to the shoe is almost necessary, to make them either safe or agreeable, setting fencing, as I observed, quite out of the question. I remember a few years since going to look at a horse in Worcestershire, that had beep winning some hunters' stakes in a canter, and which was recommended to me as likely to make a first-rate Leicestershire hunter. On trying him, I found he slipped abont in his slow paces to such a degree that I immediately dismounted him, and gave up all thought of purchasing him. This partly arose from too long a stride, and partly from a peculiar method of putting down the foot, from the shoulder.

Exclusive of brooks and timber, there is another sort of fence that should be ridden at quickly, and that is, a bushy or "blackbird" fence, as it is called, being a live white-thorn hedge, not plashed, but with a strong suspicion of a wide ditch on the other side, and " no time allowed," as the coachmen say, for looking at it. This is termed "swishing at a rasper;" and the only chance a man has of getting a horse to extend himself sufficiently over it all, and to "come well into the next field," is to put him three-parts-speed at it, and trust to the momentum for getting over it. It was precisely at a fence of this description that I witnessed the accident two years ago to $\mathrm{Mr}$. 


\section{RIDING: 'TO HOUNDS}

Osbaldeston in Leicestershice. The hor'se he rode (Cervantes) was a particularly high leaper, but apt to drop short on the other side, which was the ease in this instance, and where the momentum was more particularly rendered necessary.

I never see the word "momentum," but it brings to my recollection an anecdote of an old friend of mine - a Fellow of a college, and a good fellow too-who was user to amuse me much by talking philosophically and mathematically on riding to hounds-the words monentum, ris vivida, and impetus, being for ever on his tongue. With the nerves of a bull-dog, and no mean opinion of his prowess, he was in the habit of purchasing horses, which, from natural or acquired defects, had failed in making hunters in the hands of others. His idea was, that if Nature had unfortunately intended such brutes to carry themselves in all forms but the right, that intention could be obviated by the means of mechanical force. To effect this, all sorts of trappings were resorted to ; and it was really alarming to men with any nerves at all to see him sailing across a country with the momentum, vis vivida, and impetus, all in full operation, on horses with mouths like the heart of oak, but with their hearls confined with a strong cavesson-martingal. On one occasion a most Indicrous accident occurred. This gentleman was out with the Duke of Beaufort's hounds in Oxfordshire on a horse thus accoutred, when the cavesson he was riding in unfortumately gave way. As may be expected, having no further power over the brute, away went the philosopher, like a ship at sea without a rudder, and, as ill luck would have it, the momentum, ris vivida, and the impetus, all formed their nucleus in the person of an unfortunate butcher on his pony, who was going quietly along a road; and the two riders and their horses were laid prostrate on the ground. The breath, as may be supposed, was lnocked out of each; but the butcher first came to himself, and, looking at his opponent, whom he had not previously seen, was heard to sigh out, in the true language of the slaughter-house, " D-n your eyes-but you've killed me, by G-d!"

During my visit to Surrey, I saw some horses tackled in curious ways-in ways which I had never before seen, and which would preclude the possibility of their getting across a country, taking all kinds 
of fences as they come. In two instances, I observed the head confined to the saddle by bearing-reins, in the same manner as a postillion sometimes bears up the horse he rides, to save himself the trouble of holding up his head. One of these gentlemen I had never seen before; but the other was the well-known Mr. Dickenson, at sportsman of some standing in Surrey, and an occasional performer in Leicestershire.

Much of the pleasure and safety of the rider depends on the position of the hor'se's head; and I have good reason to think that the grreat importance of the head being at liberty in enabling a horse to struggle out of a scrape, is not sufficiently known or considered of, but it is obvious to any one who will bestow upon it a few minutes' reflection, or who will watch the motions of the animal in a state of nature. A plank placed in equilibrium cannot rise at one end till it sinks at the other; neither can a horse get his hinder parts over a very high fence when his head is in the air. If he can'ries it too low, he is equally unpleasant, but less dangerous. To earry it where it should be must depend on the mould he is cast in.

What has been said of good writing may be applied to good riding - "it is a fine art, and known only to few "-

"The chosen few alone the sport enjoy."

Did this assertion require proof, it would soon be found, not only on the race-course, but in the field. Look at the small number of first-rate rider's of a race, and the comparatively small list of the Alite when hounds rum hard! "How are you, Bruen?" said Lindo one morning in my presence, before three hundred sportsmen assembled at a favourite covert in Leicestershire. "Never better" " replied Bruen: " "a very large field to-day!"- "So much the better!" said Lindo: "only let 'em go, and it will soon be small enough!" These words savoured a little of that "saucy passion " to which Fielding has given a name; but which generaliy aeconpanies a conscious pre-eminence over other men; and if ever to

* Colonel Brueu, MI.P. for Carlow, one of the hardest riders of his day, and one of the leading character's on the Irish turf. 
be allowed in the field, must be excusable in such riders as Mr. Lindo.

Having mentioned the name of Lindo, the seat on the horse presents itself to my mind. Most persons are acquainted with his; for if they have not seen him ride over a country in the morning, they have seen him "going a slapping pace" on a snuff-box in the evening. The artist has hit him off to a nicety; and cvery man who is a judge must allow that he looks like a workman. He has got his hor'se fast by the head with a firm and steady hand, and, at the pace he is supposed to be going, he must receive no small advantage from the assistance he is giving him, by standing up in his stirrups, and thereby throwing his weight on that part of his horse's body most able to bear it.

With respect to the general propriety of standing up in the stirrups when hounds l'un hard, eircumstances must be consulted. With men like Lindo-born to ride-no doubt ean arise as to the advantage of it; but with heavy, long-legged riders, it is better to sit quietly down in the saddle, particularly over ridge and furrow, when it would be next to impossible for them to be quite steady in their stirrups. It is my decided opinion, however, that a hunter's head should never be loose, but that, over all sorts of ground, when going a good pace, he should have some support from the hand.

None but those who have had much experience in riding to hounds know how much a horse is to be recovered in the middle of a run by a little good management. Let a hunter be never so fit to go, it is possible to blow him; and when he has been going for some time in deep ground, his wind naturally fails him to a greater or lesser degree, and he becomes weak. If his rider can get him out of this deep ground, even if he goes a little out of his line for it, on to some that is quite sound, and, standing up in his stirrups, will take a good pull at his head, he will recover himself wonderfully in a few hundred yards, although he may not be allowed to slacken his pace at all. This also proves beyond all doubt the good effect of holding a horse together with a firm and steady hand.

The most masterly instance of the use of a good head in assisting a horse over a country, in the way which I have been describing, that ever came under my observation, was in that accomplished 
horseman, Sir Henry Peyton. WVe were lunning a fox very hard with Sir Thomas Mostyn's hounds, and we had a deep fallow field to encounter. Sir Henry espied a dry ditch running parallel with it; and not regarding a few thorns and brambles, he rode up it, and when he came to the top of the field, his horse had an evident advantage over the rest. This might be called a second " trick."

The greatest trial at nerve, next to being shot at, is putting a horse that is blown at stiff and high timber. His rider is not only likely to get a fall, but a fall of the worst description, as it is ten to one but the horse not only tumbles upon him, from not having the power to rise (perhaps half the height of the fence), but that he lies upon him when he is down. I remember once asking a huntsman how his horse carried him-suspecting him to be one of the wrong sort-when he answered, that he was a dunghill brute, and not content with tumbling him down, "but," added he, "he lies on me for half an hour when he is down."

A little management, however, is useful in all these matters. The mere act of turning a hunter around, if he appears much distressed for wind, before we put him at a fence, will relieve him greatly, and generally enable him to clear it, if he is of the right sort to come again.

Large fences take a great deal out of a hunter, and consequently tend to stop him; but, "it is the pace that kills." A celebrated Meltonian wrote to his father a few days since, and this was part of his epistle:-"We had a quick thing last week-eight miles, point blank, in twenty-six mimutes! If I had not had a second horse posted (luckily) half way, I could not have seen it." So much for pace! Concluding that the run was not quite straight, it was at the rate of twenty miles in the hour! This reminds me of an amusing anecdote.

A great man in Leicestershire sold a horse to a little man, assuring him that he was a very good hunter. The little man, howerer, soon found out that he was a very bad hunter, and remonstrated with the great man on the subject. "You assured me," said he, "this was as good a horse as you ever possessed in your life." - "Did I ?" replied the great man: "I think, Sir, you must be mistaken." On his being reassured that those were his precise words, he exclaimed, 


\section{RIDING: TO HOUNDS}

Oh! now, Sir, I recollect all about it. I told you he was a very good hunter; and so he is if you let him go his own pace; but when I wanted him to go mine, he did not exactly suit me." This is a common case. Depend upon it, though time is slow, it is the pace that kills.

Accounts of no less than three different persons having met with their deaths in hunting, all in one clay, have reeently been presented to the public view: the first with the Oakley, the second with Lord Darlington's, and the third with the Hurworth fox-hounds; * and, what is as singular as it is lamentable, each was oceasioned by a noble effort to get to hounds, regardless of the appalling obstacle of a dangerous and devouring element, in which these gallant sportsmen all found a watery grave. To such a pitch, however, has the system of riding to hounds now arrived, that the chanees of life and death are but a feather in the scale when opposed to the determination of a modern fox-hunter " to see the thing," and " to be in a good place."

* John Edwards, Esy., of Silsoe, Bedfordshire, was out with the Oakley houncts, when, in attempting to eross a ford at a place called Newton, in liuckinghamshire, nearly opposite to Brayfield House, the seat of Major Farrer, and which had previously been passed by many of the sportsmen in perfect safety, he with several other gentlemen who were not acquainted with the proper course they onght to have followed, took a wrong dircetion, when all of them flonnced headlong into deep water. Mr. E., who was on a very spirited horse, unliappily lost his seat, but still kept fast hold of the bridle; and it is supposed, in his exertion to sare himself, that the animal, while struggling and plunging in the water, struck him on the liead with his fore foot, which stunned him, through which accident he sank, and was drowned. His companions with great difficulty escaped with their lives, and all the horses were rescued.Mr. Walbram, of Baidersby, was crossing the River Ure with Lord Darlington's hounds, near Stainley, when, unable to stem the force of the current, he was earried out of his depth and drowned. His son had nearly shared the same fate in endeavonring to save his father.-The Rev. Marmaduke Theakston, in the ardour of the ehase with the Hurwurth hounds, was tempted to cross the river Tees at a ford near Worsall. The water was deeper than nsnal, owing to previous rains, and he unfortunately mistook the ford. Ilis horse, a powerful and spirited animal, swam with him into the middle of the river, when, getting. impatient, he reared and threw his rider backwards. Mr. Theakston was then observed to swim (apparently strong and well), and scveral gentlemen who watched him with extrene anxicty had hopes he would reach the shore; but all at once, when within tive yards ol it, he sank aud never rose again. 
It is too true that without danger there is no glory. Nevertheless, much as I may be an advocate for making every possible effort to get to hounds, yet we should not altogether despise the old saving clause-that, sometimes, discretion is the better part of valour; for, to say nothing of the individual who loses his life, the heart-rending bewailings of those who have to lament the loss of it, in a parent, husband, brother, or son, are much too great to be thus rashly hazarded for the mere gratification of a passion, however noble it may be, when attended with such (probable) fearful consequences. In one case now alluded to, a father perishes in the presence of his son ; in another, a husband leaves a widow with eight children, and pregnant with the ninth; and the third appears to have been an only ehild, born to all the pleasures of life, and highly qualified for the enjoyment of them.

Much, I repeat, as I admire the man who rides gallantly across a country, yet it is useless to attempt impossibilities; and among these 1 have no hesitation in generally classing the getting across deep and rapid streams, with a horse perhaps blown at the time, unless the rider be not only an expert swimmer, but also unless he be in the habit of swimming horses, and swimming with his clothes on. Mr. Theakston, it is evident, was a swimmer; but there is every reason to believe that the weight of his clothes sank him at last; and in the moment of alarm, he had not the presence of mind to relieve himself by floating on his back, or by any of those expedients which expert swimmers have recourse to when they find themselves exhausted. Perhaps, however, situated as he was, thesc expedients would not have availed him ; for, taking into consideriltion that the elothes a man wears when hunting eannot be estimated at less than ten pounds when dry, it may be fairly concluded that when wet, with the addition of water in the boots, pockets, \&c., this weight must be more than doubled. Conceive, then, a man swimming, perhaps in dead water, with more than twenty-four pounds dead weight hanging about him, all verging to the bottom, and opposing his efforts to sustain himself on the surface!

On reading this calamitous account over again, I see much reason to suppose that the free use of the hor'se's head when in difficulty, and which I have already so much dwelt upon, was denied to him 
in this fatal instance; and to it, perhaps, may the melancholy catastrophe be attributed. "His horse," says the writer of the paragraph in the Hull Advertiser, " a spirited and porverful animal, swam with him into the middle of the river, when getting impatient, he reared, and threw his rider backucard." Now there is every reason to believe, that had Mr. Theakston left the horse to himself, holding on hy the mane, and only directing his course when necessary with the snaftle rein, he would have borne him in safety across the stream.

I speak from practical observation on this subject. When at a watering-place in Wales, I was in the hahit of having my horse swum in the sea by a man who was in the constant practice of swimming them for a very trifling consideration. He was himself a very expert swimmer, and regularly attended the bathing machines. From this man I learnt that there were only three things to be observed in swimming a horse-first, to give him free use of his head; secondly, to hold on by the mane; and, hastly, taking the feet out of the stirrups, to lean the body obliquely forward as much as possible, which will curuse the water to get under it and float it, and thereby diminish the weight of it on the horse. It was the opinion of this person, that a horse would swim nearly as far with a man on his back, who was thus expert at the management of him, as he woukd without him.

There is a small arm of the seil, about a mile wide at high water, which dirides the northern and the southern principalities of Wales, and over which is a horse ferry. $\Lambda \mathrm{Mr}$. Evans, a gentleman of some property in that neighbourhood, was crossing it a few years ago as the tide was rumning out with great rapidity, when his horse leaped overboard, and was carried out to sea, over the bar. Mr. E. never expected to see him again; but he recovered the shore between that place and the village of Towyn in Merionethshire, after swimming more than two miles. Another gentleman swam a small Welsh galloway across this ferry with perfect safety; and happening to be in that country at the time, I saw him in half an hour after he had done it. So much for the porrer of horses in water!

Whon I was about eighteen year's of age, I had an narrow escape from being drowned with $\mathrm{MI}$. Leech's hounds. The hounds crossed 
the river Dee-naturally a very rapid river, but then increased by the rains. Sir IVatkin Wynn, who (as well as his two brothers) is like a duck in the water, went first, and was followed by about six out of the field. "Half venturing, half shrinking," I went a little way into the stream, and came back again. Seeing the hounds hitting off their fox on the other side, I made a second attempt; and being mounted on a mare of Sir IVatkin's, called Thetis, and trusting to her genii to preserve me, I made a second attempt, and was carried down the stream amongst some huge stones. Not being able to swim, I gave myself up for lost; but the resolution of the mare, and my holding on by the mane, enabled her to regain the opposite bank, and I have never tried such an aquatic excursion since. A man may attempt the Hellespont for a woman; but, on cooler reflection, he is scarcely justified in running such risks of his life for a fox.

The following excellent remarks on "anticipating a check, and making a judicious cast (when casting is necessary) - the most useful knowledge in fox-hunting" -are from the pen of John Lockley, Esq., one of the first sportsmen as well as hardest riders of his day - the result of upwards of thirty year's' experience in the best countries.* They were communicated by Nimiod, and form an apt conclusion to his admirable letters.

"At a time when all the world run mad about fox-hunting, I am surprised so few gentlemen have learned to enjoy it rationally. The fashion of the present day is hard riding; and at night, when over the convivial board, their only pleasure seems to be in relating the exploits or disasters of their own or their friends' horses: not it word about the best or the worst hound in the pack; or any idea ever started to ascertain whether by system, or by accident, they had contrived to carry a scent twenty miles over a country to kill a fox :

* An admirable memoir is given of this celebrated Sportsman, from the pen of NImrod, in the Sporting Magazine. vol. xv. N.S. p. 409; his obituary, in vol. xxiii. p. 420; and a brief notice of this extraordinary man, in vol. xxiv. l. 105. 


\section{RIDING 'TO HOUNDS}

and how so great an event has been achieved, few modern sportsmen cin with any degree of accuracy relate.

"Many years ago, I recollect a gentleman who kept ten hor'ses in Leicestershire, and who had been riding near me very often in a very fine run, in which two of the most interesting and beautiful things happened that ever I remember to have seen, and to whom I remarked them when the r'un was over. 'Good God, sir', said he, 'I saw nothing of it.' This was a hard rider, who, from his own account, saw nothing while riding his horse as hard as he could go, and as near the tail of the hounds as he could possibly get. And how should he? for a man behind the hounds cannot be a judge of what is going on in front, and is the first person (by pressing upon them) to bring them to a check.

"A good sportsman will as often as possible ride parallel with the pack, not after them, unless by short tumns he is obliged to do otherwise; by which means he can see everything that is going on, and anticipate the probable cause of hounds coming to a fault; and I believe a good huntsman, and a minute observer, will twice out of three times discover the object in the line of hounds that cansed it, and, as soon as he suspects it, pull up his horse: for instance, a church, a village, a farm-house, team at plongh, men at work, sheep, and above all, cattle, are the things most likely to impede the scent (be it remembered, that the breath of one cow will distract hounds more than a hundred sheep). When any of these oljects present themselves in the face of hounds, you may then anticipate a stop, and, by pulling up your horse, and observing which way the pack inclined before the check, you will be able (without casting) to hold them to the right or left accordingly.

"If casting is necessiry you should be directed by the pace, ol" degree of scent which you brought to the spot where the hounds threw up: if you came quick, and your hounds are not blown (be sure to attend to that), you make a quick cast in the direction which the hounds were inclining, by forming a small circle first, and a larger circle afterwards if you are not successful: but if the hounds are blown, you should invariably east them very quietly, and hold them back; for when hounds have run a long waly hald, they lose 
their noses from want of wind, and run beyond the scent, especially if there is water in their view.

"In a fair country, and hounds in condition, it is my opinion, that if the above observations conld be carried into effect, few foxes would escape. Patience is the hest performer in the chase. All hounds in these times are well enough hred; and all hounds have power enough (if judiciousty directed) to kill their fox." 


\section{I.IS'T OF NAMES}

(1)

\section{Noblemen, Gentlemen, Master's of Hounds,}

IIuntsmen, Whippers-in, de.

I DAERTEY, Mr, , $14 \%$

Agar, Nr. J., :316.

Aileshury, Marquis of, s.j.

Althorp, Lord, 77, 52.

Aranley, Loril, Li1, 335, 334, 27.

Inderson, Mr., 246.

Inson, Lord, 27, $141 \mathrm{sq} ., 188.297$.

Inson, MI. Georore, $20(1)$.

Inson, Sambiook, 142.

Irden, the Honourable Colonel, 2is, $29)$;

Atkins, ('hristopher, 57,9$) 1$.

Astley, Sir Jacub, 131.

Iylesfori, liall ol", 39.

BAlk1, r'aptain, 3:'; .

Baker, Mr., ol Ekmore ITall, 293.

liaring, Jr., jun., $11 \mathrm{~s}$.

Barkwith, Mr. IV., 313 .

Barlow, lrank, 3.2.

liartard, lord, 343.

liarnard, lier. IIr., $7 \%$

liarrett, МГajor, 118.

Barrinoton, Rev., the Viscomnt, 275.

Barrow, II ill, 30, 190.

liarry, Mr. Smith, 11;8.

Bartlett, liobert, 70 .

Bates, Ned, 227.

bawcot. Mr., 17.

Beanfort, the Duke of, 8 sqq., 131, 121.

Beaufoy, Mr. Charles, 117.

Becher, Mr.. 127.

Beckford, Mr., 7 .

Beckwith, Mr. Willian, 20it, $27: 3$.

Bedford, Duke of, :35, $\$ 4$

liell, Colonis 34 ?. liennet, Mr., :39.

Berkoley, Colonel, 361.

Berkeley, the Hononrable resterick. $336,337,372$

7icrrington, (iolone], 52.

Berwick, Tord, 2:3.

Best, Mr. Richard, 32.

liethell, Mr., of liise, 301

lieth(2)1, Mrs., 305.

lieville, ('aptain, 270 .

liddn]ph, Sir Theophilus, 27, 116, 186. Biddulplı, Mr. (of C'hirk ('astle), 217.

Biddnl] h, Mr. Middleton, :3:3T.

liolton, Duke of 253

liolion, MI., jo.

linnltbee, Mr. Charles, Is:

lionlther, Mr. Tom, 142

liowe'n, Mајor, 313.

Bower, Мr. John, :3]:.

liowser, Nr., 287.

linxall, Will, 184 so.

l'oyeott, Mr., J(j, .)2, 189.

lingnton, Sir Francis, $24: 3,30.5,3.42$

liradley, Richard, 32.

lirait hwaite, Mr., 297.

liranding, Oliarles, 342 .

Breton, Billy, 143.

Bridges, Captain, 121.

Bridgewater, Duke of, 212.

Brimer, Mr., 25ั5.

Broadhead, Colonel, $12 t$.

Brommell, $\mathrm{Hr}$. 161 .

lirooke, Sir Ricbart, 22:.

l'rooke, Colonel, "').'

Brnce, Lord, 8i).

Bindenell, 16il.

birten, Colonel, 386. 
Buccleugh, Duke of, 2:31.

Buck, Mr., 188.

Buller, Mr., 77, 98.

Burdett, Sir Francis, 174, 19!

Burdon, Mr. (of Castle Eden), 265.

fiurrell, Mr., of West Grinstead, (i8.

Burrell, Mr. John, Durham, 262, 26ij.

liurton, the tanner, 142.

Burton, Dick, 167.

Butler, Billy, 177 sy., 346.

Butler, Hon. Capt., 239.

liutler, Mr. (ieorge, 11s.

Byrne, Mr., '208.

('ampbell, Mr. H., IS.).

Canning, Mr. Robert, 15, 17, $44 \mathrm{~s} /$, 380.

Carlisle, Earl of, 241, $: 316$.

Carr, Mr. Harrison, 7:.

Carter, old, the IImntsman, :4I.

Cartwright, Mr. (of Ayuhoe Park, 123.

Catol, Colonel, (iz.

Challoner, Mrr. Robert, 239.

Chapel, Jack, 33 t.

Chapman, Tommy, 287.

Clichester, Sir Arthur, 9.).

Chifney, Sam, 366.

Childe, Mr. (of Kinlet), I.).

Cholmondeley, Thomas, 370.

Chute, William, 75, 84.

Clarence, Duke of (Willium 1Y.), 2.2S

Clay, Rev. B., 99.

Clayilon, John, 114.

Clegg, Mr., 222.

Cleveland. See Darlington.

Cleveland, Lady, 327.

Close, Captain, 120.

Clough, Mr. J. IV., 239, :316.

Cocliran, Mr., 5.2.

Coekbill, Mr., 184

Coclrington, Mir. John, 8, 13.

Coke, Mr. William, 152, 2(\%).

Collier, Captain, 120 .

Colpoys, Aimiral, 120.

Combe, Mr. Harvey, 78, 128, T29 sq.

Combermere, Lord, :219.

Compton, Mr., 162.

Cook, Colonel, 82.

Cope, Sir Johu, 75 sq., 79.

Corbet, Mr., of Sundorn, 23 sqq., 43.

Corbet, Mrs., 24, 190.

Corbet, Mr. Andrew, 207.

Cradock, Mr., 167.

Craven, Earl of, 24, 147.

(raven, IIon. Berkeley, 161

Crewe, Mr. John, :09.

Croxall, Mr. Ned, 1t?.
DLLE, Mr. (of Creakhill), 25.).

I)auby, Will, 312.

Darlington, Lord, 154, 199, 24.t syq., $293 \mathrm{sq} ., 317 \mathrm{sqq}, 340$.

Darlington, Countess of, 2.18.

Davison, Nir. John, 271.

Davey, Mr., 23I, 233, 360.

Dawson, 98.

Delamere, Lord, ji, $161, .20 .0,370$.

Delme, Mr. G., 48.

Denbigh, Earl of, '22.

Derry, Will, 232.

Dews, Mr., 18.t.

Diek (Lord Darlington's whipper-in), $248,25 \mathrm{I}, 252,253,323$.

Dick, Oliver, 343.

Dickenson, Mr., 386 .

Dilly, William, 195.

Dudsworth, Sir E., 303.

Dorchester, Lord, 126.

Dowbiggin, Captain, 304.

Drake, Mr. John, $19 \mathrm{sq} ., 1 \geq 4$.

Drake, Mr. 'T. T', 19, 124.

Dundas, Captain, 262, 286 .

Dundas, Mr., 82.

Dyer, Mr., 5..

EDGE, Mr. John, 162.

Edge, Mr. Thomas, 16:.

Edwarls, John, Esu., $3 \$ 9$.

Egremont, Earl of, 70 .

Fillice, Colonel, 246.

Elwes, Mr. 77.

livans, Ml., 13.

Evans, Mr., of Wales, 389.

Farouharson, Mr., 94.

Feilding, Mr. Evered, 199.

Feilding, Mr. Henry, 217.

Fellowes, Ilonomable Newton, ؛(i.

Fellowes, Mr. Robert, 141, 185.

Fenton, 11r., 252.

Fenwick, Bob, 281.

Ferrors, Lord, 5.

Feversham, Iord, $2+1$.

Filer, 8:2.

Flounders, Mr. 269.

Flozer, Mr., of Hints, 14:.

Foley, Lord, 16, 114, 142.

Foley, Mx., 136.

Foljambe, Mr., 346.

Ford, Mr., 222.

Forester, Lord, 20, 161, 205, 228, 362, 367 sq.

Forester, Mr. Gieorge, 217.

liorfeit, Bob, 77, 8:2.

Foster, Dick (huntsman to Mr. Villebois), 110,111 . 


\section{IAS'l () NAMES}

Fowle, Rev. Fulwar, 90.

Fox, Mr. Lane, '239.

Fryatt, Mr. John, 160.

GAGE, Lord, 67.

Gage, Hon. W., 75, 11s.

(iarforth, Mr., $2+1$.

Gascoigne, 'Tom, 343.

George IV., 110, 228.

Germain, Ilon. Genror, lij.

liiffard, Mr. 34.

Gifford, Mr., 84.

Glammis, Lord, 95

Goodall, Stephen, 7, 15.

Goodlake, Mr., 25.5.

Goodricke, Sir Harry, 152, 163. 336, 346.

Goosey, huntsman, 1.52 .

Gough, Mr. 230.

Goulburn, Mr. E., 26, 206 ;

Græme, Mr., 111.

(irafton, Duke of, 19, 1I4, 127.

Graham, Sir Bellingham, 57, 156. 189 sq., 240, 214, 294, 336, 346.

Graham, Master Golfrey, 20:3, 25], 329.

Grant, Mr. Francis, 168.

Greenwood, Captain, 118.

frregson, Mr., 287.

Griffin, Mr., 20

Grosvenor, Mr. R., 151.

ITAIGH, Mrr. Daniel, 52.

Hall, Mr., of Scorboro, 80.5.

Harlin, Ifr., 175.

Harewood, Lord, 334.

Harland, Mr., of Sutton Hall, 260, 287.

ILarrison, Mr., of Shelswell, 19.

Harry. See Brodley.

Larvey, Captain, 55.

llawke, Lord, 333.

Hawkes, Mr. John, 50.

Hawksworth, Frank, 343.

Ilay, Mr., of Warwickshire, 1kis sil. 312.

llaynes, Mrr. Chndleigh, 172 (note).

Ilead, Will, 220 sq., 223 .

llealey, Captain, $268,329$.

IIealey, Nlajor, $243,3: 9$.

IJelden, W., 82.

Hemsted, Mr., 91.

Henry the Second of Englasid, 372.

1Lerrera, the Marquis, 183.

II ertford, Marquis of, 26 .

Heysham, Mr. F., 118.

Ileysham, Mr. William, 117.

IIill, Lord, 206 sq.
Hill, Sir Robert, 209.

Hill, Sir Rowland, 209.

Hill, Mr. John, 2I7, 219, 223.

Hobson, Mr., 54.

Hodgson, Mr. T., 303, 307 sq9.

Hodgson, 'Tommy, the groom, 325.

Hodson, Irr., 7t, 34t.

Holbeeh, Mr. 26.

Ilolland, Mr. Francis, 181.

Holloway, Mrs., 12, 136i.

Holt, Mr., 55 .

Holyoake, Mr., 163, 2:30.

Hooker, Dr., 72.

Hopetoun, Lord, 314.

Horlock, Johı, 95.

IIorton, ('aptain, 343.

Hoste, Sir William, 1:0.

Hunt, Mr. (of Boreaton), 208.

Huntingfield, Lord, 161.

IInrt, Mr., 260, 270 .

TXCLEDOX, Mr., 95.

Ishim, Mr. HI., 233 .

Isham, II . Vere, 2:32.

Isted, Mr. Ambrose, :23:3.

JAckson, Harry, 144.

Jaekson, Mr., of Whiterross, 304.

Jennings, J., 94.

Jersey, Lord, 1S, 12t.

Jolliffe, C'olonel, 58 sif.

Kees, Major, 69.

Kelly, Colonel, 107.

Kennedy, Honourable Captair, 25..

Kilmorey, Lord, 207, 219.

Kingseote, Mr. HenrF, 131, 136, 146.

Kintore, Earl of, $\ln 9$.

Kuight, Dick, 357, 376.

Knight, Mr. 75.

Knight, Messrs. (of Chawton Park), 117.

Knightler, Sir Charles, 230.

Kinightley, Mr., 140.

Knivert, 'W ., 80.

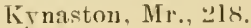

LAkF, General, 5\%.

Lamberl, Mr., 91.

lambton, Mr. Ralph, 158, 244 sqq., $259 \mathrm{scc}$.

Langston, 161.

Lascelles, Bob, $3+2$.

Lawley, Sam, $1+1$.

hee, ifr., ise.

Leech, Mr., of Carden, 117,221 sq. 
Leeds, Duke of, 25t, 2!)4.

Legard, Mr. Jigby, 211, 311. :31:3.

Legard, Mr. George, 3L1, 313.

Leigl, Mr. Chandos, 181 .

Leighton, Sir liobert, 16I, 224.

Lepper, IVilliam, 1:37.

Levet, Mr. The, I 42.

Linclo, Mr., 3, 19, 161, 357, 3(60), 386(.

Littleton, Sir Edward, :2:3.

Lloyd, Sir Edward, 19, :1, 124.

Lloyd, Mr. G., 124.

Thloyd, Mr., of Acomb, 2:3!).

Lloyd, $\mathrm{Mr}$., of Aston, $206,217$.

Lloyd, Mr., of Dongey, 208, 217.

Lloyd, Mr. Hemry, $21 \%$.

liloyd, Mr. Mostyn, 124, J:36.

Lockley, John, 32, $150,392$.

long, Will, 18I

Lonsdale, Lord, $1+9$.

Luey, Mr. G., 139.

lucy, Mr. John, 137 sq.

Luke, 70.

Lyster, Mr. Henry, 211.

Lyster, Mr. John, 217.

MACDONALD, Lord, :3UT.

Macdonald, Honourable A., $313,314$.

Maher, Mr. V., 150, 161, 336, 37.

Mainwaring, Sir Harry, 207, 220, 2023.

Marjoribinks, Mr., 129.

Markhitm, Mr., 331.

Marriott, MIr. George, 154, 159 s4., 333.5

Marshall, Iiev. Bouclier, !).

Marshall, J. M., 99.

Matthews, Mr. Stejlien, 190.

1]aude, Mr. 'T', of Nelaby, 332.

Maxse, Mr., 161, 16: sq., 203, 3:34, 36

Mleares, Mr., 118.

Medford, Mr., of Carlton, :313.

Nellish, H arry, 342.

Meyler, Mr., 161.

Meynell, Hugo, 2, 4, :33s, :itiz.

Meyrick, Mr., 13, 18:, 18\%, 2:34.

Niddleton, Lord, $23,138,14$.

Milbanke, Lady Augusta, 2.51, 325.

Nilbanke, MIr. Mlark, 254, 206 s(1., , 303.

Mildmay, Mr. Hugo, 117.

Molony, Mr., 136.

Molynenx, Lord, 139.

Monday, Ned, 14:.

Nonson, Rev. Johı, 259, 295, :33:2

Ii ontague, Mr. llemy, 201, 2I7.

Moody, Tom, the whipper-in, $37 t$.

Moore, Mr. John, 161, 162, 346.

Morant, Mr. Edward Gale, 48.

Moray, Major, 188.

Mordannt, Sir Charles, 139.

Mordaunt, Sir John, Ist.

Mostyu, sir Edward, 337.
Mostyn, Sir Thomas, 7, 8, 13 sq., 123, $1: 31$

Mountsandford, Lord, $30: 3$.

M[unday, Mr., 168.

Murray, Mr. D). 118.

Musgrave, Sir James, 1(i1, 1ti2, 1tit.

Musters, Mr. Joln1, 162, $229 \mathrm{sq} ., 252$.

Mytton, Mr., 190, 194 sqq., 22:2, 37.

NAlLER, Mr. :3t4.

Naylor, the York huntsman, :2:39, :311.

Neverd, W., 8:, 88.

Newnham, Mr., 17.

Newnbam, Mr. Bigland, 71.

Newton, Mr., of P'ickhill Hall, 2Is.

Northampton, lord, 26.

Nicoll, $11 \mathrm{r}, 172,345 \mathrm{sqq}$.

Nunes, Mr., 120.

1)CAllaghan, C'ulonel, :3:3:3.

()llaker, H., 78, 126.

()1daker, R., 126, 130.

Oldaker, 'Tom, 37, 126, 130.

()ldacre, the farmer, 167 .

Ungley, IIon. Sam, 72.

O'Neil, Mr., 168.

Ord, Mr. Benjamiu, 2tis.

Usbaldeston, Mr., $1 \mathrm{ls}, 1 \mathrm{~s} t \mathrm{sq} ., 197$, 308, 335, 337, 355.

()tway, sir loltus, 13.5, 188.

()wen, Mr. Śmythe, $161,217,219$.

()wen, Mr., 209.

PАККЕ, ('Jarles, :i:3.

Parsons, $11 \mathrm{r} ., 234$.

Patrick Mr., 18.

['aulet, Mr., I10.

Paulet, II our. C'apt. .2 Hi.

P'ayne, Mr., 1 1.0, 3336.

Payne, l'hilip, 11, 13:2, 1s!.

P'eel, Mr. L., 111, 14\%.

Penu, 'Tom, 20, 171.

Percivall, Mr., 54.

leyton, Mr., 12t, $29 \%$.

l'eyton, Sir II., 18 sq., I:4, I:27, 368.

Pierrepoint, Mr., 12.1.

P'ymonth, Lerd, 166.

l'oole, Mr. Domville, 21!, 2202, 2:23.

l'orter, Mr. Walsh, 51.

Pottertun, Mr., 234.

Prees, the Vicar of, 209

Price, Mr. Barry, 129.

Price, Captain, 117

Price, Will, 251, 294.

Puleston, Sir 1R., 15, 24, 35, 196, 225 sqq.

Pulfrey, John, 20:2. 


\section{IIST OF NAMES}

IRADCLIFFE, Mr., Z̈G).

liaven, dack, 7 .

Hawlinson, Mr., 13.

lichards, Jicke, :3:) l.

lichmond, Duke of, 70.

liirlge, Miajor, 1:0.

Riclsilale, Mr., 2:37.

Robins, Colonel, 18r.

Roffey,, $58 \mathrm{sq}$.

liork, Mr., 208, 211, 217.

Rose, Tom, 114, 127.

Ross, Captain, $168 \mathrm{sq}$.

Russell, Rev. John. Ioki.

Russell, Mr., of Hardwicke IIall, 2075.

liutlind, Duke of, 1.51 .

ŚT. PAOL, NIajor, 3:S.

Sackville, Lord, 16il.

saville, Mr., $3+1$.

icott. Mr.. I1s.

Sebright, Tom, 157, 2.42.

Sefton, Lord, ij sqq. .

Seagrave, Lord. See colonel bélicley.

siergeantson, Mr. George, 2.5.

Sliafto, Mr. 1)., 260,287 .

shafto, Mr. J.. 266 .

Shafto, Mr. 'T', $288 \mathrm{~s} y q$.

Shakerley, Mrs., 183.

Shaw, huntsman, 12, 15, $11: 3$, :(i).

Sheldon, Mr., 18.5.

Nhirley, Mr., of Fatington, 2:3, 141.

thirley, Jack, lise.

Shrewsbury, barl of, 10.

Simmonds. Mr., 7.).

sikinner (whipper in), ls!

skipwith, Sir Gray, .)1.

Slaney, Counsellor, 217 .

sloper, Mr., si3.

Sloper, Mr. Johıl, 91

smith, Mr., :3l6;

Smitl, Mr., of sholebrook [adwe, 1] I.

Simith (Mr. John of I $\mathrm{ull}$ ), 313.

- inith, Mr. Loraine, 6, 297 .

simitl, (the Tom), 1l1., 2, s9, 901. 1.5, $[59,165,232,378$.

inith, 'l'om, the whipper-in, $2: 3:$.

imythe, Sir Edward, 194, 208, 218.

Simytlers, Mr., 118.

fonerset, Lord Charles, 2.51.

Somerset, Lord Edward. I.2.

Somerset, Lord Ciranville. 12.

Southampton, Lord, 114.

Sowden, Mr. 'T., 108.

speneer, Lord, 77 .

Spurrier, Mr., $3 \pm 6$.

Standon, Captain, 150, 170.

Stanhope, MIr., 3it.

Staples, Tom, 20:2.

Staples, IVill, 19:2, $202 \mathrm{sq}$.
Staveley, Mr., of slemtord, :246.

Stcphen ( $1 \mathrm{l}$. Fellowes' huntsmin), 97.

Stejhens, Jack, :33S.

Sitorey, Ml. Jolın, 360

Stowell, Mr. Willoughby, m.

stroud, the lor'se dealer, 3:3.

ituart, Captain, 158

itublos, Walter, lisq., f(I) sq.

Sutton. Mr. of Filton, 关方.

Ninrtees, Mr.. of Mainsforth, :27:3.

Swann, Mr. George, 2:36,:31\%.

Sykes, Nir Nark, $203,2+1$.

rykes, Nir Tatton, 239,240 syq.

T.YYLOR, lier. H., 105

'Templer, Mr., 103 sq.

'Theakston, liev. MI., 3s!?.

Thompso11, Mr.. of Hil pha11, : 1:3.

Thornton, Colonel, 2:39.

'Thurlow, Robert, 144

'Tilbury, Mr., 12!9.

'Tomkinson, Major, 2.2.2.

'T'omkinson, Mr. James, 222

Tommy, whipper-in to Hurworth liounds, 297

Towers, Colonel, 293.

'Treacher, Mr. George, 239.

Trotter, Dr., 264.

Trotter, Mlr, of Staindrop, :64, 3:2s.

'Troyte, Rev, 1)r.. 96;

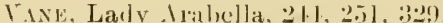

Vannexk, Jlon. Jushua, 161.

Vansittart, Mr., $16 i$

Vernoll, Lord, $1+2$.

Villebois, $11 r ., 109,113 \mathrm{sq}$

Villebois, Mr. Frederick, 11 . .

Villebois, Mr. Ilenry, 11.5.

Vivian, Nir Hnssey, 171 sq., 315.

Vivian, Mr., 17i.

\section{WAUDINGTON, 1 \%.}

Walbram, Mr., of Baidersby, 359.

IVallace, Colonel, 25.5.

Ward, Mr. John, 77 sq., :34tis]

Ward, Mrs., 92.

Warde, General Harry, il

Wardle, Colonel, 2t, 163.

Watson, Nr., of Wanbr, 31:3.

Watt, Mr., of Bishop-Burton, it

Webb, Mr., 13t, 136 .

Webster, Sir Godfrer, 57.

Welbourne, $\mathrm{ML}$ r. 306.

West, Mr., of Alscot Park, 136, 182.

Westall, Bob. 129.

ivlialles, Mr., 23t.

Wharton, Mr. J., 2 $46,33 \%$. 


\section{LIS'T OF NAMES}

White, Mr. John, 159.

Whitmore, Mr., 189.

Whitworth, Mr., 234.

Wickstead, Mr., 209.

Wilkinson, Mr., of Alresford, 119.

Wilkinson, Mr. Mat, 290 sq., 297 sqq.

Wilkinson, Mrs., 328.

Willan, Mr. John, 117.

Williams, Mr. (sou of the General), 194.

Williams, M[r. Lloyd, 2]s.

Williams, Bob, 32i.

Willianison, Mr. W., 2(i) sqq., 297 , $292,328$.

WVillonghby, Lord, Is:.

Wilson, Jack, whipper-in, 317.

IVilton, Lorr, 336.

Wing, $\mathrm{Mr} ., 368$.

Wingfield, Tum, 3, 15, 16, 124 sq., 131.

Wimiatt, Mr. Reginald, sI.

Winnington, Sir Thomas, 112.

IVinter, Jack, 281.

IVood, Jack, 138, 141, 185.

Woodbridge, Mr. E., 59.

Wormald, Mr. John, 346.

Wrigglestorth, Jack, 202.

Wroughton, Mr., 91.

Wronghton, Mrs., 8:3.

Wyatt, Mr., 185.

Wyndham, Colonel, 65.

Wyndham, Colonel H., 70.

Wynn, Sir Watkin IVilliams, 170.

Wynne, Mr., of Cricketh, 216.

Wynne, Johnny of Ryton, 29:3 note.

Wyune, Mr. of Shrewsbury, 217 .

Wyse, Mr., 119

Wyvill, Mr., 254, 294.

Z/AC, 189. 

Webster Family Library of Veterinary Medicine Cummings School of Veterinary Medicine at Tufts University

200 Westboro Road

North Grafton, MA 01536 



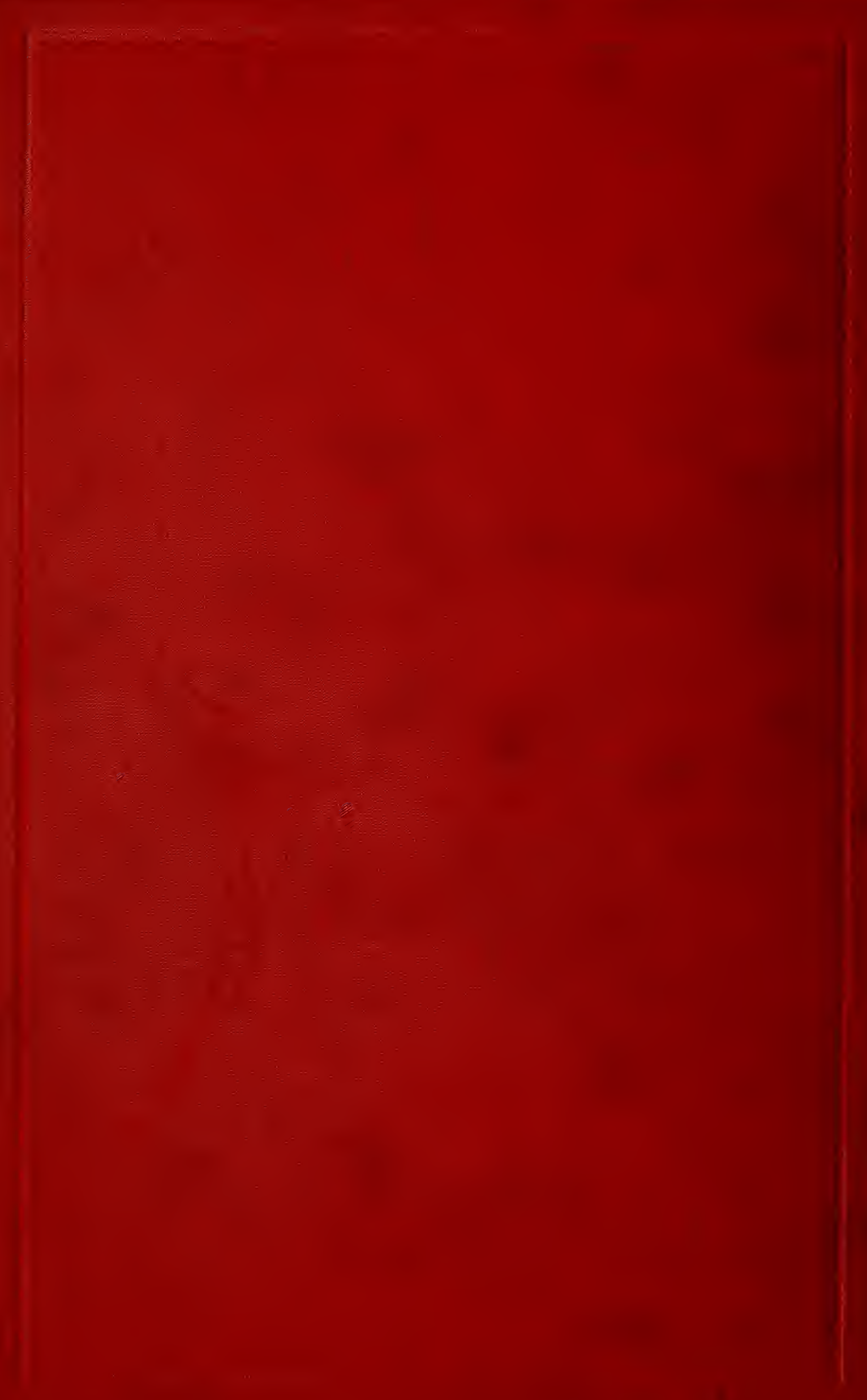

